Marlísio Oliveira Cecílio Junior

\title{
ESTUDO DO COMPORTAMENTO DE UM TÚNEL EM SOlo RESIDUAL DE GNAISSE POR MEIO DE ENSAIOS Triaxiais CoM Controle de Trajetórias de Tensões
}

Dissertação apresentada à Escola Politécnica da Universidade de São Paulo para obtenção do título de Mestre em Engenharia. 


\section{ESTUdO DO COMPORTAMENTO DE UM TÚNEL EM SOLO RESIDUAL DE GNAISSE POR MEIO DE ENSAIOS TRIAXIAIS COM CONTROLE de Trajetórias de Tensões}

Dissertação apresentada à Escola Politécnica da Universidade de São Paulo para obtenção do título de Mestre em Engenharia.

Área de Concentração: Engenharia Geotécnica Especialidade: Geomecânica

Orientador: Prof. Dr. Marcos Massao Futai 
Autorizo a reprodução e divulgação total ou parcial deste trabalho, por qualquer meio convencional ou eletrônico, para fins de estudo e pesquisa, desde que citada a fonte.

Este exemplar foi revisado e alterado em relação à versão original, sob responsabilidade única do autor e com a anuência de seu orientador.

São Paulo, de maio de 2009.

Assinatura do autor:

Assinatura do orientador:

FICHA CATALOGRÁFICA

Cecílio Junior, Marlísio Oliveira

Estudo do comportamento de um túnel em solo residual de gnaisse por meio de ensaios triaxiais com controle de trajetória de tensões / M. O. Cecílio Junior. -- ed.rev. -- São Paulo, 2009. 204 p.

Dissertação (Mestrado) - Escola Politécnica da Universidade de São Paulo. Departamento de Engenharia de Estruturas e Geotécnica.

1. Solo residual 2. Túneis 3 . Análise numérica I. Universidade de São Paulo. Escola Politécnica. Departamento de Engenharia de Estruturas e Geotécnica II. t. 
"O tempo que antecipa o fim também desata os nós"

Novamente - Fred Martins e Alexandre Lemos

Num bosque de folhas amareladas, dois caminhos havia,

E triste por não poder ser dos dois E ser caminhante, lá fiquei [...]

Havia neste bosque dois caminhos, e eu-

Eu fui pelo menos percorrido,

$\mathrm{E}$ isto fez toda a diferença.

O caminho não percorrido - Robert Frost
"Two roads diverged in a yellow wood, And sorry I could not travel both And be one traveler, long I stood [...] Two roads diverged in a wood, and II took the one less traveled by, And that has made all the difference."

The Road not taken - Robert Frost 


\section{Agradecimentos}

A Deus e à Santa Bárbara, protetora dos tuneleiros.

Ao orientador, professor e amigo, Marcos Massao Futai, pelos ensinamentos, pelo constante apoio e por me incentivar e me ajudar a trilhar "o caminho menos percorrido".

A todas as entidades e pessoas que contribuíram para a realização desta pesquisa. À Companhia do Metropolitano de São Paulo - Metrô, nas pessoas dos Engenheiros Argimiro A. Ferreira e Sérgio Renato de A. Leme, e do Geólogo Hugo Cássio Rocha. À Bureau de Projetos, nas pessoas dos Engenheiros Arsênio Negro Junior e André Yassuda. Aos professores da Pós-Graduação em Geotecnia da Escola Politécnica, em especial às marcantes aulas do professor Carlos de Sousa Pinto.

Meu reconhecido agradecimento a Arsênio Negro Junior,

Carlos de Sousa Pinto e Waldemar C. Hachich, por se disporem a participar da banca e pelas suas valiosas contribuições.

Ao Geólogo José Maria A. Sobrinho e ao Engenheiro Rodolfo Mendes, pela ajuda com a interpretação das lâminas petrográficas. Ao Físico

Flávio M. de S. Carvalho, por me ajudar a desvendar as difrações de raios-x. Aos funcionários do Laboratório de Mecânica dos Solos da Poli, os amigos Antônio C. Heitzman e Joaquim Costa Jr.

Aos amigos que pude conhecer no convívio da Poli, Alexandre Pelegrineli, Alexei G. N. Jiménez, Ilço Ribeiro Junior, João Vitor S. Godois, Lauro Massao Wada, Paula Fernanda Teixeira, Silvia Suzuki, Victor E. Pimentel e William Ito. Um obrigado especial para o Antônio, Ilço e Lauro, pela ajuda durante a coleta das amostras indeformadas da frente de escavação do túnel.

A todos os amigos e companheiros de trabalho da Figueiredo Ferraz, em especial a Carlos A. Campanhã, José Carlos O. A. Junior, Pedro T. França e Valéria Armigliato, pelas longas discussões sobre o fascinante mundo das escavações subterrâneas.

À Cintia C. Schultz, pelo apoio desde os tempos da minha graduação. $\mathrm{O}$ autor agradece ao apoio financeiro da FAPESP e do CNPq. 
Meu sincero agradecimento a todas as pessoas que, mesmo não participando diretamente da produção científica deste trabalho, foram essenciais para sua existência.

Aos meus pais, pelo amor incondicional, pela educação e oportunidade, pelo constante apoio e incentivo, por sempre acreditarem e nunca me deixarem desistir.

Aos meus irmãos, pela ajuda, pelas longas conversas sobre a vida acadêmica, pelas suas experiências de vida e por me mostrarem o caminho das pedras.

Ao grande amor da minha vida.

A todos os meus amigos.

A todos que me são tão próximos e que por vezes estive tão distante, meus pedidos de desculpa pelas privações e por todo o tempo de ausência.

"Happiness is real only when is shared" - Into the wild 


\section{ÍNDICE GERAL}

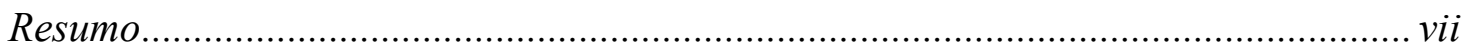

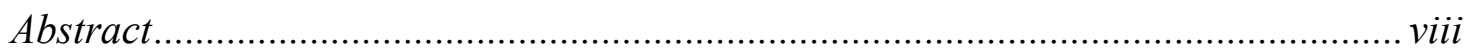

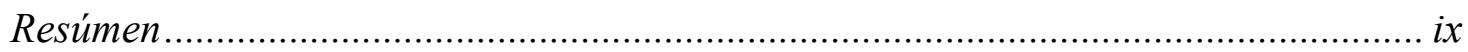

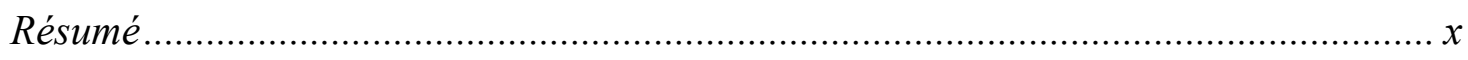

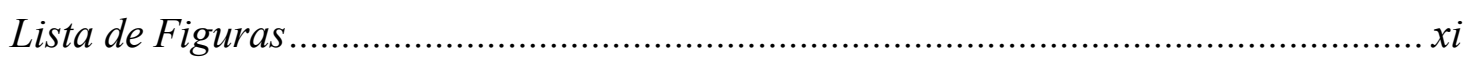

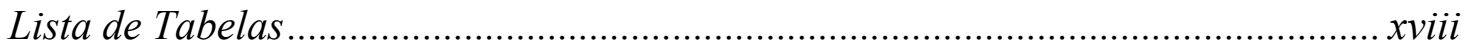

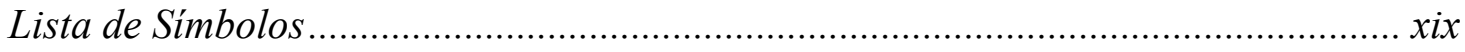

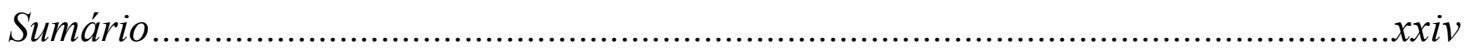

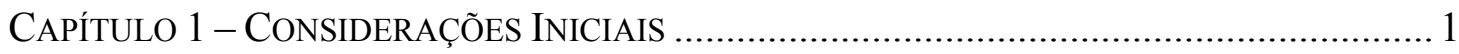

CAPÍTULO 2 - DESCRIÇÃo dA ÁREA DE ESTUDO ........................................................... 5

CAPÍtulo 3 - CaracterizaÇÃo FísicA, MineralóGiCA E MicroscóPiCA .................. 19

CAPÍTULO 4 - COMPORTAMENTO MECÂNICO ................................................................. 49

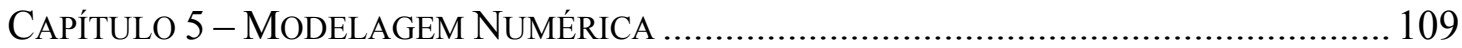

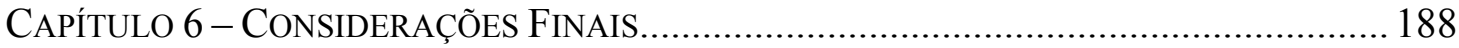

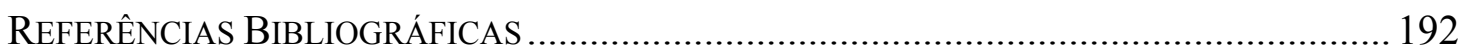

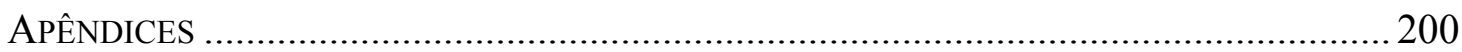


CECÍLIO JR., M. O. Estudo do comportamento de um túnel em solo residual de gnaisse por meio de ensaios triaxiais com controle de trajetórias de tensões. 2009. 204 p. Dissertação (Mestrado em Engenharia Geotécnica) - Escola Politécnica, Universidade de São Paulo, São Paulo, 2009.

\section{RESUMO}

Amostras indeformadas de um solo residual foram coletadas na zona oeste da cidade de São Paulo com o intuito de caracterizar o solo e estudar seu comportamento mecânico. Sua composição mineralógica é apresentada, assim como um estudo microscópico que identifica alguns destes minerais e evidencia sua microestrutura. Desse modo, é discutido como sua mineralogia e microestrutura influenciam em seu comportamento mecânico, estudado por meio de ensaios edométricos e de ensaios triaxiais convencionais de carregamento axial. Analisou-se sua compressibilidade, permeabilidade, seu grau de estruturação, suas relações tensão-deformação e envoltórias de escoamento, de ruptura e de Estados Críticos. O solo foi caracterizado como saprolítico, proveniente de um biotita-gnaisse milonitizado.

A partir dos resultados obtidos a respeito do comportamento do solo, três modelos constitutivos escolhidos para estudo foram calibrados: elástico linear, elasto-plástico perfeito (Mohr-Coulomb) e elasto-plástico com endurecimento (Hardening-Soil). Com esta modelagem matemática, foi concebida uma modelagem numérica tridimensional de elementos finitos, a fim de simular a escavação de um túnel e de obter as trajetórias de tensões atuantes ao seu redor devidas a sua escavação.

Outros ensaios triaxiais foram executados, desta vez seguindo-se as trajetórias de tensões obtidas numericamente. Os parâmetros elásticos dos três modelos constitutivos foram determinados para cada trajetória de tensões e o maciço envolvente à escavação foi modelado como sendo mecanicamente heterogêneo. Ou seja, limitaram-se zonas ao redor do túnel com diferentes propriedades mecânicas em função da trajetória de tensões atuante. Por fim, são comparados os parâmetros geotécnicos determinados com diferentes trajetórias de tensões, assim como os resultados obtidos com ambas as modelagens numéricas.

Palavras-chave: Túneis, Comportamento de solo residual, Ensaios triaxiais. 
CECÍLIO JR., M. O. Study of tunnel behaviour in gneiss residual soil by means of triaxial tests with stress-path control. 2009. 204 p. Thesis (Master of Sciences in Geotechnical Engineering) - Polytechnic School, São Paulo University, São Paulo, Brazil, 2009.

\section{ABSTRACT}

Undisturbed samples of a residual soil had been collected from the west zone of São Paulo city, in order to characterize the soil and study its mechanical behaviour. Its mineralogical composition is presented, as well as a microscopic study which identifies some of these minerals and evinces its microstructure. Thus, how the soil mineralogy and microstructure influence its mechanical behaviour is discussed, which was studied by means of oedometer tests and conventional axial loading triaxial tests. One analysed the soil compressibility, permeability, structuring degree, stress-strain relations and yielding, rupture and Critical State envelopes. The soil had been characterized as saprolite, derived from a biotite-gneiss.

Based on the results concerning the soil behaviour, three constitutive models were calibrated: linear elastic, elastic perfectly plastic (Mohr-Coulomb), and elastic-plastic with hardening (Hardening Soil). With this mathematical modelling, a three-dimensional numerical model with finite elements was designed, for the purpose of simulating a tunnel excavation and obtaining the stress paths around it due to its excavation.

Other triaxial tests were carried out, this time by following the stress paths numerically obtained. The elastic parameters of the three constitutive models had been determined for each stress path and the ground surrounding the excavation had been modelled as a mechanically heterogeneous media. I.e., zones around the tunnel had been limited by its different mechanical properties, as a function of the actual stress path. Finally, the geotechnical parameters determined by different stress paths are compared, as well as the results obtained for both numerical models.

Key-words: Tunnels, Residual soil behaviour, Triaxial tests. 
CECÍLIO JR, M. O. Estudio del comportamiento de un túnel en suelo residual de gnaisse por medio de ensayos triaxiales con controle de trajectórias de tensiones. 2009. 204 p. Tesis (Maestría en Ingeniería Geotécnica) - Escuela Politécnica, Universidad de São Paulo, São Paulo, 2009.

\section{RESÚMEN}

Muestras indeformadas de un suelo residual fueron recogidas en la zona oeste de la ciudad de São Paulo con el fin de caracterizar el suelo y estudiar su comportamiento mecánico. Su composición mineralógica es presentada, así como un estudio microscópico que identifica algunos de estos minerales y demuestra su microestructura. Así, es discutido como su mineralogía y microestructura influyen en su comportamiento mecánico, estudiado mediante ensayos edométricos y ensayos triaxiales convencionales de carga axial. Se analizó su compresibilidad, permeabilidad, su grado de estructuración, sus relaciones tensióndeformación y envolventes de escoamiento, de ruptura y de Estados Críticos. El suelo fue caracterizado como saprolítico, proveniente de un biotita-gneis milonitizado.

A partir de los resultados sobre el comportamiento del suelo, tres modelos constitutivos elegidos para el estudio fueron calibrados: elástico lineal, elástico-plástico perfecto (Mohr-Coulomb) y elástico-plástico con endurecimiento (Hardening-Soil). Con este modelaje matemático, fue concebida una modelación numérica tridimensional de elementos finitos, a fin de simular la excavación de un túnel y de obtener las trayectorias de tensiones que actúan a su alrededor debidas a su excavación.

Otros ensayos triaxiales fueron ejecutados, siendo de esta vez seguidas las trayectorias de tensiones obtenidas numéricamente. Los parámetros elásticos de los tres modelos constituyentes fueron determinados para cada trayectoria de tensiones y el macizo que involucra la excavación fue modelado como siendo mecánicamente heterogéneo. O sea, zonas alrededor del túnel con diferentes propriedades mecánicas fueron limitadas en función de la trayectoria de tensiones actuante. Por último, son comparados los parámetros geotécnicos determinados con diferentes trayectorias de tensiones, así como los resultados obtenidos con ambas modelaciones numéricas.

Palabras clave: Túneles, Comportamiento de suelos residuales, Ensayos triaxiales. 
CECÍLIO JR, M. O. Etude du comportement d'un tunnel dans un sol résiduel de gneiss au moyen de essais triaxiaux avec contrôle de cheminements de contraintes. 2009. $204 p$. Dissertation (Maîtrise en Ingénierie Géotechnique) - Ecole Polytechnique, Université de São Paulo, São Paulo, 2009.

\section{Résumé}

Des échantillons non perturbés de un sol résiduel ont été recueillis dans la zone ouest de la ville de São Paulo afin de caractériser le sol et d'étudier son comportement mécanique. Sa composition minéralogique est présenté, de même que une étude microscopique qui identifie certains de ces minéraux et met en évidence la microstructure. Ainsi, il est discute comme sa minéralogie et microstructure influence sur son comportement mécanique, lequel a été étudié par des essais à l'oedomètre et des essais triaxiaux conventionnels de chargement axial. On a été analysé sa compressibilité, perméabilité, son degré de structuration, leurs relations contrainte-déformation et enveloppes de écoulement, de rupture et de États Critiques. Le sol a été caractérisé comme saprolite, provient d'un biotite-gneiss.

D'après les résultats sur le comportement des sols, trois modèles constitutifs ont été étalonnés: élastique linéaire, élastique-plastique parfait (Mohr-Coulomb) et élastiqueplastique avec écrouissage (Hardening-Soil). Avec cette modélisation mathématique, une modélisation numérique de les éléments fini a été conçu en trois dimensions, destinée à simuler l'excavation d'un tunnel et à obtenir les cheminements de contraintes agissant autour de le tunnel en raison de son excavation.

Autres essais triaxiaux ont été effectués, cette fois en suivant les cheminements de contraintes obtenus numériquement. Les paramètres élastiques de ces trois modèles constitutifs ont été déterminées pour chaque cheminement de contraintes et la masse qui entoure l'excavation a été modélisé comme mécaniquement hétérogènes. C'est-à-dire, on a limité les zones autour du tunnel de différentes propriétés mécaniques en termes de les cheminements de contraintes actives. Enfin, les paramètres géotechniques déterminés avec différentes cheminements de contraintes son comparé, de même que les résultats obtenus avec les deux modélisations numériques.

Mots clés: Tunnels, Comportament de sol résiduel, Essais triaxiaux. 


\section{LISTA DE FIGURAS}

\section{CAPÍTULO 2 - DESCRIÇÃo DA ÁREA DE ESTUdo}

Figura 2.1 - Mapa da rede metroviária, Metrô-SP (2008) .................................................... 6

Figura 2.2 - Localização da área de estudos, a partir de Metrô-SP (2006a) ............................. 6

Figura 2.3 - Esquema de Estações envolvidas ........................................................................ 6

Figura 2.4 - Mapa geológico da região de estudo, a partir de EMPLASA (1980) .................... 8

Figura 2.5 - Perfil geológico-geotécnico do local de estudo, a partir de Metrô-SP (2006a) ... 10

Figura 2.6 - Modelo geológico-geotécnico conceitual ......................................................... 11

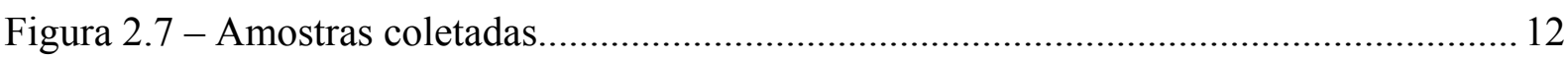

Figura 2.8 - Foto da frente de escavação durante a amostragem .......................................... 12

Figura 2.9 - Ilustração do local da amostragem .................................................................... 13

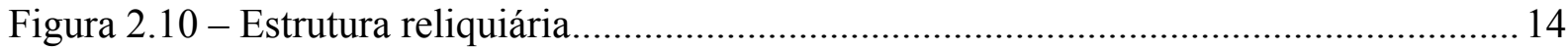

Figura 2.11 - Descontinuidades observadas nas amostras coletadas ..................................... 15

Figura 2.12 - Seção transversal do túnel, a partir de Metrô-SP (2006b) ................................. 16

Figura 2.13 - Seqüência construtiva empregada no túnel, a partir de Metrô-SP (2006b) ....... 17

\section{CAPÍTULO 3 - CARACTERIZAÇÃo FísiCA, MINERALÓGICA E MICROSCÓPICA}

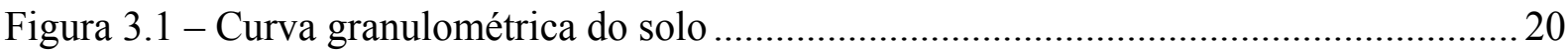

Figura 3.2 - Inserção do solo nas Cartas de Plasticidade e de Atividade.................................22

Figura 3.3 - Resultados obtidos por Pinto e Nader (1994a) para dois solos residuais............. 23

Figura 3.4 - Difratograma da fração argila do solo residual: comparação após glicolagem e

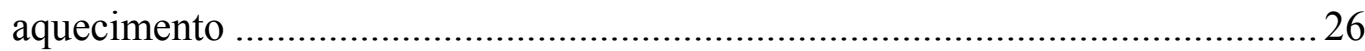

Figura 3.5 - Difratograma da fração argila do solo residual ................................................ 27

Figura 3.6 - Difratograma da fração silte do solo residual .................................................. 27

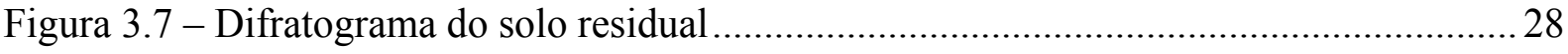

Figura 3.8 - Difratograma da fração argila do material de preenchimento de cor branca: comparação após glicolagem e aquecimento 29

Figura 3.9 - Difratograma do material de preenchimento de cor branca 30

Figura 3.10 - Difratograma da fração argila do material de preenchimento de cor laranja: comparação após glicolagem e aquecimento 
Figura 3.11 - Difratograma do material de preenchimento de cor laranja.............................. 31

Figura 3.12 - Foliação metamórfica remanescente no solo residual (MOR) ............................34

Figura 3.13 - Quartzo milonitizado (MOT) ....................................................................... 34

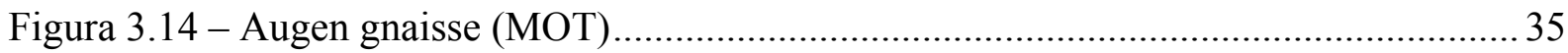

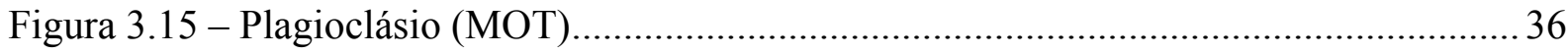

Figura 3.16 - Minerais presentes na fração areia do solo residual (MOR) .............................. 37

Figura 3.17 - Distribuição de macro-poros (MOT) ................................................................ 38

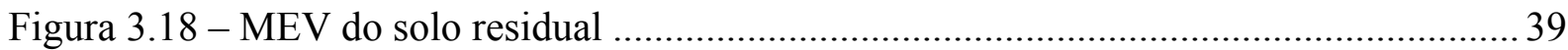

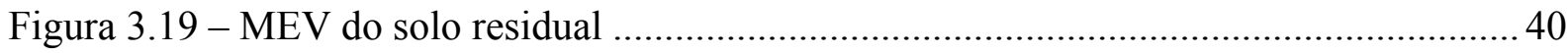

Figura 3.20 - MEV, comparação entre frações Argila e Silte................................................. 42

Figura 3.21 - Material de preenchimento de cor Branca (MOT) .......................................... 43

Figura 3.22 - MEV do material de preenchimento de cor Branca .......................................... 44

Figura 3.23 - Material de preenchimento de cor Laranja (MOT) .......................................... 45

Figura 3.24 - MEV do material de preenchimento de cor Laranja ........................................ 45

\section{CAPÍTULO 4 - COMPORTAMENTO MECÂNICO}

Figura 4.1 - Trajetórias de tensões de compressão e de extensão, de carregamento e de descarregamento, adaptado de Lambe (1967)................................................. 52

Figura 4.2 - Identificação do comportamento de cedência, a partir de Pinto e Nader (1991). 53 Figura 4.3 - Diferentes classificações de escoamento, a partir de Leroueil e Vaughan (1990)55 Figura 4.4 - Utilização de várias curvas de escoamento, a partir de Smith et al. (1992)......... 55 Figura 4.5 - Curva W-LSSV , a partir de Graham et al. (1982)...........................................57 Figura 4.6 - Implicações da escala logarítmica, a partir de Graham et al. (1982) ................... 57 Figura 4.7 - Curvas de escoamento de argilas naturais, solos residuais e rochas brandas, a partir de Leroueil e Vaughan (1990)......

Figura 4.8 - Curva de escoamento de um solo residual jovem de gnaisse, a partir de Sandroni (1981)

Figura 4.9 - Comparação entre um solo estruturado e um desestruturado em ensaio de compressão, Leroueil e Vaughan (1990).

Figura 4.10 - Ensaios drenados de compressão triaxial em amostras artificialmente cimentadas, Maccarini (1987) 
Figura 4.11 - Curvas tensão-deformação para diferentes trajetórias de tensões, a partir de Lambe e Whitman (1969)

Figura 4.12 - Esquema do conceito de superposição de efeitos, modificado de Pinto e Nader (1994a)

Figura 4.13 - Ensaios realizados por Anjos (1996) 65

Figura 4.14 - Resultados de ensaios realizados por Medeiros e Eisenstein (1983)... 66

Figura 4.15 - Processo iterativo utilizado por Najar Jiménez (2008) . 67

Figura 4.16 - Ensaios triaxiais realizados por $\mathrm{Ng}$ e Lo (1985). 68

Figura 4.17 - Curvas de adensamento dos ensaios de compressão unidimensional ................ 70

Figura 4.18 - Exemplo de encolhimento da curva de escoamento ......................................... 71

Figura 4.19 - Obtenção da tensão de escoamento para o ensaio edométrico........................... 72

Figura 4.20 - Subdivisão do trecho pré-escoamento dos ensaios edométricos........................ 72

Figura 4.21 - Obtenção dos índices de compressão e de recompressão ................................... 73

Figura 4.22 - Curvas de compressão edométrica para as amostras naturais e remoldada ....... 75

Figura 4.23 - Utilização da deformação volumétrica nas curvas de compressão edométrica 76 Figura 4.24 - Normalização das curvas de compressão edométrica ....................................... 77

Figura 4.25 - Influência da estrutura nas curvas de compressão edométrica.......................... 78

Figura 4.26 - Coeficiente de permeabilidade para os ensaios edométricos ........................... 79

Figura 4.27 - Trajetórias de tensões dos ensaios triaxiais de carregamento axial ................... 82

Figura 4.28 - Curvas de adensamento dos ensaios triaxiais de carregamento axial ................83

Figura 4.29 - Curvas tensão-deformação dos ensaios triaxiais de carregamento axial ...........84

Figura 4.30 - Ensaios de cisalhamento plano analisados por Pinto e Nader (1991) ................ 85

Figura 4.31 - Curvas de taxa de dilatância....................................................................... 86

Figura 4.32 - Influência da estrutura na localização da máxima taxa de dilatância .................86

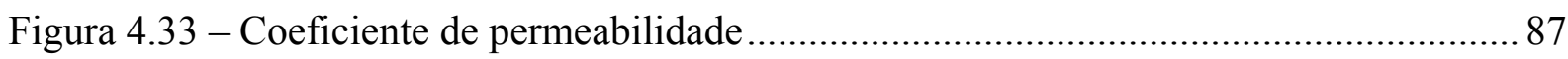

Figura 4.34 - Obtenção dos pontos de escoamento dos ensaios triaxiais ................................ 88

Figura 4.35 - Curva de escoamento obtida pelos ensaios de carregamento axial................... 90

Figura 4.36 - Envoltória de Estados Críticos ......................................................................... 91

Figura 4.37 - Envoltória de ruptura de Mohr-Coulomb..................................................... 92

Figura 4.38 - Obtenção de $\mathrm{K}_{0}$ por meio do ensaio triaxial................................................... 93

Figura 4.39 - Obtenção de $\mathrm{K}_{0}$ por meio da curva de escoamento.......................................... 94

Figura 4.40 - Trajetórias de tensões utilizadas nos ensaios triaxiais de descarregamento ...... 97 
Figura 4.41 - Curvas tensão-deformação dos ensaios triaxiais de descarregamento 98

Figura 4.42 - Obtenção dos pontos de escoamento dos ensaios triaxiais de descarregamento100

Figura 4.43 - Localização dos pontos de escoamento nas curvas tensão-deformação 101

Figura 4.44 - Curva de escoamento obtida pelos ensaios de descarregamento 101

Figura 4.45 - Envoltória de Estados Críticos para os ensaios de descarregamento. 103

Figura 4.46 - Envoltória de ruptura de Mohr-Coulomb. 104

Figura 4.47 - Planos de ruptura obtidos ao final dos ensaios triaxiais. 105

\section{CAPÍTULO 5-MODELAGEM NUMÉRICA}

Figura 5.1 - Mobilização da resistência ao cisalhamento devido ao efeito de arco, a partir de França (2006) 111

Figura 5.2 - Natureza tridimensional do arqueamento das tensões nas proximidades da frente de um túnel com suporte, a partir de Eisenstein et al. (1984) .... 111

Figura 5.3 - Ilustração da alteração das direções das tensões principais antes e após a escavação de um túnel, a partir de França (2006) 112

Figura 5.4 - Influência da frente de escavação, a partir de França (2006). 112

Figura 5.5 - Zonas características do maciço em relação aos estados de deformação, a partir de Almeida e Sousa (1998) 113

Figura 5.6 - Curvas características de maciços 115

Figura 5.7 - Interação maciço-suporte: Método da Convergência-Confinamento 116

Figura 5.8 - Perfil transversal dos deslocamentos superficiais (curva de Gauss). 118

Figura 5.9 - Distribuição transversal dos deslocamentos horizontais superficiais .... 119

Figura 5.10 - Curvas tensão-deformação do modelo Mohr-Coulomb

Figura 5.11 - Envoltórias do modelo Mohr-Coulomb

Figura 5.12 - Curvas tensão-deformação do modelo Hardening-Soil, a partir de Plaxis (2001)123

Figura 5.13 - Curvas de escoamento do modelo Hardening-Soil, a partir de Plaxis (2001) . 124

Figura 5.14 - Elementos finitos utilizados 125

Figura 5.15 - Estudo da localização da fronteira lateral da malha..... 128

Figura 5.16 - Seção transversal da malha de elementos finitos adotada. 129

Figura 5.17 - Malha tridimensional de elementos finitos adotada. 130

Figura 5.18 - Ilustração da reprodução da seqüência construtiva. 132

Figura 5.19 - Campo de tensões iniciais 
Figura 5.20 - Obtenção dos módulos de deformabilidade

Figura 5.21 - Variação dos módulos de deformabilidade com o nível de tensão

Figura 5.22 - Obtenção dos módulos cisalhante e volumétrico.

Figura 5.23 - Obtenção do coeficiente de Poisson.....

Figura 5.24 - Parâmetros de deformabilidade edométrica do modelo Hardening-Soil

Figura 5.25 - Parâmetros de resistência

Figura 5.26 - Comparação entre os resultados de ensaios de laboratório e os obtidos pelas simulações numéricas dos ensaios

Figura 5.27 - Pontos ao redor do túnel escolhidos para análise.

Figura 5.28 - Desenvolvimento das tensões com o avanço da escavação para o ponto A, localizado no teto do túnel

Figura 5.29 - Desenvolvimento das tensões com o avanço da escavação para o ponto B, localizado na diagonal superior do túnel

Figura 5.30 - Desenvolvimento das tensões com o avanço da escavação para o ponto C, localizado na lateral do túnel (nível do apoio do arco superior)

Figura 5.31 - Desenvolvimento das tensões com o avanço da escavação para o ponto D, localizado na lateral do túnel (nível do arco invertido provisório)

Figura 5.32 - Desenvolvimento das tensões com o avanço da escavação para o ponto E, localizado na diagonal inferior do túnel.

Figura 5.33 - Desenvolvimento das tensões com o avanço da escavação para o ponto $\mathrm{F}$, localizado no piso do túnel

Figura 5.34 - Comparação entre duas maneiras de se determinar a trajetória de tensões. 152

Figura 5.35 - Trajetória de tensões para o ponto A, localizado no teto do túnel 154

Figura 5.36 - Trajetória de tensões para o ponto B, localizado na diagonal superior do túnel154

Figura 5.37 - Trajetória de tensões para o ponto C, localizado na lateral do túnel (nível do apoio do arco superior)

Figura 5.38 - Trajetória de tensões para o ponto D, localizado na lateral do túnel (nível do arco invertido provisório).

Figura 5.39 - Trajetória de tensões para o ponto E, localizado na diagonal inferior do túnel156

Figura 5.40 - Trajetória de tensões para o ponto F, localizado no piso do túnel 157

Figura 5.41 - Síntese das trajetórias de tensões obtidas.

Figura 5.42 - Subdivisão do maciço em zonas de igual comportamento mecânico . 
Figura 5.43 - Variação dos parâmetros geotécnicos com o avanço da escavação 160

Figura 5.44 - Obtenção dos parâmetros elásticos de deformabilidade

Figura 5.45 - Variação dos parâmetros elásticos em função da trajetória de tensões. 162

Figura 5.46 - Trajetória de tensões para o ponto A, localizado no teto do túnel 163

Figura 5.47 - Trajetória de tensões para o ponto B, localizado na diagonal superior do túnel164 Figura 5.48 - Trajetória de tensões para o ponto C, localizado na lateral do túnel (nível do apoio do arco superior)

Figura 5.49 - Trajetória de tensões para o ponto D, localizado na lateral do túnel (nível do arco invertido provisório).

Figura 5.50 - Trajetória de tensões para o ponto E, localizado na diagonal inferior do túnel165

Figura 5.51 - Trajetória de tensões para o ponto F, localizado no piso do túnel ................... 166

Figura 5.52 - Síntese das trajetórias de tensões obtidas. 166

Figura 5.53 - Desenvolvimento dos recalques superficiais no plano vertical longitudinal de simetria do túnel (maciço mecanicamente homogêneo)

Figura 5.54 - Desenvolvimento dos recalques superficiais no plano vertical longitudinal de simetria do túnel (maciço mecanicamente heterogêneo)

Figura 5.55 - Recalques superficiais no plano vertical transversal à $18 \mathrm{~m}$ da seção analisada (maciço mecanicamente homogêneo)

Figura 5.56 - Recalques superficiais no plano vertical transversal à $18 \mathrm{~m}$ da seção analisada (maciço mecanicamente heterogêneo).

Figura 5.57 - Deslocamentos horizontais superficiais no plano vertical transversal (maciço mecanicamente homogêneo)

Figura 5.58 - Deslocamentos horizontais superficiais no plano vertical transversal (maciço mecanicamente heterogêneo)

Figura 5.59 - Deslocamentos verticais em um eixo vertical localizado no plano de simetria do túnel (maciço mecanicamente homogêneo)

Figura 5.60 - Deslocamentos verticais em um eixo vertical localizado no plano de simetria do túnel (maciço mecanicamente heterogêneo)

Figura 5.61 - Deslocamentos verticais em um eixo vertical localizado a $1 \mathrm{~m}$ do lado do túnel (maciço mecanicamente homogêneo) 173

Figura 5.62 - Deslocamentos verticais em um eixo vertical localizado a $1 \mathrm{~m}$ do lado do túnel (maciço mecanicamente heterogêneo) 
Figura 5.63 - Deslocamentos horizontais transversais em um eixo vertical localizado a $1 \mathrm{~m}$ do lado do túnel (maciço mecanicamente homogêneo)

Figura 5.64 - Deslocamentos horizontais transversais em um eixo vertical localizado a $1 \mathrm{~m}$ do lado do túnel (maciço mecanicamente heterogêneo) 174

Figura 5.65 - Tassômetro, Pinos e Cordas adotados para a análise 175

Figura 5.66 - Deslocamentos dos pinos e do tassômetro (maciço mecanicamente homogêneo)176

Figura 5.67 - Deslocamentos dos pinos e do tassômetro (maciço mecanicamente heterogêneo) 177

Figura 5.68 - Módulos de elasticidade em função da trajetória de tensões 180

Figura 5.69 - Comparação entre os módulos de carregamento e descarregamento

Figura 5.70 - Módulos tangente inicial em função do número SPT médio no teto de túneis, a partir de Negro Jr. et al. (1992b) ....

Figura 5.71 - Adaptação da curva de Gauss para representação dos recalques transversais (maciço mecanicamente homogêneo)

Figura 5.72 - Adaptação da curva de Gauss para representação dos recalques transversais (maciço mecanicamente heterogêneo) 


\section{LISTA DE TABELAS}

\section{CAPÍTULO 3 - CARACTERIZAÇÃo FísICA, MINERALÓGICA E MICROSCÓPICA}

Tabela 3.1 - Índices físicos e propriedades geotécnicas obtidos para as três amostras 20

Tabela 3.2 - Composição granulométrica do solo 21

Tabela 3.3 - Resumo das propriedades geotécnicas. 24

Tabela 3.4 - Resumo dos minerais presentes 32

\section{CAPÍTULO 4-COMPORTAMENTO MECÂNICO}

Tabela 4.1 - Estados de tensões referentes ao escoamento por carregamento 89

Tabela 4.2 - Estados de tensões referentes à ruptura dos ensaios de carregamento 90

Tabela 4.3 - Estados de tensões referentes ao escoamento por descarregamento 100

Tabela 4.4 - Estados de tensões referentes à ruptura dos ensaios de descarregamento 102

\section{CAPÍTULO 5-MODELAGEM NUMÉRICA}

Tabela 5.1 - Parâmetros do concreto projetado 133

Tabela 5.2 - Parâmetros do modelo Mohr-Coulomb ................................................................. 138

Tabela 5.3 - Parâmetros do modelo Hardening-Soil............................................................ 138

Tabela 5.4 - Parâmetros elásticos para os três modelos constitutivos ................................... 162

Tabela 5.5 - Parâmetros geotécnicos obtidos a partir de Pinto e Nader (1994b).................. 179

Tabela 5.6 - Parâmetros geotécnicos adotados por CVA (2008) .......................................... 180

Tabela 5.7 - Porcentagens de alívio obtidas para as modelagens numéricas........................ 183 


\section{LISTA DE SíMBOLOS}

Apesar dos símbolos utilizados estarem definidos no texto à medida que são citados, de forma que seus respectivos significados não gerem dúvidas, considerou-se pertinente apresentar a listagem de toda a simbologia utilizada.

\section{Alfabeto Latino}

$\mathrm{a}, \mathrm{b} \quad$ coeficientes adimensionais para estimativa de $\mathrm{i}_{\mathrm{x}}$

$\overline{\mathrm{B}} \quad$ parâmetro de Skempton referente ao grau de saturação

c' intercepto de coesão efetiva no plano $\sigma^{\prime}-\tau$

$\mathrm{C}_{\mathrm{ij}} \quad$ corda de convergência/divergência entre os pinos $\mathrm{P}_{\mathrm{i}}$ e $\mathrm{P}_{\mathrm{j}}$

$\mathrm{Cc} \quad$ coeficiente da reta de compressão

$\mathrm{CL}, \mathrm{CH}$ argila de baixa ou de alta compressibilidade, respectivamente

$\mathrm{Cr} \quad$ coeficiente da reta de recompressão

$\mathrm{Cv} \quad$ coeficiente de adensamento

d diâmetro

d intercepto de coesão efetiva no plano s'- $t$

d distância entre planos atômicos (distância basal)

$\mathrm{d}_{\mathrm{eq}} \quad$ diâmetro equivalente

D diâmetro do túnel

e índice de vazios

$\mathrm{e}_{0} \quad$ índice de vazios inicial

E' módulo de deformabilidade elástica efetivo (módulo de elasticidade)

$E^{\prime}$ eod módulo de elasticidade efetivo para a situação edométrica

$E_{\text {ur }}^{\prime}$ módulo de elasticidade efetivo para a situação de des/recarregamento

$\mathrm{E}^{\prime}{ }_{50} \quad$ módulo de elasticidade efetivo secante à $50 \%$ da ruptura

$\mathrm{E}^{\text {'ref }} \quad$ módulo de elasticidade relativo à tensão de referência

EC Estados Críticos

$\mathrm{E}_{\mathrm{c} \text { i }} \quad$ Módulo de elasticidade tangente inicial do concreto

$\mathrm{E}_{\mathrm{cs}} \quad$ Módulo de elasticidade secante do concreto

$\mathrm{f}_{\mathrm{ck}} \quad$ Resistência característica à compressão do concreto

G massa específica dos grãos

G' módulo de deformação cisalhante elástica efetivo (módulo de distorção) 


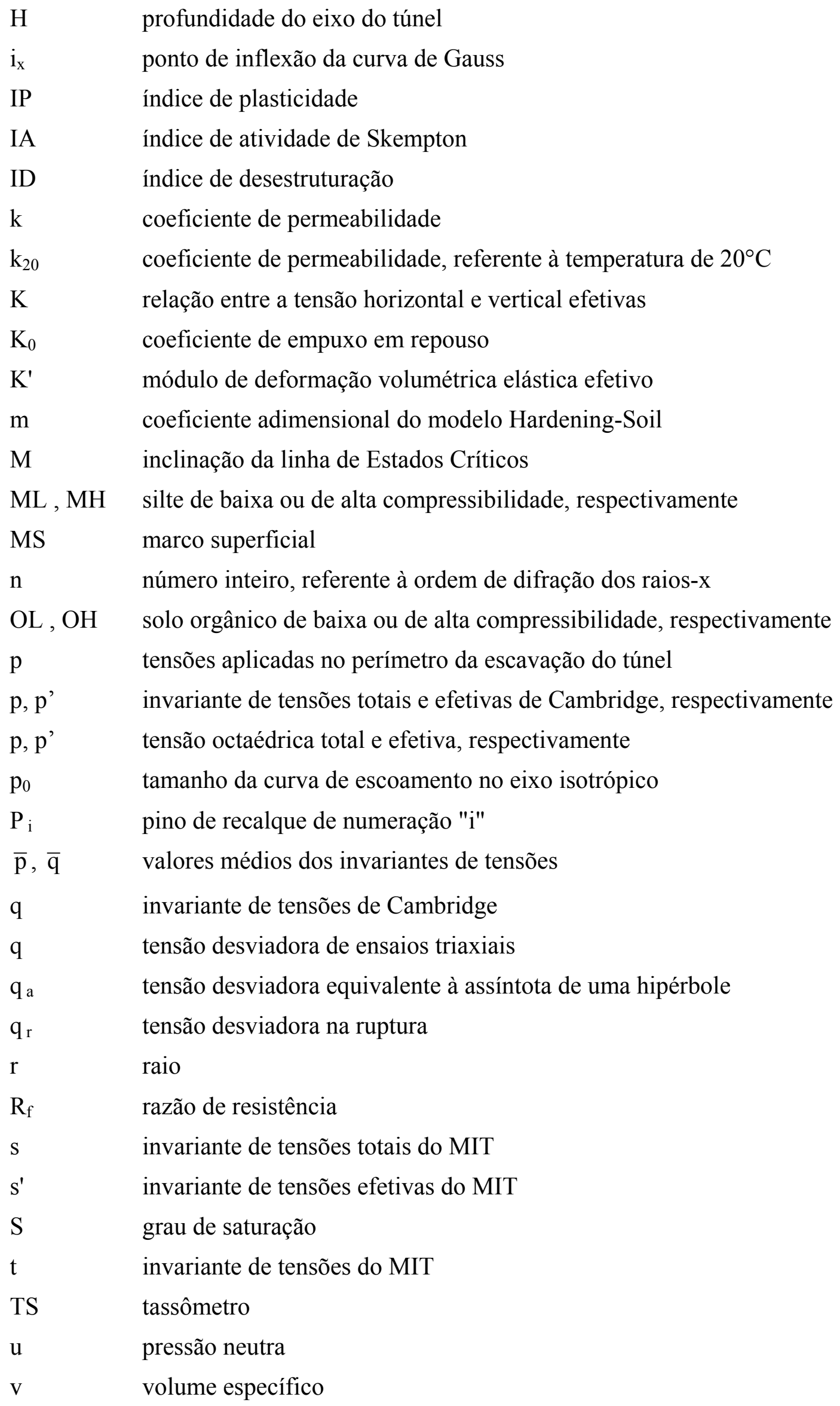




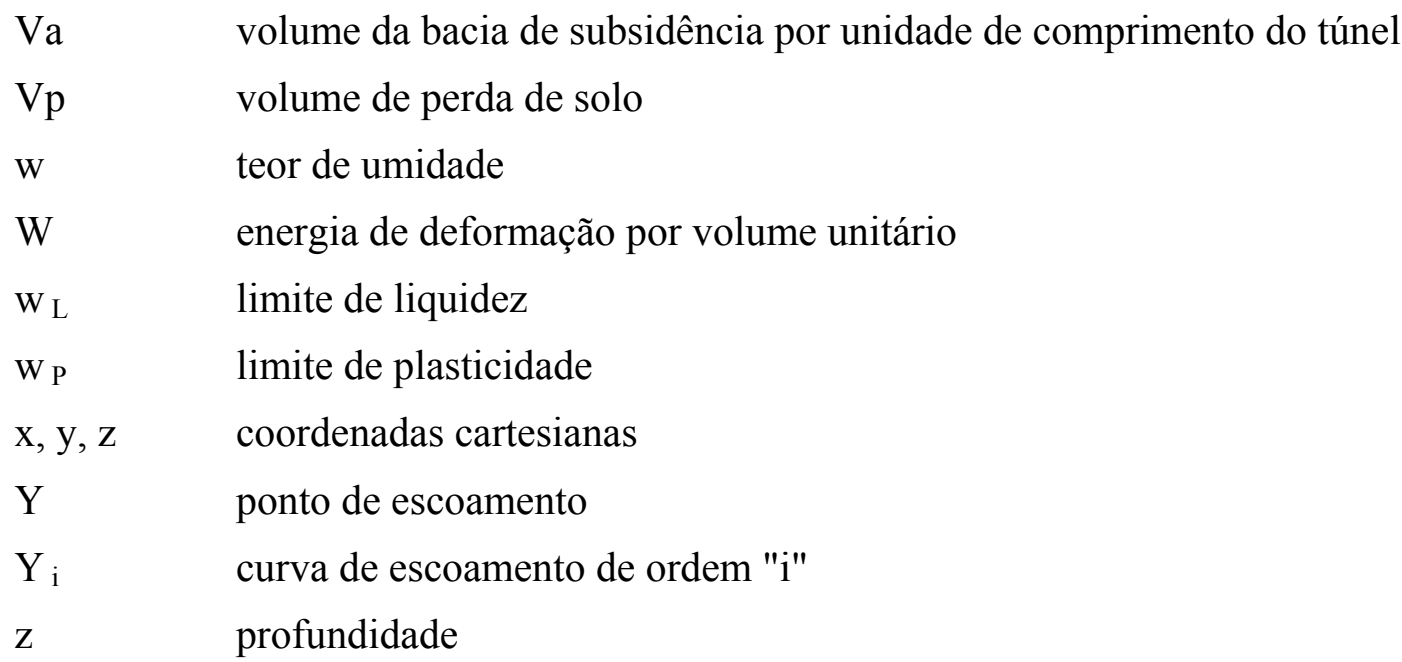

\section{Alfabeto Grego}

$\begin{array}{ll}\alpha_{\text {comp }} & \text { inclinação do plano de ruptura de ensaios de compressão } \\ \alpha_{\mathrm{ext}} & \text { inclinação do plano de ruptura de ensaios de extensão } \\ \beta & \text { ângulo de atrito interno no plano s'-t } \\ \gamma_{\mathrm{d}} & \text { peso específico seco } \\ \gamma_{\mathrm{n}} & \text { peso específico natural } \\ \gamma_{\text {sat }} & \text { peso específico saturado } \\ \gamma_{\text {sub }} & \text { peso específico submerso } \\ \delta & \text { incremento } \\ \Delta & \text { incremento } \\ \Delta & \text { deslocamento } \\ \varepsilon_{1} & \text { deformação } \\ \varepsilon_{1} & \text { deformação principal maior } \\ \varepsilon_{2} & \text { deformação principal intermediária } \\ \varepsilon_{3} & \text { deformação principal menor } \\ \varepsilon_{\mathrm{a}} & \text { deformação axial } \\ \varepsilon_{\mathrm{c}} & \text { deformação confinante } \\ \varepsilon_{\mathrm{h}} & \text { deformação horizontal } \\ \varepsilon_{\mathrm{p}} & \text { deformação volumétrica } \\ \varepsilon_{\mathrm{q}} & \text { deformação cisalhante } \\ \varepsilon_{\mathrm{r}} & \text { deformação radial } \\ \varepsilon_{\mathrm{V}} & \text { deformação vertical }\end{array}$


$\theta$

I $\varepsilon$

$\kappa$

$\lambda$

$\lambda$

$\lambda_{\text {edo }}$

$\lambda_{\mathrm{EC}}$

$v^{\prime}$

$v_{\text {ur }}^{\prime}$

$\rho, \rho_{\text {máx }}$

$\sigma, \sigma^{\prime}$

$\sigma_{1}, \sigma^{\prime}{ }_{1}$

$\sigma_{2}, \sigma_{2}^{\prime}$

$\sigma_{3}, \sigma^{\prime}{ }_{3}$

$\sigma^{\prime}{ }_{a}$

$\sigma^{\prime}{ }_{c}$

$\sigma_{h}^{\prime}$

$\sigma^{\prime}{ }_{\text {oct }}$

$\sigma^{\prime}{ }_{r}$

$\sigma^{\prime \text { ref }}$

$\sigma^{\prime}{ }_{\mathrm{v}}$

$\sigma^{\prime}{ }_{\mathrm{vm}}$

$\sigma^{\prime}{ }_{r}$

$\sigma^{\prime}{ }_{x}$

$\sigma_{\mathrm{y}}^{\prime}$

$\sigma_{z}^{\prime}$

$\Sigma$

$\tau$

$\tau_{\mathrm{r}}$

$\tau_{\text {oct }}$

$\phi$

$\varphi^{\prime}$

$\psi$

$\Psi$ ângulo de Bragg

índice de deformação normalizada

inclinação da reta de descarregamento isotrópico

comprimento de onda dos raios-x incidentes

inclinação da reta de compressão normal isotrópica

inclinação da reta de compressão obtida a partir de um ensaio edométrico

inclinação da linha de Estados Críticos

coeficiente de Poisson efetivo

coeficiente de Poisson para a situação de des/recarregamento

recalque e recalque máximo, respectivamente

tensão normal total e efetiva, respectivamente

tensão normal principal maior total e efetiva, respectivamente

tensão normal principal intermediária total e efetiva, respectivamente

tensão normal principal menor total e efetiva, respectivamente

tensão axial efetiva

tensão confinante efetiva

tensão normal efetiva horizontal

tensão normal octaédrica efetiva

tensão radial efetiva

tensão efetiva de referência

tensão normal efetiva vertical

tensão vertical efetiva máxima (tensão de escoamento edométrica)

tensão normal efetiva no plano de ruptura

tensão normal na direção horizontal transversal do modelo numérico

tensão normal na direção vertical do modelo numérico

tensão normal na direção horizontal longitudinal do modelo numérico

somatório

tensão cisalhante

tensão cisalhante no plano de ruptura

tensão cisalhante octaédrica

diâmetro

ângulo de atrito interno efetivo no plano $\sigma^{\prime}-\tau$

ângulo de dilatância

taxa de dilatância 
Abreviações

$\begin{array}{ll}\text { AID } & \text { Arco Invertido Definitivo } \\ \text { AIP } & \text { Arco Invertido Provisório } \\ \text { CAD } & \text { Ensaio triaxial adensado anisotropicamente e cisalhado com drenagem } \\ \text { CID } & \text { Ensaio triaxial adensado isotropicamente e cisalhado com drenagem } \\ \text { CRSP } & \text { Controlled Rate Strain/Pressure } \\ \text { DHP } & \text { Dreno Horizontal Profundo } \\ \text { ICDD } & \text { The International Centre for Diffraction Data } \\ \text { LEC } & \text { Linha de Estados Críticos } \\ \text { LSSV } & \text { Length of Stress/Strain Vector } \\ \text { Metrô-SP } & \text { Companhia do Metropolitano de São Paulo } \\ \text { MEV } & \text { Microscopia Eletrônica de Varredura } \\ \text { MIT } & \text { Massachusetts Institute of Technology } \\ \text { MOR } & \text { Microscopia Óptica de Reflexão } \\ \text { MOT } & \text { Microscopia Óptica de Transmissão } \\ \text { NATM } & \text { New Austrian Tunnelling Method } \\ \text { SPT } & \text { Standard Penetration Test } \\ \text { VSE } & \text { Poço de Ventilação e Saída de Emergência }\end{array}$




\section{SUMÁRIO}

CAPÍTULO 1 - CONSIDERAÇÕES INICIAIS

1.1 OBJeTIVOS

1.2 JUSTIFICATIVA

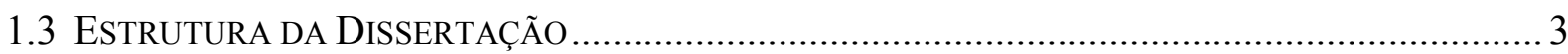

CAPÍTULO 2-DESCRIÇÃO DA ÁREA DE ESTUDO

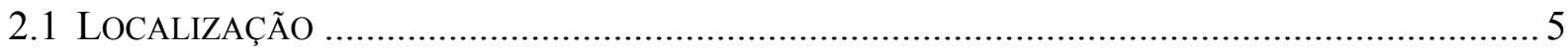

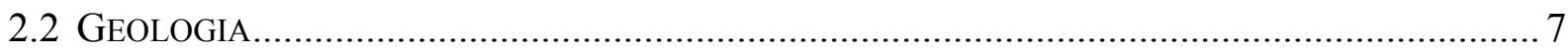

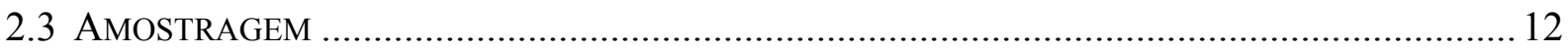

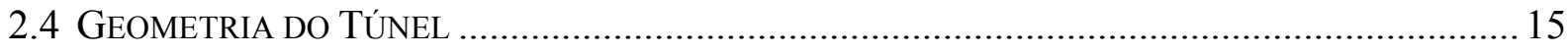

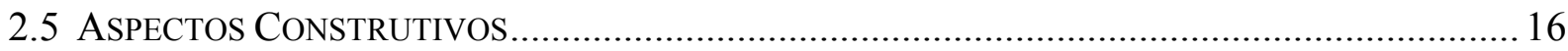

CAPÍTULO 3 - CARACTERIZAÇÃo FÍSICA, MINERALÓGICA E MICROSCÓPICA 19

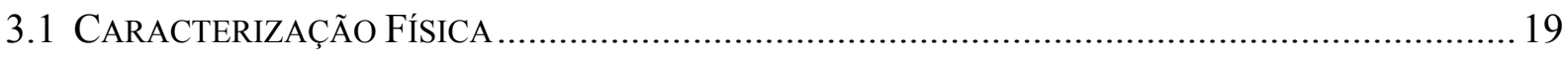

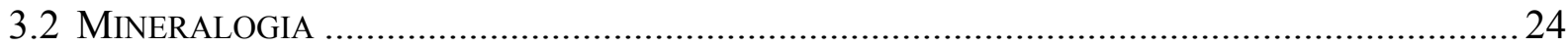

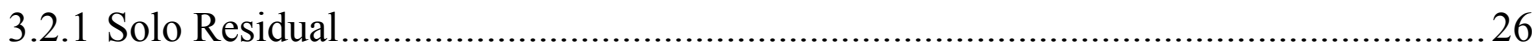

3.2.2 Material de Preenchimento de cor Branca ................................................................. 28

3.2.3 Material de Preenchimento de cor Laranja............................................................. 30

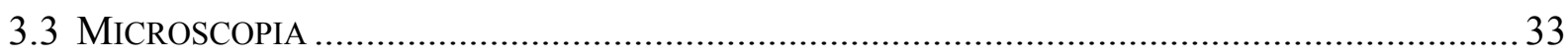

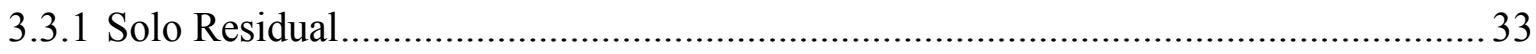

3.3.2 Material de Preenchimento de cor Branca .................................................................. 43

3.3.3 Material de Preenchimento de cor Laranja................................................................... 44

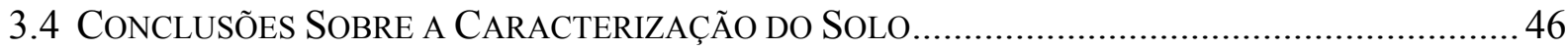

CAPÍTULO 4-COMPORTAMENTO MECÂNICO

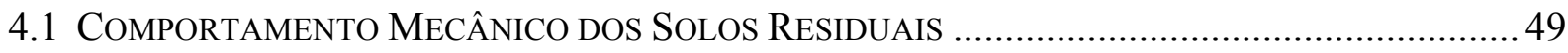

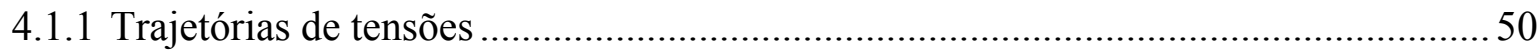

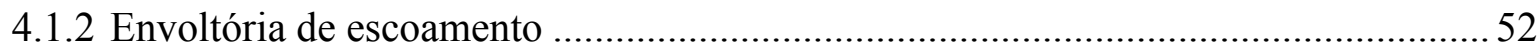

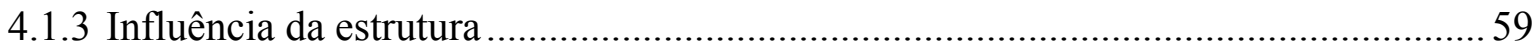

4.1.4 Variação de parâmetros em função da trajetória de tensões ....................................6 63 


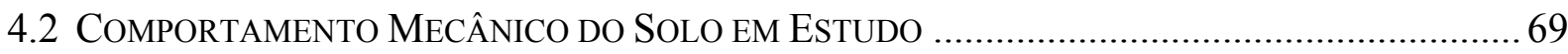

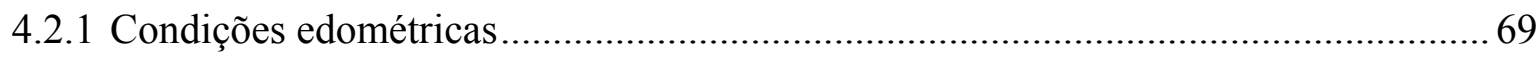

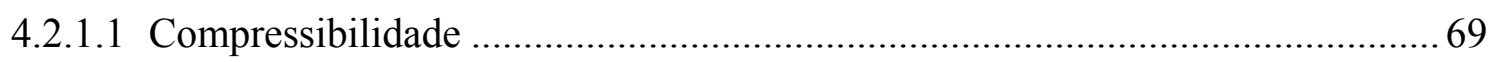

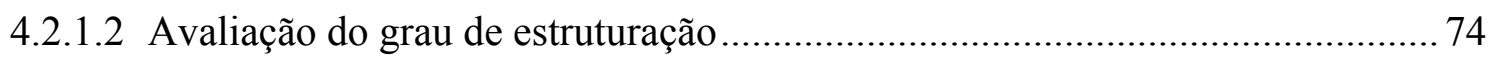

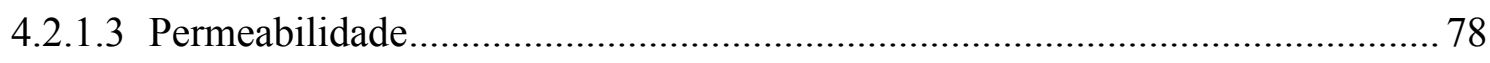

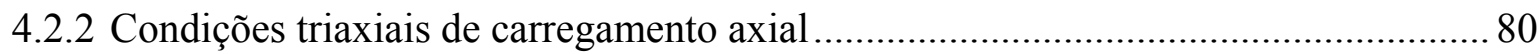

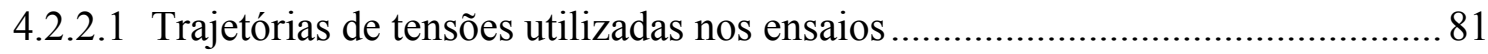

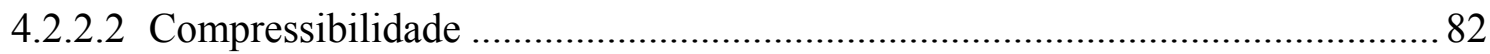

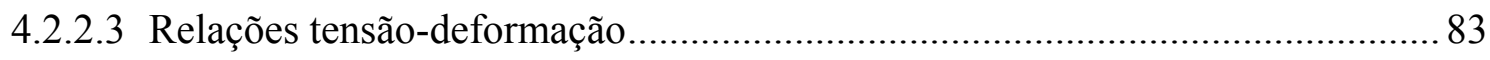

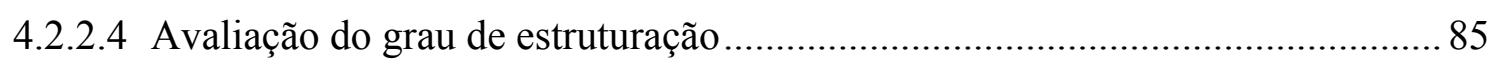

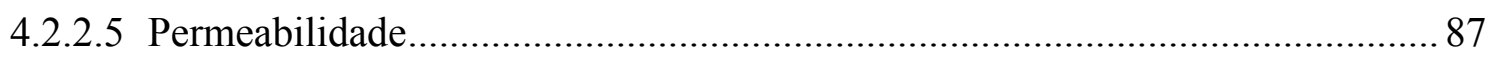

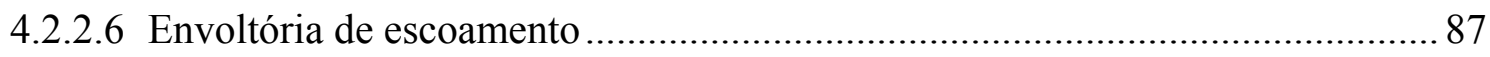

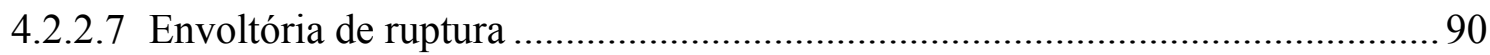

4.2.2.8 Estimativa do valor do coeficiente de empuxo em repouso ............................. 92

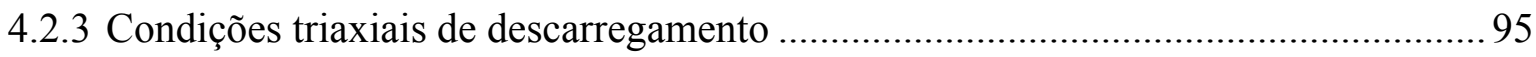

4.2.3.1 Trajetórias de tensões utilizadas nos ensaios ................................................... 96

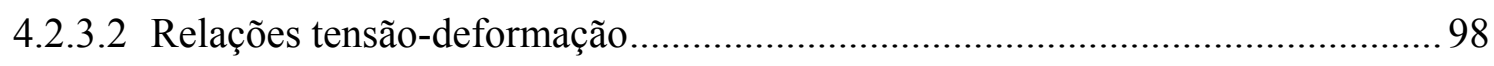

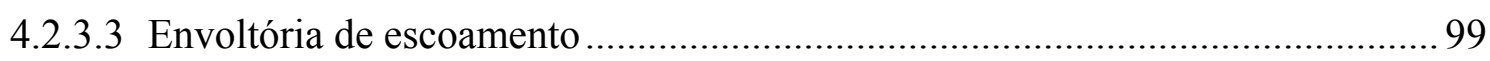

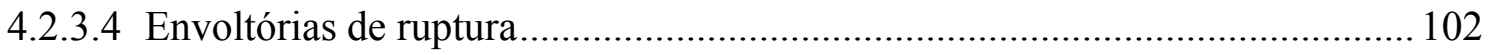

4.3 Conclusões Sobre o Comportamento MeCÂnico do Solo …….............................. 105

CAPÍTULO 5-MODELAGEM NUMÉRICA

5.1 FENÔMENOS ENVOLVENDO A ESCAVAÇÃO DE TÚNEIS EM SOLO ........................................ 109

5.1.1 Alteração do estado de tensões no maciço envolvente............................................. 110

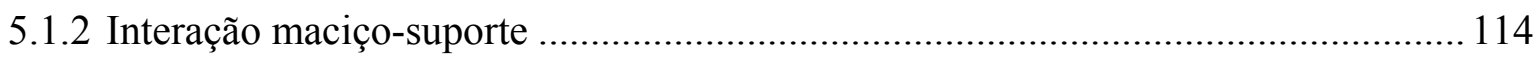

5.1.3 Previsão dos movimentos associados à escavação de um túnel ............................... 117

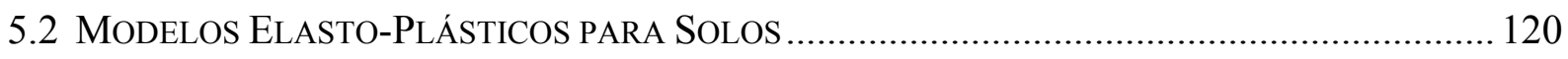

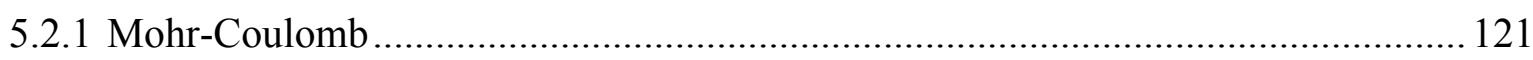

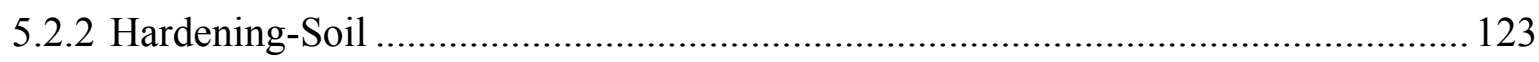

5.3 CONCEPÇÃO DA Modelagem da ESCAVAÇÃO DE UM TÚNEL......................................... 125

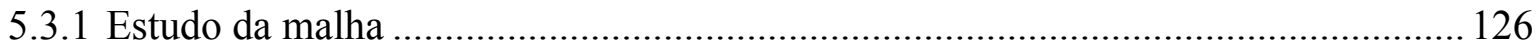

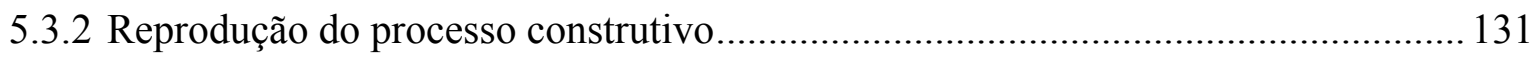

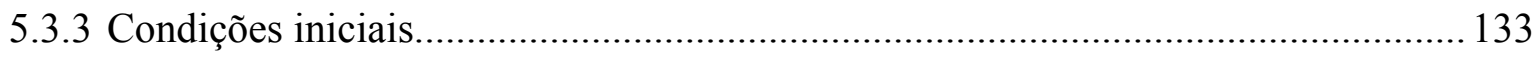


5.4 Modelagem Com o Maciço Mecanicamente HomogêNeO.......................................... 134

5.4.1 Calibração dos modelos constitutivos ..................................................................... 135

5.4.2 Desenvolvimento das tensões com o avanço da escavação ..................................... 140

5.4.3 Representação em laboratório de um estado tridimensional de tensões ................... 151

5.4.4 Trajetórias de tensões obtidas............................................................................... 153

5.5 Modelagem com o Maciço Mecanicamente Heterogêneo ......................................... 158

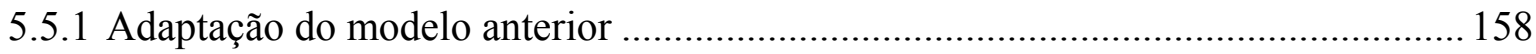

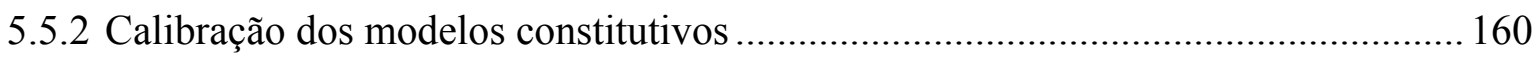

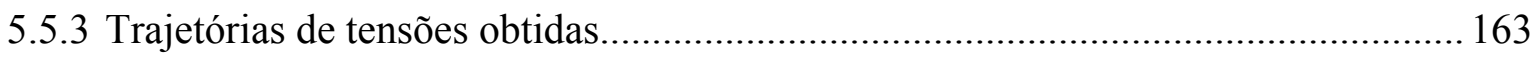

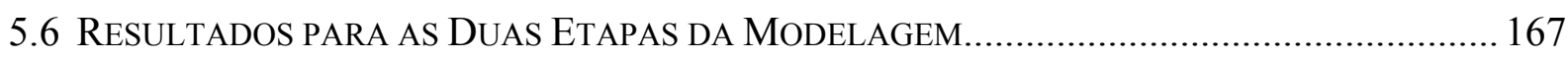

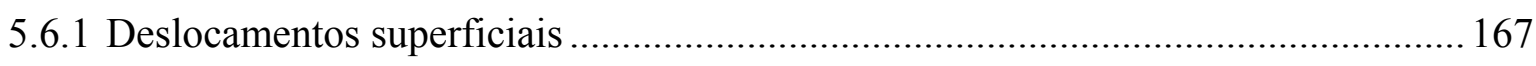

5.6.2 Deslocamentos em função da profundidade......................................................... 171

5.6.3 Deslocamentos no revestimento primário do túnel ................................................ 175

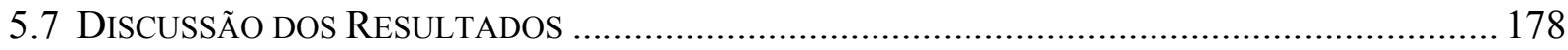

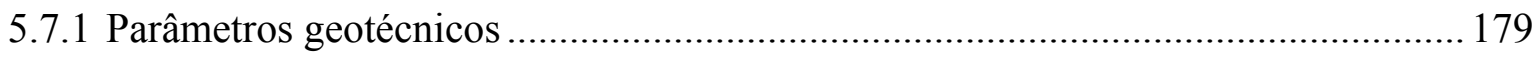

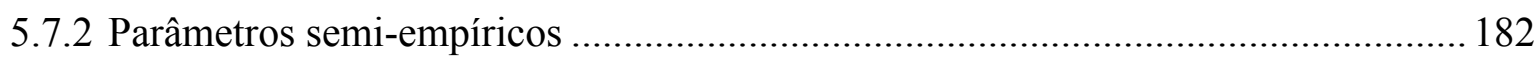

5.8 ConClusÕes SOBRE AS ModELAGENS NumÉRICAS REALIZADAS .................................... 185

CAPÍTULO 6-CONSIDERAÇÕES FINAIS

6.1 Sugestões Para Trabalmos Futuros .................................................................... 191

REFERÊNCIAS BIBLIOGRÁFICAS 192

APÊNDICES 200

Apêndice A - Procedimento para separação das frações Silte e Argila de um solo .............. 201

Apêndice B - Procedimento de execução dos ensaios triaxiais de carregamento axial......... 202

Apêndice C - Procedimento de execução dos ensaios triaxiais de descarregamento ............. 204 


\section{Capítulo 1}

\section{CONSIDERAÇÕES INICIAIS}

Um crescente aproveitamento de espaços subterrâneos tem sido notado mundialmente, principalmente ao se tratar de áreas densamente ocupadas. Devido à crescente valorização do espaço nos grandes centros urbanos e regiões metropolitanas, percebe-se uma tendência de se disporem subterraneamente obras de transporte, de distribuição de água, esgoto, gás, eletricidade e telecomunicações, obras de estocagem e até mesmo de convívio social. O emprego de obras subterrâneas tem se mostrado eficaz e vantajoso, tendo-se em vista a minimização da utilização do espaço da superfície (resguardado para usos mais nobres), do impacto físico e visual nos arredores da obra (com menos interferência no trânsito durante a construção e na paisagem durante a via útil da obra) e dos impactos ambientais (em comparação às obras com interferência direta na superfície).

A escavação de túneis em solo ocasiona movimentos inevitáveis no maciço envolvente, o que pode resultar em danos nas estruturas e infraestruturas próximas, fazendo da previsão destes movimentos um assunto de fundamental importância. Inicialmente, e durante muitos anos, os projetos de túneis foram realizados única e exclusivamente com base na vivência e experiência de obras semelhantes. Posteriormente, uma abordagem mais científica sobre o comportamento do maciço passou a ser utilizada, com o emprego de métodos semi-empíricos e métodos analíticos simplificados baseados na Teoria da Elasticidade e nas análises limites da Teoria da Plasticidade. Atualmente, mediante o desenvolvimento de diversos modelos constitutivos para solos e com uma disponibilidade crescente dos recursos computacionais, tornou-se possível a análise numérica de problemas mais complexos. 
Paralelamente ao desenvolvimento dos modelos constitutivos, um número maior de variáveis tornou-se necessário para a representação do comportamento do solo, o qual é determinado por ensaios de laboratório e de campo. Quanto maior a quantidade de parâmetros geotécnicos utilizada pelo modelo constitutivo, maior se torna a campanha de ensaios laboratoriais, como por exemplo os de cisalhamento direto, edométricos, triaxiais, entre outros. Por conta disso, a maioria dos estudos de obras subterrâneas é realizada utilizando-se modelos constitutivos simples, de fácil compreensão e familiares para os Engenheiros Geotécnicos. É o caso do modelo elástico linear e do elástico linear perfeitamente plástico com superfície de plastificação coincidente com o critério de ruptura de Mohr-Coulomb.

\subsection{OBJetivos}

O objetivo geral desta pesquisa é estudar o comportamento de um solo residual de gnaisse, com aplicação direta à simulação numérica da escavação de um túnel.

Os objetivos específicos são listados em seqüência:

- estudar o comportamento do solo, em termos de compressibilidade, permeabilidade, relações tensão-deformação, avaliação do grau de estruturação e envoltórias de escoamento, de ruptura e de Estados Críticos;

- calibrar modelos constitutivos para representar este comportamento;

- obter, a partir de um software de elementos finitos, as trajetórias de tensões geradas pela escavação de um túnel;

- representar em laboratório as trajetórias de tensões obtidas numericamente, por meio de ensaios triaxiais;

- estudar a influência dos parâmetros geotécnicos nos resultados de simulações numéricas, considerando-os como função das trajetórias de tensões, especialmente quando há inversão das tensões principais; 


\subsection{JUSTIFICATIVA}

A relevância da pesquisa em questão é obter subsídios para previsões de comportamento de obras geotécnicas mais próximas da realidade. Espera-se entender o comportamento do solo residual em estudo para a obtenção de previsões realistas.

A bibliografia existente sobre solos residuais ainda não é capaz de generalizar informações sobre o assunto, havendo necessidade de mais estudos nesta área. A publicação "Solos do interior do Estado de São Paulo", de Cintra e Albiero (1993), apresenta trabalhos sobre solos residuais, porém de regiões distantes do local de interesse desta pesquisa. Quanto à publicação "Solos da cidade de São Paulo", de Negro Jr. et al (1992a), esta enfoca o estudo dos solos sedimentares da cidade, não se aprofundando sobre os solos residuais na capital.

É comum haver diferenças entre as previsões e o comportamento real de um solo, tendo-se em vista o alto grau de complexidade existente. Entretanto, tais diferenças podem ser minimizadas se forem tomadas algumas medidas, como uma utilização mais criteriosa dos parâmetros geotécnicos envolvidos, a adoção de um modelo constitutivo mais fiel ao comportamento do solo e a confecção de uma modelagem tridimensional que simule mais refinadamente o problema.

Com a realização da presente pesquisa, espera-se chegar a resultados que demonstrem uma melhor aplicabilidade dos parâmetros geotécnicos obtidos por ensaios especiais, seguindo-se a trajetória de tensões de campo, em relação aos obtidos por ensaios convencionais.

\subsection{ESTRUTURa Da DisSERTaÇÃo}

A presente pesquisa, além deste capítulo introdutório, encontra-se estruturada em mais cinco capítulos, conformando um total de seis capítulos.

No Capítulo 2 será descrita a área de estudos da presente pesquisa, sendo apresentada sua localização, a geologia local, a amostragem realizada, a geometria do túnel em execução no local e seus respectivos aspectos construtivos.

No Capítulo 3 será apresentada a caracterização física, mineralógica e microscópica do solo residual em estudo, assim como dos materiais existentes nas descontinuidades. 
No capítulo 4 será realizada uma revisão bibliográfica sobre o comportamento mecânico de solos residuais, seguida pela discussão do comportamento mecânico do solo em estudo. A apresentação dos resultados é subdivida em três partes, quanto aos ensaios realizados: edométricos, triaxiais de carregamento axial e triaxiais de descarregamento. Será discutido como a mineralogia e microestrutura, apresentadas no capítulo anterior, influenciam o comportamento mecânico encontrado.

No Capítulo 5 será realizada uma revisão bibliográfica sobre os fenômenos decorrentes da escavação de túneis em solo e sobre modelos constitutivos elasto-plásticos, seguida pela criação de um modelo tridimensional de elementos finitos, visando simular a escavação de um túnel. Com este modelo foram realizadas duas modelagens numéricas diferentes: a primeira com o maciço mecanicamente homogêneo, utilizando os parâmetros geotécnicos obtidos com os ensaios de carregamento do capítulo anterior; e a segunda com o maciço mecanicamente heterogêneo, utilizando os parâmetros geotécnicos obtidos com os ensaios de descarregamento do capítulo anterior.

Os ensaios triaxiais de descarregamento, apresentados no Capítulo 4, foram executados após a realização da primeira etapa da modelagem numérica apresentada no Capítulo 5, seguindo as trajetórias de tensões obtidas numericamente.

No Capítulo 6 serão apresentadas as considerações finais da pesquisa, seguidas pelas sugestões de futuros trabalhos. 


\section{CApítulo 2}

\section{Descreçio da Área de Estudo}

Neste capítulo será apresentado a localização da área de estudos, assim como a geologia encontrada, as características da amostragem realizada, a geometria do túnel em execução no local e seus aspectos construtivos. Não serão analisados o projeto e a execução da obra em questão.

\subsection{LOCALIZAÇão}

O solo em estudo foi coletado de um túnel em execução da nova Linha 4 - Amarela, da Companhia do Metropolitano de São Paulo (Metrô-SP). O Consórcio Via Amarela é o responsável pela execução da obra, sendo formado pelas seis construtoras: Odebrecht, OAS, Queiroz Galvão, Camargo Corrêa, Andrade Gutierrez e Alstom.

A linha Amarela ligará o centro à zona oeste da cidade, com um sentido Nordeste-Sudoeste. O túnel onde foi realizada a amostragem está localizado na zona oeste da cidade, próximo à Universidade de São Paulo e ao Rio Pinheiros, entre a estação São Paulo - Morumbi e o poço de acesso VSE - Caxingui. Neste trecho, o túnel encontra-se aproximadamente sob a Avenida Prof. Francisco Morato, na altura do número 1900, entre as ruas transversais Carlos Lima Morel e João Scaciotti.

O traçado da Linha 4-Amarela pode ser visto na Figura 2.1, a localização da área de estudos se encontra na Figura 2.2, assim como um esquema das estações envolvidas pode ser visto na Figura 2.3. 


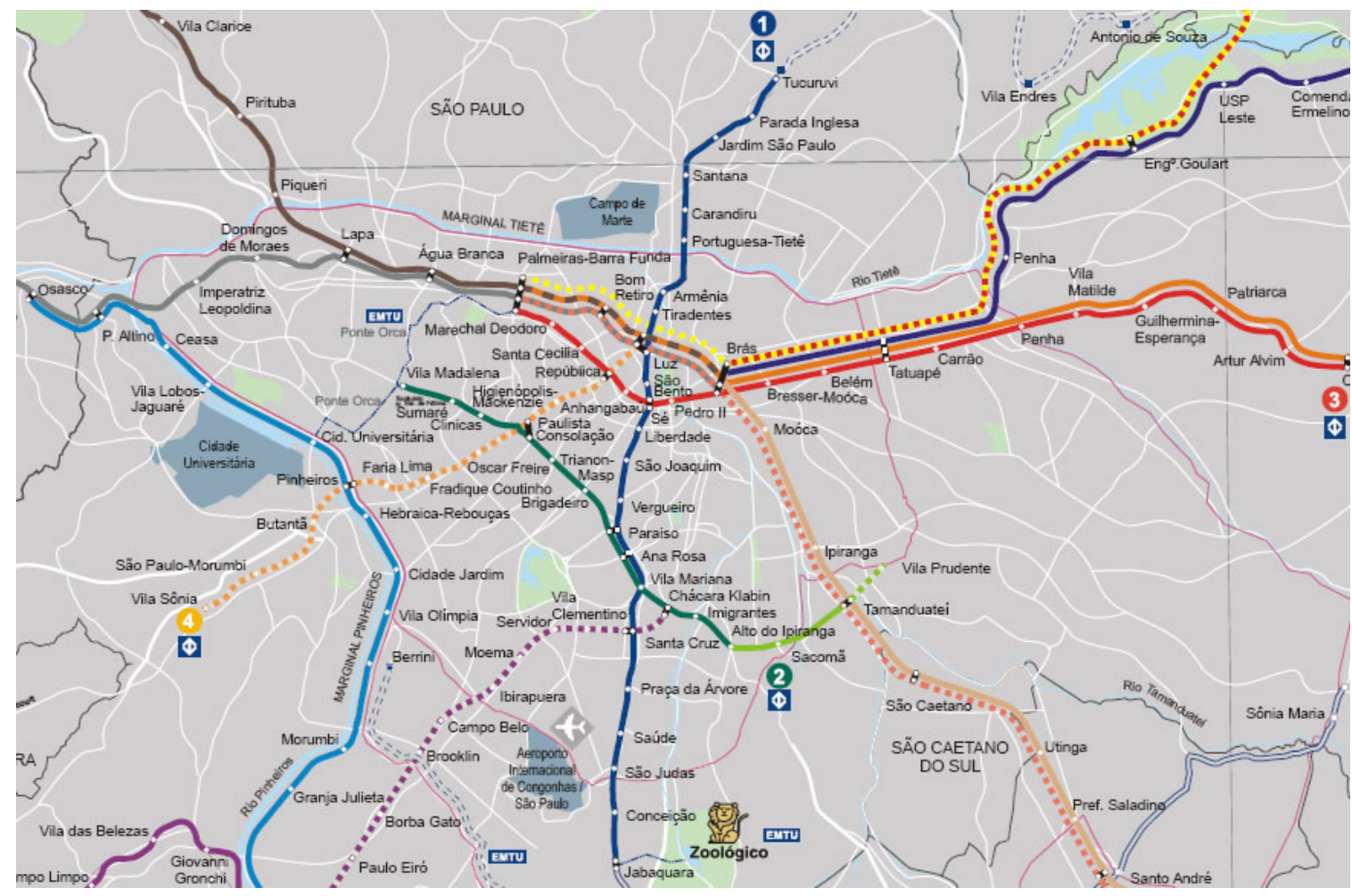

Figura 2.1 - Mapa da rede metroviária, Metrô-SP (2008)

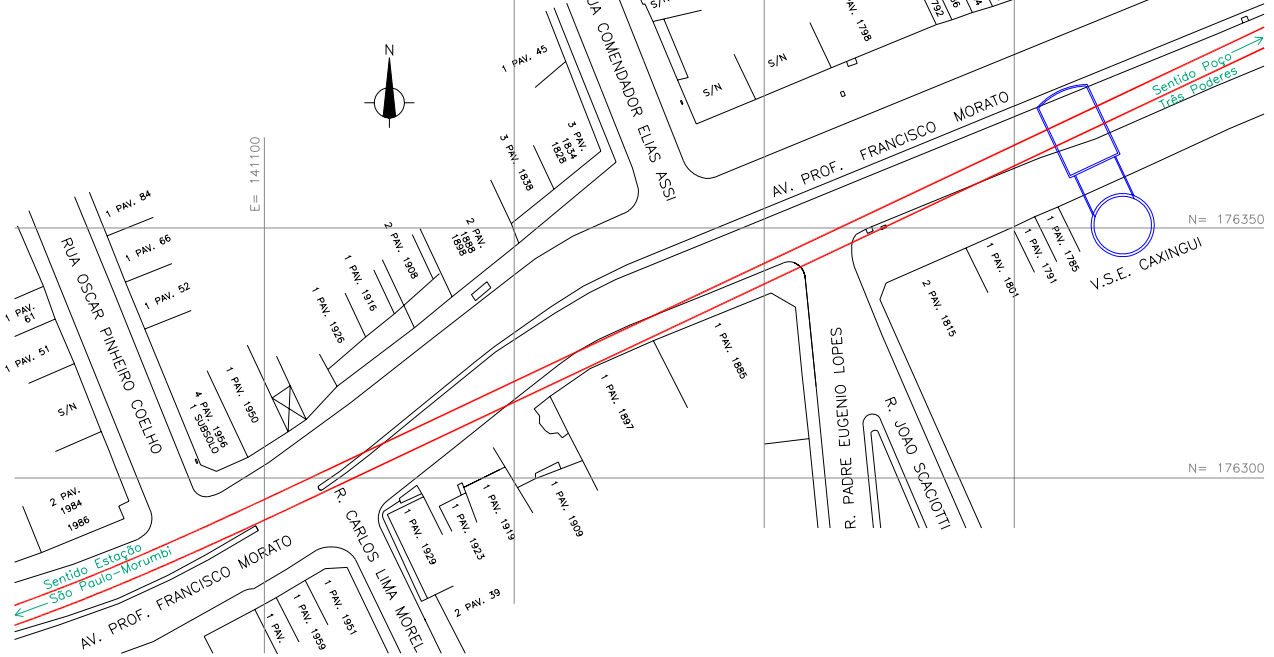

Figura 2.2 - Localização da área de estudos, a partir de Metrô-SP (2006a)

\begin{tabular}{|c|c|c|c|}
\hline $\begin{array}{c}\text { Estação } \\
\text { São Paulo - Morumbi }\end{array}$ & $\begin{array}{l}\text { Poço VSE } \\
\text { Caxingui }\end{array}$ & $\begin{array}{l}\text { Poço VSE } \\
\text { Três Poderes }\end{array}$ & $\begin{array}{l}\text { Estação } \\
\text { Butantã }\end{array}$ \\
\hline $\begin{array}{l}\text { _entido Zona Oeste } \\
\text { Pátio Vila Sônia }\end{array}$ & $\begin{array}{l}\text { trecho } \\
\text { em estudo }\end{array}$ & & $\begin{array}{l}\text { sentido Centro } \\
\text { Estação da Luz }\end{array}$ \\
\hline
\end{tabular}

Figura 2.3 - Esquema de Estações envolvidas 


\subsection{GEOLOGIA}

De acordo com Coutinho (1968), a região metropolitana de São Paulo abrange dois grupos de formações Pré-Cambrianas, recobertas parcialmente por sedimentos modernos.

O primeiro pertence ao Grupo São Roque, o qual ocupa a região norte do município de São Paulo e se estende até o estado do Paraná. De uma maneira simplificada, pode-se caracterizar o grupo como sendo constituído por rochas metamórficas de origem sedimentar, predominando os metassedimentos de natureza argilosa (atualmente metamorfoseados em filitos), mas também com presença de metassedimentos conglomeráticos, arenosos e calcários em áreas restritas.

O segundo grande conjunto litológico pertence ao chamado Complexo Cristalino, que ocupa a região sul da cidade, ao sul do rio Tietê, contornando as terminações dos metassedimentos do Grupo São Roque. Entre os rios Tietê e Pinheiros, o Complexo Cristalino encontra-se recoberto pela bacia sedimentar de São Paulo, de formação Cenozóica, emergindo na região sudoeste.

O embasamento cristalino da área de estudos encontra-se no Grupo Complexo Cristalino, mais precisamente no sub-grupo denominado de Complexo de Embu, de acordo com Coutinho (1968) e Rodriguez (1998). Trata-se de uma região dominada por gnaisses graníticos e migmatitos, como mostra o mapa geológico apresentado na Figura 2.4, confeccionado pela EMPLASA (1980).

Gnaisses são rochas metamórficas, provenientes de rochas ígneas ou sedimentares. Denomina-se de ortognaisse o resultado do metamorfismo de um granito e de paragnaisse o de rochas sedimentares. O gnaisse granítico é assim denominado por possuir a aparência homogênea de um granito, independentemente da proveniência ígnea ou sedimentar.

O migmatito é uma rocha com injeções de neosomas em um paleosoma, ou seja, novas rochas em estado de fusão são injetadas em rochas precedentes. Dentre os tipos existentes, são dominantes na área de estudo os embrechitos (homogêneos) e os epibólitos (heterogêneos, com marcada alternância de faixas escuras xistosas e claras de natureza granítica). A origem primária ígnea, sedimentar ou mista permanece incerta (COUTINHO, 1968).

O local de estudos se encontra em uma zona de movimentação tectônica intensificada, com presença de falhas. Como pode ser visto na Figura 2.4, o local de amostragem se situa próximo à Falha de Caucaia, a qual decorre paralelamente ao eixo do túnel. As rochas podem estar cisalhadas ou até em estado milonítico (trituradas antes de sofrerem metamorfismo). 


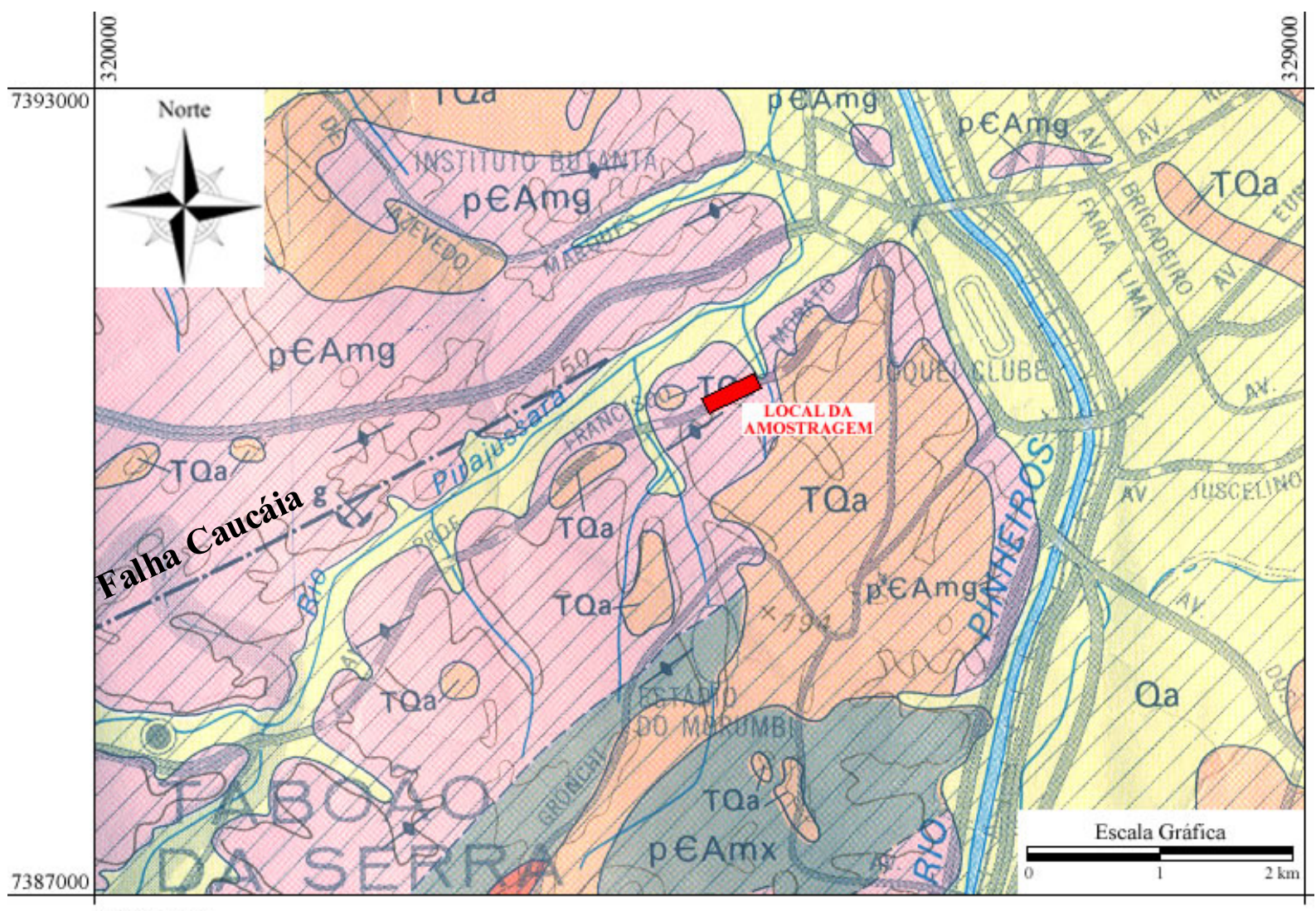

LEGENDA

CENOZÓICO

\begin{tabular}{|c|}
\hline Qa \\
\hline TQa \\
\hline
\end{tabular}

QUATERNÁRIO

Aluviōes fluviais: argila, areia e cascalho

PRÉ-CAMBRIANO

TERCIÁRIO-QUATERNÁRIO

Argilas, areias e cascalhos da Formação São Paulo e da Formação Caçapava (Grupo Taubaté). Inclui depósitos elúvio-coluviais correlatos

Figura 2.4 - Mapa geológico da região de estudo, a partir de EMPLASA (1980)

O solo encontrado acima do embasamento cristalino, na região de estudos, é denominado como solo residual. Tendo-se em vista que este termo será continuamente utilizado nesta pesquisa, de acordo com Vargas (1978) e a partir do conhecimento acumulado por diversos outros autores, pode-se definir o solo residual como o produto da decomposição local de uma rocha, devida à ação de intempéries.

O solo residual pode ser subdividido em horizontes, de acordo com o grau de alteração, dispondo-se em camadas paralelas à topografia, sem divisões distintas e com maior intensidade de intemperismo próximo à superfície. 
Em um solo residual, a lixiviação e o ataque de agentes químicos promovem a geração de vazios no solo, deixando suas partículas estruturadas e formando novos caminhos de percolação. Com isto, o processo de formação do solo residual, em geral, acarreta uma diminuição da densidade do solo e, conseqüentemente, um aumento de sua porosidade e permeabilidade.

Para esta pesquisa, os perfis de alteração típicos serão considerados constituídos, do topo para a base, pelos horizontes de:

- solo residual maduro - o horizonte relativamente mais homogêneo, onde geralmente não se encontra as características da rocha original;

- solo saprolítico - onde o solo mantém as características da rocha original, como veios, fissuras e xistosidade, mas perdeu sua competência mecânica;

- rocha sã.

Essa descrição é característica para um perfil de alteração de gnaisse, onde o topo do substrato de rocha sã é "serrilhado", caracterizado por altos e baixos que se assemelham a dentes de serra.

Um outro horizonte também pode ser encontrado, entre o solo saprolítico e o topo da rocha sã, no qual são predominantes blocos da rocha original envoltos por material de alteração. Estes blocos são delimitados pelas descontinuidades da rocha original, as quais permitem sua alteração em profundidade. Este seria o caso de um perfil de alteração típico de uma rocha granítica (ígnea), que não é o caso em estudo.

Um perfil geológico-geotécnico da área de estudos, apresentado pelo Metrô-SP (2006a), está ilustrado de maneira simplificada na Figura 2.5. A escala vertical é 2,5 vezes a escala horizontal.

No poço de ventilação e de acesso, pode-se perceber a presença de uma possível região de falha geológica, tendo-se em vista a presença de solo residual maduro a grandes profundidades e a descontinuidade do substrato rochoso. 


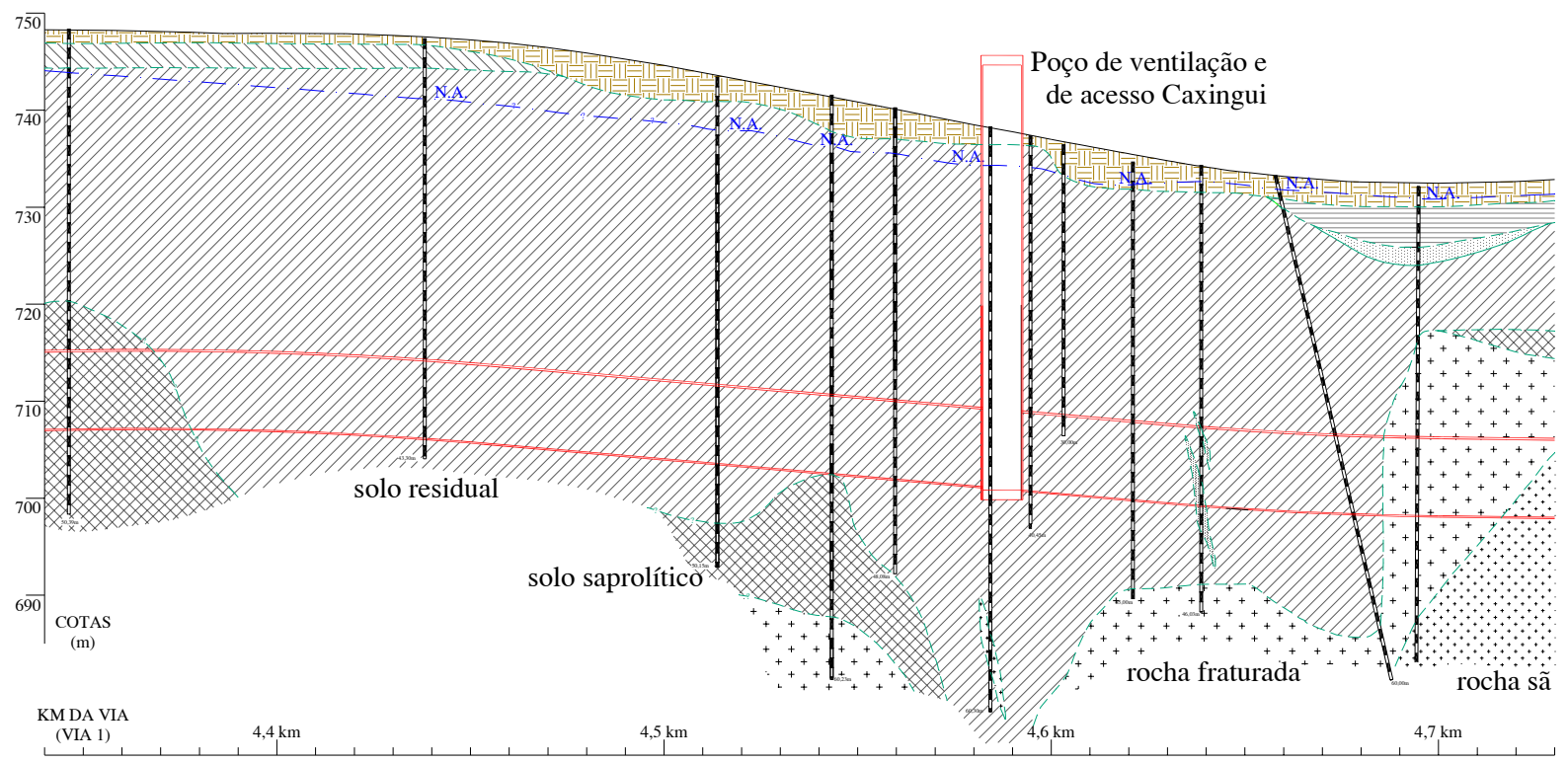

Figura 2.5 - Perfil geológico-geotécnico do local de estudo, a partir de Metrô-SP (2006a)

A partir do perfil da Figura 2.5, foi produzido o modelo geológico-geotécnico conceitual que será utilizado nesta pesquisa, o qual é condizente com o local da amostragem e se encontra na Figura 2.6.

O perfil adotado é composto por uma camada de aterro argilo siltoso, com uma espessura de 1,85 m ; abaixo é encontrado um solo residual maduro de gnaisse, caracterizado pela sondagem SP 8514 como um silte arenoso micáceo, com uma espessura de 44,55 m; em seguida é encontrado um solo saprolítico de gnaisse, também caracterizado como um silte arenoso micáceo, com uma espessura de $8,60 \mathrm{~m}$; por fim encontra-se o substrato de rocha inalterada fraturada, um gnaisse granítico, a uma profundidade de $55 \mathrm{~m}$.

O nível do lençol freático, na época da execução das sondagens, se encontrava a $6,15 \mathrm{~m}$ de profundidade.

O topo do túnel se encontra a uma profundidade de $32,00 \mathrm{~m}$ e seu piso $6,00 \mathrm{~m}$ acima da camada de solo saprolítico de gnaisse.

A parte mais superficial do solo residual maduro apresenta SPT de 10 a 20 golpes e a região mais abaixo, acima do túnel, apresenta SPT de 30 a 40 golpes. O solo saprolítico apresenta SPT em torno de 50 golpes. 


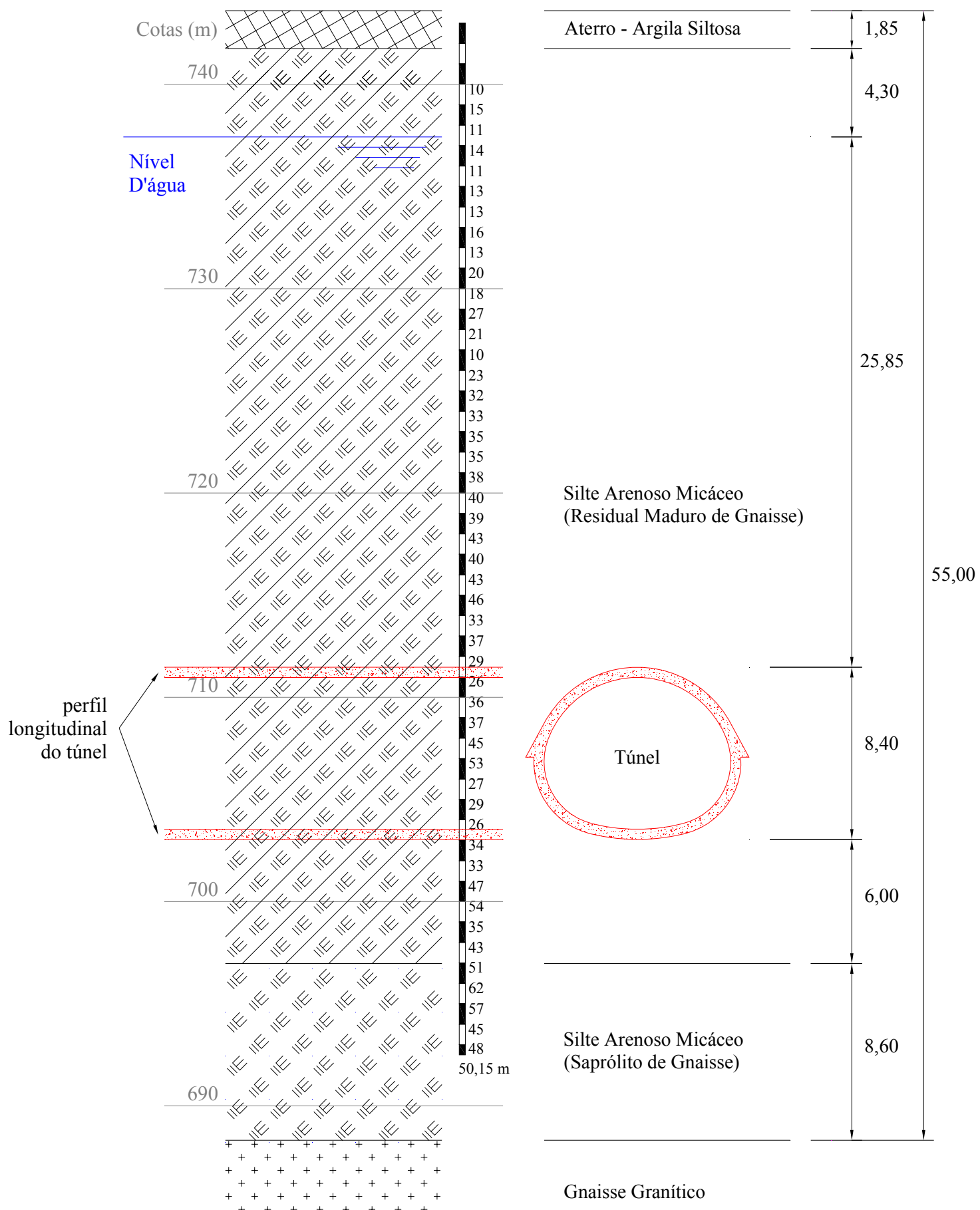

Figura 2.6 - Modelo geológico-geotécnico conceitual 


\subsection{Amostragem}

No dia 23 de maio de 2007, foram coletados três blocos de amostras indeformadas com dimensões aproximadas de $23 \mathrm{~cm}$ x $23 \mathrm{~cm}$ x $23 \mathrm{~cm}$, cujas fotos estão apresentadas na Figura 2.7.

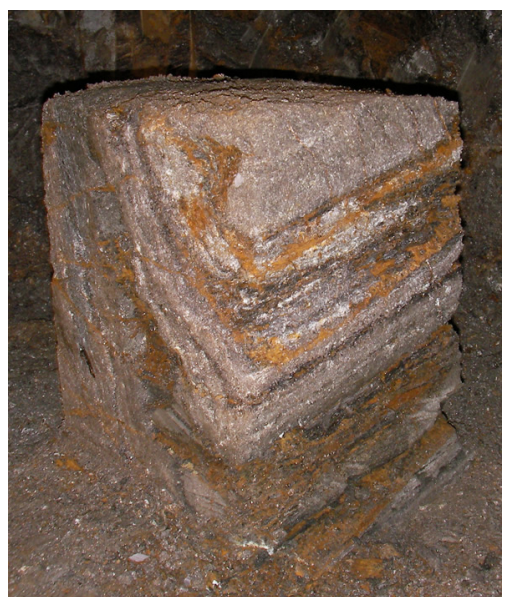

Amostra 01

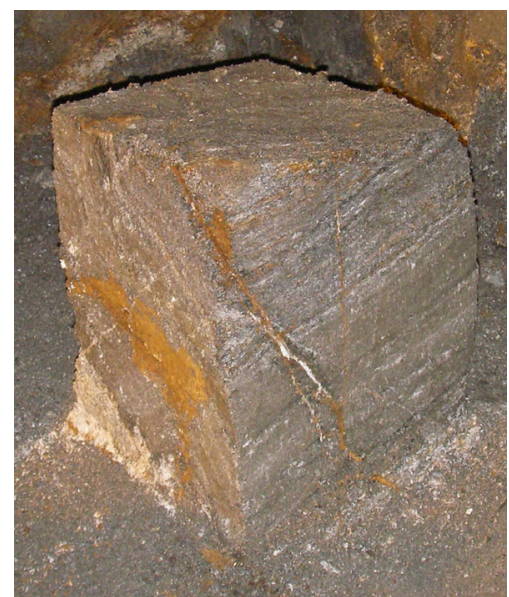

Amostra 02

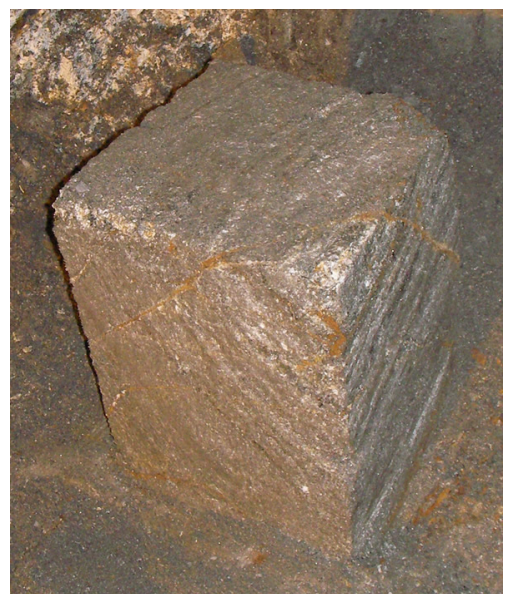

Amostra 03

Figura 2.7 - Amostras coletadas

A coleta foi realizada no núcleo da frente de escavação da calota (meia seção), vista na Figura 2.8, na estaca 4,4 km $+60,80 \mathrm{~m}$. Como pode ser visto pelo esquema da Figura 2.9, as amostras estavam a 1,0 $\mathrm{m}$ acima do nível de apoio do arco superior, a uma profundidade aproximada de $36 \mathrm{~m}$ e a uma distância de $120 \mathrm{~m}$ do Poço de Ventilação e de Acesso Caxingui.

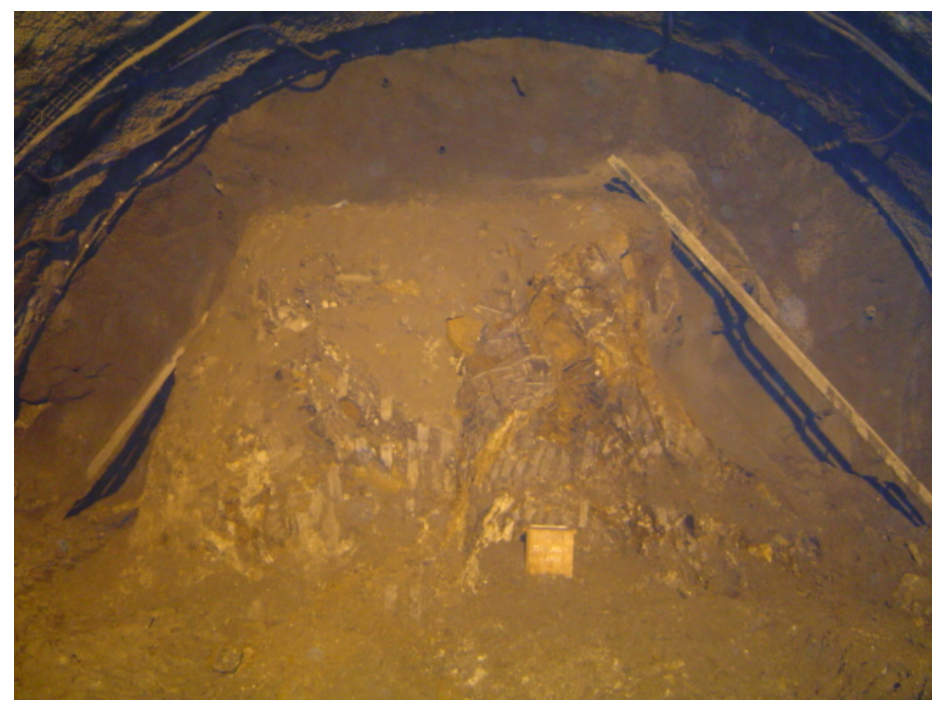

Figura 2.8 - Foto da frente de escavação durante a amostragem 


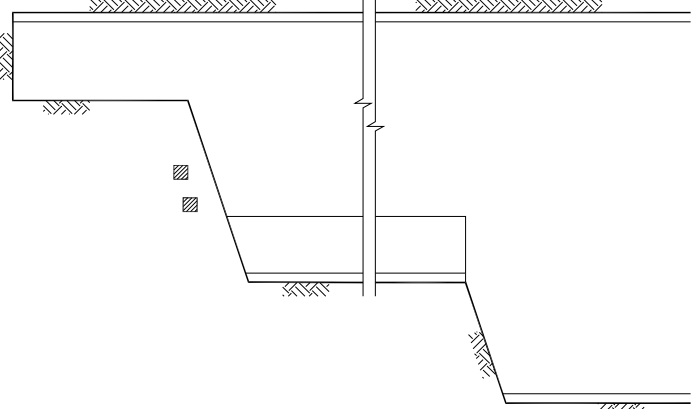

(a) Seção longitudinal

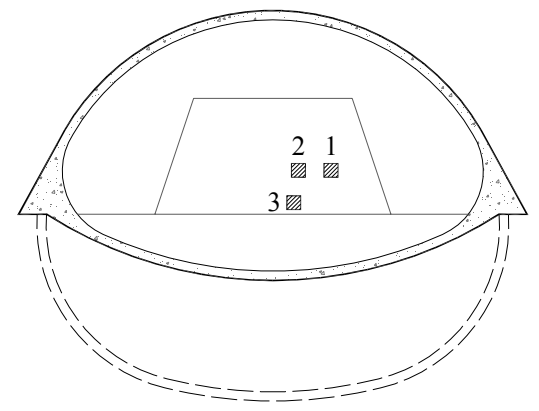

(b) Seção transversal

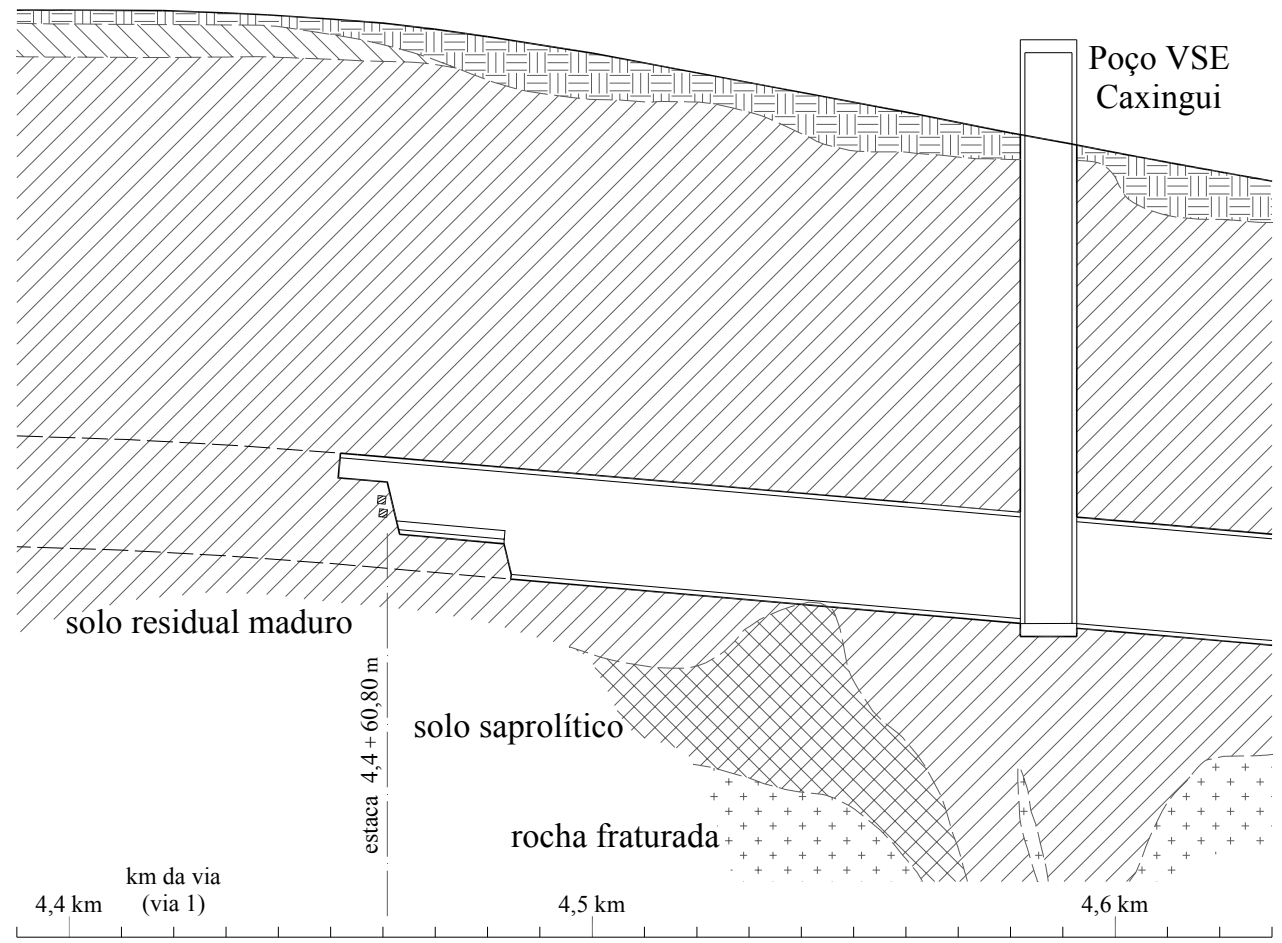

(c) Perfil longitudinal com feições geológico-geotécnicas

Figura 2.9 - Ilustração do local da amostragem

Não foi possível a coleta de amostras durante a escavação das estações ou dos poços de acesso e ventilação, os quais já haviam sido escavados na época da amostragem. Também não foi possível realizar a abertura de um poço superficial, para coleta de amostras indeformadas dos primeiros metros de profundidade.

Devido ao acidente ocorrido na estação Pinheiros da linha 4-Amarela no dia 12 de janeiro de 2007, todas as frentes de escavação foram interrompidas. Com isto, na frente de escavação de onde foram coletadas as amostras indeformadas deste estudo, foi aplicada uma camada de concreto projetado e interrompida a drenagem instalada. $\mathrm{O}$ sistema de drenagem instalado será abordado mais adiante, ao serem apresentados os aspectos construtivos da obra. 
Por meio de uma inspeção tátil, realizada no solo remanescente da amostragem, foi possível identificar uma pequena quantidade de areia fina e uma predominância de grãos micáceos na fração silte.

Visualmente, o solo possuía uma cor cinza claro com pontos brancos esparsos, com presença de alguns planos de descontinuidade. Estas descontinuidades são estruturas reliquiárias, provenientes de fraturas existentes na rocha original, preenchidas por dois materiais argilosos, um de cor laranja e outro de cor branca.

Um dos planos de descontinuidade pode ser visto na Figura 2.10 (a), presente em uma das amostras indeformadas. Com a descontinuidade exposta, os dois tipos de material de preenchimento podem ser vistos, como apresentado em detalhe na Figura 2.10 (b), configurando uma película sobre o solo residual cinza.

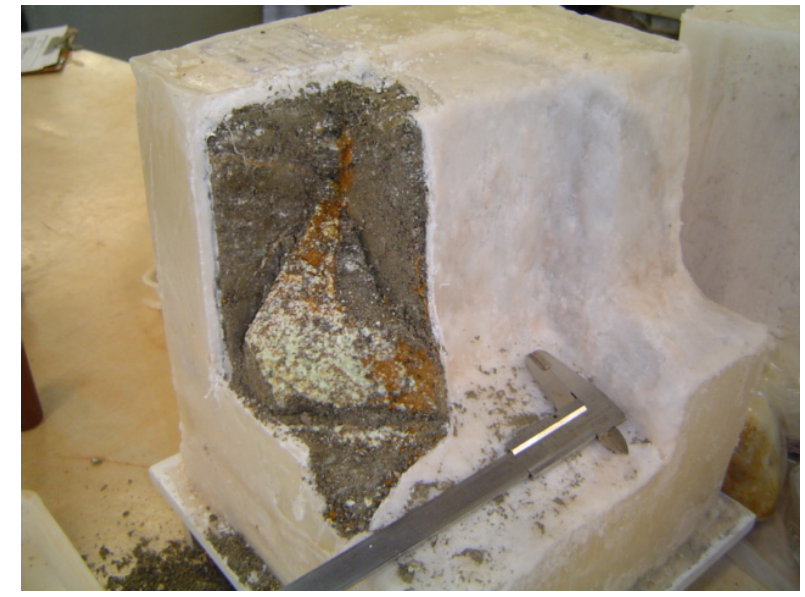

(a) plano de descontinuidade

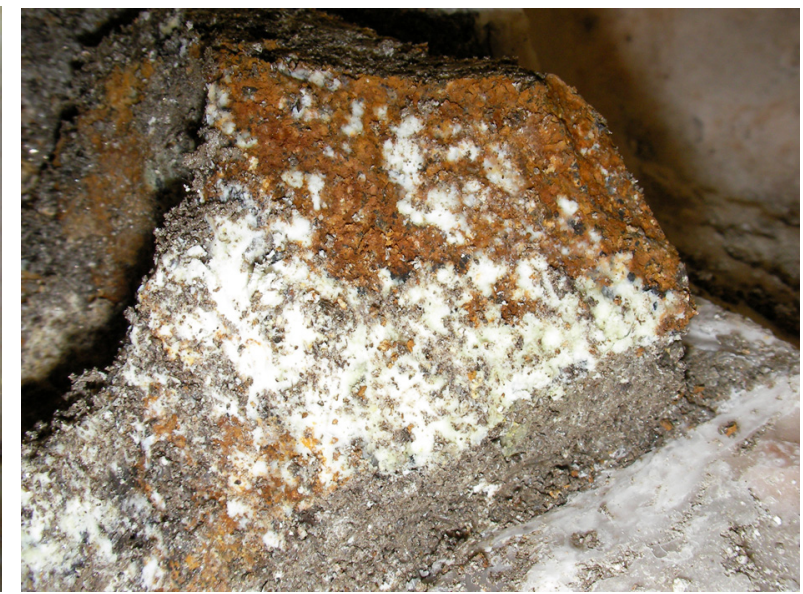

(b) detalhe dos materiais de preenchimento

Figura 2.10 - Estrutura reliquiária

As duas famílias predominantes de descontinuidades, encontradas nas amostras coletadas, estão representadas na Figura 2.11 por uma vista em planta e por uma projeção estereográfica. Não foi possível efetuar um mapeamento das descontinuidades da frente de escavação durante a amostragem.

As descontinuidades apresentaram direção aproximadamente transversal ao túnel, com um ângulo variando de 30 a 45 graus em relação ao eixo transversal do túnel, possuindo mergulhos concordantes com o sentido do avanço da escavação e variando de 55 a 65 graus (ângulo em relação à horizontal). A orientação em campo foi realizada com bússola e os ângulos obtidos a partir das amostras foram determinados com transferidor. 


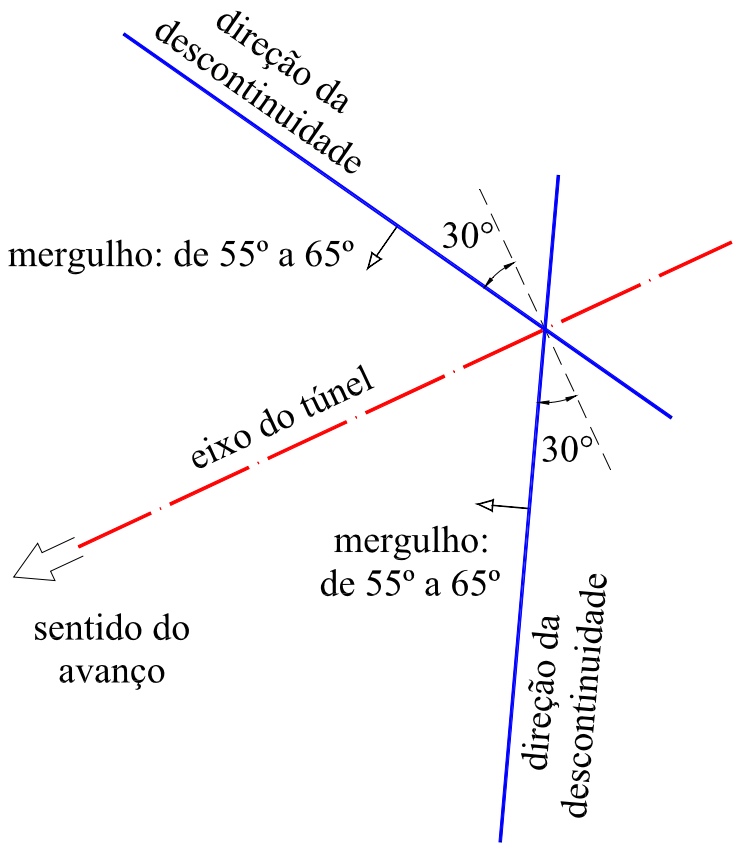

(a) representação em planta

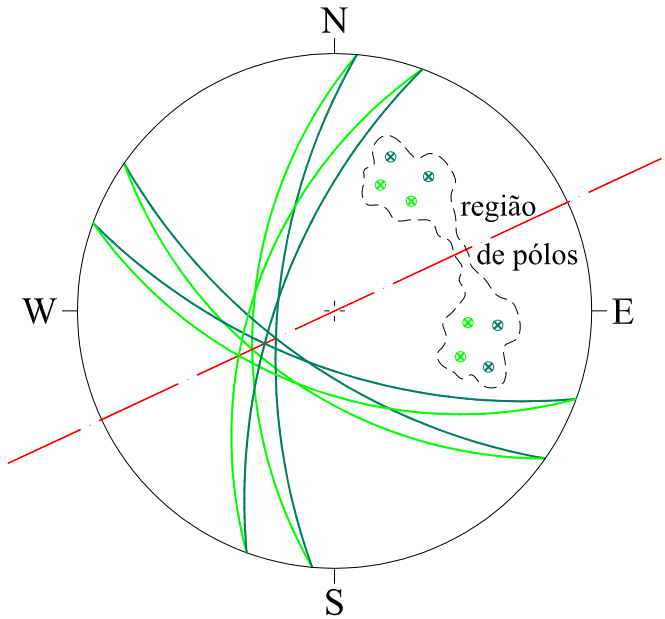

(b) projeção estereográfica

Figura 2.11 - Descontinuidades observadas nas amostras coletadas

A partir da projeção estereográfica e de acordo com conceitos apresentados por Hasui (1993), nota-se que os diedros formados pelas descontinuidades possuem arestas inclinadas no sentido Sudoeste (SW), concordantes com o sentido de avanço da escavação.

De acordo com Bieniawski (1989) e Francis e Rocha (1998), a situação em que se encontram as descontinuidades é favorável para a execução do túnel, tornando a face de escavação estável. Entretanto, a concordância dos mergulhos com o avanço da escavação possibilita a instabilização do teto, podendo ocorrer desplacamentos e quedas de blocos nos trechos não revestidos.

\subsection{GEOMETRIA DO TÚNEL}

A Figura 2.12 apresenta a seção transversal do túnel, o qual possui $8,43 \mathrm{~m}$ de altura escavada e 10,14 m de largura escavada, com revestimento primário de $20 \mathrm{~cm}$ em concreto projetado e revestimento secundário de $30 \mathrm{~cm}$ em concreto moldado. $\mathrm{O}$ diâmetro equivalente de escavação $\left(\mathrm{d}_{\mathrm{eq}}\right)$ é de $9,33 \mathrm{~m}$, ou seja, a área de um círculo com este diâmetro é equivalente à área de escavação do túnel. No sentido longitudinal, o túnel possui uma inclinação aproximada de $3,4 \%$. 


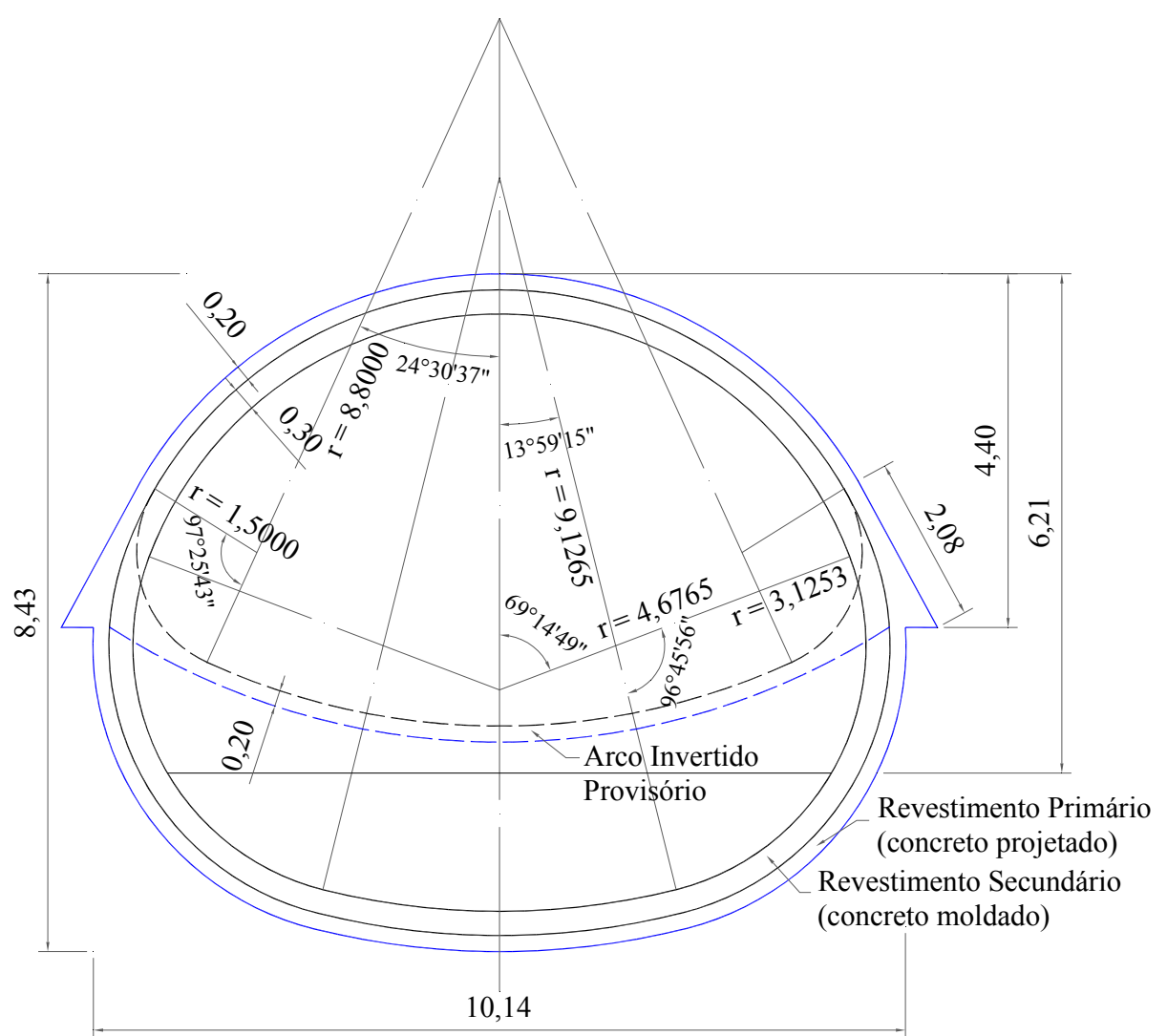

Figura 2.12 - Seção transversal do túnel, a partir de Metrô-SP (2006b)

\subsection{Aspectos Construtivos}

O túnel foi executado pelo método NATM (New Austrian Tunnelling Method), com parcialização da seção em duas partes: calota e bancada (meia seção e seção plena). A calota contou com a utilização de arco invertido provisório (AIP) e de um núcleo para contenção da frente de escavação.

As frentes de escavação partiram das estações e dos poços de acesso e de ventilação. No caso do trecho em estudo, a frente de escavação partiu do poço VSE - Caxingui em direção à estação São Paulo - Morumbi. A Figura 2.13 apresenta a seqüência construtiva de modo simplificado. 

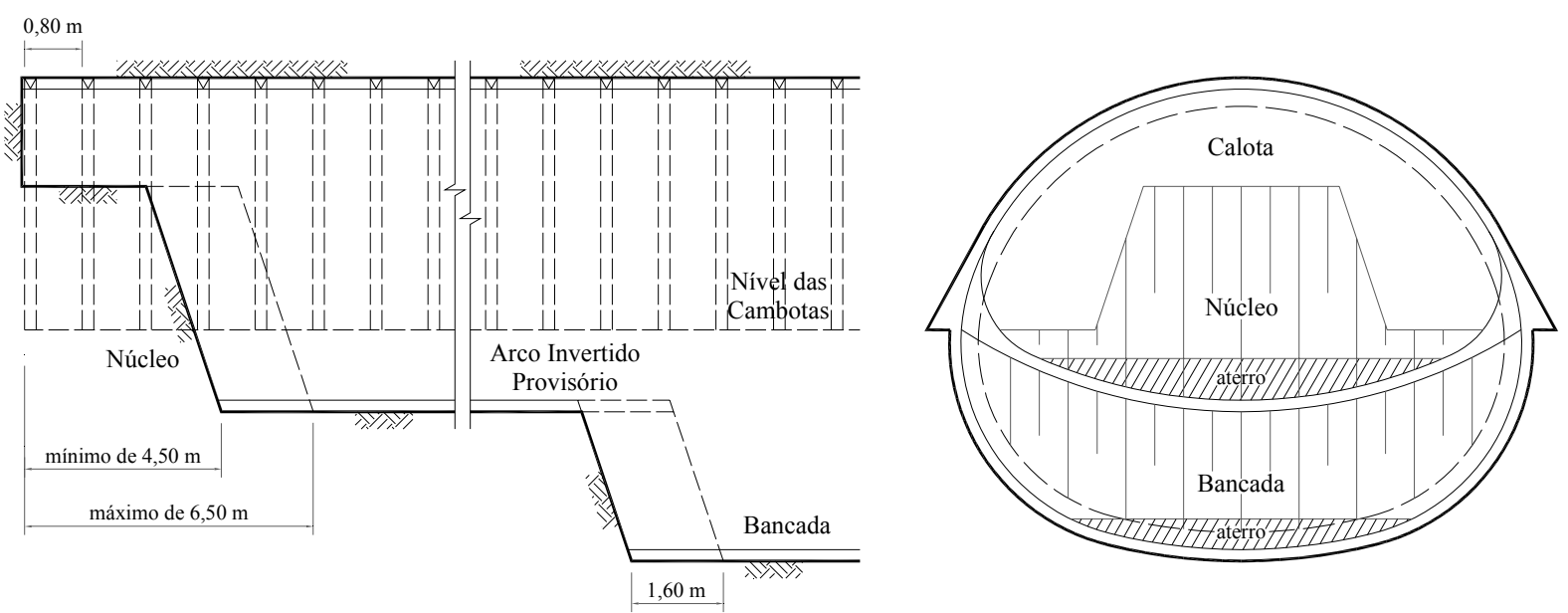

Figura 2.13 - Seqüência construtiva empregada no túnel, a partir de Metrô-SP (2006b)

A seqüência consistia na escavação da calota em um avanço de $0,80 \mathrm{~m}$, mantendo-se o núcleo, seguida da instalação imediata de uma cambota com o mesmo espaçamento e aplicação de $20 \mathrm{~cm}$ de concreto projetado do revestimento primário. Esta operação era repetida sucessivamente até o limite máximo de 6,50 m entre e frente de escavação e o arco invertido provisório. Prosseguindo, iniciava-se a escavação do núcleo e do piso da calota em um avanço de 1,60 m, seguida da aplicação de $20 \mathrm{~cm}$ de concreto projetado do arco invertido provisório. Uma camada de aterro era depositada para proteção mecânica do arco e repetia-se a operação de escavação do núcleo até o limite mínimo de 4,50m entre a frente de escavação e o arco invertido provisório.

Esta seqüência de escavação da calota e de seu núcleo (meia seção) se repetia até que fosse iniciado o rebaixo do túnel (seção plena), realizado com a escavação da bancada, a uma distância da frente de escavação não determinada pelo projeto. Removia-se um trecho de 1,60m do arco invertido provisório e se escavava a mesma distância do rebaixo, seguido pela aplicação de $20 \mathrm{~cm}$ de concreto projetado do arco invertido definitivo (AID). Uma camada de aterro era depositada para proteção mecânica do arco e repetia-se a operação de escavação da bancada, até serem retomadas as escavações da calota (meia seção).

Durante o processo construtivo, foram utilizados drenos horizontais profundos (DHPs) à vácuo, instalados na frente de escavação para possibilitar o trabalho em meio não-saturado. Não foram instalados, ao longo dos túneis de via, sistemas de drenagem a partir da superfície. 
Devido à inexistência de piezômetros e/ou medidores de nível d'água ao longo dos túneis de via, não se pode afirmar se a drenagem da frente alterou o nível do lençol freático. É possível que tenha ocorrido uma manutenção no lençol freático e a dessaturação tenha compreendido apenas um volume delimitado circunvizinho à frente de escavação.

Nos poços de acesso, onde foram instalados dispositivos capazes de detectar a variação do nível do lençol freático (como piezômetros e medidores de nível d'água), o sistema de drenagem foi instalado a partir da superfície, diferentemente da situação encontrada na frente de escavação dos túneis de via.

Devido à paralisação da obra citada anteriormente, com aplicação de concreto projetado na frente de escavação e com o sistema de drenagem desativado, é provável que as condições do nível freático tenham se restabelecido e que o solo tenha sido novamente saturado.

Após terminado todo o revestimento primário do trecho do túnel, iniciava-se a instalação do sistema de impermeabilização seguido pela execução do revestimento secundário. De acordo com Rocha et al. (2005), foi utilizado o sistema de impermeabilização total, tornando o túnel estanque e com sistema de drenagem apenas durante a fase construtiva (revestimento primário). O sistema adotado empregou geomembranas, instaladas entre as camadas de revestimento primário e secundário do túnel. $\mathrm{O}$ revestimento secundário (definitivo) foi executado em concreto moldado. 


\section{Capítulo 3}

\section{C \\ ARACTERIZAÇão FísiCA, MineralógiCa E MiCROSCÓPICA}

Todos os ensaios realizados, apresentados neste capítulo, foram executados de acordo com a NBR 6457, que trata da preparação de amostras de solo para ensaios de caracterização.

Este capítulo foi subdividido em quatro partes, tratando da caracterização física do solo em estudo, da identificação dos seus minerais e de uma análise microscópica, seguidas por conclusões parciais.

\subsection{CARACTERIZaÇÃo Física}

Ao serem abertas as amostras indeformadas, determinou-se o teor de umidade (w) para cada amostra, cujos valores estão apresentados na Tabela 3.1.

Os ensaios de determinação da massa específica dos grãos $(G)$ foram executados de acordo com a norma NBR 6508 e os valores obtidos para cada amostra também se encontram na Tabela 3.1.

Os ensaios de Limite de Liquidez $\left(\mathrm{w}_{\mathrm{L}}\right)$ e de Limite de Plasticidade $\left(\mathrm{w}_{\mathrm{P}}\right)$ foram realizados de acordo com a NBR 6459 e a NBR 7180, respectivamente. A partir da determinação dos dois limites, determina-se o Índice de Plasticidade (IP) como a diferença $\left(\mathrm{w}_{\mathrm{P}}-\mathrm{w}_{\mathrm{L}}\right)$. Os valores obtidos encontram-se na Tabela 3.1. 
Tabela 3.1 - Índices físicos e propriedades geotécnicas obtidos para as três amostras

\begin{tabular}{c|c|c|c|c|c}
\hline & $\mathbf{w} \mathbf{( \% )}$ & $\mathbf{G}$ & $\mathbf{w}_{\mathbf{L}} \mathbf{( \% )}$ & $\mathbf{w}_{\mathbf{P}}(\mathbf{\%})$ & $\mathbf{I P}$ \\
\hline Amostra 01 & 19,2 & 2,718 & 32 & 23 & 9 \\
\hline Amostra 02 & 18,1 & 2,758 & 33 & 24 & 9 \\
\hline Amostra 03 & 21,5 & 2,681 & 36 & 26 & 10 \\
\hline
\end{tabular}

A granulometria do solo em estudo foi obtida de acordo com a norma NBR 7181, utilizando-se o defloculante hexametafosfato diluído em 12,5\%. As curvas granulométricas obtidas para as três amostras estão apresentadas na Figura 3.1 e as respectivas composições granulométricas encontram-se na Tabela 3.2, obtidas de acordo com a NBR 6502.

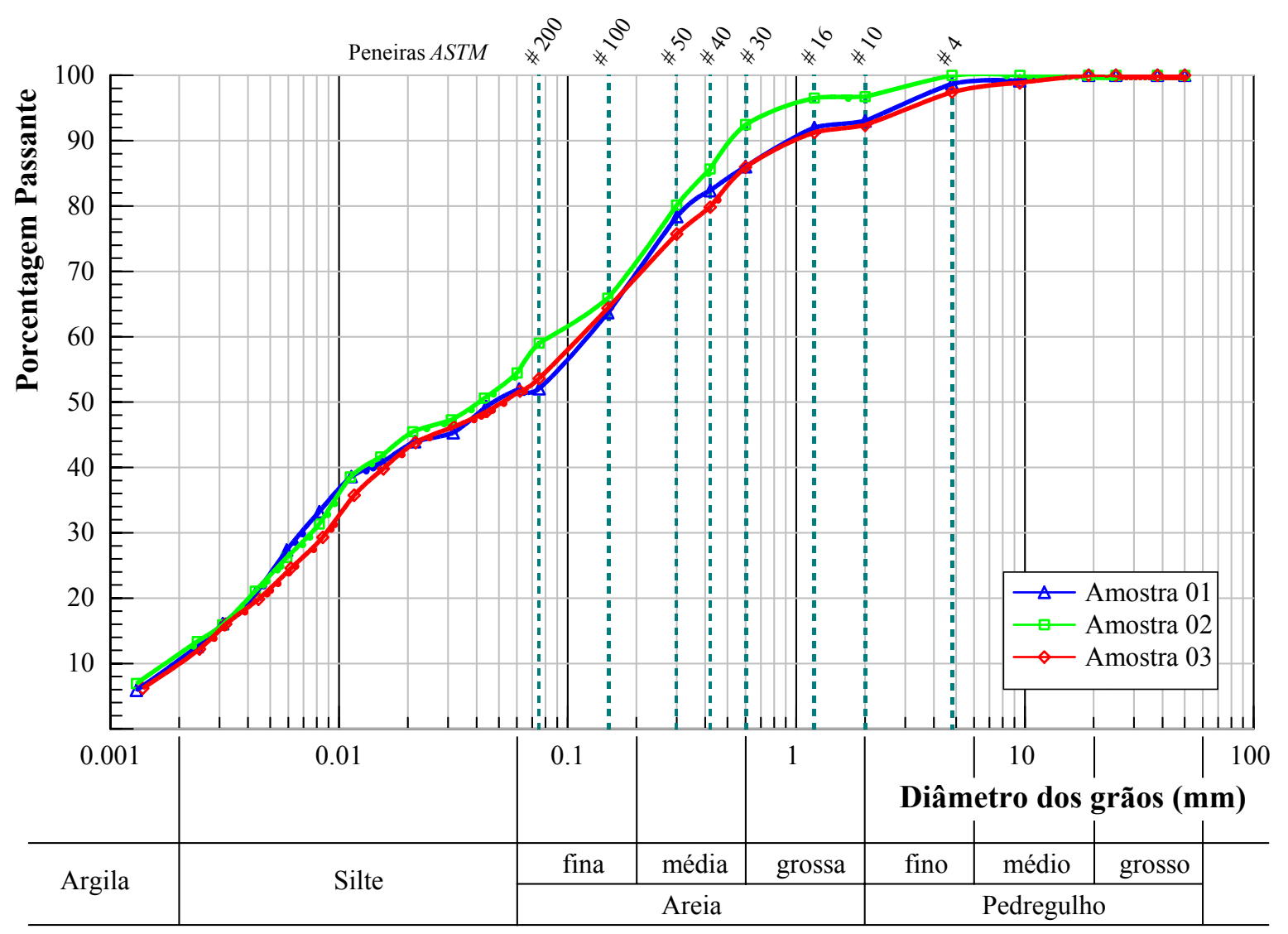

Classificação segundo a ABNT, de acordo com a NBR 6502 / 1995

Figura 3.1 - Curva granulométrica do solo 
Tabela 3.2 - Composição granulométrica do solo

\begin{tabular}{c|c|c|c|c}
\hline \multirow{2}{*}{ fração } & \multirow{2}{*}{ diâmetro (mm) } & \multicolumn{3}{|c}{ porcentagem } \\
\cline { 3 - 5 } & & Amostra 01 & Amostra 02 & Amostra 03 \\
\hline Argila & $\phi<0,002$ & $10 \%$ & $12 \%$ & $10 \%$ \\
\hline Silte & $0,002<\phi<0,06$ & $42 \%$ & $42 \%$ & $42 \%$ \\
\hline Areia Fina & $0,06<\phi<0,2$ & $18 \%$ & $17 \%$ & $17 \%$ \\
\hline Areia Média & $0,2<\phi<0,6$ & $16 \%$ & $21 \%$ & $17 \%$ \\
\hline Areia Grossa & $0,6<\phi<2$ & $7 \%$ & $4 \%$ & $6 \%$ \\
\hline Areia (total) & --- & $41 \%$ & $42 \%$ & $40 \%$ \\
\hline Pedregulho Fino & $2<\phi<6$ & $6 \%$ & $4 \%$ & $6 \%$ \\
\hline Pedregulho Médio & $6<\phi<20$ & $1 \%$ & --- & $2 \%$ \\
\hline Pedregulho Grosso & $20<\phi<60$ & --- & -- & $-1 \%$ \\
\hline Pedregulho (total) & --- & $7 \%$ & $4 \%$ & $8 \%$ \\
\hline
\end{tabular}

As três amostras apresentam um teor maior do que $50 \%$ de fração fina (material passante na peneira $\mathrm{n}^{\circ} 200$, de $0,075 \mathrm{~mm}$ ). Pela composição granulométrica, pode-se notar que a fração silte é predominante nas amostras, seguida pelas frações de areia fina e média. Entretanto, a fração total de areia possui porcentagem muito próxima à de silte, dificultando a classificação do solo quanto à fração predominante.

O Índice de Atividade de Skempton (IA), que pode ser obtido pela equação (3.1), é igual a 0,9 para a Amostra 01, 0,75 para a Amostra 02 e 1,0 para a Amostra 03.

$$
\mathrm{IA}=\frac{\mathrm{IP}}{\% \text { fração argila }}
$$

O solo em estudo foi adicionado à carta de plasticidade de Casagrande e à carta de atividade de Skempton, apresentadas na Figura 3.2.

Pela Classificação Unificada, as amostras podem ser caracterizadas como um silte de baixa compressibilidade (ML), cuja fração argila presente é considerada normal quanto à sua atividade coloidal. Por estar muito próximo à linha $\mathrm{A}$ e por possuir porcentagem de finos próxima a $50 \%$, o solo também pode ser classificado como ML-SM, ou seja, a denominação de areia siltosa também é válida. 


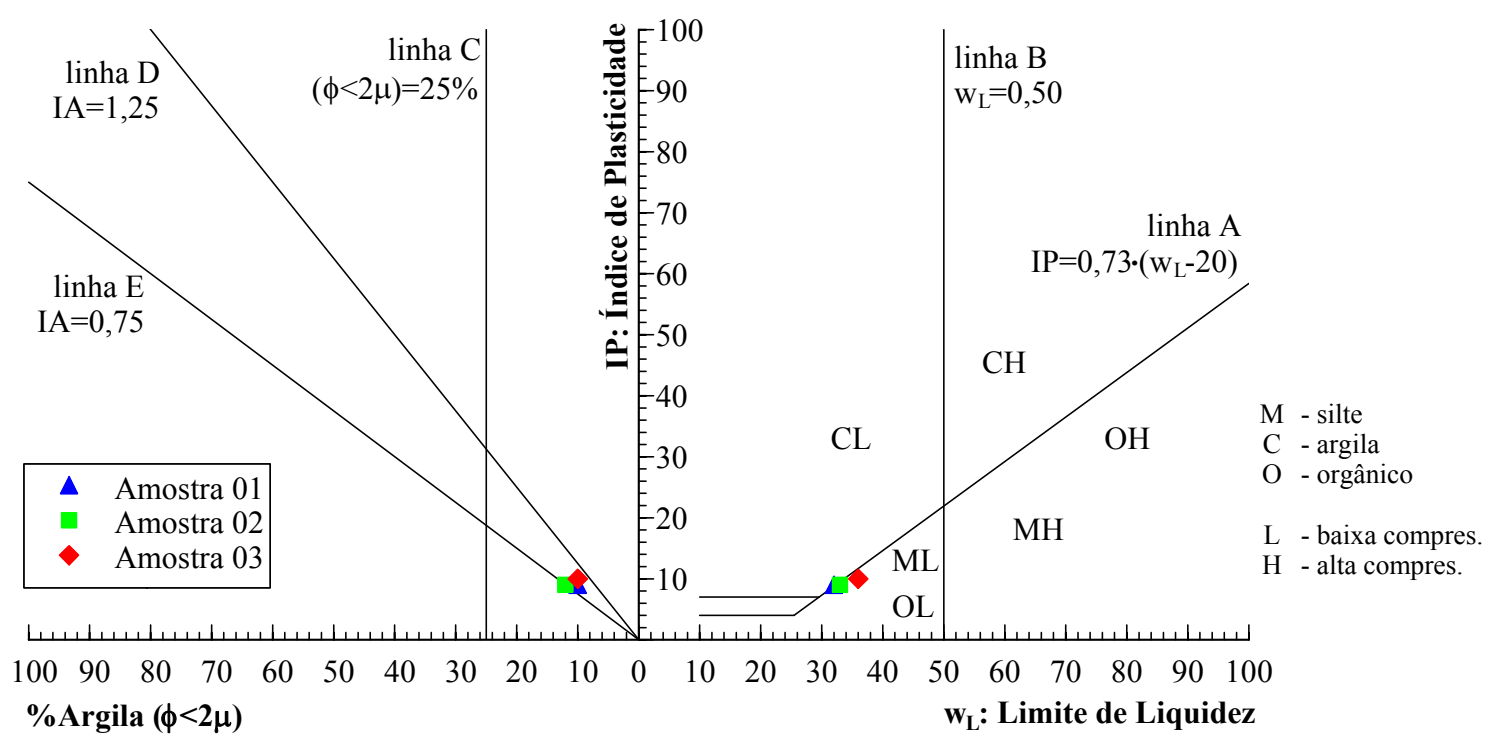

Figura 3.2 - Inserção do solo nas Cartas de Plasticidade e de Atividade

A partir da comparação entre os resultados obtidos para o teor de umidade, a massa específica dos grãos, os limites de liquidez e de plasticidade e a composição granulométrica, pode-se afirmar que as três amostras são semelhantes e que, portanto, o solo encontrado em cada uma delas pode ser considerado o mesmo.

Desta maneira, optou-se por utilizar a Amostra 03 para a execução dos demais ensaios laboratoriais de caracterização (apresentados neste capítulo) e de comportamento mecânico (apresentados no capítulo seguinte). A Amostra 03 foi escolhida por apresentar melhor qualidade de amostragem, tendo sido a última a ser coletada.

A confecção dos corpos-de-prova dos ensaios de adensamento unidimensional e dos ensaios triaxiais, os quais serão apresentados no Capítulo 4, possibilitou a determinação do peso específico natural $\left(\gamma_{\mathrm{n}}\right)$ e de novos valores para o teor de umidade. Para o peso específico natural, os valores variaram de 20,2 a $20,4 \mathrm{kN} / \mathrm{m}^{3}$, tendo sido adotado o valor de $20,4 \mathrm{kN} / \mathrm{m}^{3}$ como média dos resultados. Para o teor de umidade, obteve-se uma variação de $21,34 \%$ a $22,75 \%$, tendo sido adotado o valor médio de $21,9 \%$.

O índice de vazios (e) calculado para estes ensaios variou de 0,622 a 0,593 e o grau de saturação (S) variou de 99,3 \% a 94,5 \%. A partir dos valores adotados de teor de umidade natural e de peso específico natural, têm-se os valores de 0,602 como índice de vazios natural e $97,5 \%$ como grau de saturação natural.

Ao se executar o primeiro ensaio edométrico determinou-se o valor de $53 \mathrm{kPa}$ de sucção atuando na amostra, por meio de um tensiômetro de alta capacidade. 
Pinto e Nader (1994a) realizaram ensaios em solos residuais do Estado de São Paulo, sendo apresentados na Figura 3.3 alguns resultados para o solo residual de migmatito e para o solo residual de gnaisse. O solo residual de migmatito foi coletado na cidade de São Paulo, próximo ao local estudado na presente pesquisa, enquanto que o solo residual de gnaisse foi coletado no interior do Estado de São Paulo. Apesar do solo em estudo ser do mesmo tipo de formação de rocha originária que o solo residual de gnaisse, nota-se que o solo residual de migmatito apresenta uma melhor conformidade de resultados.

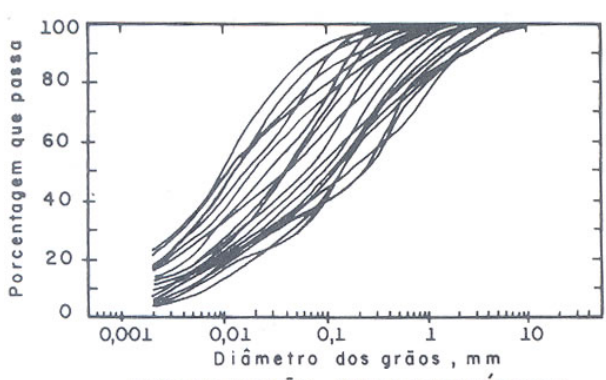

DISTRIBUICQĀO GRANULOMÉTRICA
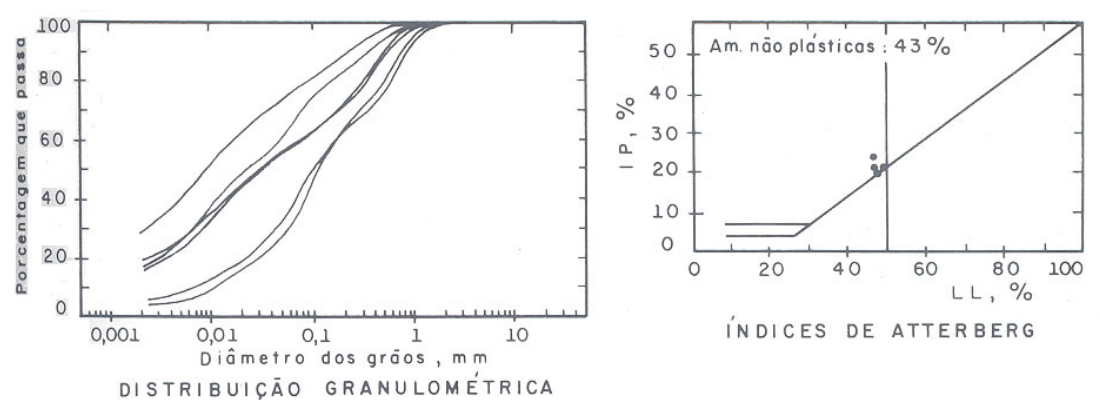

Figura 3.3 - Resultados obtidos por Pinto e Nader (1994a) para dois solos residuais

Ao se comparar o solo em estudo com os solos residuais estudados por Pinto et al. (1993) e Pinto e Nader (1994a), pode-se concluir duas situações distintas:

- para os solos próximos à saturação, o índice de vazios natural é menor do que 0,80 e o peso específico natural encontra-se próximo a $20 \mathrm{kN} / \mathrm{m}^{3}$, sendo coerente com os valores obtidos para o solo em estudo;

- para os solos com saturação menor que $80 \%$, o índice de vazios natural é maior do que a unidade e o peso específico natural é menor, em torno de $16 \mathrm{kN} / \mathrm{m}^{3}$, diferindo do solo em estudo.

A Tabela 3.3 a seguir apresenta os valores adotados para as propriedades geotécnicas do solo em estudo. Dentre os valores que foram determinados para as três amostras, foram adotados os referentes à Amostra 03. 
Tabela 3.3 - Resumo das propriedades geotécnicas

\begin{tabular}{c|cl}
\hline $\mathrm{w}$ & 21,9 & $\%$ \\
\hline $\mathrm{G}$ & 2,681 & \\
\hline$\gamma_{\mathrm{n}}$ & 20,4 & $\mathrm{kN} / \mathrm{m}^{3}$ \\
\hline$\gamma_{\mathrm{d}}$ & 16,7 & $\mathrm{kN} / \mathrm{m}^{3}$ \\
\hline$\gamma_{\mathrm{sat}}$ & 20,5 & $\mathrm{kN} / \mathrm{m}^{3}$ \\
\hline$\gamma_{\mathrm{sub}}$ & 10,5 & $\mathrm{kN} / \mathrm{m}^{3}$ \\
\hline $\mathrm{e}$ & 0,602 & \\
\hline $\mathrm{S}$ & 97,5 & $\%$ \\
\hline $\mathrm{w}_{\mathrm{L}}$ & 36 & $\%$ \\
\hline $\mathrm{w}_{\mathrm{P}}$ & 26 & $\%$ \\
\hline $\mathrm{IP}$ & 10 & $\%$ \\
\hline
\end{tabular}

\subsection{Mineralogia}

A análise mineralógica realizada neste estudo será feita baseando-se em ensaios de Difração de Raios-X. Os ensaios foram executados no Laboratório de Raios-X do Departamento de Mineralogia e Geotectônica, do Instituto de Geociências da Universidade de São Paulo. Utilizou-se o programa Diffrac Plus para a análise dos resultados, obtidos pelo equipamento Siemens D5000, com tubo $\mathrm{Cu} \mathrm{K \alpha}, 40 \mathrm{~kW}$ e $40 \mu \mathrm{A}$.

Os resultados dos ensaios, denominados difratogramas, apresentam o espectro do material analisado. Em seu eixo vertical, o difratograma apresenta a intensidade dos raios-x, e no eixo horizontal um ângulo que se refere à distância entre planos atômicos (distância basal), de acordo com a lei de Bragg:

$n \cdot \lambda=2 \cdot d \cdot \operatorname{sen} \theta$

onde: $n=$ número inteiro, referente à ordem de difração;

$\lambda=$ comprimento de onda dos raios- $\mathrm{x}$ incidentes;

$d=$ distância entre planos atômicos; e

$\theta=$ ângulo de Bragg.

Para o equipamento utilizado, pode-se obter a distância basal por:

$$
d=\frac{1,54056}{2 \cdot \operatorname{sen} \theta}
$$


Quando a energia aplicada não é suficiente para excitar os elétrons do alvo, tem-se o chamado espectro contínuo. Caso contrário, tem-se o espectro característico, os picos de intensidade do difratograma. Nestes picos, pode-se medir as distâncias basais dos minerais presentes, a partir do ângulo correspondente no eixo horizontal.

Existem bancos de dados com os picos e as distâncias basais de diversos minerais, sendo assim possível a identificação dos minerais presentes. Os ensaios foram analisados a partir do banco de dados ICDD (2001).

Foram ensaiadas amostras do solo residual em estudo, assim como também amostras do material encontrado nas descontinuidades, o qual preencheu as fraturas da rocha originária.

Para uma melhor identificação dos grupos de argilo-minerais, foram ensaiadas primeiramente as amostras de fração argila. Em seguida, as amostras de fração argila foram glicoladas e ensaiadas novamente, e depois aquecidas e ensaiadas pela última vez (cada amostra foi ensaiada três vezes). Para a etapa de glicolagem, as lâminas foram colocadas em um dessecador com etileno-glicol por uma noite. Para a etapa de aquecimento, as lâminas foram levadas para uma mufla, mantendo-se a temperatura a $500{ }^{\circ} \mathrm{C}$ por 4 horas.

Com este procedimento, pôde-se realizar uma análise de acordo com as distâncias basais encontradas em Mitchell (1993), Resende et al. (2005) e Santos (1975). A análise da fração argila em três etapas deve-se a alguns fatos:

i) alguns grupos distintos de argilo-minerais podem possuir uma mesma distância basal (por exemplo, esmectita e vermiculita com $14 \AA$ );

ii) o espectro pode apresentar picos para as distâncias basais de 14 e de $7 \AA$, acusando a presença de uma caulinita e existindo apenas o mineral de $14 \AA$, sendo o pico de $7 \AA$ resultado da reflexão dos átomos presentes em uma camada no meio do mineral;

iii) se o mineral quartzo fosse ensaiado, apresentaria pico de intensidade muito elevado no espectro da difração de raios-x, camuflando o resultado dos demais minerais de picos menores.

Após a análise dos argilo-minerais, foram realizados ensaios com o material passante na peneira $\mathrm{n}^{\mathrm{o}} 40(0,42 \mathrm{~mm})$, representando a fração total do solo. Também foi ensaiada uma amostra com a fração silte do solo residual. A separação das frações foi realizada de acordo com o procedimento que se encontra no Apêndice A.

Para as amostras em estado natural, os dados foram coletados entre $2^{\circ}$ e $65^{\circ}(2 \theta)$, com um passo de $0,05^{\circ}(2 \theta)$ e 1 segundo por passo. Para as amostras glicoladas e aquecidas, os dados foram coletados entre $2^{\circ}$ e $20^{\circ}(2 \theta)$, com um passo de $0,05^{\circ}(2 \theta)$ e 1 segundo por passo. 


\subsubsection{Solo Residual}

A primeira amostra a ser ensaiada foi a de fração argila, seguida pelos ensaios após glicolagem e após aquecimento, resultando na comparação apresentada na Figura 3.4.

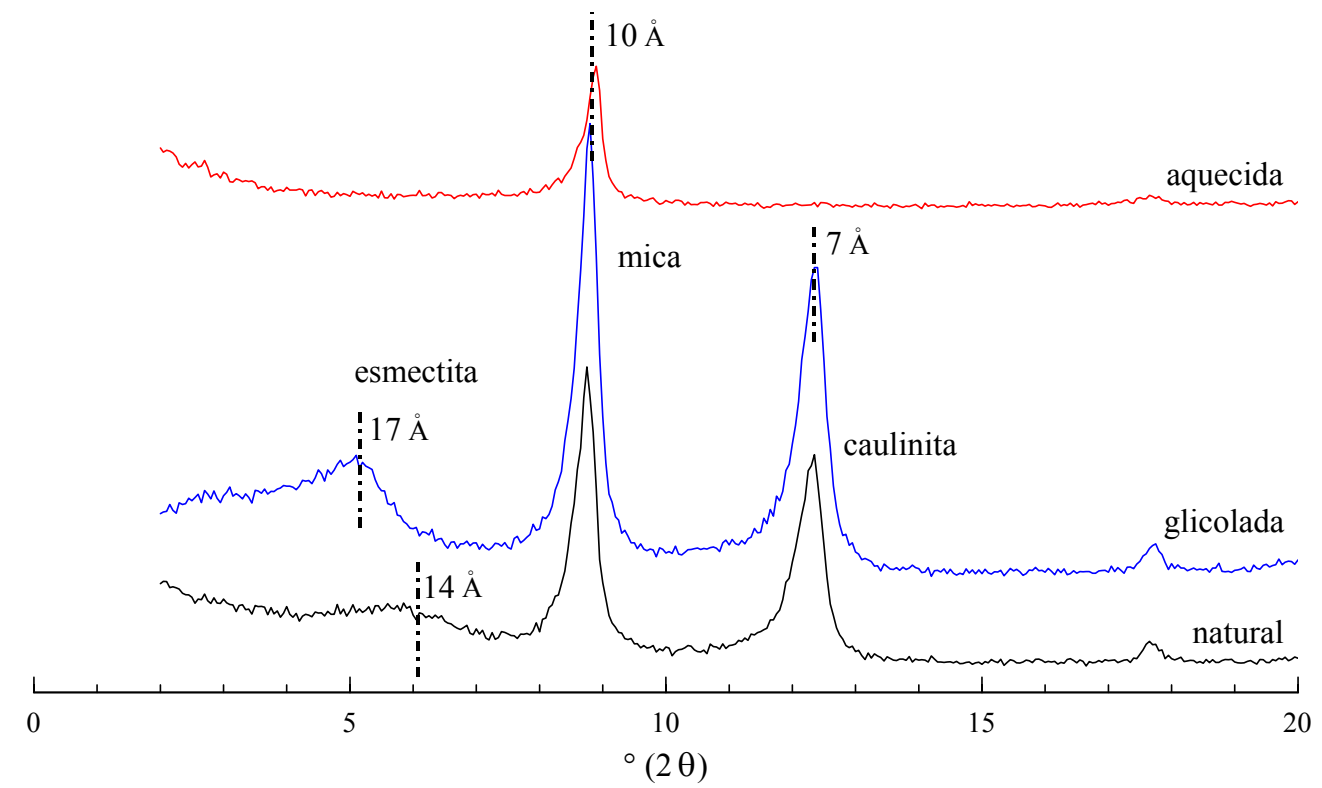

Figura 3.4 - Difratograma da fração argila do solo residual: comparação após glicolagem e aquecimento

A fração argila do solo em estudo apresentou os seguintes grupos de argilo-minerais: Caulinita (o pico permaneceu no ângulo correspondente à distância basal de $7 \AA$ após a glicolagem e desapareceu após o aquecimento); Mica (o pico permaneceu no ângulo referente à distância basal de $10 \AA$ ); ; e Esmectita (após a glicolagem o pico se deslocou para a esquerda, do ângulo referente à distância basal de 14 para $17 \AA ̊$, e após o aquecimento se deslocou para a direita até o ângulo referente a $10 \AA \AA$ ).

Este efeito de aumento da distância basal, encontrado após a glicolagem no grupo Esmectita, reflete o comportamento mecânico expansivo apresentado pelos argilo-minerais deste grupo.

Pode-se notar que o pico referente ao grupo Esmectita não é acentuado como os demais, denotando uma quantidade reduzida em relação aos outros dois grupos. O grupo Mica se apresenta em quantidade maior que a do grupo Caulinita.

Foram então analisados o resultado da fração argila, apresentado na Figura 3.5, e o da fração silte, apresentado na Figura 3.6, reafirmando a presença dos grupos de argilo-minerais Caulinita, Mica e Esmectita. 


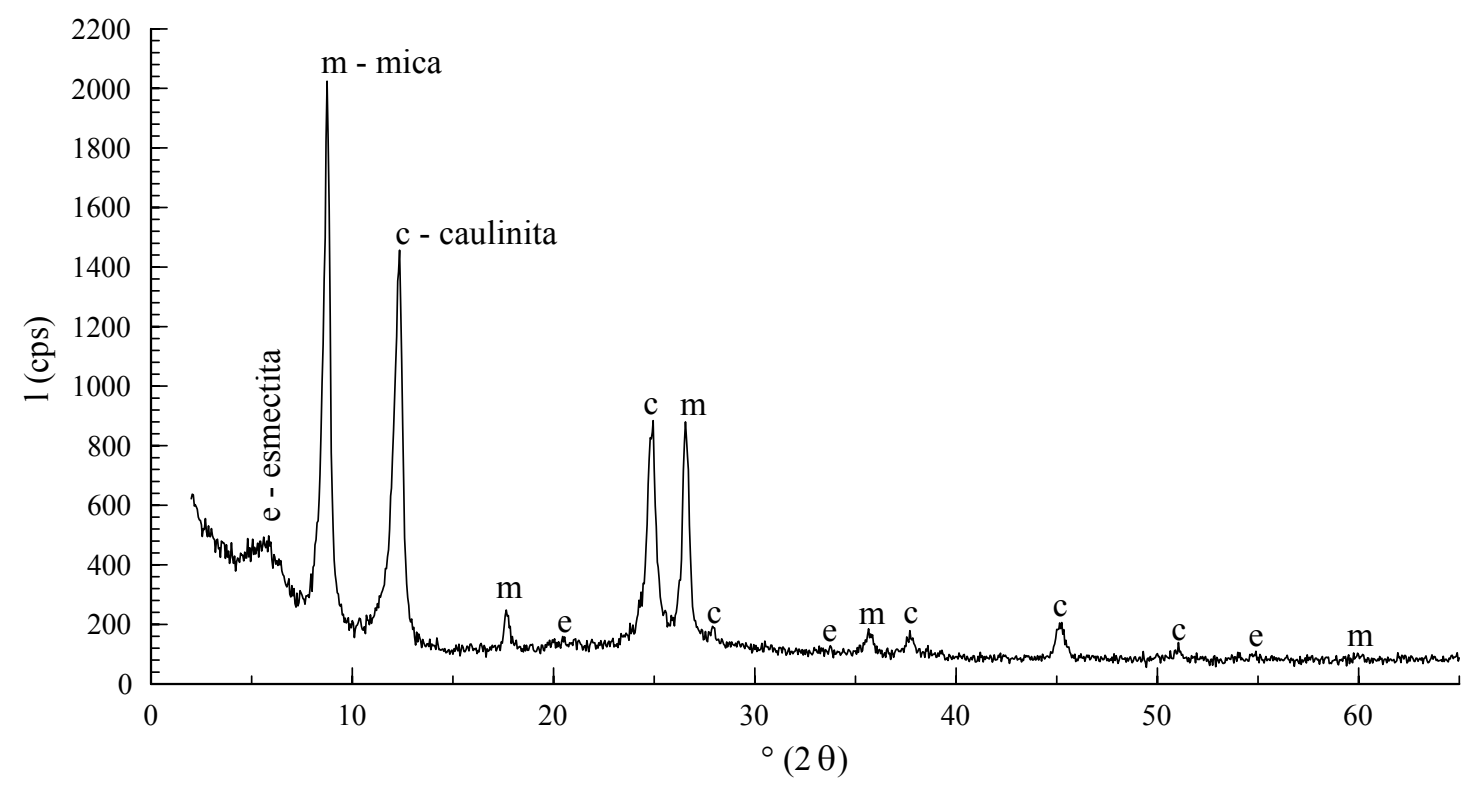

Figura 3.5 - Difratograma da fração argila do solo residual

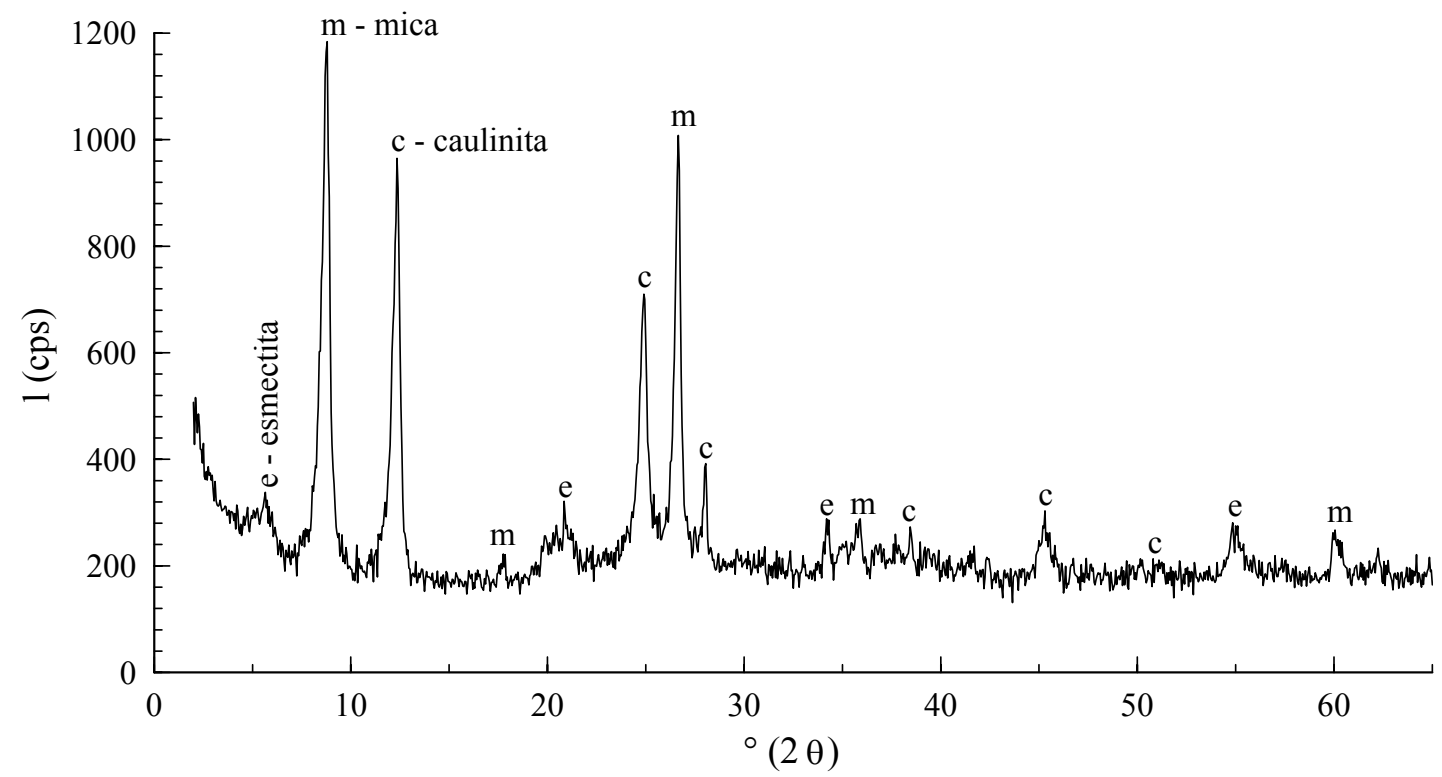

Figura 3.6 - Difratograma da fração silte do solo residual

Comparando-se os dois resultados, da fração silte e da fração argila, pode-se afirmar que possuem os mesmos argilo-minerais, sendo diferentes apenas os tamanhos de suas partículas. A diferença de intensidade dos picos, entre os dois resultados, é devida ao grau de cristalização e à quantidade dos argilo-minerais. Como os picos se localizam na mesma posição no eixo, continuam com as mesmas distâncias basais. 
A análise realizada na fração total do solo residual, apresentada na Figura 3.7, indica a presença dos minerais Quartzo e Feldspato, além dos grupos de argilo-minerais Caulinita e Mica.

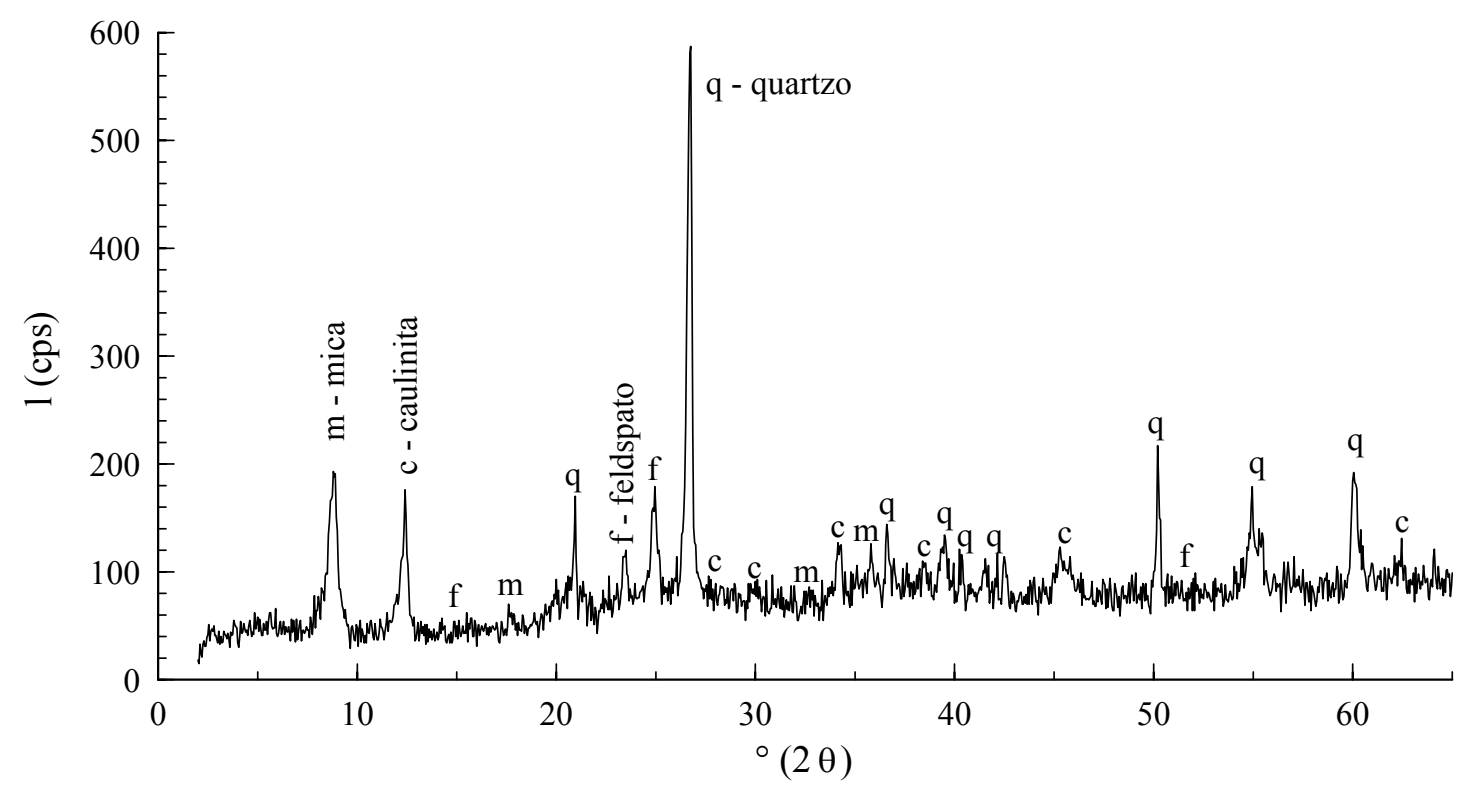

Figura 3.7 - Difratograma do solo residual

Como pode ser visto, o pico de intensidade referente ao mineral Quartzo, localizado aproximadamente no ângulo $27^{\circ}(2 \theta)$, é muito mais acentuado em relação aos demais, dificultando a identificação dos argilo-minerais.

Qualitativamente, pode-se dizer que o Quartzo é o mineral predominante e que há uma quantidade reduzida dos grupos de argilo-minerais Caulinita e Mica. O grupo Esmectita não foi identificado no difratograma.

\subsubsection{Material de Preenchimento de cor Branca}

Os primeiros ensaios com o material de cor Branca foram realizados com a amostra de fração Argila, em seu estado natural, após a glicolagem e após o aquecimento, resultando na comparação apresentada na Figura 3.8. 


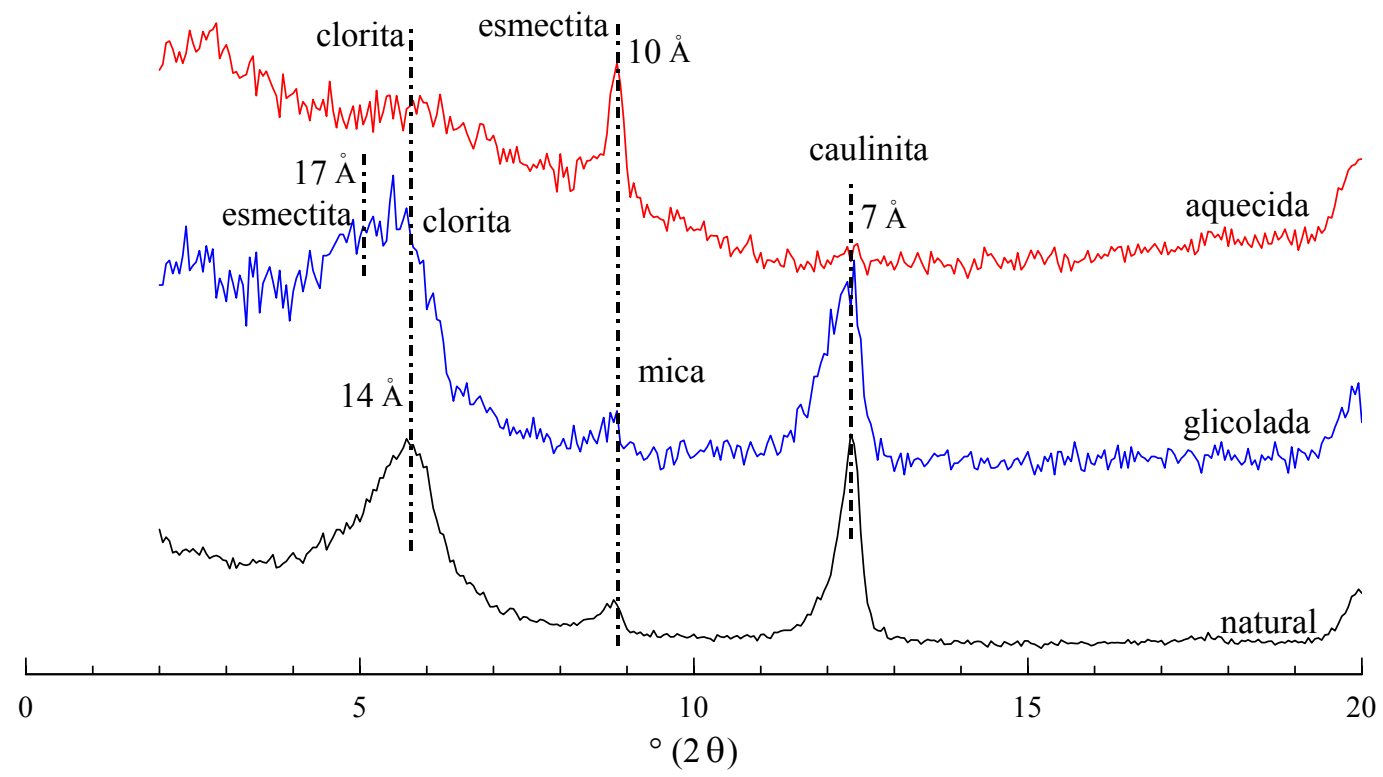

Figura 3.8 - Difratograma da fração argila do material de preenchimento de cor branca: comparação após glicolagem e aquecimento

A fração argila do material de preenchimento de cor branca apresentou os seguintes grupos de argilo-minerais: Caulinita (o pico permaneceu no ângulo correspondente à distância basal de $7 \AA$ após a glicolagem e desapareceu após o aquecimento); Mica (o pico permaneceu no ângulo referente à distância basal de $10 \AA \AA$ ); Esmectita (após a glicolagem o pico se deslocou para a esquerda, do ângulo referente à distância basal de 14 para $17 \AA$, e após o aquecimento se deslocou para a direita até o ângulo referente a $10 \AA$ ); e Clorita (o pico permaneceu no ângulo referente à distância basal de $14 \AA$ ).

Qualitativamente, pode-se afirmar que os grupos de argilo-minerais Caulinita e Esmectita são predominantes, enquanto que os grupos Mica e Clorita possuem quantidade reduzida.

A análise realizada na fração total do material de preenchimento de cor branca, apresentada na Figura 3.9, indica a presença do mineral Feldspato, além de reafirmar a presença dos grupos de argilo-minerais Caulinita, Mica, Esmectita e Clorita.

Qualitativamente, nota-se uma predominância do grupo de argilo-minerais Esmectita, uma quantidade intermediária do mineral Feldspato e do grupo Caulinita, e uma quantidade reduzida dos grupos Mica e Clorita. 


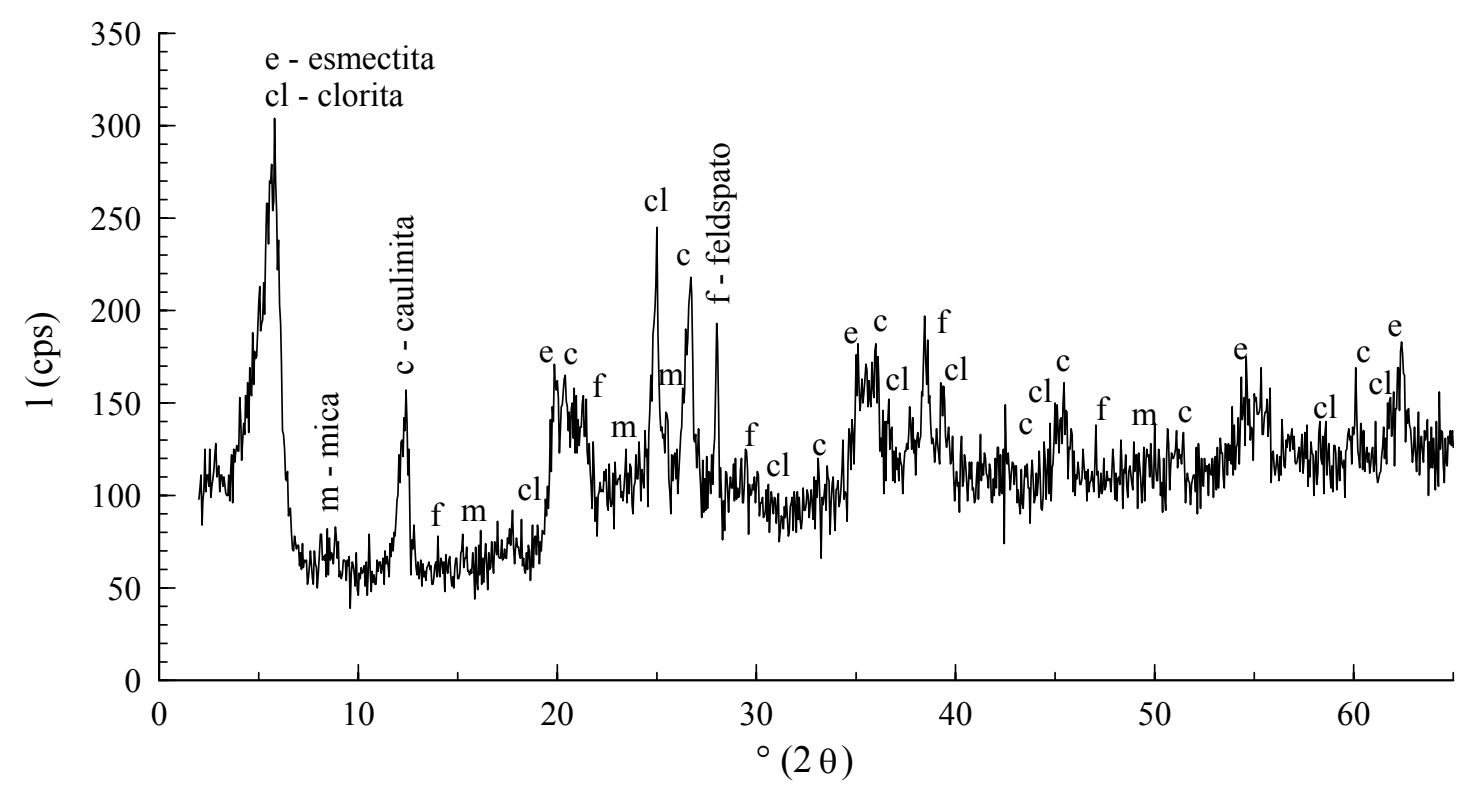

Figura 3.9 - Difratograma do material de preenchimento de cor branca

\subsubsection{Material de Preenchimento de cor Laranja}

Os primeiros ensaios com o material de cor Laranja foram realizados com a amostra de fração Argila, em seu estado natural, após a glicolagem e após o aquecimento, resultando na comparação apresentada na Figura 3.10.

A fração argila do material de preenchimento de cor laranja apresentou os seguintes grupos de argilo-minerais: Caulinita (o pico permaneceu no ângulo correspondente à distância basal de $7 \AA$ após a glicolagem e desapareceu após o aquecimento); Mica (o pico permaneceu no ângulo referente à distância basal de $10 \AA$ ); e Esmectita (após a glicolagem o pico se deslocou para a esquerda, do ângulo referente à distância basal de 14 para $17 \AA$, e após o aquecimento se deslocou para a direita até o ângulo referente a $10 \AA$ ). 


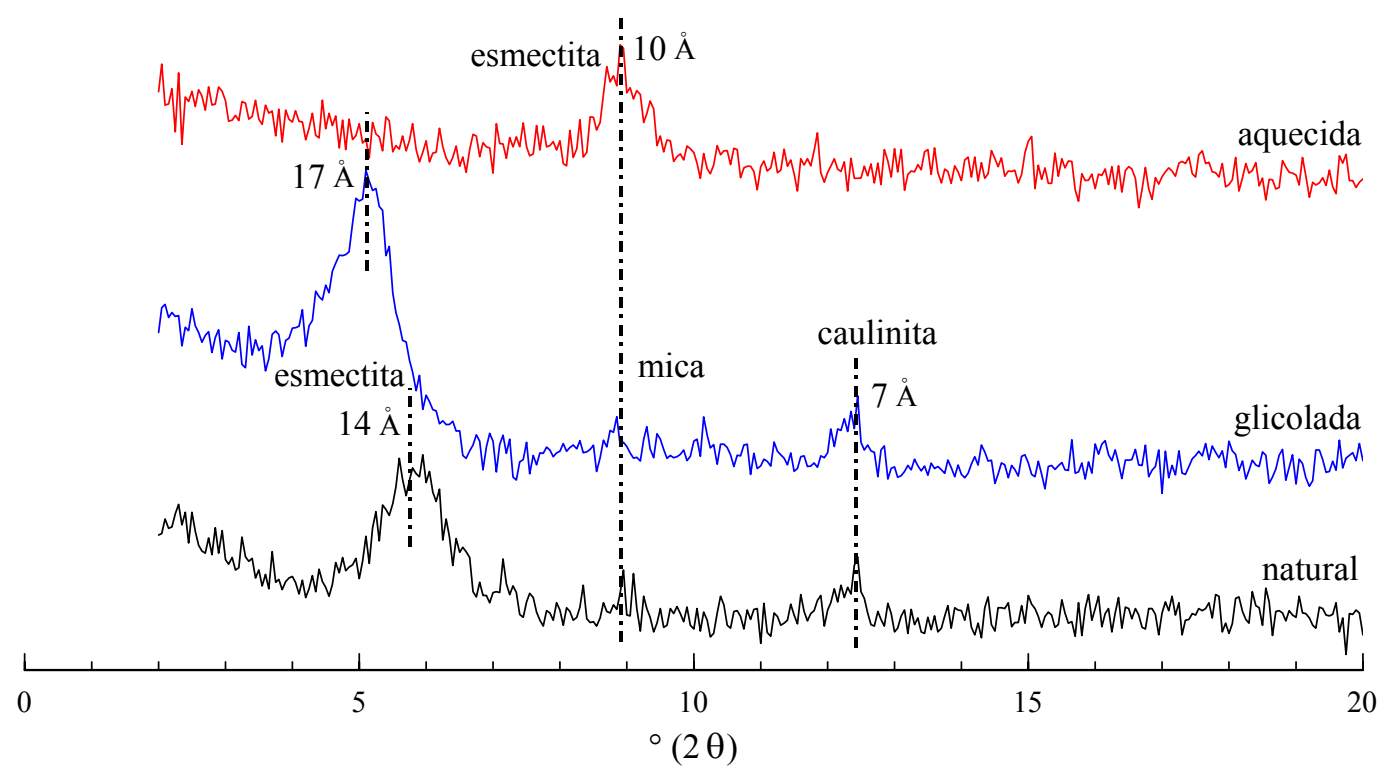

Figura 3.10 - Difratograma da fração argila do material de preenchimento de cor laranja:

comparação após glicolagem e aquecimento

Qualitativamente, pode-se notar que o grupo Esmectita é predominante e que os demais possuem quantidade reduzida.

A análise realizada na fração total do material de preenchimento de cor laranja, apresentada na Figura 3.11, indica a presença do mineral Feldspato e dos óxidos de ferro Goethita e Hematita, além de reafirmar a presença dos grupos de argilo-minerais Caulinita, Mica e Esmectita. A cor laranja deste material é devida à presença dos óxidos de ferro.

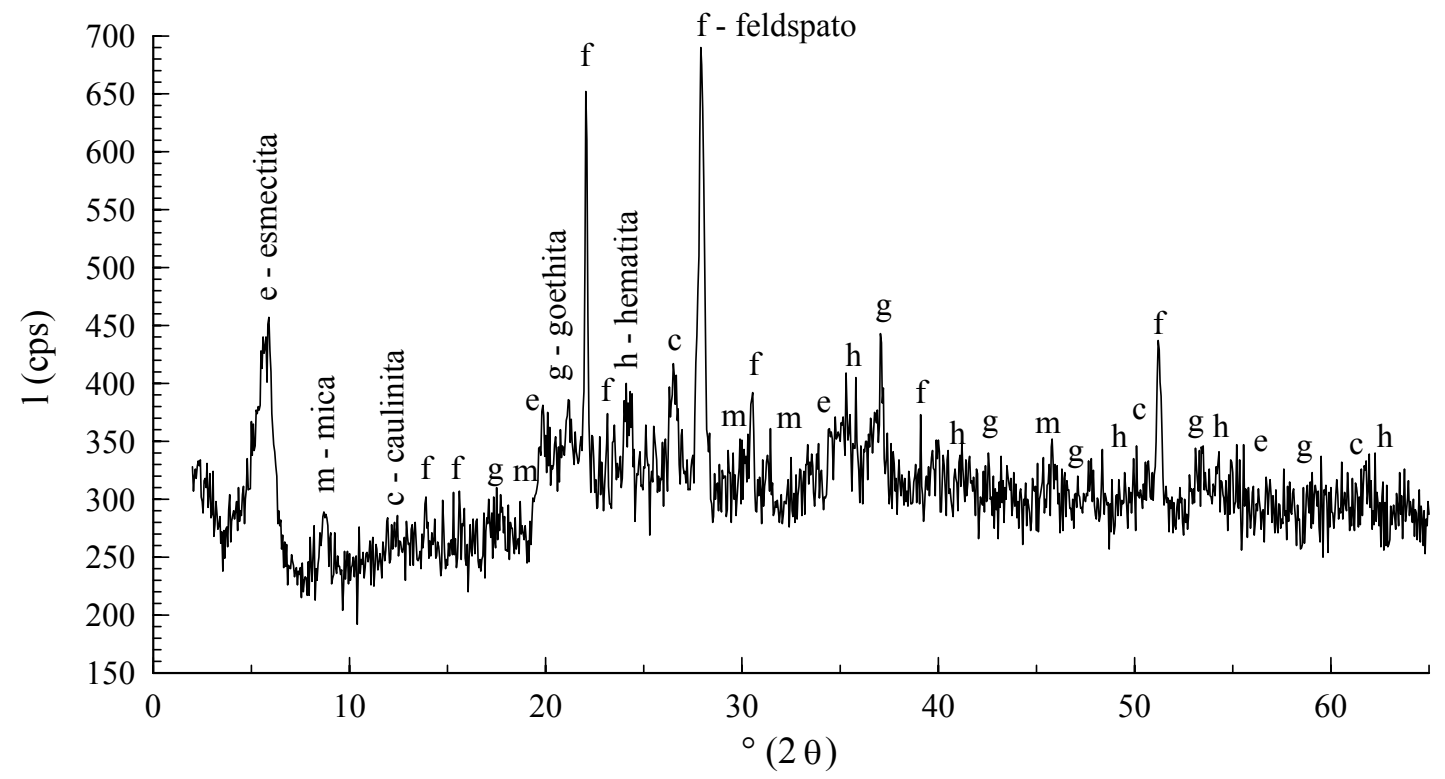

Figura 3.11 - Difratograma do material de preenchimento de cor laranja 
Qualitativamente, pode-se dizer que há uma quantidade predominante do mineral Feldspato e uma quantidade reduzida dos grupos de argilo-minerais Caulinita e Mica. A quantidade do grupo Esmectita é elevada, assim como a dos óxidos de ferro Goethita e Hematita.

A seguir é apresentada a Tabela 3.4, com um resumo dos minerais presentes no solo residual e nos materiais de preenchimento. A quantificação efetuada é estritamente qualitativa, ou seja, a quantidade dos símbolos não representa uma porcentagem.

Tabela 3.4 - Resumo dos minerais presentes

\begin{tabular}{|c|c|c|c|c|c|c|}
\hline \multicolumn{7}{|c|}{ Solo Residual - cor Cinza } \\
\hline fração & \multicolumn{2}{|c|}{ minerais } & \multicolumn{2}{|c|}{$\begin{array}{l}\text { grupos de } \\
\text { argilo-minerais }\end{array}$} & \multicolumn{2}{|l|}{ óxidos } \\
\hline Argila & & & $\begin{array}{l}\text { Caulinita } \\
\text { Mica } \\
\text { Esmectita }\end{array}$ & $\begin{array}{c}\bullet \bullet \bullet \\
\bullet \bullet \bullet \\
\bullet\end{array}$ & & \\
\hline Silte & & & $\begin{array}{l}\text { Caulinita } \\
\text { Mica } \\
\text { Esmectita }\end{array}$ & $\begin{array}{c}\bullet \bullet \\
\bullet \bullet \bullet \\
\bullet\end{array}$ & & \\
\hline Total & $\begin{array}{l}\text { Quartzo } \\
\text { Feldspato }\end{array}$ & $\bullet \bullet \bullet$ & $\begin{array}{l}\text { Caulinita } \\
\text { Mica } \\
\text { Esmectita }\end{array}$ & $\begin{array}{l} \\
\bullet \\
-\end{array}$ & & \\
\hline \multicolumn{7}{|c|}{ Material de preenchimento - cor Branca } \\
\hline fração & \multicolumn{2}{|c|}{ minerais } & \multicolumn{2}{|c|}{$\begin{array}{c}\text { grupos de } \\
\text { argilo-minerais }\end{array}$} & \multicolumn{2}{|l|}{ óxidos } \\
\hline Argila & & & $\begin{array}{l}\text { Caulinita } \\
\text { Mica } \\
\text { Esmectita } \\
\text { Clorita }\end{array}$ & $\begin{array}{c}\bullet \bullet \bullet \bullet \\
\bullet \\
\bullet \bullet \bullet \\
\bullet\end{array}$ & & \\
\hline Total & Feldspato & $\bullet \bullet$ & $\begin{array}{l}\text { Caulinita } \\
\text { Mica } \\
\text { Esmectita } \\
\text { Clorita }\end{array}$ & $\begin{array}{c}\bullet \bullet \\
\bullet \\
\bullet \bullet \bullet \\
\bullet \\
\end{array}$ & & \\
\hline \multicolumn{7}{|c|}{ Material de preenchimento - cor Laranja } \\
\hline fração & \multicolumn{2}{|c|}{ minerais } & \multicolumn{2}{|c|}{$\begin{array}{c}\text { grupos de } \\
\text { argilo-minerais }\end{array}$} & \multicolumn{2}{|l|}{ óxidos } \\
\hline Argila & & & $\begin{array}{l}\text { Caulinita } \\
\text { Mica } \\
\text { Esmectita }\end{array}$ & $\begin{array}{l}\bullet \\
\bullet \\
\bullet \bullet \bullet\end{array}$ & & \\
\hline Total & Feldspato & $\bullet \bullet \bullet$ & $\begin{array}{l}\text { Caulinita } \\
\text { Mica } \\
\text { Esmectita }\end{array}$ & $\begin{array}{l}\bullet \\
\bullet \\
\bullet \bullet\end{array}$ & $\begin{array}{l}\text { Goethita } \\
\text { Hematita }\end{array}$ & $\begin{array}{l}\bullet \bullet \\
\bullet \bullet\end{array}$ \\
\hline
\end{tabular}




\subsection{MiCROSCOPIA}

Para o estudo microscópico do solo, foram utilizadas três técnicas diferentes, sendo:

i) microscopia óptica de reflexão (MOR) - aumento de 0,63 até 5,6 vezes. Contou-se com a utilização de um microscópio do tipo lupa. As amostras utilizadas foram frações do solo separadas por peneiramento;

ii) microscopia óptica de transmissão (MOT) - aumento de 1,6 até 100 vezes. Foram utilizados feixes de luz através da amostra. Com a utilização de luz polarizada (polarizadores cruzados), é captada a cor de birrefringência, que não é a real cor do objeto. Se o objeto apresentar propriedades ópticas anisotrópicas, a birrefringência é capaz de detectá-las. Com os polarizadores paralelos, a cor visualizada é a real cor do objeto. Quando não indicado, as imagens apresentadas foram obtidas com os polarizadores cruzados. Foram confeccionadas duas lâminas delgadas de uma amostra indeformada, uma no plano vertical de campo e outra no plano horizontal; e

iii) microscopia eletrônica de varredura (MEV) - aumento de 10 até 20.000 vezes.Este microscópio utiliza feixes de elétrons que incidem sobre a amostra, dentro de uma câmara de vácuo. Foram utilizadas amostras cúbicas com aproximadamente $5 \mathrm{~mm}$ de aresta, tomando-se cuidado para a superfície não ser amolgada. Como as amostras de solo não são boas condutoras, elas foram recobertas por uma micropelícula de pó de ouro.

As fotos apresentadas em seqüência foram identificadas pelo seu processo de obtenção (MOR - grãos separados por peneiramento; MOT - lâminas delgadas; MEV - superfície não amolgada). Analisou-se a microscopia do solo residual, de cor cinza, e também a dos materiais de preenchimento de cores branca e laranja.

\subsubsection{Solo Residual}

Na Figura 3.12 pode ser visualizado um fragmento do solo residual, cuja face não havia sido talhada nem amolgada. Pode-se notar uma forte estruturação remanescente no solo, a qual deve ser proveniente de uma foliação metamórfica, com planos de alinhamento dos minerais bem definidos. A foliação metamórfica é resultante de esforços compressionais que originam planos paralelos, com orientação preferencial de componentes originais da rocha. Também é visível a presença de pontos brancos espalhados e de micas, as quais são os pontos menores e brilhantes. 


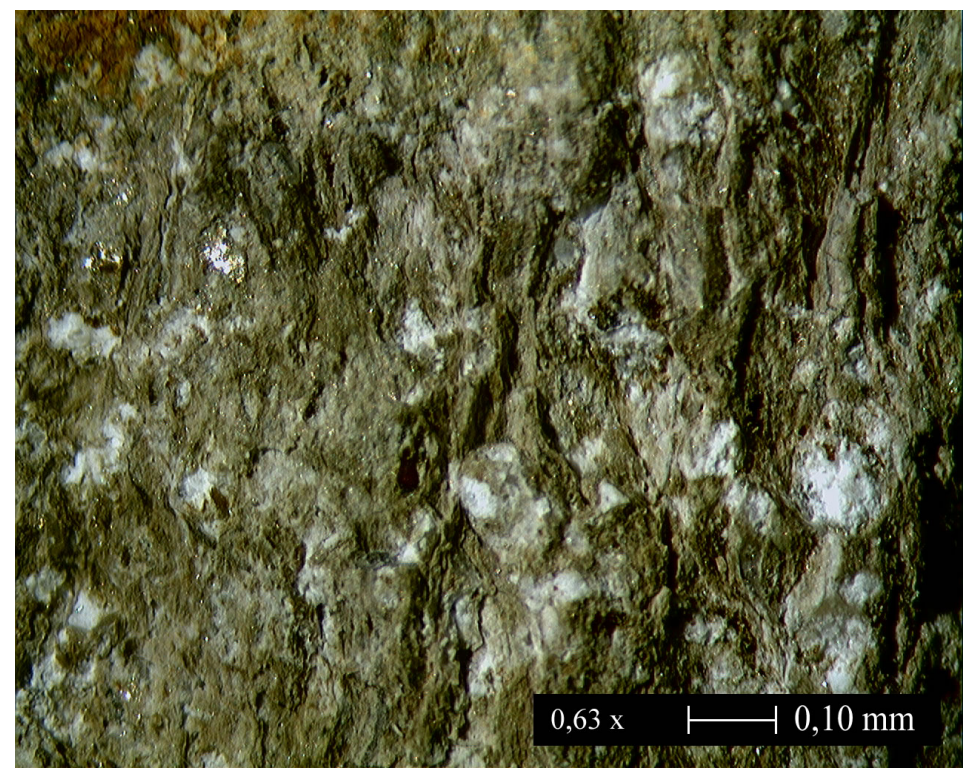

Figura 3.12 - Foliação metamórfica remanescente no solo residual (MOR)

A Figura 3.13 apresenta um agregado de quartzo policristalino deformado e fissurado, evidenciando que é proveniente de uma rocha milonítica. Milonito é uma rocha formada em planos de cisalhamento ou de falha, fortemente triturada, em processo de metamorfismo dinâmico. Seus minerais podem apresentar-se orientados, definindo uma foliação milonítica.

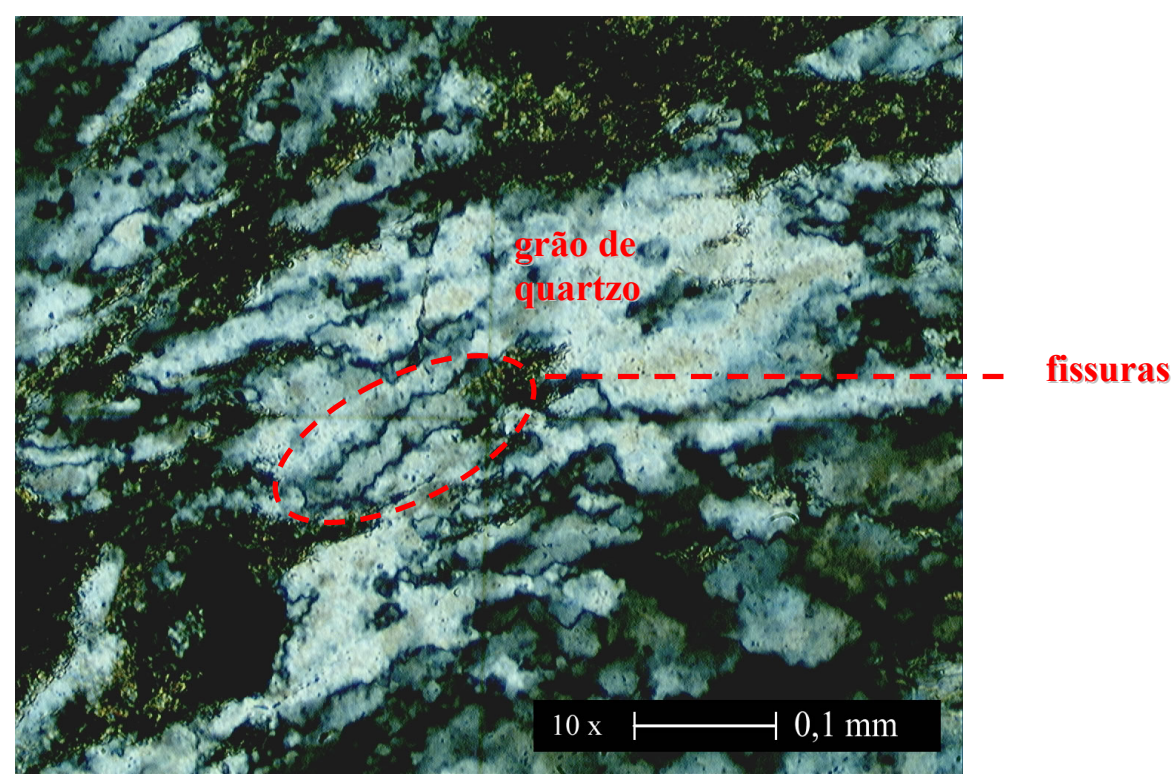

Figura 3.13 - Quartzo milonitizado (MOT) 
Na Figura 3.14 pode ser visto um porfiroclasto de feldspato, preservado da alteração, no centro à direita da foto. Uma rocha porfiroclástica é assim denominada por possuir uma textura em que um ou mais minerais se sobressaem em tamanho, por resistir mais ao processo de cataclase (quebramento e moagem). Este grão de feldspato encontra-se contornado por quartzos deformados microgranulares e por plaquetas de biotita, conferindo uma foliação milonítica. Esta configuração é denominada de augen-gnaisse (augen significa olho em alemão). Porém, não se pode afirmar que a rocha originária do solo residual se trata de um augen-gnaisse, pois esta não é a configuração predominante encontrada durante a campanha petrográfica efetuada.

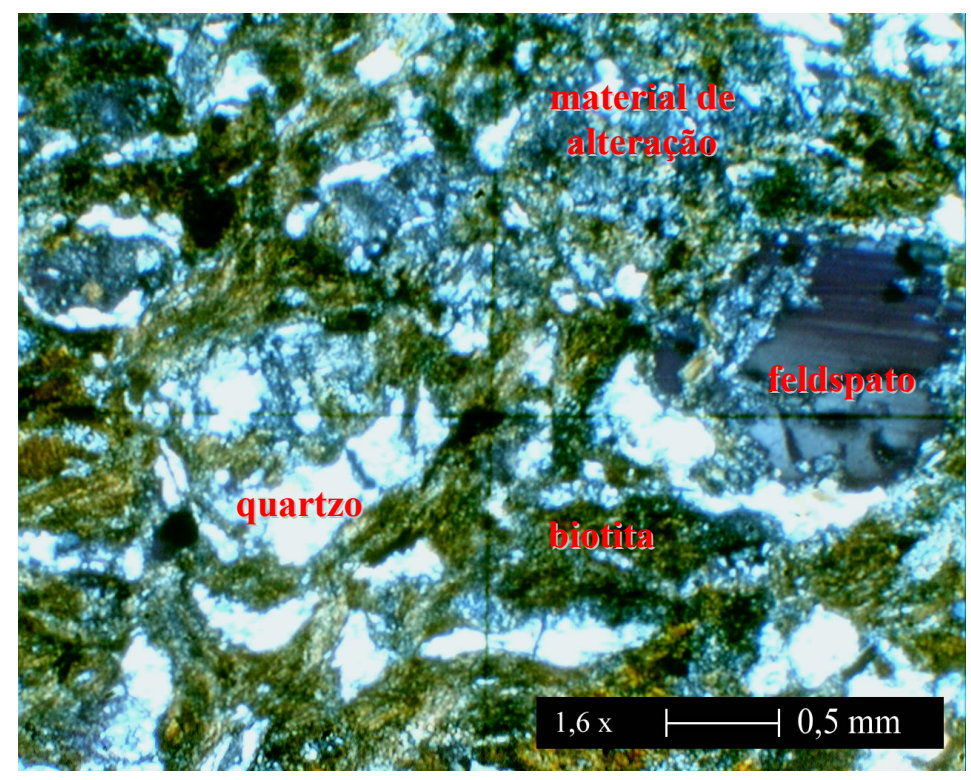

Figura 3.14 - Augen gnaisse (MOT)

Na Figura 3.15, pode-se observar grãos de plagioclásios fraturados (indicados por ' $\mathrm{P}$ '), com suas fraturas preenchidas por material de alteração (indicados por 'M'). Plagioclásio é um grupo de minerais feldspáticos, que variam desde o mais sódico (albita) até o mais cálcico (anortita). Sua alteração pode gerar caulinita, esmectita, montmorilonita e clorita. 


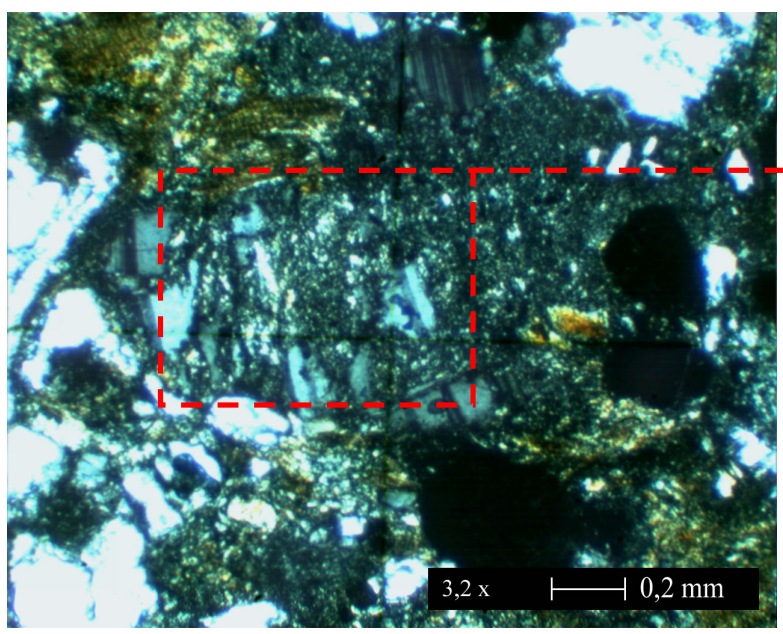

(a) aumento de 3,2 vezes

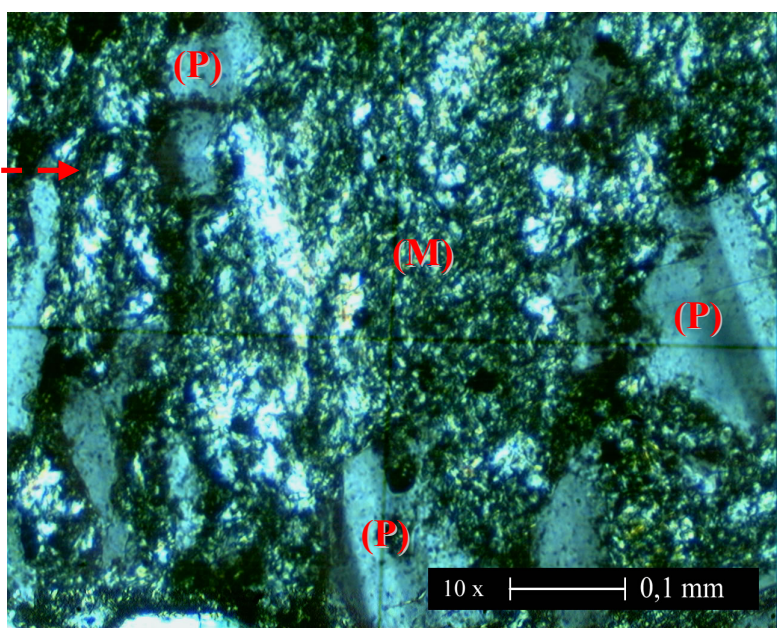

(b) aumento de 10 vezes

Figura 3.15 - Plagioclásio (MOT)

A Figura 3.16 apresenta a análise dos minerais presentes na fração areia do solo residual, separados por peneiramento. Como se pode ver na Figura 3.16 (a), encontram-se grãos de quartzo, feldspato, mica do tipo biotita, grãos de quartzo cobertos por uma película de óxido de ferro e fragmentos de rocha milonítica.

Os fragmentos de milonito são grãos remanescentes da rocha original, compostos pelos minerais quartzo, feldspato e biotita, também apresentando foliação metamórfica. Um grão de rocha milonítica pode ser visto na Figura 3.16 (b).

Dentre os grãos retidos na peneira $\mathrm{n}^{\circ} 16(1,2 \mathrm{~mm})$, que constituem a areia grossa e que podem ser vistos na Figura 3.16 (c), predominam os grãos de rocha milonítica, com poucos grãos de quartzo e raros feldspatos e micas isolados. Quanto aos grãos retidos na peneira $\mathrm{n}^{\mathrm{o}} 50$ $(0,30 \mathrm{~mm})$ - areia média, vistos na Figura 3.16 (d) - ainda ocorre bastante fragmentos de rocha, mas aumenta o número de quartzo isolado, aumenta a freqüência de plaquetas de biotita isoladas e o feldspato torna-se raro, já tendo sido alterado para fração argila.

No material retido na peneira $\mathrm{n}^{\mathrm{o}} 100(0,15 \mathrm{~mm})$, os grãos de quartzo e de fragmento de rocha milonítica se igualam em quantidade, enquanto são notados mais grãos de mica. Nos grãos retidos na peneira $\mathrm{n}^{\mathrm{o}} 200(0,075 \mathrm{~mm})$, vistos na Figura 3.16 (e), predominam grãos de quartzo e biotita, com raros fragmentos isolados de rocha milonítica. Dentre os grãos retidos na peneira $\mathrm{n}^{\mathrm{o}} 270(0,06 \mathrm{~mm})$, vistos na Figura 3.16 (f), os grãos de quartzo e de mica se igualam em quantidade e os grãos de rocha milonítica tornam-se inexistentes. Estas três frações correspondem à areia fina. 
Devido à foliação metamórfica e à presença dos grãos de rocha milonítica, pode-se reafirmar a classificação de saprolítico para o solo.

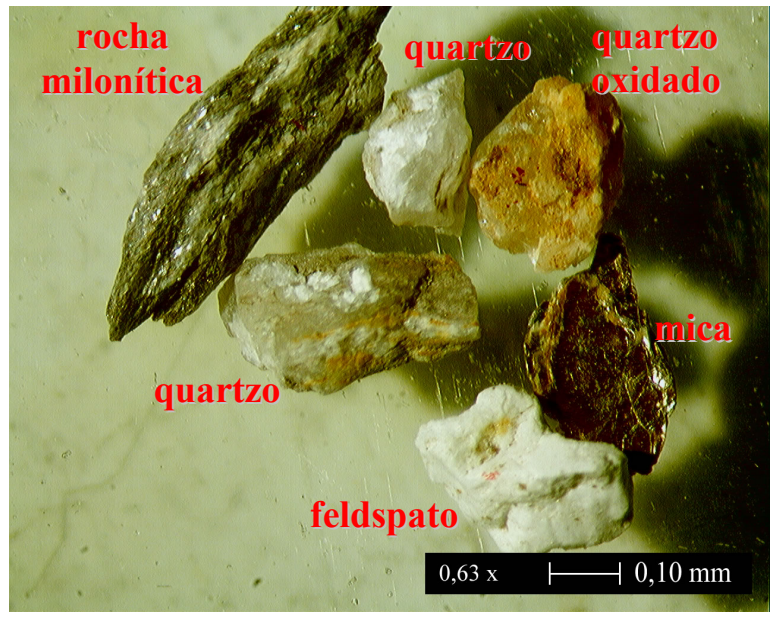

(a) minerais presentes

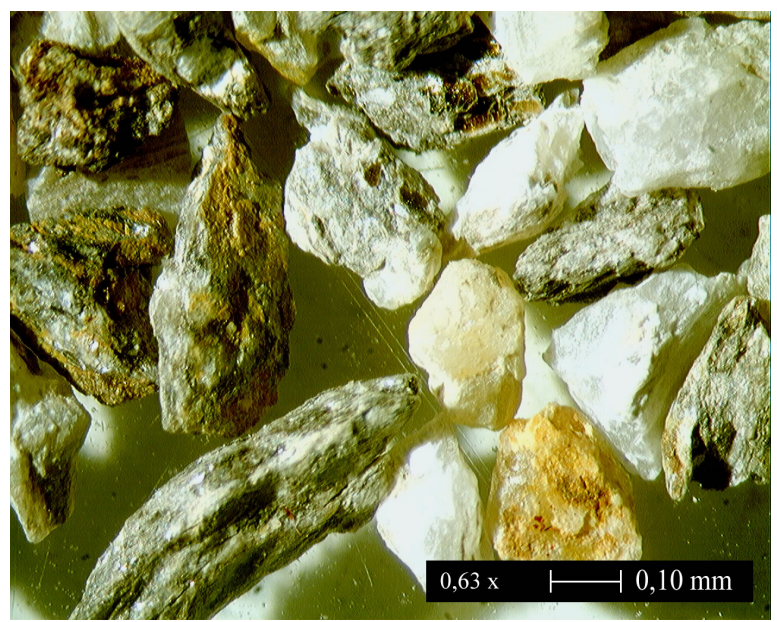

(c) grãos retidos na peneira $n^{\circ} 16$

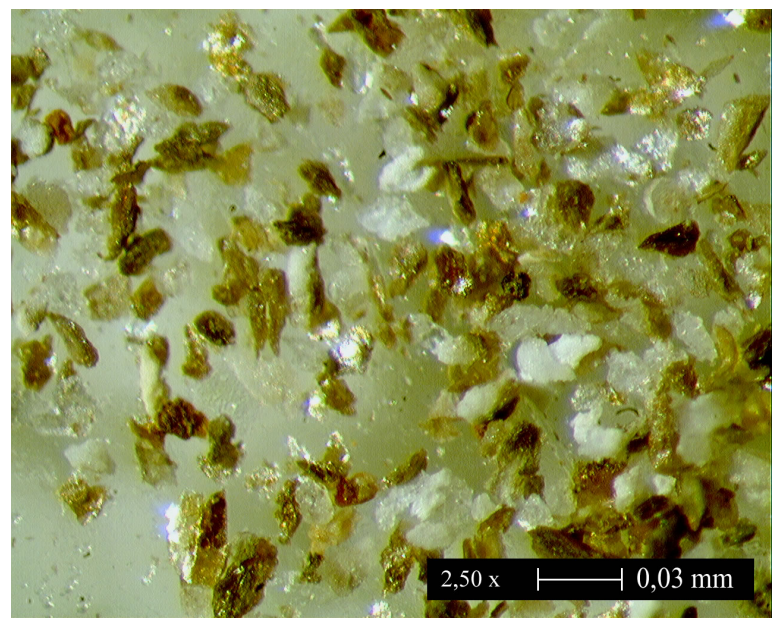

(e) grãos retidos na peneira $n^{\circ} 200$

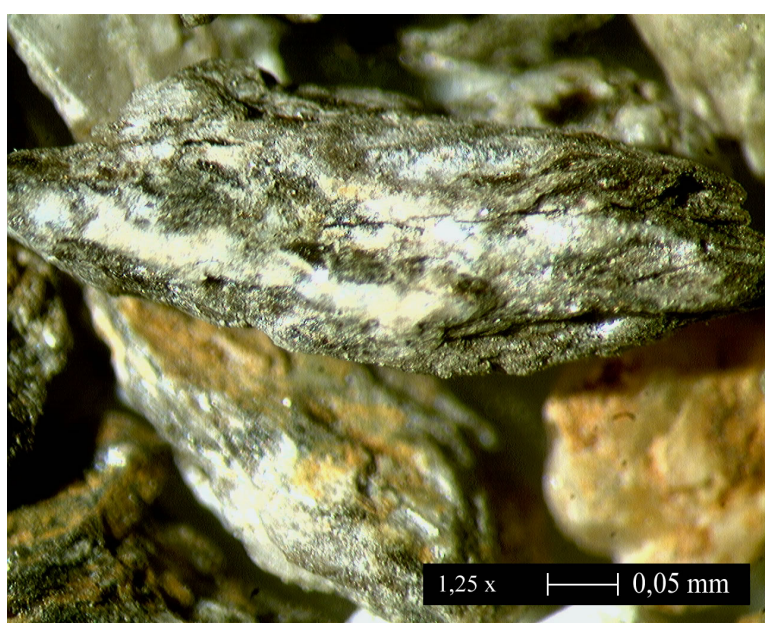

(b) grão de rocha milonítica

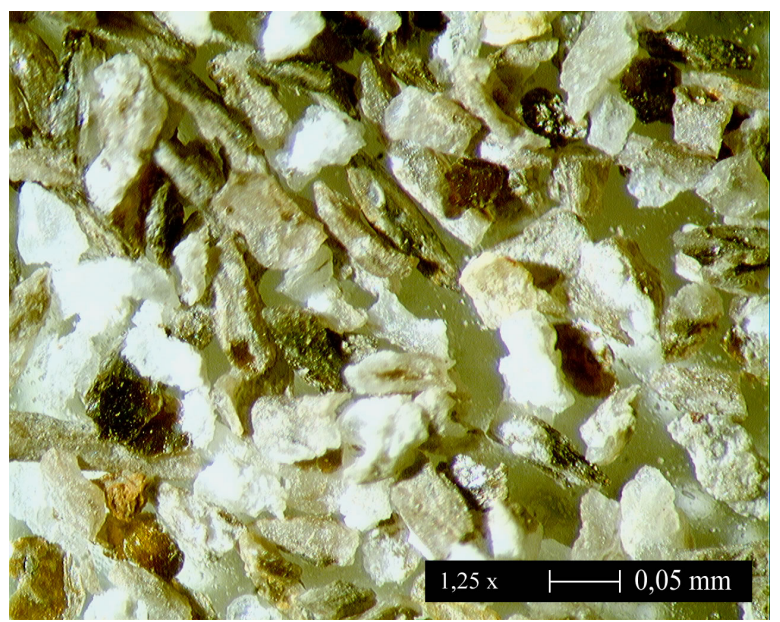

(d) grãos retidos na peneira $n^{\circ} 50$

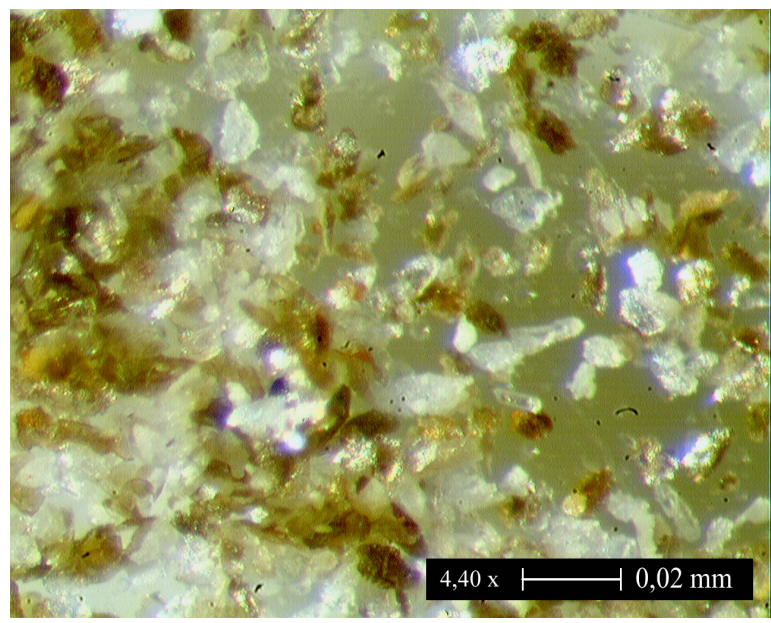

(f) grãos retidos na peneira $n^{\circ} 270$

Figura 3.16 - Minerais presentes na fração areia do solo residual (MOR) 
Pode-se observar a tendência de que quanto mais se diminui o diâmetro dos grãos, mais se encontram minerais isolados de quartzo e mica, e menos fragmentos de rocha milonítica. Grãos de feldspato são encontrados apenas na fração de areia grossa, tendo-se em vista que é um mineral que se altera mais facilmente. $\mathrm{O}$ formato dos grãos, de um modo geral, é pouco esférico e muito anguloso.

A este ponto, pode-se afirmar que a rocha originária do solo saprolítico se trata de um biotita-gnaisse milonitizado.

Alguns dos macro-poros podem ser visualizados na Figura 3.17, onde se observa que alguns poros (indicados por ' $\mathrm{V}$ ') são da ordem de $1 \mathrm{~mm}$ e outros da ordem de $0,1 \mathrm{~mm}$.
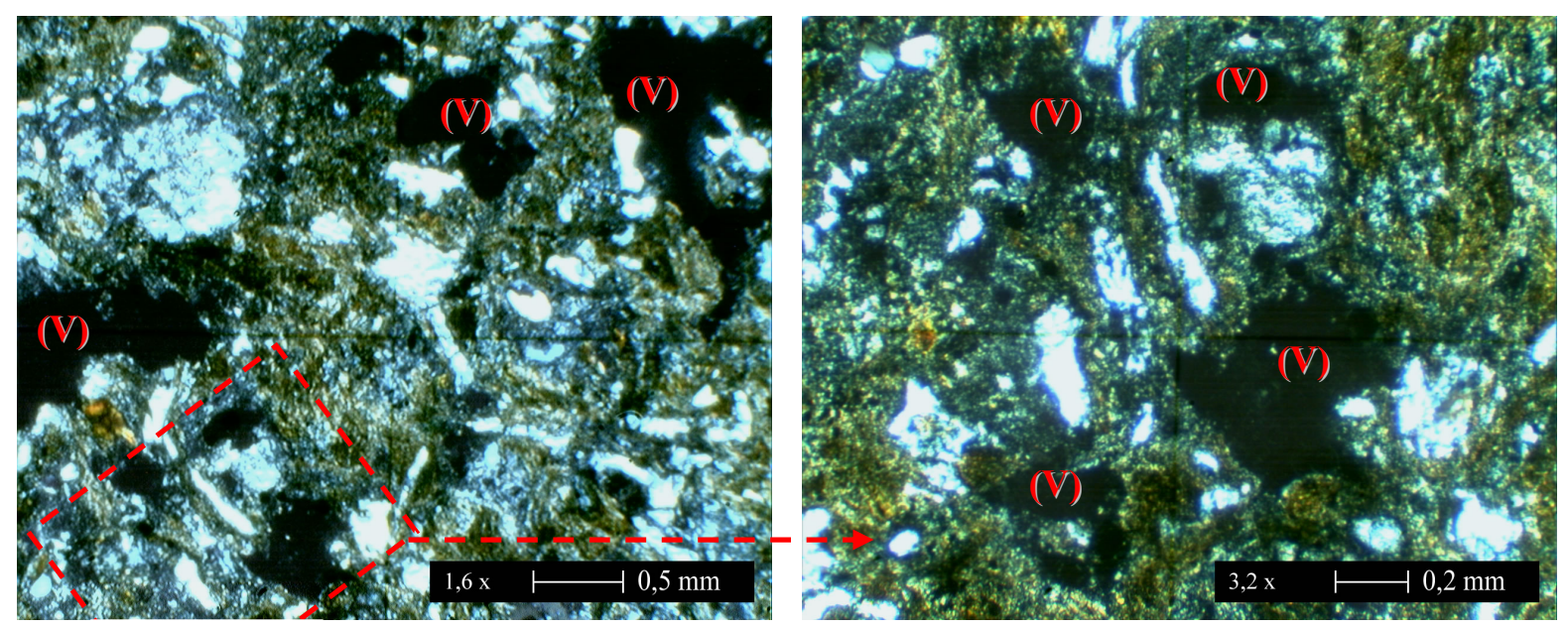

Figura 3.17 - Distribuição de macro-poros (MOT)

Alguns micro-poros e a estrutura dos argilo-minerais podem ser visualizadas na Figura 3.18 e na Figura 3.19, onde são apresentadas imagens de microscopia eletrônica de varredura. A partir dos macro e micro-poros presentes no solo e da estrutura dos argilo-minerais, pode-se evidenciar um baixo volume de vazios, o que justifica o reduzido valor de índice de vazios e a elevada densidade natural do solo, encontrados durante a etapa de caracterização (Tabela 3.3). Isto pode ser resultado de um baixo grau de alteração, característico de solo residual jovem. 

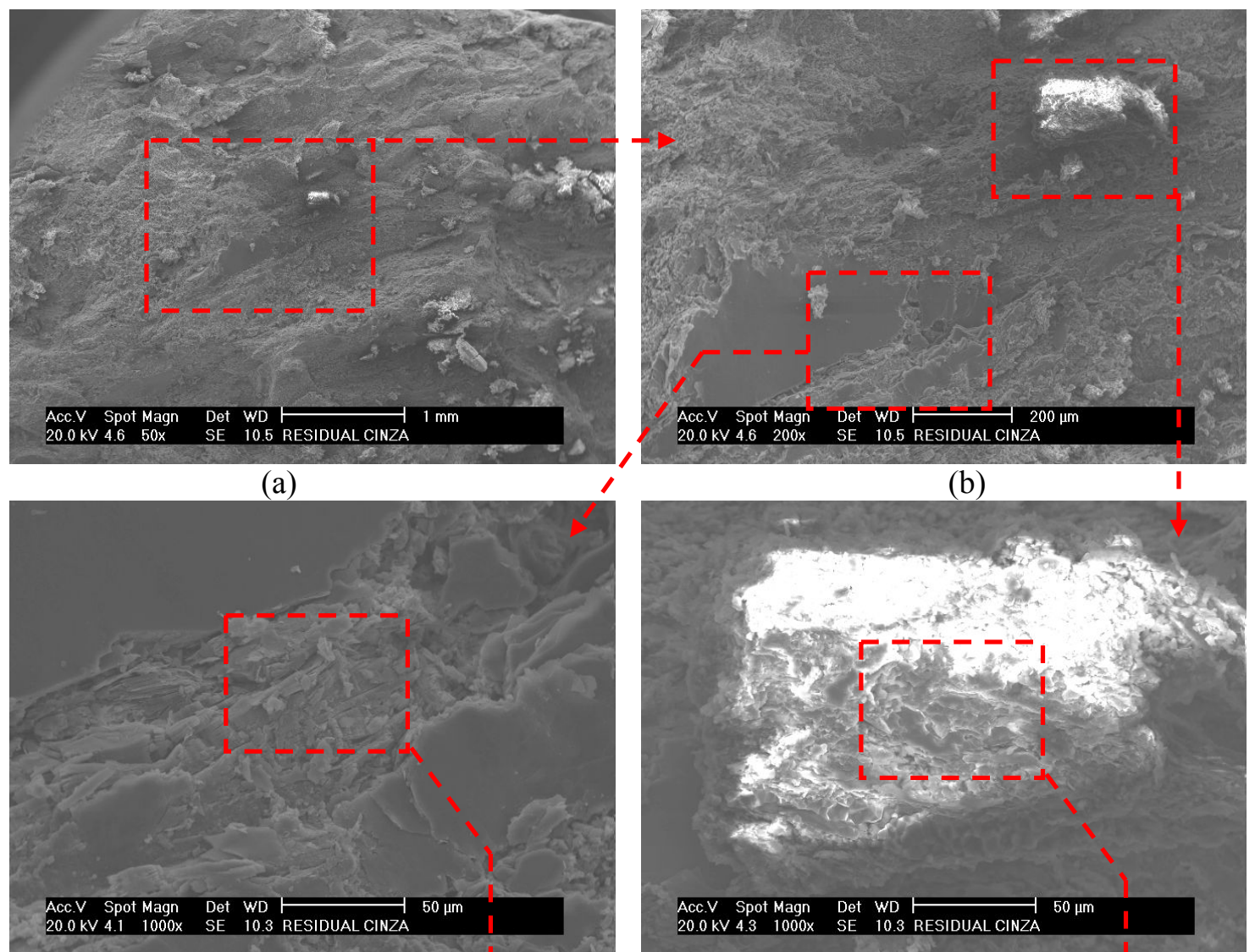

(c)

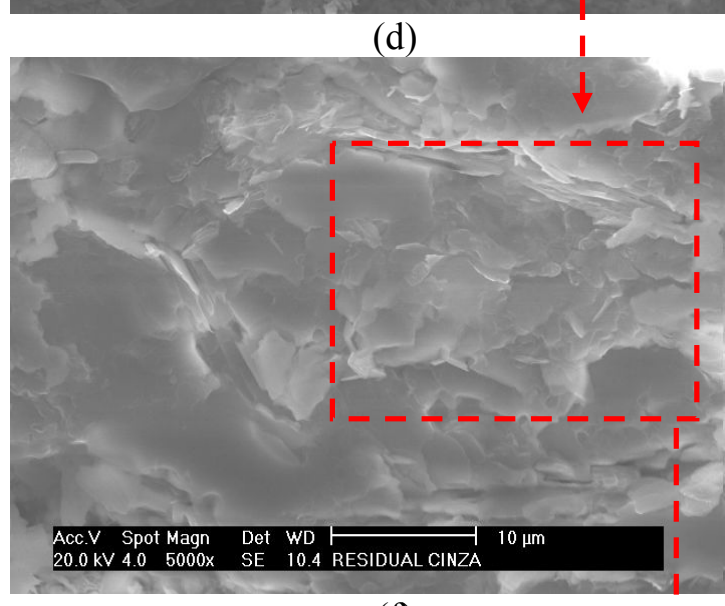

(e)

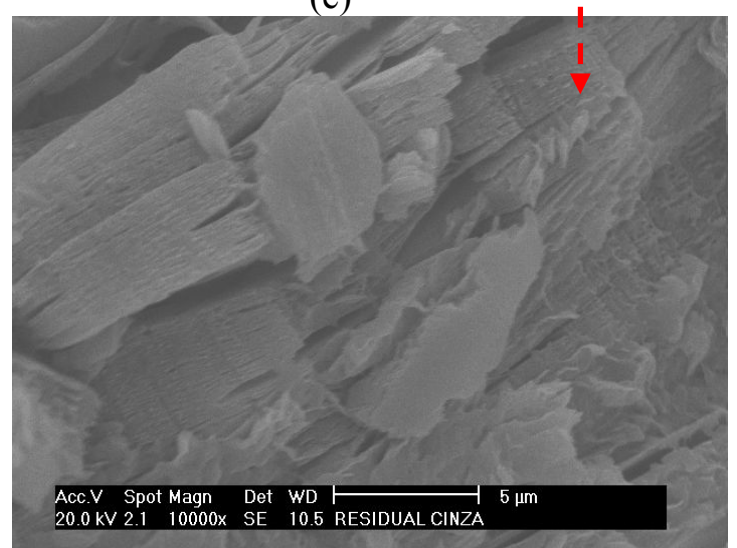

(g) (f)

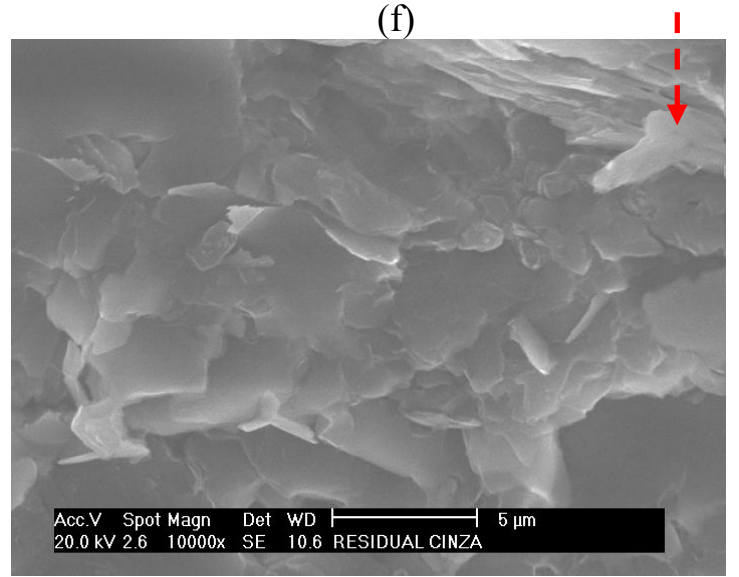

(h)

Figura 3.18 - MEV do solo residual 


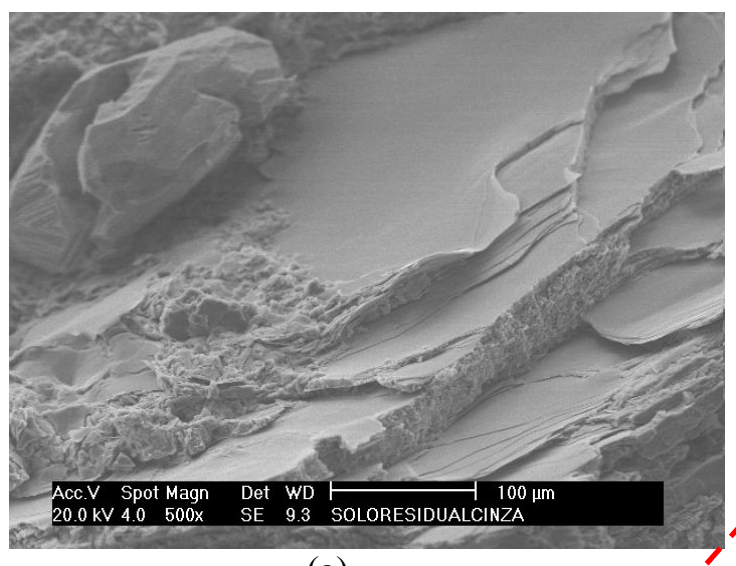

(a)

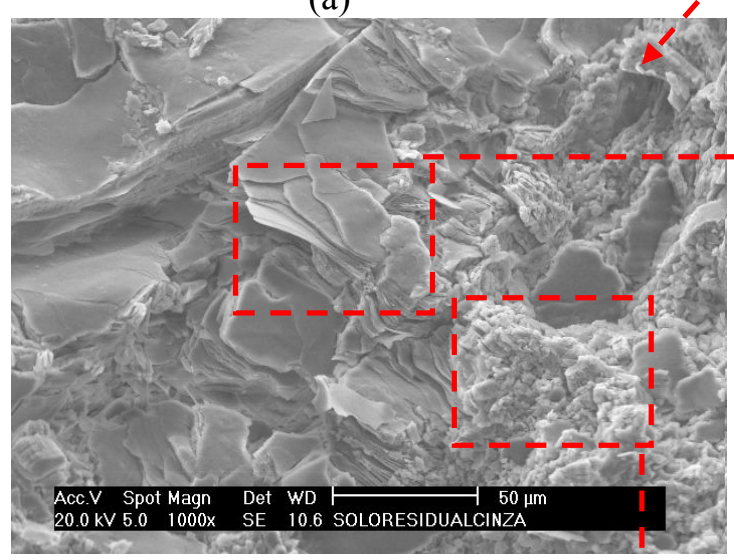

(c)

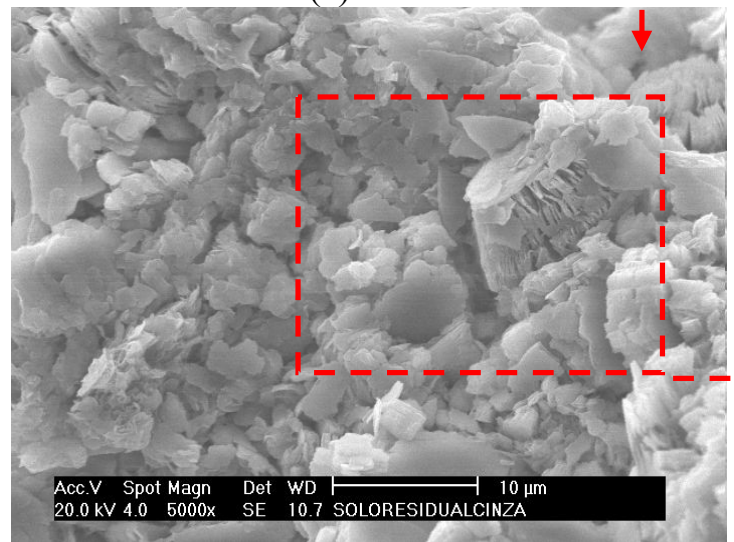

(e)

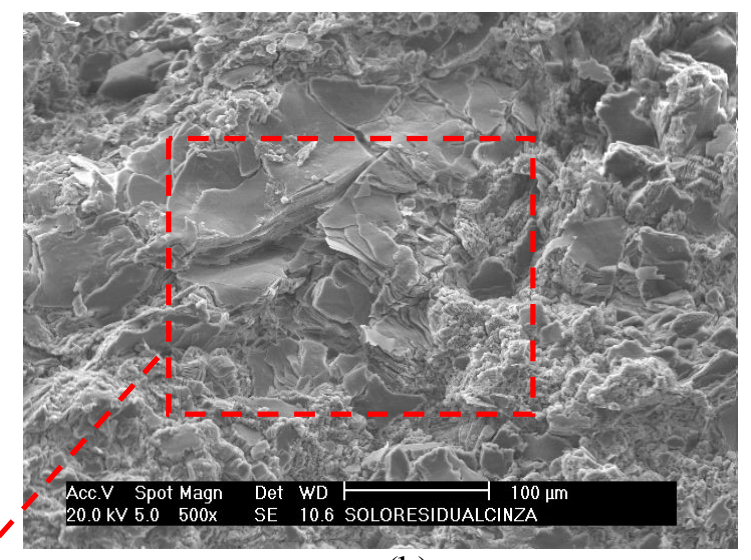

(b)

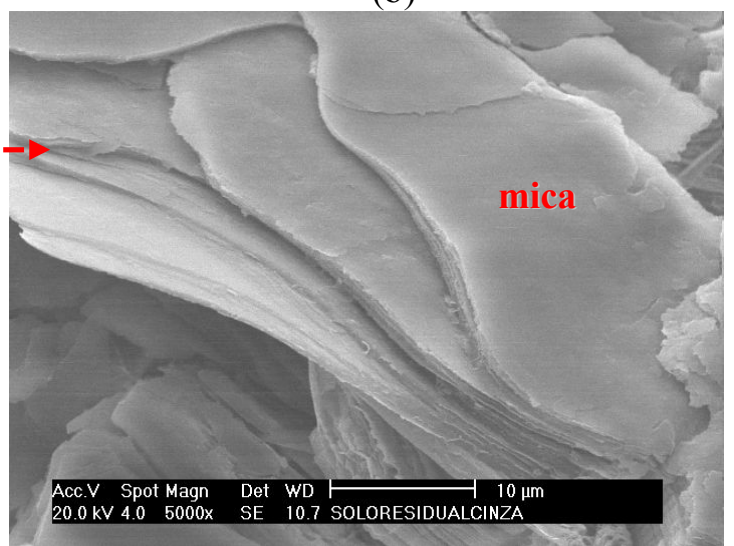

(d)

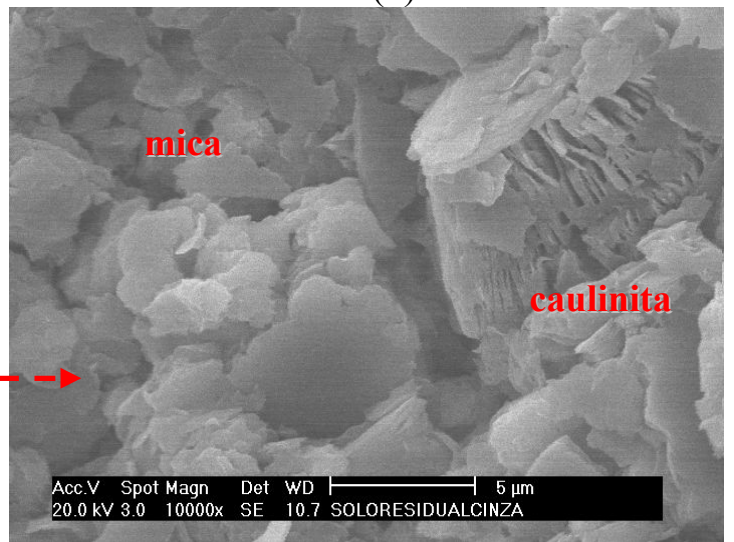

(f)

Figura 3.19 - MEV do solo residual 
Por meio de comparações entre fotografias de MEV de argilo-minerais apresentadas por Mitchell (1993) e Santos (1975), e das fotografias de MEV do solo em estudo, alguns argilo-minerais detectados pelas difrações de raios-x puderam ser identificados.

Na Figura 3.18 (d), é possível visualizar um dos pontos brilhantes que podem ser notados a olha nu, citados anteriormente. Nota-se que ele é composto por inúmeras placas micáceas, resultado da alteração de um bloco maior de um mineral de mica.

Na Figura 3.19 (d), podem ser visualizadas placas de mica no tamanho de silte. Na Figura 3.18 (g), pode-se observar o processo de alteração de uma placa de mica, iniciando-se sua folheação e originando argilo-minerais placóides.

Como pode ser visto na Figura 3.18 (c) e na Figura 3.19 (c), as placas de mica no tamanho de silte encontram-se envoltas por uma massa argilosa, a qual pode ser vista na Figura 3.19 (e) como sendo principalmente composta pelo argilo-mineral biotita (mica).

$\mathrm{O}$ argilo-mineral caulinita pode ser identificado à direita da Figura 3.19 (f), apresentado em pilhas e notadamente existente em uma quantidade menor do que a de mica. Não foi possível a identificação do argilo-mineral do grupo esmectita, o qual possui quantidade muito reduzida no solo em estudo (quantidade reduzida na fração argila, que representa $10 \%$ do solo).

Quanto à microestrutura do solo em estudo, pode-se notar pelas figuras anteriores que as partículas da fração fina não são orientadas, como esperado de um solo residual. As únicas orientações que podem ser notadas encontram-se na macroestrutura, nas já citadas foliações metamórficas. O material existente na fração fina é composto por partículas micáceas, conectadas por aglomerações argilosas, sem maiores indícios de cimentação. Não é nítida a presença de partículas estruturadas por cimentação, o que novamente acentua a observação do solo em estudo não ser evoluído pedologicamente.

A Figura 3.20 apresenta uma comparação de ensaios MEV entre as frações Argila e Silte do solo residual, separadas de acordo com o procedimento encontrado no Apêndice A. Para a realização dos ensaios, o pó resultante da separação de cada fração foi polvilhado sobre uma fita colante.

Além de validar o procedimento utilizado para a separação das frações, a Figura 3.20 mostra como a fração argila é composta por partículas placóides e a fração silte tem predominância de placas de mica, com presença de aglomerações argilosas. 


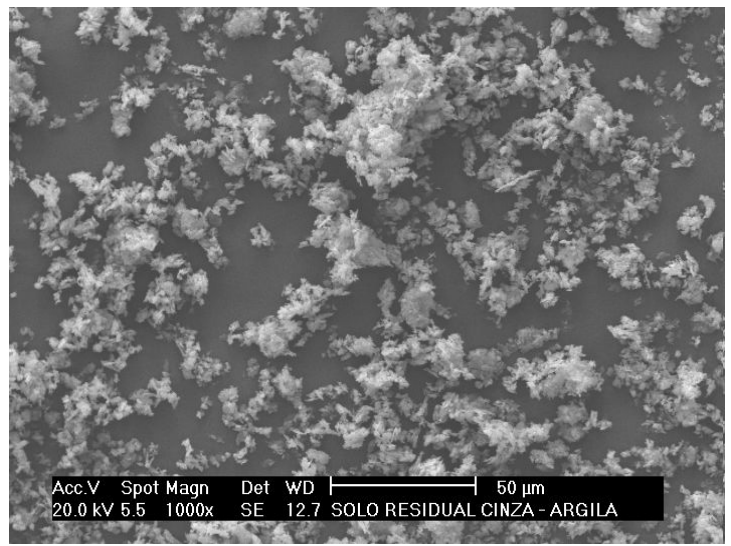

(a) argila - aumento de $1.000 \mathrm{x}$

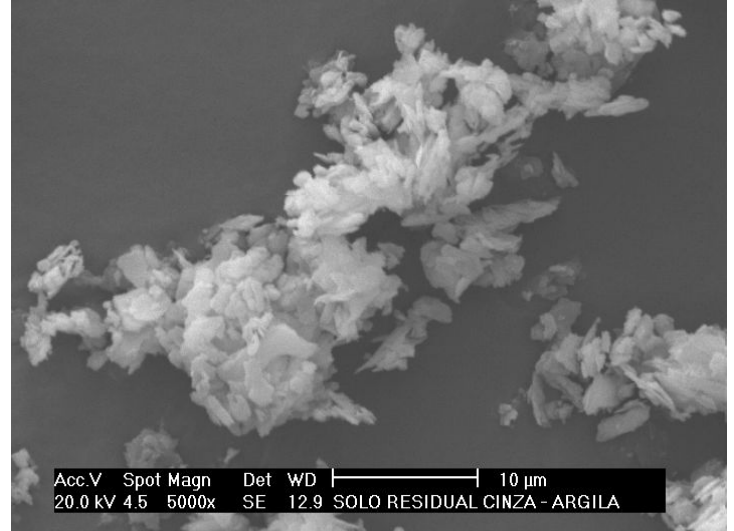

(b) argila - aumento de $5.000 \mathrm{x}$

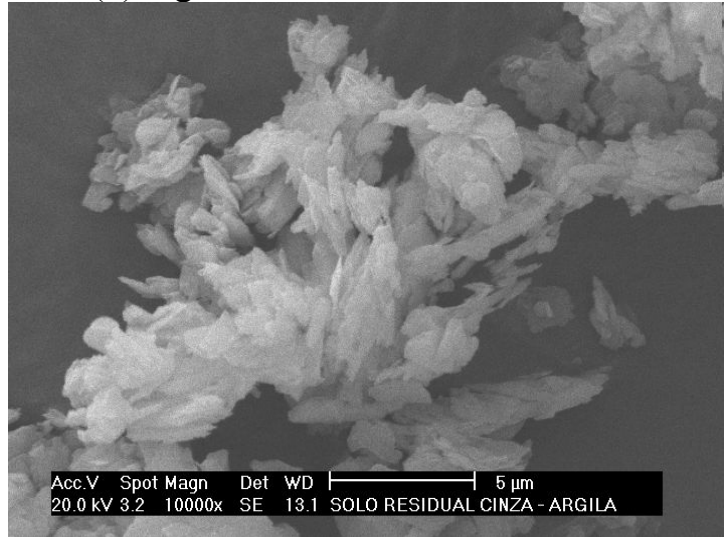

(c) argila - aumento de $10.000 \mathrm{x}$

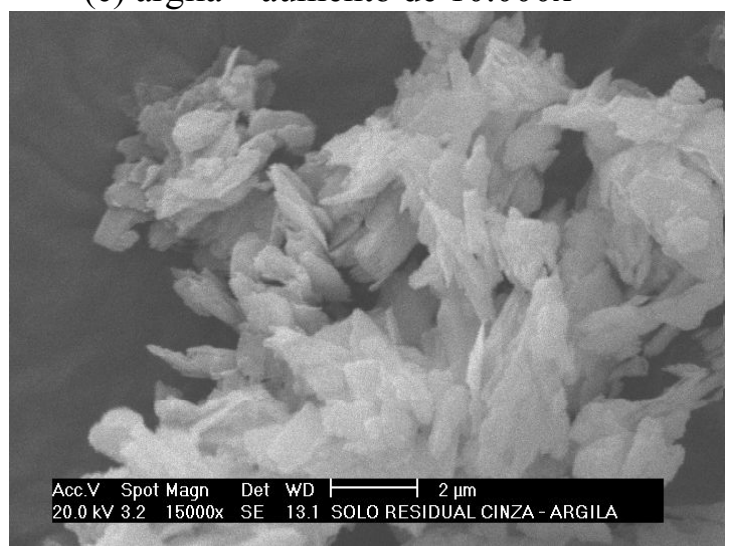

(d) argila - aumento de $15.000 \mathrm{x}$

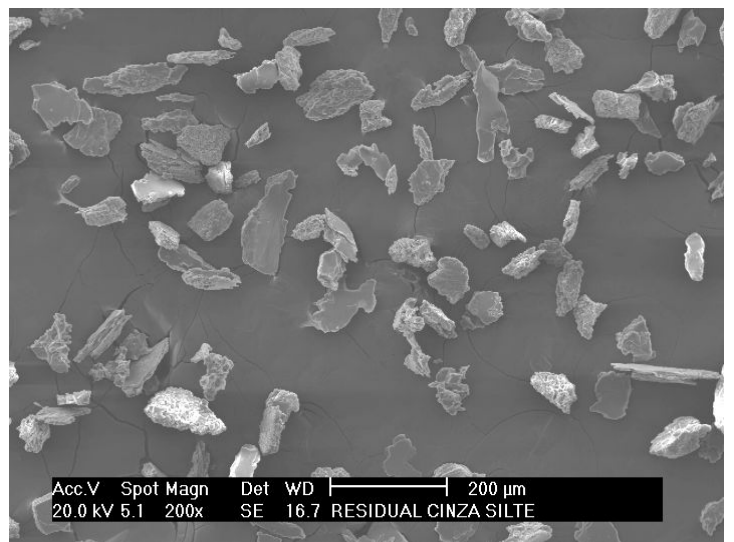

(e) silte - aumento de $200 \mathrm{x}$

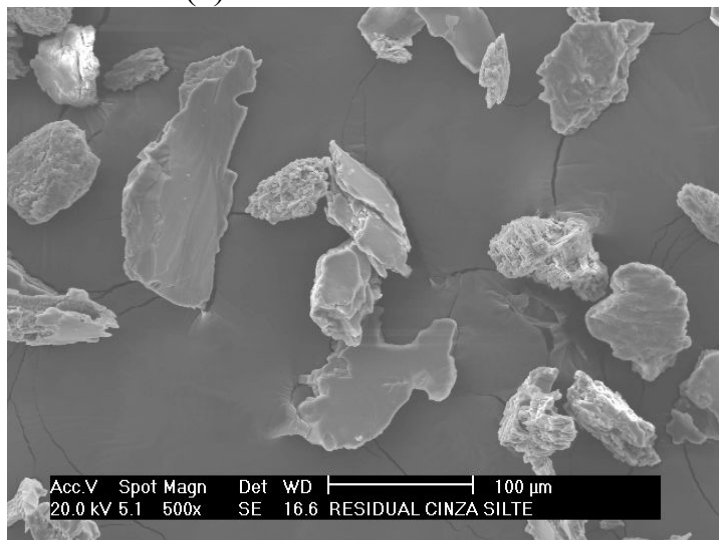

(f) silte - aumento de $500 \mathrm{x}$

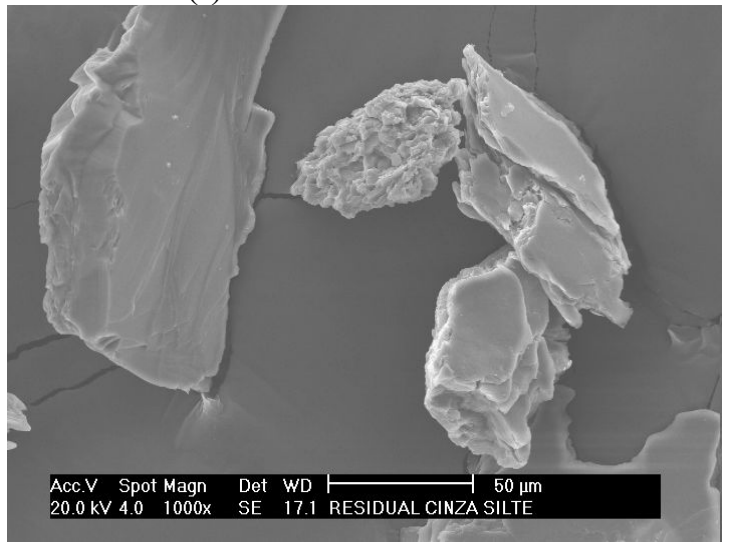

(g) silte - aumento de $1.000 \mathrm{x}$

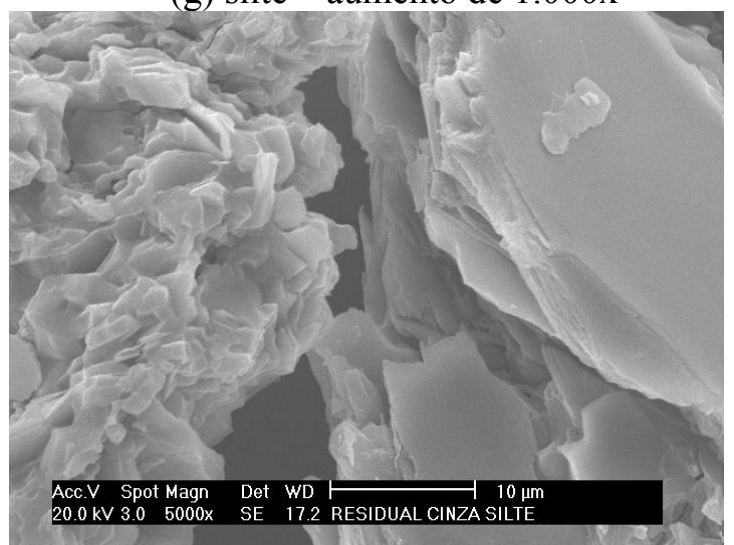

(h) silte - aumento de $5.000 \mathrm{x}$

Figura 3.20 - MEV, comparação entre frações Argila e Silte 


\subsubsection{Material de Preenchimento de cor Branca}

A análise microscópica do material de preenchimento de cor Branca, apresentada na Figura 3.21, mostra grãos de feldspato envoltos por uma massa de alteração composta por argilo-minerais incolores e opacos. Pelos resultados da mineralogia, tratam-se dos argilo-minerais esmectita (predominante), caulinita (quantidade intermediária) e mica e clorita (quantidade reduzida). Na Figura 3.21 (a), pode-se perceber as fraturas dos grãos de feldspato. A Figura 3.21 (b), com os polarizadores paralelos, apresenta a cor real da amostra.

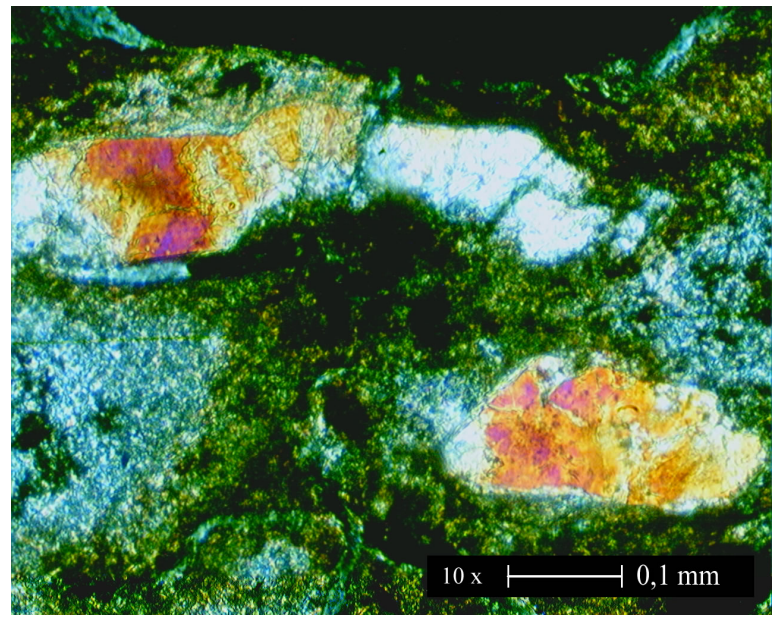

(a) polarizadores cruzados

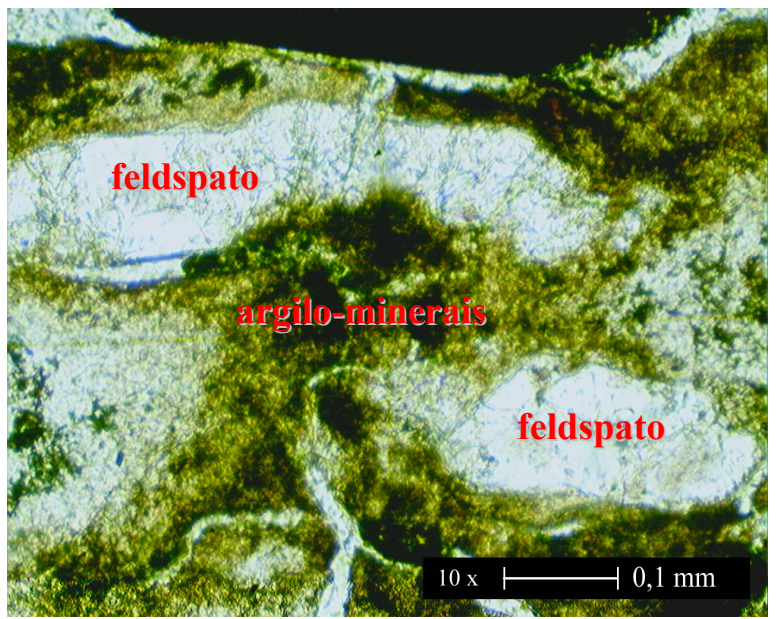

(b) polarizadores paralelos

Figura 3.21 - Material de preenchimento de cor Branca (MOT)

Pela Figura 3.22, pode-se visualizar a microestrutura do material de preenchimento de cor Branca. Na Figura 3.22 (a) e (b), percebe-se uma estrutura coesa, com uma superfície aparentemente lisa e um volume de vazios menor do que o encontrado no solo residual cinza. Na Figura 3.22 (c) e (d), nota-se uma fissura ocasionada pela secagem do material, o que confirma a presença de argilo-minerais expansivos. Pela Figura 3.22 (e), é possível visualizar argilo-minerais placóides (mica, caulinita ou clorita), envolto por um material de aparência enevoada, esfumaçada (esmectita). 


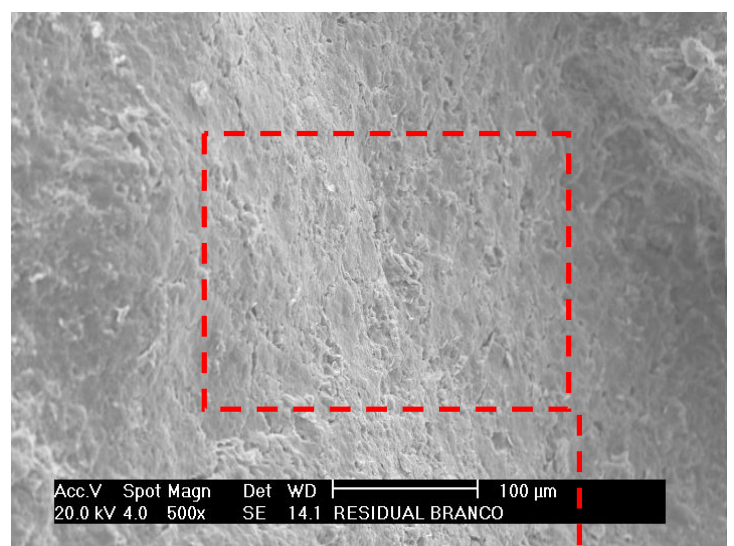

(a)

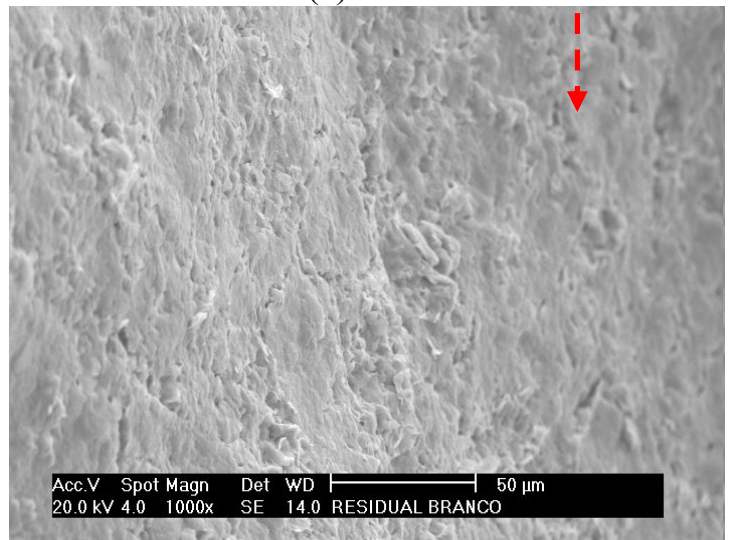

(b)

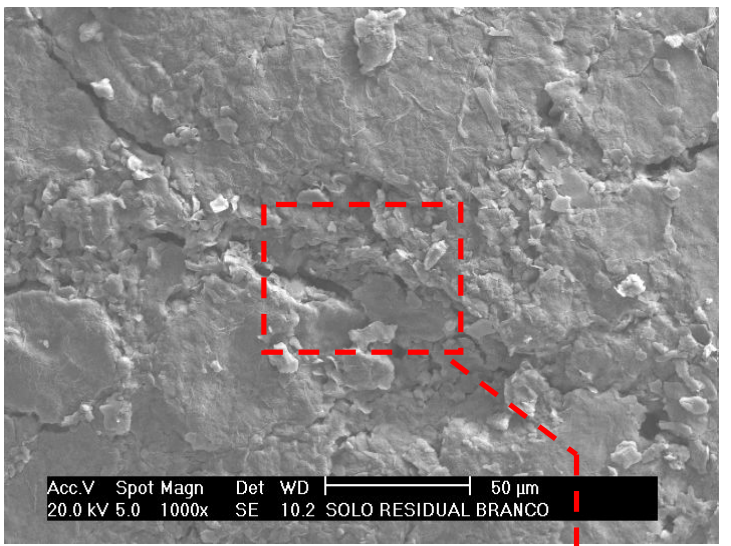

(c)

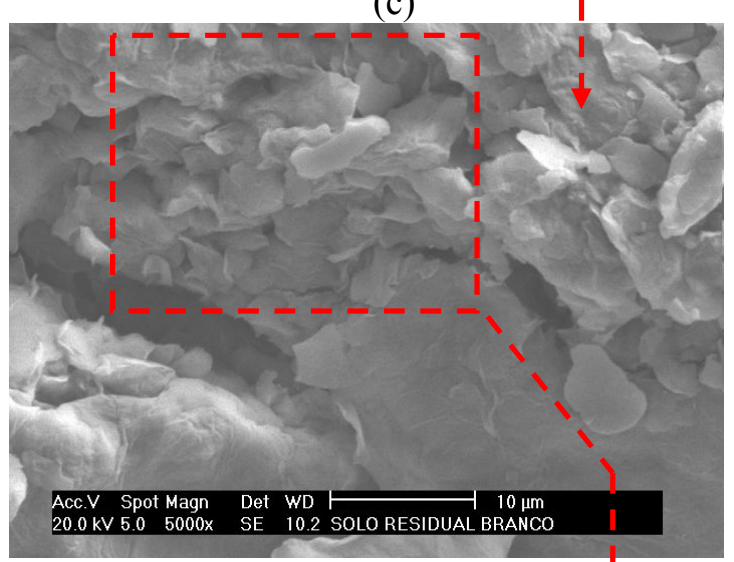

(d)

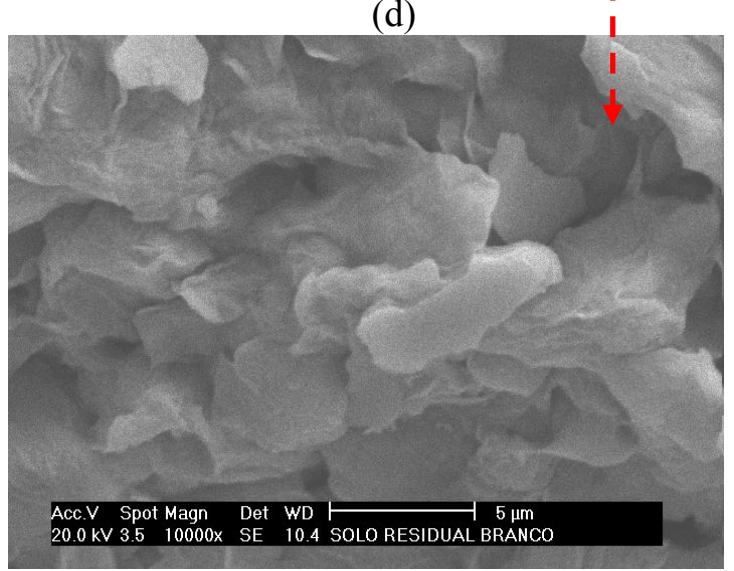

(e)

Figura 3.22 - MEV do material de preenchimento de cor Branca

\subsubsection{Material de Preenchimento de cor Laranja}

A análise microscópica do material de preenchimento de cor Laranja, apresentada na Figura 3.23, apresenta uma massa de goethita, resultante da oxidação de partículas de biotita. O óxido de ferro hematita não foi identificado, por sua baixa quantidade. 


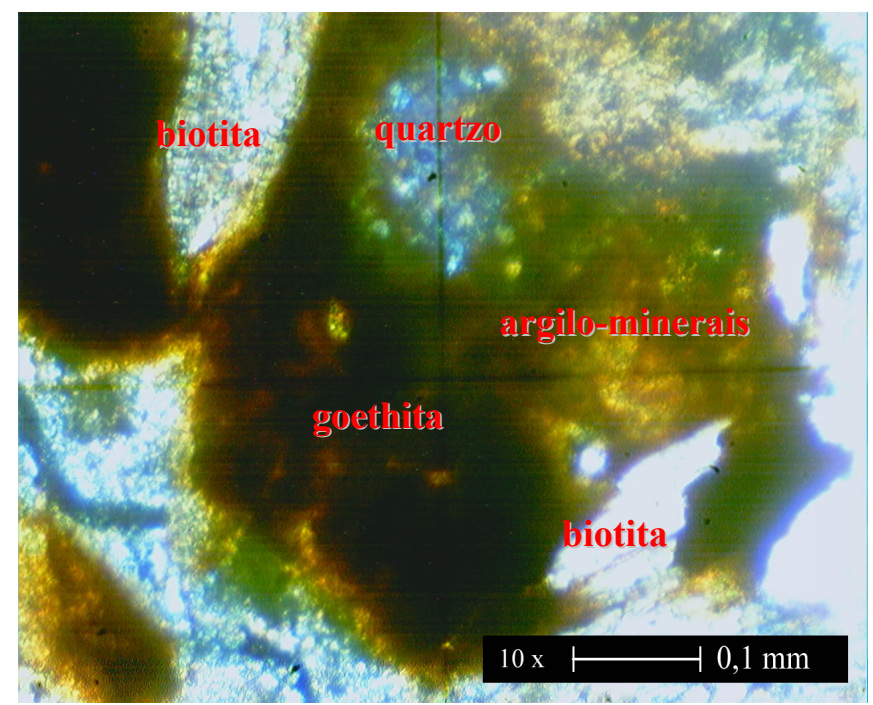

Figura 3.23 - Material de preenchimento de cor Laranja (MOT)

Na Figura 3.24 pode-se observar a microestrutura do material de cor Laranja. Percebese uma estrutura floculada, composta por aglomerações, com uma superfície aparentemente bastante rugosa e um volume de vazios maior do que o encontrado no solo residual cinza. Nota-se que estas aglomerações são partículas de mica (biotita) envoltas por óxidos de ferro.

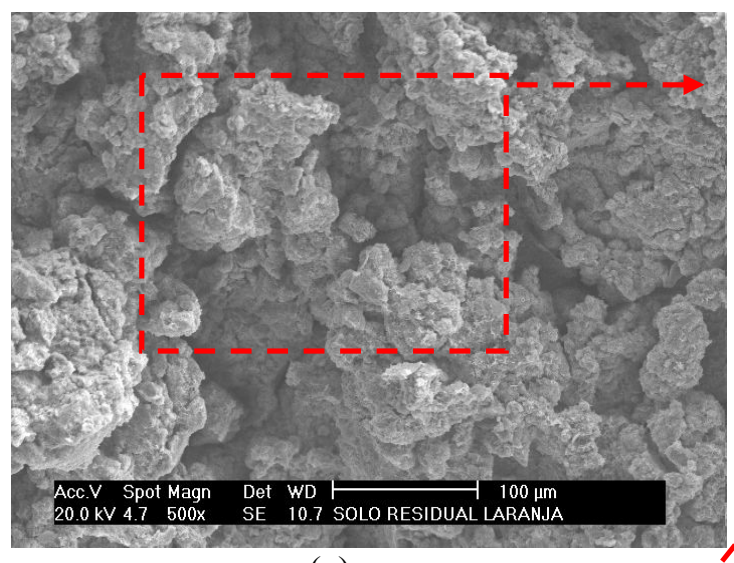

(a)

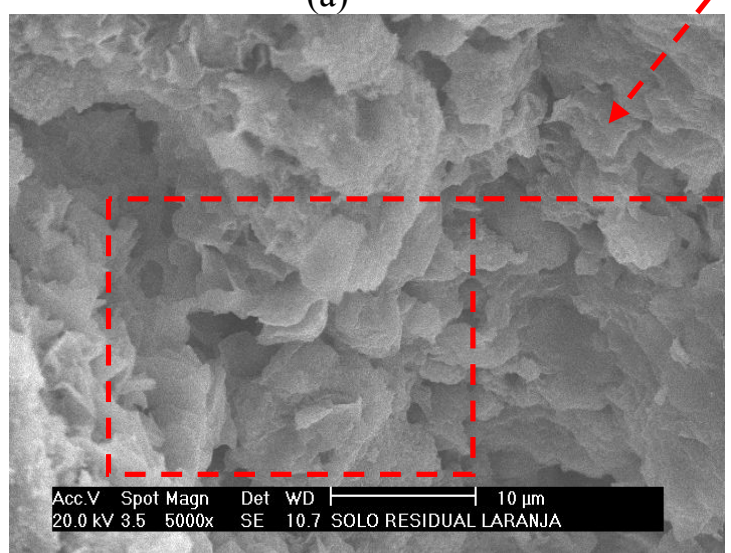

(c)

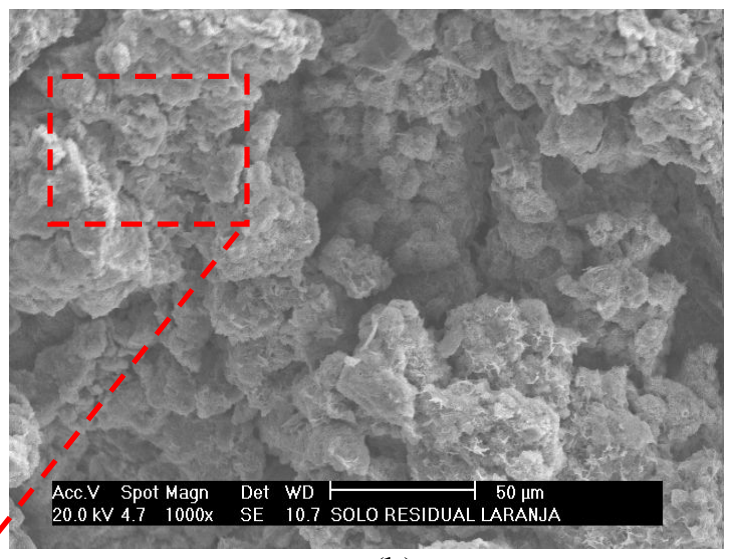

(b)

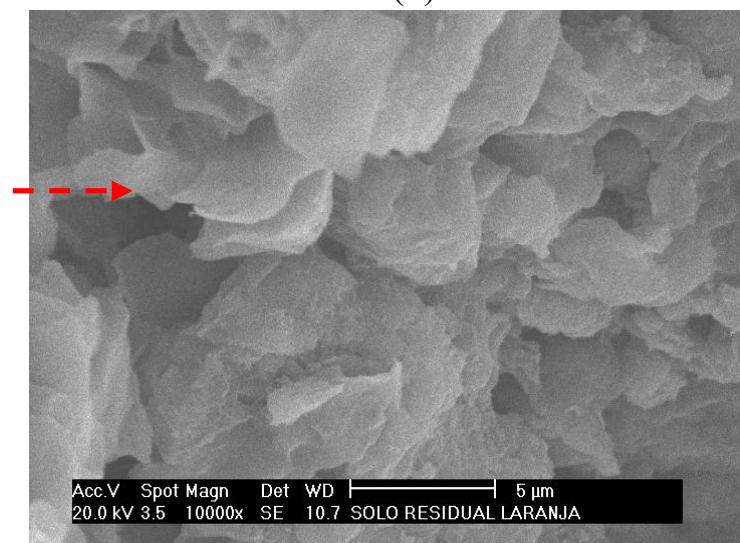

(d)

Figura 3.24 - MEV do material de preenchimento de cor Laranja 


\subsection{CONClusões Sobre a CARACTERIZAÇão do Solo}

O solo em estudo é um solo residual saprolítico, cuja rocha matriz é um biotita-gnaisse milonítico. O solo apresenta estruturas reliquiárias da rocha mãe, tais como as fraturas e foliações metamórficas.

A classificação efetuada durante as prospecções geotécnicas subdividiu o perfil de alteração do local de estudo em solo residual maduro, solo residual saprolítico e rocha alterada, como pode ser visto na Figura 2.6. O local de coleta das amostras foi caracterizado com a presença de um solo residual maduro. Esta classificação é contrariada baseando-se na caracterização física e, principalmente, na microscopia do solo em estudo, indicando tratar-se de um solo residual saprolítico. Provavelmente, a metodologia utilizada para localização do início do horizonte de solo residual saprolítico baseou-se no número SPT, sendo considerado um solo saprolítico a camada com SPT maior do que 50.

Ambas camadas de solo residual maduro e solo residual saprolítico, foram classificadas pelas prospecções geotécnicas como um silte arenoso micáceo. Esta classificação foi confirmada pelos resultados do presente estudo. Entretanto, cabe lembrar que parte da fração silte é composta por aglomerações de partículas argilosas e que, como citado anteriormente durante a caracterização física do solo, a porcentagem de fração areia está muito próxima à de fração silte, podendo o solo também ser classificado como uma areia siltosa micácea. Contudo, esta pesquisa adotará a classificação de silte arenoso micáceo, de acordo com as prospecções geotécnicas.

Os minerais que constituem o solo são o quartzo, o feldspato e a biotita, isolados em cristais ou em grãos de milonito (fragmentos do biotita-gnaisse milonítico). Os argilominerais encontrados são a biotita (proveniente do mineral biotita), a caulinita, a esmectita e a clorita (resultantes da alteração do feldspato).

Os pontos brancos esparsos, encontrados no solo a olho nu, são concentrações de material de alteração do feldspato, possivelmente onde se encontravam grãos de plagioclásio. Os argilo-minerais caulinita e esmectita, encontrados na análise do solo cinza, devem ser provenientes deste material. 
As fraturas da rocha mãe, por onde se estabeleceu um caminho preferencial de percolação de água, foram preenchidas por dois materiais de alteração da própria rocha. $\mathrm{Ou}$ seja, o preenchimento não ocorreu por um material proveniente de outro local, carreado pela percolação. O mecanismo ocorrido foi de um maior grau de alteração nas faces das fraturas, diferenciando o material resultante.

Este material de preenchimento é predominantemente argiloso, devido ao seu maior grau de alteração. Nos locais onde houve concentração do mineral biotita, esta se oxidou formando goethita e hematita, resultando no material de cor laranja. Nos locais onde houve concentração do mineral feldspato, estes formaram os argilo-minerais caulinita, esmectita e clorita, resultando no material de cor branca, o qual é expansivo.

Por meio de análises microscópicas do solo em estudo, notou-se um reduzido volume de vazios e não se pôde evidenciar uma estruturação por cimentação das partículas, salientando que o solo não é evoluído pedologicamente. Um alto grau de evolução pedológica não era esperado, pois o solo encontra-se permanentemente abaixo do nível do lençol freático.

A microestrutura formada por empilhamento de placas e a baixa quantidade de macro e micro-poros explicam o elevado peso específico natural encontrado. Além de este fato evidenciar o baixo grau de alteração do solo, ele justifica o reduzido índice de vazios inicial obtido.

Solos com a fração silte de natureza micácea, com pouca ou nenhuma quantidade de argila, podem apresentar índices de plasticidade diferentes de zero. O tamanho, o formato e as características da superfície das partículas determinam sua interação com a fase líquida do solo, fazendo com que a predominância do argilo-mineral biotita justifique a existência de um índice de plasticidade de 10\%. De acordo com Mitchell (1993), a biotita possui superfície específica maior do que a caulinita, por exemplo, necessitando de mais água para se tornar plástica.

De acordo com Vargas (1988), a existência desta plasticidade associada à baixa quantidade de argila induz a um "índice de atividade fictício", acima da linha $\mathrm{E}(\mathrm{IA}=0,75)$ na carta de atividade. Entretanto, este grau de atividade não está associado ao comportamento coloidal do solo, justificando o IA=1,00 do solo em estudo. 
Entretanto, o Índice de Atividade não é muito representativo para os solos residuais, devido ao seu processo evolutivo de formação do solo. A partícula argila de um solo sedimentar, por exemplo, foi bem mais desgastada do que a partícula de um solo residual. A partícula de comportamento coloidal de um solo residual acaba possuindo um tamanho maior do que $2 \mu \mathrm{m}$ (definido por Skempton para solos sedimentares). Além disso, o argilo-mineral mica no tamanho silte também fornece plasticidade ao solo (devido ao seu formato placóide) e a presença de partículas de argila aglomeradas na fração silte reduz a real porcentagem de argila existente no solo.

As propriedades mecânicas de um solo podem ser medidas diretamente por meio de ensaios, como será realizado no próximo capítulo. Entretanto, elas podem ser esclarecidas e algumas previsões podem ser efetuadas com a consideração da composição mineralógica e da microestrutura presentes no solo. Pela existência do argilo-mineral esmectita, é possível prever que o solo apresente expansibilidade, mas que esta seja baixa devido à reduzida quantidade do argilo-mineral.

De acordo com Souza Neto (2000), a influência dos argilo-minerais na resistência não é de grande expressão (com exceção dos argilo-minerais expansivos). A existência de óxidos de ferro (goethita e hematita) no solo em estudo pode conduzir a um considerável aumento em sua coesão, refletindo na resistência como um todo. Ainda de acordo com o autor, existe uma clara tendência de redução da resistência do solo com o aumento na quantidade de mica. Esta baixa resistência dos solos micáceos, como o solo em estudo, pode ser atribuída à forma plana das partículas, as quais tendem a dificultar o entrosamento entre os grãos e ocasionar perda de resistência devido à quebra de grãos durante o cisalhamento.

Aspectos estruturais de alguns solos residuais, como planos de foliação, xistosidades e zonas de fraqueza herdadas da rocha mãe, especialmente de rochas metamórficas, poderão comandar a resistência do maciço como um todo. Nestes solos, assim como no solo em estudo, é comum encontrar uma macroestrutura anisotrópica e orientada, podendo induzir a variações na resistência com a direção de cisalhamento. Nestes casos, é possível que a resistência medida em laboratório não reflita o real comportamento do solo em campo. 


\section{Capítulo 4}

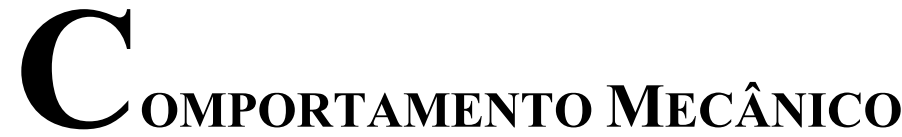

O objetivo deste capítulo é caracterizar o comportamento mecânico do solo residual de gnaisse estudado neste trabalho. Para isso, foram realizados ensaios edométricos e triaxiais, caracterizando-se o solo em termos de compressibilidade, permeabilidade, grau de estruturação, relações tensão-deformação e envoltórias de escoamento e de Estado Crítico.

Este capítulo foi subdividido em três partes, sendo a primeira composta por uma revisão de autores que estudaram o comportamento de solos residuais, a segunda parte destinada à apresentação do comportamento do solo em estudo e a terceira apresentando as conclusões parciais referentes a este capítulo.

\subsection{COMPORTAMENTo MecÂNICO dos Solos Residuais}

Devido ao processo de intemperismo e às ligações físico-químicas remanescentes da rocha original, os solos residuais são comumente caracterizados pela presença de estruturação das partículas e por maiores valores de índices de vazios.

Outras características marcantes são sua anisotropia e heterogeneidade, ambas também reproduzindo as propriedades da rocha original. Em alguns casos, a interpretação dos resultados de ensaios de laboratório torna-se difícil, pois corpos-de-prova moldados de uma única amostra podem apresentar feições e propriedades distintas. Por isso, os solos residuais são comumente conhecidos como solos "heterogeneamente homogêneos", ou "homogeneamente heterogêneos" (PINTO, 2006). 
A heterogeneidade dos solos residuais limita a utilização dos resultados de ensaios em que poucas amostras foram analisadas. Faz-se necessária uma abordagem estatística, que contemple um maior número de amostras e que mostre uma tendência no comportamento do solo, diminuindo a dispersão dos resultados.

Deve-se enfatizar que os parâmetros geomecânicos obtidos em ensaios de laboratório não representam completamente o comportamento dos solos residuais, o qual é governado algumas vezes por peculiaridades geológicas não refletidas nos ensaios (PINTO et al., 1993). Contudo, a pesquisa em questão foi realizada somente com dados de ensaios de laboratório, tendo-se em vista que a geologia e as condições de contorno do local de estudo são conhecidas e compreendidas.

A revisão bibliográfica apresentada a seguir abordará assuntos referentes ao comportamento de solos residuais frente à Geomecânica, tais como trajetórias de tensões, envoltória de escoamento, influência da estruturação das partículas e a variação de parâmetros geotécnicos em função da trajetória de tensões.

\subsubsection{Trajetórias de tensões}

A trajetória de tensões é uma curva representativa do estado de tensões de um ponto do solo, para diversas fases da construção. A trajetória é representada em um plano, formado pelas tensões atuantes ou por invariantes de tensões.

Lambe (1967) definiu os invariantes "s" e "t", apresentados nas equações (4.1) e (4.2).

$$
\begin{aligned}
& s=\frac{\sigma_{1}+\sigma_{3}}{2} ; \quad s^{\prime}=\frac{\sigma_{1}^{\prime}+\sigma_{3}^{\prime}}{2}=s-u \\
& t=\frac{\sigma_{1}-\sigma_{3}}{2} ; \quad t^{\prime}=\frac{\sigma_{1}^{\prime}-\sigma_{3}^{\prime}}{2}=t-u
\end{aligned}
$$

O termo $u$ refere-se à pressão neutra. Os invariantes do MIT, "s" e " $\mathrm{t}$ ", representam $\mathrm{o}$ ponto de maior tensão cisalhante do círculo de Mohr das tensões atuantes e consideram apenas, no entanto, as tensões normais principais maior e menor, $\sigma_{1}$ e $\sigma_{3}$, respectivamente. Os invariantes também podem ser calculados a partir das tensões vertical e horizontal, $\sigma_{\mathrm{v}}$ e $\sigma_{\mathrm{h}}$, respectivamente.

Roscoe e Burland (1968) propuseram os invariantes de Cambridge, "p" e "q", apresentados nas equações (4.3) e (4.4), onde a tensão normal principal intermediária $\sigma_{2}$ também é considerada. 


$$
\begin{aligned}
& p=\sigma_{\text {oct }}=\frac{\sigma_{1}+\sigma_{2}+\sigma_{3}}{3} ; \quad p^{\prime}=\frac{\sigma_{1}^{\prime}+\sigma_{2}^{\prime}+\sigma_{3}^{\prime}}{3}=p-u \\
& \mathrm{q}=\frac{3}{2} \cdot \tau_{\text {oct }}=\frac{\left[\left(\sigma_{1}-\sigma_{2}\right)^{2}+\left(\sigma_{2}-\sigma_{3}\right)^{2}+\left(\sigma_{1}-\sigma_{3}\right)^{2}\right]^{1 / 2}}{\sqrt{2}}
\end{aligned}
$$

O invariante $p$ é caracterizado como a média das tensões normais principais, a tensão normal octaédrica $\left(\sigma_{o c t}\right)$, e é responsável pela mudança de volume do corpo-de-prova. $\mathrm{O}$ invariante $q$ é proporcional à tensão cisalhante octaédrica $\left(\tau_{\mathrm{oct}}\right)$, que provoca mudança de forma do corpo-de-prova.

Para ensaios triaxiais, onde $\sigma_{2}=\sigma_{3}$, as expressões dos invariantes são simplificadas para as equações (4.5) e (4.6). O invariante $q$ equivale então à diferença entre a tensão normal principal maior e a menor, a tensão desviadora de um ensaio triaxial.

$$
\begin{aligned}
& p=\frac{\sigma_{1}+2 \cdot \sigma_{3}}{3} ; p^{\prime}=\frac{\sigma_{1}^{\prime}+2 \cdot \sigma_{3}^{\prime}}{3}=p-u \\
& q=\sigma_{1}-\sigma_{3}
\end{aligned}
$$

Para as trajetórias de tensões, cabe ressaltar que:

i) uma trajetória de tensões totais, quando se encontra à direita de uma de tensões efetivas, indica uma pressão neutra positiva;

ii) quando definidos pelas tensões principais, os invariantes $t$ ou $q$ possuem sempre valores positivos; quando definidos pelas tensões vertical e horizontal, um valor negativo indica que a tensão horizontal é maior do que a vertical.

Algumas trajetórias de ensaios triaxiais estão apresentadas na Figura 4.1, em termos de tensões efetivas, sendo juntamente indicados exemplos de caso de obra em que elas ocorrem. É possível simular estas trajetórias através de ensaios triaxiais com controle de trajetórias de tensões.

As trajetórias de compressão se referem a ensaios em que o corpo-de-prova sofre diminuição de sua altura e as de extensão se referem a ensaios com aumento da altura. As trajetórias podem também ser de carregamento e de descarregamento, de acordo com as variações de tensões impostas. 


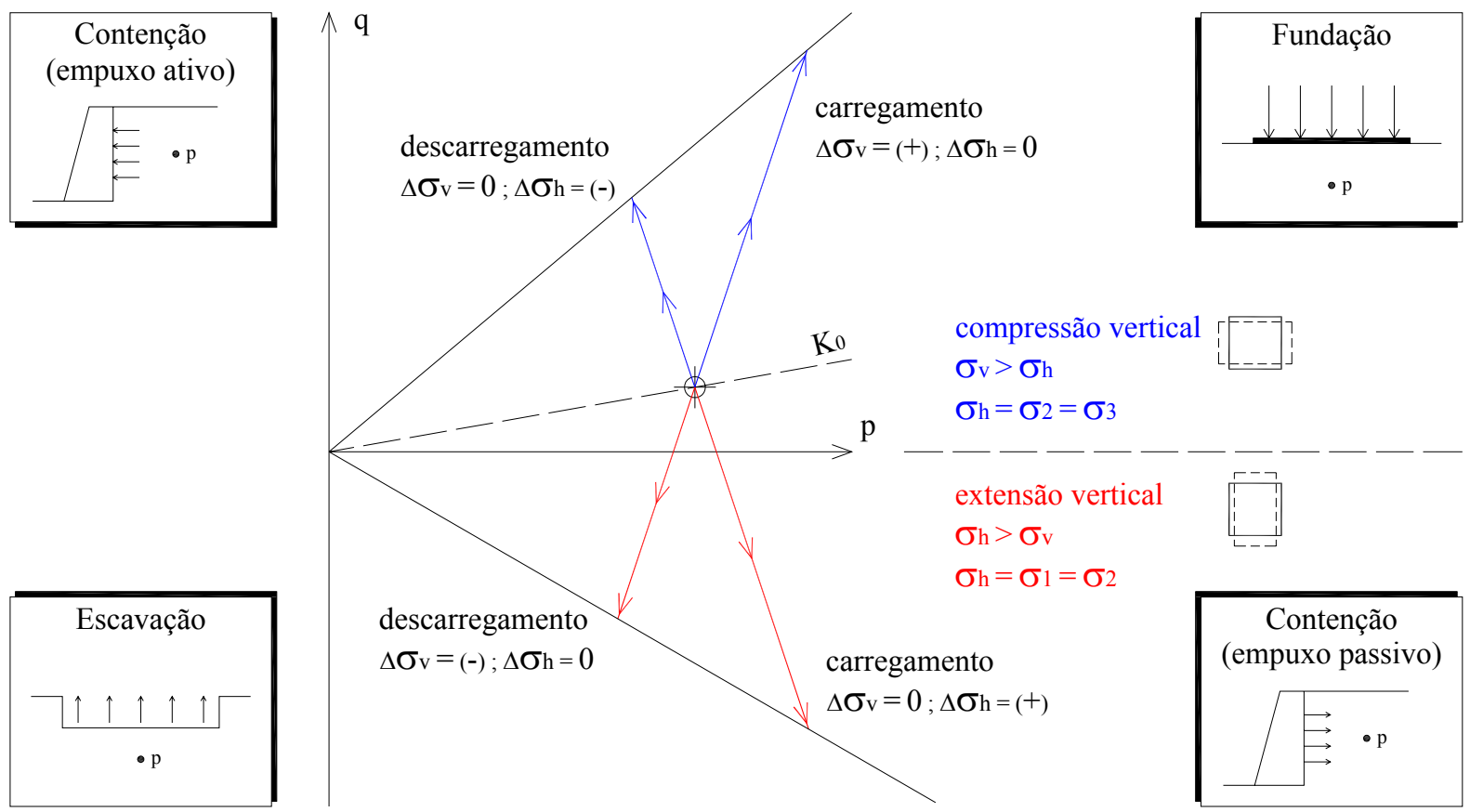

Figura 4.1 - Trajetórias de tensões de compressão e de extensão, de carregamento e de descarregamento, adaptado de Lambe (1967)

\subsubsection{Envoltória de escoamento}

Inicialmente, uma distinção será realizada entre os termos "cedência", "plastificação" e "escoamento".

Em ensaios de adensamento isotrópico ou edométrico, pode-se observar um nível de tensões a partir do qual, para uma mesma variação da tensão aplicada, a redução dos índices de vazios se apresenta mais acentuada. Este nível de tensões, ao qual ocorre a ruptura da cimentação do solo e o rearranjo das partículas (perda da estrutura), é denominado de tensão de cedência.

Por semelhança ao comportamento das argilas saturadas, a tensão de cedência é comumente chamada de tensão de pré-adensamento. Entretanto, tal denominação não é adequada, pois o comportamento de cedência não é devido a um carregamento prévio que o solo tenha sofrido, como no caso das argilas sobre-adensadas. 
Os diversos estados de tensões em que ocorre a cedência do solo podem ser posicionados em um diagrama de tensões, formando uma envoltória de cedência. Esta envoltória delimita a região do espaço de tensões onde o comportamento sofre a influência da cimentação e estruturação do solo, sendo adicionada uma parcela de coesão à resistência. Exteriormente a esta envoltória, a cimentação não mais atua e o comportamento do solo é totalmente devido ao atrito entre as partículas.

De acordo com Leroueil e Vaughan (1990), o formato de uma envoltória que considere a cedência é similar ao formato de uma que considere o sobre-adensamento. Os efeitos da estrutura e do histórico de tensões podem se desenvolver juntos e o uso de uma mesma terminologia para descrever o efeito de ambos é aceitável. Entretanto, é interessante que o tipo de efeito envolvido seja identificado e salientado.

Ensaios edométricos foram executados em um solo residual saprolítico de migmatito, com núcleos brancos de caulim, e analisados por Pinto e Nader (1991). Um dos resultados obtidos para a amostra de migmatito está apresentado na Figura 4.2 (a), onde é possível identificar um ponto de cedência no gráfico com escala linear. No caso do gráfico com escala semi-logarítmica, entretanto, o ponto de cedência não fica bem definido. Para a amostra de caulim, cujos resultados estão apresentados na Figura 4.2 (b), em nenhuma das escalas pôdese notar a ocorrência de cedência e, segundo os autores, isto não impede que se apliquem os processos de Casagrande (1936) e de Pacheco Silva (1970), normalmente utilizados para determinação da "tensão de pré-adensamento" de argilas.
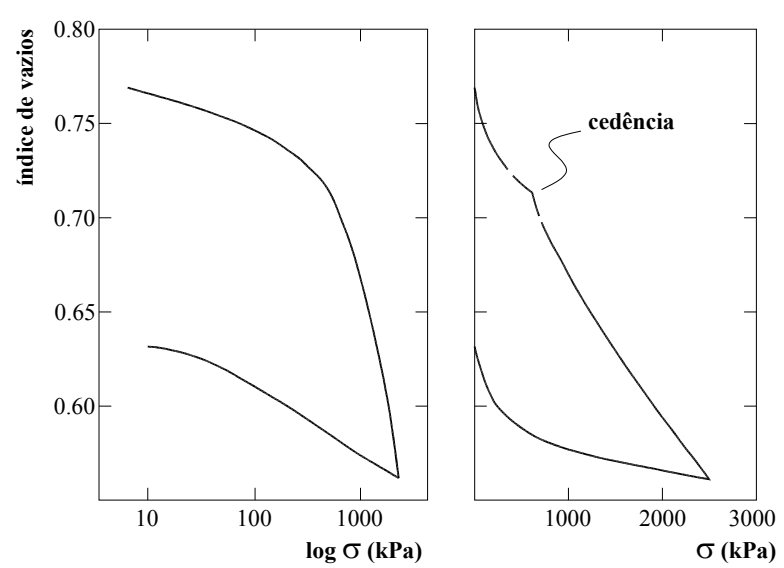

(a) amostra de migmatito
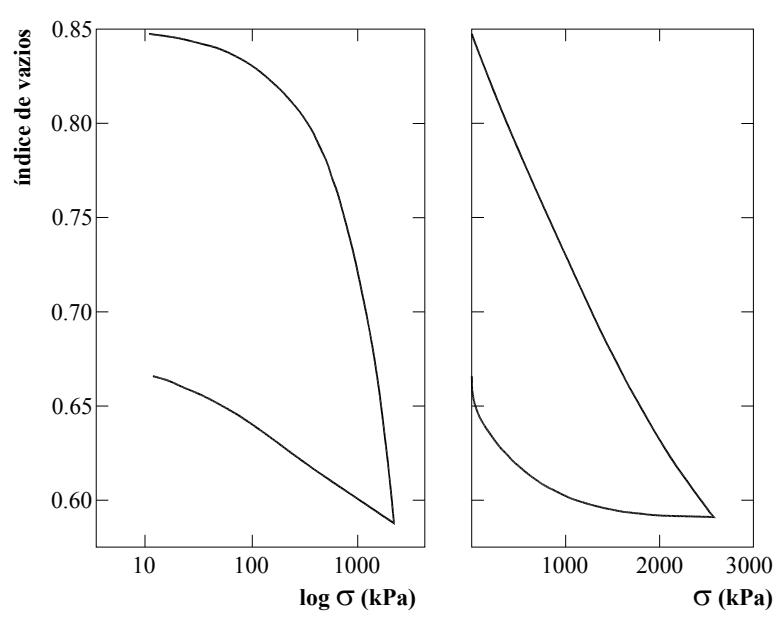

(b) amostra de caulim

Figura 4.2 - Identificação do comportamento de cedência, a partir de Pinto e Nader (1991) 
Pinto et al. (1993) analisaram ensaios executados em diversos solos residuais, inclusive o migmatito estudado anteriormente por Pinto e Nader (1991), e observaram que freqüentemente não se encontrava nenhum ponto característico de cedência nos gráficos de adensamento edométrico com escala linear. Para os solos que não apresentavam cedência, as tensões de "pré-adensamento" foram determinadas pelos processos convencionais de Casagrande (1936) e de Pacheco Silva (1970), utilizando os gráficos com escala semilogarítmica. Existindo tais pontos característicos de cedência, Pinto et al. (1993) concluíram que também era possível a utilização dos processos convencionais, uma vez que as tensões obtidas desta maneira se situaram próximas às tensões de cedência.

O fenômeno de plastificação também pode ser representado por uma envoltória, a qual delimita o comportamento mais rígido (pseudo-elástico), separando-o do comportamento elasto-plástico.

A envoltória de cedência (referente à perda de cimentação e estrutura) e a de plastificação (referente ao pré-adensamento e à mudança no comportamento mecânico) serão tratadas neste estudo como sendo coincidentes e serão descritas como uma única envoltória, denominada como envoltória de escoamento.

O escoamento em materiais estruturados é descrito por Leroueil e Vaughan (1990) como uma mudança irreversível na rigidez e na resistência do material, podendo ocorrer com qualquer trajetória de tensões. Seu início, entretanto, não destrói totalmente a cimentação, necessitando de um nível maior de deformação, sendo considerado um processo de dano contínuo (MACCARINI, 1987; FUTAI, 2002).

Leroueil e Vaughan (1990) consideraram a natureza do escoamento de argilas estruturadas e identificaram três situações onde ele ocorre de diferentes maneiras, dividindo a curva de escoamento como mostrado na Figura 4.3. As três classificações são as seguintes:

- escoamento na compressão (BC): ocorre distante da envoltória de resistência de pico e é devido ao aumento de tensão efetiva média, de tensão desviadora ou de ambas;

- escoamento no cisalhamento $(\mathrm{AB}, \mathrm{CD})$ : precede a ruptura de maneira próxima, de modo que ambos confundem-se, gerando descontinuidades e orientação das partículas;

- escoamento na expansão (AD): ocorre distante da envoltória de ruptura, devido à impossibilidade da estrutura de conservar a energia de deformação armazenada. 


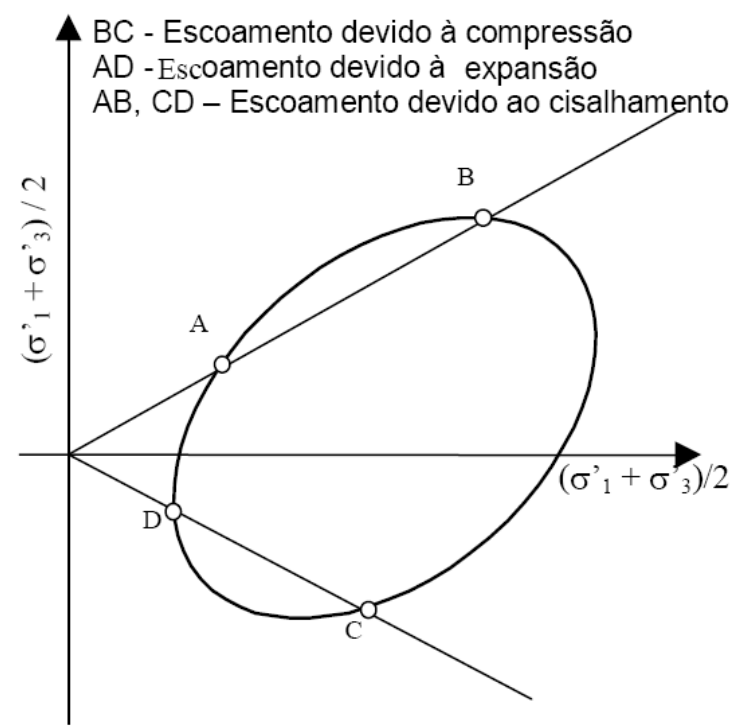

Figura 4.3 - Diferentes classificações de escoamento, a partir de Leroueil e Vaughan (1990)

Quando não apresenta escoamento devido à expansão, de acordo com Futai (2002), o solo é caracterizado por uma curva de escoamento que passa pela origem do espaço das tensões.

Smith et al. (1992) propuseram subdividir o comportamento tensão-deformação por três curvas de escoamento diferentes, como mostrado na Figura 4.4.

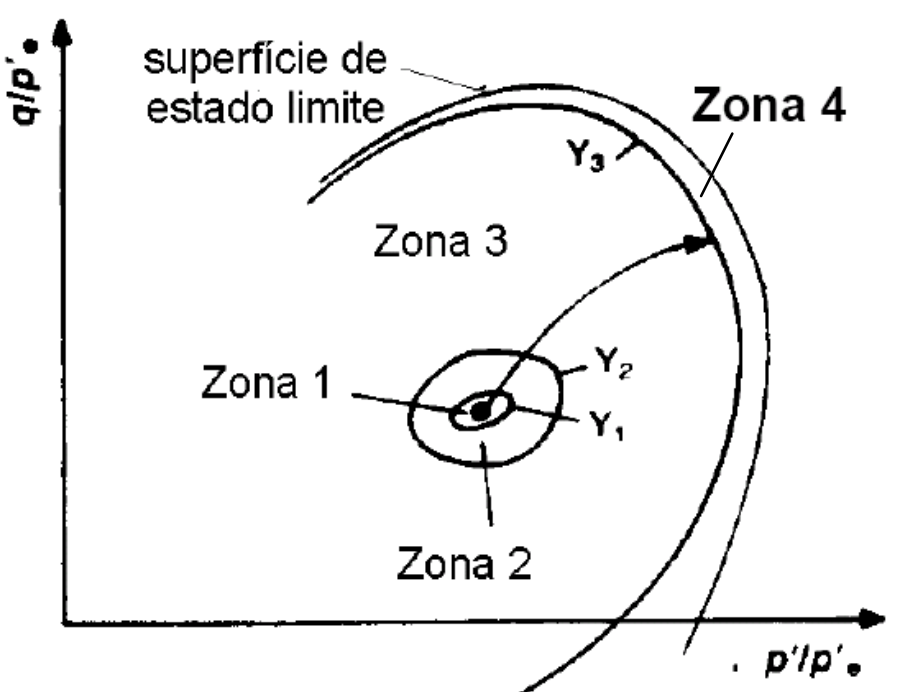

Zona1 (até $\mathrm{Y}_{1}$ ): comportamento elástico linear;

Zona2 (até $\mathrm{Y}_{2}$ ): comportamento elástico não-linear;

Zona3 (até $\mathrm{Y}_{3}$ ): comportamento elasto-plástico;

Zona4 (até estado limite): início da movimentação entre partículas;

Estado Limite: escoamento do solo.

Figura 4.4 - Utilização de várias curvas de escoamento, a partir de Smith et al. (1992)

Nesta proposta, a primeira curva $\left(\mathrm{Y}_{1}\right)$ compreende o comportamento elástico linear, cujo comportamento não é necessariamente isotrópico, mas possuindo deformações totalmente recuperáveis. Esta primeira curva delimita uma região que, por ser muito pequena, 
é de difícil determinação, referente ao módulo de elasticidade tangente inicial obtido a pequenas deformações. Após a curva $\mathrm{Y}_{1}$, o comportamento torna-se elástico não-linear, com a rigidez tangente diminuindo rapidamente, até alcançar a segunda curva, denominada como "sub-escoamento" $\left(\mathrm{Y}_{2}\right)$. Ao se ultrapassar esta curva, parte das deformações é irrecuperável, sendo que as deformações plásticas aumentam progressivamente à medida que a trajetória de tensões se aproxima da curva $\mathrm{Y}_{3}$. A partir desta terceira curva, iniciam-se as mudanças em larga escala no entrosamento entre as partículas, progredindo até que a trajetória de tensões alcance a superfície de estado limite, produzindo o que comumente é chamado de escoamento do solo, cujo entrosamento entre as partículas é marcadamente alterado.

Algo similar pode ser feito para solos estruturados, podendo definir-se uma primeira envoltória a partir da qual se inicia o processo de degradação da cimentação, e uma segunda a partir da qual o solo já se encontre desestruturado.

Quanto à definição da curva de escoamento, torna-se necessário enfatizar o método utilizado para definir sua forma (MASÍN, 2004). Alguns métodos utilizados para definir o formato da envoltória de escoamento foram sintetizados por Graham et al. (1988).

Os métodos mais comuns identificam as tensões de escoamento pela intersecção de duas linhas retas, obtidas pela representação de curvas tensão-deformação por dois trechos razoavelmente lineares, separados por um trecho curvo transicional (GRAHAM et al., 1982). É comum utilizar uma série de gráficos como e-log p' $, \sigma^{\prime}{ }^{-} \varepsilon_{1}, \sigma_{3^{-}} \varepsilon_{3}, p^{\prime}-\varepsilon_{\mathrm{p}}, \mathrm{q}-\varepsilon_{\mathrm{q}}$. Os termos $\varepsilon_{\mathrm{p}}$ e $\varepsilon_{\mathrm{q}}$ representam as deformações volumétrica e cisalhante, respectivamente.

Outro método, menos usual, utilizado por Graham et al. (1982), Graham et al. (1983), Kuwano e Jardine (2007) e Smith et al. (1992), identifica o escoamento de curvas tensãodeformação em gráficos de energia de deformação por volume unitário (W) em função do comprimento do vetor tensão (LSSV), obtidos pelas equações (4.7) e (4.8) respectivamente:

$$
W=\sum\left(\bar{p}^{\prime} \cdot \delta \varepsilon_{p}+\bar{q} \cdot \delta \varepsilon_{q}\right)
$$

onde $\bar{p}^{\prime}$ e $\bar{q}$ são os valores médios dos invariantes de tensão, referentes ao incremento $\delta$ de deformação; e

$$
L S S V=\sum \sqrt{\left(\delta \sigma_{1}^{\prime}\right)^{2}+\left(\delta \sigma_{2}^{\prime}\right)^{2}+\left(\delta \sigma_{3}^{\prime}\right)^{2}}
$$

onde $\delta \sigma^{\prime}$ é um incremento de tensão.

A Figura 4.5 apresenta uma curva W-LSSV, com sua respectiva obtenção do ponto de escoamento. Nela também se pode observar a separação de dois trechos razoavelmente lineares por um curvo transicional, citada anteriormente. 


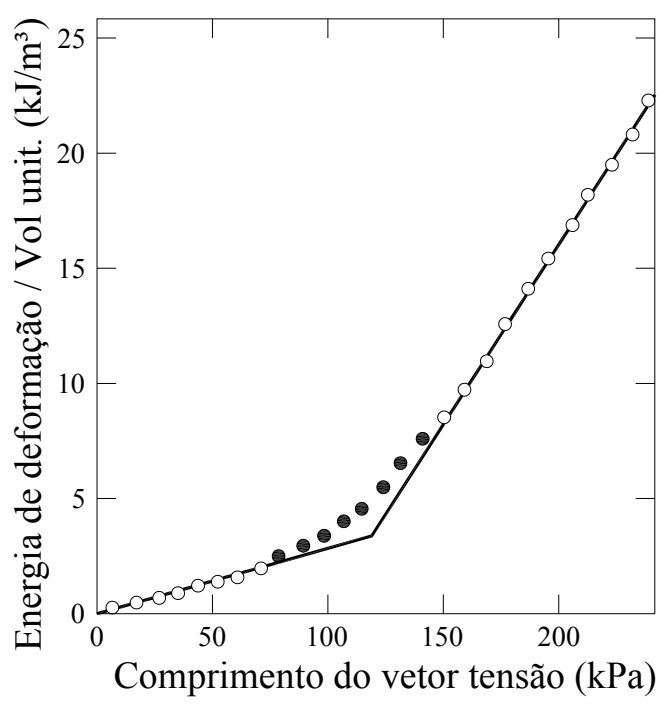

Figura 4.5 - Curva W-LSSV, a partir de Graham et al. (1982)

Um cuidado que se deve tomar, de acordo com Graham et al. (1982) e Pinto et al. (1993), diz respeito à técnica de se utilizar escala logarítmica nos gráficos, como ilustrado pela Figura 4.6. Resultados de ensaios edométricos de solos que claramente não escoam, se apresentados em escala semi-logarítmica, instigam a adoção de um valor de tensão de escoamento.

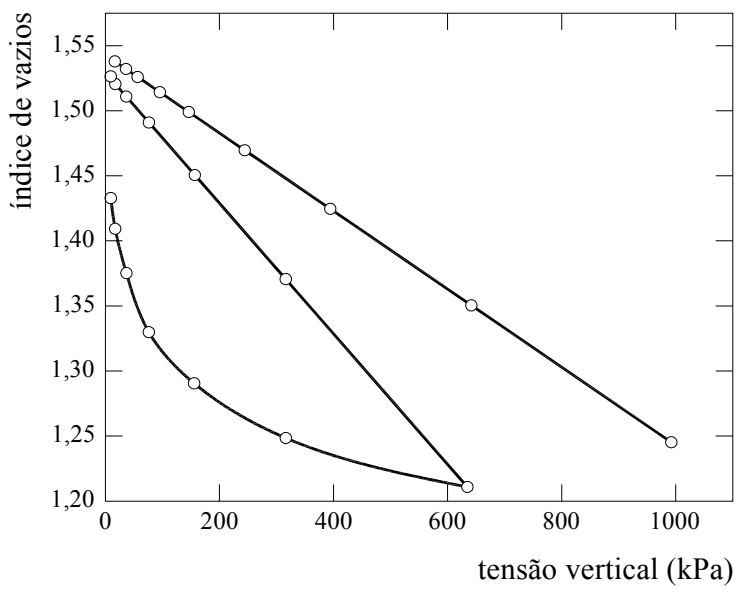

(a) escala linear

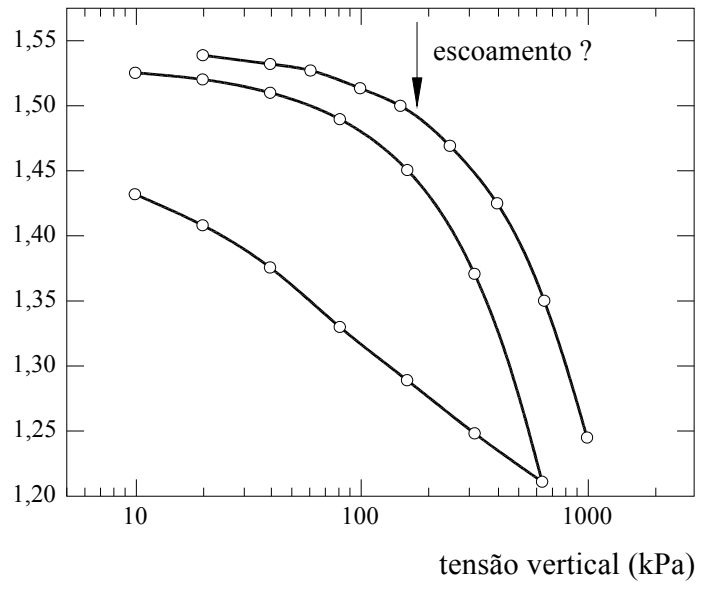

(b) escala semi-logarítmica

Figura 4.6 - Implicações da escala logarítmica, a partir de Graham et al. (1982)

De acordo com Graham et al. (1988), os valores obtidos pelos diversos métodos são, em geral, notavelmente similares e sugerem que os ensaios medem um real componente do comportamento do solo. 
Ainda segundo Graham et al. (1988), as técnicas utilizadas para avaliar o escoamento, por necessidade, precisam ser parcialmente empíricas. Existe tipicamente uma região de transição no comportamento mecânico, entre as deformações antes e depois do escoamento. Conseqüentemente, um grau de julgamento deve ser empregado na escolha da tensão de escoamento. Entretanto, é importante que as técnicas utilizadas sejam o mais genéricas possível, que não levem a conclusões incitadas e que suas limitações sejam compreendidas.

As curvas de escoamento de argilas naturais, de acordo com Futai (1999), Graham et al. (1983) e Graham et al. (1988), possuem simetria ao longo da linha $\mathrm{K}_{0}$, como pode ser visto na Figura 4.7. Além disso, Leroueil e Vaughan (1990) acrescentam que os solos residuais e as rochas brandas possuem curvas de escoamento centradas ao longo do eixo hidrostático, no plano p'-q, por possuírem comportamento geomecânico isotrópico.

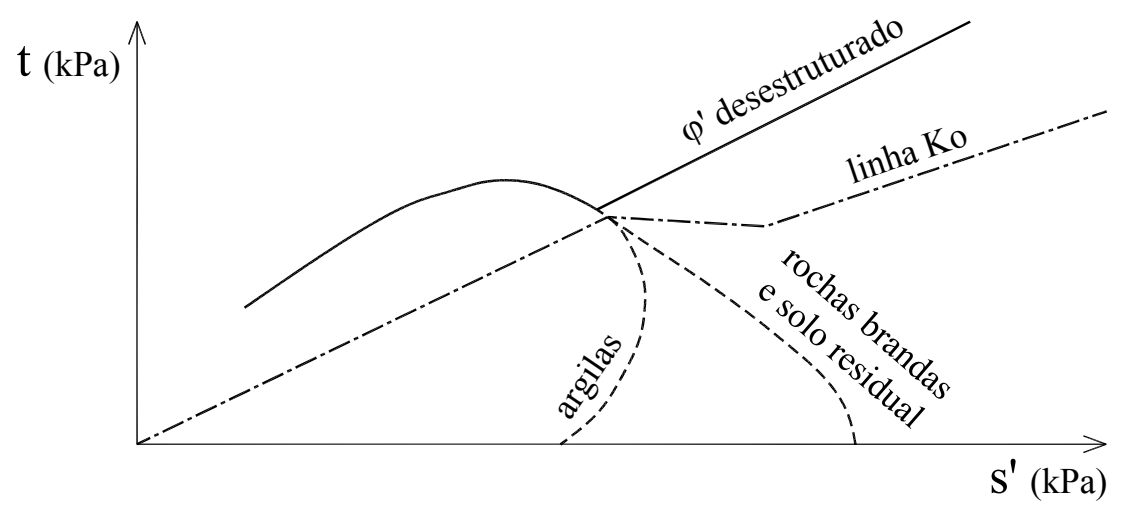

Figura 4.7 - Curvas de escoamento de argilas naturais, solos residuais e rochas brandas, a partir de Leroueil e Vaughan (1990)

Sandroni (1981) obteve a curva de escoamento de um solo residual jovem de gnaisse, apresentada na Figura 4.8, com ensaios triaxiais de compressão anisotrópica, definindo bem a curva no domínio levemente sobre-adensado. Contrariamente às conclusões de Leroueil e Vaughan (1990), notam-se pontos na curva de escoamento que se encontram à direita do escoamento hidrostático.

Futai e Almeida (2005) e Futai et al. (2004) também obtiveram curvas de escoamento de solos residuais não centradas no eixo isotrópico, afirmando serem possivelmente devido à anisotropia remanescente da rocha mãe. De acordo com Futai (2002), não existe uma generalização sobre a centralização das curvas de escoamento de solos residuais, havendo ainda necessidade de mais informações sobre o assunto. 


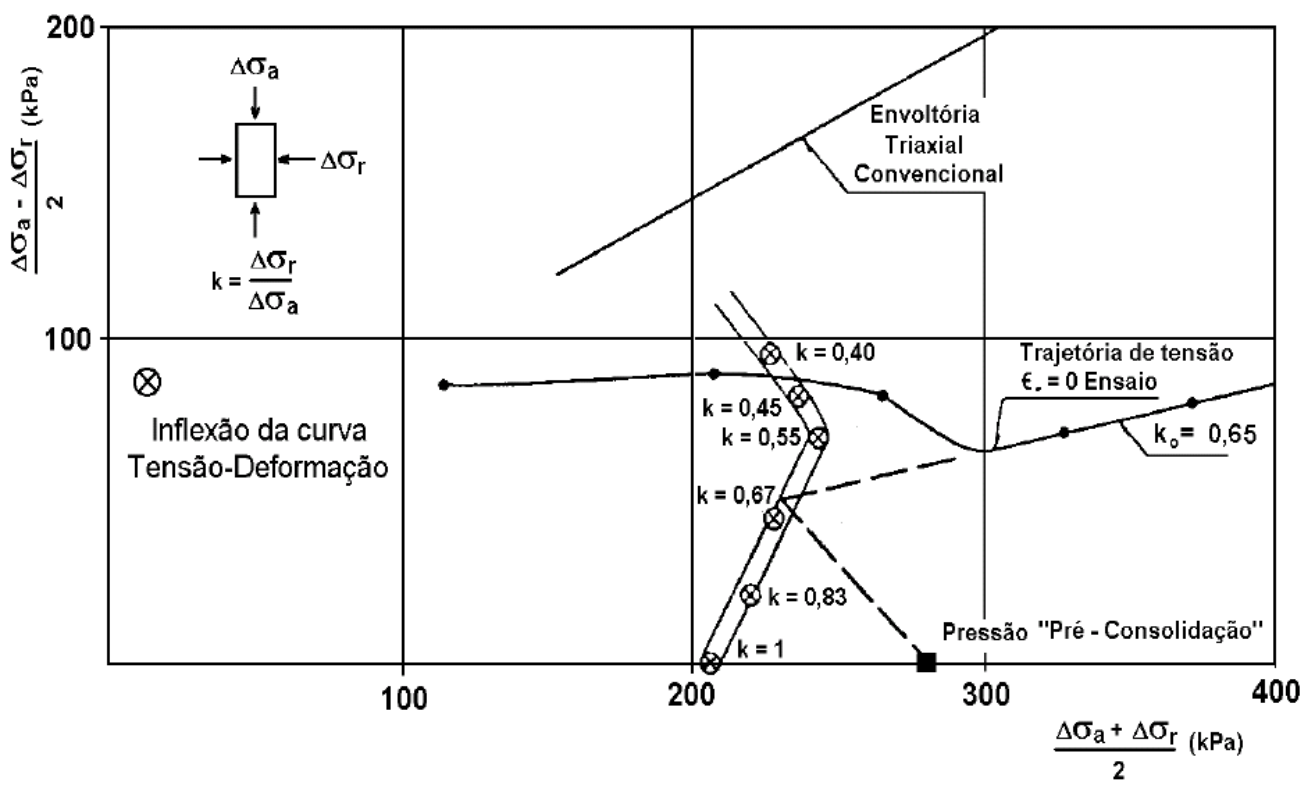

Figura 4.8 - Curva de escoamento de um solo residual jovem de gnaisse, a partir de Sandroni (1981)

Uma curva de escoamento com eixo de simetria ao longo da linha $\mathrm{K}_{0}$ no plano s'-t , segundo Graham et al. (1988), deixa de ser simétrica no plano p'-q, com os mesmos dados de tensões. É sugerido que curvas centradas na linha $\mathrm{K}_{0}$ sejam tratadas no plano s'-t, assim como curvas centradas no eixo isotrópico sejam tratadas no plano p'-q.

\subsubsection{Influência da estrutura}

As características de resistência e deformabilidade dos solos sedimentares são resultantes do escorregamento e rolagem entre as partículas. Baseados nisto, os modelos clássicos da Mecânica dos Solos relacionam o conceito de índice de vazios com a sua conseqüente modificação causada pelo histórico de tensões.

Para os solos residuais, entretanto, estas características são diretamente afetadas pelos fenômenos de cimentação e de colagem dos contatos entre as partículas. Estes fenômenos podem surgir por diversas causas, como deposição de carbonatos e hidróxidos, recristalização de minerais, fusão dos contatos entre as partículas sob altas pressões, entre outros (LEROUEIL; VAUGHAN, 1990).

Os solos que apresentam estes fenômenos serão descritos neste estudo como "estruturados", os que não apresentam serão denominados como "não-estruturados" e os solos em que este fenômeno foi removido serão descritos como "desestruturados". Segundo 
Leroueil e Vaughan (1990), a remoção da estrutura pode ocorrer submetendo-se o solo a um nível suficiente de deformações, ou simplesmente pela remoldagem da amostra.

A estrutura de um solo (fabric) é considerada como sendo o arranjo entre suas partículas, causado pelas forças físico-químicas que as une. É esta estrutura que justifica a resistência no estado natural superior à resistência após remoldagem, ainda que a argila se apresente com o mesmo índice de vazios, dando origem ao fenômeno de sensitividade das argilas.

Apesar de sua variável e complexa origem, o efeito da estrutura de um solo pode ser descrito de maneiras simplificadas, geralmente relacionadas à perda da cimentação existente, sendo tanto mais sensível quanto maior o índice de vazios.

De acordo com Leroueil e Vaughan (1990), o efeito da estrutura pode ser identificado obtendo-se propriedades de um solo estruturado e comparando-as com as de um solo cuja estrutura foi removida. A estrutura pode ser evidenciada, por exemplo, em uma comparação de ensaios edométricos realizados em amostras naturais e remoldadas (estruturadas e desestruturadas, respectivamente), como mostrado na Figura 4.9. O solo estruturado apresenta maior índice de vazios do que o solo cuja estrutura foi removida, pois o arranjo das partículas dos solos estruturados é, de maneira geral, mais floculado.

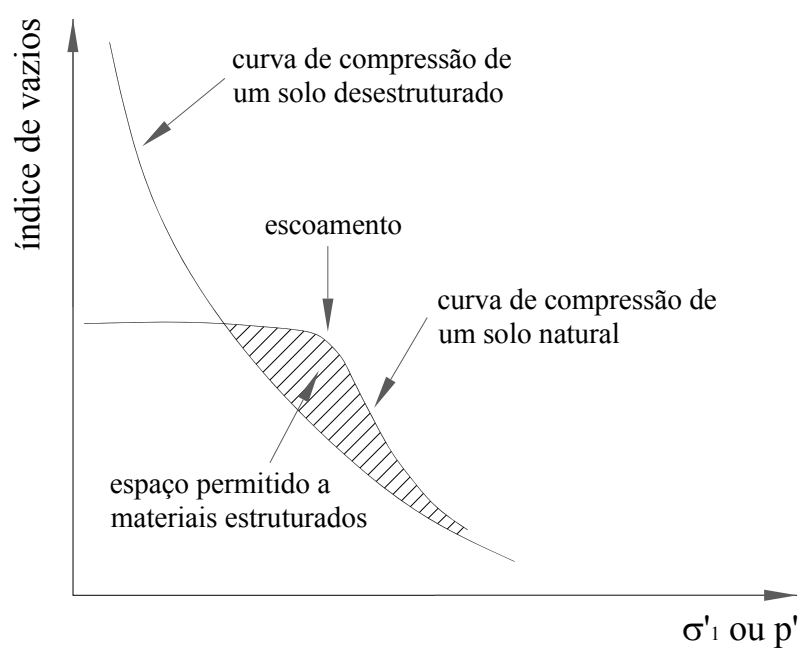

Figura 4.9 - Comparação entre um solo estruturado e um desestruturado em ensaio de compressão, Leroueil e Vaughan (1990)

A influência da estrutura no comportamento mecânico dos solos também pode ser observada nos resultados de ensaios triaxiais, como os da Figura 4.10. 


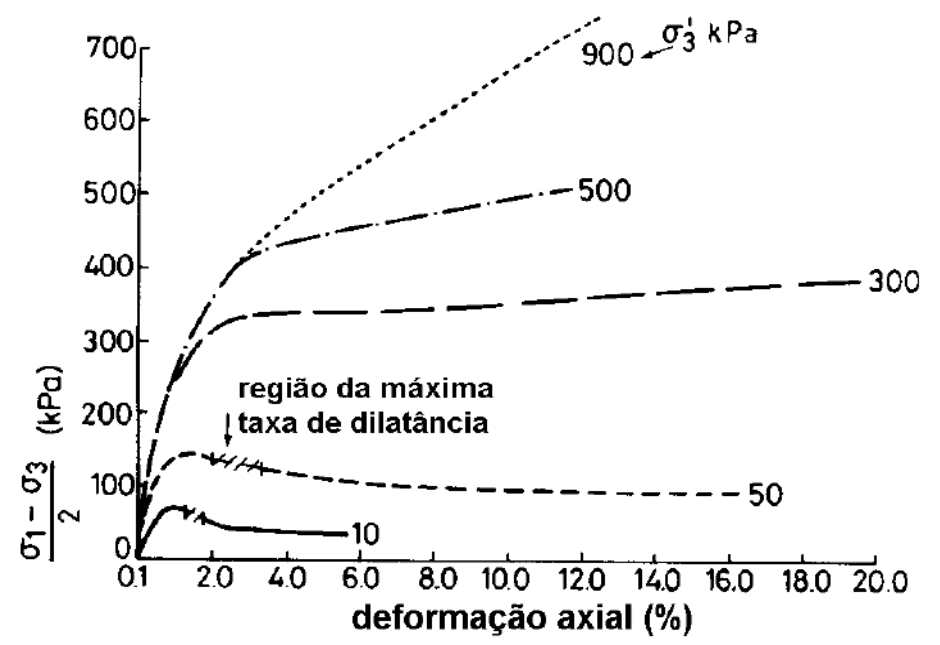

Figura 4.10 - Ensaios drenados de compressão triaxial em amostras artificialmente cimentadas, Maccarini (1987)

Pinto (2006), descreve três tipos de comportamento que podem ser observados em ensaios de compressão triaxial:

i) Para uma tensão confinante bem abaixo da tensão de escoamento, a resistência máxima é alcançada a pequenas deformações, quando a cimentação é destruída. Em seguida a tensão desviadora se estabiliza num nível mais baixo, quando a resistência passa a ser devida ao atrito entre as partículas. É um comportamento semelhante ao de solos não coesivos densos, com resistência de pico seguida por um amolecimento;

ii) Para uma tensão confinante mais alta, mas ainda abaixo da tensão de escoamento, a curva tensão-deformação apresenta uma mudança de comportamento quando a cimentação é destruída. Entretanto, a resistência final é maior, devida ao atrito entre grãos que passa a ser mobilizado;

iii) Para tensões confinantes acima do escoamento, o comportamento do material é típico de solos não estruturados, pois o próprio confinamento destrói a cimentação.

O posicionamento da máxima taxa de dilatância em curvas tensão-deformação de ensaios em solos sobre-adensados também pode evidenciar a influência da estrutura do solo. A taxa de dilatância ( $\Psi$ ) é definida pela expressão (4.9):

$$
\Psi=-\frac{\delta \varepsilon_{\mathrm{p}}}{\delta \varepsilon_{\mathrm{q}}}
$$

sendo $\varepsilon_{\mathrm{p}}$ a deformação volumétrica e $\varepsilon_{\mathrm{q}}$ a deformação cisalhante, definidas por 


$$
\begin{aligned}
& \varepsilon_{\mathrm{p}}=\varepsilon_{\mathrm{v}}+\left(2 \cdot \varepsilon_{\mathrm{h}}\right) \\
& \varepsilon_{\mathrm{q}}=\frac{2}{3} \cdot\left(\varepsilon_{\mathrm{v}}-\varepsilon_{\mathrm{h}}\right)
\end{aligned}
$$

onde $\varepsilon_{\mathrm{v}}$ é a deformação vertical e $\varepsilon_{\mathrm{h}}$ a deformação horizontal, em ensaios triaxiais.

Maccarini (1987) realizou ensaios triaxiais drenados em um solo artificialmente cimentado, conforme mostrado na Figura 4.10. Os ensaios realizados com baixas tensões confinantes (10 e $50 \mathrm{kPa}$ ) apresentaram resistência de pico que não coincide com a máxima taxa de dilatância, a qual ocorreu em deformações maiores e com resistência menor. Sabendo que o pico de resistência de solos não coesivos densos ocorre na máxima taxa de dilatância, Vaughan et al. (1988) atribuíram esta diferença à cimentação do solo, indicando que a resistência de pico é controlada pela estrutura e não pela densidade. Nos ensaios com maiores tensões confinantes, o escoamento ocorreu bem antes da ruptura, a qual foi alcançada sob grandes deformações e acompanhada por uma significante contração.

Como pode ser visto na Figura 4.7, Leroueil e Vaughan (1990) idealizaram a trajetória de tensões de um ensaio edométrico de solos estruturados, a qual sofre uma significante mudança de inclinação ao ser destruída a estrutura existente, aumentando o valor do coeficiente de empuxo em repouso. Na Figura 4.8 pode-se visualizar que Sandroni (1981) obteve resultados semelhantes, simulando a condição edométrica com ensaios triaxiais de deformação horizontal nula.

A estrutura de um solo também influencia em sua permeabilidade, de acordo com Vargas (1978), que demonstrou a variação da permeabilidade de um solo sob condição natural, compactada e remoldada em forma de lama. Ele obteve permeabilidades maiores para os solos compactados, em relação aos solos no estado natural, e permeabilidades muito menores para os solos amolgados no limite de liquidez.

A permeabilidade do solo compactado depende diretamente da densidade seca e do teor de umidade utilizado, ou seja, quanto mais compacto for o solo e maior o teor de umidade utilizado (ramo úmido da curva de compactação) menor a permeabilidade. Isto pode ocasionar uma permeabilidade para o solo compactado menor até mesmo do que a permeabilidade para o solo amolgado.

Em contrapartida, a permeabilidade do solo no estado natural é sempre maior que a do solo amolgado, tendo-se em vista que a estruturação existente entre as partículas propicia caminhos de percolação que aumentam a permeabilidade do solo. 


\subsubsection{Variação de parâmetros em função da trajetória de tensões}

A prática comum nos laboratórios de Mecânica dos Solos, para obtenção de parâmetros geotécnicos, é a realização de ensaios triaxiais nomeados como convencionais, nos quais a tensão confinante é mantida constante e a axial é acrescida até a ruptura do corpode-prova. Entretanto, o mecanismo de alteração do campo de tensões do maciço nem sempre é análogo a tais ensaios convencionais. De acordo com a trajetória de tensões seguida, as relações tensão-deformação serão diferentes.

Será aqui demonstrada a influência da trajetória de tensões no comportamento geomecânico de um solo, tendo-se como base alguns dos autores que estudaram este assunto.

De maneira simplificada, pode-se imaginar a trajetória de tensões ao redor de um túnel, de acordo com Ng e Lo (1985), da seguinte maneira: a escavação altera o estado de tensões inicial do solo, ocorrendo uma redistribuição de tensões e aliviando as tensões em suas proximidades, o que resulta em um efeito de descarregamento na massa de solo.

Lambe e Whitman (1969) apresentaram resultados de ensaios triaxiais em amostras de areia para diferentes trajetórias de tensão, como visto na Figura 4.11 a seguir, obtendo deformabilidades e variações volumétricas diferentes para cada trajetória.
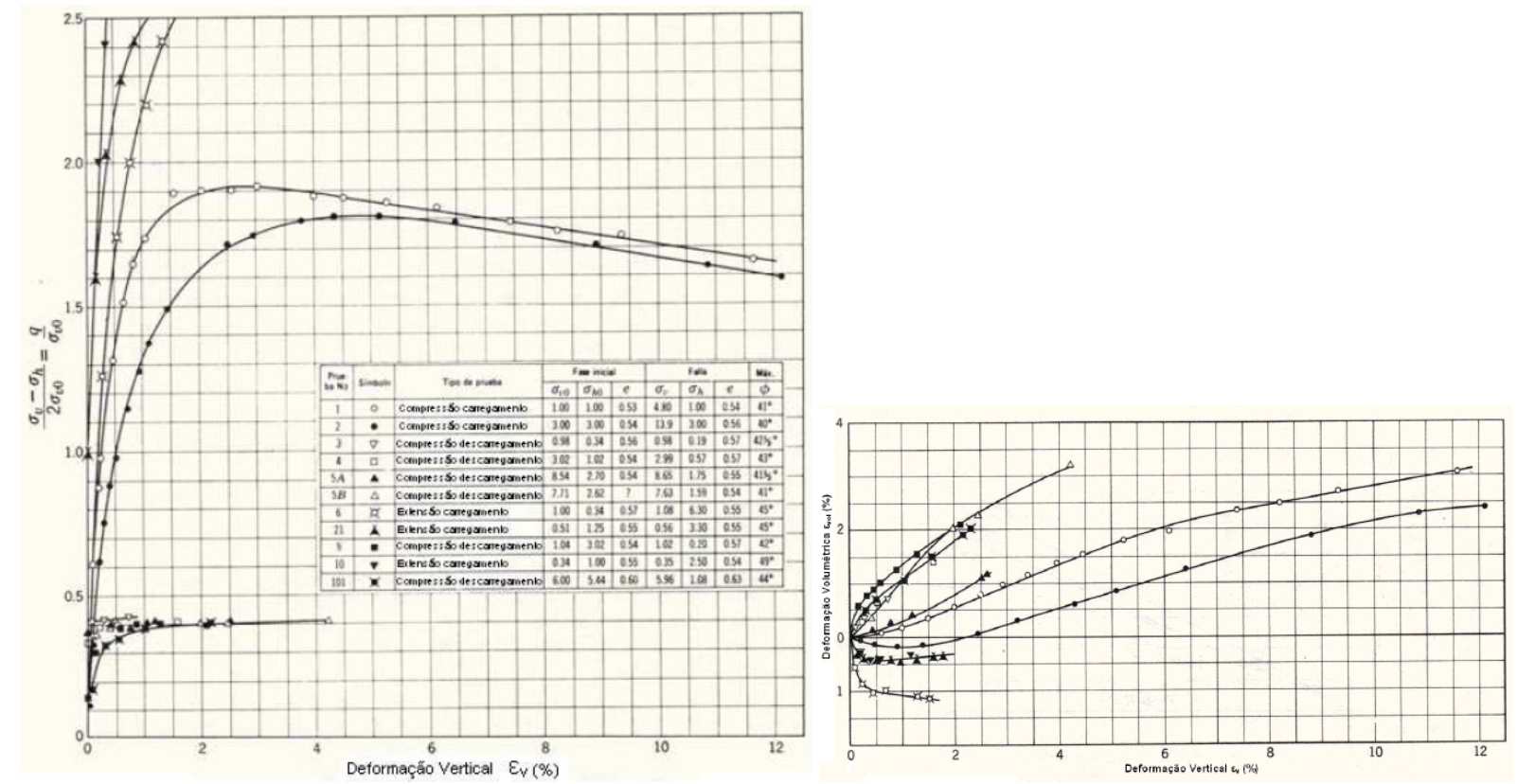

Figura 4.11 - Curvas tensão-deformação para diferentes trajetórias de tensões, a partir de Lambe e Whitman (1969) 
Ensaios de laboratório em um solo siltoso residual de migmatito foram analisados por Pinto e Nader (1991), discutindo sua heterogeneidade e anisotropia, seu comportamento mecânico, os estados de tensões in situ e sua resistência residual.

Utilizando o mesmo solo residual de migmatito, coletado na cidade de São Paulo, Nader (1993) realizou ensaios triaxiais variando suas trajetórias de tensões, desde 45 graus em relação à horizontal no plano s'-t (compressão axial), até 135 graus (descarregamento lateral). Ou seja, não foram realizados ensaios de extensão axial, com tensão desviadora decrescente. Como o intuito era a obtenção de parâmetros para a aplicação nos modelos constitutivos estudados pelo autor, os ensaios foram executados com o solo desestruturado.

A partir deste estudo, Pinto e Nader (1994a) desenvolveram o modelo constitutivo SUEF (superposição de efeitos), com base no modelo hiperbólico proposto por Duncan e Chang (1970), considerando o módulo de elasticidade e o coeficiente de Poisson como função das tensões atuantes. Este modelo utiliza um módulo de elasticidade e um coeficiente de Poisson para a situação de compressão axial, e outro par distinto para a situação de descarregamento lateral, tendo-se em vista que o comportamento do solo varia em função da trajetória de tensões a que é submetido. Para uma trajetória qualquer, em que as tensões vertical e lateral variam simultaneamente, como mostrado na Figura 4.12, o modelo considera a superposição dos efeitos das duas ações isoladas.

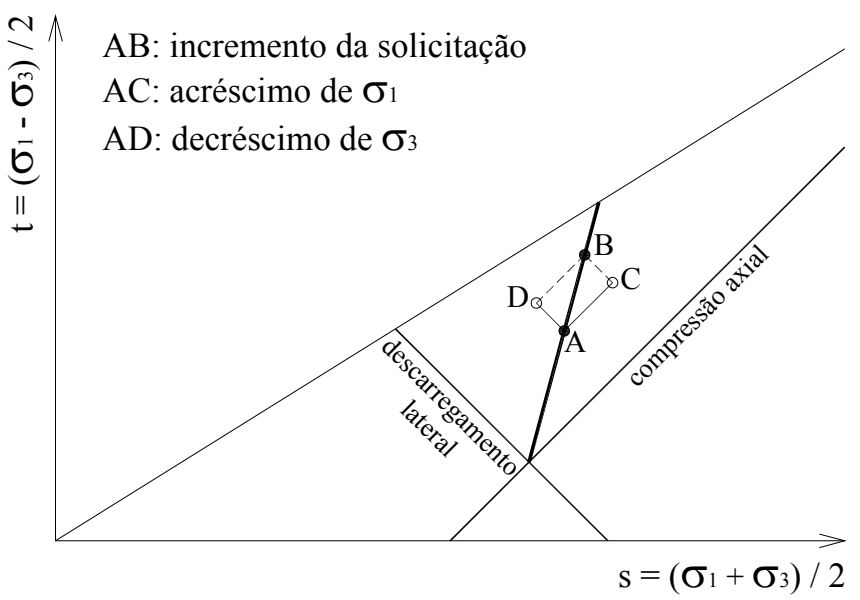

Figura 4.12 - Esquema do conceito de superposição de efeitos, modificado de Pinto e Nader (1994a) 
O mesmo solo siltoso residual de migmatito foi estudado por Anjos (1996), o qual realizou ensaios triaxiais em amostras remoldadas seguindo as trajetórias de tensões apresentadas na Figura 4.13 (a), complementares às utilizadas por Nader (1993) por incluírem ensaios de extensão axial. Os ensaios foram adensados anisotropicamente até o estado de tensões in situ e em seguida cisalhados até a ruptura, resultando nas curvas tensão-deformação apresentadas na Figura 4.13 (b). Segundo o autor, pôde-se comprovar como o comportamento tensão-deformação é dependente da trajetória de tensões seguida. Críticas foram efetuadas aos resultados obtidos por Anjos (1996) em relação às etapas de adensamento dos ensaios realizados, as quais não foram uniformes. O solo em questão, por possuir características de fluência, apresentou propriedades diferentes em função do tempo destinado ao adensamento.

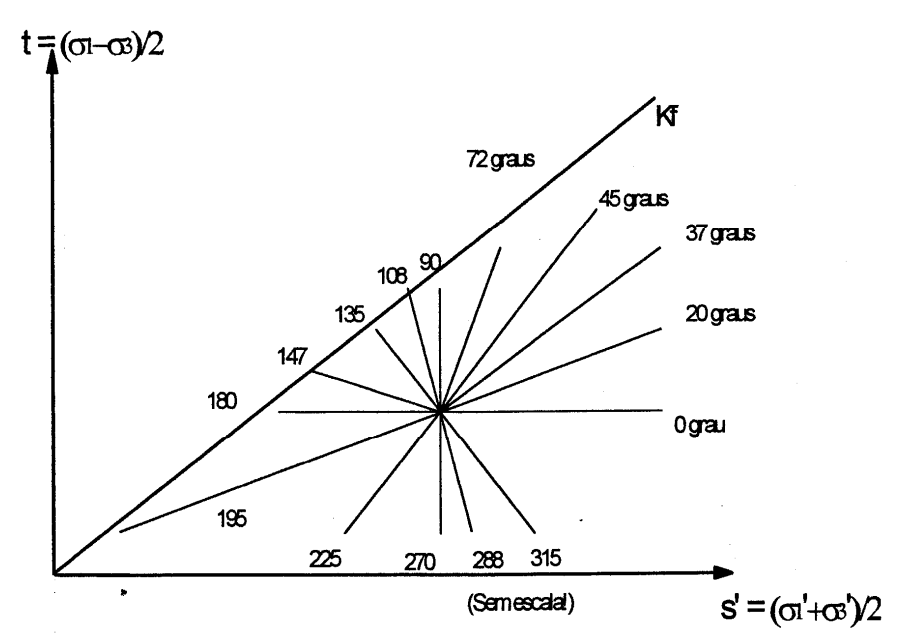

(a) trajetórias de tensões

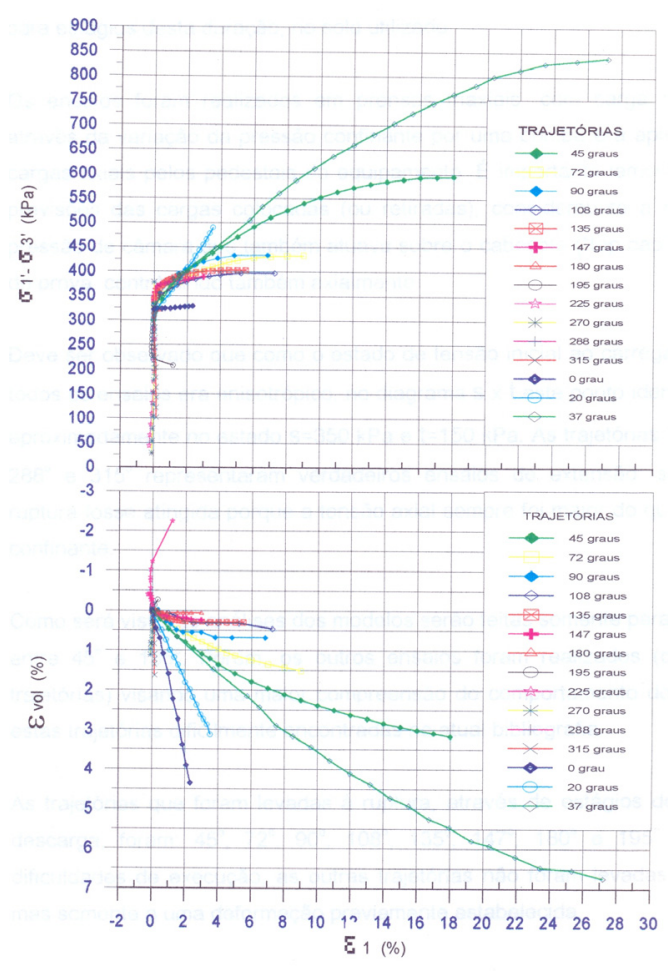

(b) curvas tensão-deformação obtidas

Figura 4.13 - Ensaios realizados por Anjos (1996)

São apresentados na Figura 4.14 resultados de ensaios de triaxiais drenados em uma argila siltosa rija e em uma areia densa, realizados por Medeiros e Eisenstein (1983). Os valores de módulos de elasticidade tangente podem ser comparados, notando-se uma variação principalmente em função do tipo de trajetória de tensão a que o solo foi submetido. 


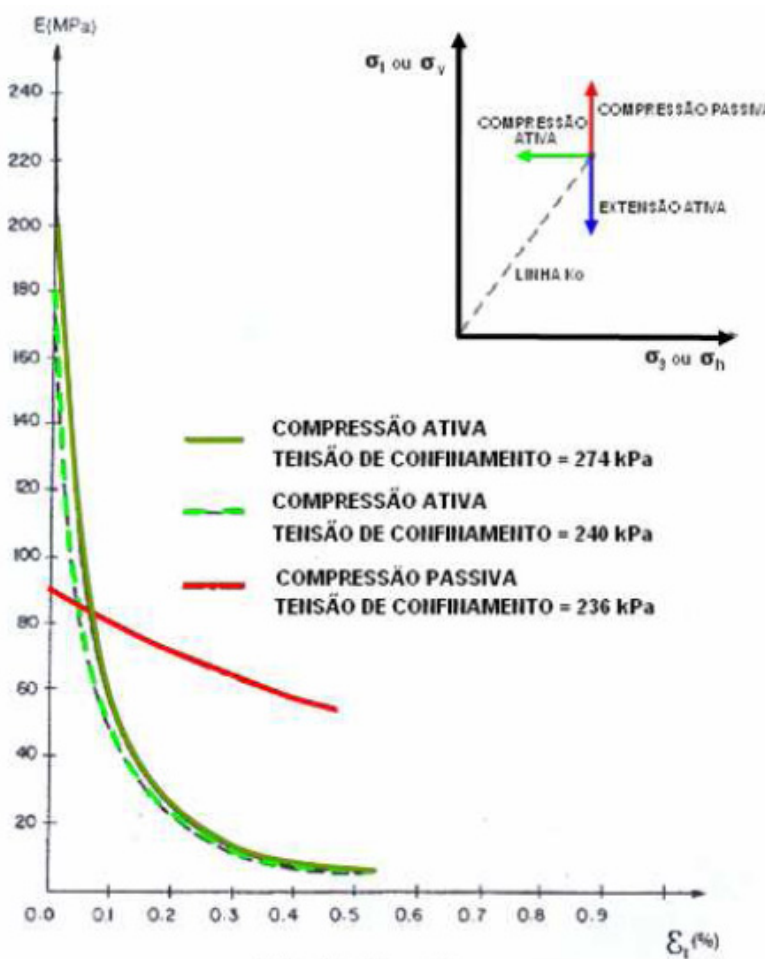

(a) Argila siltosa rija

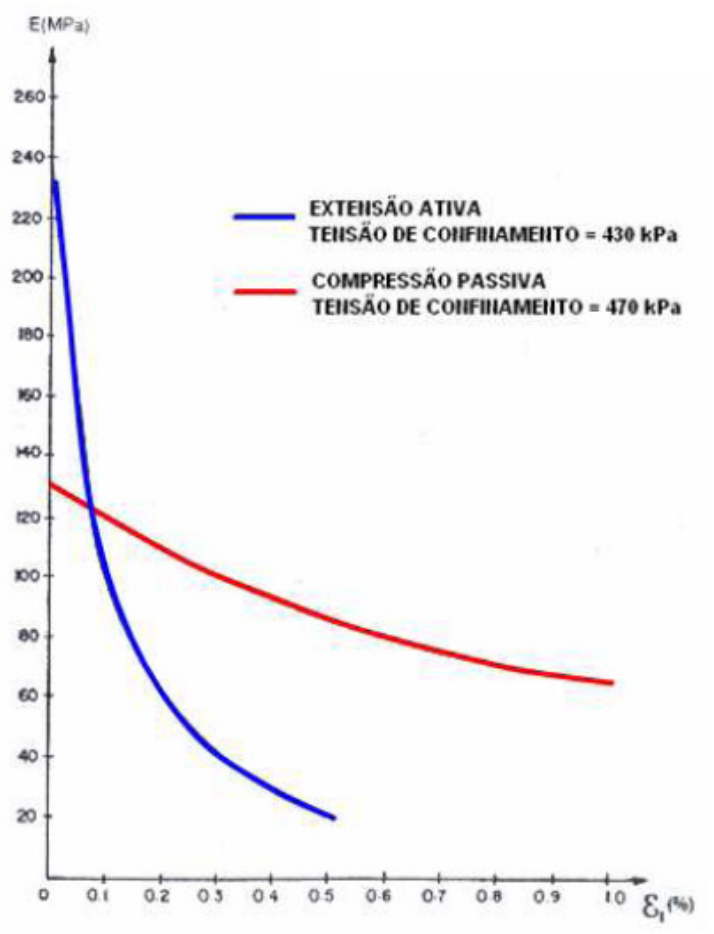

(b) Areia densa

Figura 4.14 - Resultados de ensaios realizados por Medeiros e Eisenstein (1983)

Lima (2002) apresentou dois fatores de correção que aplicou ao módulo de elasticidade obtido mediante um ensaio de compressão por carregamento, a fim de utilizá-lo na modelagem numérica de uma escavação em solo residual jovem. O primeiro fator está relacionado com as diferenças entre o campo e o laboratório (amolgamento, história de tensões, entre outros) e o segundo é relativo à diferença entre a trajetória de tensões empregada no ensaio e a trajetória de campo.

Uma modelagem numérica da escavação de uma contenção em solo grampeado foi realizada por Najar Jiménez (2008). Dentre outros assuntos, o autor analisou as trajetórias de tensões decorrentes da escavação e a influência dos parâmetros geomecânicos utilizados na modelagem, a qual contou com uma malha bidimensional de elementos finitos e com um modelo constitutivo elástico linear. Najar Jiménez (2008) efetuou uma análise iterativa, partindo de um maciço homogêneo e com parâmetros para a situação de compressão por carregamento, como visto na Figura 4.15 (a). Para a primeira iteração, o maciço foi subdivido de acordo com as trajetórias de tensões obtidas, utilizando-se parâmetros diferentes para cada tipo de trajetória. Ao final de cada iteração, a subdivisão das zonas mecanicamente heterogêneas do maciço eram readaptadas de acordo com as trajetórias de tensões obtidas, até a convergência dos resultados. Após a sétima iteração, o autor obteve a configuração final da 
subdivisão do maciço, apresentada na Figura 4.15 (b), na qual se encontra a situação de compressão por descarregamento atrás da parede de contenção (cor laranja), a de extensão por descarregamento no piso da escavação (cor verde) e a situação de compressão por carregamento no pé da contenção (cor cinza).

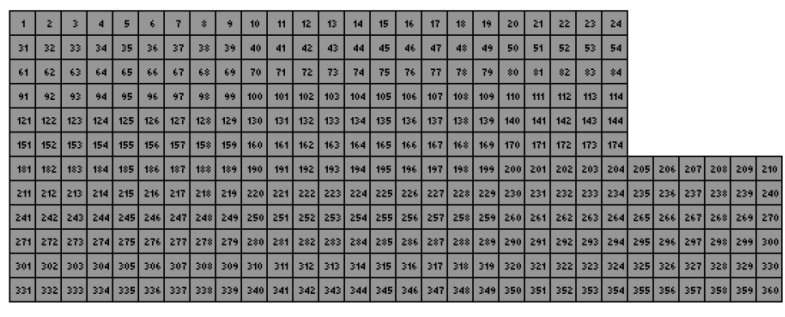

a) fase inicial, antes da $1^{\mathrm{a}}$ iteração

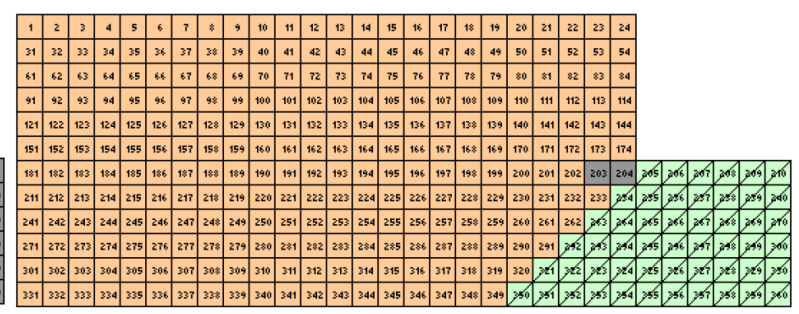

b) fase final, após a $7^{\mathrm{a}}$ iteração

Figura 4.15 - Processo iterativo utilizado por Najar Jiménez (2008)

Um estudo sobre as características de expansibilidade do solo, por meio de ensaios triaxiais, foi realizado por Barla (1999) e Barla e Barla (2001). Foram executadas modelagens numéricas bidimensionais e tridimensionais de um túnel circular, com o intuito de obter as trajetórias de tensões geradas pela sua escavação. As características de expansibilidade foram estudadas a partir de ensaios triaxiais que seguiram as trajetórias de tensões obtidas.

$\mathrm{Ng}$ e Lo (1985) realizaram ensaios triaxiais em amostras de uma argila siltosa, coletadas no local onde se encontra o Túnel Neebing McIntyre, no Canadá. Foram executados ensaios de compressão (carregamento axial) e de extensão (descarregamento lateral), drenados e não-drenados, de acordo com as trajetórias de tensões apresentadas na Figura 4.16 (a). As trajetórias dos ensaios não-drenados estão apresentadas em termos de tensões efetivas. Os autores puderam chegar às seguintes conclusões:

i) o valor módulo de deformabilidade (E') no descarregamento é cerca de duas vezes o valor do módulo no carregamento;

ii) o coeficiente de Poisson ( $v$ ') no descarregamento é cerca de três vezes o valor do coeficiente no carregamento;

iii) o módulo de deformação cisalhante (G') é relativamente não afetado no descarregamento ou carregamento;

iv) o módulo de deformabilidade é sensível quanto ao modo de adensamento (isotrópico ou anisotrópico), à drenagem e à direção da trajetória de tensões;

v) os estados de tensões referentes à ruptura obedecem a uma das duas possíveis envoltórias de ruptura, de compressão ou de extensão. 


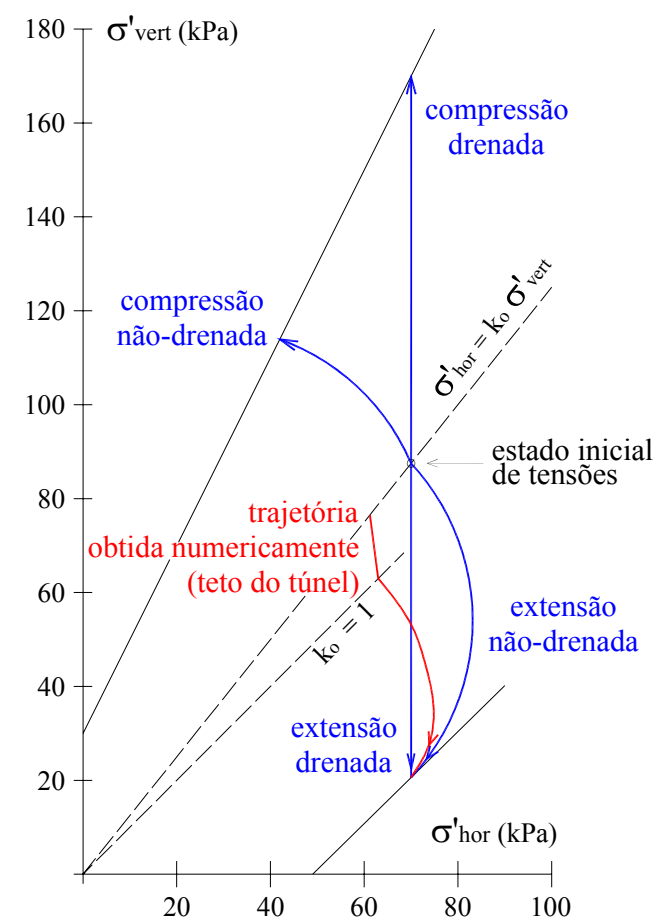

a) trajetórias de tensões

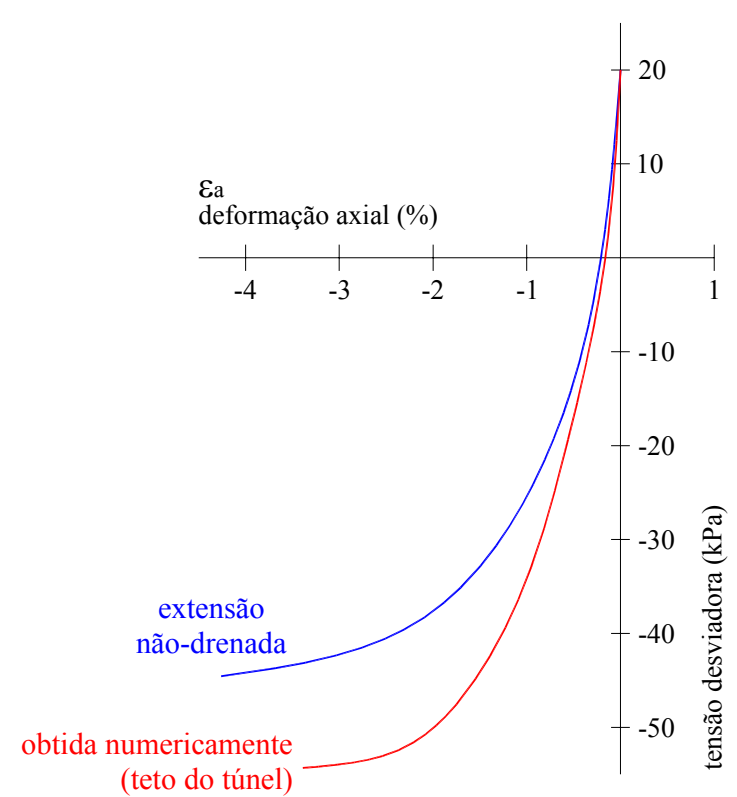

b) curvas tensão-deformação

Figura 4.16 - Ensaios triaxiais realizados por $\mathrm{Ng}$ e Lo (1985)

Além destes ensaios, $\mathrm{Ng}$ e Lo (1985) também realizaram ensaios triaxiais seguindo trajetórias de tensões obtidas numericamente. Foram utilizados elementos finitos com um modelo constitutivo elasto-plástico para simular a execução do túnel e, assim, obter as trajetórias para um ponto no teto do túnel e outro em sua lateral.

A trajetória de tensões para o teto do túnel, também apresentada na Figura 4.16 (a), foi escolhida por ser semelhante à trajetória do ensaio de extensão não-drenada. Segundo Ng e Lo (1985), como pode se observar na Figura 4.16 (b), a comparação entre estes dois ensaios sugere que a variação do módulo de deformabilidade não é excessivamente sensível quanto à exatidão com que é seguida a trajetória de tensão. Entretanto, esta afirmação é válida apenas para pequenas deformações, sendo que para as deformações elasto-plásticas, ou até mesmo para as maiores deformações ainda do regime elástico, houve uma grande variação entre os dois ensaios. 


\subsection{COMPortamento MECÂNICO do SOlo EM ESTUdo}

O estudo do comportamento mecânico do solo será realizado em termos de compressibilidade, permeabilidade, relações tensão-deformação, avaliação do grau de estruturação e envoltórias de escoamento, de ruptura e de Estados Críticos. Para isso, três séries de ensaios laboratoriais foram executadas, sendo elas: ensaios sob condições edométricas, sob condições triaxiais de carregamento e sob condições triaxiais de descarregamento.

\subsubsection{Condições edométricas}

Foram executados três ensaios de compressão unidimensional com deformação lateral nula (ensaios edométricos), de acordo com a norma NBR 12007. Os ensaios foram realizados com incrementos de tensão axial, dobrando-se a carga a cada estágio de carregamento e tendo os estágios um intervalo de 24 horas (exceto aos finais de semana). Os corpos-de-prova foram inundados após o término do primeiro estágio de carregamento (de 1,25 kPa).

Dentre os três ensaios edométricos, dois foram executados em amostras indeformadas e um com uma amostra remoldada.

Para a apresentação dos resultados, foram calculados os índices de vazios referentes ao final do adensamento primário, com o intuito de se evitar a interferência da viscosidade do solo (adensamento secundário).

\subsubsection{Compressibilidade}

O estudo da compressibilidade foi baseado nos dois ensaios realizados em amostras indeformadas.

Para o nível de tensões ao qual a amostra estava submetida em campo, foram determinadas as tensões verticais efetivas antes e depois de um possível rebaixamento do lençol freático, utilizando-se as expressões (4.12) e (4.13), respectivamente.

$$
\begin{aligned}
& \sigma^{\prime}{ }_{v}=\gamma_{\text {sub }} \cdot z=10,5 \cdot 36 \cong 370 \mathrm{kPa} \\
& \sigma^{\prime}{ }_{v}=\gamma_{\text {nat }} \cdot z=20,4 \cdot 36 \cong 730 \mathrm{kPa}
\end{aligned}
$$


A partir destes valores aproximados, o segundo ensaio edométrico (nomeado de "edométrico cíclico") foi executado com dois ciclos de carregamento-descarregamentorecarregamento. Primeiramente, a amostra foi carregada até a tensão de $370 \mathrm{kPa}$ e descarregada. Em seguida, ela foi carregada até a tensão de $730 \mathrm{kPa}$ e descarregada novamente. Por fim, elevou-se o carregamento até a tensão máxima de $2560 \mathrm{kPa}$ e efetuou-se o último descarregamento. Este procedimento foi adotado para ajudar na visualização da tensão de escoamento, baseando-se nas condições de campo.

Na Figura 4.17 estão apresentados os resultados dos dois ensaios. Pode-se notar uma boa semelhança entre ambos, corroborando a coerência dos resultados.

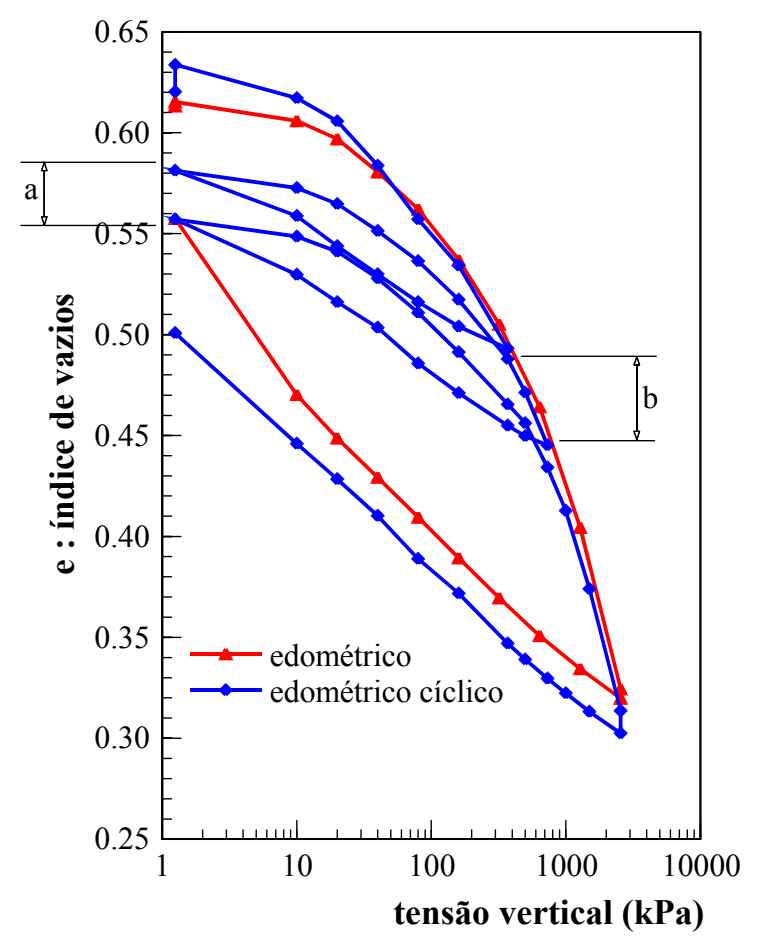

Figura 4.17 - Curvas de adensamento dos ensaios de compressão unidimensional

Ao final do primeiro ciclo de carga, pode-se notar que a amostra já apresenta deformação plástica irreversível. A deformação irreversível do segundo ciclo de carregamento (representada por “a”), referente à diferença entre o final do segundo descarregamento e o final do primeiro, pode ser comparada com a deformação total referente ao acréscimo de carga de 370 para $730 \mathrm{kPa}$ ("b"). Esta comparação mostra que os acréscimos de deformação possuem ordem de grandeza aproximada $(\mathrm{a} \approx \mathrm{b})$, sendo grande a parcela plástica. 
Ainda não se podem realizar afirmações sobre o escoamento do solo. É possível que a amostra tenha sofrido escoamento durante a amostragem, como ilustrado na Figura 4.18, interferindo nas conclusões. Ao ser atingida a curva de escoamento "de campo"durante o descarregamento (ponto B), esta pode se deslocar, sofrer rotação e encolher, obtendo o formato caracterizado posteriormente em laboratório. Cabe salientar que a trajetória A-B não é necessariamente a ocasionada pela amostragem, tendo sido apresentada desta forma unicamente como uma ilustração explicativa.
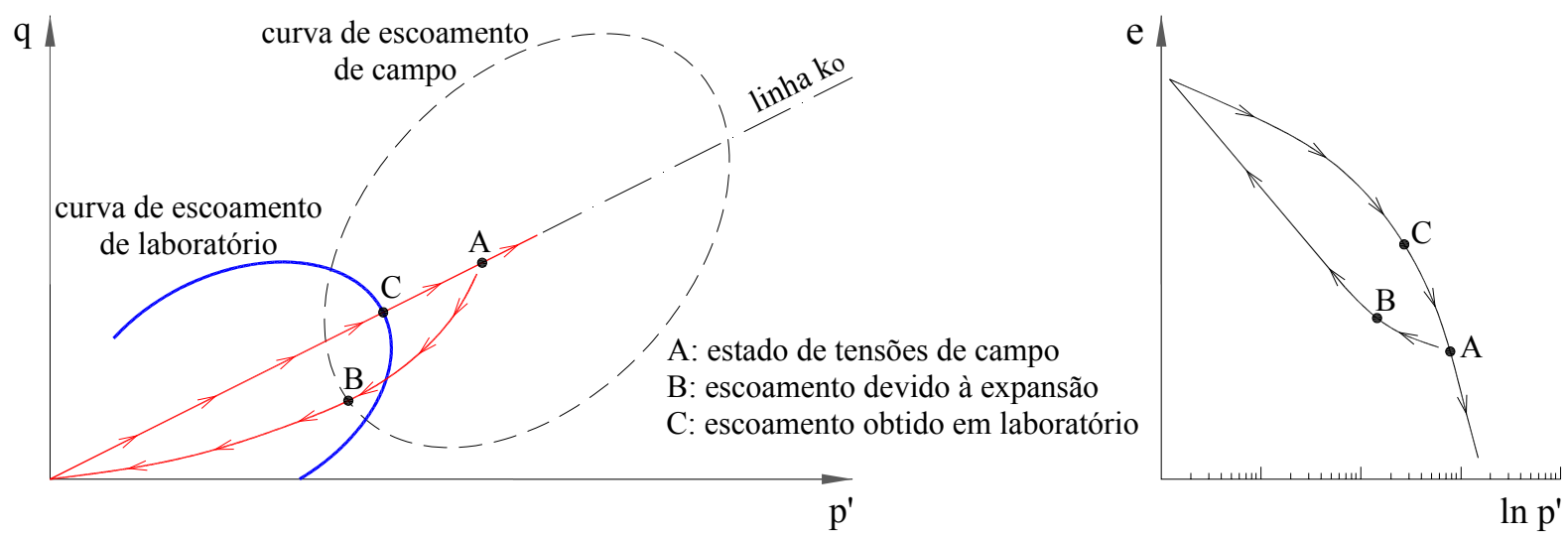

Figura 4.18 - Exemplo de encolhimento da curva de escoamento

Para a determinação da tensão de escoamento utilizou-se apenas o primeiro ensaio edométrico, tendo-se em vista que os ciclos de carregamento efetuados para o segundo ensaio interferiram em seu "sobre-adensamento". Quando representado em escala linear, como na Figura 4.19 (a), o gráfico de adensamento não apresenta nenhum ponto característico de mudança no comportamento mecânico. De acordo com Pinto e Nader (1991) e Pinto et al. (1993), nesta situação, é possível a aplicação dos processos convencionais para determinação da tensão de escoamento, em gráficos com escala semi-logarítmica. A tensão de escoamento, para os ensaios edométricos, foi obtida de acordo com a Figura 4.19 (b), pelo processo de Pacheco Silva (1970), sendo igual a $370 \mathrm{kPa}$.

Pode-se verificar um comportamento aproximadamente linear após o escoamento, caracterizando a linha de compressão normal (ou "reta virgem"). Quanto à curva de compressão antes do escoamento, baseando-se em Smith et al. (1992), podem-se definir claramente dois trechos lineares (um ponto de escoamento a mais), como visto na Figura 4.20, dividindo o trecho elástico em duas partes: quasi-elástico e pseudo-elástico. 


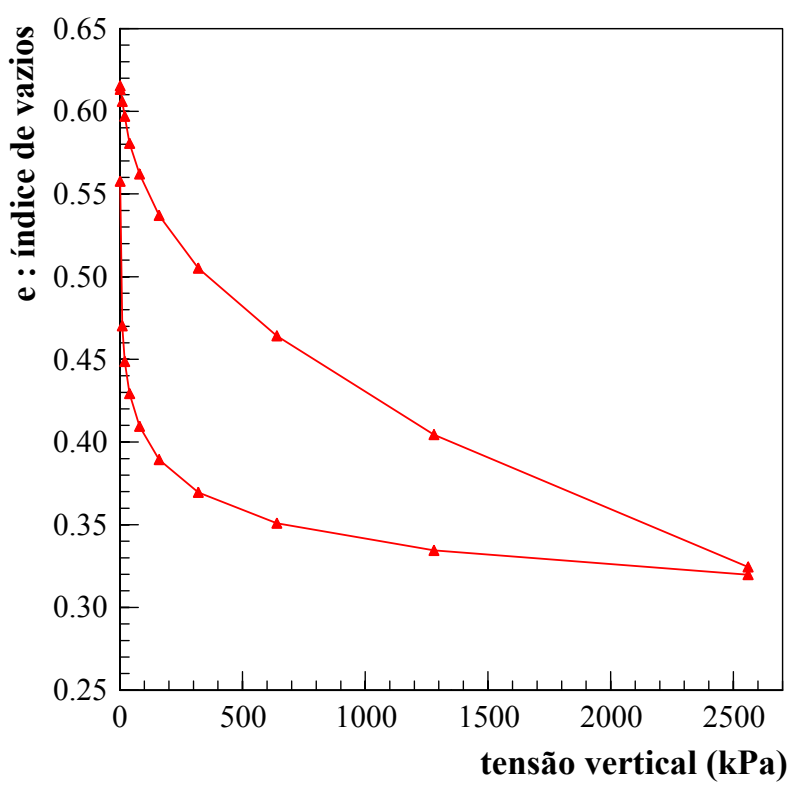

a) escala linear

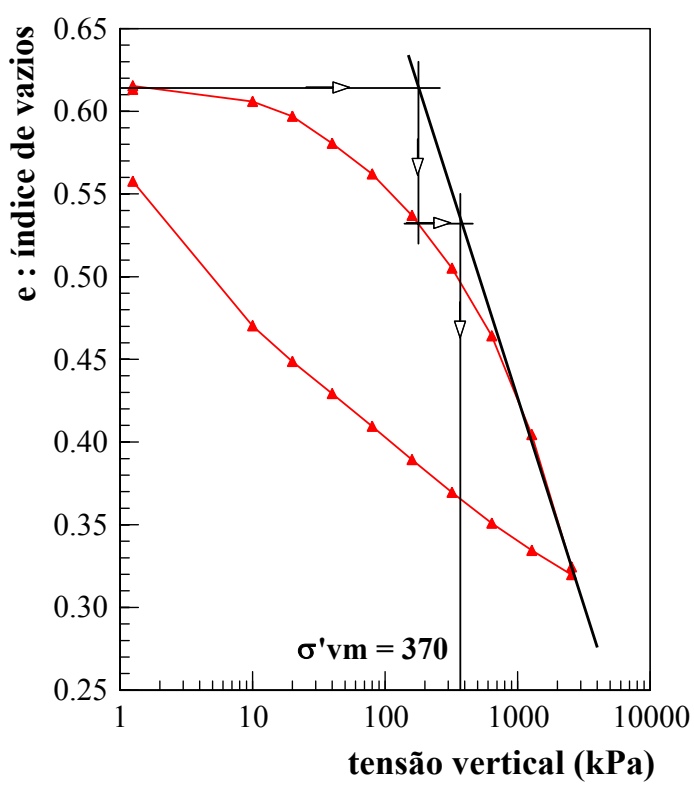

b) escala semi-logarítmica

Figura 4.19 - Obtenção da tensão de escoamento para o ensaio edométrico

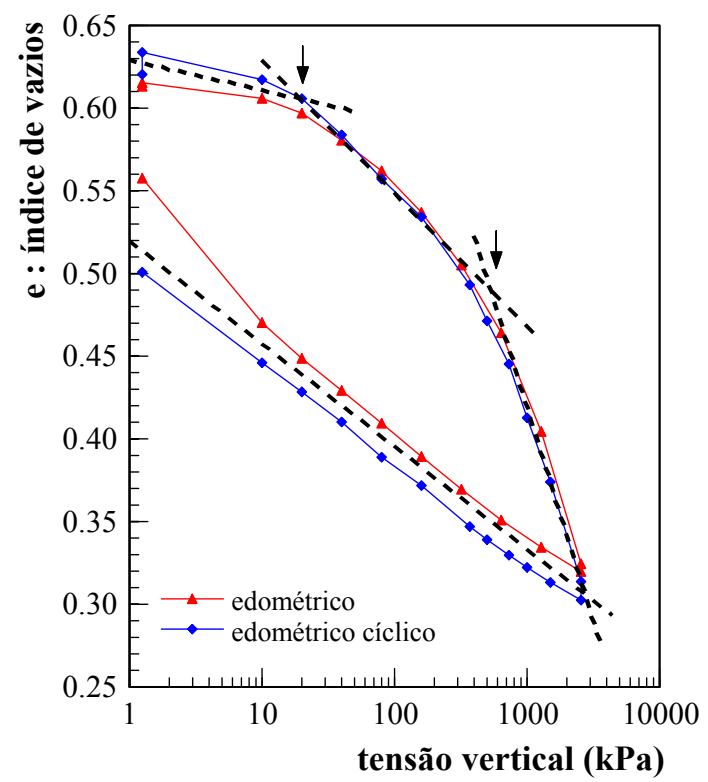

Figura 4.20 - Subdivisão do trecho pré-escoamento dos ensaios edométricos

O valor obtido da tensão de escoamento está próximo ao da tensão vertical efetiva de campo, ao nível da amostragem. Entretanto, isto não significa que o solo se encontra na situação de normalmente adensado. Aparentemente, este fato não passa de mera coincidência, tendo-se em vista que a diminuição da pressão neutra, decorrente da drenagem instalada no túnel, acarretou um aumento de tensão efetiva na amostra. O fato mais provável de ter ocorrido é a hipótese de que a envoltória de escoamento tenha encolhido e/ou se deslocado, devido ao descarregamento causado pela amostragem. 
O Índice de Compressão (Cc) e o Índice de Recompressão (Cr) foram obtidos de acordo com a Figura 4.21 (a), sendo iguais a 0,214 e 0,062, respectivamente.
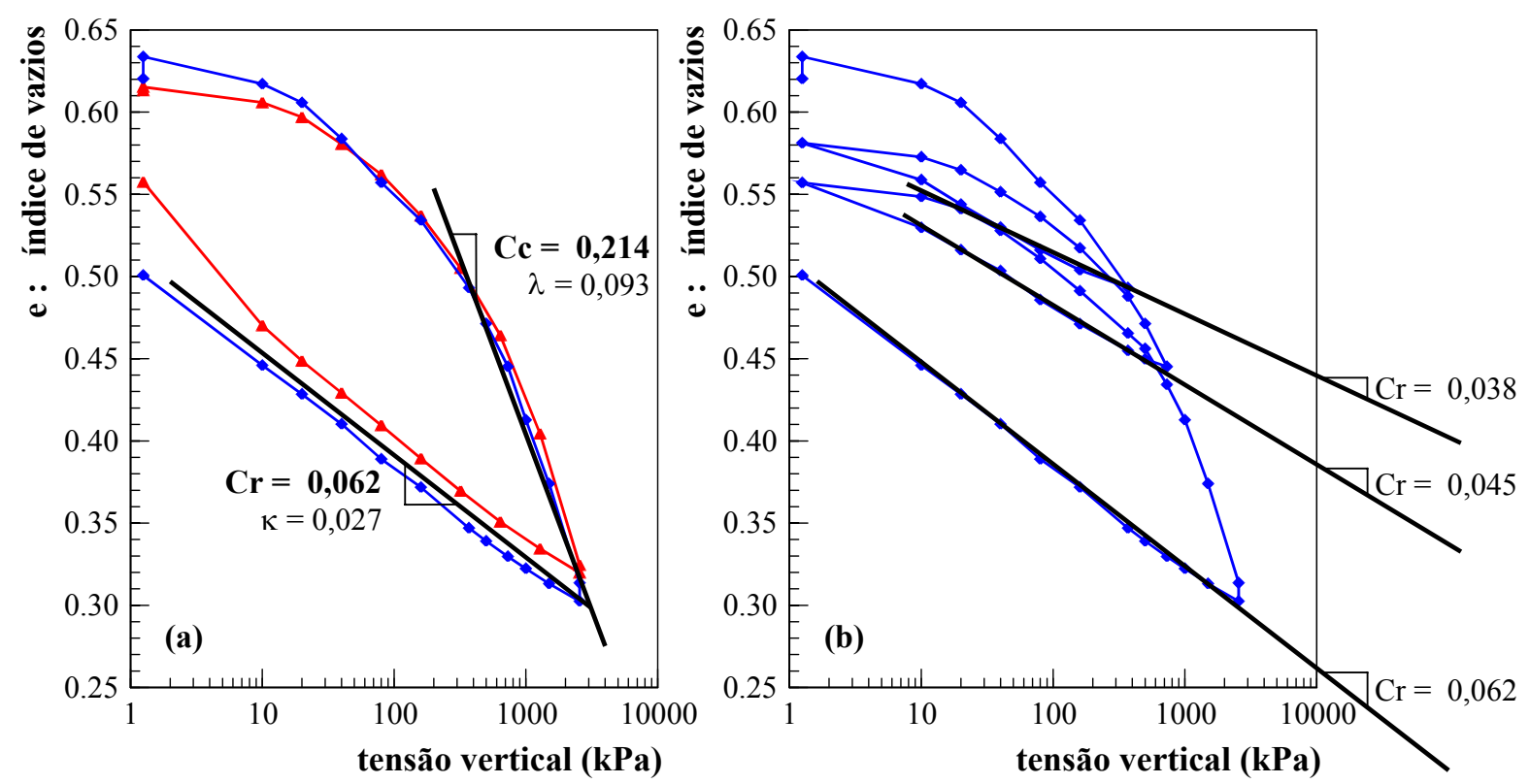

Figura 4.21 - Obtenção dos índices de compressão e de recompressão

A expansão "mecânica", devida ao descarregamento, assume um aspecto linear bem definido e com uma inclinação acentuada. A inclinação da reta de descarregamento, que neste caso está representada pelo índice $\mathrm{Cr}$, usualmente possui valor igual a $10 \%$ de $\mathrm{Cc}$. No caso do solo em estudo, Cr é igual a $29 \%$ de Cc (cerca de três vezes mais inclinada).

A reta de descarregamento não possui inclinação coincidente com o trecho de carregamento pré-escoamento. Se este trecho for considerado subdividido, como apresentado na Figura 4.20, o início do carregamento (quasi-elástico) continua com uma inclinação bem diferente e o trecho seguinte (pseudo-elástico) apresenta uma inclinação próxima à da reta de descarregamento.

Como pode ser observado na Figura 4.21 (b), à medida que o solo é submetido a maiores níveis de tensão e em seguida descarregado, a inclinação da reta de descarregamento aumenta. Ou seja, o solo apresenta uma expansividade maior se carregado a uma tensão maior. Este fenômeno é devido à presença (e predominância) do mineral micáceo biotita, nas frações silte e argila, e à microestrutura composta pelo empilhamento destas placas. As partículas de mica poderiam trabalhar como pequenas lajes apoiadas que são fletidas ao serem carregadas e, ao serem descarregadas, elas voltam ao seu estado plano. 
Ambos os ensaios apresentaram expansão inicial, após o estágio de saturação da amostra. $O$ primeiro ensaio obteve $\varepsilon_{\mathrm{p}}=-0,125 \%$ e o segundo ensaio (edométrico cíclico) obteve $\varepsilon_{\mathrm{p}}=-0,825 \%$. A partir destes valores, o solo em estudo pode ser classificado como não expansivo. Esta expansão por saturação é devida à existência do grupo de argilo-minerais esmectita, cuja identificação no solo foi apresentada no capítulo anterior. Sabe-se que a expansão causada por inundação é tão maior quanto mais seca a amostra. Com isto, acreditase que o solo apresentaria uma maior expansão caso estivesse com um grau de saturação menor do que o existente, que é de 97,5\%.

$\mathrm{O}$ fato de apresentar uma expansividade maior tanto quanto mais carregado, indica que o solo, mesmo sendo não-expansivo no estado natural, torna-se muito expansivo quando compactado.

Em ambos os ensaios edométricos, para cada estágio de carregamento, tentou-se determinar o valor do coeficiente de adensamento $(\mathrm{Cv})$ de acordo com o processo de Taylor. Porém, como o adensamento primário de cada estágio ocorreu antes de 30 segundos, os primeiros pontos necessários para o traçado da reta de adensamento primário ocorreram antes da primeira leitura, de 7 segundos. Ou seja, devido à elevada velocidade de adensamento, não foi possível a determinação do coeficiente de adensamento do solo em estudo.

\subsubsection{Avaliação do grau de estruturação}

O grau de estruturação do solo em estudo foi avaliado sob condições edométricas, utilizando-se três ensaios: os dois primeiros com amostras naturais saturadas, apresentados anteriormente; e um último com uma amostra remoldada, espatulada vigorosamente e colocada acima do limite de liquidez, com aspecto de lama. A Figura 4.22 apresenta os resultados destes ensaios.

A idealização de comportamento proposta por Leroueil e Vaughan (1990), anteriormente apresentada na Figura 4.9, de que a curva de um solo desestruturado é mais compressível e cruza a curva do solo na condição natural saturada, não é verificada para o solo em estudo. Pode-se notar uma clara diferença entre as curvas, mas não se pode afirmar ainda que esta diferença é devida à presença de estruturação entre as partículas. 


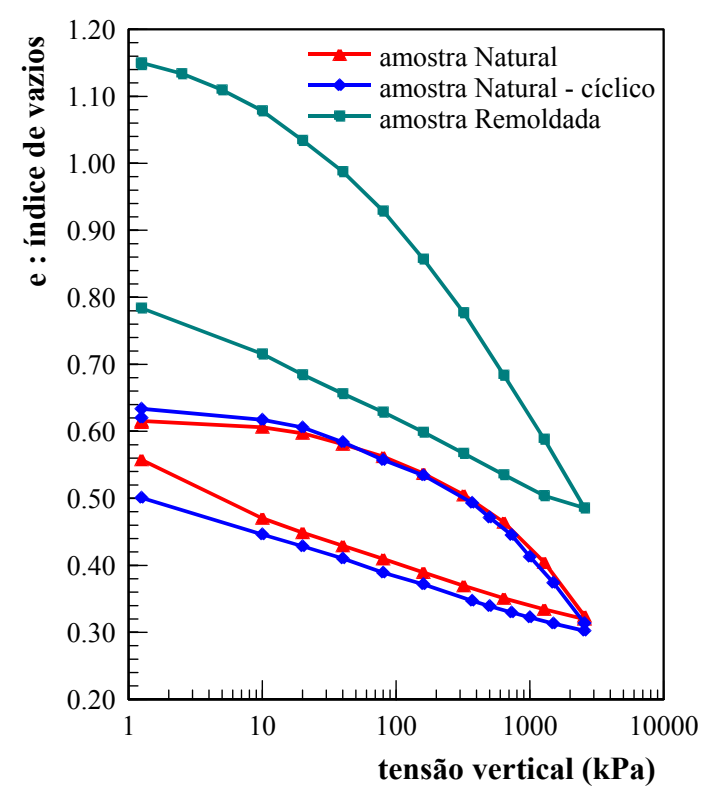

(a) escala semi-logarítmica

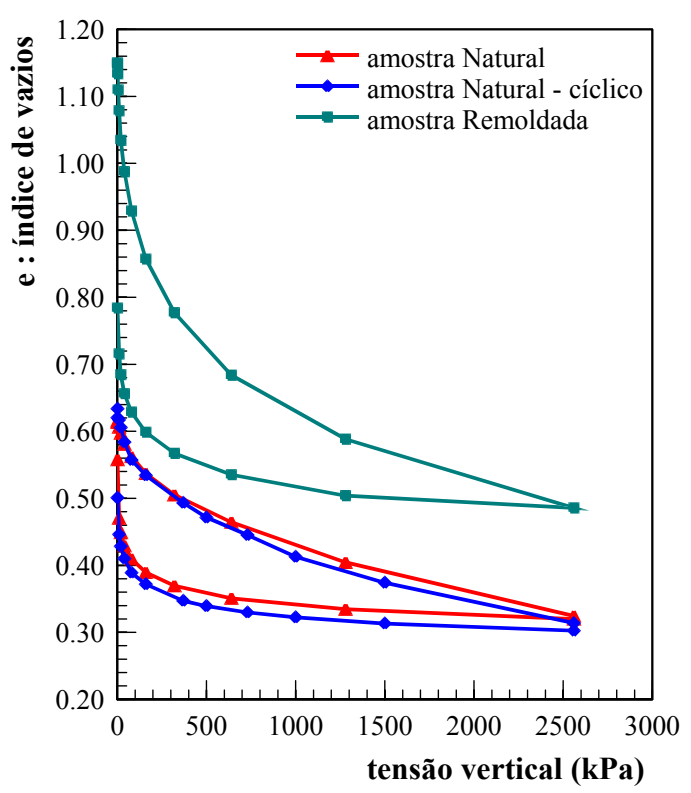

(b) escala linear

Figura 4.22 - Curvas de compressão edométrica para as amostras naturais e remoldada

Algumas observações podem ser feitas a respeito dos resultados de compressão apresentados: a amostra remoldada na condição de lama é menos rígida (mais compressível) e possui maiores índices de vazios, mas sua curva possui formato semelhante às curvas das amostras naturais, em ambas as escalas semi-logarítmica e aritmética. A amostra remoldada não deveria apresentar tensão de escoamento, apesar de o gráfico instigar a adoção de um valor próximo a $40 \mathrm{kPa}$.

Para uma melhor identificação da presença de estruturação, foram seguidos os procedimentos indicados por Futai (2002), descritos na seqüência, para normalizar as curvas de compressão.

Existem casos como o do solo em estudo, em que amostras na condição remoldada em $\mathrm{W}_{\mathrm{L}}$ apresentam índices de vazios maiores do que as amostras naturais, mesmo após adensadas a elevados níveis de tensão; ou então casos com índices de vazios menores do que as amostras naturais. Em ambos os casos, a simples comparação das curvas de adensamento não fornece resultados suficientes sobre a estruturação. Frente a esta grande variação dos índices de vazios iniciais, pode-se utilizar a deformação volumétrica $\left(\varepsilon_{\mathrm{p}}\right)$ para comparar as curvas de compressão, como apresentado na Figura 4.23. 


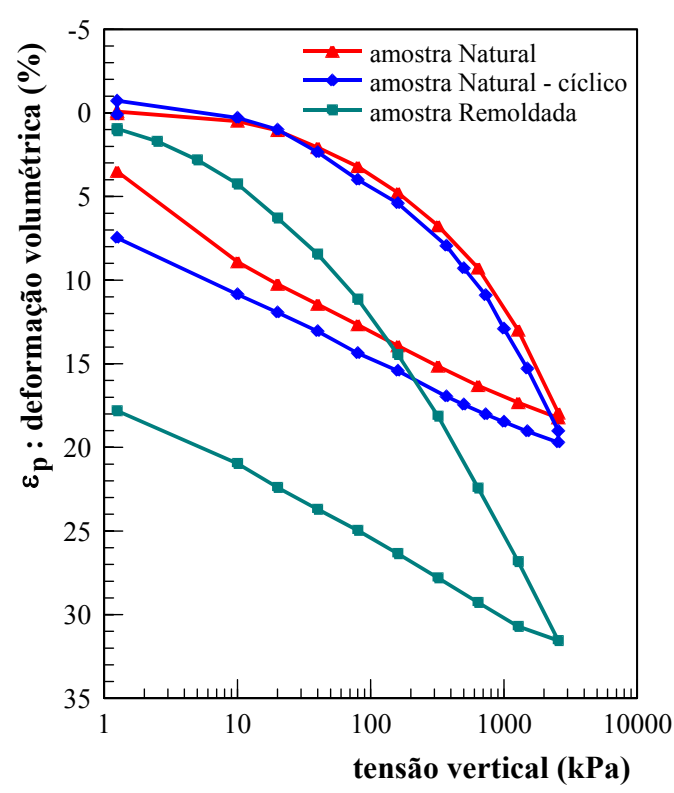

(a) escala semi-logarítmica

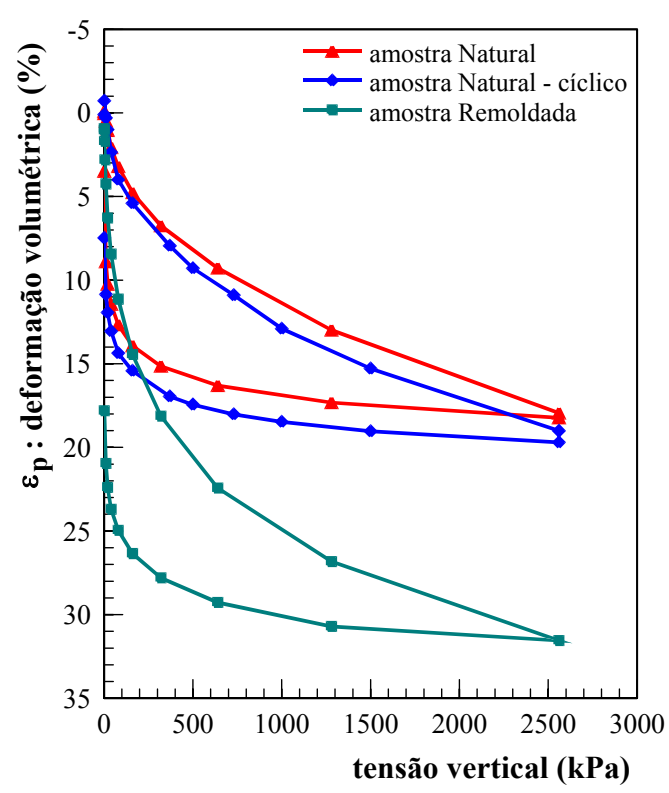

(b) escala linear

Figura 4.23 - Utilização da deformação volumétrica nas curvas de compressão edométrica

A utilização da deformação volumétrica normaliza a parte inicial das curvas (antes do escoamento), sendo válida para solos de mesma gênese e diferentes índices de vazios iniciais. Com a utilização do índice de vazios, as curvas tendem a convergir para uma mesma linha de compressão normal. Porém, ao se utilizar a deformação volumétrica, as curvas passam a divergir após o escoamento.

Para induzir a convergência após o escoamento, foi utilizado o Índice de deformação normalizada $\left(\mathrm{I}_{\varepsilon}\right)$, caracterizado por uma variação máxima de índice de vazios igual ao índice de vazios inicial e apresentado na equação (4.14). Obviamente, não podem ser expulsos por compressão todos os vazios existentes no solo, devido às limitações físicas e físico-químicas, mas esta simplificação foi adotada para se obter a deformação volumétrica máxima. Também não foi considerada a deformação dos grãos sólidos.

$$
I_{\varepsilon}=\frac{\varepsilon_{p}}{\varepsilon_{p} \operatorname{máx}}=\frac{\frac{\Delta e}{1+e_{0}}}{\frac{e_{0}}{1+e_{0}}}=\frac{\Delta e}{e_{0}}
$$

As curvas de compressão com a deformação volumétrica normalizada são apresentadas na Figura 4.24. Nota-se que agora as curvas convergem após o escoamento. 


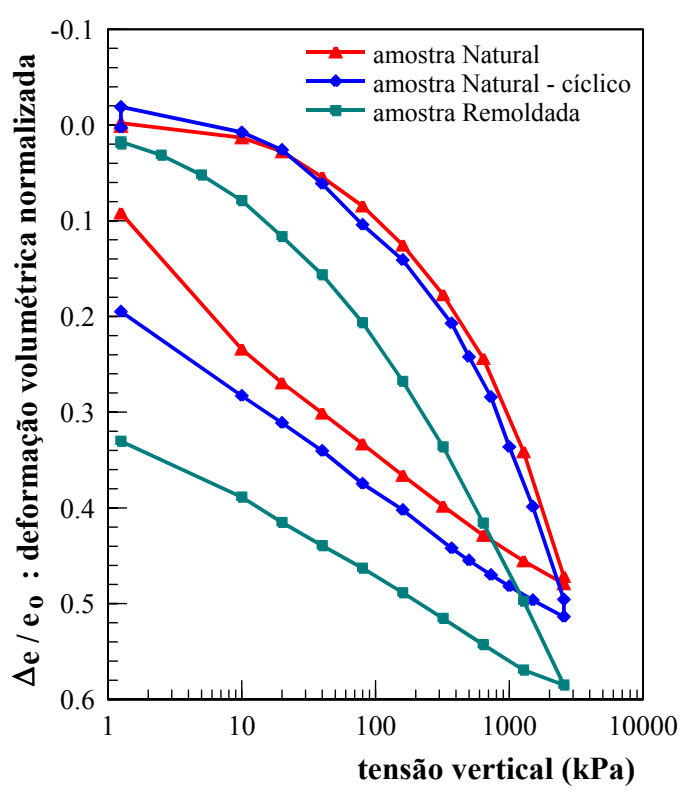

(a) escala semi-logarítmica

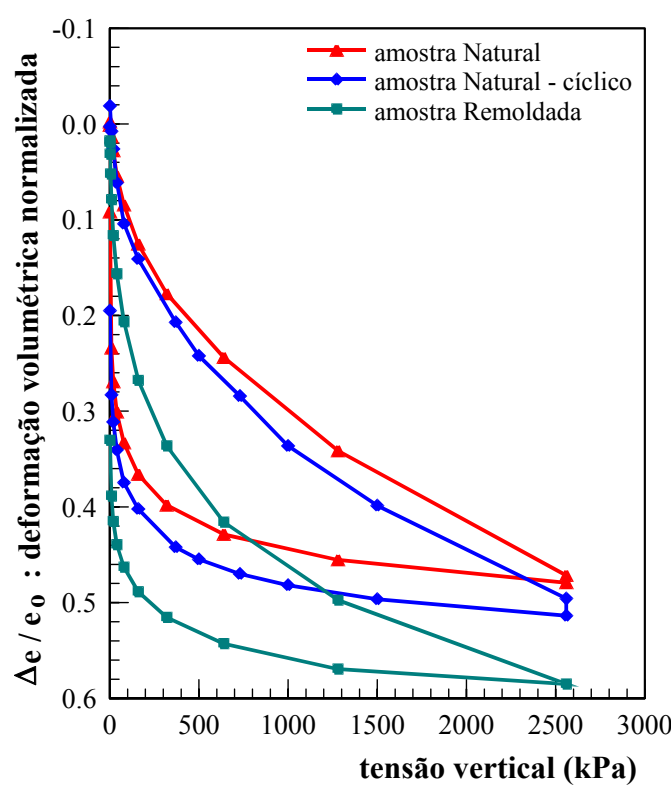

(b) escala linear

Figura 4.24 - Normalização das curvas de compressão edométrica

Após ser reduzida a influência dos índices de vazios iniciais, pode-se notar que as tensões de escoamento continuam diferentes. Para se reduzir também o efeito da tensão de escoamento, utilizou-se o conceito de índice de desestruturação (ID), idealizado por Futai (1999) e apresentado na equação (4.15), caracterizado como a relação entre a tensão efetiva e a tensão de escoamento.

$$
I D=\frac{\sigma_{{ }_{v}}^{\prime}}{\sigma_{v m}^{\prime}}
$$

As curvas de compressão com a deformação volumétrica normalizada e o índice de desestruturação são apresentadas na Figura 4.25, onde todas as curvas têm escoamento em ID igual 1, além de não existir mais a influência dos índices de vazios iniciais.

$\mathrm{Na}$ Figura 4.25, considerou-se uma tensão de escoamento igual a $40 \mathrm{kPa}$ para a amostra remoldada. No gráfico em escala semi-logarítmica, observa-se um trecho inicial curvo antes de ser alcançada a reta de compressão normal. É possível que, após a remoldagem, o solo tenha se reestruturado um pouco, em função da presença de placas micáceas nas frações silte e argila. 


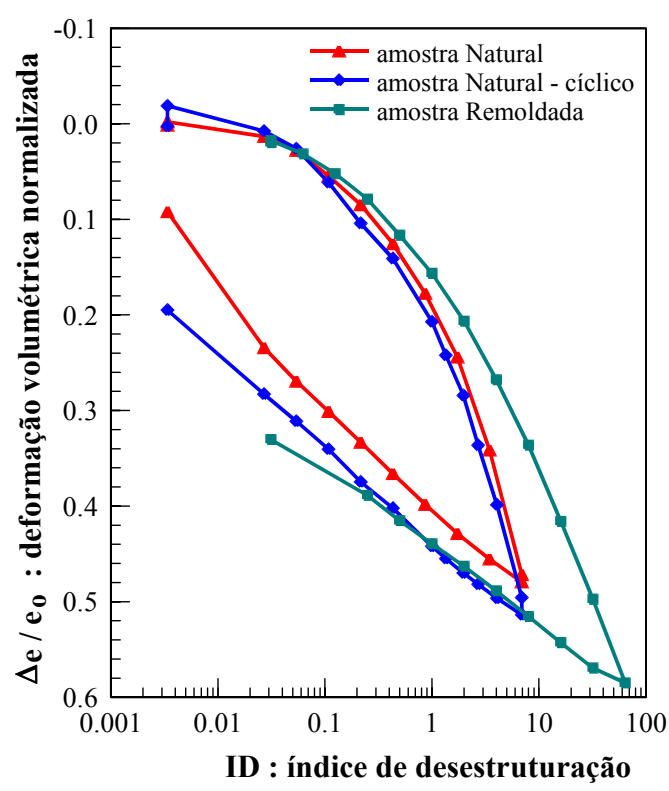

(a) escala semi-logarítmica

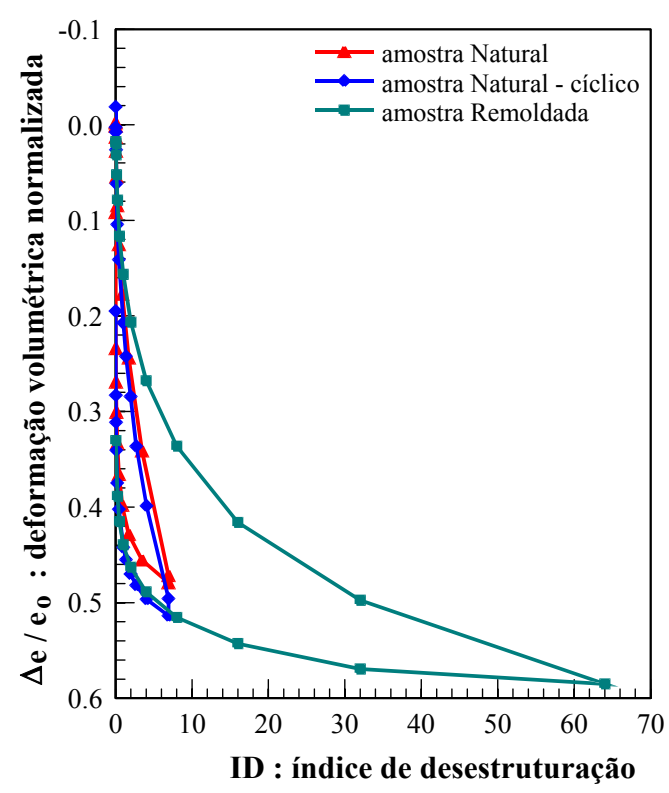

(b) escala linear

Figura 4.25 - Influência da estrutura nas curvas de compressão edométrica

Pode-se afirmar que a tensão de escoamento é influenciada por dois fatores principais: o índice de vazios e a estruturação. Segundo Futai (2002), tendo-se minimizado o efeito do índice de vazios e tendo todas as curvas com escoamento no mesmo valor de ID, conclui-se que o efeito da estruturação de um solo é o responsável pela diferença existente entre curvas de compressão.

Pela Figura 4.25, percebe-se uma diferença entre as curvas de compressão, principalmente nos trechos referentes à linha de compressão normal, podendo-se afirmar que o solo é estruturado. A estrutura é governada pelo arranjo e organização das partículas não cimentadas. O escoamento do solo, portanto, depende diretamente da perda de estruturação, e não exclusivamente da variação de sua densidade relativa (índice de vazios).

\subsubsection{Permeabilidade}

Foram realizados ensaios de permeabilidade com carga hidráulica variável, de acordo com a NBR 14545, ao término de cada estágio de carregamento dos ensaios edométricos. Os ensaios foram executados instalando-se uma bureta graduada conectada a um dos drenos da base da célula de adensamento, resultando em um fluxo ascendente no corpo-de-prova.

Todos os valores obtidos para o coeficiente de permeabilidade $(\mathrm{k})$ estão apresentados referidos à temperatura de $20^{\circ} \mathrm{C}$, podendo ser visualizados na Figura 4.26. 


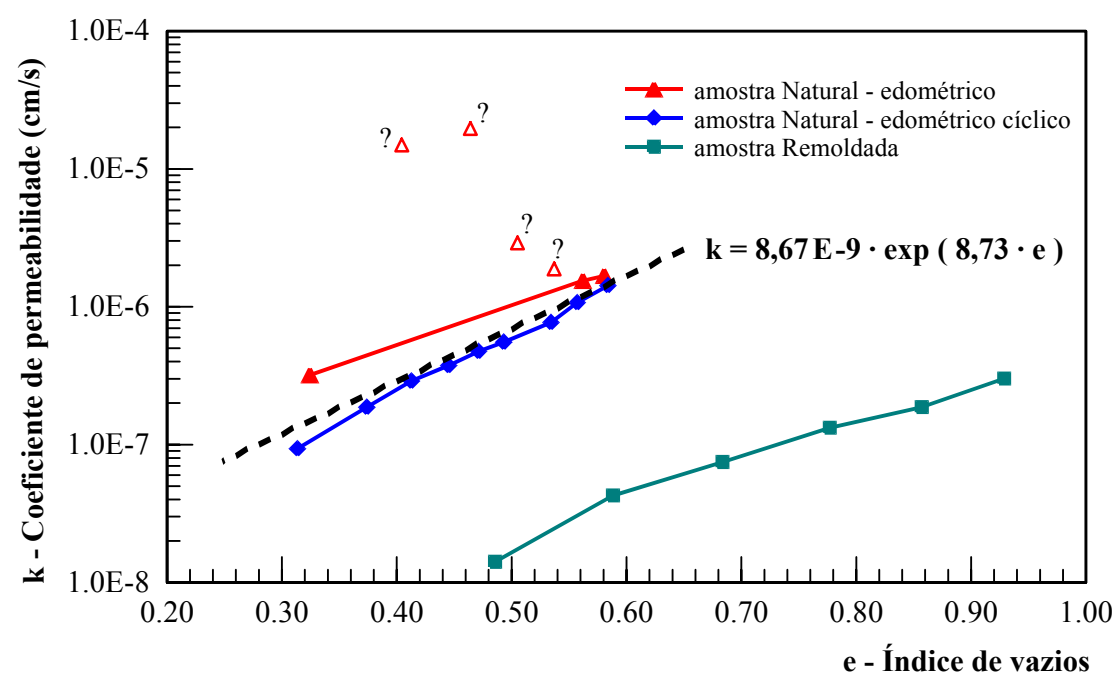

Figura 4.26 - Coeficiente de permeabilidade para os ensaios edométricos

Os resultados foram coerentes, tendo-se em vista que a permeabilidade diminuiu com o aumento da tensão e conseqüente diminuição do índice de vazios. Os pontos de maior dispersão estão indicados na figura pelo símbolo “?”, sendo possível que durante seus respectivos estágios de carregamento tenha se formado um caminho preferencial, interrompido com o aumento de tensão.

Desprezando-se estes valores de maior dispersão, os demais possibilitaram a obtenção da equação da melhor reta:

$$
\mathrm{k}=8,67 \cdot 10^{-9} \cdot \exp (8,73 \cdot \mathrm{e})
$$

Apesar do índice de vazios natural ser igual a 0,602, para o nível de tensões de campo $(370 \mathrm{kPa})$ o correspondente índice de vazios é aproximadamente igual a 0,500. A partir deste valor, pode-se adotar um coeficiente de permeabilidade da ordem de $7.10^{-7} \mathrm{~cm} / \mathrm{s}$.

Também foram obtidos valores de coeficiente de permeabilidade durante o ensaio edométrico com a amostra remoldada. Como pode ser visto na figura apresentada, para um mesmo valor de índice de vazios (ou para um mesmo nível de tensão), a permeabilidade da amostra remoldada é menor do que a da amostra natural, como esperado (VARGAS, 1978).

Os valores dos coeficientes de permeabilidade obtidos em laboratório são comumente criticados quanto ao fato dos corpos-de-prova não representarem toda a heterogeneidade, anisotropia, fissuras e outras características encontradas em campo. Entretanto, as condições de ensaio são muito melhor estabelecidas, resultando em uma caracterização melhor controlada. Cabe ressaltar que tais parâmetros são independentes das variações de campo. 


\subsubsection{Condições triaxiais de carregamento axial}

Foram realizados seis ensaios triaxiais nomeados de (1) a (6), denominados como sendo de "carregamento axial" por ter sido imposto um aumento de tensão axial durante a fase de cisalhamento e mantida constante a tensão confinante. O procedimento de execução destes ensaios triaxiais pode ser encontrado no Apêndice B.

Para a realização dos ensaios, utilizou-se uma prensa Bishop-Wesley servo controlada, apresentada em Bishop e Wesley (1975), existente no Laboratório de Mecânica dos Solos da Escola Politécnica da USP.

Os corpos-de-prova foram moldados mantendo-se o sentido vertical de campo e saturados por percolação de água, da base para o topo, seguida da aplicação de contra-pressão. O corpo-de-prova foi considerado saturado desde que o parâmetro $\bar{B}$ de Skempton (1954) calculado tenha sido maior do que 0,98 .

Os dois primeiros ensaios executados, nomeados como (3) e (6), foram realizados com aumento da tensão axial (tensão controlada). Os ensaios seguintes foram realizados impondose ao corpo-de-prova um deslocamento vertical ascendente (deformação controlada), utilizando-se um pistão CRSP (Controlled Rate Strain/Pressure) que aplicou uma velocidade de deformação de $0,025 \% / \mathrm{min}$. A trajetória de tensões desejada foi obtida controlando-se a tensão confinante.

Foi utilizada drenagem pela base e pelo topo em todos os ensaios, durante as fases de adensamento e cisalhamento. Foram realizados dois tipos de ensaios: o CID (adensado isotropicamente e cisalhado com drenagem) e o CAD (adensado anisotropicamente e cisalhado com drenagem).

O adensamento seguiu a trajetória de tensões referente a cada ensaio, com a velocidade citada anteriormente. Ao ser alcançado o nível de tensões desejado, este foi mantido até o dia seguinte, momento no qual se iniciou a fase de cisalhamento. Ou seja, o adensamento teve duração aproximada de um dia.

A fase de cisalhamento se iniciou após serem zerados os valores de deslocamento axial e variação volumétrica, calculando-se as novas dimensões do corpo-de-prova e o valor do índice de vazios.

A medida da carga axial foi efetuada por uma célula de carga submersível, instalada internamente à câmara triaxial. Foram utilizados transdutores para medir a tensão confinante e a contra-pressão da base e do topo do corpo-de-prova. O deslocamento axial foi medido 
externamente por um transdutor, o qual foi acoplado ao pistão responsável pela aplicação da carga axial. A variação de volume do corpo-de-prova foi obtida por meio de um medidor de volume automático, exigindo a saturação do corpo-de-prova. Não foram utilizados transdutores internos, devido à sua indisponibilidade no laboratório.

Os dados foram coletados automaticamente pelo sistema de aquisição e, após serem analisados pelo sistema de controle, este providenciava as correções necessárias para as tensões. Em seqüência iniciava-se um novo ciclo de leitura de dados e correções de tensões.

\subsubsection{Trajetórias de tensões utilizadas nos ensaios}

As trajetórias de tensões dos ensaios triaxiais realizados podem ser visualizadas na Figura 4.27.

Com o intuito de simular a trajetória de tensões seguida na condição edométrica, realizou-se o ensaio triaxial (4) com deformação axial igual à deformação volumétrica, para a etapa de adensamento. Mais detalhes serão discutidos no item 4.2.2.8, ao ser estimado o valor do coeficiente de empuxo em repouso.

Devido a um problema de controle da tensão confinante, ocorrido durante a execução da fase de cisalhamento do ensaio (5), foram considerados apenas os dados referentes ao adensamento e à ruptura para este ensaio. A fase de cisalhamento (apresentada em tracejado na trajetória de tensões) não foi considerada para análise.

Os ensaios (1), (2) e (6) foram denominados como "ensaios de carregamento", pois foram submetidos à etapa de cisalhamento logo após a de adensamento. Os demais ensaios (3), (4) e (5) foram denominados como "ensaios de recarregamento", pois foram descarregados e recarregados durante a etapa de adensamento, antes de serem cisalhados. 


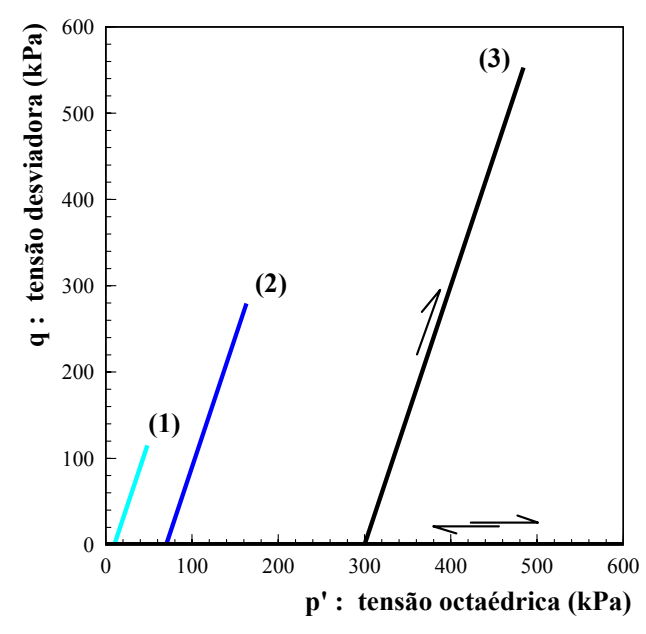

(a) ensaios CID

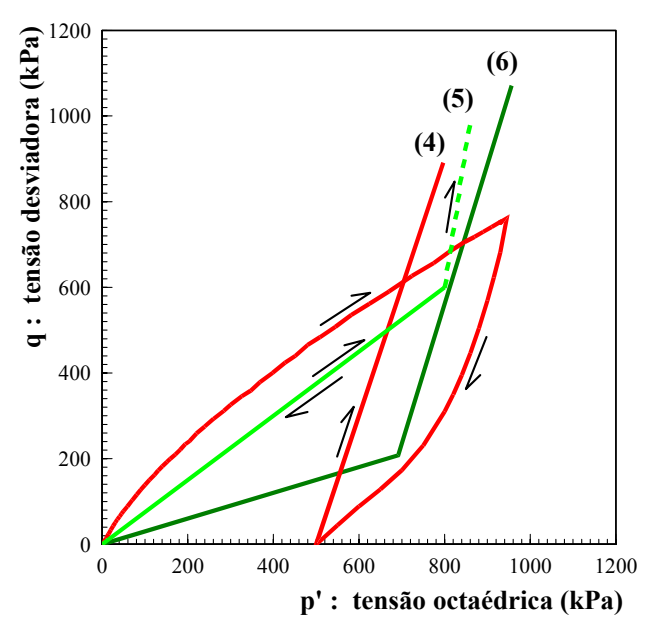

(b) ensaios CAD
(1) adensado isotropicamente até $\mathrm{p}^{\prime}=10 \mathrm{kPa}$, cisalhado com aumento da tensão axial e sem alteração da confinante $\left(\sigma^{\prime}{ }_{\mathrm{c}}=10 \mathrm{kPa}\right)$.

(2) adensado isotropicamente até $\mathrm{p}^{\prime}=70 \mathrm{kPa}$, cisalhado com aumento da tensão axial e sem alteração da confinante $\left(\sigma_{\mathrm{c}}=70 \mathrm{kPa}\right)$.

(3) adensado isotropicamente até p' $=600 \mathrm{kPa}$, descarregado isotropicamente até $\mathrm{p}^{\prime}=2 \mathrm{kPa}$, recarregado isotropicamente até p' $=300 \mathrm{kPa}$, cisalhado com aumento da tensão axial e sem alteração da confinante $\left(\sigma^{\prime}{ }_{\mathrm{c}}=300 \mathrm{kPa}\right)$.

(4) adensado de maneira que a deformação axial se igualasse à volumétrica $\left(\varepsilon_{\mathrm{a}}=\varepsilon_{\mathrm{p}}\right)$ até p' $=945 \mathrm{kPa}$, descarregado para o eixo isotrópico em p' $=500 \mathrm{kPa}$, cisalhado com aumento da tensão axial e sem alteração da confinante $\left(\sigma_{\mathrm{c}}{ }_{\mathrm{c}}=500 \mathrm{kPa}\right)$.

(5) adensado com $\mathrm{K}=0,50$ até p' $=800 \mathrm{kPa}$, descarregado com o mesmo $\mathrm{K}$ até $\mathrm{p}^{\prime}=2 \mathrm{kPa}$, recarregado com o mesmo $\mathrm{K}$ até p' $=800 \mathrm{kPa}$, cisalhado com aumento da tensão axial e variação da tensão confinante.

(6) adensado com $\mathrm{K}=0,75$ até $\mathrm{p}^{\prime}=675 \mathrm{kPa}$, cisalhado com aumento da tensão axial e sem alteração da confinante $\left(\sigma^{\prime}{ }_{\mathrm{c}}=600 \mathrm{kPa}\right)$.

Figura 4.27 - Trajetórias de tensões dos ensaios triaxiais de carregamento axial

\subsubsection{Compressibilidade}

Os resultados dos ensaios de compressão isotrópica e anisotrópica estão apresentados na Figura 4.28, referentes à etapa de adensamento dos ensaios triaxiais. Para fins de comparação, também foi inserido o resultado de um ensaio edométrico.

Todos os ensaios tiveram sua etapa de adensamento com duração aproximada de um dia, com o intuito de se evitar a interferência da viscosidade do solo (adensamento secundário). 


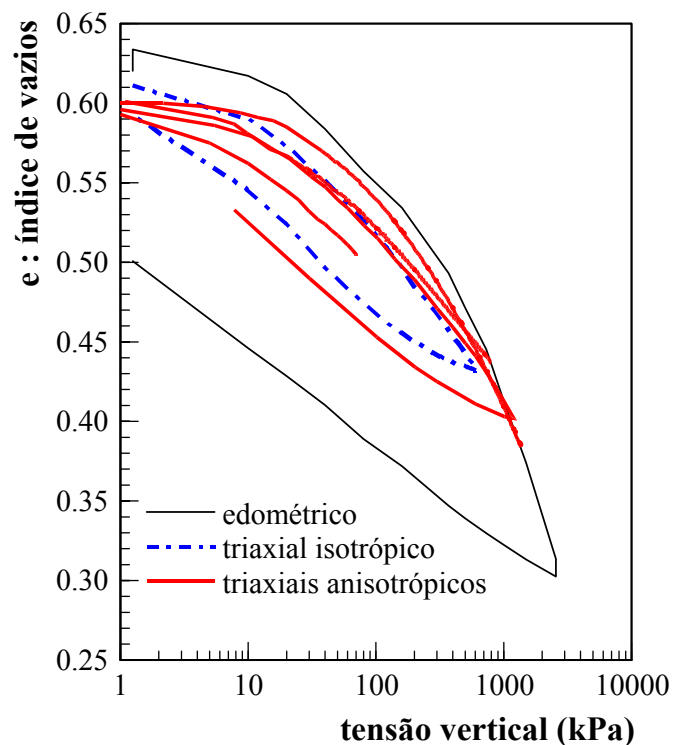

Figura 4.28 - Curvas de adensamento dos ensaios triaxiais de carregamento axial

Pode-se notar que as curvas dos ensaios triaxiais convergem para uma linha de compressão normal, porém não alcançaram o nível de tensões suficiente para que esta linha pudesse ser definida, como pôde ser feito com os ensaios edométricos. Em virtude disto, não puderam ser definidas as tensões de escoamento destes ensaios através da mesma metodologia utilizada para os ensaios edométricos.

Nas curvas de compressão triaxial, também podem ser encontrados os dois trechos lineares iniciais, quasi-elástico e pseudo-elástico.

As curvas de descarregamento dos ensaios triaxiais apresentam inclinação coerente em relação aos ensaios edométricos, sendo aproximadamente paralelas.

\subsubsection{Relações tensão-deformação}

As relações tensão-deformação estão apresentadas na Figura 4.29, resultantes dos ensaios triaxiais cujas trajetórias de tensões foram apresentadas na Figura 4.27.

Os ensaios (3) e (6) foram realizados com tensão controlada, por isso possuem ruptura abrupta (sem patamar de ruptura bem definido). Os demais ensaios foram realizados com deformação controlada, com uma velocidade média de $0,025 \% / \mathrm{min}$.

Todos os ensaios tiveram suas deformações zeradas ao início da etapa de cisalhamento. 


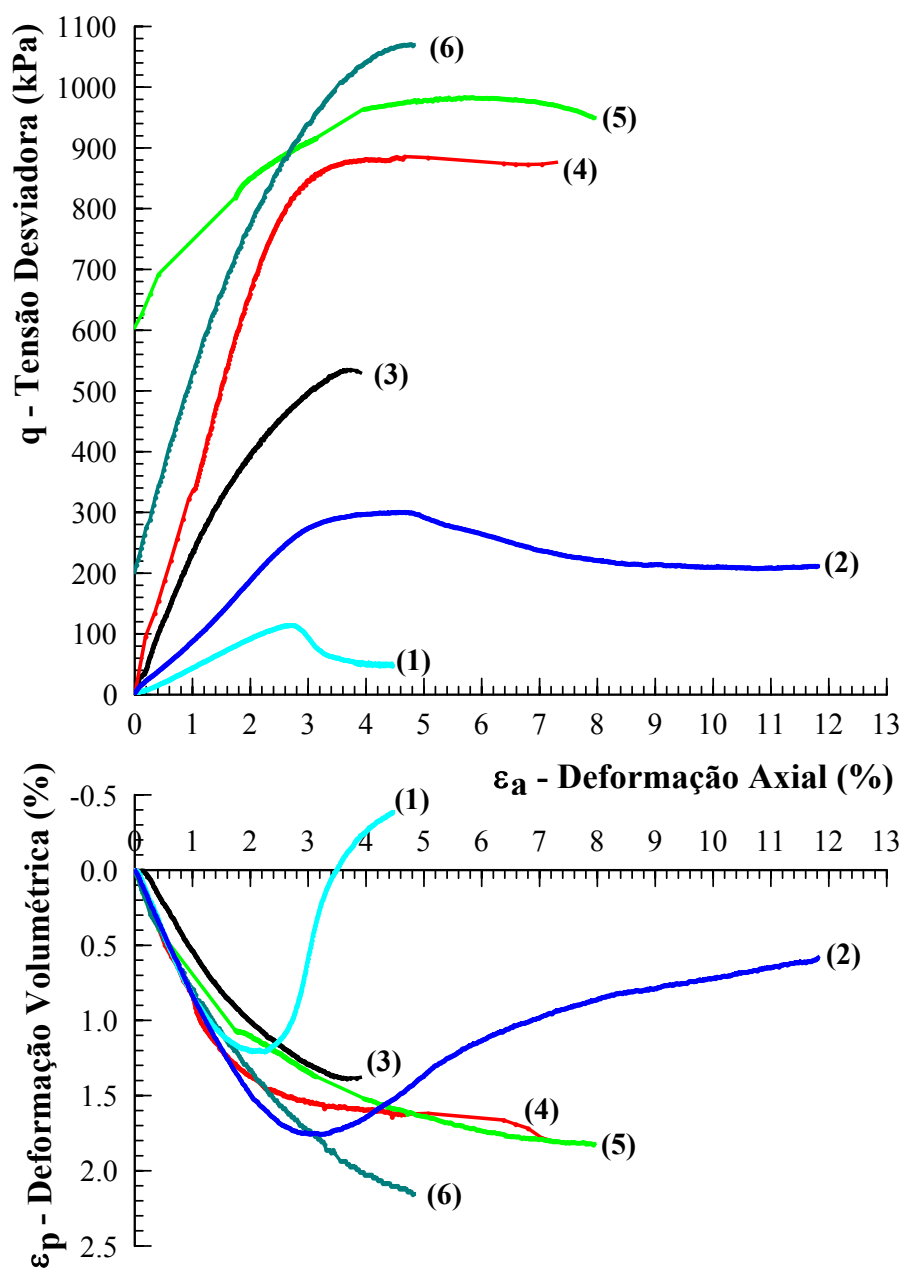

Figura 4.29 - Curvas tensão-deformação dos ensaios triaxiais de carregamento axial

Como pode ser observado na Figura 4.29, os ensaios apresentaram um aumento da rigidez em função do aumento da tensão confinante, como esperado. $O$ ensaio (5) não pode ser incluído nesta comparação, por ser o único com variação da tensão confinante durante a etapa de cisalhamento.

Pode-se notar um trecho inicial linear para os ensaios sobre-adensados (1) e (2), como esperado, e também para os ensaios sobre-adensados por recarregamento (3) e (4). Entretanto, isto também ocorre para o ensaio normalmente adensado (6).

Os ensaios fortemente sobre-adensados (1) e (2) obtiveram resistência de pico seguida de amolecimento, sendo os únicos a apresentar dilatância durante a ruptura.

Os ensaios (3) e (6) foram os únicos a apresentar plano de ruptura coincidente com um plano de descontinuidade, com ângulo em torno de 60 graus em relação à horizontal e cujo material de preenchimento foi estudado no capítulo anterior. O sentido vertical dos corpos-deprova é coincidente com o da amostra em campo. 
Todavia, não se podem efetuar afirmações sobre a resistência ao cisalhamento do material de preenchimento, tendo-se em vista que um conjunto de ensaios triaxiais deveria ter sido planejado com este propósito específico, incluindo uma variação no ângulo do plano de descontinuidade nos corpos-de-prova.

Por apresentar uma foliação metamórfica macroscópica marcante e nítidos planos de descontinuidade, não há dúvidas de que o solo em estudo deva apresentar uma anisotropia de comportamento mecânico. Entretanto, além dos ensaios triaxiais, ensaios de cisalhamento plano (plain strain tests) também deveriam ser executados para que esta anisotropia pudesse ser avaliada. Não foi possível realizar tais ensaios.

Pinto e Nader (1991) analisaram a heterogeneidade e anisotropia por meio de resultados de ensaios de cisalhamento plano. No caso de um material homogêneo e isotrópico, como o apresentado na Figura 4.30 (a), a ruptura é restrita aos planos perpendiculares ao plano principal intermediário, onde ocorre a maior obliqüidade de tensões. Neste caso, as resistências obtidas foram da mesma ordem de grandeza das resultantes dos ensaios de compressão triaxial. Para o material heterogêneo e anisotrópico, como o apresentado na Figura 4.30 (b), observaram-se planos de ruptura nas mais diversas posições. As resistências obtidas para este caso foram superiores às resultantes dos ensaios triaxiais.

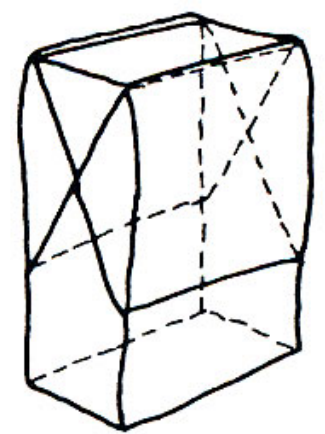

(a) material homogêneo

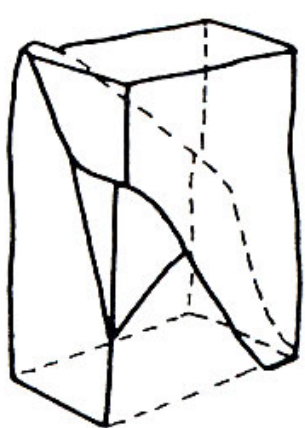

(b) material heterogêneo

Figura 4.30 - Ensaios de cisalhamento plano analisados por Pinto e Nader (1991)

\subsubsection{Avaliação do grau de estruturação}

A influência da estrutura no comportamento mecânico pode ser avaliada pelo posicionamento da máxima taxa de dilatância em curvas tensão-deformação de ensaios triaxiais sobre-adensados, como realizado por Maccarini (1987). 
As regiões de máxima taxa de dilatância dos ensaios com baixa tensão confinante (10 e $70 \mathrm{kPa}$ ) foram obtidas por meio da Figura 4.31, de acordo com a equação (4.9), e seu posicionamento encontra-se localizado na Figura 4.32.

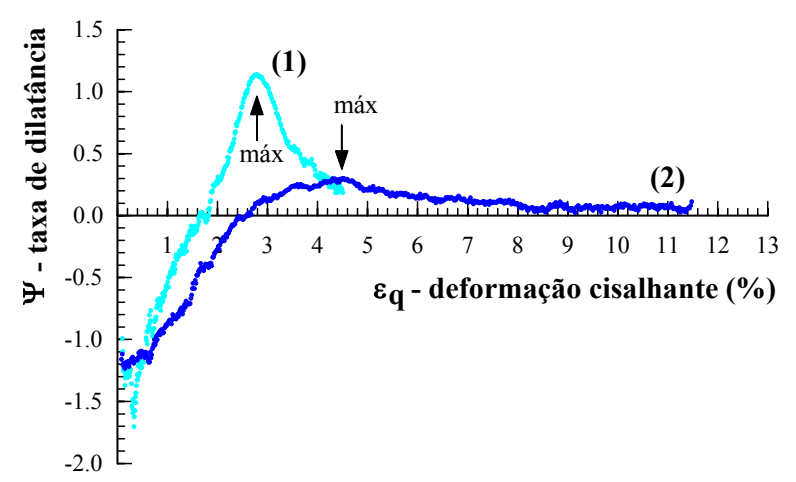

Figura 4.31 - Curvas de taxa de dilatância
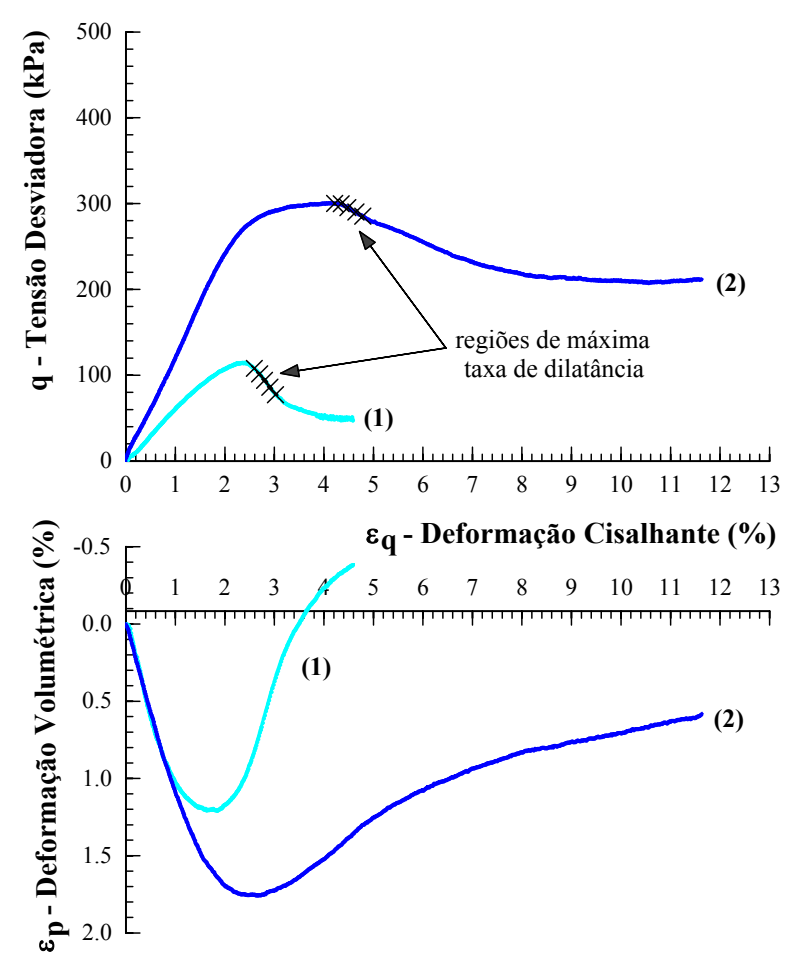

Figura 4.32 - Influência da estrutura na localização da máxima taxa de dilatância

A máxima taxa de dilatância não coincidiu com o pico de resistência, ocorrendo em deformações ligeiramente maiores. A razão desta diferença pode ser atribuída à cimentação do solo, como proposto por Vaughan et al. (1988). Apesar do solo em estudo não apresentar cimentação, a estrutura existente é composta por partículas placóides encaixadas. A resistência de pico encontrada em ambos os ensaios sobre-adensados demonstra ser controlada por esta estruturação. 


\subsubsection{Permeabilidade}

Foram realizados ensaios de permeabilidade com carga hidráulica constante, de acordo com a NBR 13292, durante a etapa de saturação dos corpos-de-prova dos ensaios triaxiais, descrita no Apêndice B. Os ensaios foram executados aplicando-se uma contra-pressão constante e medindo-se o tempo necessário para certo volume de água percolar pelo corpo-deprova (vazão).

Os valores obtidos para o coeficiente de permeabilidade $(\mathrm{k})$ estão apresentados na Figura 4.33, na qual também foram incluídos os resultados referentes aos ensaios edométricos, apresentados anteriormente. Pode-se notar uma boa coerência entre os valores obtidos pelos ensaios triaxiais e pelos edométricos, corroborando os resultados.

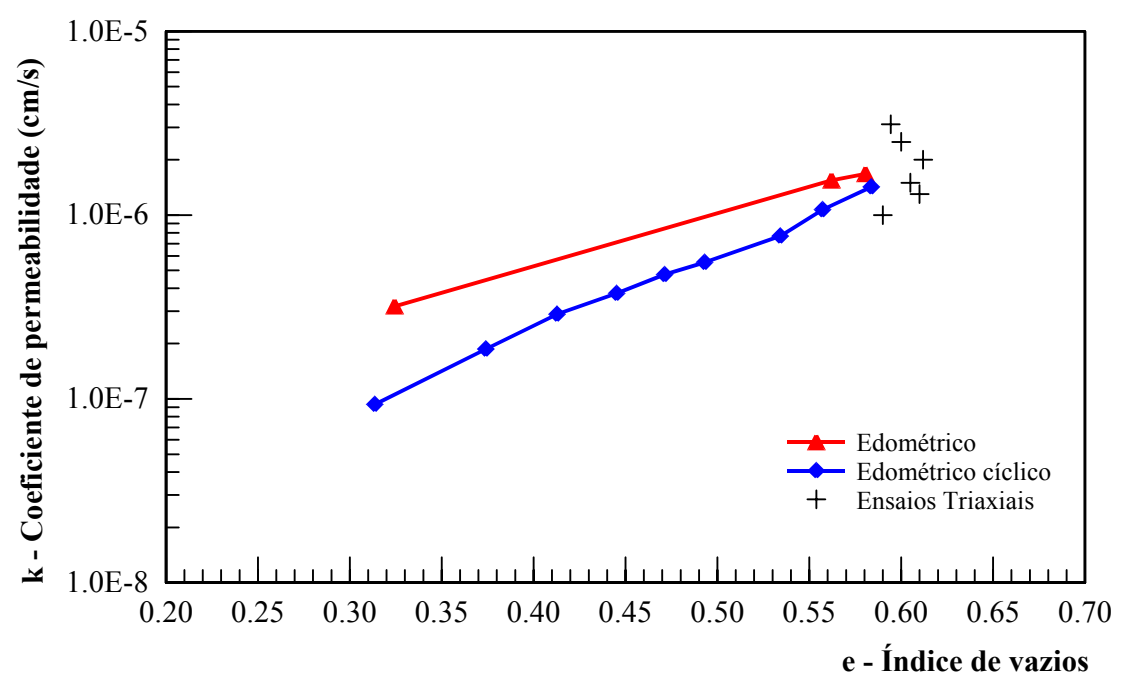

Figura 4.33 - Coeficiente de permeabilidade

\subsubsection{Envoltória de escoamento}

Como discutido anteriormente, os ensaios triaxiais não alcançaram o nível de tensões necessário, durante a etapa de adensamento, para que se fosse atingida a linha de compressão normal (ou "reta virgem"). Com isto, a utilização dos tradicionais gráficos de índice de vazios em função do logaritmo da pressão aplicada levaria a valores incorretos, pois a adoção de uma reta com uma inclinação menor, devido ao menor nível de tensões, induziria a um valor menor da tensão de escoamento. Além disto, as curvas tensão-deformação não apresentaram pontos nítidos de mudança no comportamento. 
Em virtude disto, utilizaram-se os gráficos de energia de deformação (W) em função do comprimento do vetor tensão (LSSV), calculadas por meio das equações (4.7) e (4.8), como discutido por Graham et al. (1982), Graham et al. (1983), Kuwano e Jardine (2007) e Smith et al. (1992). Os gráficos estão apresentados na Figura 4.34 e, para uma melhor visualização dos resultados, os ensaios foram separados de acordo com o máximo valor de comprimento do vetor tensão.

A Figura 4.34 (a) refere-se aos ensaios com nível de tensões mais elevado, com a trajetórias de tensões de adensamento mais afastada do eixo isotrópico. A Figura 4.34 (b) refere-se aos ensaios de adensamento isotrópico $(K=1)$ e com trajetória de tensões próxima ao eixo isotrópico $(K=0,75)$. Nestes quatro ensaios, os escoamentos foram identificados durante a etapa de adensamento e foram classificados como devidos à compressão, segundo a classificação de Leroueil e Vaughan (1990) apresentada anteriormente na Figura 4.3.

Quanto aos ensaios adensados com baixas tensões confinantes (sobre-adensados), apresentados na Figura 4.34 (c) e (d), os escoamentos foram identificados durante a etapa de cisalhamento pelo início do efeito de amolecimento (resistência de pico). Eles foram classificados de acordo com Leroueil e Vaughan (1990) como devidos ao cisalhamento.
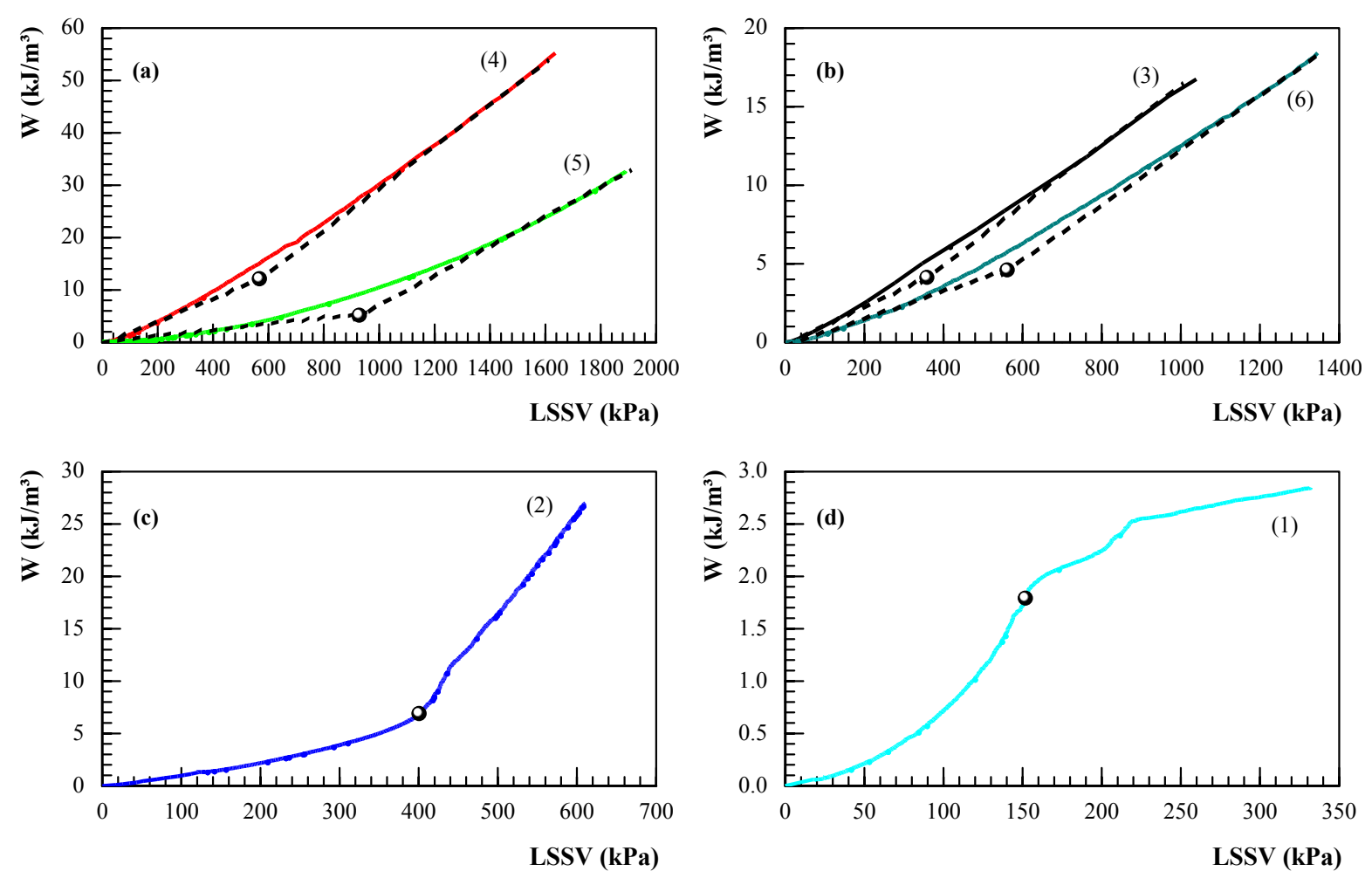

Figura 4.34 - Obtenção dos pontos de escoamento dos ensaios triaxiais 
Na curva apresentada na Figura 4.34 (c), pode-se perceber que o escoamento foi definido por dois trechos razoavelmente lineares, e não mais pelo prolongamento de dois trechos lineares separados por um curvo transicional, como nas quatro curvas anteriores.

$\mathrm{Na}$ Figura 4.34 (d), pode-se visualizar um comportamento diferente de todos os anteriores, pois o ponto de escoamento foi definido na inflexão da curva. Isto é explicado pela presença ou não do efeito de dilatância. Como pode ser visto na Figura 4.29, o ensaio (2) apresentou uma tendência de dilatação, mas não dilatou, enquanto que o ensaio (1) apresentou uma forte dilatância. Analisando-se a equação (4.7), referente à energia de deformação, verifica-se que antes do começo da dilatação, ambas parcelas da equação possuem sinal positivo, e após o começo da dilatação a parcela contendo o incremento de deformação volumétrica torna-se negativa.

As curvas W - LSSV possibilitaram determinar pontos de mudança no comportamento mecânico, caracterizados como escoamento do solo. Os estados de tensões referentes aos escoamentos, encontrados na Tabela 4.1, foram utilizados para a obtenção da curva de escoamento, apresentada na Figura 4.35 (a). Para se discutir seu formato e simetria, ela também está apresentada no espaço s'- t , Figura 4.35 (b).

Pode-se notar claramente que a curva de escoamento não possui seu eixo de simetria sobre o eixo isotrópico, mas não se pode afirmar que esteja ao longo da linha $\mathrm{K}_{0}$.

A tensão de escoamento obtida com os ensaios edométricos não foi considerada para o desenho da curva de escoamento, tendo-se em vista que o ensaio permite o conhecimento apenas da tensão vertical e que o incremento de deformação varia durante o ensaio, impossibilitando a utilização do método gráfico W - LSSV.

Tabela 4.1 - Estados de tensões referentes ao escoamento por carregamento

\begin{tabular}{l|c|c|c|c|c|c}
\hline \multicolumn{1}{c|}{ ensaio } & $\boldsymbol{\sigma}_{\mathbf{a}}$ & $\boldsymbol{\sigma}_{\mathbf{c}}$ & $\mathbf{p}$ & $\mathbf{q}$ & $\mathbf{s}^{\prime}$ & $\mathbf{t}$ \\
\hline (1) cisalhamento $\sigma_{\mathrm{c}}=10 \mathrm{kPa}$ & 125,0 & 10,0 & 48,3 & 115,0 & 67,5 & 57,5 \\
\hline (2) cisalhamento $\sigma_{\mathrm{c}}=70 \mathrm{kPa}$ & 349,4 & 70,0 & 163,1 & 279,4 & 209,7 & 139,7 \\
\hline (4) adensamento $\varepsilon_{\mathrm{a}}=\varepsilon_{\mathrm{p}}$ & 492,4 & 180,8 & 284,7 & 311,6 & 336,6 & 155,8 \\
\hline (5) adensamento $\mathrm{K}=0,50$ & 472,6 & 237,5 & 315,9 & 235,1 & 355,1 & 117,6 \\
\hline (6) adensamento $\mathrm{K}=0,75$ & 299,7 & 224,8 & 249,8 & 74,9 & 262,3 & 37,5 \\
\hline (3) adensamento isotrópico & 207,0 & 207,0 & 207,0 & 0,0 & 207,0 & 0,0 \\
\hline
\end{tabular}



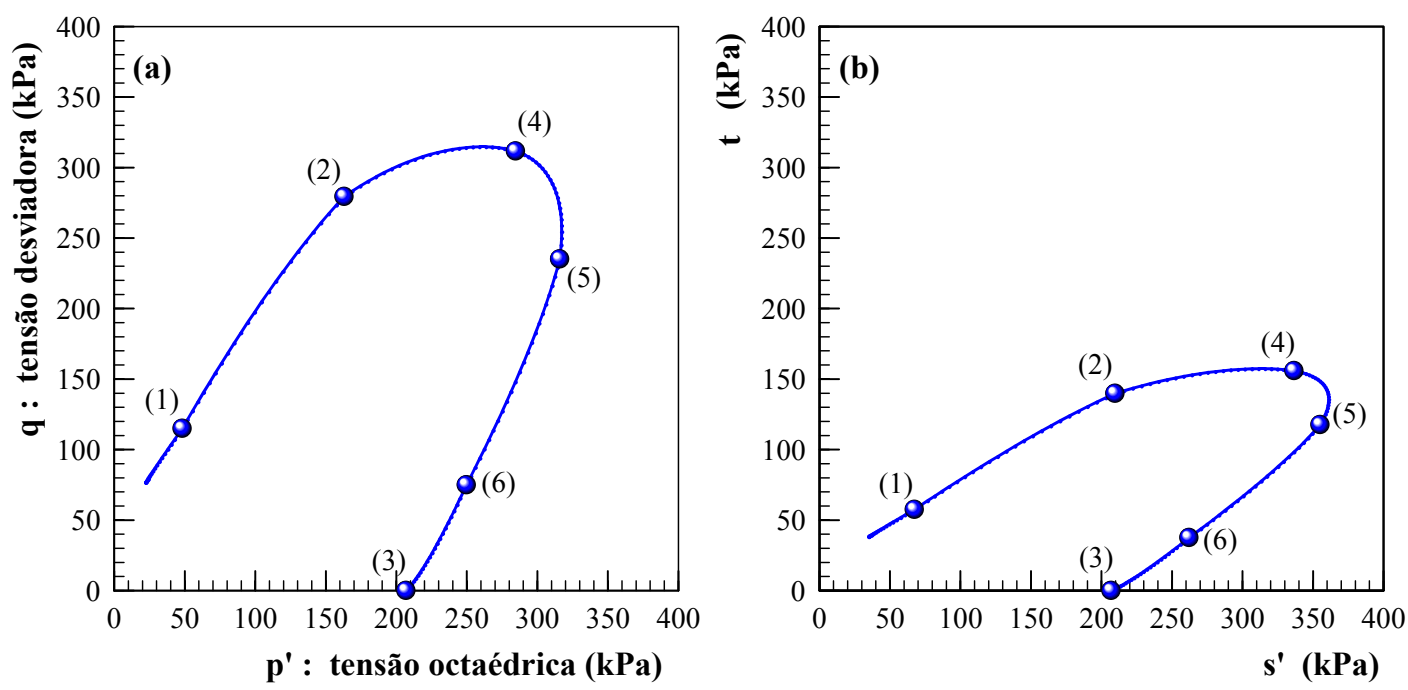

Figura 4.35 - Curva de escoamento obtida pelos ensaios de carregamento axial

\subsubsection{Envoltória de ruptura}

A ruptura do solo foi caracterizada sob dois critérios, o de Estados Críticos e o de Mohr-Coulomb. Os estados de tensões referentes à ruptura dos ensaios triaxiais de carregamento axial estão apresentados na Tabela 4.2.

Tabela 4.2 - Estados de tensões referentes à ruptura dos ensaios de carregamento

\begin{tabular}{|c|c|c|c|c|c|c|c|}
\hline ensaio & $\begin{array}{c}\boldsymbol{\sigma}_{\mathbf{a}} \\
(\mathrm{kPa})\end{array}$ & $\begin{array}{c}\boldsymbol{\sigma}_{\mathbf{c}} \\
(\mathrm{kPa})\end{array}$ & $\mathbf{e}$ & $\begin{array}{c}\mathbf{p}^{\prime} \\
(\mathrm{kPa})\end{array}$ & $\begin{array}{c}\mathbf{q} \\
(\mathrm{kPa})\end{array}$ & $\begin{array}{c}\mathbf{s}^{\prime} \\
(\mathrm{kPa})\end{array}$ & $\begin{array}{c}\mathbf{t} \\
(\mathrm{kPa})\end{array}$ \\
\hline \multicolumn{8}{|c|}{ resistência de pico } \\
\hline (1) adensado até $\sigma_{\mathrm{c}}{ }_{\mathrm{c}}=10 \mathrm{kPa}$ & 125,0 & 10,0 & & 48,3 & 115,0 & 67,5 & 57,5 \\
\hline (2) adensado até $\sigma_{\mathrm{c}}=70 \mathrm{kPa}$ & 349,4 & 70,0 & & 163,1 & 279,4 & 209,7 & 139,7 \\
\hline \multicolumn{8}{|c|}{ patamar de ruptura } \\
\hline (1) adensado até $\sigma_{c}^{\prime}=10 \mathrm{kPa}$ & 57,7 & 10,0 & 0,581 & 25,9 & 47,7 & 33,9 & 23,9 \\
\hline (2) adensado até $\sigma_{c}^{\prime}=70 \mathrm{kPa}$ & 281,7 & 70,0 & 0,495 & 140,6 & 211,7 & 175,9 & 105,9 \\
\hline (3) adensamento isotrópico & 852,9 & 300,0 & 0,431 & 484,3 & 552,9 & 576,5 & 276,5 \\
\hline (4) adensado com $\varepsilon_{\mathrm{a}}=\varepsilon_{\mathrm{p}}$ & 1389,5 & 500,0 & 0,363 & 796,5 & 889,5 & 944,8 & 444,8 \\
\hline (5) adensado com $\mathrm{K}=0,50$ & 1513,7 & 530,0 & 0,378 & 857,9 & 983,7 & 1021,9 & 491,9 \\
\hline (6) adensado com $K=0,75$ & 1671,2 & 600,0 & 0,406 & 957,1 & 1071,2 & 1135,6 & 535,6 \\
\hline
\end{tabular}


De acordo com Wood (1990), a condição de Estados Críticos é caracterizada como um cisalhamento contínuo, sem variação do estado de tensões e do volume. A Mecânica dos Solos dos Estados Críticos utiliza o espaço tridimensional de tensão octaédrica efetiva (p'), tensão desviadora (q) e volume específico (v), como visto na Figura 4.36, confeccionada a partir do estado último dos ensaios triaxiais.

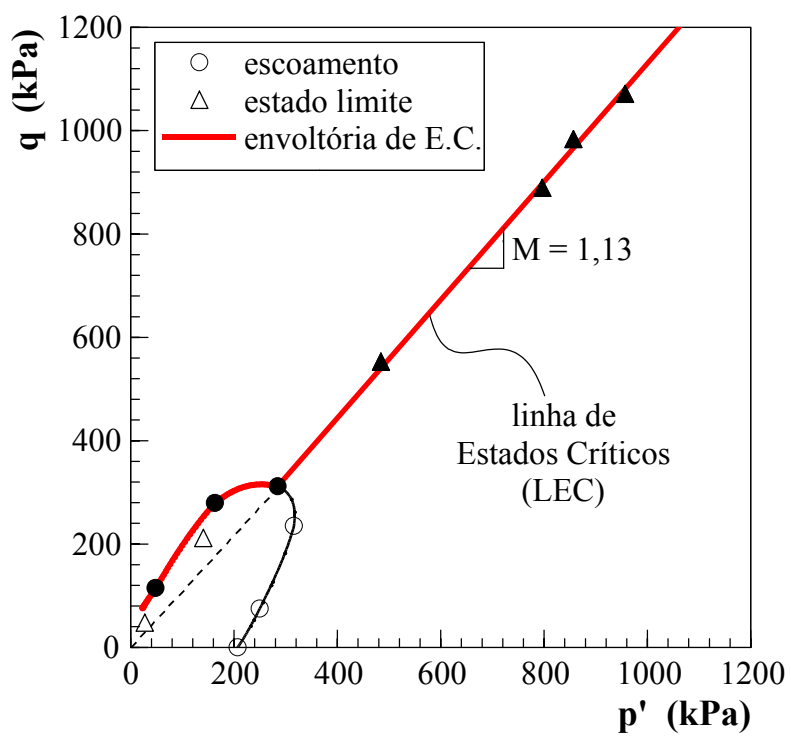

(a) espaço q:p'

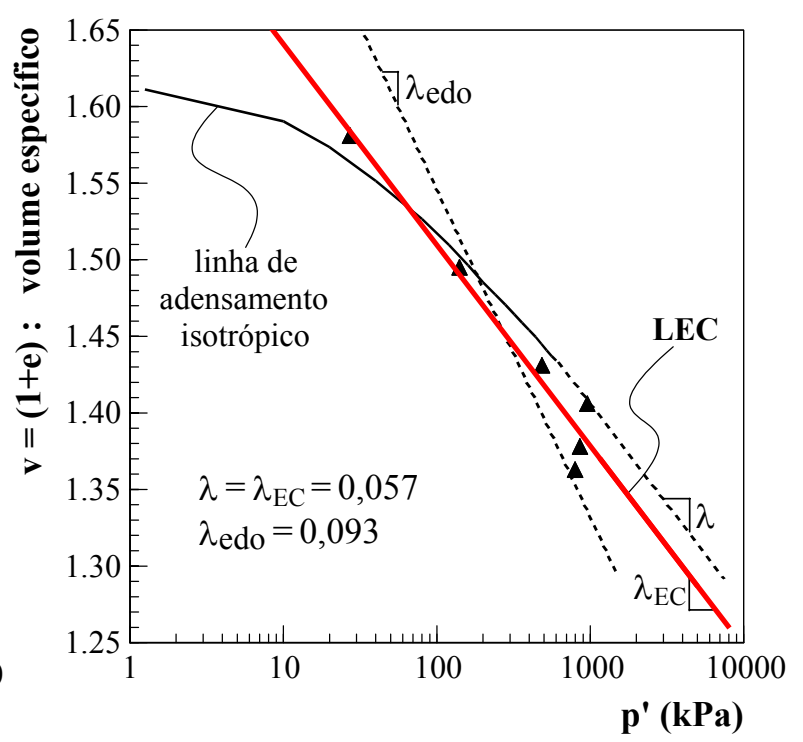

(b) espaço $v: \ln$ p'

Figura 4.36 - Envoltória de Estados Críticos

Pode-se notar que, na Figura 4.36 (a), para a região em que o comportamento apresenta uma resistência de pico seguida de amolecimento, a ruptura é representada pela curva de escoamento.

Como pode ser visto na Figura 4.36 (b), o ensaio de compressão isotrópica alcançou o nível de tensão de $600 \mathrm{kPa}$, não sendo suficiente para caracterizar a reta de compressão normal isotrópica, de inclinação $\lambda$. Porém, ao se inferir uma possível extensão do ensaio isotrópico, nota-se um paralelismo com a linha de Estados Críticos $\left(\lambda=\lambda_{\mathrm{EC}}\right)$.

A inclinação da linha de Estados Críticos no espaço v: ln p' obtida é igual a $\lambda_{\mathrm{EC}}=0,057$ e não coincide com a inclinação da reta de compressão normal dos ensaios edométricos $\left(\lambda_{\text {edo }}=0,093\right)$, como pode ser visto na Figura $4.36(\mathrm{~b})$.

A envoltória de ruptura do solo, de acordo com o critério de Mohr-Coulomb, encontrase na Figura 4.37 e foi composta pelos estados de tensões referentes à máxima tensão desviadora dos ensaios triaxiais (ruptura de pico). 


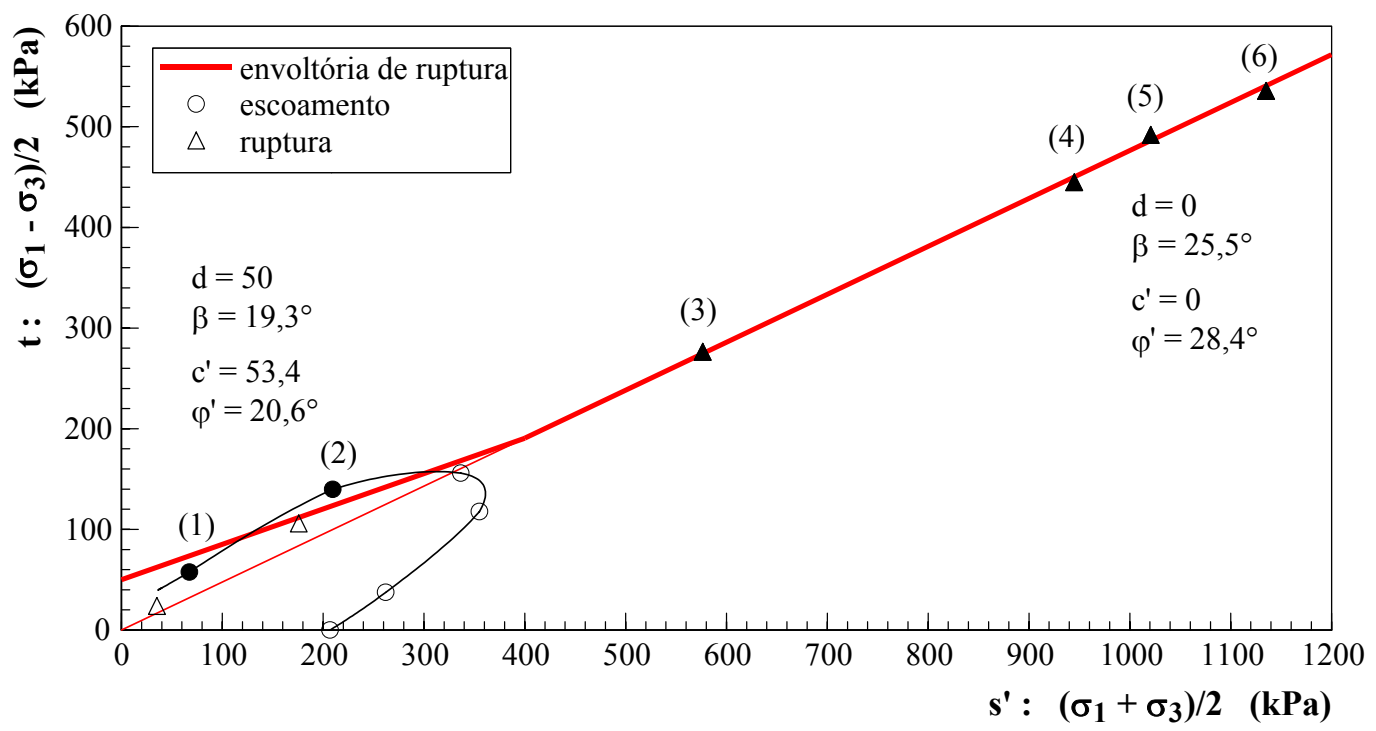

Figura 4.37 - Envoltória de ruptura de Mohr-Coulomb

Nota-se pouca dispersão dos pontos em relação à envoltória de ruptura, a qual notoriamente pode ser representada por dois trechos lineares distintos. A região de sobreadensamento é representada pela reta de equação (4.17) e a região normalmente adensada pela reta de equação (4.18).

$$
\begin{array}{ll}
\tau=\sigma^{\prime} \cdot \operatorname{tg}\left(20,6^{\circ}\right)+53,4 & \text { para } \mathrm{s}^{\prime} \leq 400 \mathrm{kPa} \\
\tau=\sigma^{\prime} \cdot \operatorname{tg}\left(28,4^{\circ}\right) & \text { para } \mathrm{s}^{\prime} \geq 400 \mathrm{kPa}
\end{array}
$$

O solo possui, portanto, um ângulo de atrito interno de 28 graus e um intercepto de coesão de nulo, para a condição de desestruturado.

\subsubsection{Estimativa do valor do coeficiente de empuxo em repouso}

O coeficiente de empuxo em repouso do solo $\left(\mathrm{K}_{0}\right)$ concebe a tensão horizontal como uma proporção da tensão vertical, em termos efetivos. O processo de formação do solo influencia diretamente no modo como ocorre o contato entre as partículas que o conformam e, conseqüentemente, nas forças horizontais existentes.

Isto pode ser evidenciado por uma comparação entre dois solos de formação distinta. Os solos sedimentares apresentam, de um modo geral, tensões horizontais menores que as verticais $\left(\mathrm{K}_{0}<1\right)$, pois as partículas foram depositadas e simplesmente encostadas umas contra as outras. Os solos residuais apresentam tensões horizontais relativas às tensões que existiam na rocha originária, podendo ser maiores que as tensões verticais. 
Uma estimativa preliminar para o valor do coeficiente de empuxo em repouso pode ser efetuada através da proposta de Jacky

$$
K_{0}=1-\operatorname{sen} \varphi^{\prime}
$$

chegando-se ao valor de $\mathrm{K}_{0}=0,53$. Salienta-se que esta estimativa é válida para solos sedimentares.

Outra maneira de se estimar o valor do coeficiente pôde ser efetuada com a realização do ensaio triaxial (4), apresentado na Figura 4.27, cuja etapa de adensamento tentou simular uma situação edométrica, controlando a tensão horizontal de maneira a igualar as deformações axial e volumétrica. Entretanto, cabe ressaltar que durante a execução do ensaio não foi controlada a deformação lateral, devido à indisponibilidade no laboratório de transdutores internos capazes de medir a variação do diâmetro do corpo-de-prova. Este procedimento foi realizado por Sandroni (1981) e os resultados deste tipo de ensaio foram anteriormente apresentados na Figura 4.8.

O estado de tensões referente ao escoamento do ensaio (4), obtido pelo método gráfico W - LSSV, pode ser visto na Figura 4.38, localizado na trajetória de tensões do ensaio.

Assim como a idealização feita por Leroueil e Vaughan (1990) e os resultados obtidos por Sandroni (1981), ambos apresentados respectivamente na Figura 4.7 e na Figura 4.8, a trajetória de tensões de um ensaio triaxial com deformação lateral nula sofre uma mudança de inclinação ao ser destruída a estrutura existente no solo, estabilizando-se com um valor maior de $\mathrm{K}_{0}$ (no caso, $\mathrm{K}_{0}$ desestruturado). Isto não ocorre no ensaio triaxial (4), onde o valor de $\mathrm{K}_{0}$ é igual à 0,37 no escoamento, com contínuo aumento em seu valor.

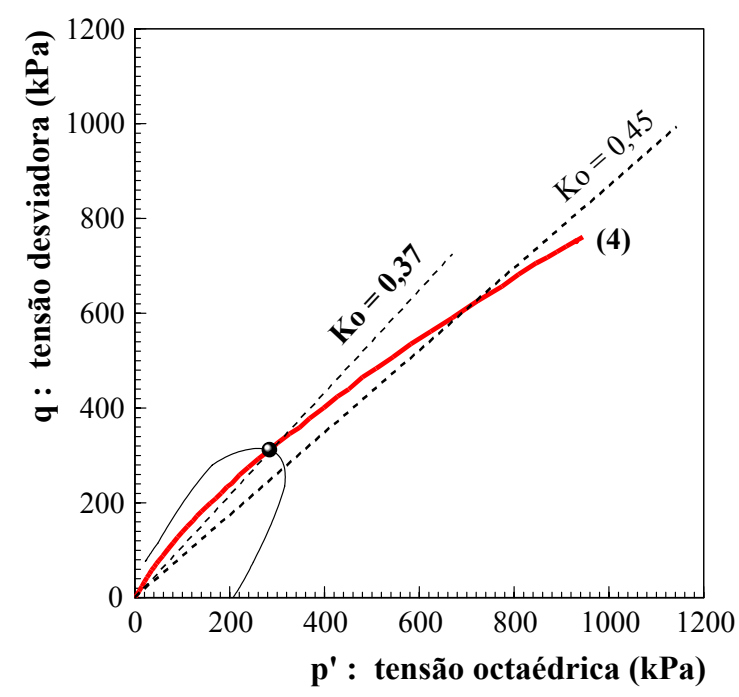

Figura 4.38 - Obtenção de $\mathrm{K}_{0}$ por meio do ensaio triaxial 
A partir da curva de escoamento do solo, apresentada novamente na Figura 4.39, foi possível estimar-se o valor de $\mathrm{K}_{0}=0,63$, utilizando-se a tensão vertical de escoamento dos ensaios edométricos, a qual foi determinada pelo processo de Pacheco Silva (1970) como igual a $370 \mathrm{kPa}$. Foi utilizado o plano s'- t para a curva de escoamento, por ela ser claramente não centrada no eixo isotrópico, em concordância com Graham et al. (1988).

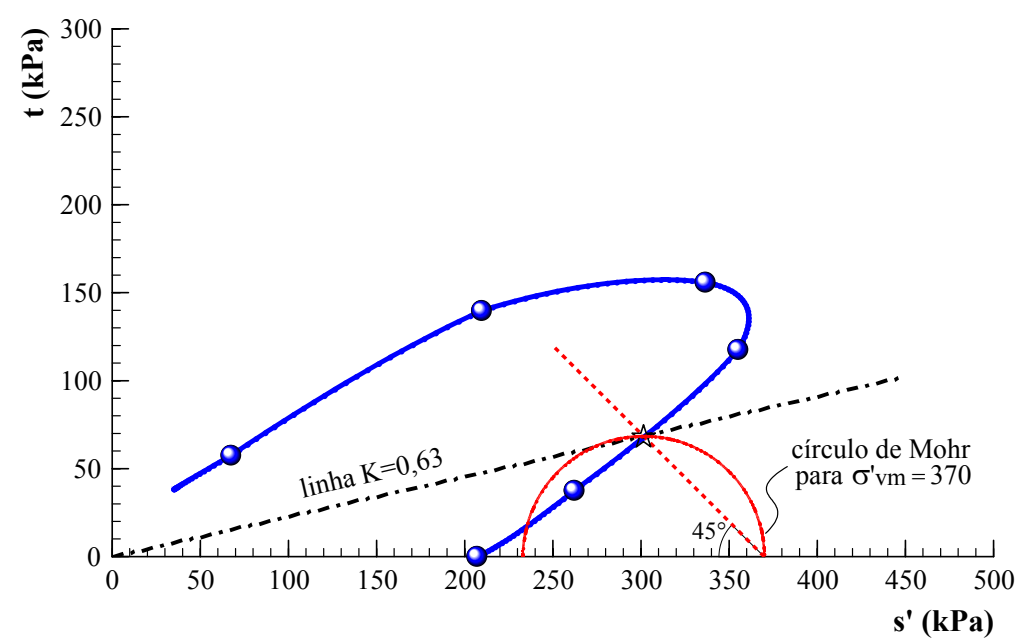

Figura 4.39 - Obtenção de $\mathrm{K}_{0}$ por meio da curva de escoamento

Os valores de $\mathrm{K}_{0}$ estimados em laboratório, entretanto, são comumente criticados pelo fato de que qualquer tipo de amostragem altera o estado de tensões de campo e a tensão horizontal que existia não pode ser determinada. De acordo com Pinto e Nader (1994b), é impossível a determinação laboratorial de $\mathrm{K}_{0}$, sobretudo para solos residuais, mas também para solos de história geológica simples.

Ensaios executados em campo devem ser realizados para a determinação de $\mathrm{K}_{0}$, com o mínimo possível de perturbação do solo, como explica Rocha Filho (1991) ao discutir a aplicabilidade de ensaios "in situ" em solos residuais.

Pinto e Abramento (2005) apresentaram resultados de ensaios com um pressiômetro auto-perfurante de Cambridge (COMKOMETER), executados no local de escavação do Poço VSE Caxingui, dentro da área de estudos da presente pesquisa e alcançando a profundidade aproximada de $25 \mathrm{~m}$. Foram determinados valores de $\mathrm{K}_{0}$ variando de 1 a 3.

Provavelmente, esta tensão horizontal elevada é devida à atividade tectônica marcante da região, a qual propiciou esforços compressionais na rocha originária do solo em uma direção predominante, gerando as foliações metamórficas discutidas anteriormente no Capítulo 3 e deixando remanescentes esforços elevados. 
Estes valores de $\mathrm{K}_{0}$ maiores do que a unidade são impossíveis de se obter em laboratório, como discutido anteriormente. Tendo-se em vista que esta pesquisa pretende analisar o comportamento mecânico do solo por meio de ensaios de laboratório e que a adoção de $\mathrm{K}_{0}>1$ traria conflitos entre os resultados (por exemplo, entre a inclinação da curva de escoamento e a direção da linha $\mathrm{K}_{0}$ ), optou-se pela não utilização dos resultados obtidos por Pinto e Abramento (2005).

Por ser a equação de Jacky destinada a solos sedimentares e o solo em estudo ser de origem residual, o valor de $\mathrm{K}_{0}=0,56$ não foi adotado. Pelo procedimento idealizado no ensaio triaxial (4) ser incorreto, pois as deformações laterais não foram mantidas nulas, desconsiderou-se o valor de $\mathrm{K}_{0}=0,37$. Adotou-se então o valor de $\mathrm{K}_{0}=0,63$ obtido pela localização da tensão de escoamento dos ensaios edométricos na curva de escoamento.

Contudo, deve-se enfatizar que o valor adotado para o coeficiente de empuxo em repouso trata-se apenas de uma estimativa, com o intuito de se prosseguir com o estudo e de possibilitar a realização de modelagens numéricas.

\subsubsection{Condições triaxiais de descarregamento}

Foram realizados quatro ensaios triaxiais nomeados de (7) a (10), denominados como sendo de "descarregamento" por ter sido imposto um decréscimo de tensão em pelo menos uma direção (axial ou confinante) durante a fase de cisalhamento. O procedimento de execução destes ensaios triaxiais pode ser encontrado no Apêndice C.

Para a realização dos ensaios, utilizou-se o mesmo equipamento e os mesmos transdutores utilizados para os ensaios de carregamento axial. Entretanto, o cabeçote utilizado para os ensaios de descarregamento é diferente, pois a célula de carga é fixada ao cabeçote por um sistema de rosca.

Esta fixação se faz necessária para que o cabeçote seja capaz de transmitir à célula de carga uma força de tração, gerando uma tensão desviadora negativa. Caso contrário, os ensaios de extensão poderiam ser executados apenas até um valor de tensão desviadora nulo, momento no qual o cabeçote perde o contato com a célula de carga.

O fato de a tensão desviadora ser negativa não significa que o corpo-de-prova esteja submetido à tração, mas simplesmente que a tensão horizontal é maior do que a tensão vertical. A tensão desviadora pode continuar a ser decrescida até que a tensão vertical seja 
nula, momento este em que o cabeçote perde o contato com o corpo-de-prova e a membrana é impelida entre os dois.

Procedimento similar foi executado por Lins e Lacerda (1980), ao executar ensaios triaxiais de compressão e de extensão.

As fases de saturação, adensamento e cisalhamento, possuem procedimentos de execução idênticos aos apresentados para os ensaios triaxiais de carregamento axial.

Todos os ensaios de descarregamento foram executados impondo-se ao corpo-deprova um deslocamento vertical (deformação controlada), cujo sentido (ascendente ou descendente) variou de acordo com a trajetória de tensões a ser seguida. Para tal, utilizou-se um pistão CRSP (Controlled Rate Strain/Pressure) a uma velocidade de deformação de $0,025 \% / \mathrm{min}$. A trajetória de tensões desejada foi obtida controlando-se a tensão confinante.

\subsubsection{Trajetórias de tensões utilizadas nos ensaios}

As trajetórias de tensões dos ensaios triaxiais de descarregamento realizados podem ser visualizados na Figura 4.40. Os ensaios foram nomeados de acordo com o ângulo formado pela trajetória de tensões no plano $s^{\prime}-t$ em relação à horizontal, e numerados de (7) a (10), dando continuidade à numeração dos ensaios triaxiais de carregamento axial.

Como pode ser observado, todos os ensaios foram adensados anisotropicamente mantendo-se a relação $\mathrm{K}=0,63$, até ser alcançada a tensão vertical efetiva de $735 \mathrm{kPa}$ e a horizontal de $463 \mathrm{kPa}$, simulando a situação encontrada em campo. Para a estimativa deste estado de tensões "in situ”, o nível do lençol freático foi considerado totalmente rebaixado, ocasionando uma tensão vertical efetiva maior do que a existente no caso do solo estar submerso. Como discutido anteriormente, não há informações sobre a alteração do nível do lençol freático, devido à inexistência de equipamentos capazes de detectar sua variação.

Esta medida foi tomada com o intuito de garantir que o solo, após o adensamento, se encontrasse na condição de normalmente adensado (tivesse atingido a curva de escoamento), assegurando-se assim que as trajetórias de tensões de descarregamento estivessem na região de domínio elástico. 


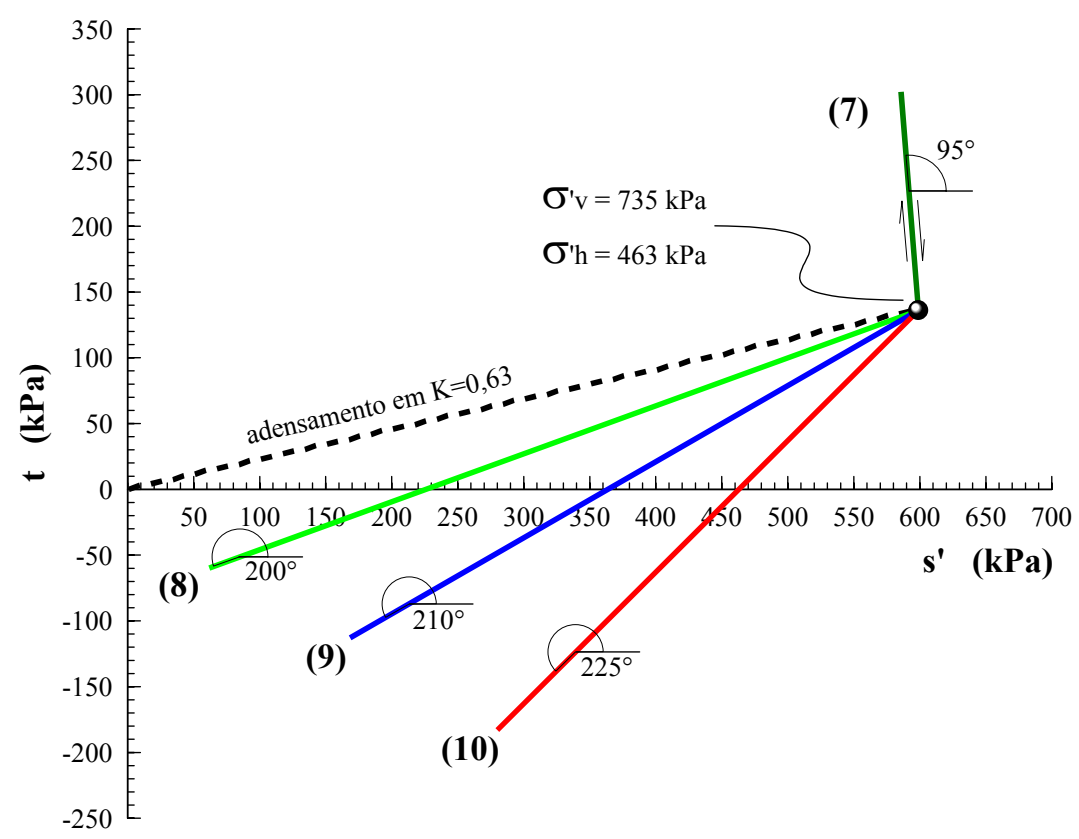

Figura 4.40 - Trajetórias de tensões utilizadas nos ensaios triaxiais de descarregamento

Assim como nos ensaios de carregamento axial, os ensaios de descarregamento tiveram sua etapa de adensamento com duração aproximada de um dia, com o intuito de minimizar a influência da viscosidade do solo nos resultados obtidos.

Após o adensamento, os ensaios foram cisalhados com drenagem até a ruptura (ensaios CAD), reduzindo-se a tensão confinante de maneira a conformar a trajetória de tensões com a inclinação especificada. O ensaio (7) foi o único com recarregamento, tendo sido cisalhado até uma tensão desviadora de $530 \mathrm{kPa}$, retornado para o estado de tensões inicial e cisalhado novamente pela mesma trajetória de tensões.

O ensaio (7) é denominado como de compressão, pois o corpo-de-prova teve sua altura reduzida (aumento da tensão desviadora e da deformação axial). Os ensaios (8), (9) e (10) são denominados como de extensão, pois as alturas dos corpos-de-prova sofreram acréscimo (diminuição da tensão desviadora e da deformação axial).

A trajetória de tensões seguida pelo ensaio (7) contou com uma diminuição da tensão confinante e um aumento da tensão axial. Para os ensaios (8) e (9), ambas as tensões foram reduzidas. O ensaio (10) teve uma redução da tensão axial, enquanto que a tensão confinante foi mantida constante.

A escolha destas trajetórias de tensões para a realização dos ensaios será justificada no próximo capítulo. Por ora, cabe explicar que elas foram planejadas a partir de resultados obtidos por uma modelagem numérica e que representam trajetórias de tensões de alguns pontos localizados ao redor da escavação de um túnel. 


\subsubsection{Relações tensão-deformação}

As relações tensão-deformação resultantes dos ensaios triaxiais de descarregamento, cujas trajetórias de tensões encontram-se na Figura 4.40, estão apresentadas na Figura 4.41. Todos os ensaios tiveram suas deformações zeradas ao inicio da etapa de cisalhamento
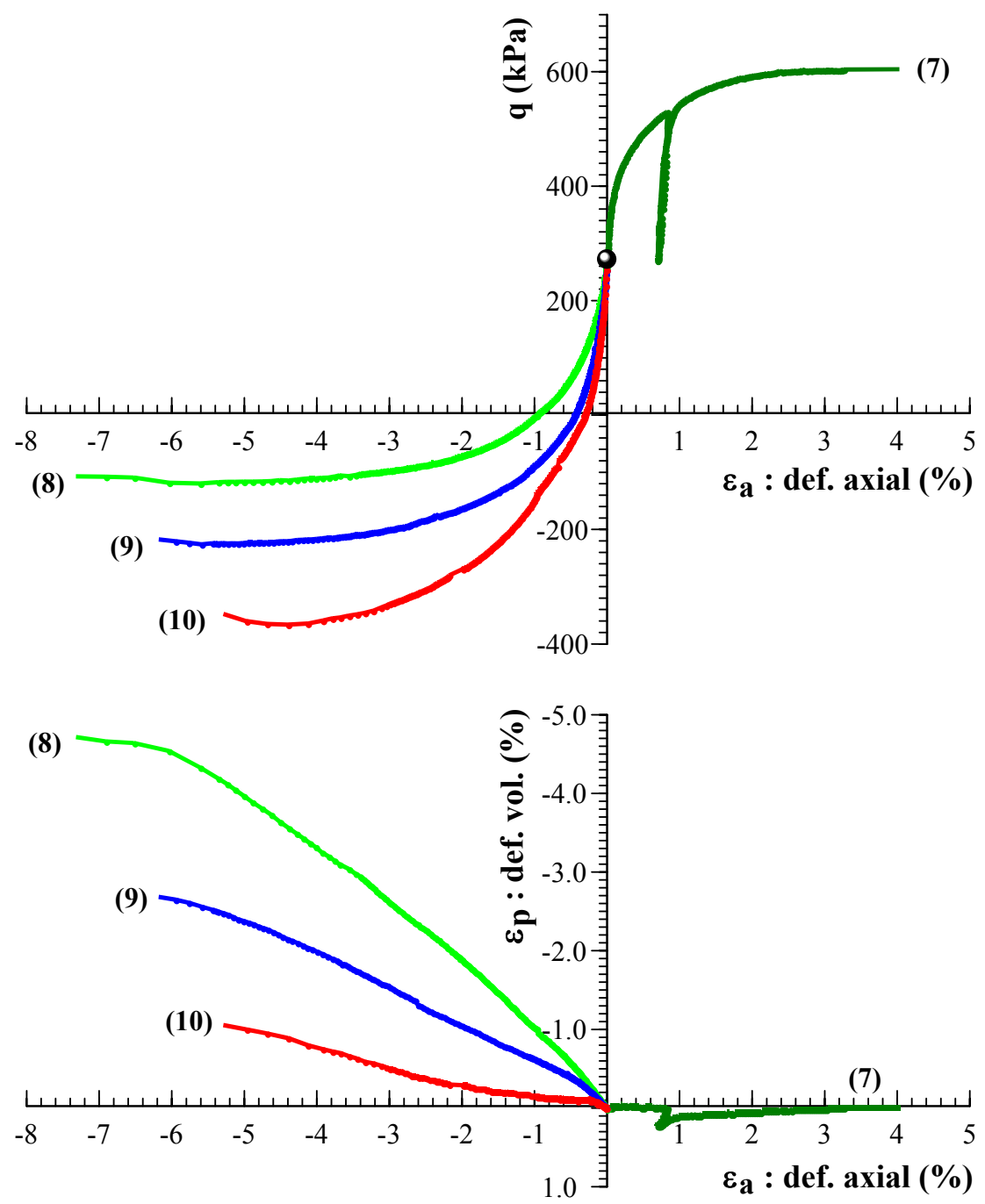

Figura 4.41 - Curvas tensão-deformação dos ensaios triaxiais de descarregamento

Todos os ensaios apresentaram trecho inicial linear e patamares de ruptura (sem presença de resistência de pico).

Os ensaios de extensão (8), (9) e (10) dilataram durante toda a etapa de cisalhamento (deformação volumétrica negativa), como esperado. O ensaio (7) também apresentou variação volumétrica negativa, porém esta foi ínfima. Isto se deve à inclinação da trajetória de tensão, a qual ocasionou uma alteração na tensão octaédrica efetiva (p') negativa, mas muito reduzida. 
Pode-se observar que o solo apresentou variação de deformabilidade de acordo com a variação da trajetória de tensões, o que implica na variação de parâmetros geotécnicos em função da trajetória seguida em ensaio.

O ensaio (8) mostrou-se menos rígido que o ensaio (9), tendo sido executado com uma maior redução da tensão confinante durante o cisalhamento. O ensaio (10) mostrou-se mais rígido que estes dois ensaios, tendo sido mantida constante a tensão confinante durante o cisalhamento. Demonstra-se uma forte tendência de aumento da deformabilidade (perda de rigidez) para trajetórias com redução da tensão confinante.

$\mathrm{O}$ trecho linear inicial do ensaio (7) apresenta rigidez semelhante à do trecho linear de recarregamento.

Nenhum dos ensaios apresentou plano de ruptura coincidente com um plano de descontinuidade, cujo material de preenchimento foi estudado no capítulo anterior.

\subsubsection{Envoltória de escoamento}

Com o intuito de se manter a mesma metodologia utilizada anteriormente, foram utilizadas as curvas de Energia de deformação (W) em função do Comprimento do vetor tensão (LSSV) para a determinação do escoamento do solo. A Figura 4.42 apresenta as curvas W - LSSV para os ensaios triaxiais de descarregamento.

Contrariamente aos ensaios de carregamento axial, os ensaios de descarregamento apresentaram mudanças no comportamento mecânico que poderiam ser identificadas pelas curvas tensão-deformação. Em contrapartida, nos gráficos W-LSSV estes pontos de mudança no comportamento são de difícil determinação.

Os pontos de escoamento foram determinados pela intersecção do prolongamento de dois trechos lineares, separados por um trecho curvo transicional.

O gráfico para o ensaio (7), apresentado na Figura 4.42 (a), é o único a ter um aumento na energia de deformação, como ocorrido com os ensaios de carregamento axial, devido a apresentar um aumento na tensão desviadora. Os demais ensaios, com redução da tensão desviadora (de extensão), apresentam diminuição da energia de deformação.

O ensaio (7) apresentou dois pontos de escoamento, devido ao ciclo de recarregamento a que foi submetido. O segundo ponto é referente ao máximo nível de tensão a que havia sido submetido no carregamento anterior, durante o qual o primeiro ponto foi atingido. 

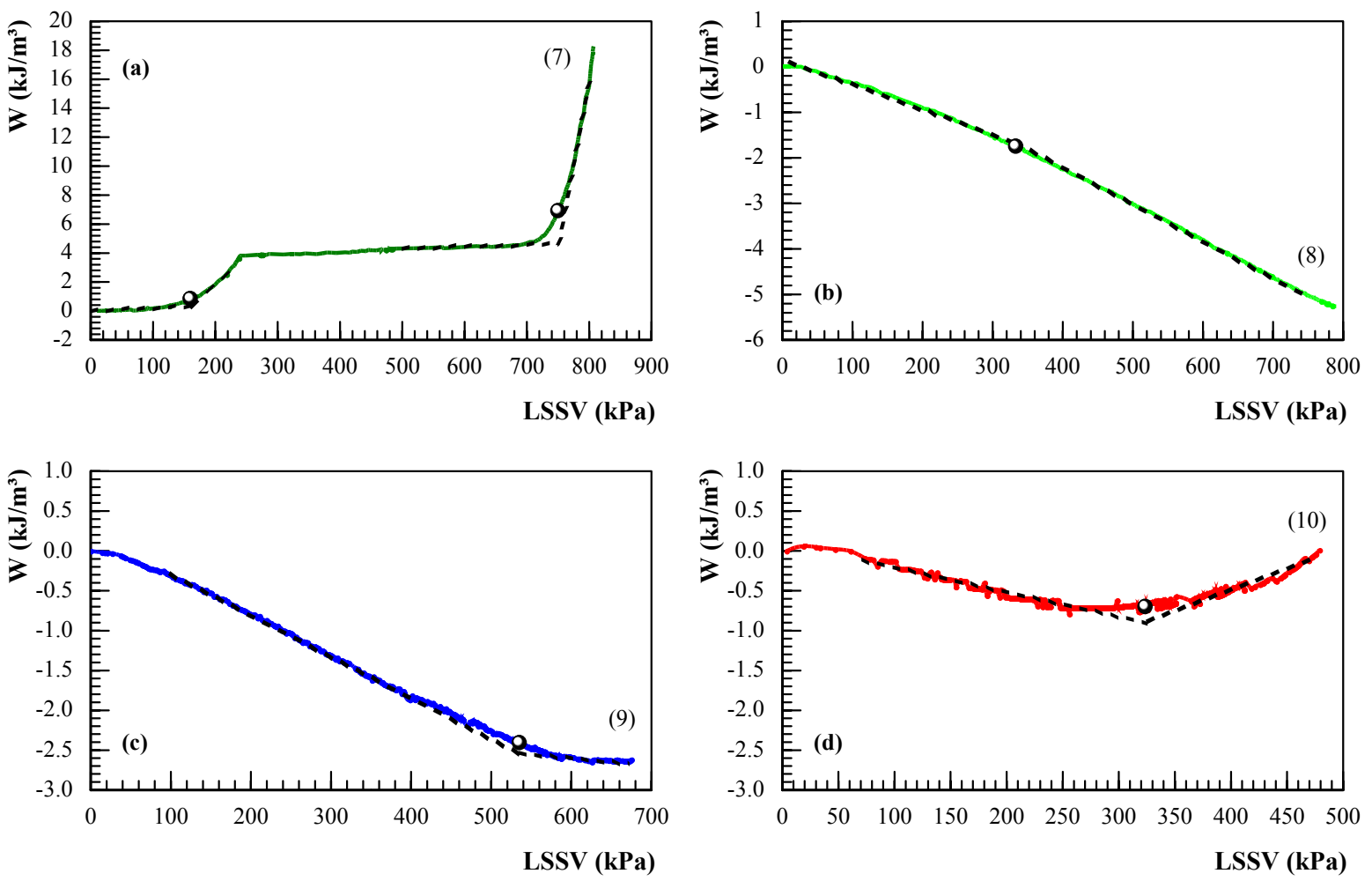

Figura 4.42 - Obtenção dos pontos de escoamento dos ensaios triaxiais de descarregamento

Os ensaios de extensão de (8) a (10) apresentaram uma variação de energia de deformação com ordem de grandeza inferior à variação apresentada pelos ensaios de compressão de (1) a (7).

Os estados de tensões referentes aos pontos de mudança no comportamento mecânico, obtidos pelos gráficos W - LSSV (Figura 4.42), podem ser encontrados na Tabela 4.3. Estes pontos foram localizados nas curvas tensão-deformação da fase de cisalhamento dos ensaios triaxiais de descarregamento, as quais estão reapresentadas na Figura 4.43.

Pode-se observar que os pontos obtidos pela energia de deformação demonstram coerência com o comportamento apresentado pelas curvas tensão-deformação, comprovando a validade do método utilizado para a identificação do escoamento

Tabela 4.3 - Estados de tensões referentes ao escoamento por descarregamento

\begin{tabular}{l|c|c|c|c|c|c}
\hline \multicolumn{1}{c|}{ ensaio } & $\boldsymbol{\sigma}_{\mathbf{a}}^{\prime}$ & $\boldsymbol{\sigma}_{\mathbf{c}}$ & $\mathbf{p}$ & $\mathbf{q}$ & $\mathbf{s}^{\prime}$ & $\mathbf{t}$ \\
\hline$(7) 95^{\circ}$ & 804,0 & 382,9 & 523,3 & 421,1 & 593,5 & 210,6 \\
\hline$(8) 200^{\circ}$ & 454,3 & 332,5 & 373,1 & 121,8 & 393,4 & 60,9 \\
\hline$(9) 210^{\circ}$ & 294,0 & 345,7 & 328,5 & $-51,7$ & 319,9 & $-25,9$ \\
\hline$(10) 225^{\circ}$ & 425,0 & 463,0 & 450,3 & $-38,0$ & 444,0 & $-19,0$ \\
\hline
\end{tabular}



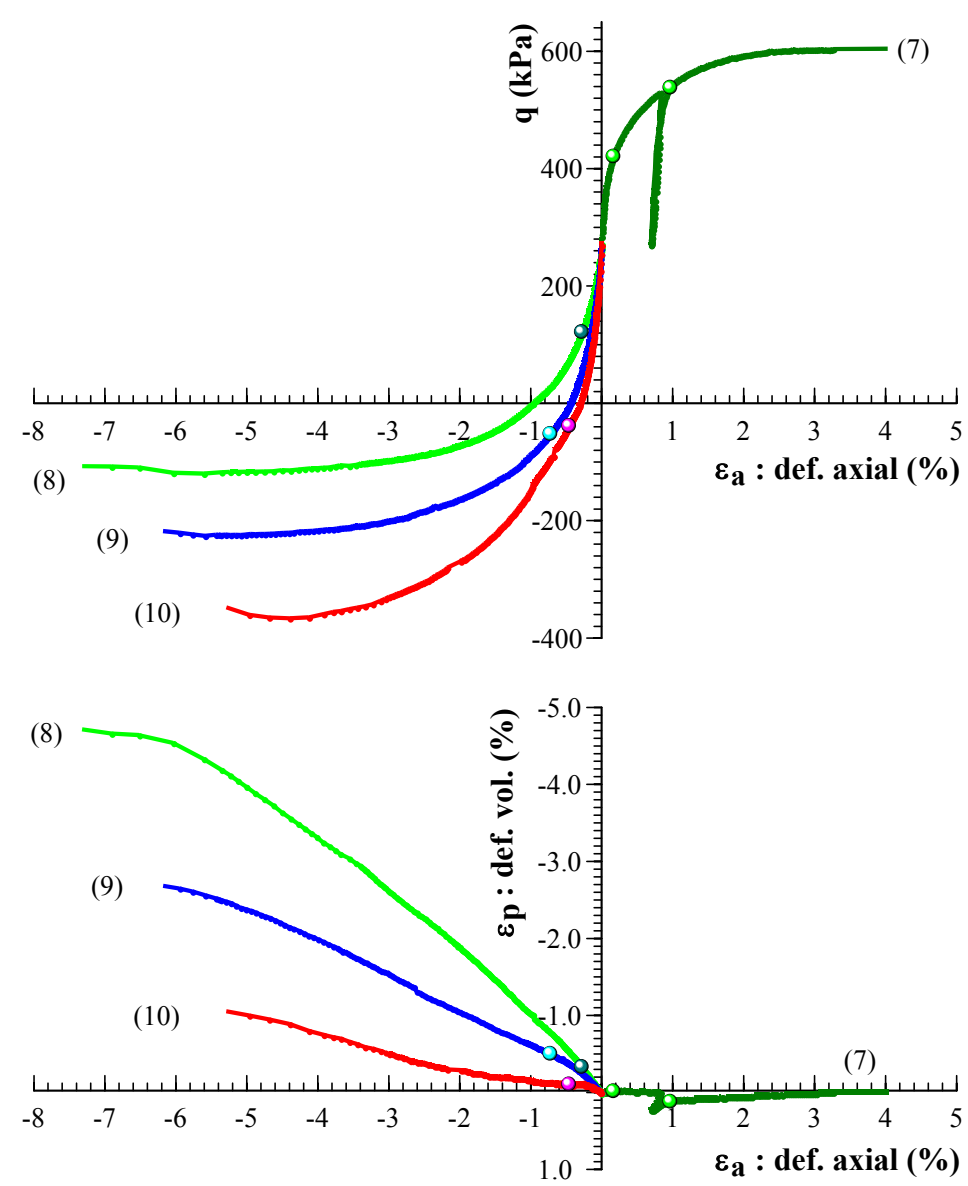

Figura 4.43 - Localização dos pontos de escoamento nas curvas tensão-deformação

Os estados de tensões apresentados na Tabela 4.3, obtidos pelos ensaios triaxiais de descarregamento, foram utilizados para a obtenção da curva de escoamento, apresentada na Figura 4.44.
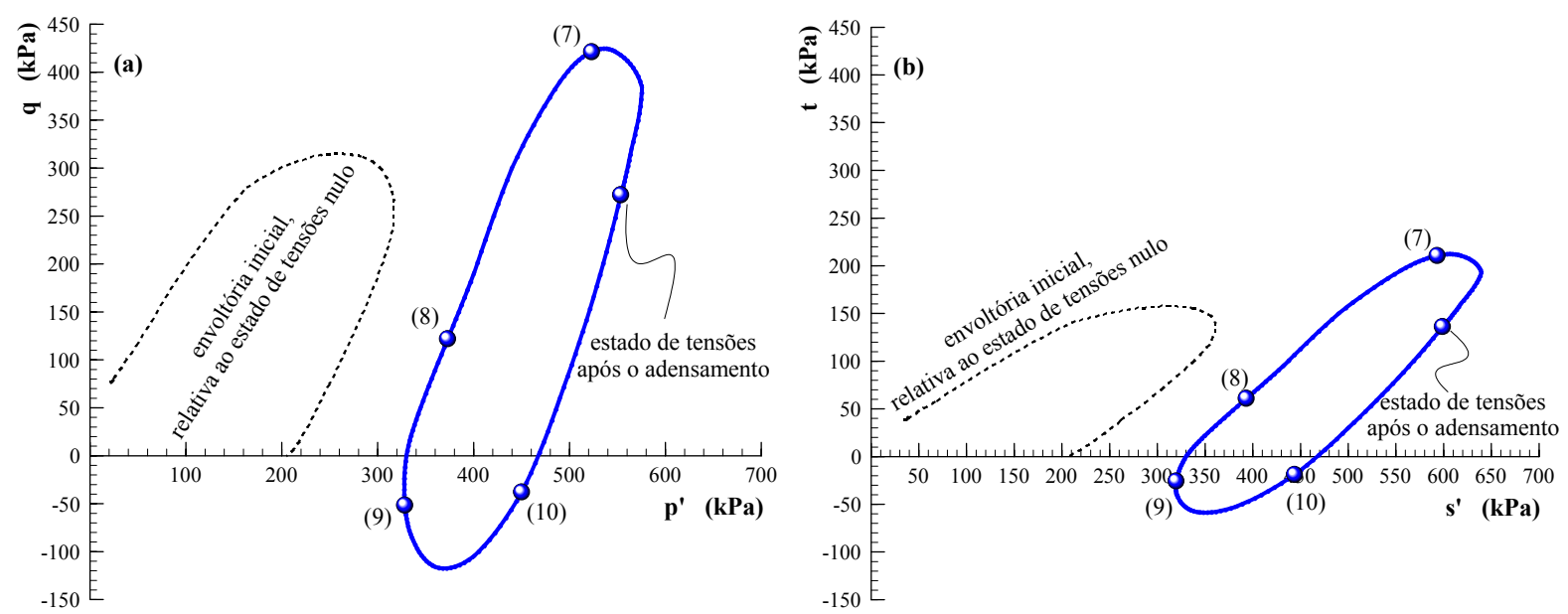

Figura 4.44 - Curva de escoamento obtida pelos ensaios de descarregamento 
Pode-se observar que a curva de escoamento obtida pelos ensaios triaxiais de descarregamento manteve as características da curva obtida por adensamento, a partir do estado nulo de tensões. Nota-se que a envoltória de escoamento continua com formato alongado, que não possui seu eixo de simetria sobre o eixo isotrópico e que sua inclinação continua aproximadamente a mesma.

O solo possui, portanto, uma envoltória de escoamento com comportamento cinemático marcante, não apresentando rotação e com encolhimento/expansão não significativos. Isto indica que o solo pode ter plastificado por descarregamento devido à amostragem.

\subsubsection{Envoltórias de ruptura}

A ruptura do solo foi caracterizada sob dois critérios, o de Estados Críticos e o de Mohr-Coulomb. Para ambos os critérios, puderam ser identificadas duas envoltórias de ruptura distintas, uma para a situação de compressão e outra para a de extensão. Os estados de tensões referentes à ruptura dos ensaios de descarregamento estão apresentados na Tabela 4.4.

Tabela 4.4 - Estados de tensões referentes à ruptura dos ensaios de descarregamento

\begin{tabular}{l|c|c|c|c|c|c|c}
\hline \multicolumn{1}{c|}{ ensaio } & $\begin{array}{c}\boldsymbol{\sigma}_{\mathbf{a}}^{\prime} \\
(\mathrm{kPa})\end{array}$ & $\begin{array}{c}\boldsymbol{\sigma}_{\mathbf{c}}^{\prime} \\
(\mathrm{kPa})\end{array}$ & $\mathbf{e}$ & $\begin{array}{c}\mathbf{p}^{\prime} \\
(\mathrm{kPa})\end{array}$ & $\begin{array}{c}\mathbf{q} \\
(\mathrm{kPa})\end{array}$ & $\begin{array}{c}\mathbf{s}^{\prime} \\
(\mathrm{kPa})\end{array}$ & $\begin{array}{c}\mathbf{t} \\
(\mathrm{kPa})\end{array}$ \\
\hline$(7) 95^{\circ}$ & 885,0 & 285,0 & 0,464 & 485,0 & 600,0 & 585,0 & 300,0 \\
\hline$(8) 200^{\circ}$ & 24,5 & 131,6 & 0,532 & 95,9 & $-107,1$ & 78,1 & $-53,6$ \\
\hline$(9) 210^{\circ}$ & 57,3 & 281,7 & 0,489 & 206,9 & $-224,4$ & 169,5 & $-112,2$ \\
\hline$(10) 225^{\circ}$ & 97,0 & 463,0 & 0,431 & 341,0 & $-366,0$ & 280,0 & $-183,0$ \\
\hline
\end{tabular}

A envoltória de Estados Críticos, apresentada no espaço tridimensional de tensão octaédrica efetiva (p'), tensão desviadora (q) e volume específico (v), encontra-se na Figura 4.45 .

Pode-se notar, na Figura 4.45 (a), que a envoltória não é mais representada pela curva de escoamento na região de baixas tensões confinantes. A trajetória de tensões, ao alcançar esta região, está em contato com a curva de escoamento, deslocando-a (o solo está normalmente adensado). O comportamento de resistência de pico seguida por amolecimento somente é obtido quando a curva de escoamento do solo encontra-se interseccionando a envoltória de ruptura, como no caso dos resultados dos ensaios de carregamento axial. 

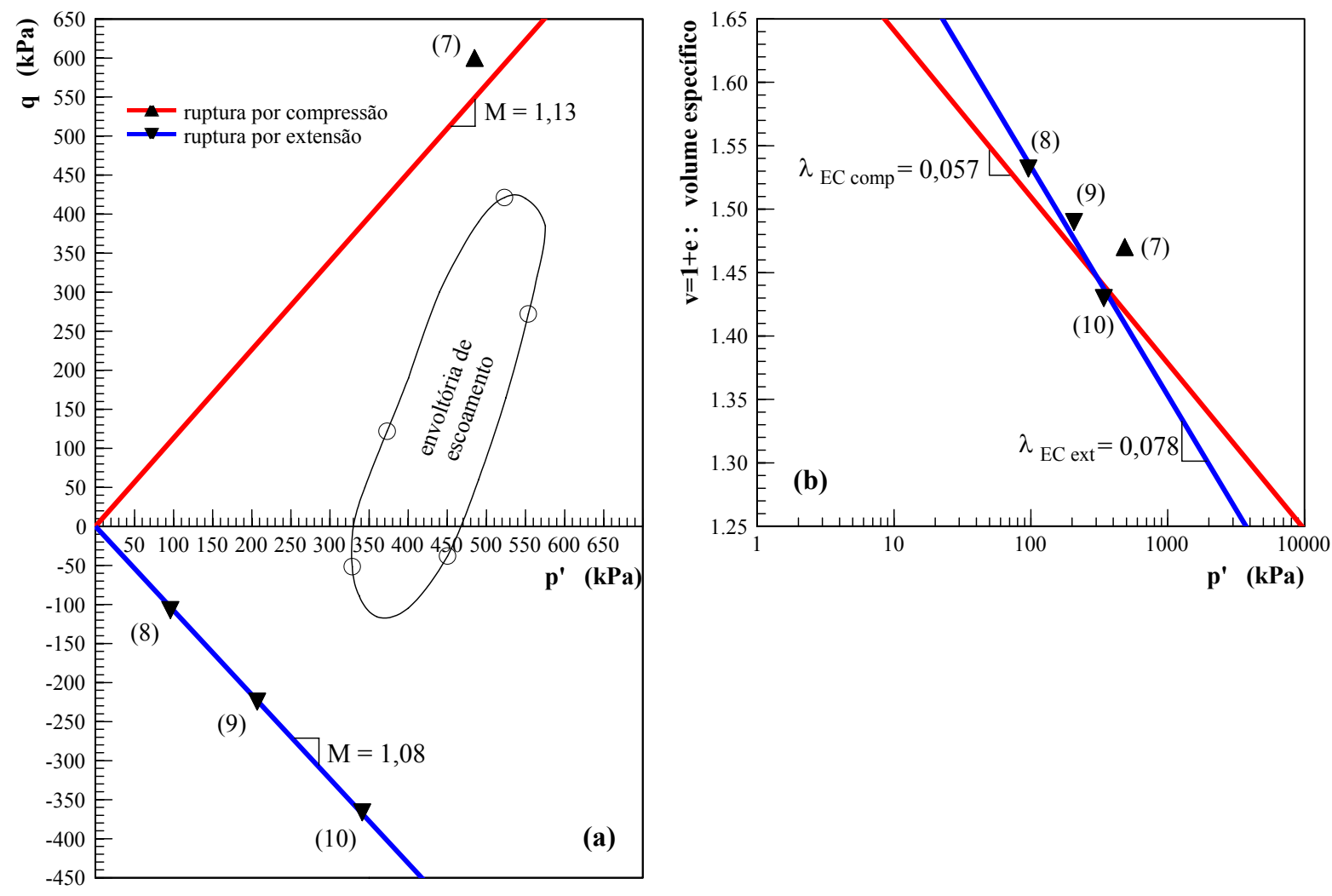

Figura 4.45 - Envoltória de Estados Críticos para os ensaios de descarregamento

A envoltória para a condição de compressão foi inserida na Figura 4.45 de acordo com os resultados obtidos anteriormente, para os ensaios de carregamento axial de (1) a (6).

Nota-se que o resultado para o ensaio (7) possui uma dispersão em relação à envoltória de compressão, sendo mais expressiva no espaço $\mathrm{v}: \ln \mathrm{p}$ '.

No espaço de tensões p': q, observa-se que a linha de Estados Críticos obtida para os ensaios de extensão não possui a mesma inclinação $\left(\mathrm{M}_{\mathrm{ext}}=1,08\right)$ do que a linha obtida para os ensaios de carregamento axial $\left(\mathrm{M}_{\text {comp }}=1,13\right)$.

No espaço v : ln p', encontrado na Figura 4.45 (b), a linha de Estados Críticos com os ensaios (8), (9) e (10) possui inclinação igual a $\lambda_{\mathrm{EC} \text { ext }}=0,078$ e não coincide, entretanto, com a inclinação da reta obtida com os ensaios de carregamento axial, igual a $\lambda_{\mathrm{EC} \mathrm{comp}}=0,057$.

A inclinação da reta de compressão normal dos ensaios edométricos $\left(\lambda_{\text {edo }}=0,093\right)$ se aproxima mais dos resultados obtidos para os ensaios de extensão.

A envoltória de ruptura do solo de acordo com o critério de Mohr-Coulomb, apresentada no plano s'- t, encontra-se na Figura 4.37. 


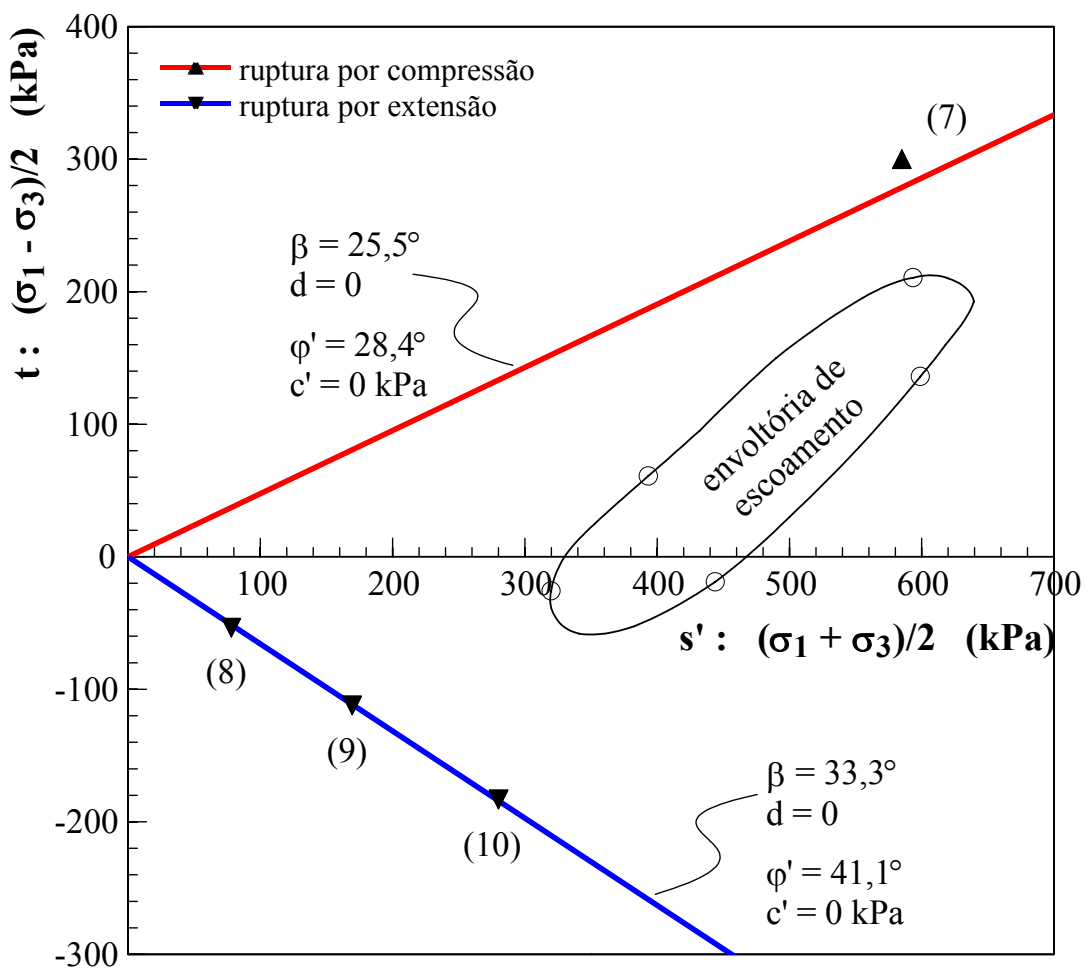

Figura 4.46 - Envoltória de ruptura de Mohr-Coulomb

A envoltória para a condição de compressão apresentada na Figura 4.46 é a mesma que foi apresentada anteriormente, para os ensaios de carregamento axial de (1) a (6).

Pode-se observar que os resultados dos ensaios de extensão apresentam pouca dispersão em relação à envoltória de ruptura, a qual é representada por uma reta passando pela origem do espaço de tensões:

$$
\tau=\sigma^{\prime} \cdot \operatorname{tg}\left(41,1^{\circ}\right)
$$

Para a situação de extensão, portanto, o solo possui um ângulo de atrito interno de 41 graus e um intercepto de coesão de nulo.

Por meio da Figura 4.47, pode-se observar como as diferentes envoltórias de ruptura, para as duas distintas situações de compressão e de extensão, refletem em diferentes inclinações dos planos de ruptura. As linhas tracejadas foram colocadas paralelas aos planos de ruptura, para uma melhor visualização. Os ângulos dos planos de ruptura foram medidos a partir dos corpos-de-prova, por meio de um transferidor, não podendo ser obtidos a partir da Figura 4.47 devido à perspectiva existente nas fotografias. 


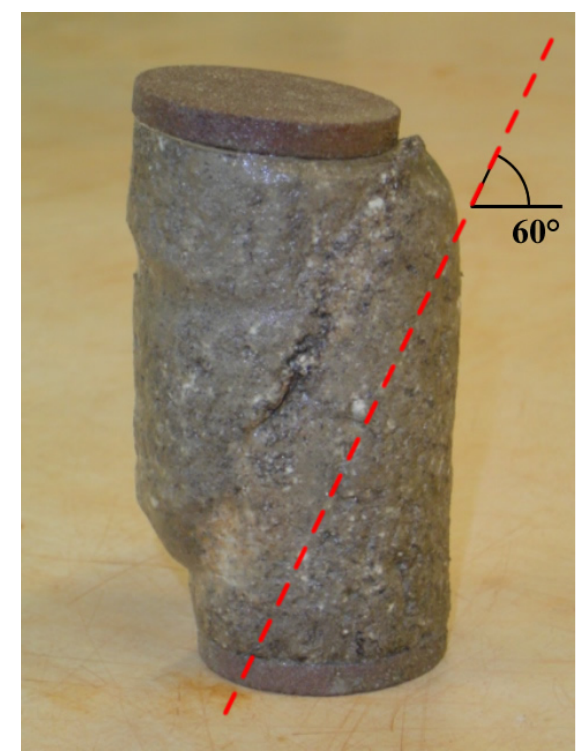

a) ruptura por compressão, ensaio (3)

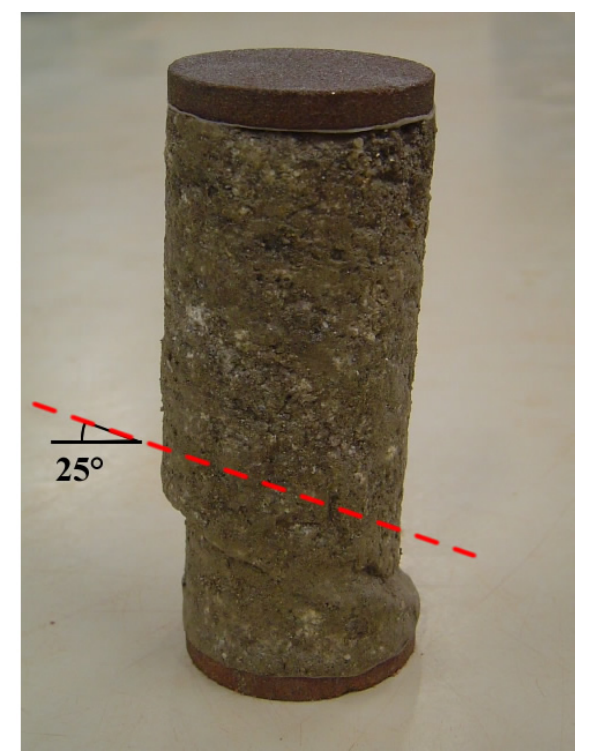

b) ruptura por extensão, ensaio (10)

Figura 4.47 - Planos de ruptura obtidos ao final dos ensaios triaxiais

Os ensaios de compressão obtiveram planos de ruptura $(\alpha$ comp $)$ com aproximadamente 60 graus de inclinação, em relação à horizontal. Isto corrobora o ângulo de atrito obtido anteriormente, por meio da relação:

$$
\alpha_{\text {comp }}=45+\frac{\varphi^{\prime}}{2} \Rightarrow \alpha_{\text {comp }}=45+\frac{28,4}{2}=59,2^{\circ}
$$

Os ensaios de extensão obtiveram planos de ruptura $(\alpha$ ext $)$ com aproximadamente 25 graus de inclinação. Novamente, o ângulo de atrito obtido mostra-se coerente:

$$
\alpha_{\text {ext }}=45-\frac{\varphi^{\prime}}{2} \Rightarrow \alpha_{\text {ext }}=45-\frac{41,1}{2}=24,5^{\circ}
$$

Lins e Lacerda (1980) também encontraram envoltórias diferentes para as situações de compressão e de extensão, dos ensaios triaxiais que realizaram.

\subsection{Conclusões Sobre o COMPortamento MeCÂnico do Solo}

Os resultados de mineralogia e microscopia, obtidos no Capítulo 3, serviram como base para a explanação do comportamento mecânico do solo residual saprolítico em estudo, como discutido em seqüência.

A existência de expansividade em um baixo grau é justificada pela quantidade reduzida do argilo-mineral esmectita presente no solo. 
A inclinação acentuada da reta de descompressão (elevado índice de recompressão), determinada pelos ensaios edométricos, é devida à microestrutura do solo composta pela predominância de placas de mica nas frações silte e argila. O índice de recompressão é tão maior quanto mais elevado o nível de tensões a que o solo foi submetido antes de ser descarregado. A presença do argilo-mineral expansivo esmectita, mesmo que em quantidade reduzida, também é responsável pela acentuação da reta de descompressão.

O estudo microscópico apresentado no capítulo anterior demonstrou que a microestrutura do solo é formada pelo empilhamento de placas micáceas, mas não pôde evidenciar uma estruturação por cimentação das partículas. Ao ser analisado o comportamento mecânico do solo em estudo, pôde-se concluir que ele apresenta estruturação entre as partículas. Esta conclusão foi realizada comparando-se ensaios edométricos em amostras naturais e em uma amostra remoldada, e localizando-se a máxima taxa de dilatância nas curvas tensão-deformação de ensaios triaxiais fortemente sobre-adensados.

A permeabilidade determinada para o solo mostra-se coerente, por ser reduzida com o aumento do nível de tensão e com a perda de estruturação.

O solo apresenta um comportamento mecânico anisotrópico, o qual pôde ser evidenciado pelo formato e inclinação da curva de escoamento e pela obtenção de envoltórias de resistência distintas para a situação de compressão e de extensão. Este comportamento pode estar associado à anisotropia existente na rocha originária, remanescente no solo residual saprolítico.

A envoltória de escoamento foi determinada pelo método gráfico de energia de deformação em função do comprimento do vetor tensão. Para as trajetórias de tensões em que o aumento do invariante $p$ ' era mais expressivo, as curvas W - LSSV demonstraram melhor eficiência, enquanto que para as trajetórias em que o aumento do invariante $q$ era mais expressivo, as curvas $\mathrm{q}-\varepsilon_{\mathrm{q}}$ demonstraram melhor facilidade de utilização.

Com base nos resultados dos ensaios edométricos, dos triaxiais de carregamento axial e dos triaxiais de descarregamento, acredita-se que o estado de tensões "in situ" (antes de qualquer alteração devida à obra do túnel) esteja localizado no centro da envoltória de escoamento e que possua tensão vertical efetiva próxima ao valor de $370 \mathrm{kPa}$. Com a alteração deste estado de tensões e ao ser atingida a envoltória de escoamento, esta se desloca juntamente com a trajetória de tensões, sem sofrer grandes variações de rotação, encolhimento e/ou expansão. Ou seja, o comportamento da envoltória de escoamento é essencialmente cinemático. 
Ao ser efetuada a amostragem, o estado de tensões de campo foi reduzido a um nível próximo de zero, deslocando a envoltória de escoamento. Devido a isto, a envoltória determinada durante a fase de adensamento dos ensaios triaxiais de carregamento axial está localizada na origem do espaço das tensões. Nesta região, a envoltória de escoamento intersecciona a envoltória de ruptura, ocasionando um comportamento de resistência de pico seguida por amolecimento.

Após a amostra ser carregada a um nível de tensões elevado, a envoltória de escoamento determinada durante a fase de cisalhamento dos ensaios triaxiais de descarregamento localizou-se distante da envoltória de ruptura. Neste caso, o solo não apresenta um comportamento de resistência de pico seguida por amolecimento, mesmo se submetido a estados de tensões reduzidos. Isto ocorre porque a trajetória de tensões, ao alcançar esta região, está em contato com a curva de escoamento (o solo está normalmente adensado e as duas envoltórias não se interseccionam).

Nos trechos das curvas de compressibilidade anteriores ao escoamento, tanto para os ensaios edométricos quanto para os triaxiais, notou-se uma possível divisão em outros dois trechos, um quasi-elástico e outro pseudo-elástico.

Nos ensaios triaxiais realizados, pôde-se notar um aumento da rigidez do solo com o aumento da tensão confinante. Os ensaios muito sobre-adensados (1) e (2), os ensaios sobreadensados por recarregamento (3) e (4) e os ensaios de descarregamento (7), (8) e (9) apresentaram um trecho inicial linear. Porém, o ensaio triaxial normalmente adensado (6) também apresentou um trecho inicial razoavelmente representável por uma reta.

Devido à presença de estruturação e ao comportamento tensão-deformação semelhante apresentado pelos ensaios triaxiais sobre-adensados e normalmente adensados, pode-se afirmar que o escoamento do solo refere-se principalmente à mudança de comportamento devido à perda de estrutura entre as partículas, e não à mudança de comportamento do regime elástico para o regime elasto-plástico.

Para ambas as situações de compressão e de extensão, o solo apresentou um intercepto de coesão nulo.

O valor reduzido da resistência do solo, refletido no valor de 28 graus para o ângulo de atrito interno (situação de compressão), é devido à predominância de partículas micáceas. De acordo com Souza Neto (2000), isto é atribuído à forma plana das partículas, as quais tendem a dificultar o entrosamento entre os grãos e a ocasionar perda de resistência devido à quebra dos grãos durante o cisalhamento. 
A presença dos planos de descontinuidade e da macroestrutura orientada, ambas herdadas da rocha metamórfica original, poderá comandar a resistência do maciço como um todo.

Evidenciou-se um comportamento viscoso atuante no solo em estudo, a fluência no caso dos ensaios edométricos (aumento da deformação com carregamento constante) e a relaxação no caso dos ensaios triaxiais (diminuição da tensão com deformação constante). Entretanto, resultados de fluência e de relaxação não serão apresentados, por possuírem um grau de complexidade que requereria um estudo à parte. Para minimizar os efeitos da viscosidade e sua influência no comportamento mecânico do solo, procurou-se manter o mesmo tempo de adensamento para todos os ensaios, no caso o período de um dia. 


\section{CAPítulo 5}

\section{Modelagem numérica}

O objetivo deste capítulo é obter as trajetórias de tensões de pontos localizados ao redor do túnel em estudo, por meio de uma modelagem numérica e tendo-se como base o comportamento mecânico estudado no capítulo anterior.

Este capítulo foi subdividido em seis partes, das quais a primeira e a segunda são destinadas à revisão bibliográfica sobre túneis e modelos constitutivos, a terceira, a quarta e a quinta são destinadas à concepção da modelagem e a sexta parte para as conclusões parciais referentes a este capítulo.

\subsection{FENÔMENOS ENVOLVENDO A ESCAVAÇÃO DE TÚNEIS EM SOLO}

O intuito de se estudar os principais fenômenos envolvidos com a escavação de um túnel em solo é de se obter uma base de conhecimentos, a qual seja suficiente para embasar teoricamente a análise dos resultados que serão obtidos com as modelagens numéricas desta pesquisa. Serão abordados assuntos como o arqueamento de tensões, zonas de influência da escavação, bacias de subsidência, entre outros. 


\subsubsection{Alteração do estado de tensões no maciço envolvente}

Sob um ponto de vista mecânico, o ato de se escavar subterraneamente um maciço de solo, previamente em equilíbrio, resulta na remoção das tensões ao longo da superfície escavada. Dessa maneira, à medida que avança a frente de escavação do túnel, o campo de tensões do maciço envolvente é significativamente alterado.

De modo geral, este mecanismo origina um movimento da frente de escavação em direção à cavidade criada, assim como também uma convergência das paredes, até que um novo estado de equilíbrio seja alcançado. Este novo estado de tensões pode ser atingido com uma mobilização parcial ou total da resistência do maciço, a qual pode ser complementada pela adição de sistemas auxiliares de suporte.

Em casos menos freqüentes, o equilíbrio final pode ser atingido sem a necessidade de uma estrutura de suporte. Nestes casos, o maciço é considerado autoportante, capaz de suportar o descarregamento ocasionado pela remoção das tensões no contorno da escavação, em condições de estabilidade e com deformações limitadas.

Para o caso de túneis em solos, de maneira geral, a instalação de sistemas de suporte é praticamente obrigatória, o mais próximo possível da frente de escavação, devido à necessidade de controle de grandes deformações ou simplesmente pelo fato do maciço ter sua resistência totalmente mobilizada (não autoportante).

As deformações permitidas ao maciço, antes e após a instalação da estrutura de suporte, acarretam em redistribuições de tensões para zonas vizinhas não escavadas, o que se denomina efeito de arco. Segundo Langer e Stockmann (1985), o arqueamento das tensões somente ocorre quando há mobilização de resistência ao cisalhamento do maciço envolvente. Esse fenômeno pode ser melhor compreendido ao se analisar uma faixa de solo situada acima da abóbada do túnel, como ilustrado na Figura 5.1. Os elementos A, B e C situam-se exatamente no perímetro da escavação, antes da execução da abertura; após a escavação, o elemento A se desloca mais do que o elemento B, o qual se desloca mais do que o elemento C. Essa diferença de deslocamento induz tensões de cisalhamento entre os elementos e, caso o maciço seja incapaz de mobilizar sua resistência ao cisalhamento, os elementos se deslocam por igual e o túnel entra em colapso. 


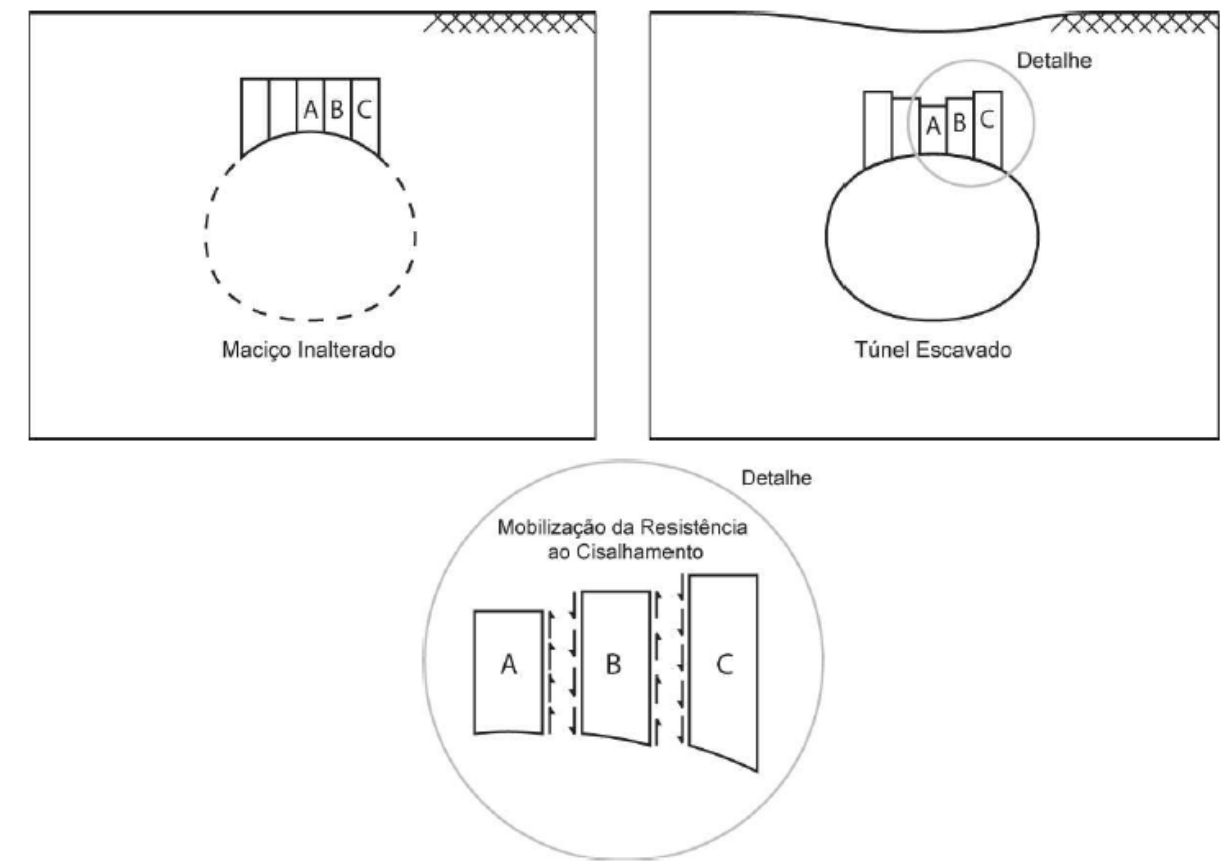

Figura 5.1 - Mobilização da resistência ao cisalhamento devido ao efeito de arco, a partir de França (2006)

Eisenstein et al. (1984) salientaram que o arqueamento das tensões não ocorre apenas na seção transversal do túnel, como ilustrado na Figura 5.2. Mecanismos análogos também se desenvolvem em seções longitudinais verticais e horizontais, sendo responsáveis pelas transferências de tensões da região já escavada (ainda sem suporte) para a região ainda não escavada à frente e para o suporte (situado logo atrás).

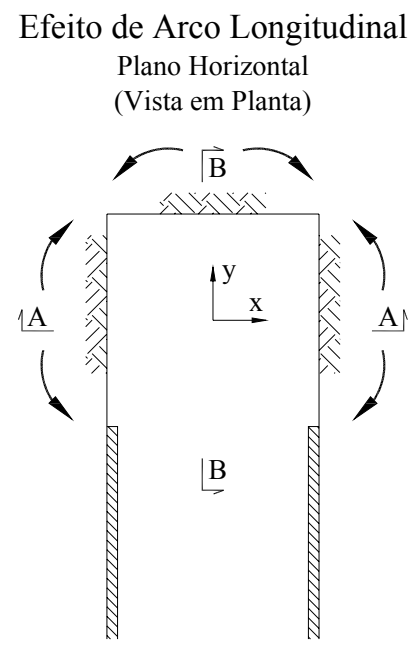

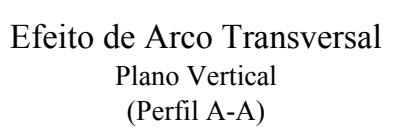

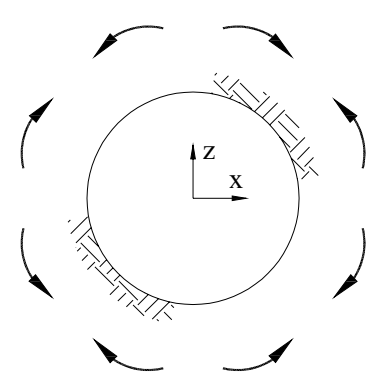

Efeito de Arco Longitudinal Plano Vertical (Perfil B-B)

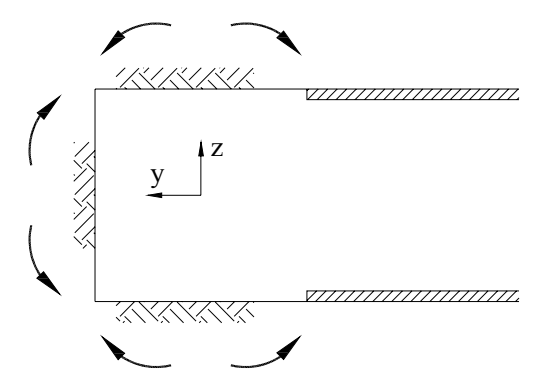

Figura 5.2 - Natureza tridimensional do arqueamento das tensões nas proximidades da frente de um túnel com suporte, a partir de Eisenstein et al. (1984) 
Assim sendo, pode-se afirmar que o efeito de arco nas proximidades da frente de escavação de um túnel, o qual é responsável pela redistribuição das tensões no interior do maciço, é de natureza essencialmente tridimensional.

Em se tratando das tensões principais, o arqueamento também é observado na alteração das rosetas de tensões. Em um maciço com superfície horizontal, como o ilustrado na Figura 5.3, as tensões principais maiores e menores coincidem com os eixos vertical e horizontal. Após a escavação da abertura, as tensões cisalhantes mobilizadas pelo efeito de arco ao redor do túnel causam a rotação das direções das tensões principais, uma vez que os planos de cisalhamento nulo não mais coincidem com os planos vertical e horizontal.
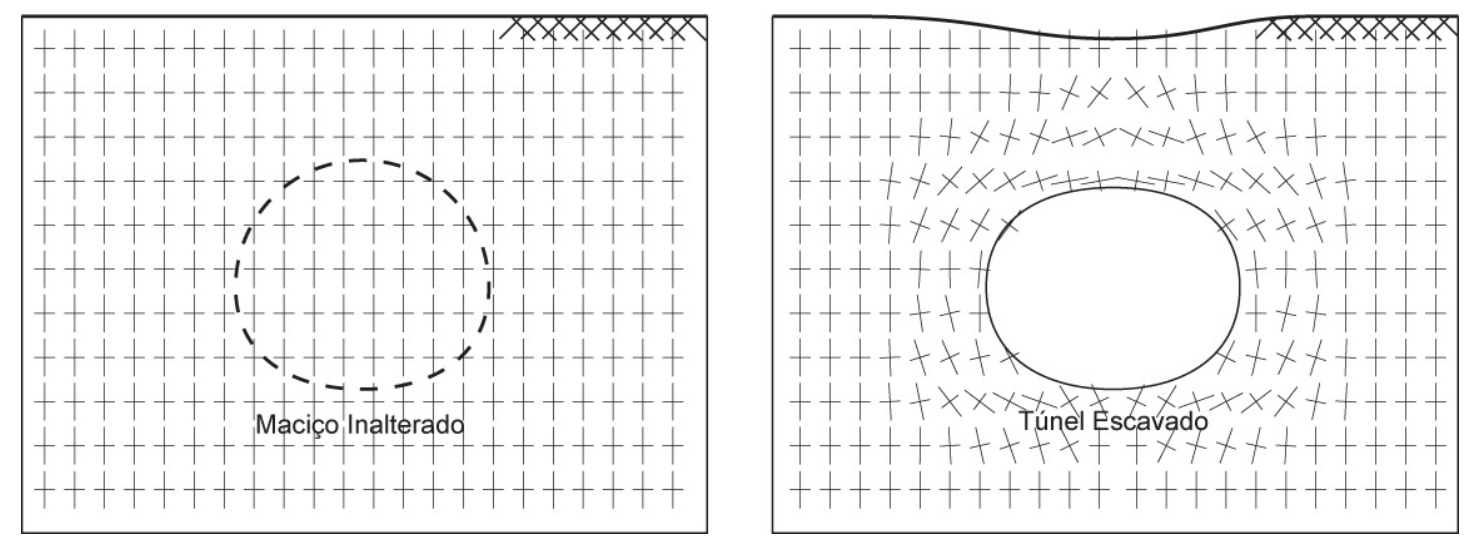

Figura 5.3 - Ilustração da alteração das direções das tensões principais antes e após a escavação de um túnel, a partir de França (2006)

De acordo com Almeida e Sousa (1998) e França (2006), a influência da abertura do túnel é sentida adiante da frente de escavação, como ilustrado na Figura 5.4.

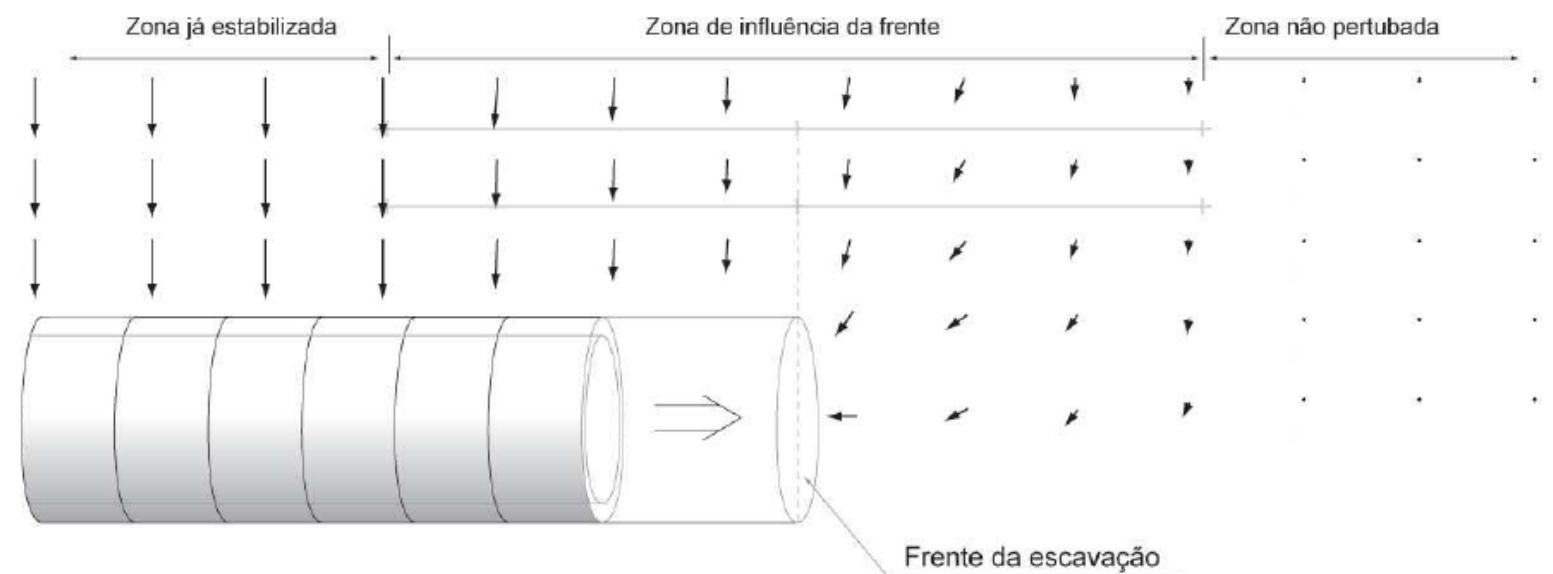

Figura 5.4 - Influência da frente de escavação, a partir de França (2006) 
$\mathrm{Na}$ região adiante da frente de escavação, os deslocamentos ocorrem fundamentalmente na direção longitudinal. Com o avanço do túnel, esta componente longitudinal dos deslocamentos cresce e atinge um valor máximo no momento da passagem da frente de escavação, começando a diminuir com o afastamento da frente até se anular a certa distância. De maneira contrária, os deslocamentos radiais aumentam bruscamente no momento da passagem da frente de escavação, não variando após o afastamento da frente. As variações dos deslocamentos longitudinais e radiais podem ser observadas na Figura 5.5.

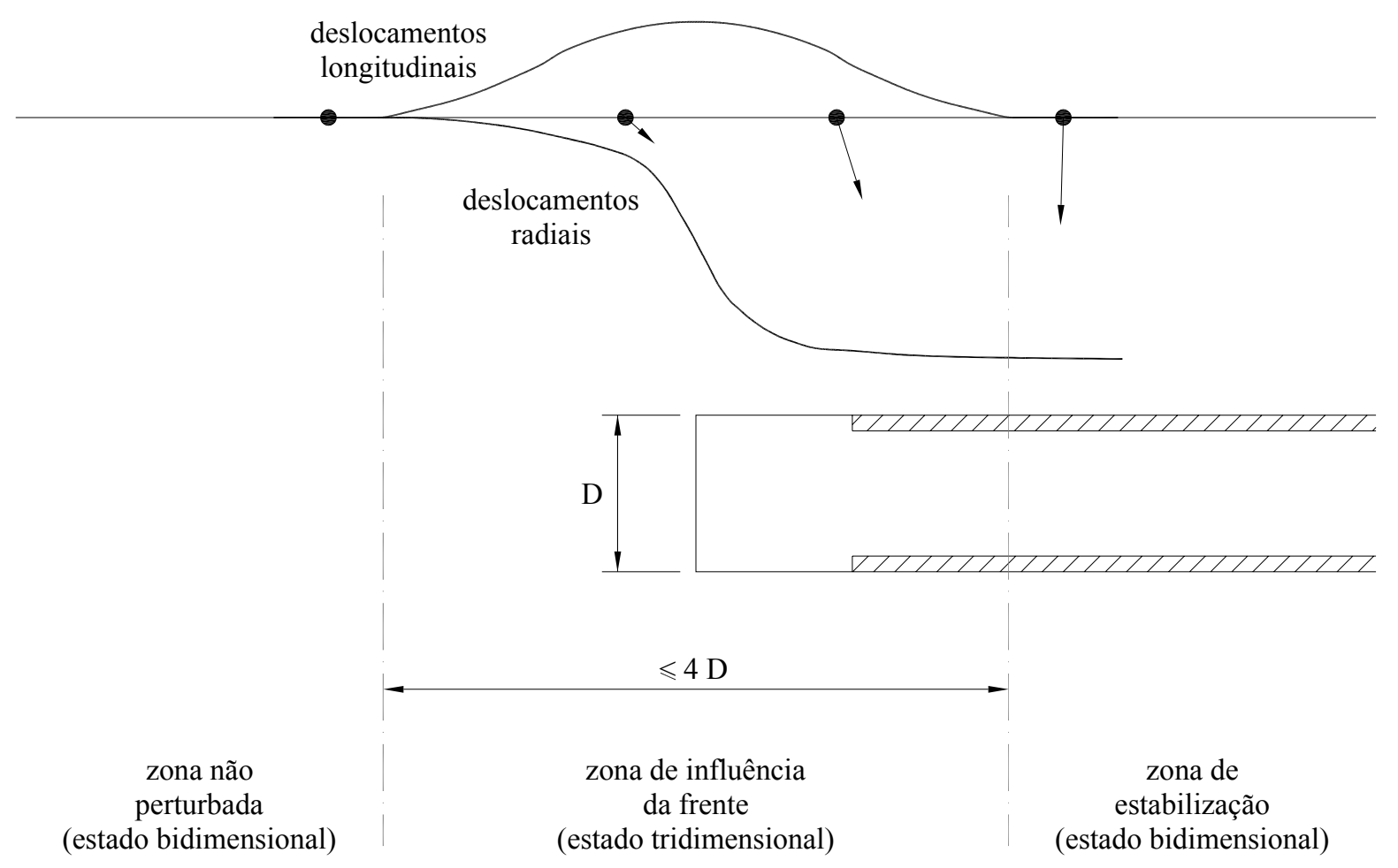

Figura 5.5 - Zonas características do maciço em relação aos estados de deformação, a partir de Almeida e Sousa (1998)

Observa-se que os deslocamentos longitudinais não são nulos durante o avanço da frente de escavação, mas que eles podem ser desconsiderados na situação final de equilíbrio se comparados aos deslocamentos radiais. Com isto, pode-se concluir que a escavação de um túnel origina nas proximidades da frente de escavação uma zona do maciço onde o estado de deformação é de natureza tridimensional, sendo o equilíbrio final atingido numa zona onde a influência da frente já não é sentida e em condições muito próximas de um estado plano de deformação. 
Na maioria dos casos práticos, o efeito da escavação é sentido até aproximadamente dois diâmetros adiante e dois diâmetros atrás da frente de escavação, conforme afirmam Almeida e Sousa (1998) e França (2006).

O desenvolvimento da zona de influência da frente de escavação é determinado, fundamentalmente, pelas características do maciço e do sistema de suporte instalado, de acordo com Almeida e Sousa (1998) e Galli et al. (2004).

Segundo Shahrour e Ghorbanbeigi (1996), quanto menor a resistência do maciço, maior é o desenvolvimento da zona plastificada e conseqüentemente maior a distância necessária para o estabelecimento do equilíbrio final e da condição de estado plano de deformação. De maneira análoga, a influência da escavação é sentida tão mais adiante da frente quanto menor a resistência do maciço. De acordo com Almeida e Sousa (1998), havendo sistema de suporte, independentemente do comportamento do solo, a condição de deformação plana é alcançada a uma distância de sua instalação não maior do que um diâmetro. Em relação ao sistema de suporte utilizado, Shahrour e Ghorbanbeigi (1996) afirmam que quanto mais rígido e mais rápido ele for instalado, mais próximo do local de sua instalação ocorrerá o estabelecimento do equilíbrio final.

\subsubsection{Interação maciço-suporte}

De acordo com Almeida e Sousa (1998), a interação entre o maciço e o suporte constitui um sistema altamente hiperestático, cujo estado de tensão-deformação não é de fácil determinação. Devido à redistribuição das tensões, o carregamento atuante no suporte, os esforços nele mobilizados e os deslocamentos que nele ocorrem são interdependentes e correlacionados. Por isso, conclui-se que a grandeza e a distribuição das tensões sobre o suporte não podem ser determinadas estaticamente. As tensões não são apenas função das tensões iniciais do maciço e das características geométricas da escavação, mas dependem também das propriedades geomecânicas do maciço envolvente e do processo construtivo adotado (sistema de escavação, velocidade de avanço, o tipo e as características do suporte e o momento de sua instalação).

Devido ao fato das tensões exercidas sobre os suportes estarem relacionadas ao estado tridimensional de deformações estabelecido com o avanço da escavação, em princípio, sua determinação exige a realização de análises tridimensionais, com incrementos de escavação e de instalação do suporte. Entretanto, as dificuldades intrínsecas a uma análise tridimensional, 
somadas ao fato do equilíbrio final ser alcançado em condições de deformação plana, estimulam a abordagem do problema com conceitos e formulações em estado plano de deformação, utilizando-se metodologias simplificadas para a representação da tridimensionalidade.

Dentre as diversas metodologias propostas existentes para a conversão de um problema tridimensional em um de deformação plana, a mais utilizada consiste em aplicar uma tensão em todo o contorno escavado. A simulação do avanço da escavação é feita pela sucessiva redução da tensão aplicada, desde um valor inicial equivalente ao estado inicial de tensão do maciço, até um valor nulo equivalente ao deslocamento máximo do contorno da escavação (no caso, sem sistema de suporte instalado).

Ao se manter uma fração do valor inicial desta tensão aplicada no contorno da escavação, obtém-se um valor intermediário de deslocamento, representando-se desta maneira a ação estabilizadora do maciço situado adiante da frente (ainda não escavado), o qual se opõe às deformações que ocorrem em direção à abertura executada.

Para uma análise deste tipo, são utilizadas as curvas características (ou de convergência) do maciço, que relacionam as tensões aplicadas no contorno da abertura (p) com os deslocamentos da periferia do túnel $(\Delta)$. Três tipos de curvas características são exemplificados na Figura 5.6.

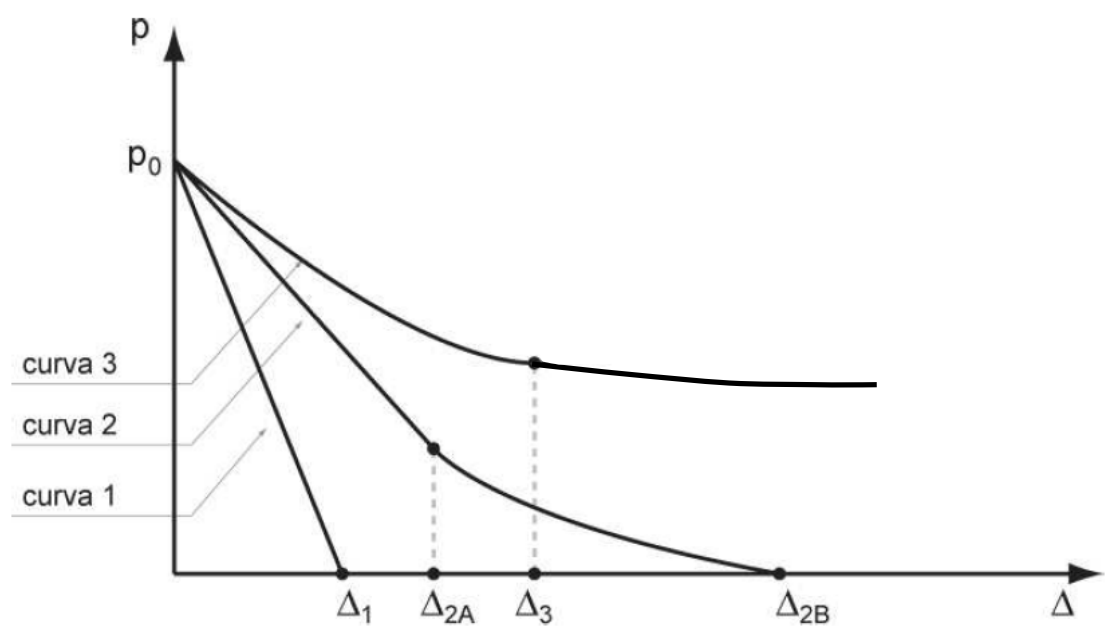

Figura 5.6 - Curvas características de maciços

A curva 1 corresponde a um maciço com comportamento linear elástico, até a liberação total das tensões, tendo o deslocamento final de um ponto do contorno da escavação o valor $\Delta_{1}$, não sendo necessário complementar sua capacidade resistente (maciço autoportante). A curva 2 também representa um maciço autoportante, sendo possível manter a 
abertura sem suporte até o valor de deslocamento final de $\Delta_{2 \mathrm{~B}}$. Entretanto, após atingir a deformação $\Delta_{2 \mathrm{~A}}$, o maciço deixa de apresentar uma resposta elástica ao descarregamento e passa a refletir uma resposta não-linear devida às plastificações induzidas, típica de um comportamento elasto-plástico. A curva 3 corresponde a um maciço que não é autoportante, sendo necessária a instalação de uma estrutura de suporte antes de ser atingida a deformação $\Delta_{3}$, a fim de ser evitado o colapso da abertura.

Cabe salientar que, mesmo o maciço sendo autoportante, a adoção de um sistema de suporte por muitas vezes se faz necessária, tendo-se em vista que pode ser inaceitável para a obra a amplitude dos deslocamentos finais. O suporte minimizaria a perda de solo do volume escavado e os recalques superficiais.

Sendo adotado um sistema de suporte para a escavação do túnel, o equilíbrio passa a ser tipicamente um problema de interação solo-estrutura e, segundo Almeida e Sousa (1998), a rigidez relativa do conjunto e o tempo até a instalação do suporte passam a desempenhar papel fundamental. A análise desta interação solo-estrutura, utilizando-se o conceito de curvas características (ou de confinamento) do suporte, assim como feito para o maciço, é conhecida como método da convergência-confinamento.

A curva característica do suporte relaciona a tensão que o maciço escavado transmite ao suporte com sua correspondente deformação, sendo exemplificada na Figura 5.7.

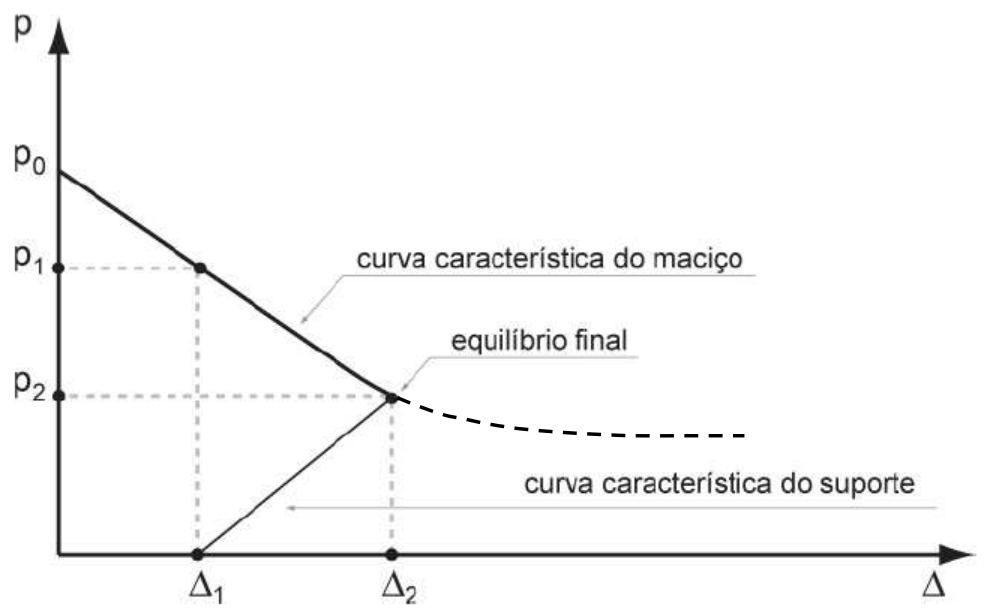

Figura 5.7 - Interação maciço-suporte: Método da Convergência-Confinamento

Tendo-se em vista que a instalação da estrutura de suporte é realizada após certo tempo de escavada a frente (atraso do suporte), o deslocamento $\Delta_{1}$ ocorrido ocasiona um alívio das tensões iniciais até $\mathrm{P}_{1}$. Se, neste instante, o suporte instalado fosse infinitamente rígido, o deslocamento final do conjunto seria $\Delta_{1}$ e o carregamento transmitido à estrutura 
seria $\mathrm{P}_{1}$. Entretanto, como o suporte também se deforma, as tensões no maciço continuam a ser aliviadas, à medida que o carregamento transmitido à estrutura aumenta. Este fenômeno continua até que seja alcançado o equilíbrio da interação maciço-suporte, correspondente à intersecção das duas curvas e dependente da rigidez relativa do conjunto e do atraso do suporte. Nesta situação de equilíbrio final, o deslocamento de um ponto do contorno da escavação é igual a $\Delta_{2}$, o deslocamento ocorrido na estrutura é igual à diferença $\Delta_{2}-\Delta_{1}$ e o carregamento atuante na estrutura é $\mathrm{P}_{2}$.

A Figura 5.7 apresentada anteriormente ilustra bem o efeito da rigidez relativa e do atraso do suporte: o quanto antes o túnel for revestido e mais rígido for o suporte em relação ao solo, maior será a tensão atuante no suporte e menor o deslocamento do solo.

\subsubsection{Previsão dos movimentos associados à escavação de um túnel}

A escavação de túneis, inevitavelmente e indubitavelmente, ocasiona movimentos no maciço envolvente e pode resultar em danos nas estruturas e infra-estruturas situadas nas proximidades das obras.

A qualidade do projeto do túnel está diretamente associada às medidas tomadas para prevenção de danos induzidos pela escavação. É importante que sejam realizadas estimativas dos deslocamentos no maciço, principalmente dos recalques (componente vertical dos deslocamentos) na superfície do terreno.

Duas origens diferentes podem ser identificadas para estes deslocamentos. A primeira está associada a fenômenos como o adensamento e a compressão causados pela redução da pressão neutra e conseqüente aumento da tensão efetiva (o rebaixamento do nível freático, por exemplo), sendo mais importante para solos argilosos e ocorrendo de forma diferida no tempo. A segunda origem dos deslocamentos está associada ao movimento do solo para o vazio criado pela escavação do túnel, podendo ser mensurado pelo denominado volume de solo perdido $(\mathrm{Vp})$, o qual é definido como o volume do maciço que cruza o perímetro teórico de escavação ao deformar-se.

A previsão dos deslocamentos devidos à escavação de um túnel deve considerar inúmeros fatores, exigindo a utilização de cálculos numéricos. Entretanto, a complexidade dos modelos faz com que tal previsão seja realizada recorrendo-se a maneiras mais simplificadas, como os métodos analíticos e os de natureza empírica ou semi-empírica. 
Em relação aos recalques que ocorrem em uma seção transversal ao túnel, a maioria dos métodos existentes se baseia na hipótese de que sua distribuição tem a forma aproximada de uma curva de distribuição normal (curva de Gauss) invertida. De acordo com esta hipótese, os recalques transversais podem ser descritos pela função

$$
\rho(x)=\rho_{\text {máx }} \cdot \exp \left(\frac{-x^{2}}{2 \cdot i_{x}{ }^{2}}\right)
$$

sendo $\rho(\mathrm{x})$ o recalque em qualquer ponto da curva à distância $\mathrm{x}$ do eixo de simetria, $\rho_{\text {máx }} \mathrm{o}$ recalque máximo no eixo de simetria e $i_{x}$ o valor de $x$ correspondente ao ponto de inflexão da curva, no qual ocorre a máxima distorção angular (máximo declive) e onde o recalque é igual a $60,65 \%$ do recalque máximo, como pode ser observado na Figura 5.8.

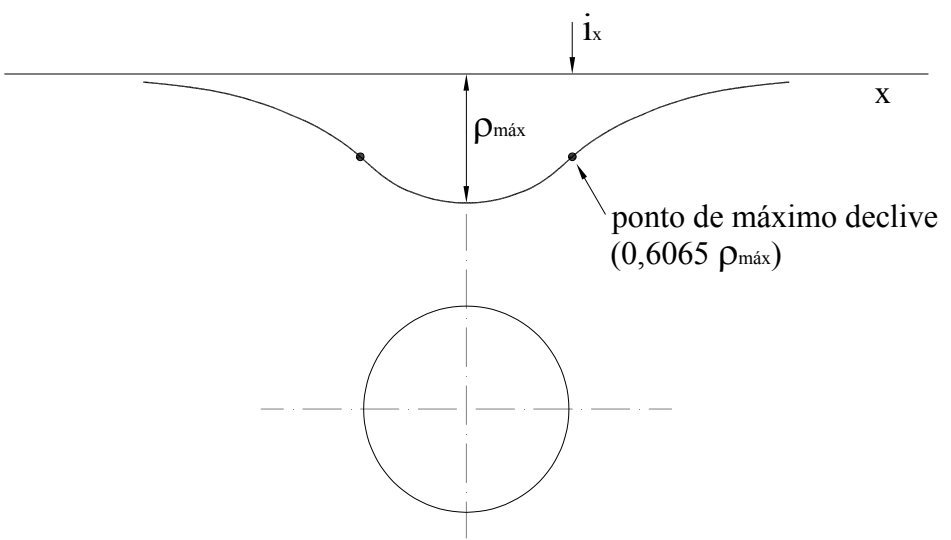

Figura 5.8 - Perfil transversal dos deslocamentos superficiais (curva de Gauss)

Integrando-se a curva de Gauss, obtém-se o volume da bacia de subsidência (volume de solo deslocado à superfície) por unidade de comprimento de túnel (Va):

$$
V a=\int \rho(x) \cdot d x=\sqrt{2 \pi} \cdot i_{x} \cdot \rho_{\operatorname{máx}}
$$

Desta maneira, pode-se obter o recalque em função do volume da bacia de subsidência, substituindo-se a equação (5.2) em (5.1) e obtendo-se

$$
\rho(x)=\frac{V a}{\sqrt{2 \pi} \cdot i_{x}} \cdot \exp \left(\frac{-x^{2}}{2 \cdot i_{x}^{2}}\right)
$$

Derivando-se a equação anterior em relação a x, obtém-se o declive do perfil transversal dos recalques

$$
\frac{d \rho(x)}{d x}=\frac{-V a \cdot x}{\sqrt{2 \pi} \cdot i_{x}^{3}} \cdot \exp \left(\frac{-x^{2}}{2 \cdot i_{x}^{2}}\right)
$$


Admitindo-se que os movimentos de todas as partículas do solo são dirigidos para o centro do túnel, a distribuição transversal dos deslocamentos horizontais na superfície do terreno pode ter a forma que está apresentada na Figura 5.9.

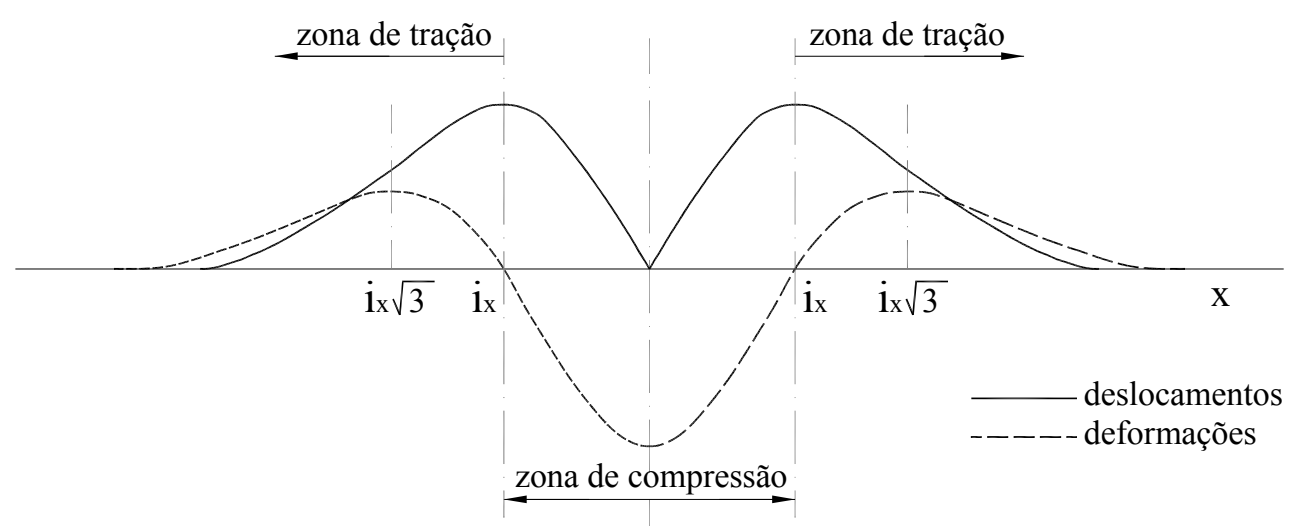

Figura 5.9 - Distribuição transversal dos deslocamentos horizontais superficiais

Observa-se que os deslocamentos horizontais na superfície são nulos sobre o eixo de simetria e que seus valores máximos ocorrem no ponto de inflexão da curva de distribuição normal dos recalques. As deformações horizontais ocasionadas por estes deslocamentos são de compressão na região compreendida entre os pontos de inflexão e de tração na região exterior. A máxima deformação de compressão ocorre sobre o eixo de simetria, enquanto que a tração máxima ocorre a uma distância de $\mathrm{i}_{\mathrm{x}} \sqrt{3}$ do eixo de simetria.

De acordo com Almeida e Sousa (1998), a diferença básica entre os diferentes métodos que utilizam a curva de Gauss para representar o perfil transversal de recalques consiste na maneira de se estimar os dois únicos parâmetros necessários para se definir a curva: a distância do ponto de inflexão e o recalque máximo (ou o volume da bacia).

O modo mais usual de se estimar a distância do ponto de inflexão da curva de Gauss, o qual define a largura da bacia de subsidência, é avaliá-lo como função da geometria do problema (diâmetro do túnel ' $D$ ' e profundidade de seu eixo ' $H$ '), como o caso da expressão comum a diversos autores

$$
\left(\frac{2 \cdot \mathrm{i}_{\mathrm{x}}}{\mathrm{D}}\right)=\mathrm{a} \cdot\left(\frac{\mathrm{H}}{\mathrm{D}}\right)^{\mathrm{b}}
$$

onde ' $a$ ' e ' $b$ ' são fatores adimensionais empíricos, cujos valores variam de acordo com o solo. Em geral, utiliza-se $a$ igual a 1,0 e $b$ variando de 0,8 a 1,0 para solos argilosos; $\mathrm{a}=0,5$ e $\mathrm{b}=1,0$ para solos granulares. 
O volume da bacia de subsidência (Va) comumente é estimado como sendo correspondente ao volume de perda de solo (Vp), o qual pode ser expresso como uma porcentagem do volume de solo escavado (área teórica de escavação por unidade de comprimento do túnel). A perda de solo é composta basicamente por duas parcelas, as deformações que ocorrem na frente de escavação e as deformações de convergência das paredes. A perda depende diretamente do processo construtivo adotado (aplicação de pressão de suporte na frente de escavação, parcialização da seção), das propriedades do maciço e do sistema de suporte, da qualidade executiva da escavação e do tempo de atraso da instalação do suporte. Na maioria dos casos práticos, a estimativa de Vp é feita de acordo com a experiência e com base em casos históricos. Para túneis escavados em NATM, Vp é estimado como variando de 1 a 5\% da área de escavação, enquanto que para túneis escavados sob a proteção de escudos e pressurização da frente, Vp é estimado como variando de 0,2 a $1 \%$.

A diferença entre o volume da bacia de subsidência e o volume de perda de solo corresponde à variação do volume global do maciço, dependente fortemente da natureza dos terrenos. Solos argilosos coesivos, de comportamento não drenado, apresentam volumes iguais, enquanto que solos granulares, solos argilosos a longo prazo, solos expansivos e solos colapsíveis apresentam diferença entre os dois volumes.

\subsection{Modelos Elasto-Plásticos Para Solos}

Muito da experiência divulgada sobre a representação do comportamento de solos por modelos elasto-plásticos, segundo Azevedo et al. (2002), tem sido sobre a sua utilização para argilas reconstituídas e areias. Pouca experiência foi acumulada sobre a representação de estruturas geotécnicas por modelos elasto-plásticos envolvendo solos não-deformados (não desestruturados) e não-saturados, como o solo residual em estudo.

Para a representação do comportamento do solo em estudo, foram escolhidos dois modelos constitutivos elasto-plásticos, o Mohr-Coulomb e o Hardening-Soil, sendo ambos apresentados a seguir. 


\subsubsection{Mohr-Coulomb}

Com o intuito de uma simplificação, este modelo será tratado com o nome de Mohr-Coulomb, entretanto sabe-se que este é apenas seu critério de ruptura e não o modelo em si. Ele é o mais comumente utilizado, devido ao seu número reduzido de parâmetros e pela familiaridade dos Engenheiros Geotécnicos com seus conceitos.

Trata-se de um modelo elasto-plástico perfeito, como visto na Figura 5.10 (a), cujo comportamento elástico é isotrópico e controlado pelo Módulo de Elasticidade (E') e pelo coeficiente de Poisson ( $\left.v^{\prime}\right)$, representado por:

$$
\begin{aligned}
& \varepsilon_{1}=\frac{1}{E^{\prime}} \cdot\left[\sigma_{1}^{\prime}-v^{\prime} \cdot\left(2 \cdot \sigma_{3}^{\prime}\right)\right] \\
& \varepsilon_{3}=\frac{1}{E^{\prime}} \cdot\left[\sigma_{3}^{\prime}-v^{\prime} \cdot\left(\sigma_{1}^{\prime}+\sigma_{3}^{\prime}\right)\right]
\end{aligned}
$$

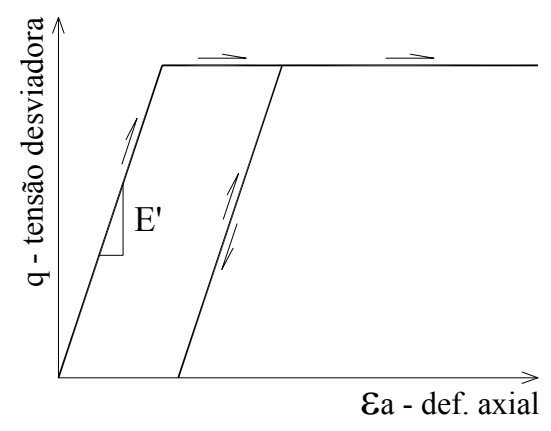

(a) curva tensão-deformação

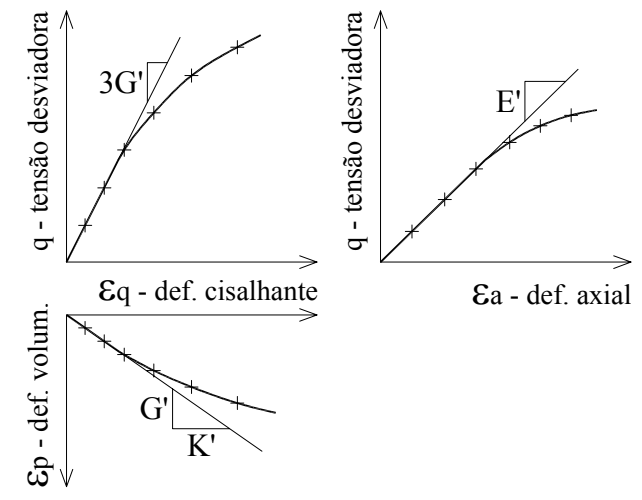

(b) obtenção dos parâmetros elásticos

Figura 5.10 - Curvas tensão-deformação do modelo Mohr-Coulomb

De acordo com Wood (1990), a deformação elástica total pode ser dividida em deformação cisalhante $\left(\varepsilon_{\mathrm{q}}\right)$, responsável apenas pela mudança de forma, e deformação volumétrica $\left(\varepsilon_{\mathrm{p}}\right)$, responsável apenas pela mudança de volume, de maneira que cada parcela possa se correlacionar com as tensões através do Módulo Cisalhante (G') e do Módulo Volumétrico (K') por meio de:

$$
\begin{aligned}
& \Delta \mathrm{q}=3 \mathrm{G}^{\prime} \cdot \Delta \varepsilon_{\mathrm{q}} \\
& \Delta \mathrm{p}^{\prime}=\mathrm{K}^{\prime} \cdot \Delta \varepsilon_{\mathrm{p}} \\
& \Delta \varepsilon_{\mathrm{p}}=\frac{\mathrm{G}^{\prime}}{\mathrm{K}^{\prime}} \cdot \Delta \varepsilon_{\mathrm{q}}
\end{aligned}
$$


Os módulos cisalhante e volumétrico podem ser obtidos por meio de ensaios triaxiais drenados, como mostrado na Figura 5.10 (b), e se correlacionam com o módulo de elasticidade e coeficiente de Poisson por:

$$
\begin{aligned}
G^{\prime} & =\frac{E^{\prime}}{2\left(1+v^{\prime}\right)} \\
K^{\prime} & =\frac{E^{\prime}}{3\left(1-2 v^{\prime}\right)}
\end{aligned}
$$

Como dito, neste modelo é utilizado o critério de ruptura de Mohr-Coulomb, coincidente com a envoltória de escoamento e representado pela reta da Figura 5.11 (a). A envoltória é definida pelo intercepto de coesão (c') e pelo ângulo de atrito interno ( $\varphi$ '):

$$
\tau_{\mathrm{r}}=\mathrm{c}^{\prime}+\sigma_{\mathrm{r}}^{\prime} \cdot \operatorname{tg} \varphi^{\prime}
$$

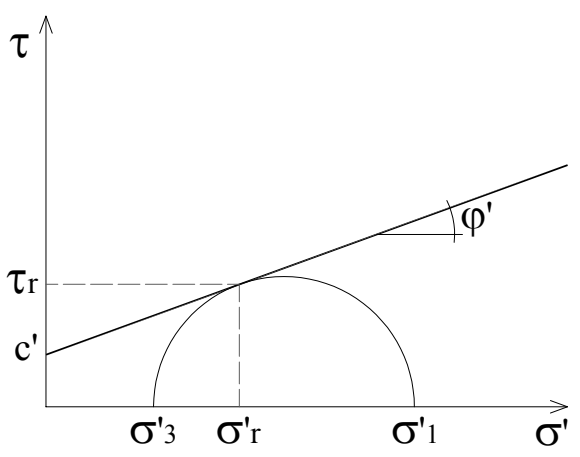

(a) envoltória de ruptura

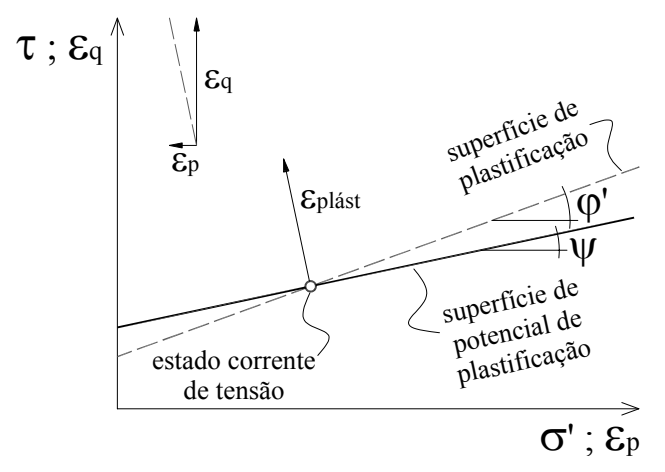

(b) lei de fluxo não associado

Figura 5.11 - Envoltórias do modelo Mohr-Coulomb

Adotando-se a opção de fluxo não associado, a superfície de potencial plástico não coincide com a de plastificação, como mostrado na Figura 5.11 (b). Como se pode notar, o vetor de incremento de deformação plástica é inclinado, indicando deformação volumétrica negativa (dilatância). Com o ângulo de dilatância $(\psi)$ igual a zero, durante a plastificação há ocorrência de apenas deformações cisalhantes, sendo nulas as volumétricas.

Como visto, são necessários cinco parâmetros para a utilização do modelo, sendo dois deles para representar o comportamento elástico ( $E^{\prime}$ e $\left.v^{\prime}\right)$ e três para o comportamento plástico (c', $\varphi^{\prime}$ e $\left.\psi\right)$. Também pode ser prevista a variação do módulo de deformabilidade com o nível de tensões, incluindo-se mais três parâmetros (E' referencial, a tensão de referência e E' incremental). 


\subsubsection{Hardening-Soil}

Este é um modelo elasto-plástico com endurecimento que, em contraste ao modelo elasto-plástico perfeito, possui uma curva de escoamento que não é fixa no espaço de tensões, podendo expandir-se devido a uma deformação plástica. A ruptura ocorre com plasticidade perfeita e os parâmetros que controlam o comportamento plástico são os mesmos utilizados pelo modelo Mohr-Coulomb (c', $\varphi^{\prime}$ e $\psi$ ).

A formulação matemática do modelo é apresentada na seqüência, para casos de ensaios triaxiais drenados convencionais, de acordo com Schanz et al. (1999).

A curva tensão-deformação deste modelo, apresentada na Figura 5.12 (a), é baseada no modelo proposto por Duncan e Chang (1970), cujo comportamento hiperbólico é descrito por

$$
\varepsilon_{1}=\frac{\mathrm{q}_{\mathrm{a}}}{2 \cdot \mathrm{E}_{50}^{\prime}} \frac{\mathrm{q}}{\mathrm{q}_{\mathrm{a}}-\mathrm{q}} \text {, para } q<q_{r}
$$

sendo E' ${ }_{50}$ o Módulo de Elasticidade Secante à $50 \%$ da ruptura, $q_{a}$ a tensão desviadora equivalente à assíntota da hipérbole e $q_{r}$ a tensão desviadora na ruptura. A razão de resistência $\left(\mathrm{R}_{\mathrm{f}}\right)$ é dada por

$$
\mathrm{R}_{\mathrm{f}}=\frac{\mathrm{q}_{\mathrm{r}}}{\mathrm{q}_{\mathrm{a}}}
$$

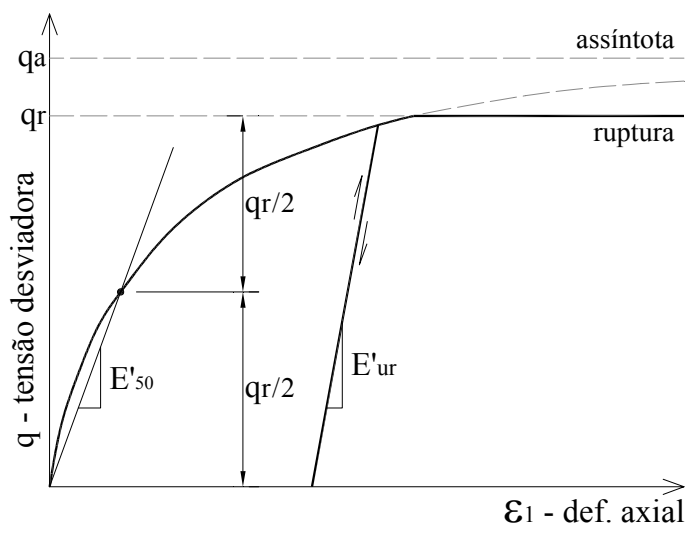

(a) ensaio triaxial

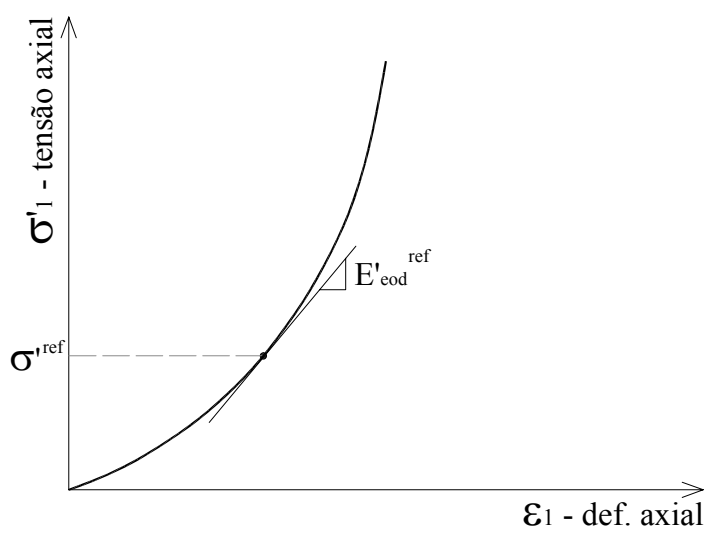

(b) ensaio edométrico

Figura 5.12 - Curvas tensão-deformação do modelo Hardening-Soil, a partir de Plaxis (2001)

A curva tensão-deformação para a situação de descarregamento/recarregamento é representada linearmente pelo Módulo de Elasticidade de descarregamento/recarregamento $\left(E_{\text {ur }}\right)$ e pelo coeficiente de Poisson de descarregamento/recarregamento ( $\left.v^{\prime}{ }_{\text {ur }}\right)$. 
Em contraste a outros modelos, neste se faz necessário definir uma rigidez para a situação edométrica diferente da adotada para a situação de ensaio triaxial, por meio do Módulo Edométrico (E' eod), obtido de acordo com a Figura 5.12 (b).

O modelo prevê a variação da rigidez do solo de acordo com o nível de tensão, para as situações de carregamento, recarregamento e edométrica, respectivamente de acordo com:

$$
\begin{aligned}
& E_{50}^{\prime}=E_{50}^{\prime r e f}\left(\frac{\sigma_{c}^{\prime}+c^{\prime} \cdot \cot \varphi^{\prime}}{\sigma^{\prime r e f}+c^{\prime} \cdot \cot \varphi^{\prime}}\right)^{m} \\
& E_{\text {ur }}^{\prime}=E_{\text {ur }}^{\prime \text { ref }}\left(\frac{\sigma_{c}^{\prime}+c^{\prime} \cdot \cot \varphi^{\prime}}{\sigma^{\prime r e f}+c^{\prime} \cdot \cot \varphi^{\prime}}\right)^{\mathrm{m}} \\
& E_{\text {eod }}^{\prime}=E_{\text {eod }}^{\prime \quad r e f}\left(\frac{\sigma_{v}^{\prime}}{\sigma^{\text {ref }}}\right)^{m}
\end{aligned}
$$

sendo $E^{\text {ref }}$ o módulo de deformabilidade relativo à tensão de referência $\sigma^{\text {'ref }}$.

O endurecimento neste modelo pode ser classificado como devido à compressão, com a adição da curva do tipo cap da Figura 5.13 (a), ou como devido ao cisalhamento, com a curva da Figura 5.13 (b). Esta, ao ser atingida, expande-se até encontrar a envoltória de ruptura de Mohr-Coulomb e possui forma dependente do coeficiente $\mathrm{m}$. Para m=1,0 obtém-se uma reta e para $m=0,5$ obtém-se a curvatura apresentada na figura. $\mathrm{O}$ tamanho das curvas de escoamento por cisalhamento e por compressão depende de E' ${ }_{50}$ e de E' eod, respectivamente.

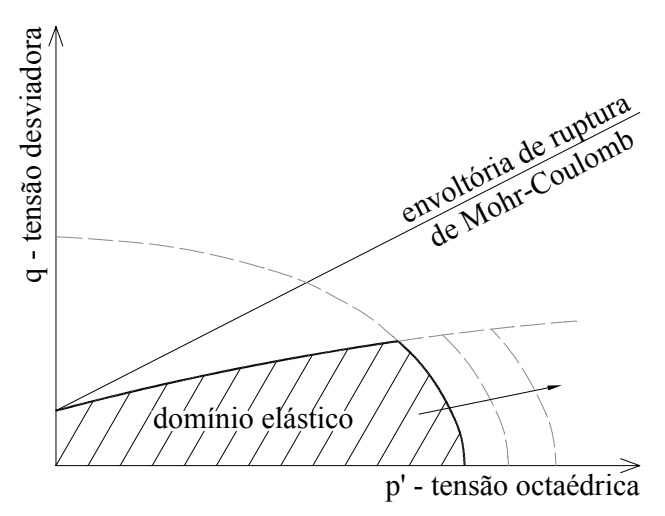

(a) escoamento por compressão

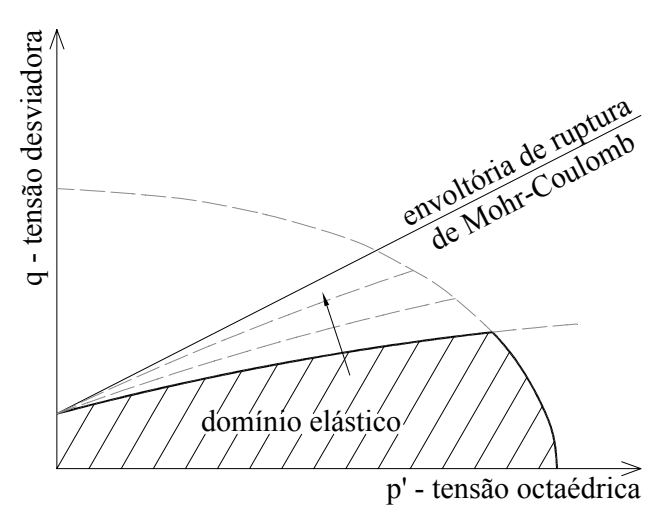

(b) escoamento por cisalhamento

Figura 5.13 - Curvas de escoamento do modelo Hardening-Soil, a partir de Plaxis (2001)

São necessários dez parâmetros para a utilização deste modelo, sendo três iguais aos utilizados pelo modelo Mohr-Coulomb (c', $\varphi^{\prime}$ e $\psi$ ) e sete específicos do Hardening-Soil $\left(E_{50}^{\prime}{ }^{\text {ref }}, p^{\text {ref }}, R_{f}, m, E_{\text {ur }}^{\prime}, v_{\text {ur }}^{\prime}\right.$ e E' $\left.{ }_{\text {eod }}\right)$. 


\subsection{CONCEPÇÃO DA MODELAGEM DA ESCAVAÇÃO DE UM TÚNEL}

O modelo numérico confeccionado para esta pesquisa não visa representar com exatidão o túnel de onde foram coletadas as amostras indeformadas para este estudo. Apenas a geometria do túnel foi representada com precisão, sendo que algumas simplificações tiveram que ser efetuadas, visando possibilitar a confecção do modelo. À medida que o modelo numérico for apresentado, tais simplificações serão discutidas. É importante salientar que não serão analisados o projeto ou a execução da obra em questão.

Tendo-se isto em vista, os resultados aqui obtidos não serão comparados com dados provenientes da instrumentação instalada em campo.

A modelagem numérica da escavação do túnel foi realizada com o auxílio do programa de elementos finitos Plaxis $3 D$ Tunnel, comercializado pela empresa Plaxis BV. O programa foi inicialmente desenvolvido pela Technical University of Delft, na Holanda, e após ser implementada uma série de melhorias por diversas universidades na Europa e nos Estados Unidos, ele deixou de ser essencialmente acadêmico e passou a ser utilizado por diversas empresas de projetos de túneis em todo o mundo.

O programa Plaxis 3D Tunnel permite a utilização unicamente de elementos prismáticos de 15 nós, reduzindo a questão sobre escolha da malha apenas ao número de elementos utilizado. O elemento finito utilizado pode ser visto na Figura 5.14, sendo constituído nos planos transversais por elementos triangulares de 6 nós de deslocamentos e na direção longitudinal por elementos quadrangulares de 8 nós. O elemento conta com 6 pontos de integração, onde são calculados os valores de tensões por interpolação quadrática (de segunda ordem). A direção longitudinal dos elementos é formada pela repetição sucessiva de planos transversais (extrusão de elementos no sentido longitudinal).

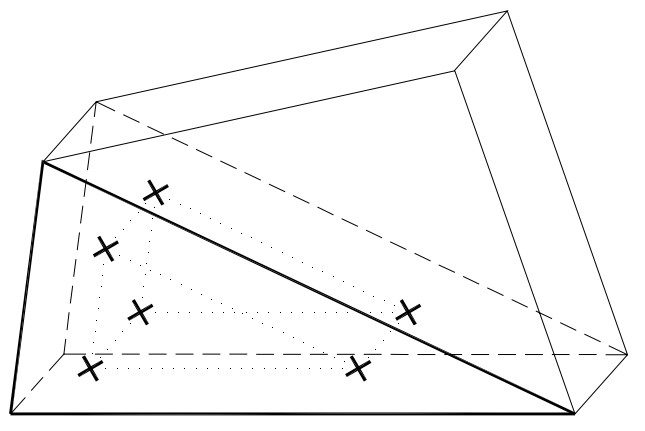

(a) pontos de tensão

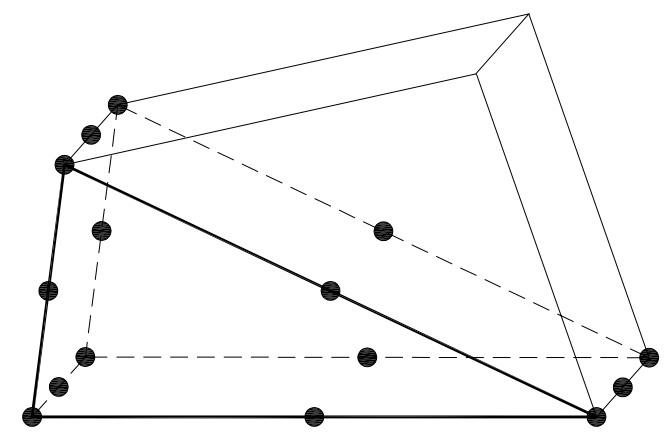

(b) nós de deslocamento

Figura 5.14 - Elementos finitos utilizados 
A escolha de uma modelagem tridimensional para representação da escavação de um túnel é justificada pela revisão bibliográfica efetuada anteriormente, na qual se demonstrou que o efeito de arco longitudinal altera o estado de tensões inicial de seções adiante da frente de escavação, de acordo com Almeida e Sousa (1998) e Eisenstein et al. (1984).

Além dos autores citados durante a revisão, alguns outros estudos contribuíram para concepção da modelagem e para a interpretação de seus resultados, sendo apresentados a seguir.

Uma modelagem do comportamento do túnel Heathrow Express, em Londres, foi realizada por Masín (2004). Foram utilizados parâmetros avaliados com base em ensaios realizados com uma argila reconstituída, chegando a predições de comportamento próximas às observações de campo, considerando a sensitividade (sensibilidade) da argila em seu estado natural. Foram feitas simplificações na modelagem, como a utilização de um modelo bidimensional e a adoção de uma seção circular do túnel. A metodologia para obtenção dos parâmetros geotécnicos a partir dos resultados de laboratório foi bastante proveitosa.

Parreira (1991) estudou o comportamento do túnel Paraíso, da linha 2-Verde do Metrô de São Paulo. Foram analisados resultados obtidos por cálculos numéricos baseados em elementos finitos, comparando-os com os dados provenientes de instrumentação. O mesmo túnel Paraíso foi estudado por outros autores, comparando os resultados obtidos com os dados de instrumentação: Azevedo et al. (2002) utilizaram o modelo Lade; França (2006) utilizou os modelos Mohr-Coulomb e Hardening-Soil.

\subsubsection{Estudo da malha}

O emprego do método dos elementos finitos, nos dias atuais, ainda enseja a discussão entre precisão e custo computacional. A precisão da solução é alcançada ao se melhor discretizar a geometria do problema, reduzindo o tamanho dos elementos finitos. Com isto, é aumentado o número de elementos e, em conseqüência, o tempo requerido para o processamento dos dados aumenta exponencialmente. 
Diante disto, torna-se necessária uma etapa inicial de experimentação de possíveis malhas de elementos finitos a serem utilizadas, com o intuito de se obter a mais indicada para a solução do problema. Para a modelagem em estudo, uma malha pouco refinada foi adotada a partir do modelo geológico-geotécnico visualizado na Figura 2.6, servindo como base para que outras malhas mais refinadas fossem confeccionadas.

Alguns critérios auxiliaram o desenvolvimento da primeira malha, como exemplo, zonas onde se esperavam maiores alterações de tensões foram representadas por discretizações mais refinadas, ao passo que em zonas com pouca alteração de tensões foram utilizados elementos de maiores dimensões.

Um modelo bidimensional foi adotado para o estudo sobre o refinamento da malha, sem preocupações quanto à simulação da seqüência construtiva do túnel. A escavação foi simulada em seção plena e sem revestimento, em um maciço elástico linear com módulo de deformabilidade igual a $30 \mathrm{MPa}$ e coeficiente de Poisson igual a 0,20. O modelo foi concebido de maneira propositadamente simplória e com parâmetros geotécnicos estimados, por se tratar apenas de uma etapa inicial que necessitava de rapidez em sua execução. Ou seja, os resultados obtidos não devem ser levados em consideração, apenas a sua variação em função do refinamento da malha.

Um total de sete malhas foi analisado pelo programa de elementos finitos. A partir de um certo nível de refinamento, o aumento do tempo de processamento despendido pelo programa representou um ônus que superou o ganho em precisão, a qual passou a apresentar modesta melhora. A malha referente a este nível de refinamento foi a adotada no estudo.

Outro aspecto importante é a definição dos limites da malha de elementos finitos. As fronteiras que não apresentam restrições impostas pela geometria ou geologia, devem ser locadas de maneira que as condições de contorno não influenciem nos resultados. De maneira geral, utiliza-se como zona de influência do túnel uma área afastada de 2 a 5 vezes o seu diâmetro.

Para a definição do limite lateral transversal, foi utilizado o mesmo modelo bidimensional simplório anterior. Realizou-se um estudo onde foram analisadas malhas com diferentes distâncias da fronteira lateral em relação ao eixo de simetria do túnel. Neste estudo, os recalques superficiais em um plano vertical transversal ao túnel foram escolhidos como elemento comparativo entre as malhas analisadas, as quais possuíam distâncias de 30, 40, 50, 60, 70, 80, 90 e 100 metros. Os resultados estão apresentados na Figura 5.15. 


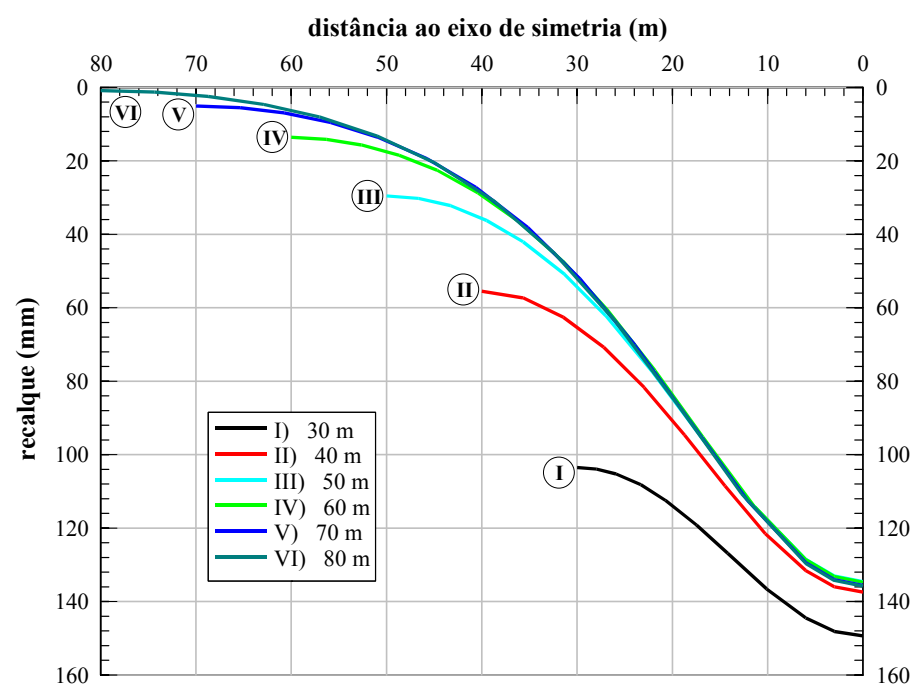

Figura 5.15 - Estudo da localização da fronteira lateral da malha

Para que a fronteira não interfira nos resultados, o ideal seria dispô-la o mais distante possível, onde não haja alteração de tensões. Como observado na Figura 5.15, para que seja alcançada a condição de recalque nulo na fronteira lateral, é necessária uma distância de $80 \mathrm{~m}$, o que torna a modelagem pouco viável em se tratando de capacidade computacional. Portanto, adotou-se $40 \mathrm{~m}$ como a menor distância possível para que não ocorram alterações significativas no recalque máximo (no eixo de simetria), em relação ao obtido com a fronteira lateral locada a $100 \mathrm{~m}$ do eixo de simetria do túnel.

Cabe lembrar que os valores dos resultados obtidos não devem ser levados em consideração, sendo válida apenas a análise de sua variação em função do distanciamento da fronteira lateral da malha de elementos finitos.

A análise dos estudos de Almeida e Sousa (1998), Azevedo et al. (2002), Barla (1999), Barla e Barla (2001), França (2006), Franzius e Potts (2005), Franzius et al. (2005), Masín (2004) e Parreira (1991) permitiu estabelecer recomendações quanto à distância das fronteiras, condições de contorno e refinamento da malha, além de como representar o processo construtivo da escavação do túnel. A partir da análise destes autores e dos estudos apresentados sobre o refinamento da malha e sobre a localização de sua fronteira lateral, foi confeccionada a seção transversal da malha de elementos finitos escolhida para estudo, apresentada na Figura 5.16. 


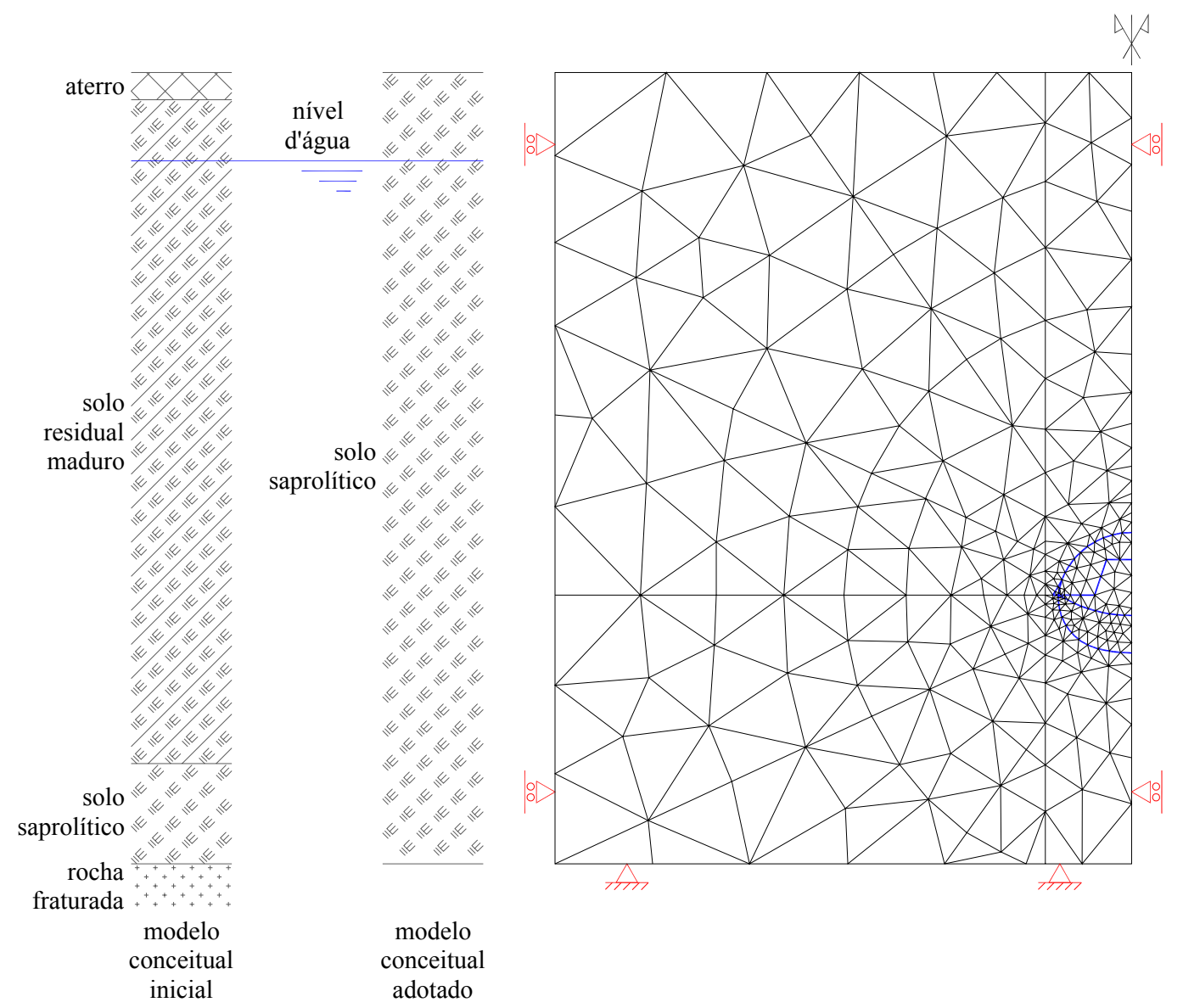

Figura 5.16 - Seção transversal da malha de elementos finitos adotada

O modelo geológico-geotécnico conceitual inicialmente adotado foi alterado, como indicado na Figura 5.16, passando-se a representar o perfil com apenas uma camada de solo residual saprolítico. Tomou-se esta medida por não se ter maiores informações sobre a camada superficial de aterro e sobre a divisão entre o solo saprolítico em estudo e o solo residual maduro. A profundidade do topo da camada de rocha fraturada não foi alterada.

Os resultados de Franzius e Potts (2005) contribuíram para a definição da geometria longitudinal da malha. Os autores realizaram algumas análises tridimensionais com variação da dimensão longitudinal da malha de elementos finitos, sem variação da geometria transversal, investigando a influência de três fatores, variados independentemente:

i) a distância da face de escavação até o limite longitudinal da malha (ao final da modelagem);

ii) a distância entre os limites verticais longitudinais (comprimento da malha); e

iii) o tamanho de cada avanço (comprimento de escavação).

A malha tridimensional de elementos finitos adotada encontra-se na Figura 5.17. 


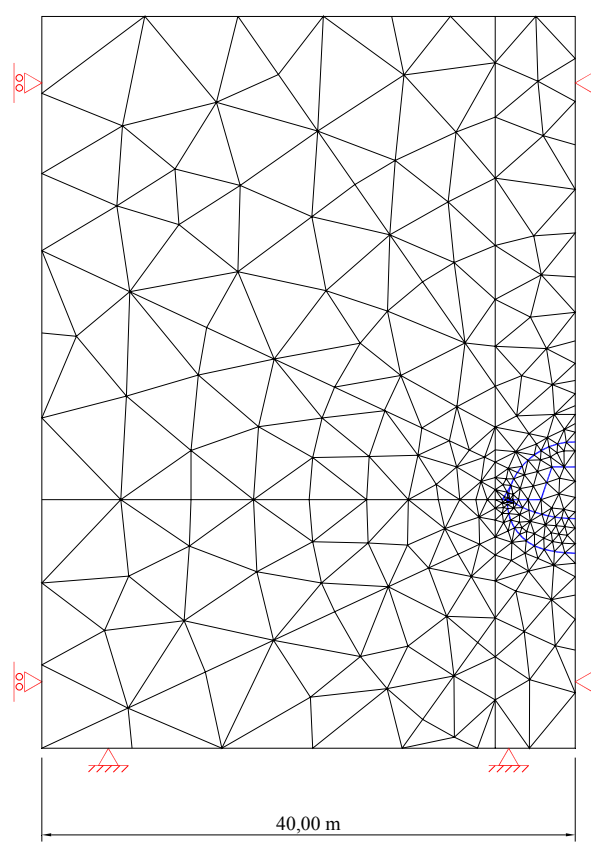

(a) seção transversal

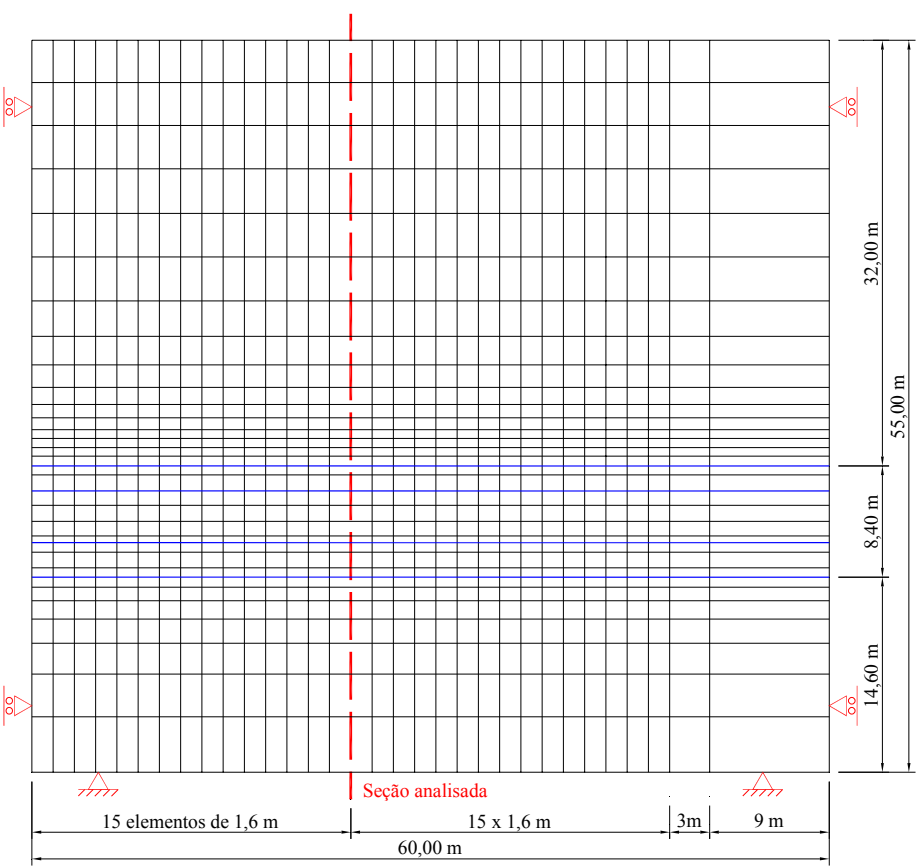

(b) perfil longitudinal

Figura 5.17 - Malha tridimensional de elementos finitos adotada

Não foi possível a análise de alguns arranjos de malhas, com o intuito de analisar a interferência das fronteiras laterais longitudinais, pois o tempo despendido para tal inviabilizaria o cronograma da presente pesquisa.

O condicionante para a escolha da geometria longitudinal foi a quantidade máxima de elementos permitida pelo software, resultando em um avanço de 1,60 metros (o dobro do executado em campo) e um comprimento de 60,00 metros.

Na Figura 5.17 (b), a escavação ocorre da esquerda para a direita. A seção transversal a ser analisada se encontra a uma distância de 24,00 metros do início da escavação (fronteira lateral longitudinal esquerda), o equivalente a 15 avanços.

O último avanço de escavação também foi disposto a uma distância de 24,00 metros da seção analisada, também equivalente a 15 avanços. Após o último elemento escavado, foram dispostos outros dois elementos, para que a fronteira lateral longitudinal direita não fosse escavada. Esta medida tem o intuito de possibilitar o acionamento do efeito de arco longitudinal, mantendo a configuração tridimensional de alteração das tensões.

Como pode ser visto na Figura 5.17, a discretização assume uma simetria no plano vertical que contém o eixo longitudinal do túnel. Suas condições de contorno são de deslocamentos horizontais restringidos para as fronteiras laterais e de deslocamentos totalmente restringidos para a fronteira inferior (subleito em rocha fraturada). 
A inclinação longitudinal do túnel, existente em campo, não pôde ser representada na modelagem, tendo-se em vista que o software permite apenas a extrusão dos elementos com um ângulo nulo em relação à horizontal.

A distribuição dos elementos da malha, na seção transversal e na longitudinal, foi definida de maneira a permitir a reprodução do processo construtivo do túnel, o qual foi descrito na seção 2.5. Nota-se um maior refinamento na região próxima ao túnel, onde será analisado o histórico de tensões.

A malha resultou em um total de 15.584 elementos, 42.792 nós de deslocamento e 93.504 pontos de tensão. Para fins de comparação com futuras modelagens, registra-se que foi utilizado um computador com processador DualCore 2,93 GHz e 1 GB de memória RAM, despendendo um tempo médio aproximado de 5 dias para os cálculos.

\subsubsection{Reprodução do processo construtivo}

A seqüência construtiva foi simulada pela adição e remoção (ativação e desativação) de elementos da malha. Em toda a modelagem, considerou-se a existência unicamente do revestimento primário do túnel.

Em relação à desativação dos elementos finitos, a seqüência construtiva concebida para a modelagem contou com as seguintes etapas:

i) escavação de um avanço de 1,60 metros no arco superior da calota, equivalente a um elemento na longitudinal da malha.

ii) repetição do item (i) por mais três vezes;

iii) escavação de um avanço de 1,60 metros no núcleo, equivalente a um elemento na longitudinal da malha;

iv) repetição do item (iii) por mais uma vez. Cabe salientar que a escavação do núcleo permanece com uma defasagem de dois avanços;

v) repetição do item (i) por mais duas vezes e do item (iii) por mais duas vezes;

vi) repetição do item (v) até o final da escavação da calota, deixando-se dois elementos sem escavar entre a frente de escavação e o limite longitudinal da malha;

vii) escavação de um avanço de 3,20 metros na bancada, equivalente a dois elementos na longitudinal da malha;

viii) repetição do item (vii) até o final da escavação da bancada, deixando-se dois elementos sem escavar entre a frente de escavação e o núcleo da calota. 
O revestimento primário, constituído de concreto projetado, foi modelado com elementos do tipo barra (do tipo casca, no caso tridimensional). O trecho escavado foi revestido na etapa seguinte, durante a qual se escavou um novo avanço. Em uma nova etapa, representou-se um aumento da rigidez do concreto projetado. Esta seqüência pode ser observada na Figura 5.18

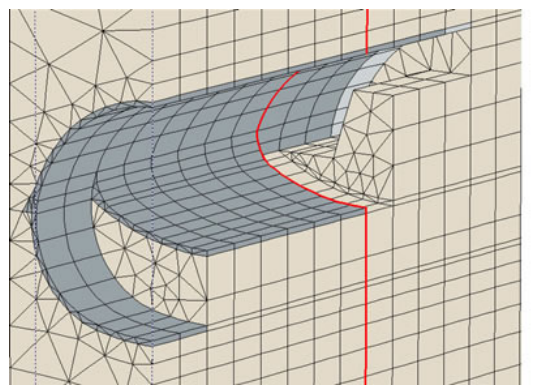

(a) escavação

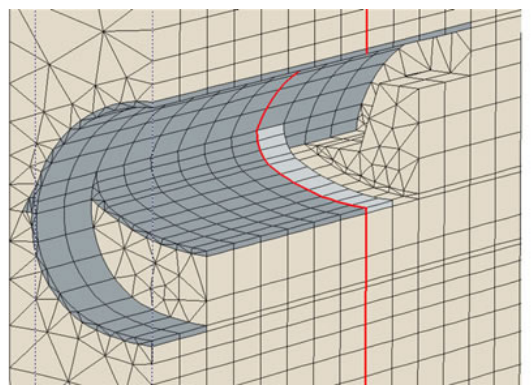

(b) revestimento

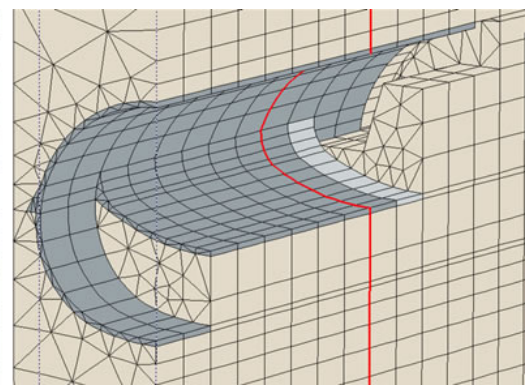

(c) aumento da rigidez

Figura 5.18 - Ilustração da reprodução da seqüência construtiva

Em suma, cada trecho (intervalo de espaço longitudinal da modelagem) foi alterado em três avanços diferentes e cada avanço (intervalo de tempo, etapa da modelagem) possuiu os três tipos de ações: escavação, revestimento e amadurecimento.

A seguir é apresentado um exemplo da seqüência utilizada na modelagem:

- etapa “j-1" - escavação do trecho " $\mathrm{i}$ ”, revestimento "i-1", aumento da rigidez "i-2"

- etapa “j” - escavação do trecho “ $i+1$ ”, revestimento “i”, aumento da rigidez "i-1"

- etapa “ $j+1$ ” - escavação do trecho “ $i+2$ ", revestimento " $i+1$ ”, aumento da rigidez “ $i$ ”.

A resistência característica à compressão $\left(\mathrm{f}_{\mathrm{ck}}\right)$ do concreto projetado utilizado em obra é de $35 \mathrm{MPa}$. Para a modelagem, foi utilizado o módulo de elasticidade secante do concreto $\left(E_{c s}\right)$, obtido de acordo com a NBR 6118, que estabelece:

$$
\mathrm{E}_{\mathrm{cs}}=0,85 \cdot \mathrm{E}_{\mathrm{ci}}
$$

onde $\mathrm{E}_{\mathrm{ci}}$ é o módulo de elasticidade tangente inicial do concreto, dado por

$$
\mathrm{E}_{\mathrm{ci}}=5600 \cdot \mathrm{f}_{\mathrm{ck}}^{1 / 2}
$$

onde $\mathrm{E}_{\mathrm{ci}}$ e $\mathrm{f}_{\mathrm{ck}}$ necessariamente devem ser dados em MPa.

O concreto projetado do revestimento primário foi modelado como um material elástico linear, com os parâmetros apresentados na Tabela 5.1. 
Tabela 5.1 - Parâmetros do concreto projetado

\begin{tabular}{lc|c|c}
\cline { 2 - 3 } & $\begin{array}{c}\mathrm{E} \\
(\mathrm{GPa})\end{array}$ & $v^{\prime}$ & $\begin{array}{c}\gamma \\
(\mathrm{kPa})\end{array}$ \\
\hline após a execução & 10 & \multirow{2}{*}{0,15} & 25 \\
\hline após o aumento da rigidez & 28 & & \\
\hline
\end{tabular}

\subsubsection{Condições iniciais}

Para o início dos cálculos, foi necessária a determinação do estado inicial de tensões e dos parâmetros do modelo constitutivo utilizado, ambos discutidos a seguir.

O estado de tensões inicial foi estimado suponde-se que o nível do lençol freático tenha sido totalmente rebaixado. Como discutido anteriormente, não há informações sobre a alteração do nível do lençol freático ocasionada pelos DHPs instalados, devido à inexistência de equipamentos capazes de detectar sua variação. Esta medida foi tomada para que a tensão efetiva do solo, utilizada na modelagem, possuísse ordem de grandeza similar à encontrada em campo ao redor da abertura do túnel.

Desta maneira, ao nível da amostragem, a tensão vertical é igual a $735 \mathrm{kPa}$ e a horizontal é igual a $463 \mathrm{kPa}$. O campo de tensões iniciais está apresentado na Figura 5.19 e para sua determinação foram considerados os valores de peso específico natural $\left(\gamma_{\mathrm{n}}\right)$ igual a $20,4 \mathrm{kN} / \mathrm{m}^{3}$ e de coeficiente de empuxo em repouso $\left(\mathrm{K}_{0}\right)$ igual a 0,63 .

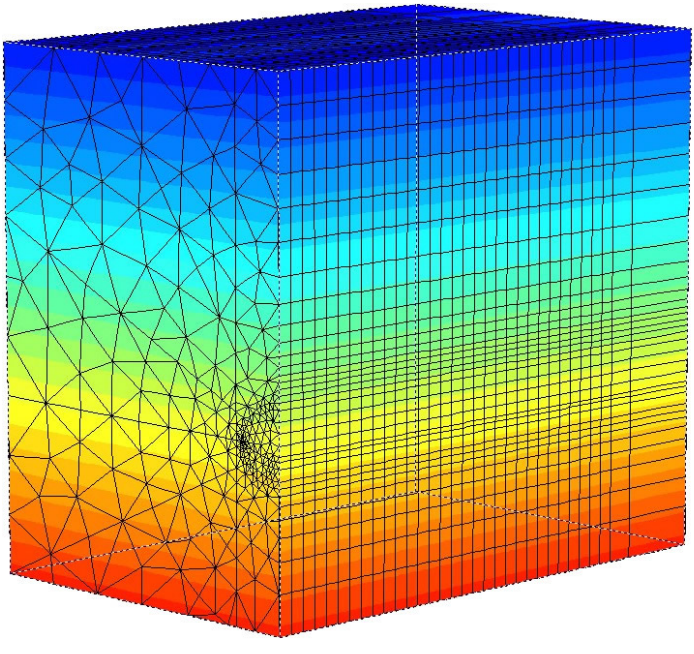

(a) tensões verticais

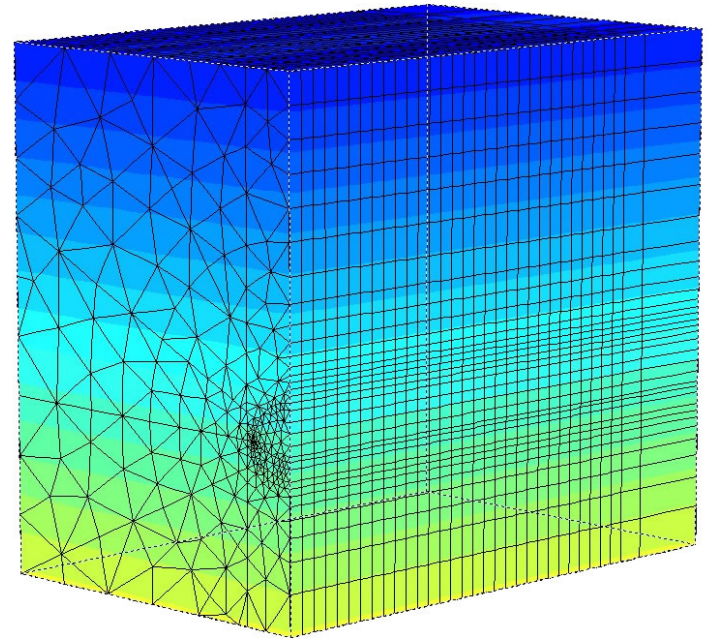

(b) tensões horizontais

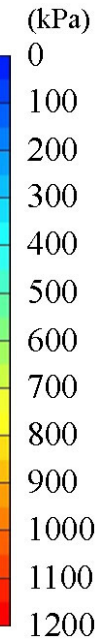

Figura 5.19 - Campo de tensões iniciais 
A tensão horizontal na direção longitudinal $\left(\sigma_{z}\right)$ da malha de elementos finitos (sentido de escavação do túnel) foi considerada igual à tensão horizontal na direção transversal $\left(\sigma_{\mathrm{x}}\right)$ da malha. Ou seja, os coeficientes de empuxo em repouso para ambas as direções foram considerados como sendo iguais $\left(\mathrm{K}_{0, \mathrm{X}}=\mathrm{K}_{0, \mathrm{Z}}\right)$.

Os módulos de elasticidade (E') utilizados foram inicializados variando-se seus valores com a profundidade. Com isto, um ponto da malha de elementos finitos com maior profundidade, por exemplo, possui mais rigidez do que um ponto na superfície. Esta variação do módulo foi determinada em função do nível de tensão horizontal, apenas para a condição inicial. Ou seja, a variação das tensões devida à escavação do túnel não altera o valor do módulo de elasticidade, concebido na etapa inicial. Os demais parâmetros geotécnicos foram inicializados de maneira a possuir um único valor para todos os pontos da malha.

O modelo será calculado sob a condição drenada, tendo-se em vista a consideração do rebaixamento total do nível do lençol freático. Desta maneira, as tensões efetivas serão iguais às tensões totais, não sendo necessária sua distinção.

Qual das condições, drenada ou não-drenada, são mais aplicáveis a túneis durante o avanço de sua frente de escavação, de acordo com Mair e Taylor (1997), é um assunto que depende primeiramente da permeabilidade do solo, da taxa de escavação e do tamanho do túnel. Em se tratando de solos argilosos, condições não-drenadas são assumidas como verdadeiras. Por tratar-se de um silte arenoso com permeabilidade de $10^{-6} \mathrm{~cm} / \mathrm{s}$, a modelagem do solo em estudo sob a condição drenada é a mais apropriada.

\subsection{Modelagem CoM O MaciÇo Mecanicamente HoMogêneo}

Para a modelagem em estudo, utilizaram-se os modelos constitutivos Elástico linear, Mohr-Coulomb e Hardening-Soil, cujas equações constitutivas foram apresentadas anteriormente no item 5.2.

Nesta primeira etapa, a modelagem tem o intuito de simular a escavação de um túnel no solo em estudo, em um maciço considerado como mecanicamente homogêneo. Ou seja, todo o maciço será representado por apenas um conjunto de parâmetros geotécnicos.

Para a calibração dos parâmetros geotécnicos desta primeira etapa da modelagem, foram utilizados apenas os ensaios edométricos e os ensaios triaxiais de carregamento axial, cujos resultados foram apresentados e discutidos anteriormente no capítulo 4.2. 


\subsubsection{Calibração dos modelos constitutivos}

Três diferentes condições de ensaio foram consideradas para a obtenção dos parâmetros elásticos de deformabilidade:

i) ensaios de carregamento (1), (2) e (6), referentes ao módulo E' ${ }_{50}$;

ii) ensaios de recarregamento (3) e (4), referentes ao módulo $E_{\text {ur }}$; e

iii) ensaios edométricos, referentes ao módulo E' eod.

É válido lembrar que, na formulação matemática dos modelos constitutivos estudados, os módulos de descarregamento e recarregamento são considerados iguais, mas que para o caso do solo em estudo os módulos podem diferir. Os parâmetros de descarregamento serão utilizados apenas para a próxima modelagem, onde serão calibrados.

Os módulos de deformabilidade (E') foram obtidos de acordo com a Figura 5.20, sendo prevista a possibilidade de variação da rigidez do solo de acordo com o nível de tensão a que ele está submetido, de acordo com a Figura 5.21.

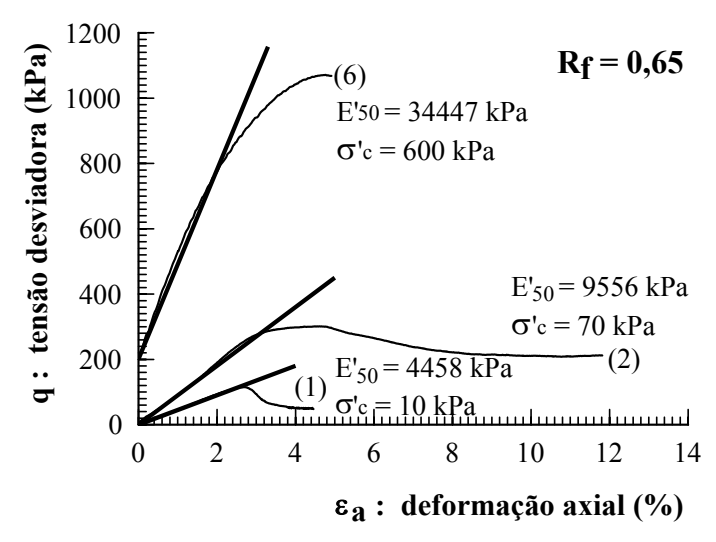

(a) ensaios triaxiais de carregamento

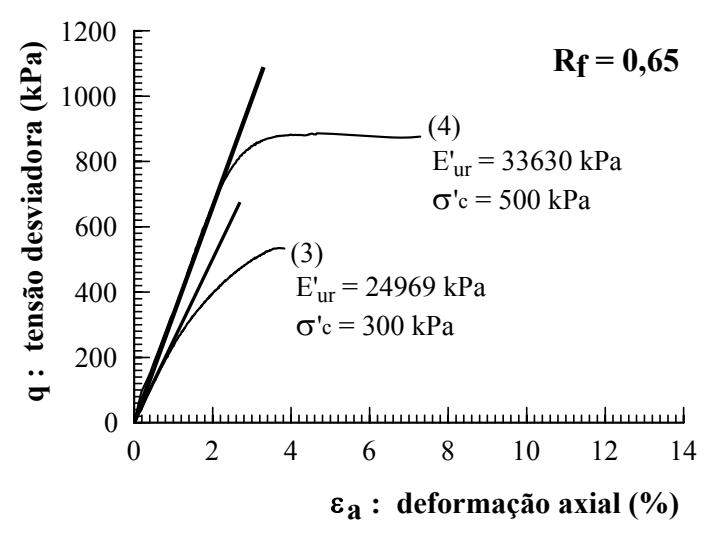

(b) ensaios triaxiais de recarregamento

Figura 5.20 - Obtenção dos módulos de deformabilidade

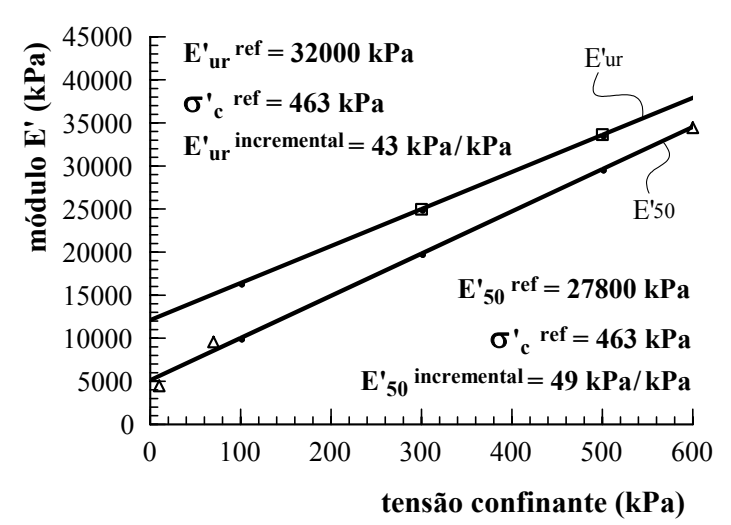

(a) para o modelo Mohr-Coulomb

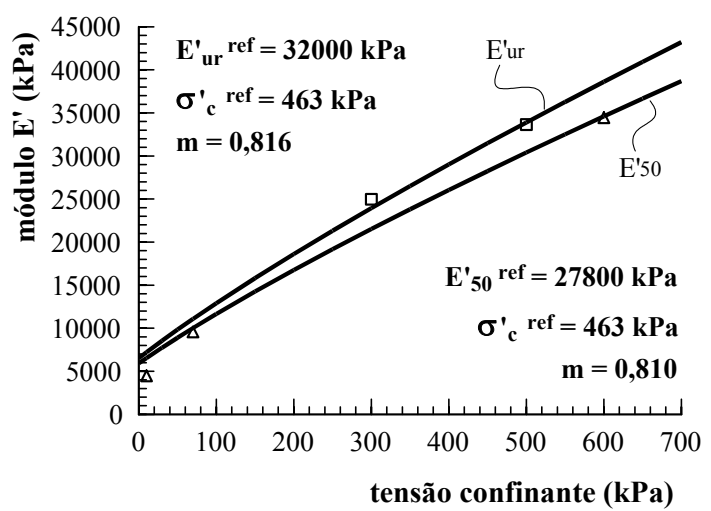

(b) para o modelo Hardening-Soil

Figura 5.21 - Variação dos módulos de deformabilidade com o nível de tensão 
Os módulos de deformabilidade cisalhante (G') e volumétrico (K') foram obtidos de acordo com a Figura 5.22 e com as equações (5.8) e (5.10). A partir destes módulos, foram calculados os valores para o coeficiente de Poisson ( $\left.v^{\prime}\right)$, de acordo com as equações (5.11) e (5.12) e apresentados na Figura 5.23.
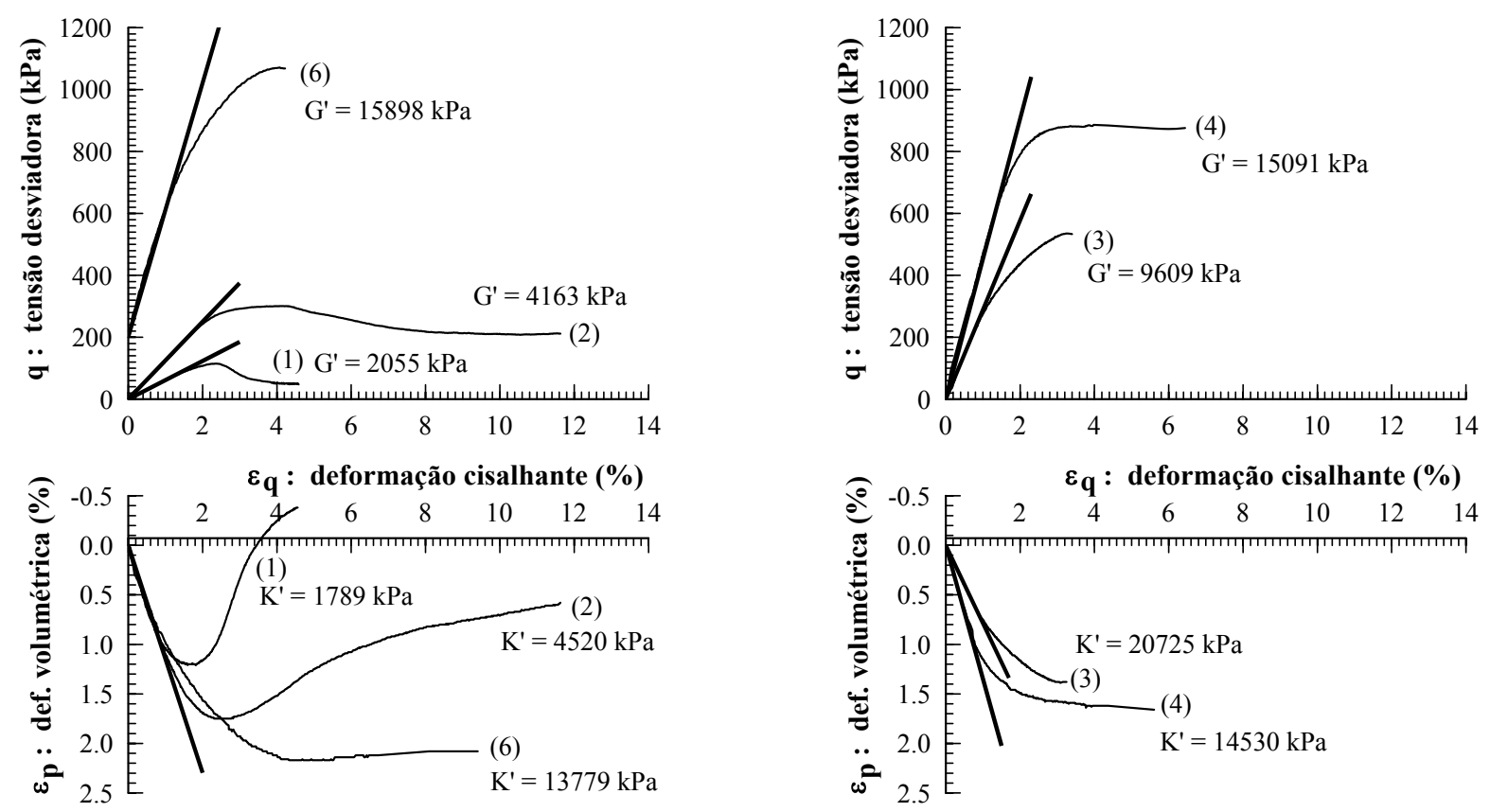

(a) ensaios triaxiais de carregamento

(b) ensaios triaxiais de recarregamento

Figura 5.22 - Obtenção dos módulos cisalhante e volumétrico

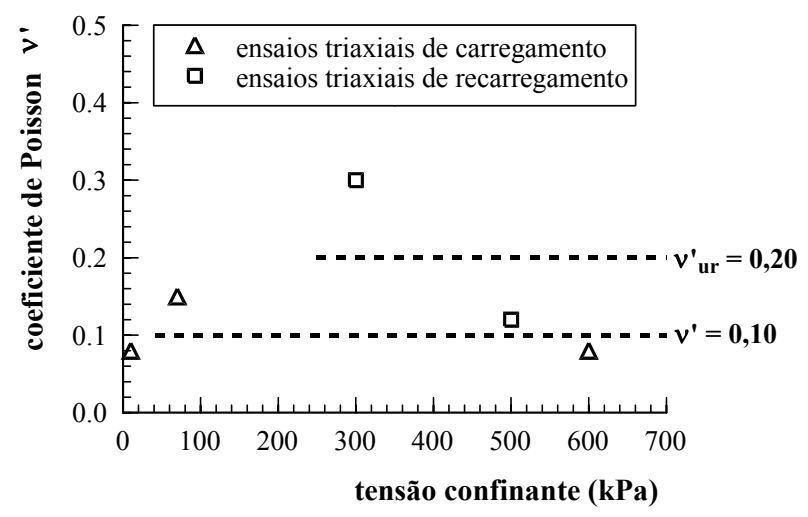

Figura 5.23 - Obtenção do coeficiente de Poisson

Nota-se uma grande variação dos resultados obtidos para v'. Tendo-se em vista que o coeficiente de Poisson é um parâmetro intrínseco ao solo e que não varia com o nível de tensões, adotou-se como resultado a média dos valores. 
A deformabilidade edométrica e sua variação com o nível de tensão, utilizadas pelo modelo Hardening-Soil, foram obtidas de acordo com a Figura 5.24.

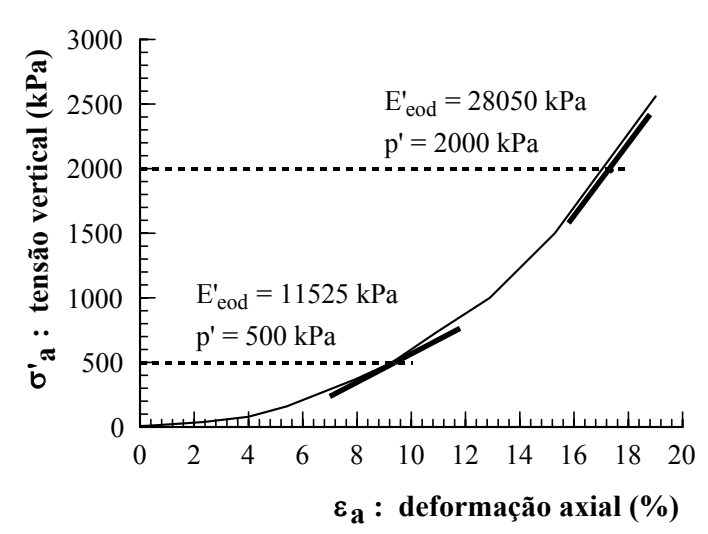

(a) ensaios edométricos

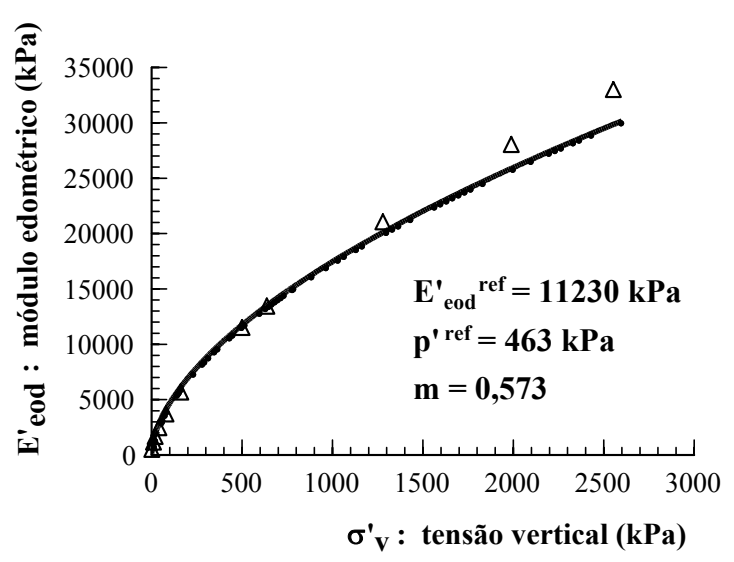

(b) variação do módulo com o nível de tensão

Figura 5.24 - Parâmetros de deformabilidade edométrica do modelo Hardening-Soil

Os parâmetros de ruptura foram obtidos de acordo com a Figura 5.25, utilizando-se os pontos referentes à ruptura de pico. Os parâmetros $\beta$ e $d$ da envoltória obtida no espaço s'- $\mathrm{t}$ foram convertidos para os parâmetros $\varphi^{\prime}$ e c' do espaço $\sigma^{\prime}-\tau$, respectivamente.

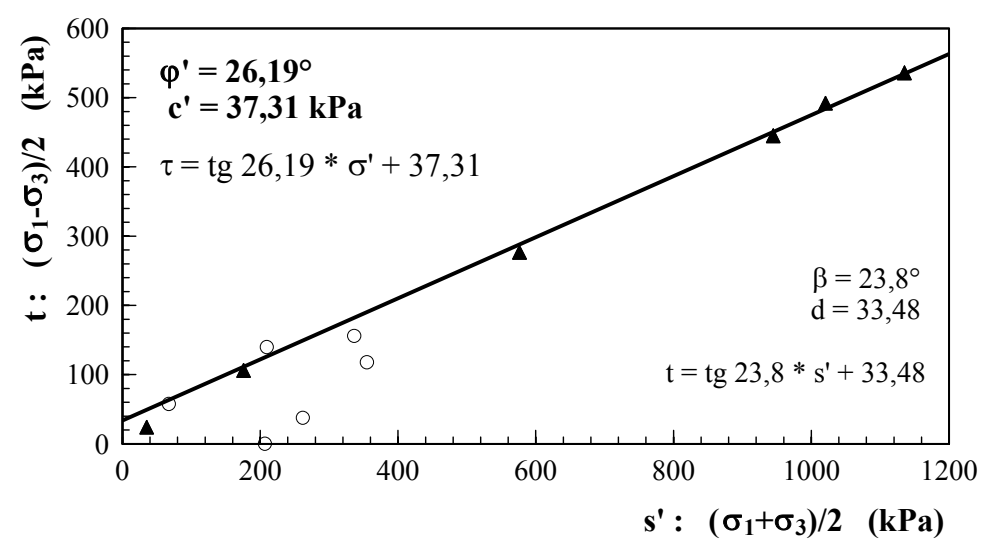

Figura 5.25 - Parâmetros de resistência

Como pode-se observar, a envoltória de ruptura representou a região fortemente sobreadensada pelos pontos da envoltória de escoamento, referentes ao comportamento de resistência de pico seguida de amolecimento. Esta medida foi tomada por não ser possível a utilização de duas envoltórias de ruptura diferentes. Desta maneira, resultou-se em uma redução do ângulo de atrito interno do solo (de 28 para 26 graus) e na utilização de um intercepto de coesão de $37,3 \mathrm{kPa}$. É válido lembrar que o solo não possui coesão. 
O ângulo de dilatância foi considerado igual a zero, tendo em vista que o solo apresentou aumento de volume durante a plastificação unicamente nos ensaios (1) e (2), fortemente sobre-adensados. Considerando um ângulo diferente de zero, os demais ensaios apresentariam dilatância.

A seguir, são apresentadas tabelas com um resumo dos parâmetros geotécnicos adotados para cada modelo constitutivo em estudo.

Tabela 5.2 - Parâmetros do modelo Mohr-Coulomb

\begin{tabular}{l|c|c|c|c|c|c|c}
\hline & $\begin{array}{c}\mathrm{E}^{\prime \text { ref }} \\
(\mathrm{kPa})\end{array}$ & $\begin{array}{c}\sigma_{\mathrm{c}}^{\prime} \text { ref } \\
(\mathrm{kPa})\end{array}$ & $\begin{array}{c}\mathrm{E}^{\text {,increm }} \\
(\mathrm{kPa} / \mathrm{kPa})\end{array}$ & $v^{\prime}$ & $\begin{array}{c}\varphi^{\prime} \\
\text { (graus) }\end{array}$ & $\begin{array}{c}\mathrm{c}^{\prime} \\
(\mathrm{kPa})\end{array}$ & $\begin{array}{c}\psi \\
\text { (graus) }\end{array}$ \\
\hline carregamento & 27800 & 463 & 49 & 0,10 & 26 & 37,3 & 0 \\
\hline recarregamento & 32000 & 463 & 43 & 0,20 & & \\
\hline
\end{tabular}

Tabela 5.3 - Parâmetros do modelo Hardening-Soil

\begin{tabular}{|c|c|c|c|c|c|c|c|c|c|}
\hline & $\begin{array}{l}\mathrm{E}^{, \text {ref }} \\
(\mathrm{kPa})\end{array}$ & $\begin{array}{l}\mathrm{p}^{\mathrm{ref}} \\
(\mathrm{kPa})\end{array}$ & $\mathrm{m}$ & $v^{\prime}$ & $\mathrm{K}_{0}$ & $\begin{array}{c}\varphi^{\prime} \\
\text { (graus) }\end{array}$ & $\begin{array}{c}\mathrm{c}^{\prime} \\
(\mathrm{kPa})\end{array}$ & $\begin{array}{c}\psi \\
\text { (graus) }\end{array}$ & $\mathrm{Rf}$ \\
\hline carregamento & 27800 & 463 & 0,810 & 0,10 & \multirow{3}{*}{0,63} & \multirow{3}{*}{26} & \multirow{3}{*}{37,3} & \multirow{3}{*}{0} & \multirow{3}{*}{0,65} \\
\hline recarregamento & 32000 & 463 & 0,816 & 0,20 & & & & & \\
\hline edométrico & 11230 & 463 & 0,573 & --- & & & & & \\
\hline
\end{tabular}

Os parâmetros para o modelo Elástico linear são os mesmos utilizados para o modelo elástico linear perfeitamente plástico (Mohr-Coulomb), excluindo-se os parâmetros referentes à plastificação/ruptura ( $\varphi^{\prime}, c^{\prime}$ e $\left.\psi\right)$.

Com o intuito de se verificar a aplicabilidade dos parâmetros geotécnicos obtidos, alguns ensaios foram simulados em uma modelagem numérica com elementos finitos, utilizando-se os modelos constitutivos em estudo. Os resultados obtidos podem ser visualizados na Figura 5.26.

Comparando-se os resultados de ensaios edométricos com simulações numéricas do mesmo tipo de ensaio, como observado na Figura 5.26 (a), pôde-se notar que o modelo Hardening-Soil não conseguiu representar bem o descarregamento do solo, não possuindo uma reta acentuada como a dos ensaios. Entretanto, o modelo Mohr-Coulomb foi o que pior representou o comportamento do solo em estudo, apresentando descarregamento coincidente com o carregamento e estando distante da linha de compressão normal ("reta virgem"). 


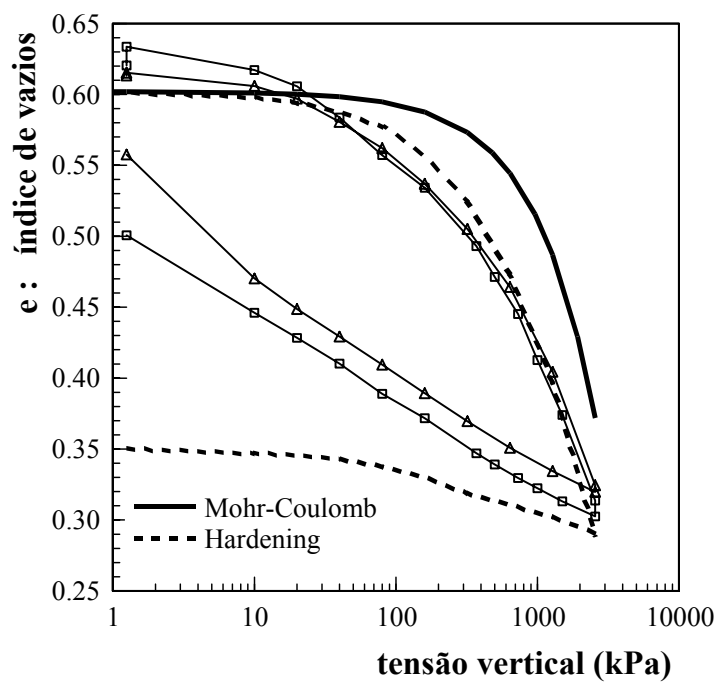

(a) ensaios edométricos

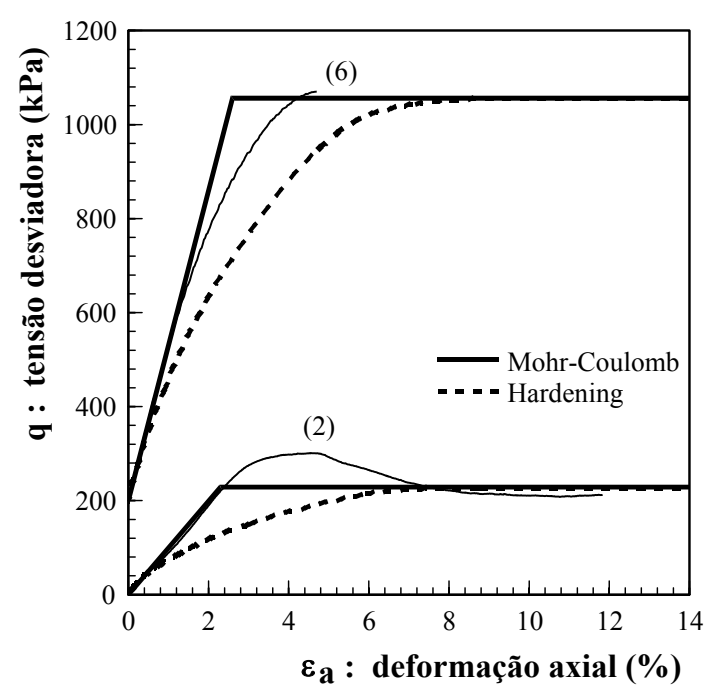

(b) ensaios triaxiais de carregamento

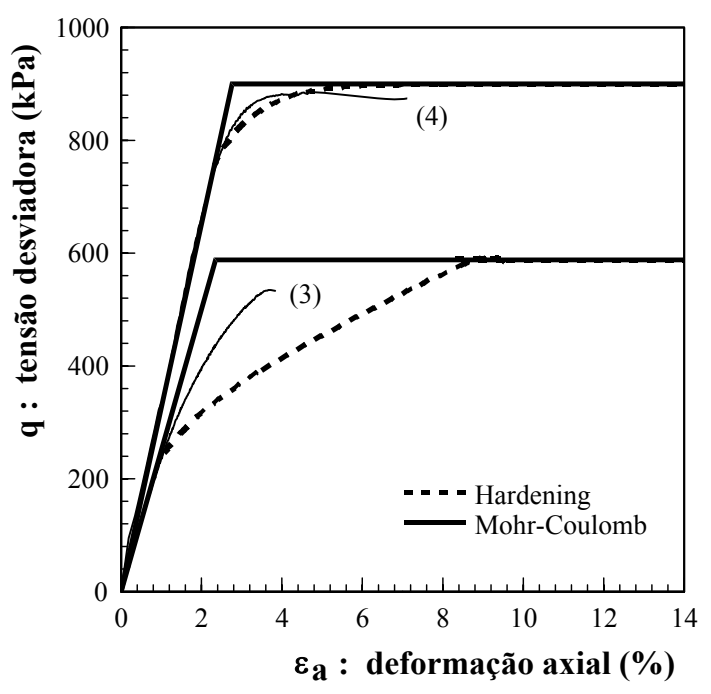

(c) ensaios triaxiais de recarregamento

Figura 5.26 - Comparação entre os resultados de ensaios de laboratório e os obtidos pelas simulações numéricas dos ensaios

$\mathrm{Na}$ Figura 5.26 (b) são apresentados os ensaios triaxiais de carregamento. Quanto ao ensaio normalmente adensado (6), percebe-se um trecho inicial linear, tornando o modelo Mohr-Coulomb o melhor representativo. Para o ensaio fortemente sobre-adensado (2), fica claro como ambos os modelos não representam o comportamento de amolecimento após a resistência de pico.

Os ensaios triaxiais de recarregamento (3) e (4), apresentados na Figura 5.26 (c), foram melhor representados pelo modelo Hardening-Soil, por apresentarem trecho inicial linear (referente à região elástica sobre-adensada) seguido por trecho não-linear (referente ao domínio elasto-plástico normalmente adensado). 
Torna-se evidente que não é possível a escolha de um único modelo constitutivo como o melhor representativo do comportamento do solo, devendo-se escolher o modelo de acordo com a situação que se pretende representar. Para o caso em estudo, onde o solo ao redor de um túnel sofre descarregamento (de maneira geral), aconselha-se a utilização do modelo constitutivo Hardening-Soil.

A modelagem numérica da escavação de um túnel foi realizada com os três modelos constitutivos, a fim de serem efetuadas comparações entre os resultados.

\subsubsection{Desenvolvimento das tensões com o avanço da escavação}

Serão aqui apresentados e discutidos os resultados de alteração dos campos de tensões verticais e horizontais (transversais e longitudinais), no maciço envolvente à escavação. Os demais resultados obtidos pela modelagem numérica, especificamente os de deslocamentos, serão apresentados e discutidos mais adiante. A razão de serem apresentados somente os resultados de alteração de tensões é devida a esta ser necessária para a realização da próxima etapa da modelagem numérica.

Para a análise desta alteração de tensões, foram escolhidos 6 pontos ao redor do túnel, nomeados de A a F, como se observa na Figura 5.27. Considera-se que estes pontos sejam representativos do comportamento da região onde estão localizados.

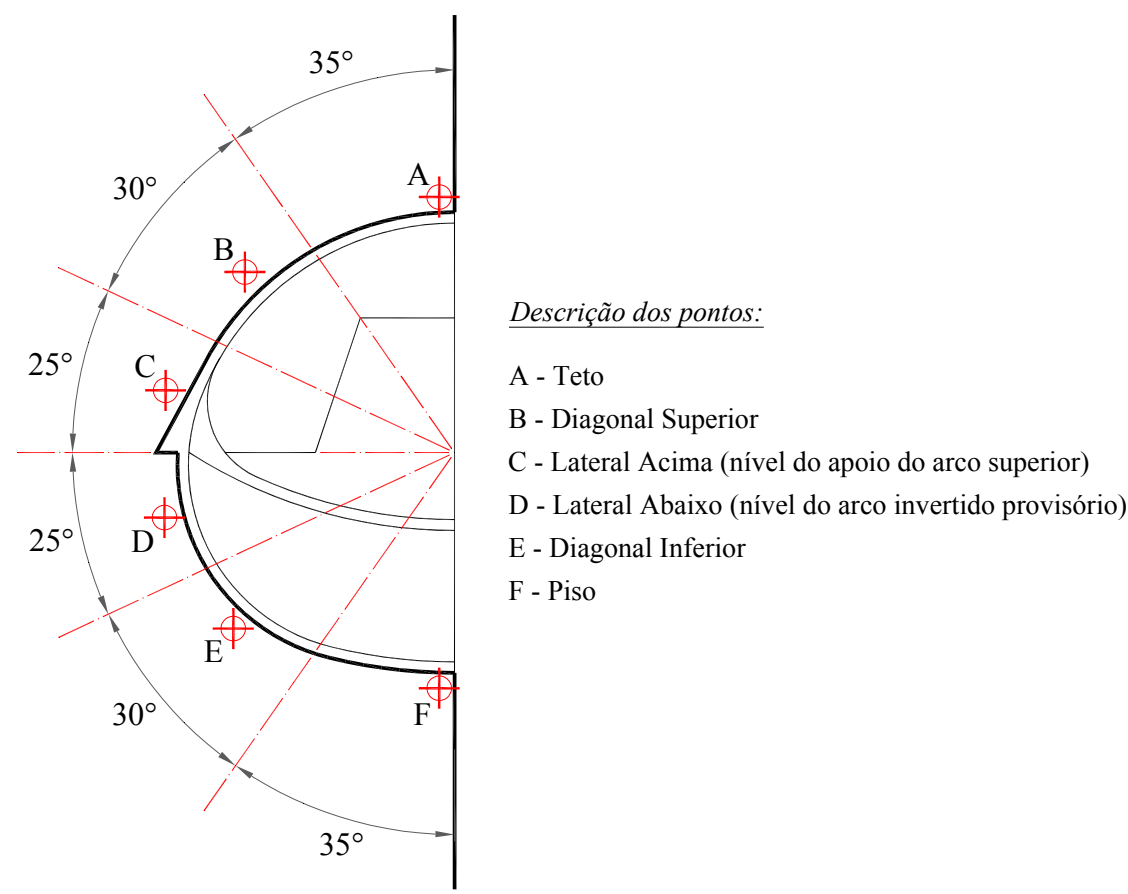

Figura 5.27 - Pontos ao redor do túnel escolhidos para análise 
A variação das tensões será analisada em função do avanço da escavação do túnel, sendo identificados alguns instantes significativos da modelagem. Suas notações estão descritas a seguir e serão utilizadas até o final deste capítulo:

- $\mathrm{t}_{0}$ - início da modelagem;

- $\mathrm{t}_{1}$ - aproximação da frente de escavação da calota;

- $\mathrm{t}_{2}$ - imediatamente antes da escavação do arco superior da calota;

- $t_{3}$ - imediatamente após a escavação do arco superior da calota;

- $\mathrm{t}_{4}$ - após o revestimento do arco superior;

- $\mathrm{t}_{5}$ - após o revestimento do arco invertido provisório;

- $\mathrm{t}_{6}$ - imediatamente antes da escavação da bancada;

- $\mathrm{t}_{7}$ - imediatamente após a escavação da bancada;

- $\mathrm{t}_{8}$ - final da modelagem.

A Figura 5.28 apresenta a variação das tensões para o ponto A, localizado no teto do túnel. Como se pode observar, um aumento da tensão vertical ocorre com a aproximação da frente de escavação da calota, causado pelo efeito de arco longitudinal. Ao ser escavada a calota na seção analisada, a tensão vertical é reduzida para um valor próximo de zero e, depois de revestido o arco superior, a tensão é elevada para um valor próximo de $400 \mathrm{kPa}$. Este aumento na tensão também é devido ao efeito de arco longitudinal, o qual redistribui as tensões verticais da seção escavada para regiões adiante e atrás da frente de escavação. Com o afastamento da frente, a tensão vertical se estabiliza em um patamar, sem ocorrer variações significativas devido à escavação da bancada (rebaixo).

Quanto ao desenvolvimento das tensões horizontais no ponto A, pode-se notar que a escavação do túnel não representa influência significativa nos resultados com o modelo Elástico linear. Para os outros dois modelos, entretanto, ocorre uma diminuição das tensões ao ser escavada a calota da seção analisada. Isto se deve ao fato de que, ao ser reduzida a tensão vertical, a tensão desviadora é elevada e o ponto de estado de tensões atinge a envoltória de plastificação/ruptura. Para possibilitar a redução da tensão vertical, a plastificação também reduz a tensão horizontal. Para as tensões horizontais, também não é observada influência da escavação da bancada.

É possível se estabelecer, pela análise do desenvolvimento das tensões no ponto $\mathrm{A}$, uma zona de influência da frente de escavação a uma distância de 15 metros, o que equivale a aproximadamente 1,5 vezes o diâmetro equivalente do túnel. 

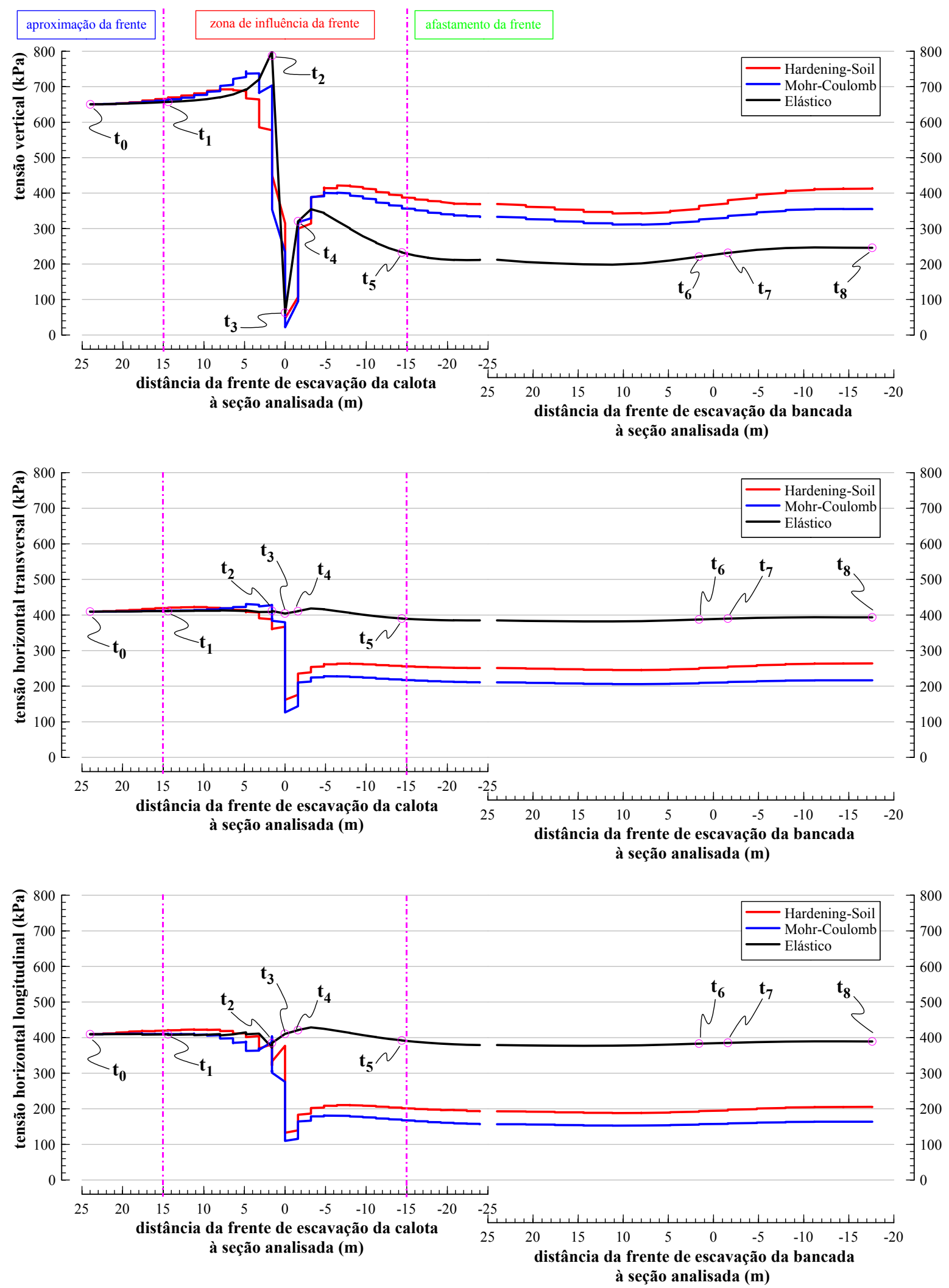

Figura 5.28 - Desenvolvimento das tensões com o avanço da escavação para o ponto A, localizado no teto do túnel 
A variação das tensões para o ponto B, localizado na diagonal superior do túnel, está apresentada na Figura 5.29. Observa-se um aumento da tensão vertical com a aproximação da frente de escavação da calota, resultante do efeito de arco longitudinal. Com a escavação da calota, a tensão vertical não é reduzida para um valor próximo de zero, como ocorrido no teto do túnel. Isto é devido ao efeito de arco transversal, que redistribui as tensões do teto do túnel para suas laterais. Ao ser revestido o arco superior, a tensão vertical aumenta e se estabiliza em um patamar, antes mesmo do afastamento da frente de escavação da calota. Este aumento é devido ao efeito de arco longitudinal. Com a passagem da frente de escavação da bancada, a tensão vertical sofre uma pequena redução.

Para as tensões horizontais no ponto B, nota-se uma diferença de comportamento entre a tensão na direção transversal e a tensão na direção longitudinal durante a passagem da frente de escavação da calota. A tensão horizontal transversal sofre uma pequena redução, enquanto que a longitudinal é aumentada. Ambas não são influenciadas pelo afastamento da frente de escavação. A redução da tensão transversal é devida ao ponto estar na diagonal do túnel, sofrendo desconfinamento. Ao ser escavada a bancada, nota-se um pequeno aumento da tensão transversal.

É possível observar uma diferença entre os resultados obtidos com o modelo Elástico linear e com os demais modelos, devido à plastificação ocorrida. As tensões nas três direções são reduzidas ao ser escavada a calota, sendo aumentadas após o revestimento do arco superior.

Para o ponto $B$, também é possível se estabelecer uma zona de influência da escavação da calota a uma distância de 1,5 vezes o diâmetro equivalente do túnel, e uma influência não significativa da escavação da bancada.

O desenvolvimento das tensões para o ponto $\mathrm{C}$, localizado na lateral do túnel, ao nível do apoio do arco superior, encontra-se na Figura 5.30. Como se pode observar, os resultados obtidos com o modelo Elástico linear diferem dos obtidos com os outros dois modelos, principalmente para a tensão vertical.

Devido ao arqueamento transversal, a tensão vertical no teto do túnel é redistribuída para sua lateral, sofrendo um aumento no ponto C. Em razão do desconfinamento lateral, a tensão horizontal transversal é reduzida, enquanto que a longitudinal sofre um pequeno aumento. Como a tensão horizontal transversal necessariamente é diminuída, a tensão desviadora é aumentada e o ponto de estado de tensões sofre plastificação, ocasionando a diminuição da tensão vertical e da tensão horizontal longitudinal. 

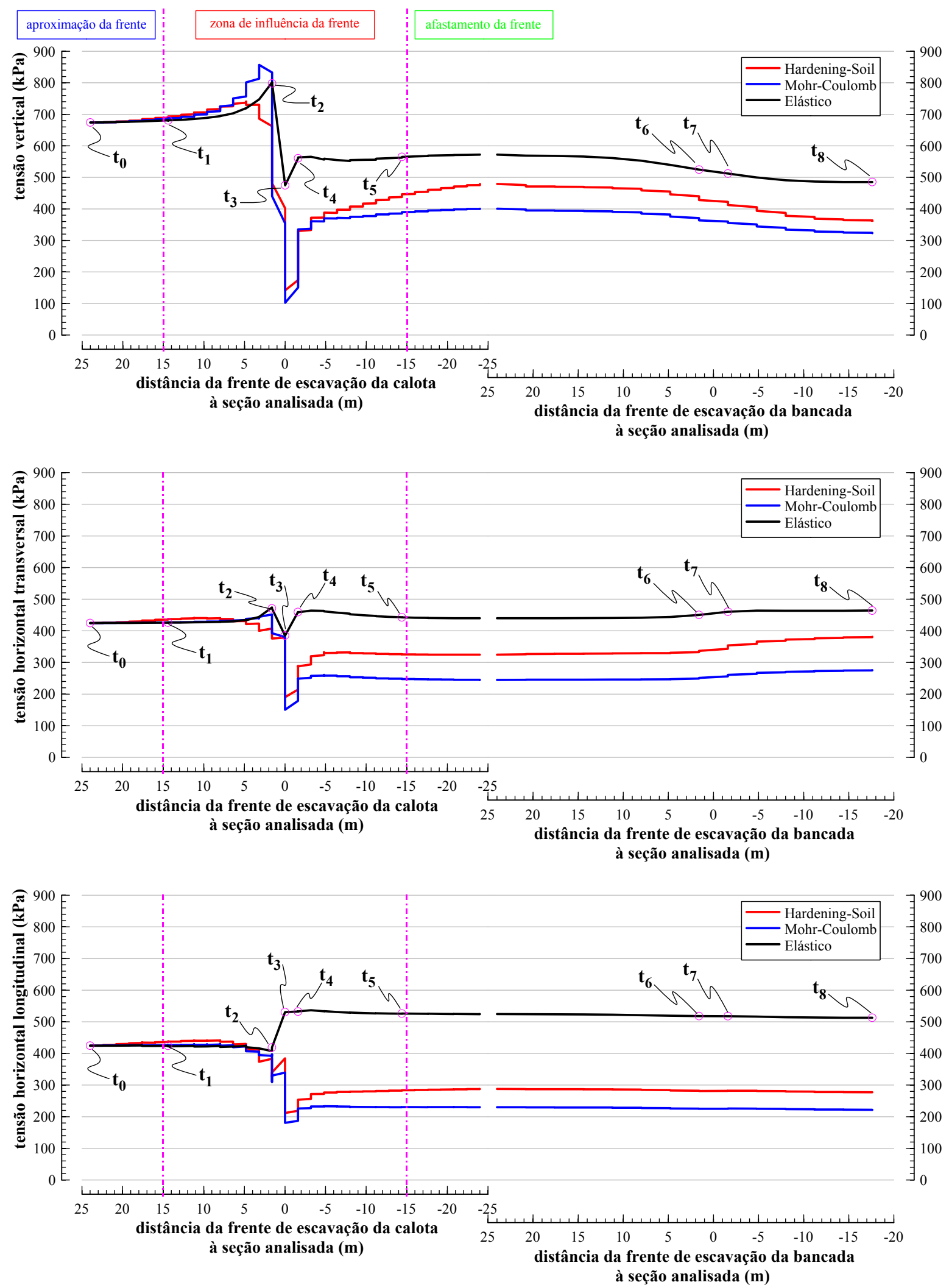

Figura 5.29 - Desenvolvimento das tensões com o avanço da escavação para o ponto B, localizado na diagonal superior do túnel 

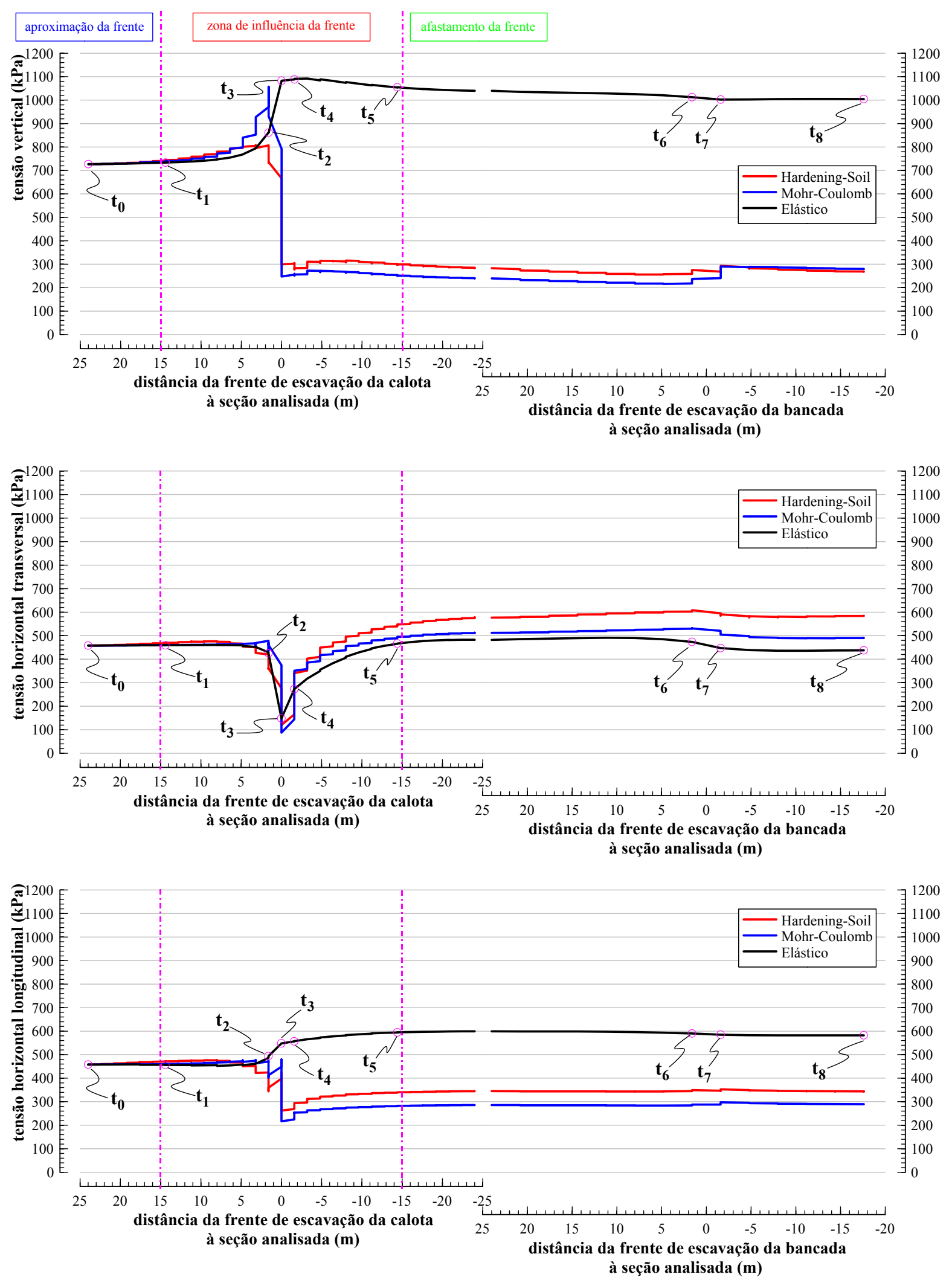

Figura 5.30 - Desenvolvimento das tensões com o avanço da escavação para o ponto C, localizado na lateral do túnel (nível do apoio do arco superior) 
Após o revestimento do arco superior, a tensão horizontal transversal no ponto $\mathrm{C}$ é elevada até um patamar de estabilização, enquanto as demais permanecem sem alteração. Com a passagem da frente de escavação da bancada, as tensões não sofrem influência significativa.

Também é possível se estabelecer uma zona de influência da escavação da calota para o ponto $\mathrm{C}$, a uma distância de 1,5 vezes o diâmetro equivalente do túnel.

O desenvolvimento das tensões para o ponto $\mathrm{D}$, localizado na lateral do túnel, no nível do arco invertido provisório, está apresentado na Figura 5.31. Observa-se que a escavação da calota exerce influência sobre a tensão vertical, mas que não altera significativamente as tensões horizontais. A tensão horizontal transversal sofre uma pequena redução após a passagem da frente de escavação, enquanto que a tensão longitudinal sofre um pequeno aumento, ambas sendo estabilizadas após o revestimento do arco invertido provisório. Após o revestimento do arco superior, este passa a carregar a área localizada abaixo de seu apoio, onde se encontra o ponto D. Com isto, a tensão vertical tende a aumentar até que o arco invertido provisório seja revestido, como mostram os resultados para o modelo Elástico linear. Entretanto, devido ao carregamento imposto pelo arco superior, o estado de tensões atinge a plastificação e acarreta a diminuição da tensão vertical, como demonstram os resultados para os modelos elasto-plásticos.

A passagem da frente de escavação da bancada ocasiona uma importante alteração das tensões nas três direções, diferentemente dos resultados para os pontos anteriores. Nota-se que, devido ao desconfinamento, a tensão horizontal é reduzida para um valor próximo de zero, sofrendo um pequeno aumento após o revestimento do arco invertido definitivo. Em razão do arqueamento de tensões no sentido transversal, a tensão vertical tende a aumentar, como mostram os resultados para o modelo Elástico linear. Entretanto, o aumento da tensão desviadora ocasiona a plastificação do estado de tensões, acarretando em uma diminuição da tensão vertical e da tensão horizontal longitudinal.

A zona de influência da frente de escavação da calota também pode ser determinada como igual a 1,5 vezes o diâmetro equivalente do túnel, como para os pontos anteriores. Entretanto, para a frente de escavação da bancada, a zona de influência pode ser considerada como igual a apenas 0,5 vezes o diâmetro. 

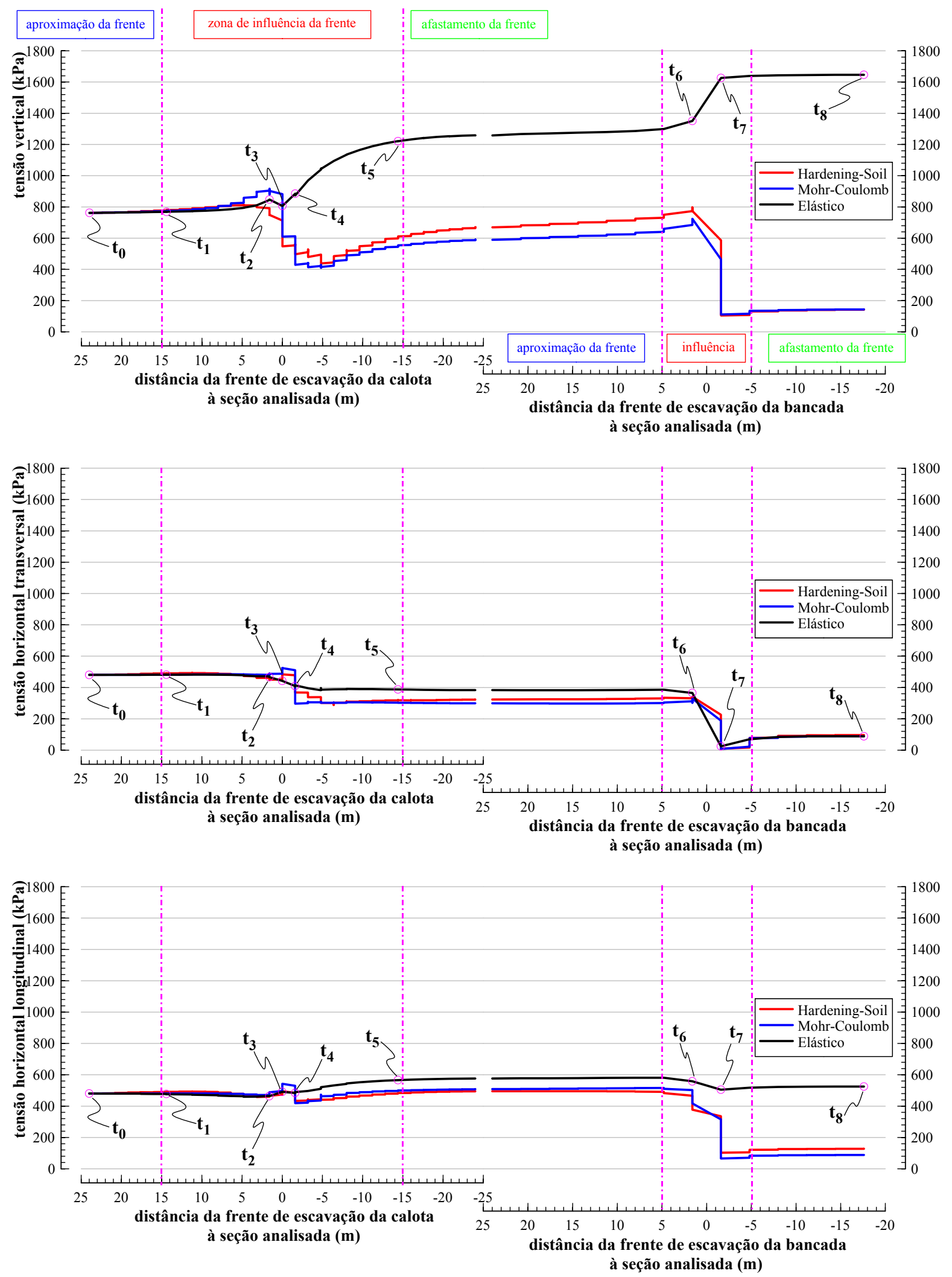

Figura 5.31 - Desenvolvimento das tensões com o avanço da escavação para o ponto D, localizado na lateral do túnel (nível do arco invertido provisório) 
A Figura 5.32 apresenta a variação das tensões para o ponto E, localizado na diagonal inferior do túnel. Pode-se observar que a escavação da calota não altera significativamente as tensões horizontais e que a tensão vertical é reduzida após a passagem da frente de escavação, aumentando após o revestimento do arco superior e se estabilizando após o revestimento do arco invertido provisório.

A escavação da bancada, entretanto, exerce maior influência na alteração das tensões. A tensão vertical sofre uma redução após a passagem da frente, aumentando seu valor após o revestimento do arco invertido provisório até atingir um patamar de estabilização. A tensão horizontal transversal, por sua vez, tende a ser aumentada em razão do arqueamento das tensões no sentido transversal, como mostram os resultados para o modelo Elástico linear. Entretanto, devido à redução das tensões vertical e longitudinal, o estado de tensões atinge a plastificação e acarreta na redução da tensão horizontal transversal. As duas tensões horizontais rapidamente alcançam um patamar de estabilização.

Para o ponto E, a zona de influência da escavação da calota também se encontra a uma distância de 1,5 vezes o diâmetro equivalente do túnel, assim como a zona de influência da escavação da bancada permanece igual a 0,5 vezes o diâmetro.

O desenvolvimento das tensões para o ponto $\mathrm{F}$, localizado no piso do túnel, encontrase na Figura 5.33. Observa-se que as tensões horizontais não são significativamente alteradas e que a tensão vertical sofre redução devido à escavação da calota. Diferentemente dos outros, o ponto $\mathrm{F}$ sofre redução da tensão vertical antes mesmo da passagem da frente de escavação, sendo esta alteração estabilizada apenas após o revestimento do arco invertido provisório. Esta redução acarreta uma plastificação do estado de tensões, gerando uma pequena redução da tensão horizontal transversal e um alívio maior da tensão vertical.

A passagem da frente de escavação da bancada reduz as tensões nas três direções, sendo que a tensão vertical se aproxima do valor nulo. $\mathrm{O}$ afastamento da frente de escavação praticamente não influencia a alteração das tensões. Devido ao descarregamento, o estado de tensões atinge a plastificação e as tensões horizontais sofrem um alívio maior.

A zona de influência da escavação da calota manteve-se a uma distância aproximada de 1,5 vezes o diâmetro equivalente do túnel, assim como a zona de influência da escavação da bancada, que também manteve-se a uma distância de 0,5 vezes o diâmetro. 

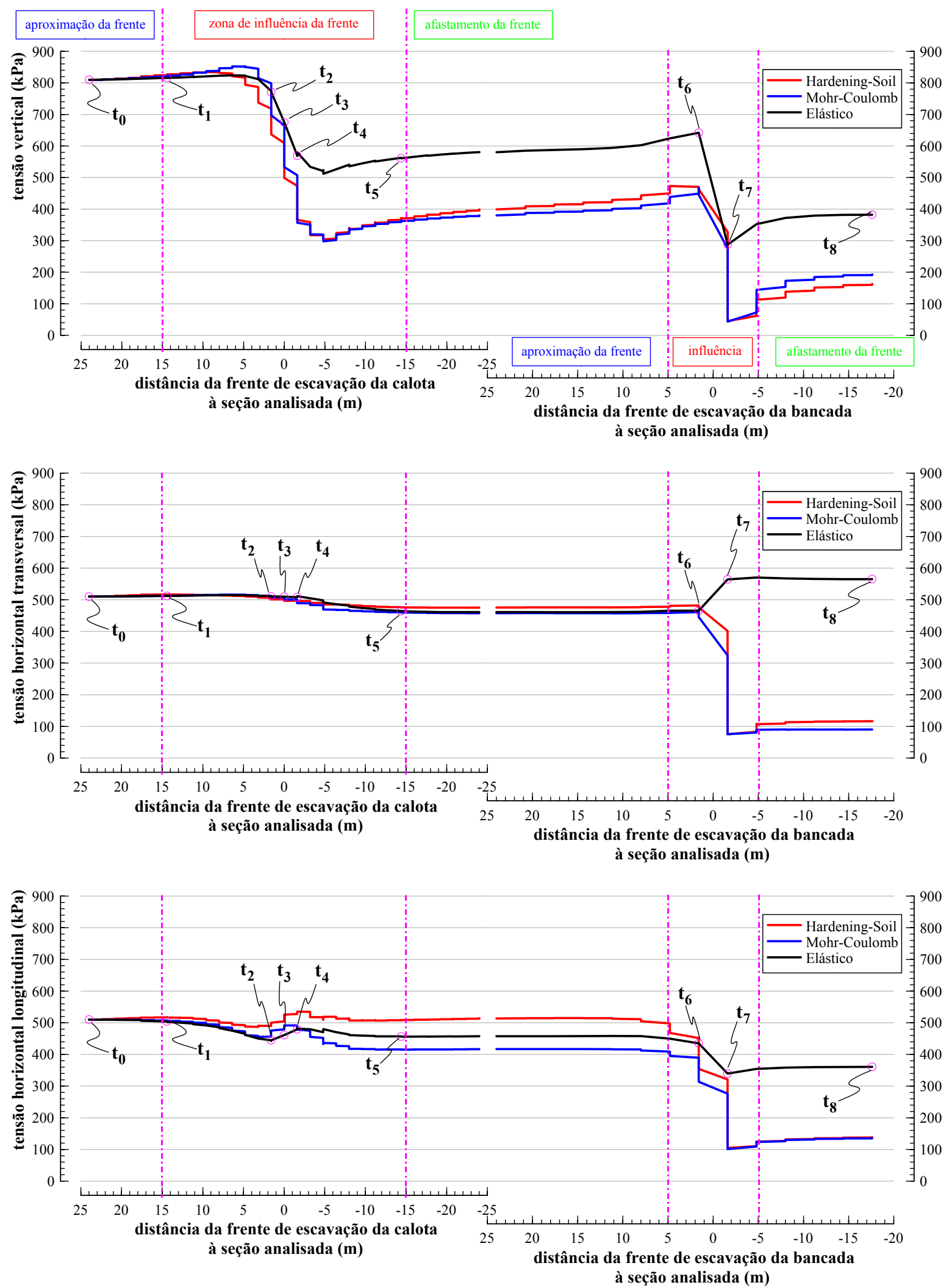

Figura 5.32 - Desenvolvimento das tensões com o avanço da escavação para o ponto E, localizado na diagonal inferior do túnel 

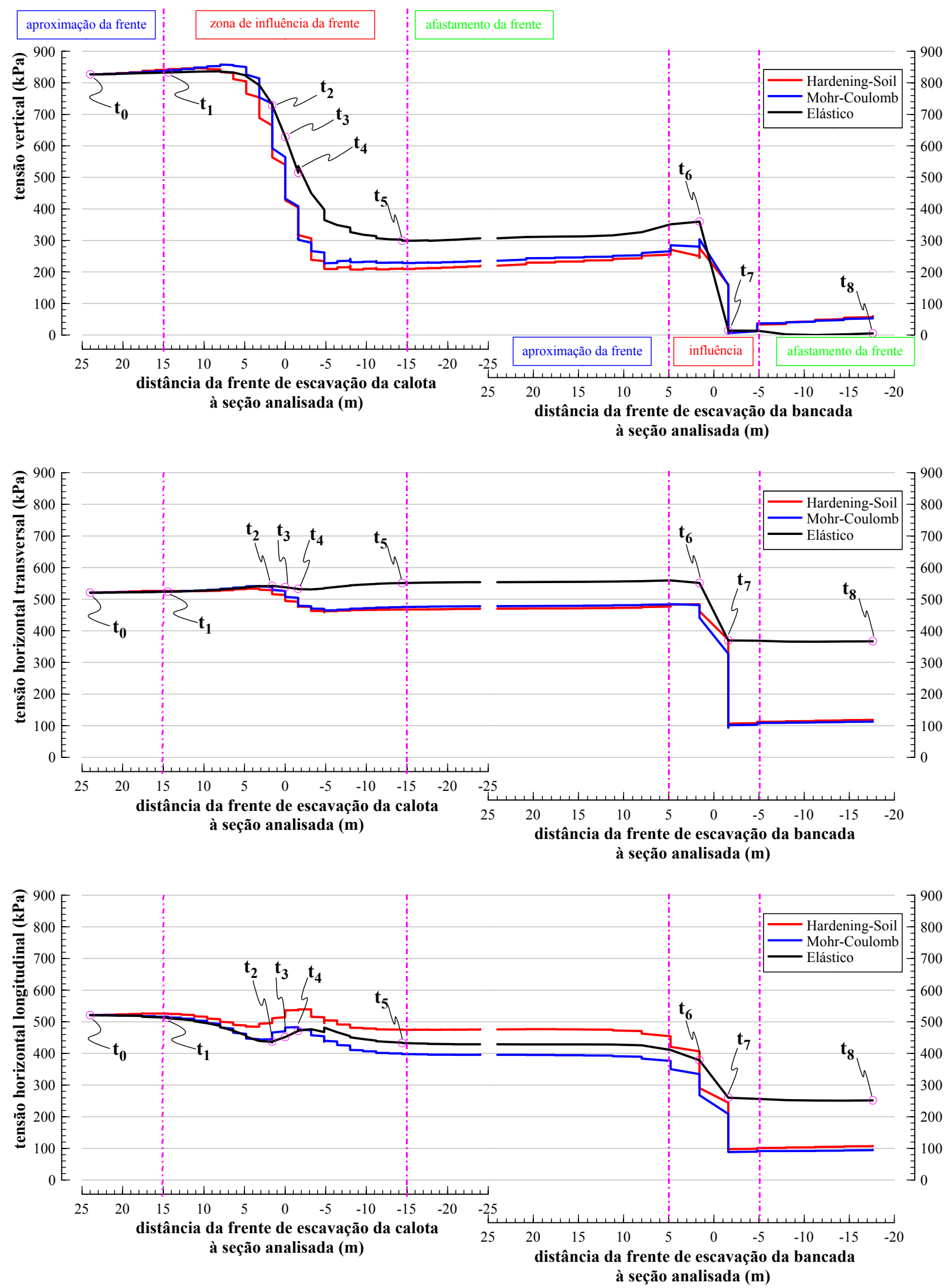

Figura 5.33 - Desenvolvimento das tensões com o avanço da escavação para o ponto F, localizado no piso do túnel 


\subsubsection{Representação em laboratório de um estado tridimensional de tensões}

Como estudado anteriormente, um arqueamento das tensões ocorre após a execução da abertura de um túnel em um maciço, mobilizando as tensões cisalhantes e redistribuindo as tensões ao redor da abertura. Tendo-se isto em vista, torna-se fácil compreender que, além das tensões normais na direção vertical $\left(\sigma_{\mathrm{y}}\right)$, transversal $\left(\sigma_{\mathrm{x}}\right)$ e longitudinal $\left(\sigma_{\mathrm{z}}\right)$, tensões cisalhantes também atuam nos mesmos três planos $\left(\tau_{\mathrm{xy}}, \tau_{\mathrm{xz}}, \tau_{\mathrm{yz}}\right)$.

Com isto, para ser representado em laboratório um estado tridimensional de tensões, sendo este proveniente de uma simulação numérica da escavação de um túnel, se faz necessária a imposição de tensões normais nas três direções e de tensões cisalhantes nos três planos.

Uma alternativa à necessidade de imposição de tensões cisalhantes seria a determinação das tensões normais principais atuantes. A aplicação apenas das três tensões principais, apesar de representar o mesmo estado de tensões $\left(\sigma_{\mathrm{x}}, \sigma_{\mathrm{y}}, \sigma_{\mathrm{z}}, \tau_{\mathrm{xy}}, \tau_{\mathrm{xz}}, \tau_{\mathrm{yz}}\right)$, necessita de uma rotação dos planos de aplicação das tensões. Isto impossibilita a execução de ensaios em que o corpo-de-prova não pode se deslocar em relação ao sistema de aplicação de cargas, ou ao contrário.

O intuito desta primeira etapa da modelagem numérica é de obter estados de tensões referentes ao processo de escavação de um túnel, para que possam ser representados em laboratório.

O equipamento capaz de representar um estado tridimensional de tensões, mais próximo do real, é conhecido como hollow cylinder. Para este equipamento, é necessária a confecção de corpos-de-prova cilíndricos perfurados, no formato de tubo, o que dificulta sua utilização. Com ele, além das tensões normais em três direções, pode-se aplicar uma tensão cisalhante ao ser aplicada uma torção ao corpo-de-prova.

Outro equipamento com variação simultânea de tensões normais em três direções é conhecido como triaxial verdadeiro, ou triaxial cúbico. Nele são ensaiados corpos-de-prova cúbicos, aplicando-se as tensões normais nas faces do cubo. Não é possível, entretanto, a aplicação de tensões cisalhantes.

Para esta pesquisa, encontra-se disponível o equipamento triaxial existente no Laboratório de Mecânica dos Solos da Escola Politécnica. Nele são ensaiados corpos-deprova cilíndricos, sendo possível apenas a aplicação de carregamentos axissimétricos, nos quais as tensões normais horizontais são necessariamente iguais. 
Com o intuito de tornar possível a utilização do equipamento triaxial disponível, algumas simplificações devem ser feitas. Duas alternativas foram analisadas, sendo explanadas a seguir.

A primeira alternativa se baseia na utilização das tensões normais principais, fazendo com que as tensões cisalhantes fossem consideradas. Entretanto, as tensões deveriam ser rotacionadas para as direções vertical e horizontal, o que torna a interpretação dos resultados mais difícil. Além disso, uma das tensões não poderia ser considerada, pois as duas tensões horizontais devem ser iguais.

A segunda alternativa, escolhida para dar prosseguimento com a pesquisa, consiste em utilizar apenas os resultados para a tensão vertical e a tensão horizontal transversal. Em um âmbito geral, não há muita variação entre as duas tensões horizontais, tendo sido escolhida a tensão transversal por ser mais representativa do comportamento existente com a escavação de um túnel. $\mathrm{O}$ arqueamento longitudinal de tensões não deixa de ser importante, porém ele pode ser representado pelo aumento da tensão vertical com a aproximação da frente de escavação, por exemplo.

Na Figura 5.34 é apresentada uma comparação entre as trajetórias de tensões para o ponto A, localizado no teto do túnel, determinadas com as tensões normais principais e com apenas as tensões vertical e horizontal transversal.

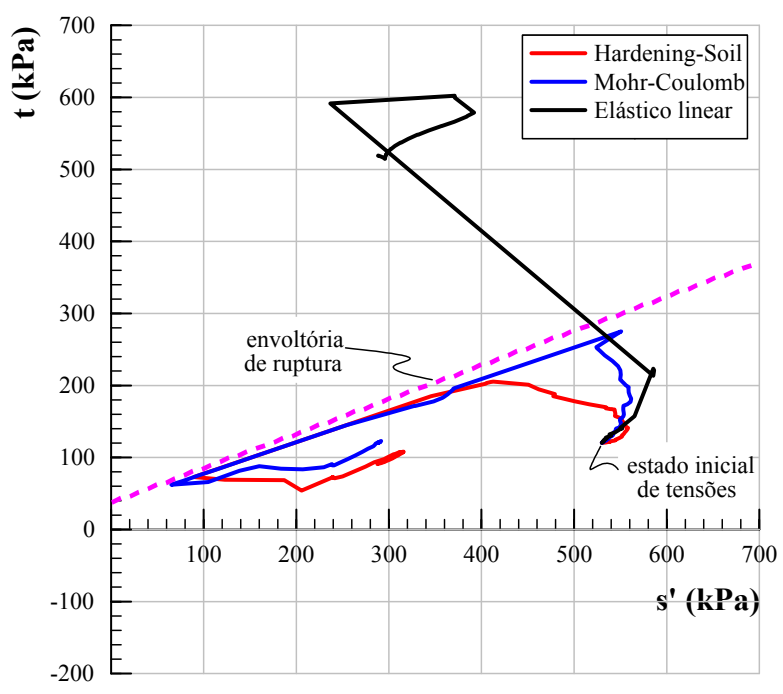

a) considerando o estado tridimensional de tensões

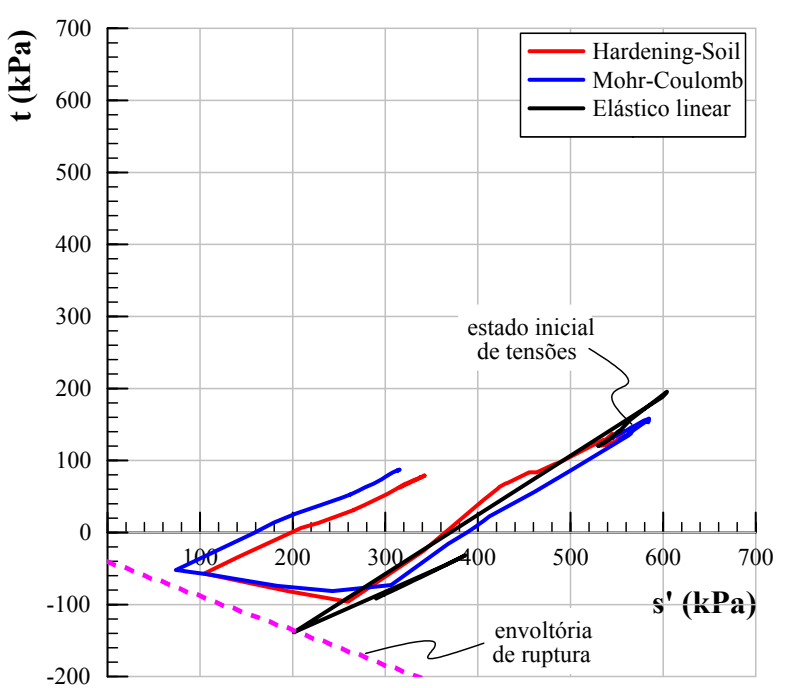

b) considerando apenas $\sigma \mathrm{x}$ e $\sigma \mathrm{y}$

Figura 5.34 - Comparação entre duas maneiras de se determinar a trajetória de tensões 
Como é possível observar-se na Figura 5.34, a utilização das tensões normais principais faz com que o invariante de tensões $t$ possua sempre valor positivo, mesmo para o caso em que as tensões horizontais sejam maiores do que a vertical. Isto é devido à rotação das tensões principais, tornando a tensão horizontal a tensão principal maior e a vertical a tensão principal menor. Ao serem utilizadas apenas as tensões vertical e horizontal para o cálculo do invariante, a diferença das tensões pode resultar em um valor negativo.

Outra comparação que pode ser efetuada diz respeito à envoltória de ruptura. Com a Figura 5.34 (a), nota-se como a trajetória de tensões obtida com o modelo Elástico linear ultrapassa a envoltória, enquanto os estados de tensões obtidos com os demais modelos plastificam até ser encontrado o equilíbrio. Ao serem utilizadas as tensões vertical e horizontal para o cálculo dos invariantes, entretanto, nota-se como as trajetórias de tensões obtidas com os modelos elasto-plásticos não atingem a envoltória de ruptura. Isto é devido ao cálculo numérico ser efetuado a partir das tensões normais principais.

\subsubsection{Trajetórias de tensões obtidas}

Para a determinação das trajetórias de tensões obtidas para os seis pontos ao redor do túnel (de A a F), foram utilizadas unicamente as tensões vertical e horizontal transversal. Os instantes significativos da modelagem ( $\mathrm{de}_{0} \mathrm{a}_{\mathrm{s}}$ ), descritos anteriormente, continuarão servindo como base para as análises.

O desenvolvimento das tensões foi simplificado para trechos retos entre os instantes da modelagem, com o intuito de ajudar na interpretação das trajetórias, fazendo com que elas também possuam trechos retos. As simplificações foram baseadas nos resultados obtidos com o modelo Elástico Linear, tendo-se em vista que as trajetórias serão utilizadas para obtenção dos parâmetros elásticos de deformabilidade dos ensaios triaxiais de descarregamento.

A Figura 5.35 apresenta a trajetória de tensões para o ponto A, localizado no teto do túnel. Como pode ser observado, com a aproximação da frente de escavação da calota, o solo sofre uma compressão por carregamento (trajetória de 45 graus). Com a escavação da calota, ocorre uma extensão por descarregamento (trajetória de 225 graus), sendo o solo carregado novamente (trajetória de 45 graus) após a instalação do revestimento do arco superior. Com o afastamento da frente de escavação, o solo é descarregado novamente (trajetória de 225 graus) até a estabilização das tensões, o que ocorre ao ser revestido o arco invertido provisório. A frente de escavação da bancada não exerce influência sobre as tensões do ponto A. 


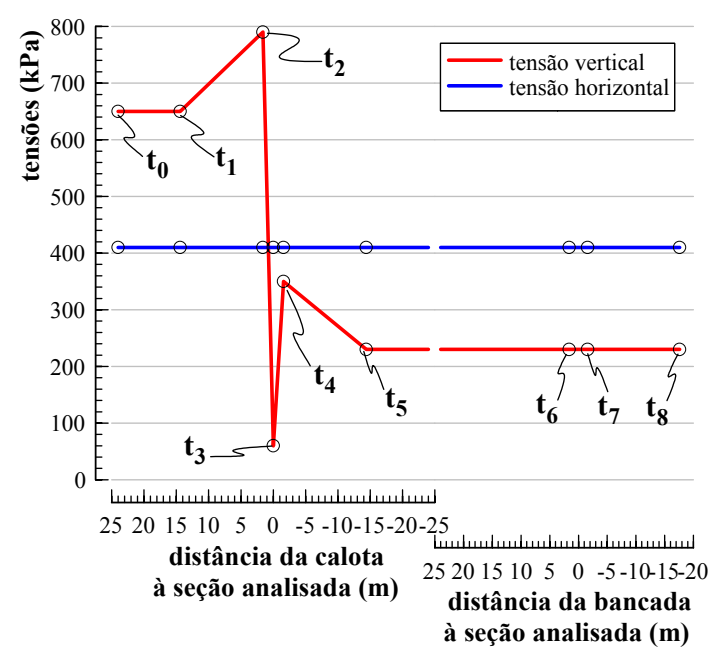

a) simplificação do desenvolvimento das tensões

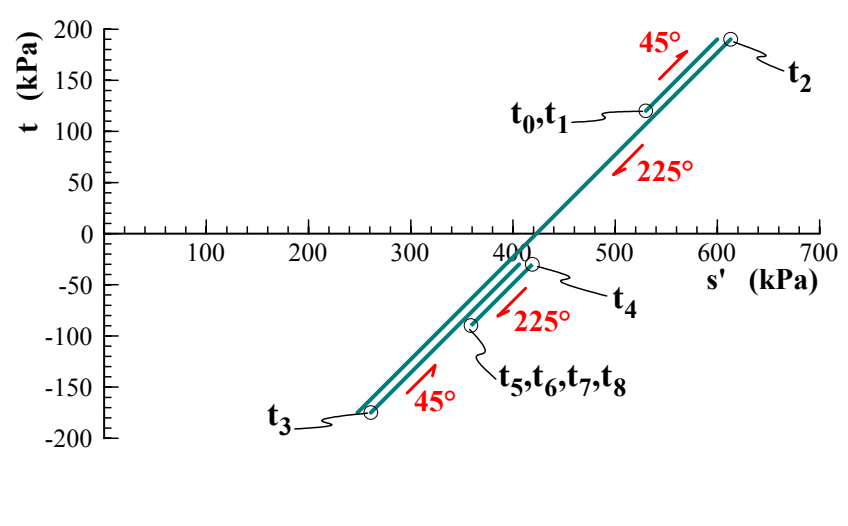

(b) trajetória de tensões

Figura 5.35 - Trajetória de tensões para o ponto A, localizado no teto do túnel

A trajetória de tensões para o ponto $\mathrm{B}$, localizado na diagonal superior do túnel, está apresentada na Figura 5.36. Observa-se que a aproximação da frente de escavação da calota implica uma compressão por carregamento (trajetória de 45 graus). Ao ser escavada a calota, ocorre um descarregamento (trajetória de 210 graus), sendo o solo carregado novamente (trajetória de 0 graus) após a instalação do revestimento do arco superior, estabilizando as tensões em seguida. A passagem da frente de escavação da bancada e seu afastamento provocam uma extensão no solo (trajetória de 270 graus).

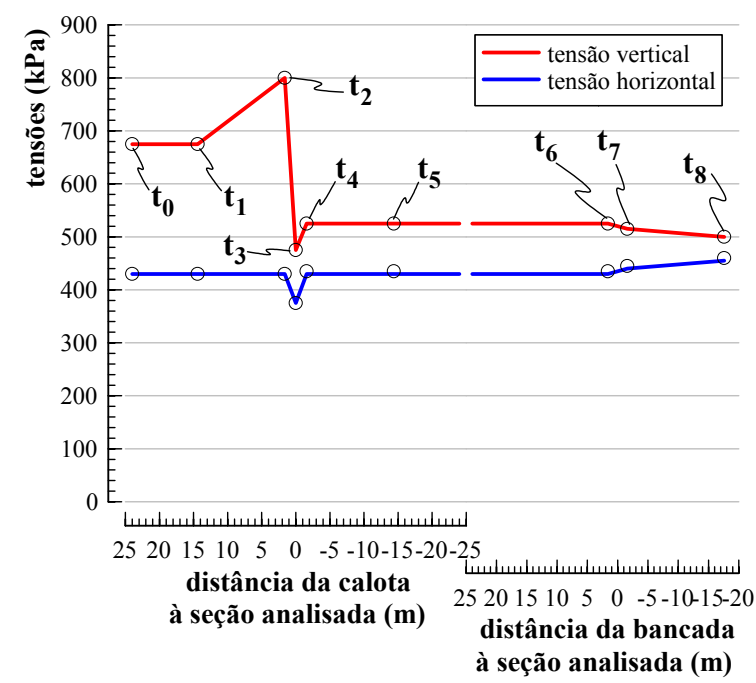

a) simplificação do desenvolvimento das tensões

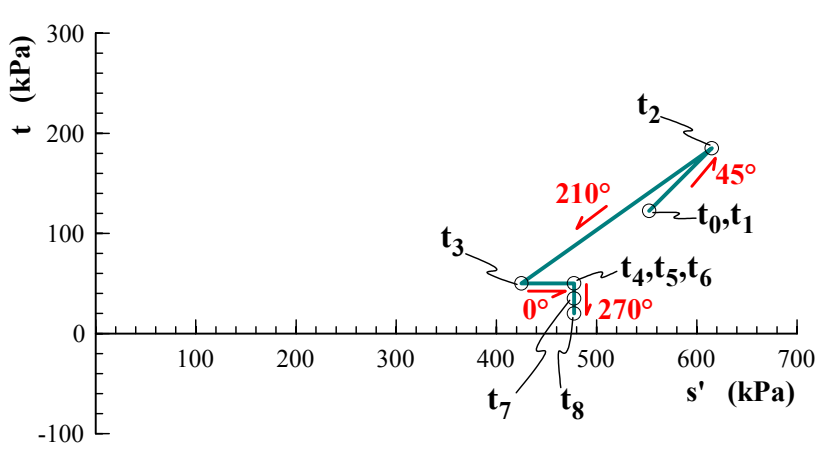

(b) trajetória de tensões

Figura 5.36 - Trajetória de tensões para o ponto B, localizado na diagonal superior do túnel 
A Figura 5.37 apresenta a trajetória de tensões para o ponto $\mathrm{C}$, localizado na lateral do túnel, ao nível do apoio do arco superior. Nota-se que a aproximação da frente de escavação da calota ainda realiza uma compressão por carregamento (trajetória de 45 graus). Com a escavação da calota, ocorre uma compressão (trajetória de 95 graus), sendo a tensão lateral restabelecida (trajetória de 315 graus) até a estabilização das tensões, o que ocorre ao ser revestido o arco invertido provisório. As tensões do ponto C não sofrem influência da frente de escavação da bancada.

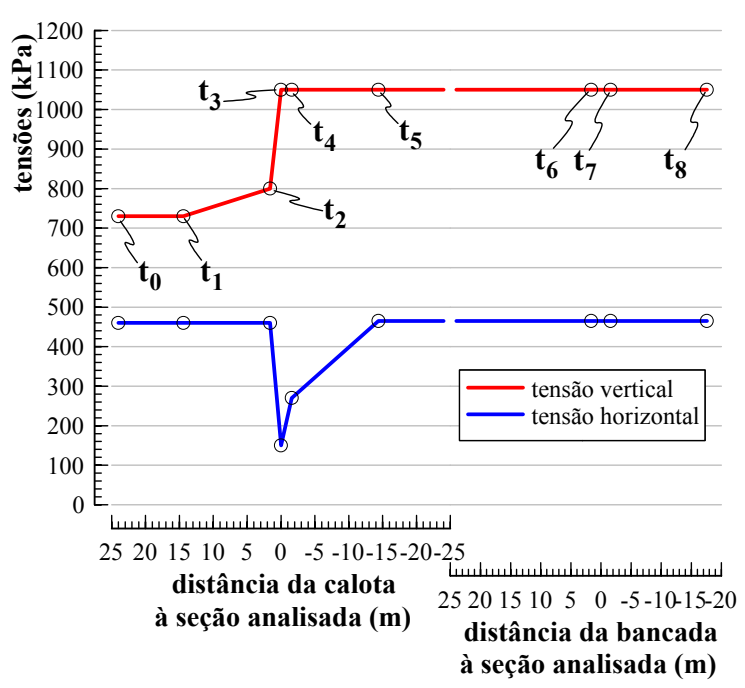

a) simplificação do desenvolvimento das tensões

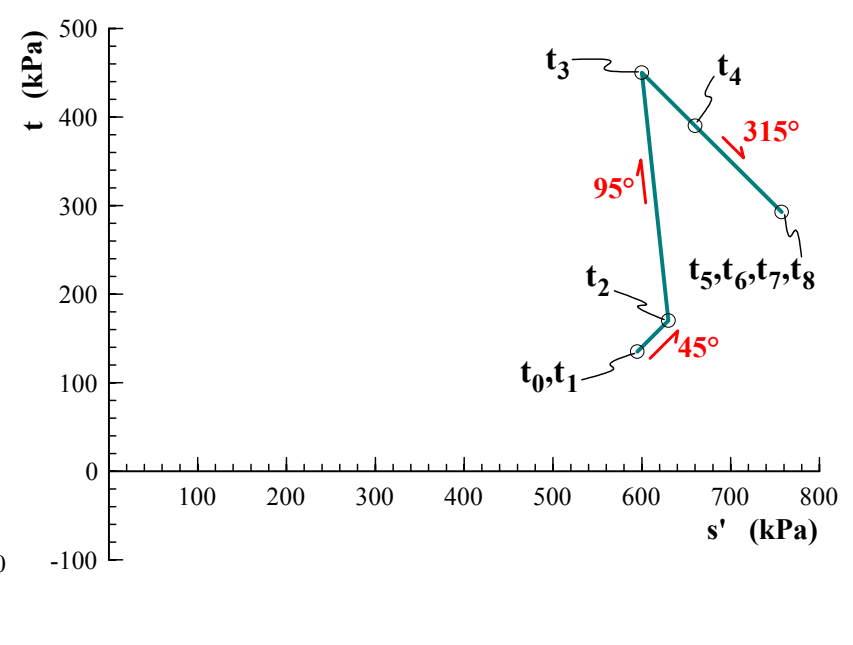

(b) trajetória de tensões

Figura 5.37 - Trajetória de tensões para o ponto C, localizado na lateral do túnel (nível do apoio do arco superior)

A trajetória de tensões para o ponto $\mathrm{D}$, localizado na lateral do túnel, ao nível do arco invertido provisório, está apresentada na Figura 5.38. Diferentemente dos pontos anteriores, a aproximação da frente de escavação da calota não altera as tensões do ponto analisado. Com a escavação da calota, ocorre uma compressão (trajetória de 95 graus) até ser revestido o arco superior. Em seguida, o solo sofre carregamento axial (trajetória de 45 graus) até que o arco invertido provisório seja instalado. A passagem da frente de escavação da bancada exerce uma compressão (trajetória de 95 graus) e com seu afastamento ocorre um carregamento lateral (trajetória de 315 graus). 


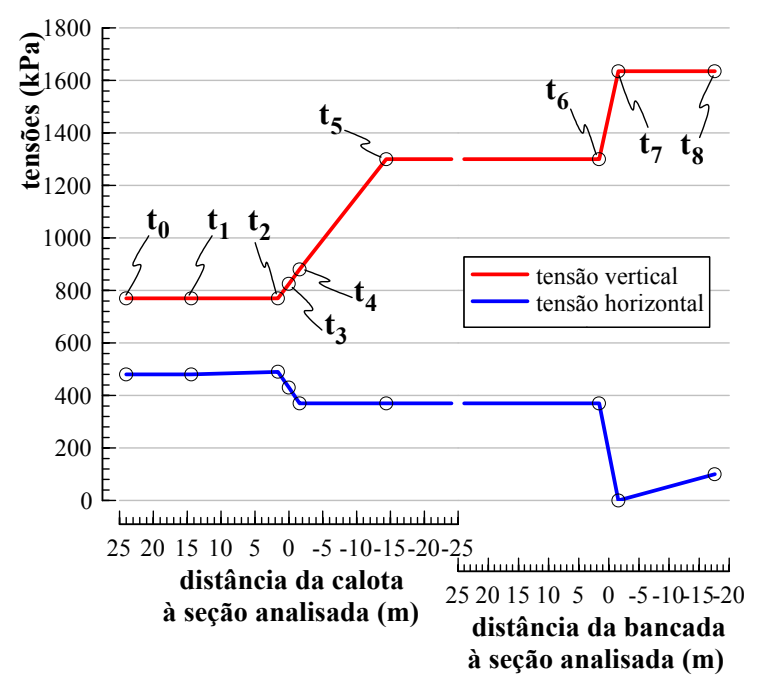

a) simplificação do desenvolvimento das tensões

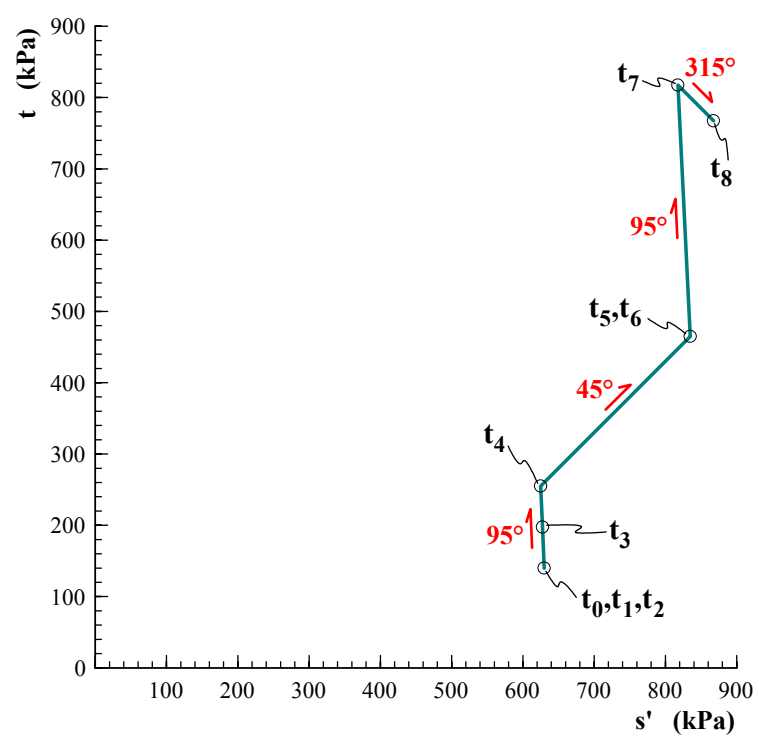

(b) trajetória de tensões

Figura 5.38 - Trajetória de tensões para o ponto D, localizado na lateral do túnel (nível do arco invertido provisório)

A Figura 5.39 apresenta a trajetória de tensões para o ponto E, localizado na diagonal inferior do túnel. Nota-se que a aproximação da frente de escavação da calota também não influencia as tensões do ponto analisado. Com a escavação da calota, ocorre uma extensão por descarregamento (trajetória de 225 graus), sendo o solo carregado novamente após a instalação do revestimento do arco superior (trajetória de 95 graus). A passagem da frente de escavação da bancada exerce uma extensão (trajetória de 270 graus) e com seu afastamento ocorre um carregamento (trajetória de 45 graus).

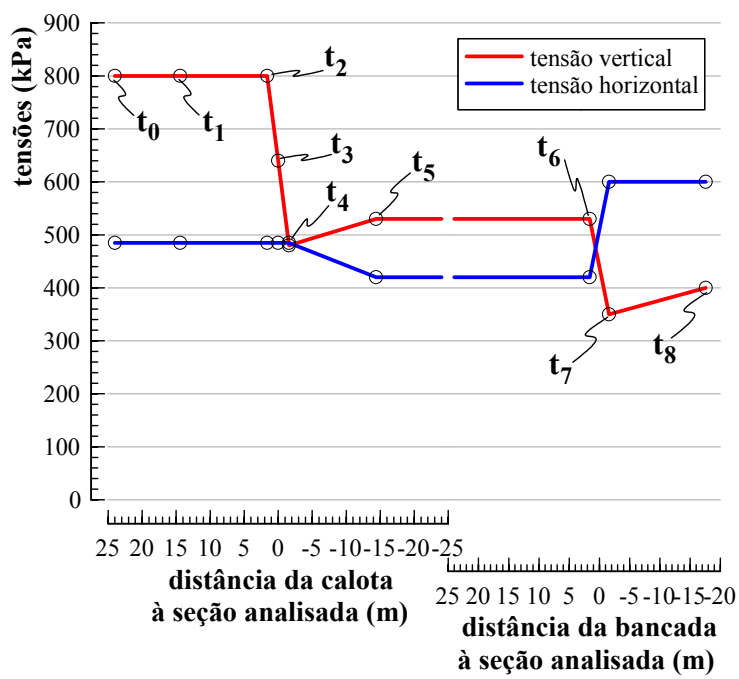

a) simplificação do desenvolvimento das tensões

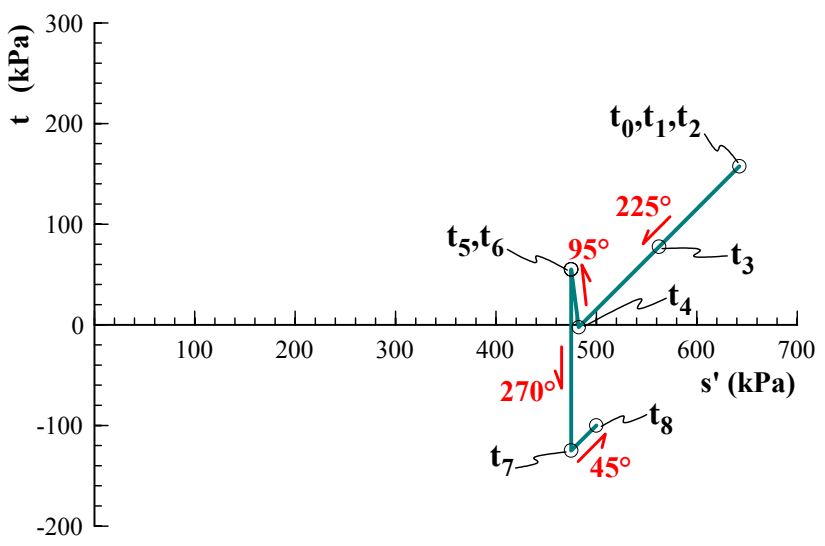

(b) trajetória de tensões

Figura 5.39 - Trajetória de tensões para o ponto E, localizado na diagonal inferior do túnel 
A Figura 5.40 apresenta a trajetória de tensões para o ponto $\mathrm{F}$, localizado no piso do túnel. Observa-se que a aproximação da frente e a escavação da calota exercem uma extensão por descarregamento (trajetória de 225 graus), até que o arco invertido provisório seja revestido. A passagem da frente de escavação da bancada também acarreta um descarregamento no solo (trajetória de 200 graus), estabilizando-se as tensões em seguida.

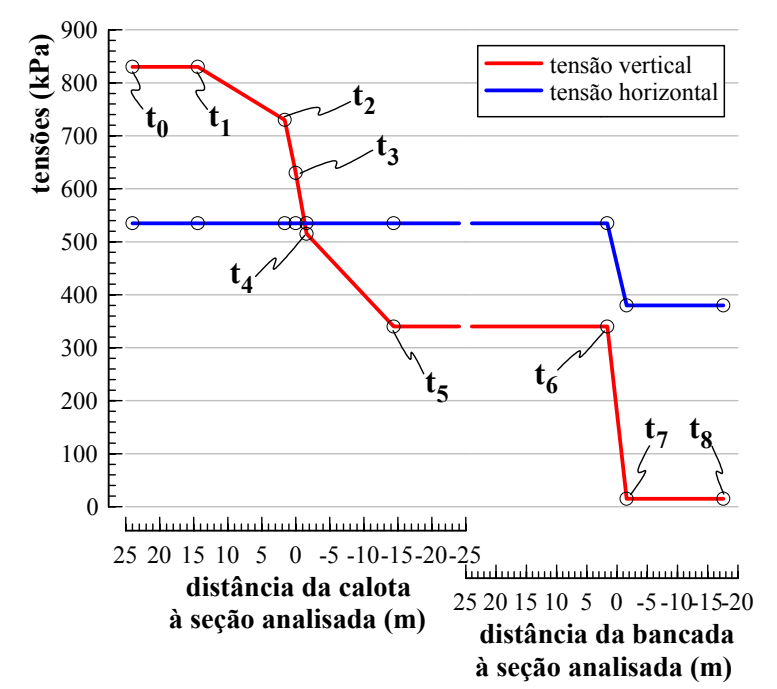

a) simplificação do desenvolvimento das tensões

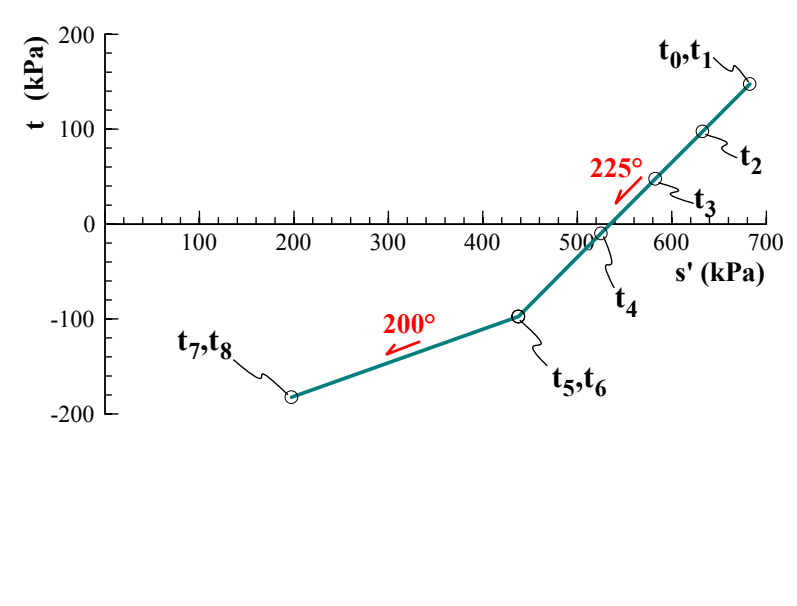

(b) trajetória de tensões

Figura 5.40 - Trajetória de tensões para o ponto F, localizado no piso do túnel

Uma síntese de todas as direções encontradas para as trajetórias de tensões obtidas encontra-se na Figura 5.41, resultando em oito ângulos diferentes: $0^{\circ}, 45^{\circ}, 95^{\circ}, 200^{\circ}, 210^{\circ}$, $225^{\circ}, 270^{\circ}$ e $315^{\circ}$.

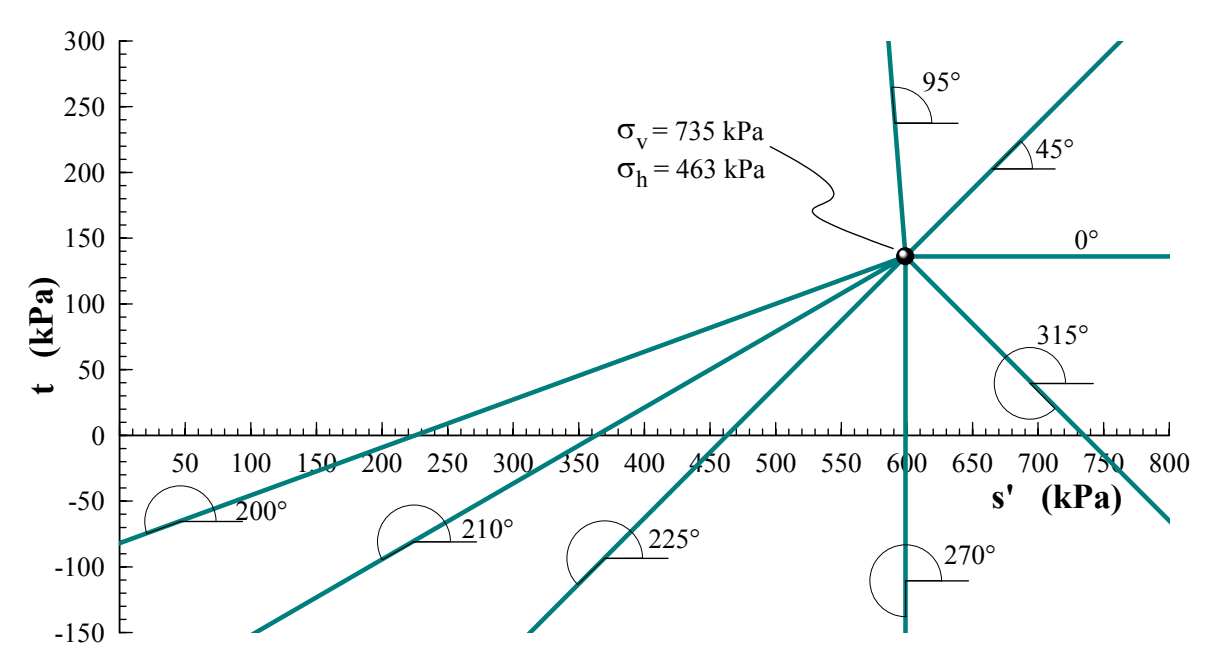

Figura 5.41 - Síntese das trajetórias de tensões obtidas 
A trajetória de $45^{\circ}$ foi executada para os ensaios triaxiais de carregamento axial, cujos resultados foram apresentados no capítulo anterior no item 4.2.2 e utilizados para calibração dos modelos constitutivos para esta primeira etapa da modelagem numérica.

As trajetórias com ângulos de $95^{\circ}, 200^{\circ}, 210^{\circ}$ e $225^{\circ}$ foram utilizadas para execução dos ensaios triaxiais de descarregamento, cujos resultados foram apresentados no capítulo anterior no item 4.2 .3 e serão utilizados para a segunda etapa da modelagem numérica.

As trajetórias com ângulos de $0^{\circ}, 270^{\circ}$ e $315^{\circ}$ não puderam ser executadas, tendo-se em vista que elas são resultantes de um aumento na tensão horizontal e que o equipamento triaxial utilizado para os ensaios possui um limite de $500 \mathrm{kPa}$ para a tensão confinante.

\subsection{Modelagem Com O MaCiÇo MeCaniCAMente Heterogêneo}

Dando prosseguimento ao estudo, ensaios triaxiais de descarregamento foram executados a partir das trajetórias de tensões obtidas com a modelagem anterior.

Para esta segunda etapa da modelagem numérica do túnel, foram novamente utilizados os modelos constitutivos Elástico linear, Mohr-Coulomb e Hardening-Soil. Além disso, o maciço foi considerado como mecanicamente heterogêneo, ou seja, ele foi subdividido em zonas de comportamento mecânico diferente, resultando em um conjunto de parâmetros geotécnicos diferente para cada zona.

Para a calibração dos parâmetros geotécnicos desta segunda etapa da modelagem, foram utilizados os ensaios triaxiais de descarregamento, cujos resultados foram apresentados e discutidos anteriormente no capítulo 4.2.3.

\subsubsection{Adaptação do modelo anterior}

A única alteração efetuada no modelo da primeira etapa foi a subdivisão do maciço em zonas de igual comportamento mecânico, de acordo com os pontos escolhidos para determinação das trajetórias de tensões da etapa anterior, como se observa na Figura 5.42.

Cada uma das seis zonas foi nomeada de acordo com o ponto representativo de sua trajetória de tensões, ou seja, com letras que variam de A a F. 


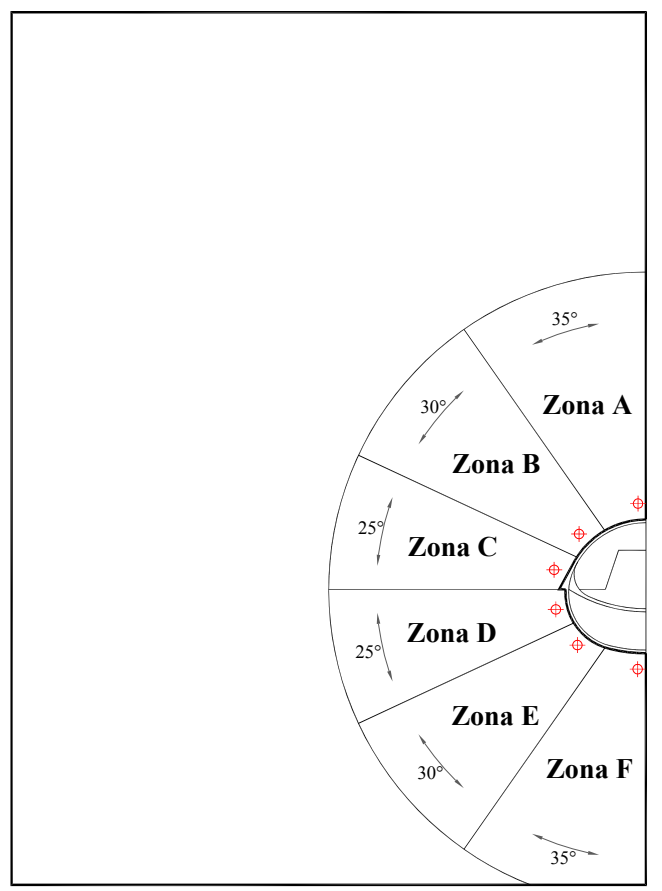

Figura 5.42 - Subdivisão do maciço em zonas de igual comportamento mecânico

Os pontos utilizados para obtenção das trajetórias de tensões foram tomados como representativos das zonas às quais pertencem. Cabe ressaltar que esta medida trata-se de uma simplificação, pois as alterações de tensões para pontos pertencentes à mesma zona são diferentes em função da distância da escavação.

O limite destas zonas foi estabelecido a uma distância aproximada de 1,5 vezes o diâmetro equivalente do túnel, a partir de seu perímetro. Ou seja, 2 vezes o $\mathrm{d}_{\mathrm{eq}}$ do túnel, a partir de seu eixo de simetria. Isto resultou em uma área delimitada por um círculo, referente à região de alteração de tensões ao redor do túnel.

O valor de 1,5 vezes $d_{\text {eq }}$ foi adotado a partir dos gráficos de desenvolvimento das tensões em função do avanço da escavação. Neles, pode-se perceber que a frente de escavação começa a influenciar a alteração de tensões de uma seção localizada 15 metros adiante, e deixa de influenciar esta seção ao se afastar 15 metros, aproximadamente.

O restante do maciço continuou sendo representado como homogêneo, com os mesmos parâmetros geotécnicos utilizados na modelagem anterior (obtidos a partir dos ensaios de carregamento axial, com trajetória de 45 graus).

Para as zonas de A a F, a alteração dos parâmetros geotécnicos na modelagem numérica foi efetuada em função do avanço da frente de escavação do túnel. Todas as seções do modelo, não somente a analisada, tiveram a seqüência de alteração dos parâmetros elásticos indicada na Figura 5.43. 

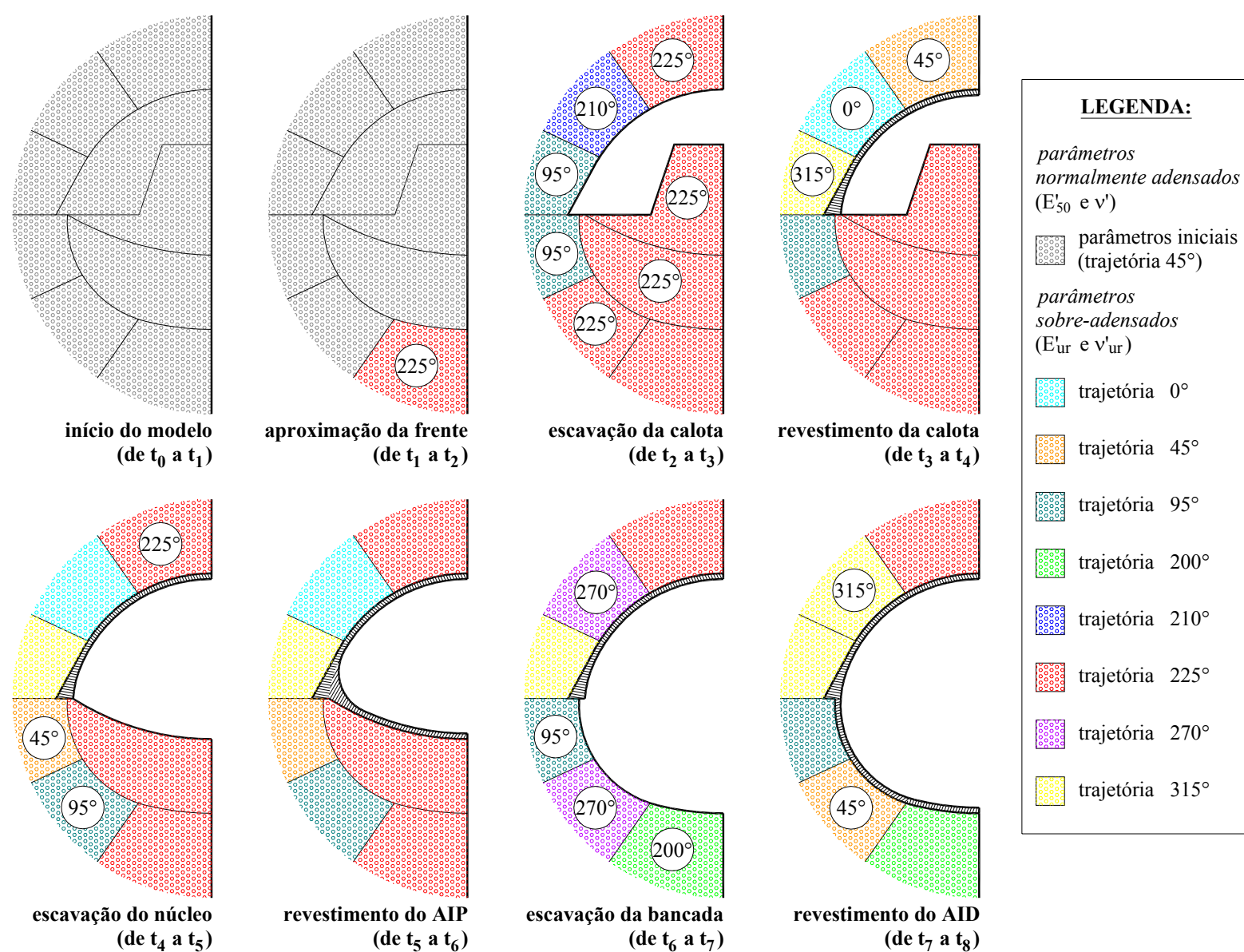

normalmente adensados

$\left(E_{50}^{\prime}\right.$ e $\left.v^{\prime}\right)$

parâmetros iniciais

(trajetória $45^{\circ}$ )

parâmetros

sobre-adensados

(E $\mathrm{E}_{\text {ur e }}^{\prime} v_{\text {ur }}$ )

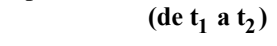

(de $t_{2}$ a $t_{3}$ )

(de $t_{3}$ a $t_{4}$ )

trajetória $0^{\circ}$
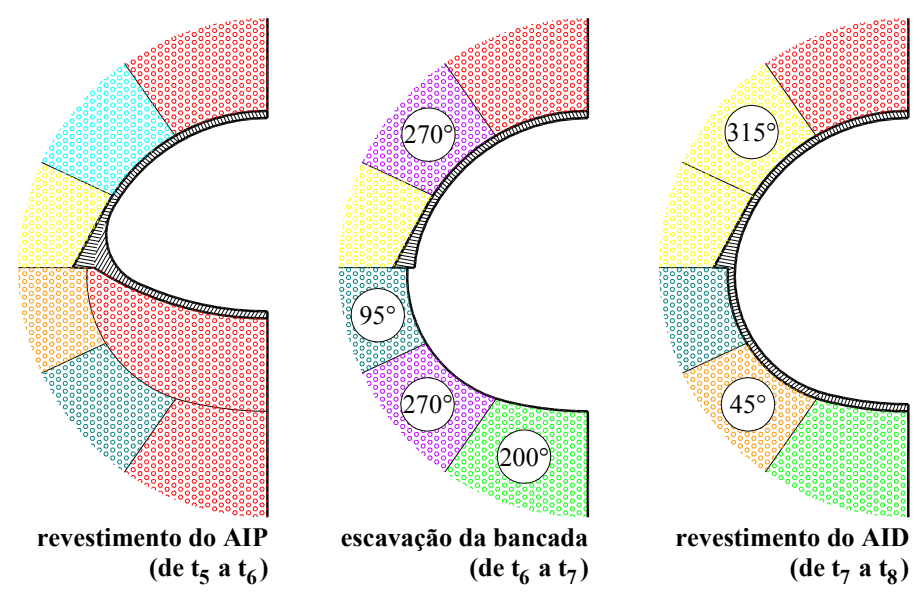

trajetória $45^{\circ}$

trajetória $95^{\circ}$

trajetória $200^{\circ}$

trajetória $210^{\circ}$

trajetória $225^{\circ}$

trajetória $270^{\circ}$

trajetória $315^{\circ}$

Figura 5.43 - Variação dos parâmetros geotécnicos com o avanço da escavação

Na Figura 5.43, cada vez que uma zona tem sua trajetória de tensões alterada, é indicado seu novo ângulo dentro de um círculo e sua respectiva nova cor é utilizada. Com o avanço da escavação, se a trajetória de tensões não é alterada, a mesma cor permanece para a zona em questão e não é utilizada a indicação do ângulo da trajetória.

\subsubsection{Calibração dos modelos constitutivos}

Os modelos constitutivos utilizados não possibilitam a utilização de envoltórias de escoamento e de ruptura no quadrante negativo do espaço de tensões (tensão desviadora negativa). Isto é devido aos cálculos serem efetuados em termos de tensões principais, resultando em invariantes de tensões sempre positivos. Portanto, os parâmetros elásticos de deformabilidade serão os únicos a serem determinados. 
O comportamento elástico foi obtido pela representação de uma reta no trecho inicial de cada ensaio, como visto na Figura 5.44. Devido à variação da tensão confinante existente em alguns ensaios, os módulos de deformabilidade (E') não puderam ser determinados diretamente pela inclinação das retas. Para determiná-los, assim como os valores dos coeficientes de Poisson para cada ensaio, foram utilizadas as equações (5.6) e (5.7).

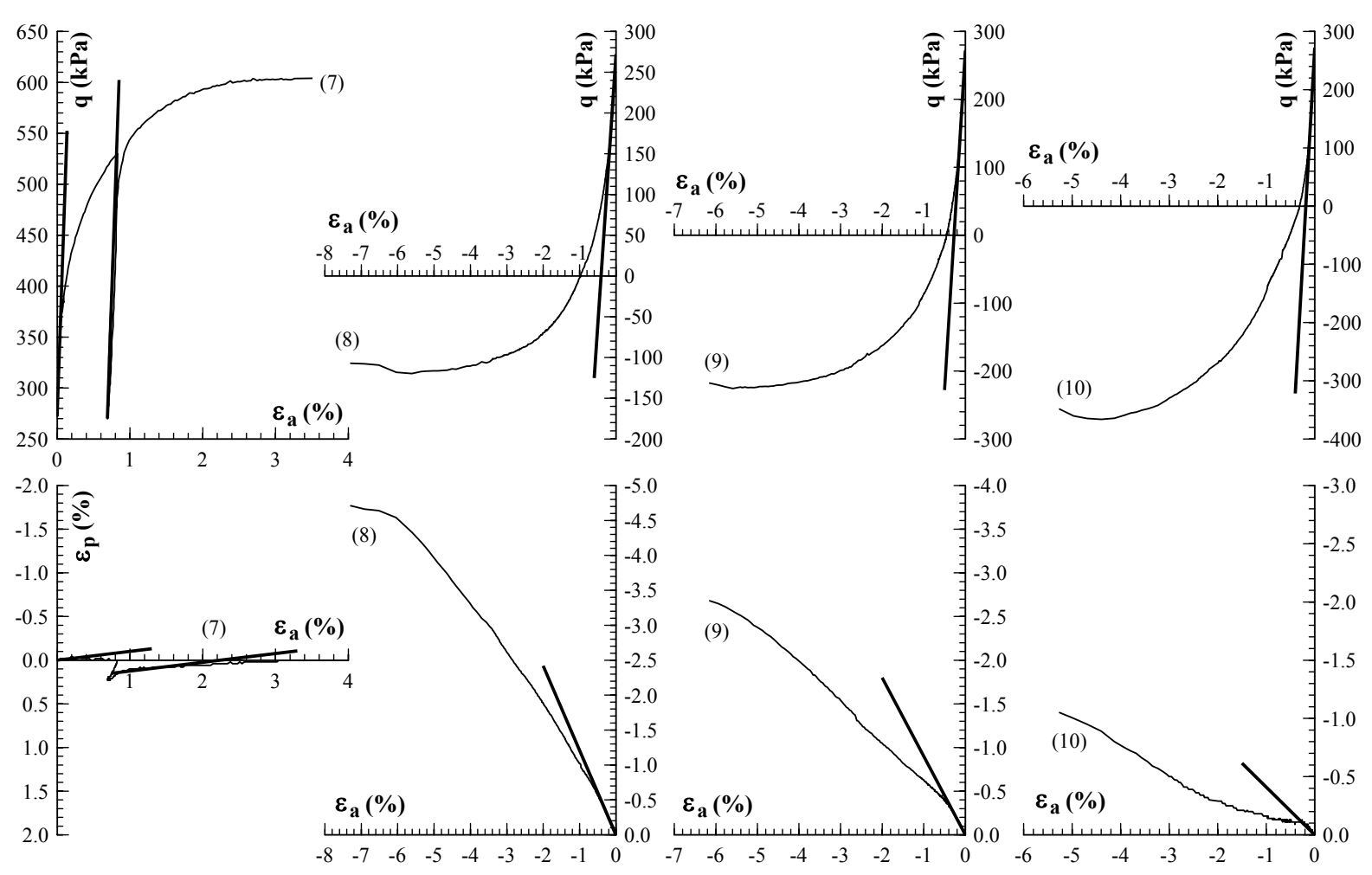

Figura 5.44 - Obtenção dos parâmetros elásticos de deformabilidade

Tendo-se em vista que não puderam ser executadas todas as trajetórias de tensões necessárias, os parâmetros para algumas trajetórias deverão ser estimados. Para tal, utilizou-se a variação dos parâmetros elásticos em função da trajetória de tensões, a qual está apresentada na Figura 5.45. A discussão desta variação dos parâmetros será realizada ao final deste capítulo.

As trajetórias de tensões estão representadas pelos ângulos que elas formam com a direção horizontal, no plano s'- t.

Para a trajetória de 45 graus (ensaio triaxial de carregamento axial), foram utilizados os valores dos parâmetros elásticos de recarregamento $E^{\prime}{ }_{u r}$ e $v^{\prime}$ ur, apresentados anteriormente na Tabela 5.2 e na Tabela 5.3. 

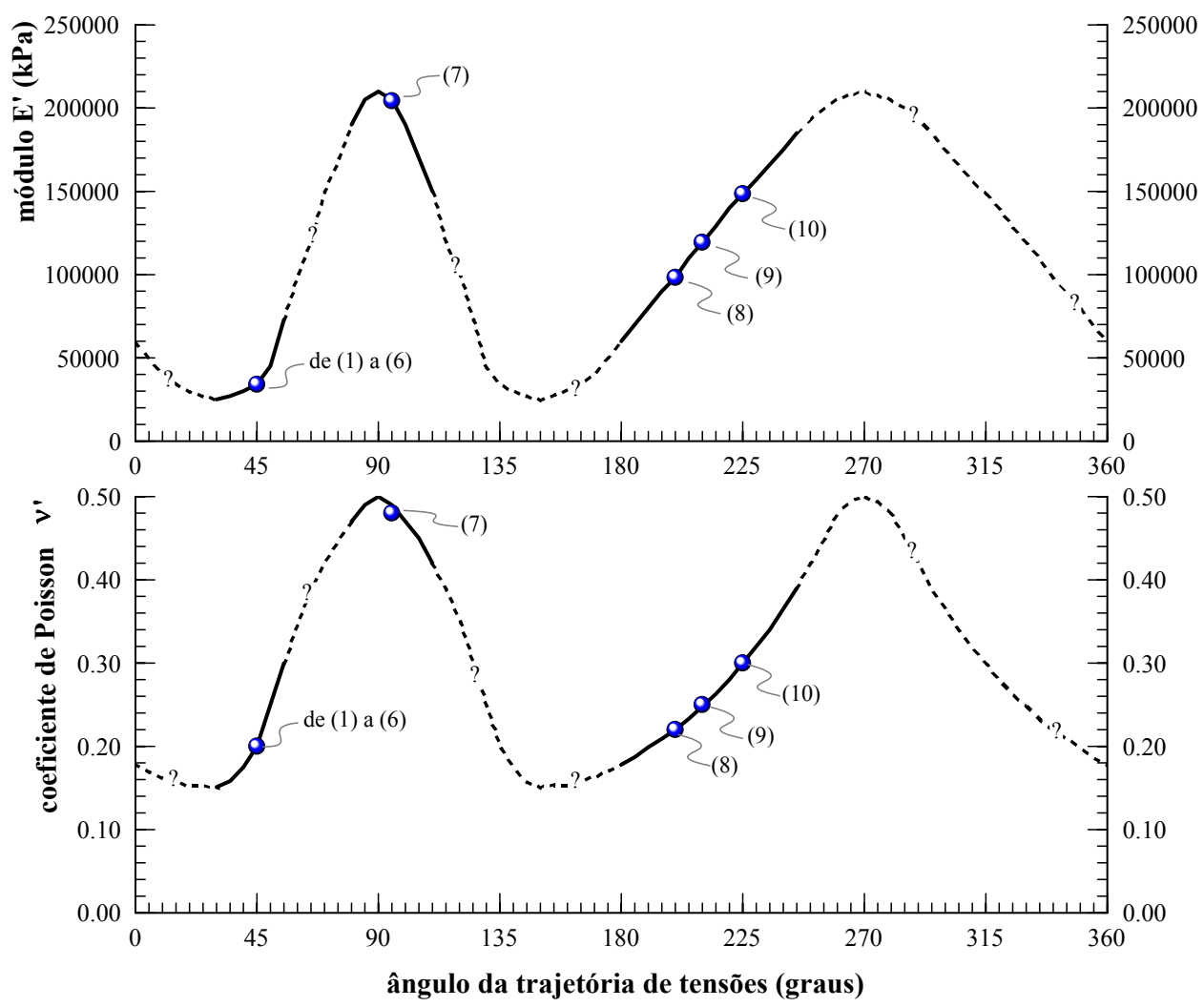

Figura 5.45 - Variação dos parâmetros elásticos em função da trajetória de tensões

Não foi determinada a variação da rigidez do solo de acordo com o nível de tensão a que ele está submetido, por não terem sido executados ensaios triaxiais de descarregamento para um nível de tensões diferente.

A Tabela 5.4 apresenta os parâmetros elásticos adotados para os três modelos constitutivos em estudo.

Tabela 5.4 - Parâmetros elásticos para os três modelos constitutivos

\begin{tabular}{c|c|c|c}
\hline ensaio & $\begin{array}{c}\text { ângulo da } \\
\text { trajetória }\end{array}$ & $\begin{array}{c}\text { Eur'} \\
(\mathrm{kPa})\end{array}$ & $\mathbf{v}^{\prime}$ \\
\hline - estimativa - & $0^{\circ}$ & 60000 & 0,18 \\
\hline $\mathrm{de}(1) \mathrm{a}(6)$ & $45^{\circ}$ & 32000 & 0,20 \\
\hline$(7)$ & $95^{\circ}$ & 204300 & 0,48 \\
\hline$(8)$ & $200^{\circ}$ & 98200 & 0,22 \\
\hline$(9)$ & $210^{\circ}$ & 119300 & 0,25 \\
\hline$(10)$ & $225^{\circ}$ & 148400 & 0,30 \\
\hline - estimativa - & $270^{\circ}$ & 210000 & 0,50 \\
\hline - estimativa - & $315^{\circ}$ & 148400 & 0,30 \\
\hline
\end{tabular}




\subsubsection{Trajetórias de tensões obtidas}

Os resultados de desenvolvimento das tensões vertical, horizontal transversal e horizontal longitudinal em função do avanço da escavação, para esta segunda etapa da modelagem, não serão apresentados com o intuito de se evitar repetições.

Para esta etapa, os resultados de alteração de tensões obtiveram o mesmo comportamento encontrado com a modelagem anterior. Para os pontos A, B e C (localizados no hemisfério superior do túnel), a frente de escavação da calota é a que mais exerce influência na alteração das tensões, sendo sentida a uma distância aproximada de 15 metros adiante e atrás da frente. Para os pontos D, E e F (localizados no hemisfério inferior do túnel), a frente de escavação da bancada é a razão principal de alteração das tensões, exercendo influência a uma distância de 5 metros adiante e atrás da frente.

Portanto, será apresentada somente a simplificação do desenvolvimento da tensão vertical e da tensão horizontal transversal, ambas utilizadas para a determinação das trajetórias de tensões dos pontos analisados.

Apesar do comportamento encontrado nesta etapa ser similar ao obtido com a modelagem anterior, os valores obtidos para as variações das tensões são diferentes, resultando em uma alteração nos ângulos das trajetórias de tensões.

A Figura 5.46 apresenta a trajetória de tensões para o ponto A, localizado no teto do túnel. Observam-se as trajetórias de 45, 200 e 220 graus.
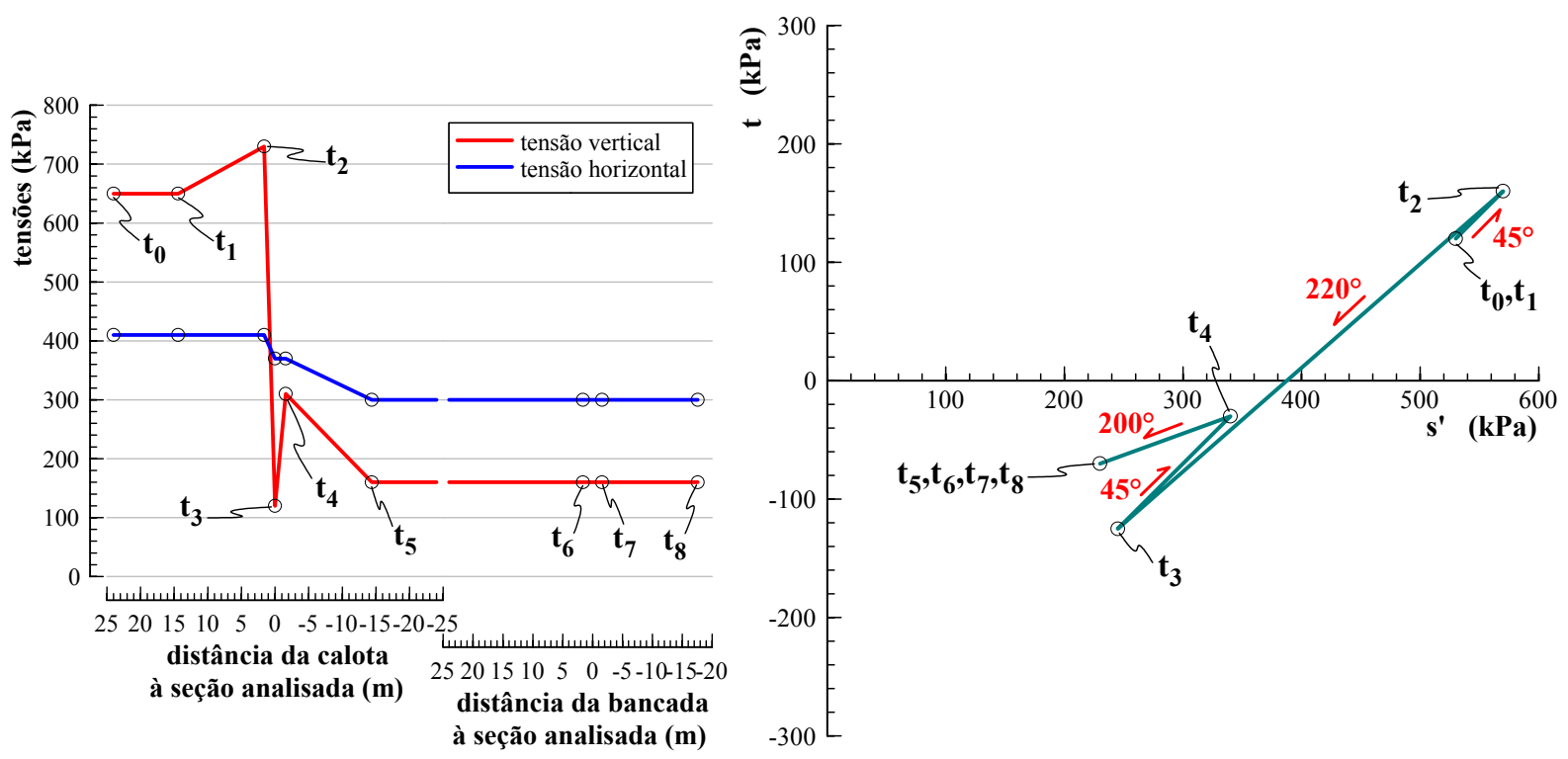

a) simplificação do desenvolvimento das tensões

(b) trajetória de tensões

Figura 5.46 - Trajetória de tensões para o ponto A, localizado no teto do túnel 
A trajetória de tensões para o ponto $\mathrm{B}$, localizado na diagonal superior do túnel, está apresentada na Figura 5.47. Observam-se as trajetórias de 0, 45, 220 e 225 graus.
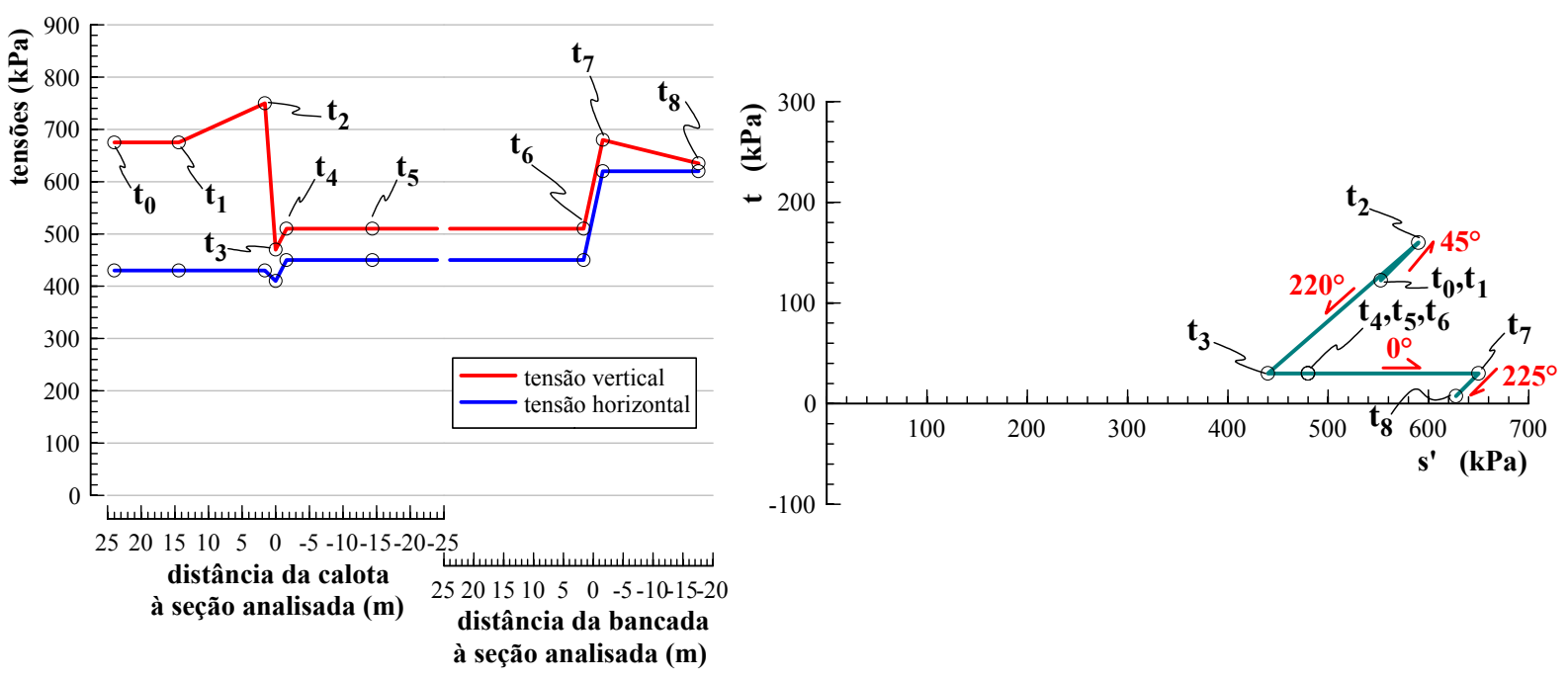

a) simplificação do desenvolvimento das tensões

(b) trajetória de tensões

Figura 5.47 - Trajetória de tensões para o ponto B, localizado na diagonal superior do túnel

A Figura 5.48 apresenta a trajetória de tensões para o ponto $\mathrm{C}$, localizado na lateral do túnel, ao nível do apoio do arco superior. Observam-se as trajetórias de 45, 65, 160 e 315 graus.
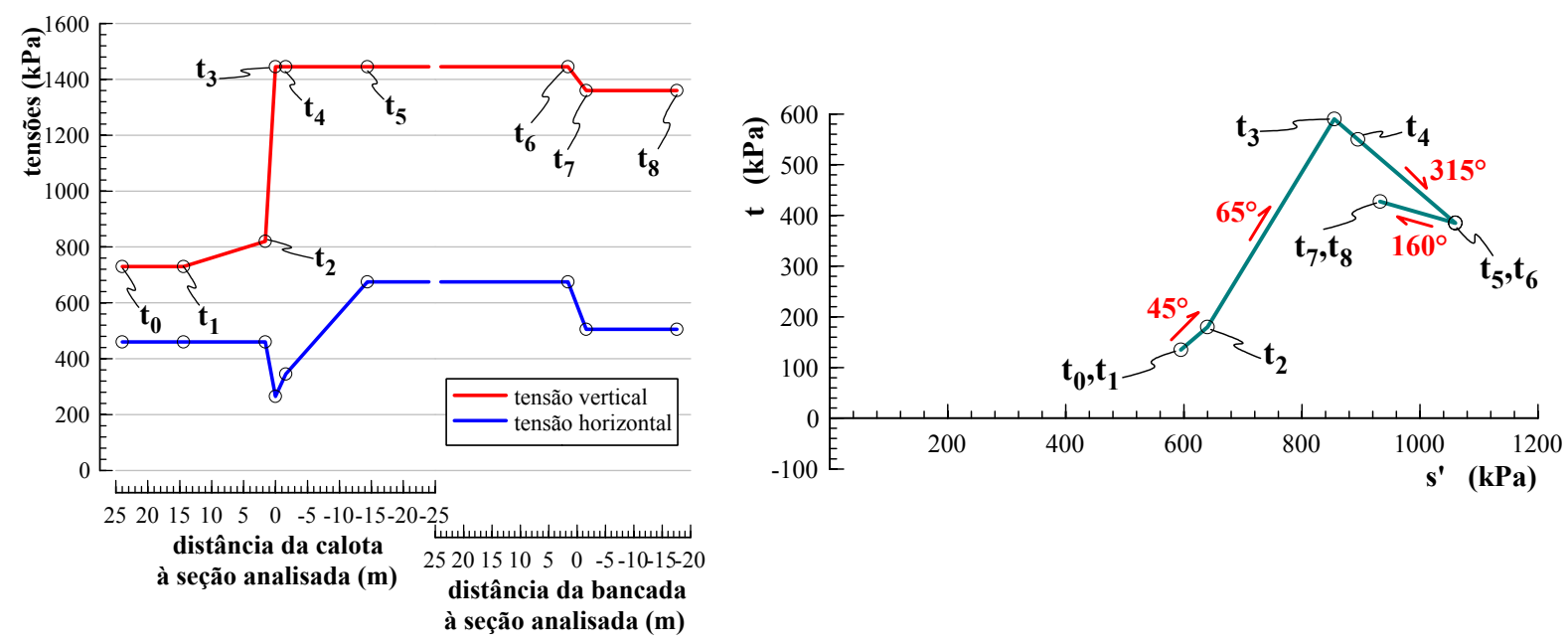

a) simplificação do desenvolvimento das tensões

(b) trajetória de tensões

Figura 5.48 - Trajetória de tensões para o ponto C, localizado na lateral do túnel (nível do apoio do arco superior) 
A trajetória de tensões para o ponto $\mathrm{D}$, localizado na lateral do túnel, ao nível do arco invertido provisório, está apresentada na Figura 5.49. Observam-se as trajetórias de 0, 45, 85 e 110 graus.

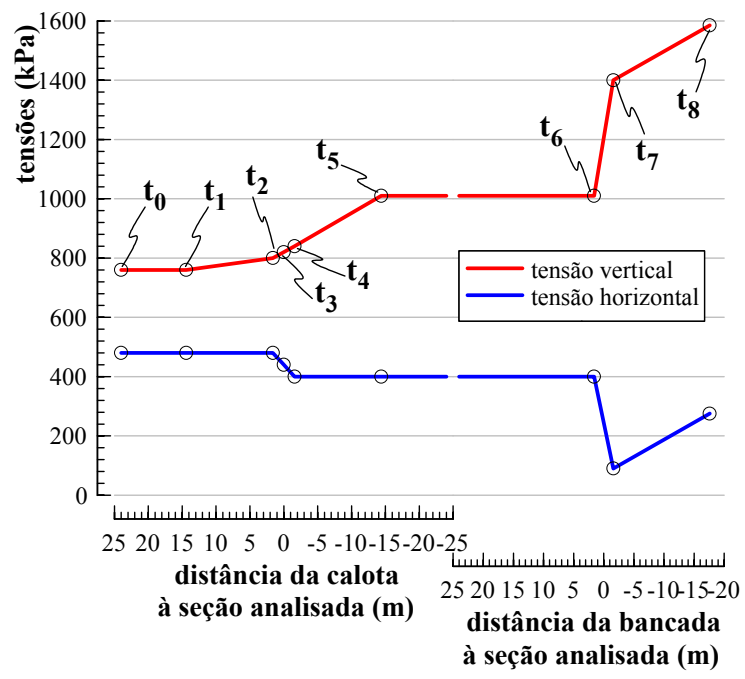

a) simplificação do desenvolvimento das tensões

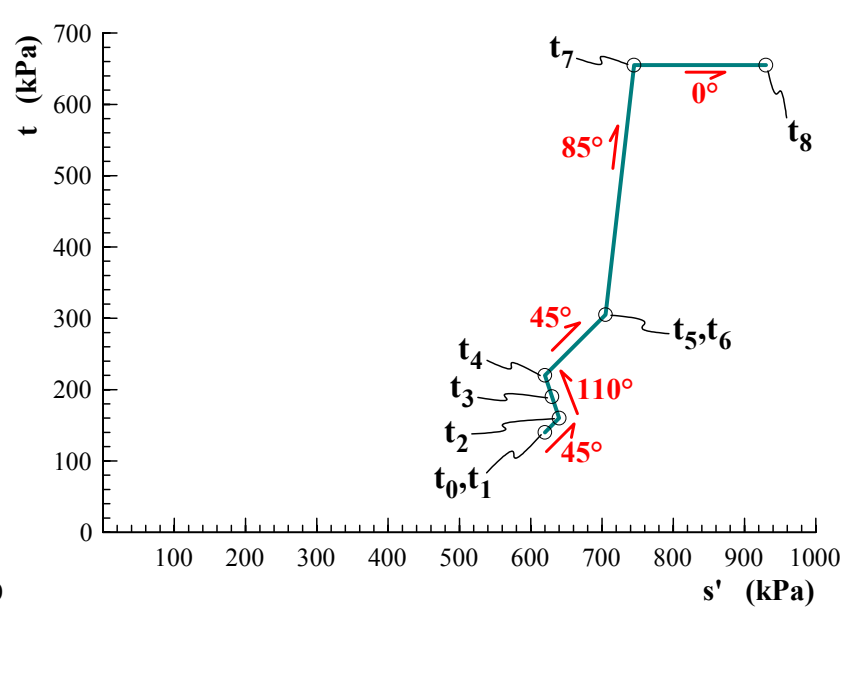

(b) trajetória de tensões

Figura 5.49 - Trajetória de tensões para o ponto D, localizado na lateral do túnel (nível do arco invertido provisório)

A Figura 5.50 apresenta a trajetória de tensões para o ponto E, localizado na diagonal inferior do túnel. Observam-se as trajetórias de 0, 45, 215 e 315 graus.

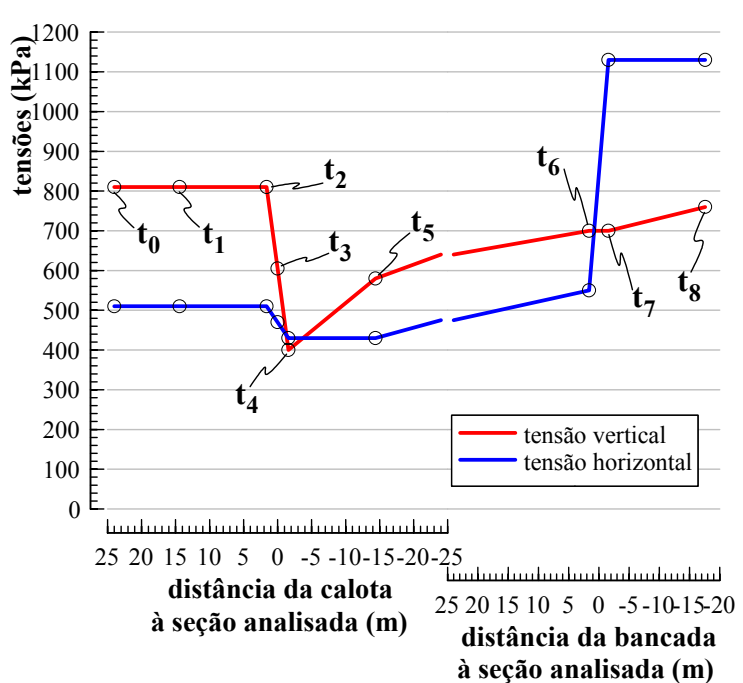

a) simplificação do desenvolvimento das tensões

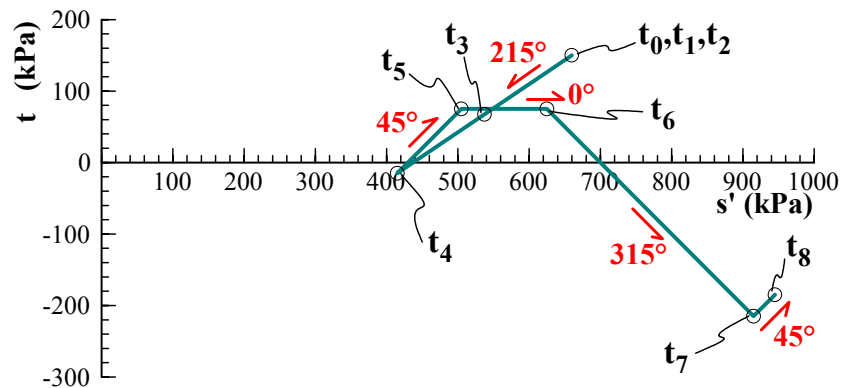

(b) trajetória de tensões

Figura 5.50 - Trajetória de tensões para o ponto E, localizado na diagonal inferior do túnel 
A trajetória de tensões para o ponto $\mathrm{F}$, localizado no piso do túnel, está apresentada na Figura 5.51. Observam-se as trajetórias de 180, 220 e 250 graus.

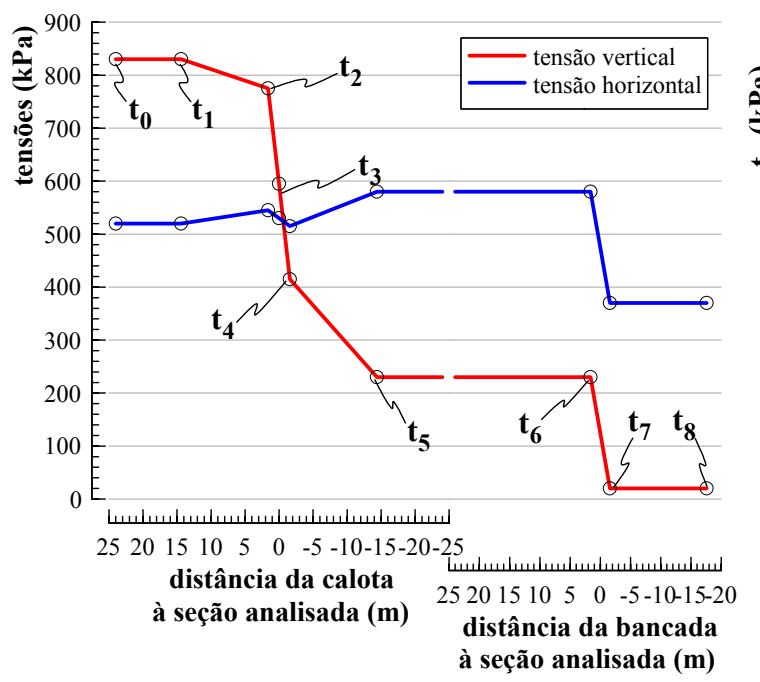

a) simplificação do desenvolvimento das tensões

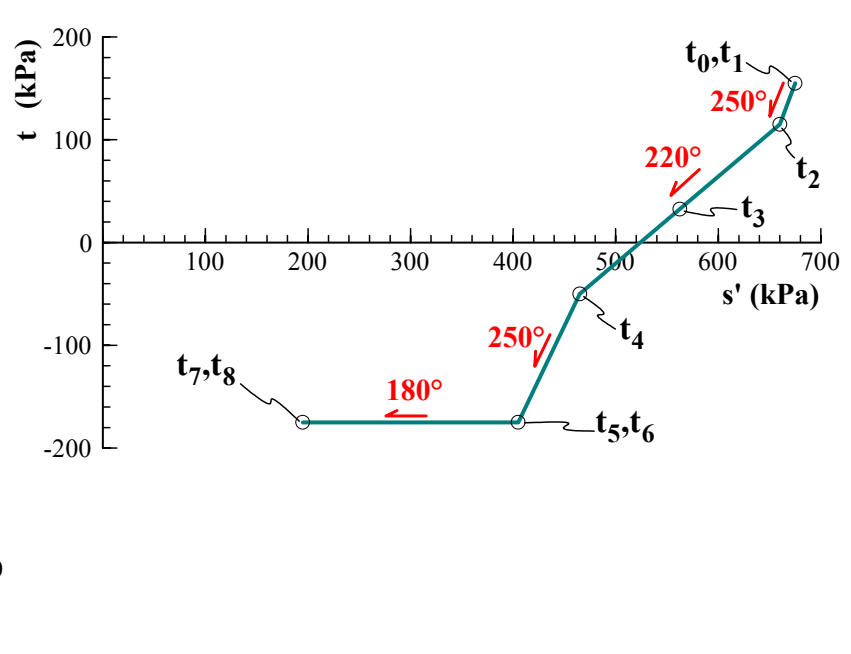

(b) trajetória de tensões

Figura 5.51 - Trajetória de tensões para o ponto F, localizado no piso do túnel

Uma síntese de todas as direções encontradas para as trajetórias de tensões encontra-se na Figura 5.41, obtidas com a segunda etapa da modelagem numérica, resultando em doze ângulos diferentes: $0^{\circ}, 45^{\circ}, 65^{\circ}, 85^{\circ}, 110^{\circ}, 160^{\circ}, 200^{\circ}, 215^{\circ}, 220^{\circ}, 225^{\circ}, 250^{\circ}$ e $315^{\circ}$.

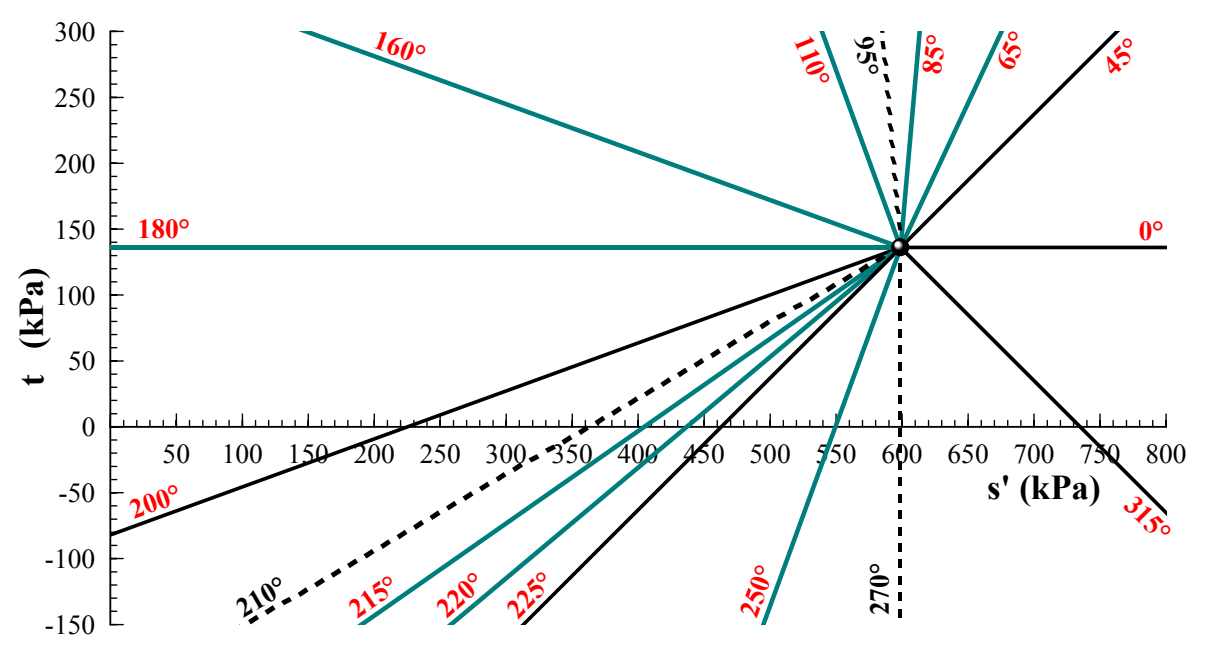

Figura 5.52 - Síntese das trajetórias de tensões obtidas

As trajetórias de $95^{\circ}, 210^{\circ}$ e $270^{\circ}$, obtidas com a primeira etapa da modelagem, deixaram de ser necessárias nesta etapa. As trajetórias de $0^{\circ}, 45^{\circ}, 200^{\circ}, 225^{\circ}$ e $315^{\circ}$ já haviam sido obtidas na modelagem anterior e se repetiram para esta segunda etapa. 


\subsection{Resultados Para as DUAS Etapas da Modelagem}

Ao término das duas etapas da modelagem numérica, seus resultados podem ser comparados entre si. Serão aqui apresentados resultados referentes a deslocamentos, especificamente quanto à bacia de subsidência, a uma prumada vertical ao lado do túnel e a alguns pontos do revestimento primário do túnel.

\subsubsection{Deslocamentos superficiais}

Primeiramente, serão analisados os recalques obtidos no sentido longitudinal do túnel, em um plano vertical contendo seu eixo de simetria. A Figura 5.53 apresenta os resultados para a primeira etapa da modelagem numérica e a Figura 5.54 para a segunda etapa.

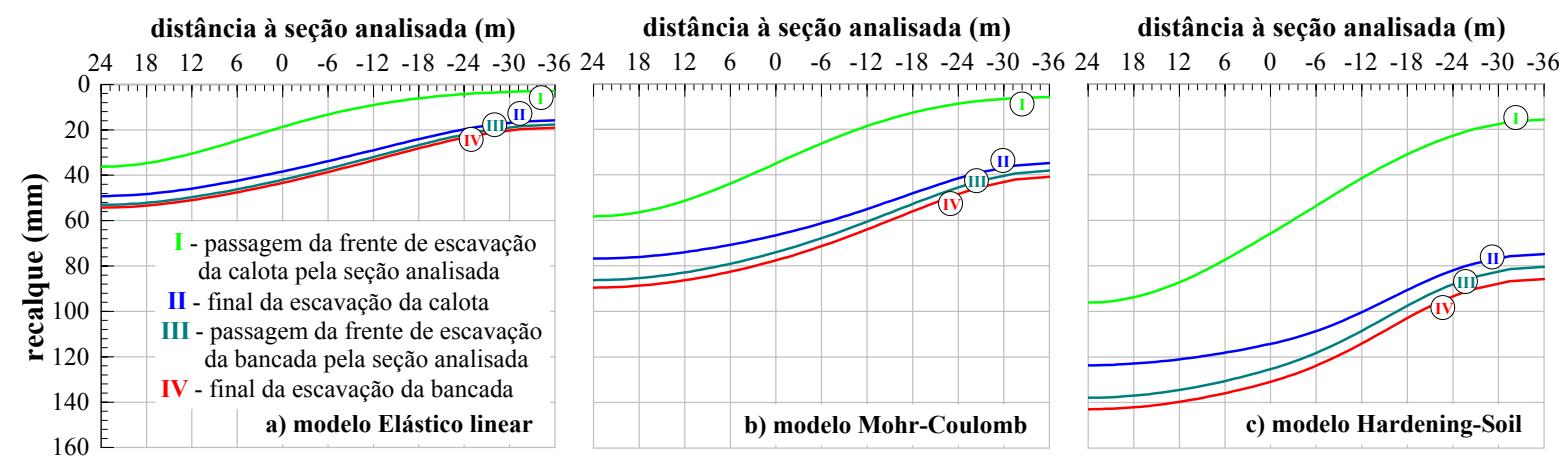

Figura 5.53 - Desenvolvimento dos recalques superficiais no plano vertical longitudinal de simetria do túnel (maciço mecanicamente homogêneo)

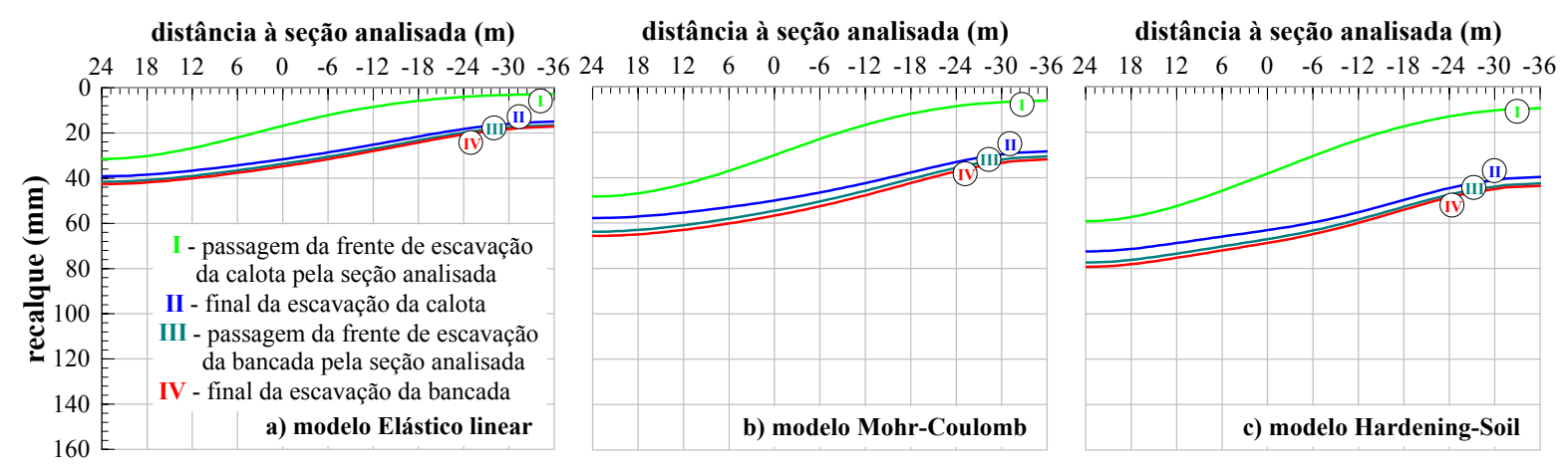

Figura 5.54 - Desenvolvimento dos recalques superficiais no plano vertical longitudinal de simetria do túnel (maciço mecanicamente heterogêneo) 
Como é possível observar na Figura 5.53, os recalques para a primeira etapa da modelagem numérica possuem maior ordem de grandeza quando obtidos com o modelo Hardening-Soil, o que é explicado pela possibilidade de plastificação do maciço anteriormente à ruptura. $\mathrm{O}$ modelo Mohr-Coulomb resultou em recalques menores, tendo-se em vista que a plastificação do maciço ocorre apenas ao ser atingida a ruptura. $\mathrm{O}$ modelo Elástico linear apresentou os recalques com menor ordem de grandeza, justamente por não apresentar plastificação.

Ao se comparar os resultados da primeira etapa com a segunda, nota-se que permanece o mesmo comportamento de maiores recalques para o modelo Hardening-Soil e de menores para o modelo Elástico linear. Entretanto, para os três modelos, os resultados obtidos com a segunda modelagem são menores em relação aos obtidos com a primeira. Isto é devido ao aumento de rigidez do maciço envolvente à escavação, ao serem utilizadas zonas com maiores valores de módulo de deformabilidade.

Outra observação a ser feita diz respeito à localização das fronteiras verticais longitudinais da malha de elementos finitos. Ao ser escavada a calota do túnel na seção analisada, recalques ocorrem na fronteira longitudinal do final do modelo (distância de $-36 \mathrm{~m}$ ). A fronteira deveria ser localizada mais distante da seção analisada, onde não haja alteração de tensões e, conseqüentemente, os recalques sejam nulos.

Os resultados obtidos para os três modelos e para as duas etapas da modelagem demonstram que a escavação da bancada do túnel não representa aumentos significativos dos os recalques superficiais.

Para todos os resultados referentes à escavação da calota, é possível avaliar que o ponto de inflexão das curvas, onde ocorre a maior distorção angular, encontra-se alinhado com a frente de escavação (na posição de $0 \mathrm{~m}$ com a passagem da frente pela seção analisada e na posição de $-24 \mathrm{~m}$ ao final da escavação da calota). Quanto à bancada, esta análise não pode ser efetuada tendo-se em vista que o perfil dos recalques não é horizontal quando é iniciada sua escavação.

Ao final da escavação da calota, nota-se a formação de um patamar de estabilização dos recalques a uma distância aproximada de $18 \mathrm{~m}$ da seção analisada, para os três modelos e para as duas etapas da modelagem. Isto indica que a escavação deveria prosseguir por mais $18 \mathrm{~m}$ para que a seção analisada pudesse ser estabilizada (aumento de $18 \mathrm{~m}$ na distância da fronteira longitudinal). 
Pelo fato deste comportamento de estabilização dos recalques a uma distancia de $18 \mathrm{~m}$ não ter sido alterado da primeira para a segunda modelagem, é possível afirmar que a influência da frente de escavação depende principalmente da redistribuição das tensões no maciço (parâmetros de plastificação e de ruptura), e não do aumento da rigidez.

Tendo-se em vista este patamar de estabilização não ter sido alcançado pela seção analisada, os perfis transversais de recalques apresentados na Figura 5.55 e na Figura 5.56 são referentes a uma seção localizada a $18 \mathrm{~m}$ da seção analisada.

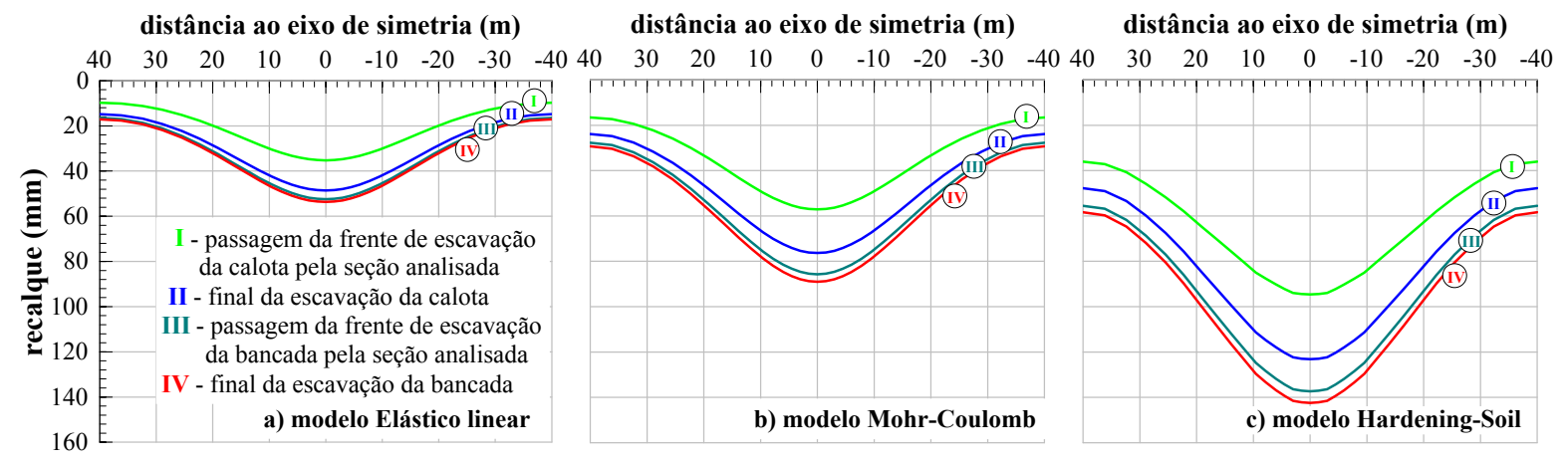

Figura 5.55 - Recalques superficiais no plano vertical transversal à $18 \mathrm{~m}$ da seção analisada (maciço mecanicamente homogêneo)

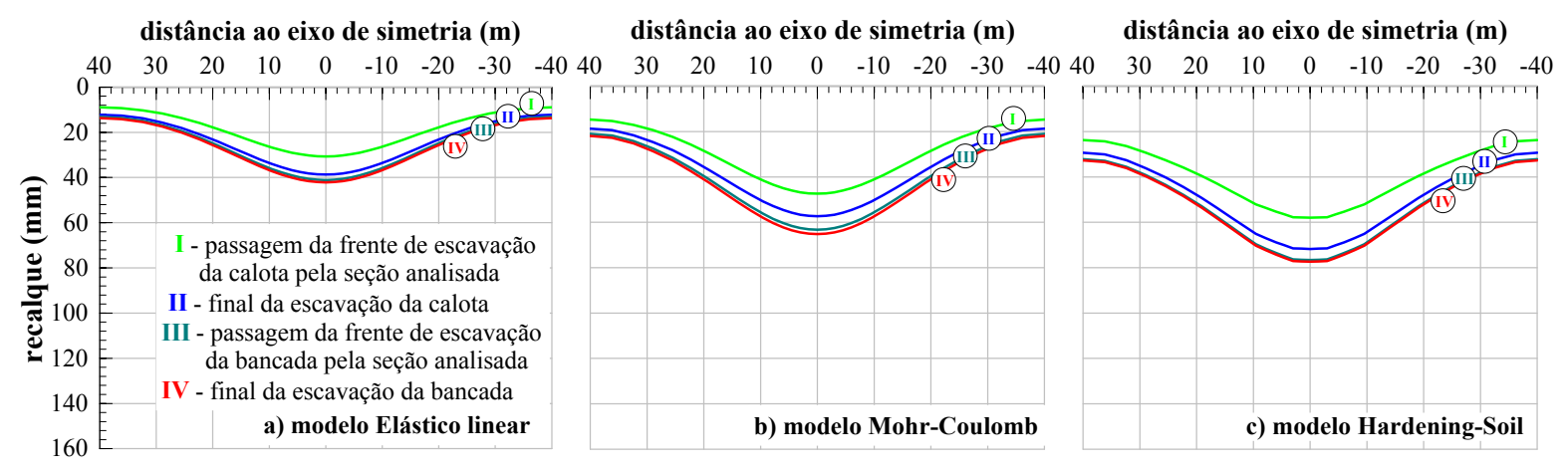

Figura 5.56 - Recalques superficiais no plano vertical transversal à $18 \mathrm{~m}$ da seção analisada (maciço mecanicamente heterogêneo)

Todos os recalques máximos no plano vertical transversal, localizados no eixo de simetria do túnel, são correspondentes ao recalques apresentados anteriormente para o plano vertical longitudinal.

Como é possível observar, os três modelos apresentam recalque nas fronteiras laterais, para as duas etapas da modelagem. Como discutido anteriormente durante a concepção da malha de elementos finitos, as fronteiras laterais deveriam ser localizadas mais distantes do eixo de simetria. 
Nota-se que o ponto de inflexão das curvas localiza-se a uma distância aproximada de $20 \mathrm{~m}$ do eixo de simetria do túnel, o que significa estar localizado na metade da largura da malha de elementos finitos. Com o afastamento da fronteira lateral, o ponto de inflexão das curvas se afastaria do eixo de simetria do túnel.

A Figura 5.57 apresenta os deslocamentos horizontais na superfície para a primeira etapa da modelagem, e a Figura 5.58 apresenta os resultados para a segunda etapa.
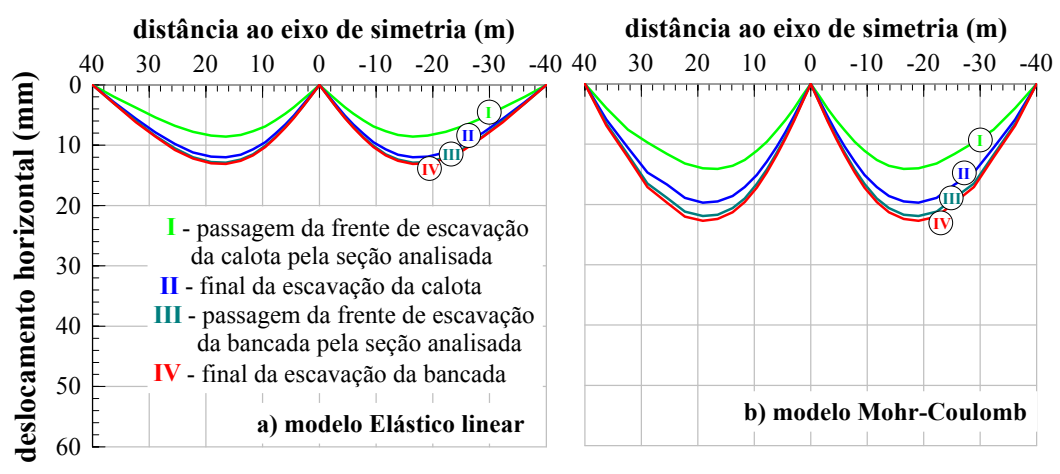

distância ao eixo de simetria (m)

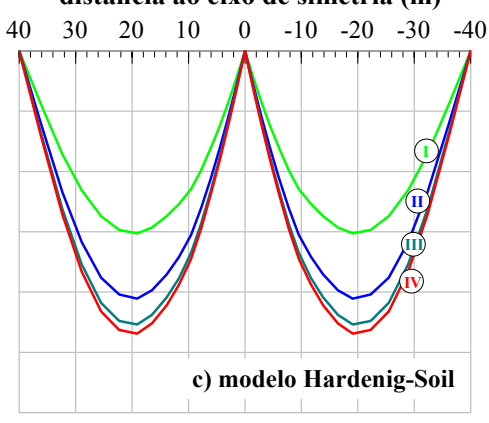

Figura 5.57 - Deslocamentos horizontais superficiais no plano vertical transversal (maciço mecanicamente homogêneo)

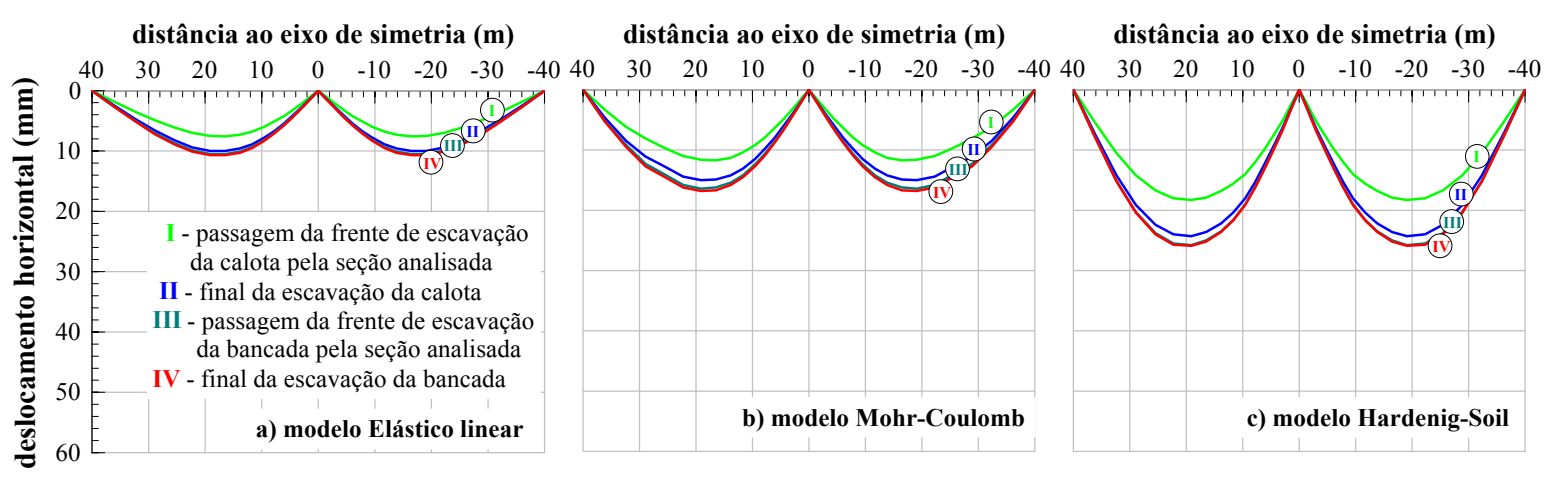

Figura 5.58 - Deslocamentos horizontais superficiais no plano vertical transversal (maciço mecanicamente heterogêneo)

Todos os resultados apresentam deslocamento horizontal nulo no eixo de simetria do túnel. É importante salientar que o valor positivo do deslocamento, obtido em todos os resultados, significa um movimento em direção ao eixo de simetria.

É possível notar que, para os três modelos constitutivos e para as duas etapas da modelagem, os valores de máximo deslocamento horizontal encontram-se a uma distância aproximada de $20 \mathrm{~m}$ do eixo de simetria, coincidente com o ponto de inflexão das curvas no plano vertical transversal. 
Para os deslocamentos horizontais, novamente é encontrado o comportamento de maiores valores para o modelo Hardening-Soil e de menores para o modelo Elástico linear, assim como a redução da ordem de grandeza dos deslocamentos na segunda etapa da modelagem.

\subsubsection{Deslocamentos em função da profundidade}

Os deslocamentos em função da profundidade serão analisados em duas prumadas, a primeira localizada a $6 \mathrm{~m}$ do eixo de simetria, aproximadamente a $1 \mathrm{~m}$ do lado do túnel, e a segunda localizada no eixo de simetria da seção transversal. Estes dois eixos verticais encontram-se a $18 \mathrm{~m}$ da seção transversal analisada, onde ocorre o patamar de estabilização dos recalques superficiais.

Todos os valores de deslocamentos verticais e horizontais, ao nível da superfície, são correspondentes aos valores apresentados anteriormente nos planos verticais longitudinal e transversal.

Para o caso dos deslocamentos verticais, o eixo vertical seria similar a extensômetros instalados em campo, sendo que os valores positivos significam movimentos concordantes com o sentido da gravidade. Para o caso dos deslocamentos horizontais, o eixo vertical representaria um inclinômetro instalado em campo, sendo que os valores positivos significam movimentos no sentido do eixo de simetria (em direção à abertura do túnel).

A Figura 5.59 apresenta os deslocamentos verticais no eixo de simetria para a primeira etapa da modelagem e a Figura 5.60 os deslocamentos verticais para a segunda etapa.

Observa-se que os deslocamentos verticais crescem com a profundidade na região acima do túnel, ou seja, o coroamento do túnel apresenta maiores valores de recalque e estes são dissipados até a superfície. Em ambas as etapas da modelagem, os deslocamentos acima do túnel são novamente maiores para o modelo Hardening-Soil e menores para o modelo Elástico linear.

Quanto à região abaixo do túnel, pode-se perceber que há um levantamento de fundo (extensão do solo), originado pelo descarregamento vertical causado pela escavação. Nota-se que o valor de deslocamento obtido no arco invertido provisório é o mesmo valor obtido no arco invertido definitivo após a escavação da bancada. Para esta região, entretanto, os valores obtidos para os três modelos são da mesma ordem de grandeza. 

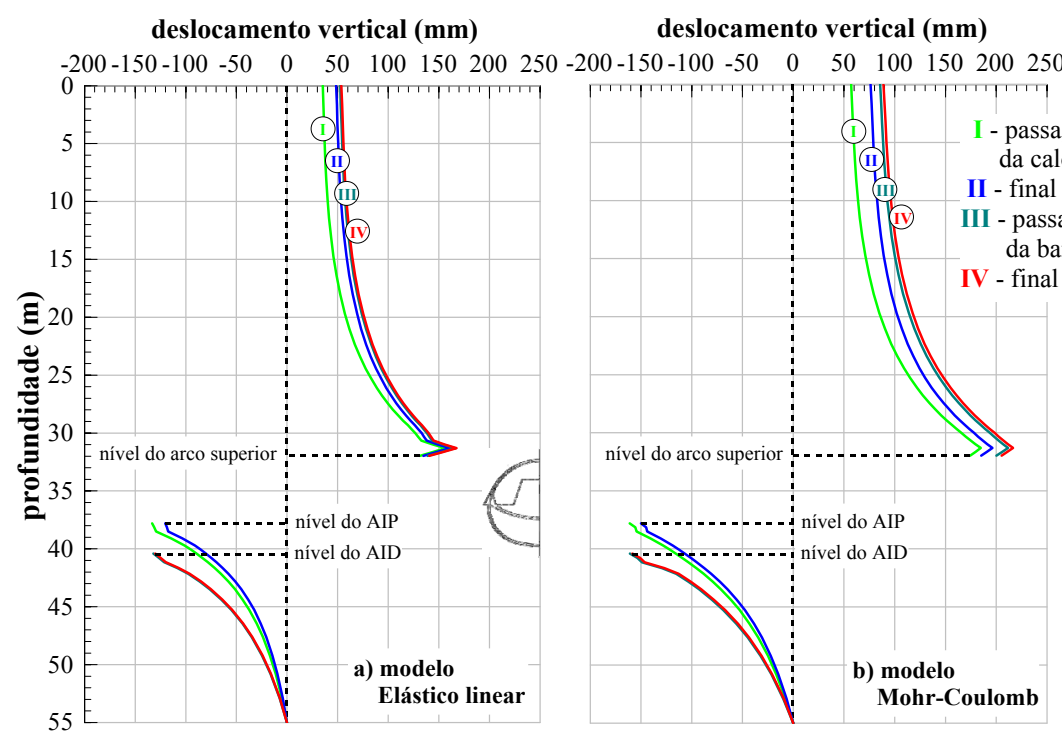

deslocamento vertical $(\mathrm{mm})$

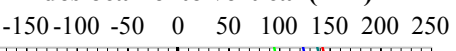

Figura 5.59 - Deslocamentos verticais em um eixo vertical localizado no plano de simetria do túnel (maciço mecanicamente homogêneo)

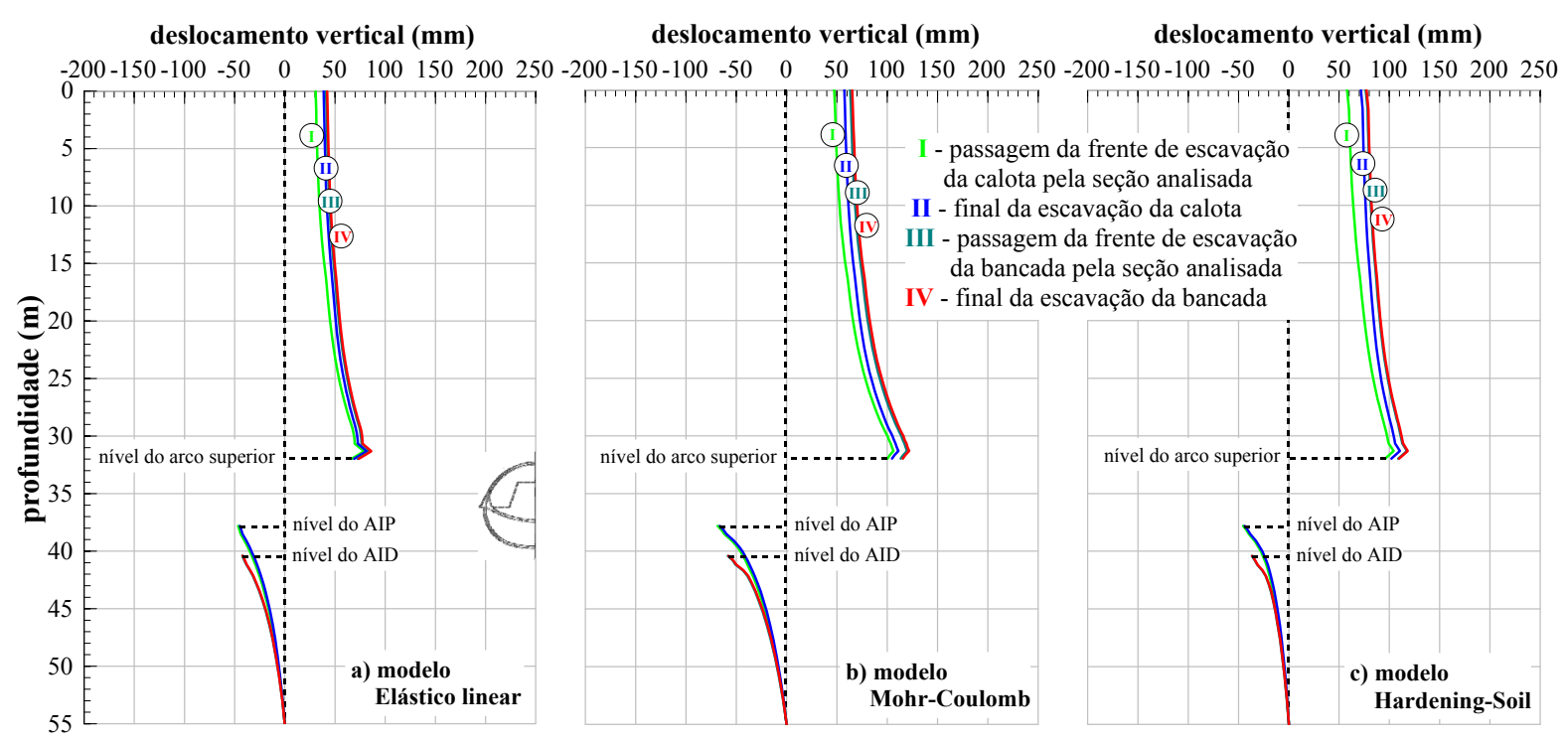

deslocamento vertical ( $\mathrm{mm})$

deslocamento vertical $(\mathrm{mm})$

Figura 5.60 - Deslocamentos verticais em um eixo vertical localizado no plano de simetria do túnel (maciço mecanicamente heterogêneo)

A Figura 5.61 apresenta os deslocamentos verticais ao lado do túnel para a primeira etapa da modelagem e a Figura 5.62 os deslocamentos verticais para a segunda etapa.

É possível observar como a região ao lado do túnel encontra-se comprimida, devido ao arqueamento transversal das tensões, enquanto que ao nível do piso do túnel o sentido dos deslocamentos se inverte e estes passam a representar uma extensão ocasionada pelo descarregamento do solo. 


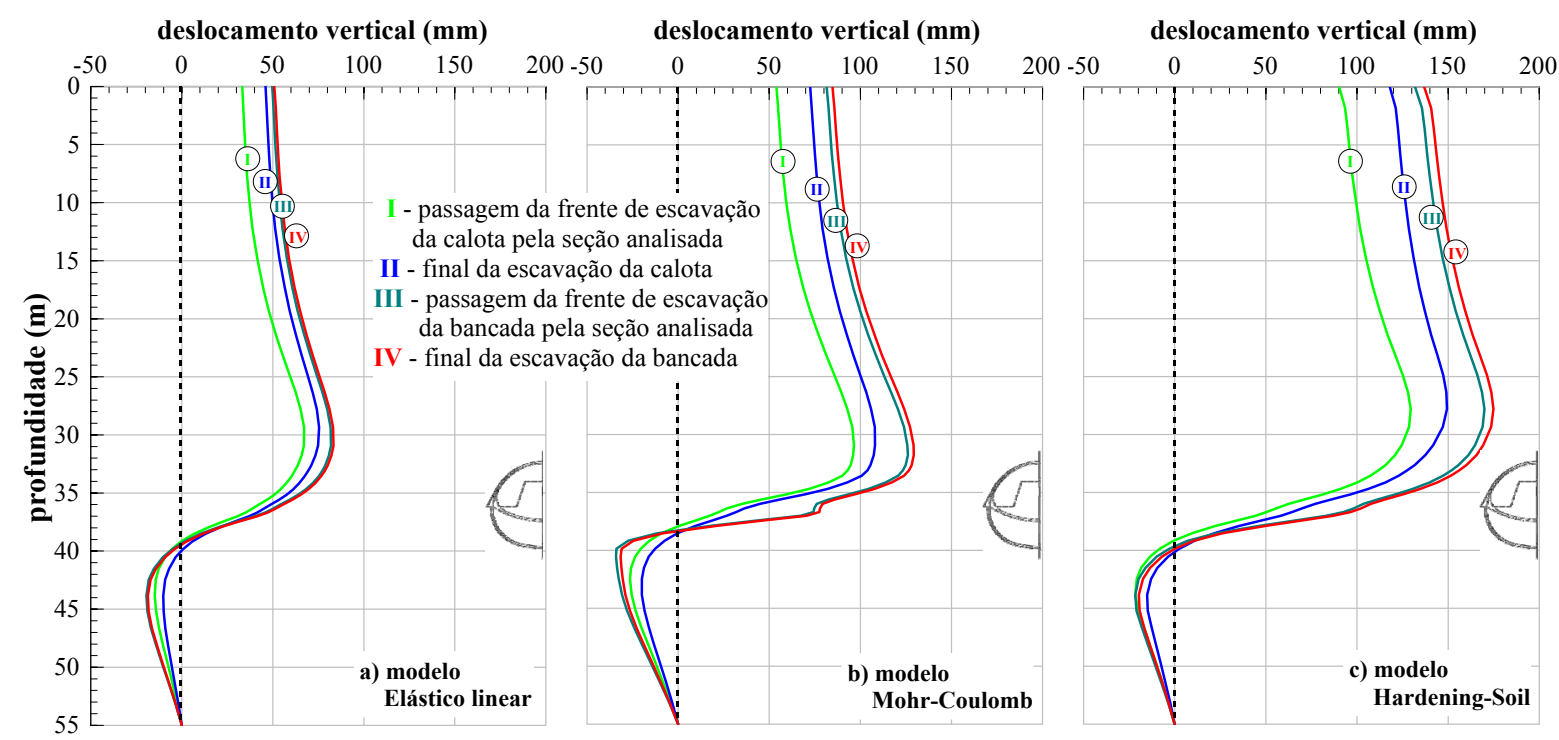

Figura 5.61 - Deslocamentos verticais em um eixo vertical localizado a 1m do lado do túnel (maciço mecanicamente homogêneo)

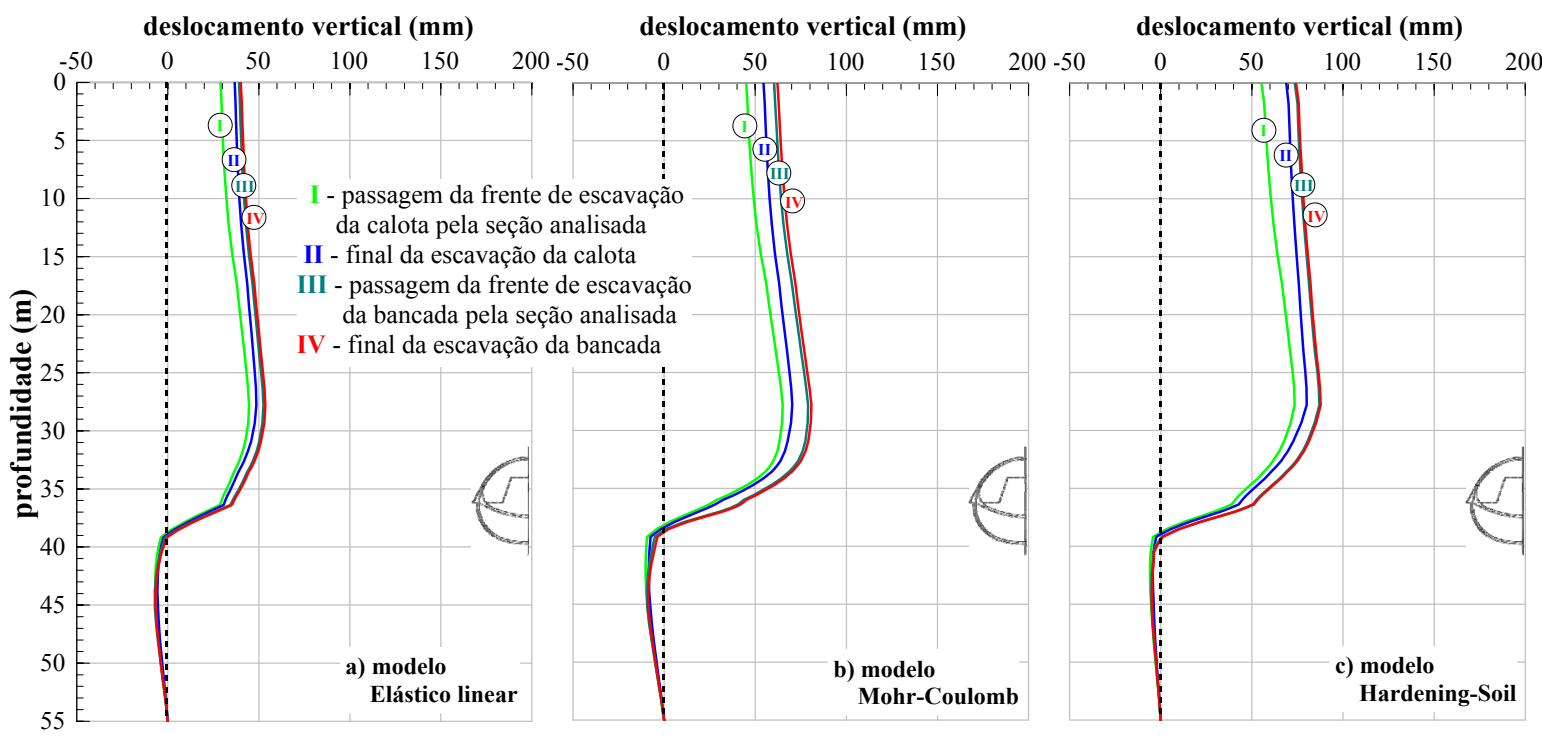

Figura 5.62 - Deslocamentos verticais em um eixo vertical localizado a $1 \mathrm{~m}$ do lado do túnel (maciço mecanicamente heterogêneo)

$\mathrm{Na}$ prumada localizada ao lado do túnel também se percebe um aumento dos deslocamentos com a profundidade, para níveis acima do túnel. Para a segunda modelagem, a alteração dos deslocamentos com a profundidade não é significativa.

A Figura 5.63 apresenta os deslocamentos horizontais de uma prumada ao lado do túnel, para a primeira etapa da modelagem, e a Figura 5.64 apresenta os deslocamentos horizontais para a segunda etapa. 


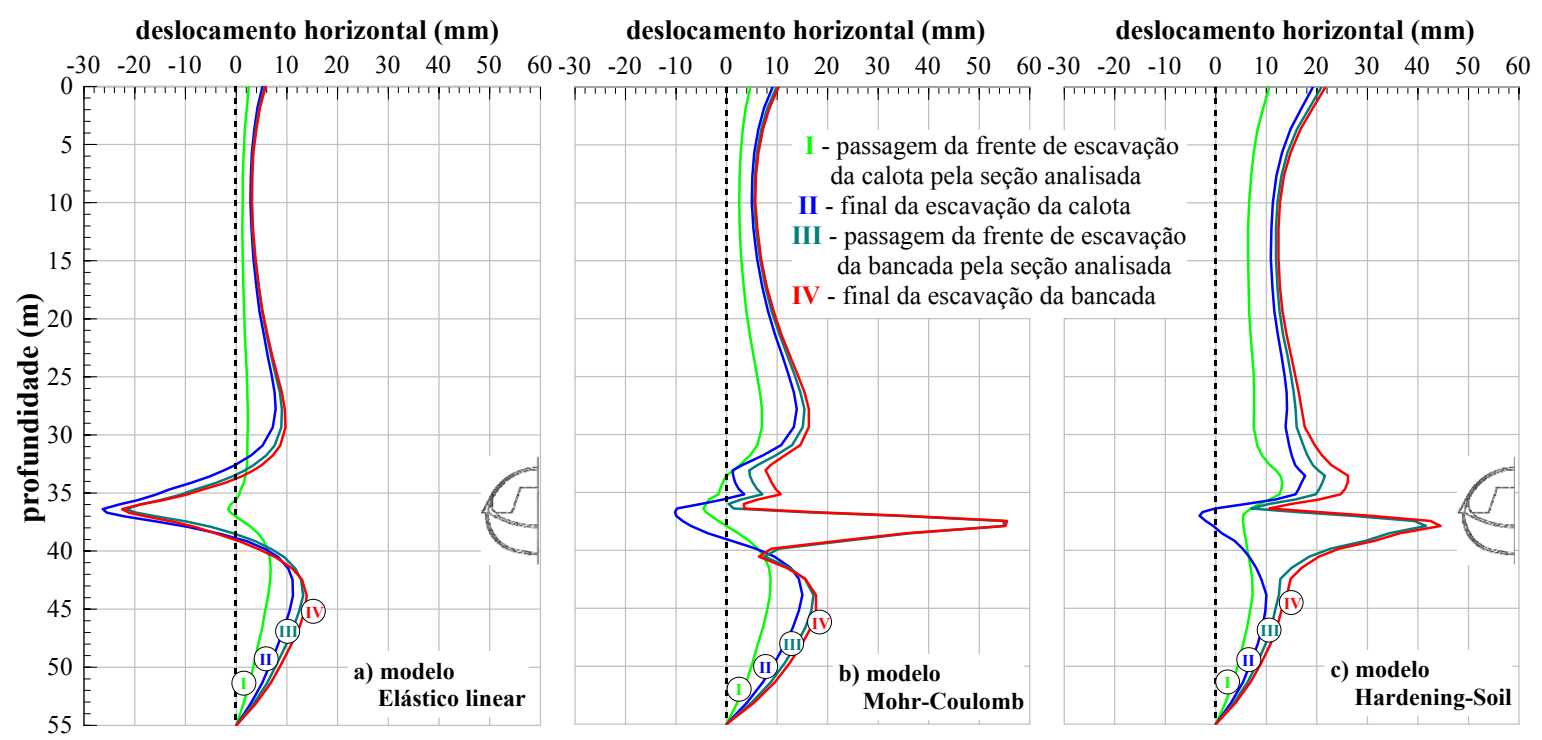

Figura 5.63 - Deslocamentos horizontais transversais em um eixo vertical localizado a $1 \mathrm{~m}$ do lado do túnel (maciço mecanicamente homogêneo)

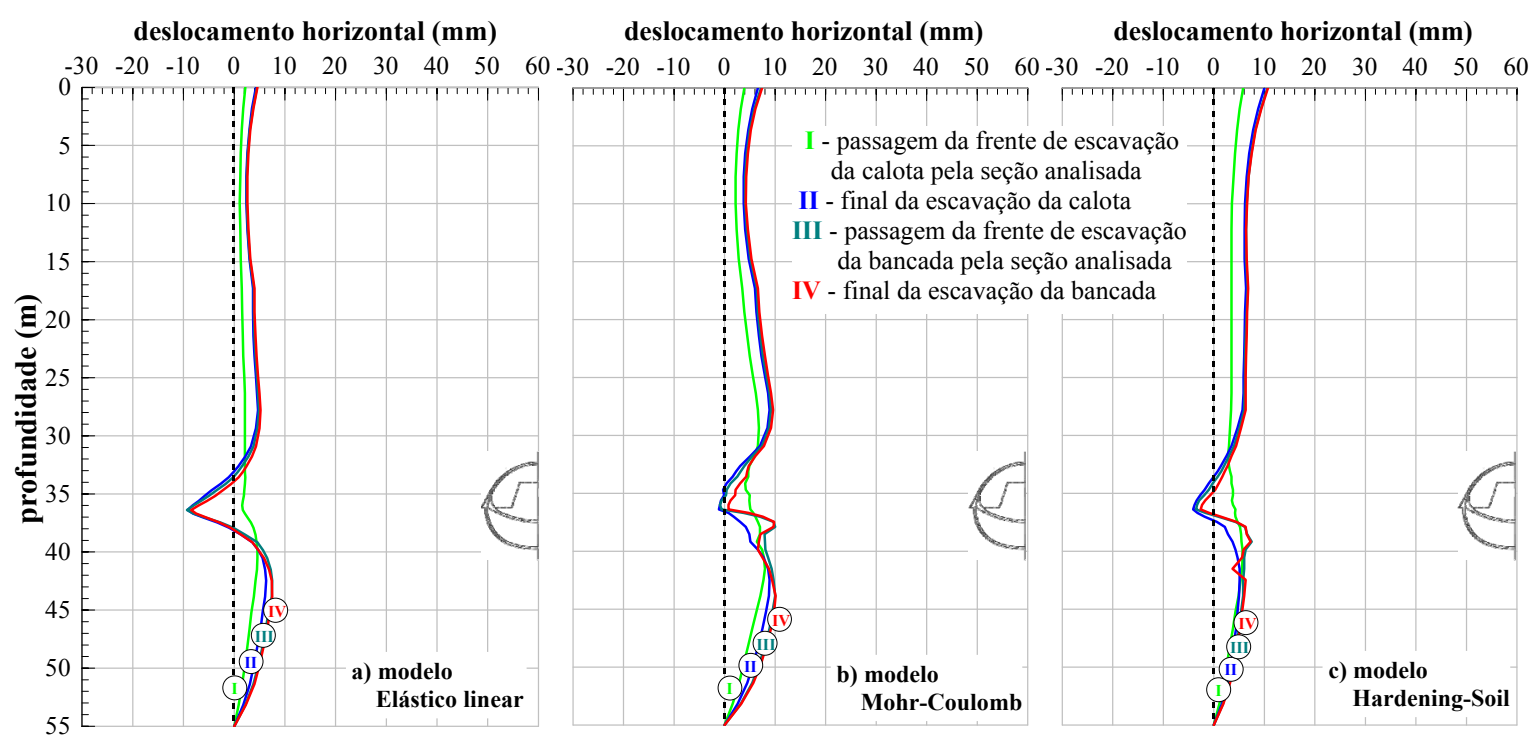

Figura 5.64 - Deslocamentos horizontais transversais em um eixo vertical localizado a $1 \mathrm{~m}$ do lado do túnel (maciço mecanicamente heterogêneo)

É possível notar que a escavação da calota estabelece uma divergência ao lado do túnel (deslocamento para fora do túnel). Após a escavação da bancada, os resultados obtidos com os modelos elasto-plásticos apresentam uma convergência (deslocamento em direção à abertura do túnel), devida à plastificação ocorrida.

Nos níveis acima do túnel, os deslocamentos assumem maiores valores na superfície e no coroamento do túnel. 
Nos níveis abaixo do túnel, os deslocamentos são bruscamente zerados na fronteira inferior da malha, não sendo suavemente estabilizados a menores profundidades. Isto indica que a fronteira deveria estar localizada a maiores profundidades.

\subsubsection{Deslocamentos no revestimento primário do túnel}

Para a análise dos deslocamentos da estrutura do túnel, alguns pontos característicos foram analisados, apresentados na Figura 5.65, representando três pinos de recalque e um tassômetro instalados em campo. Apesar de o tassômetro indicar a movimentação do maciço acima do teto do túnel, ele foi incluído nesta análise para uma melhor compreensão dos demais resultados. As cordas para medida de convergência e divergência foram tomadas como a distância entre os pinos de recalque.

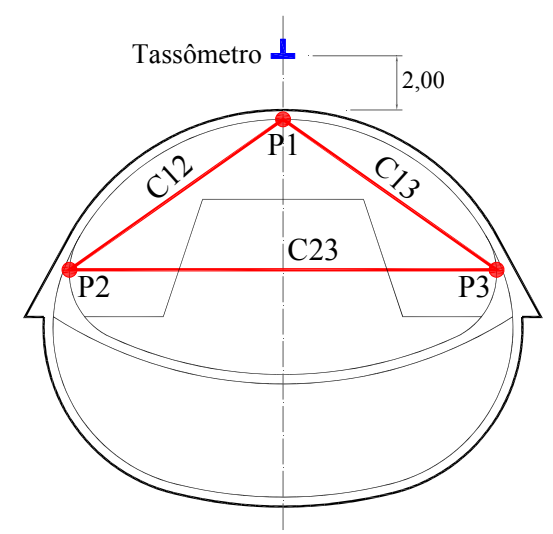

Figura 5.65 - Tassômetro, Pinos e Cordas adotados para a análise

A Figura 5.66 apresenta os deslocamentos verticais dos pinos e do tassômetro em função do avanço da frente de escavação, assim como a alteração das cordas de convergência, para a primeira etapa da modelagem. A Figura 5.67 apresenta o desenvolvimento dos deslocamentos e divergência para a segunda etapa da modelagem.

Os recalques dos pinos e as convergências das cordas apresentam valores somente após a passagem da frente de escavação, momento no qual se torna possível sua leitura. $\mathrm{O}$ início dos resultados de convergência da corda inferior é defasado de 4,80m devido ao obstáculo físico que o núcleo da calota representa, impossibilitando leituras antes de sua escavação. 

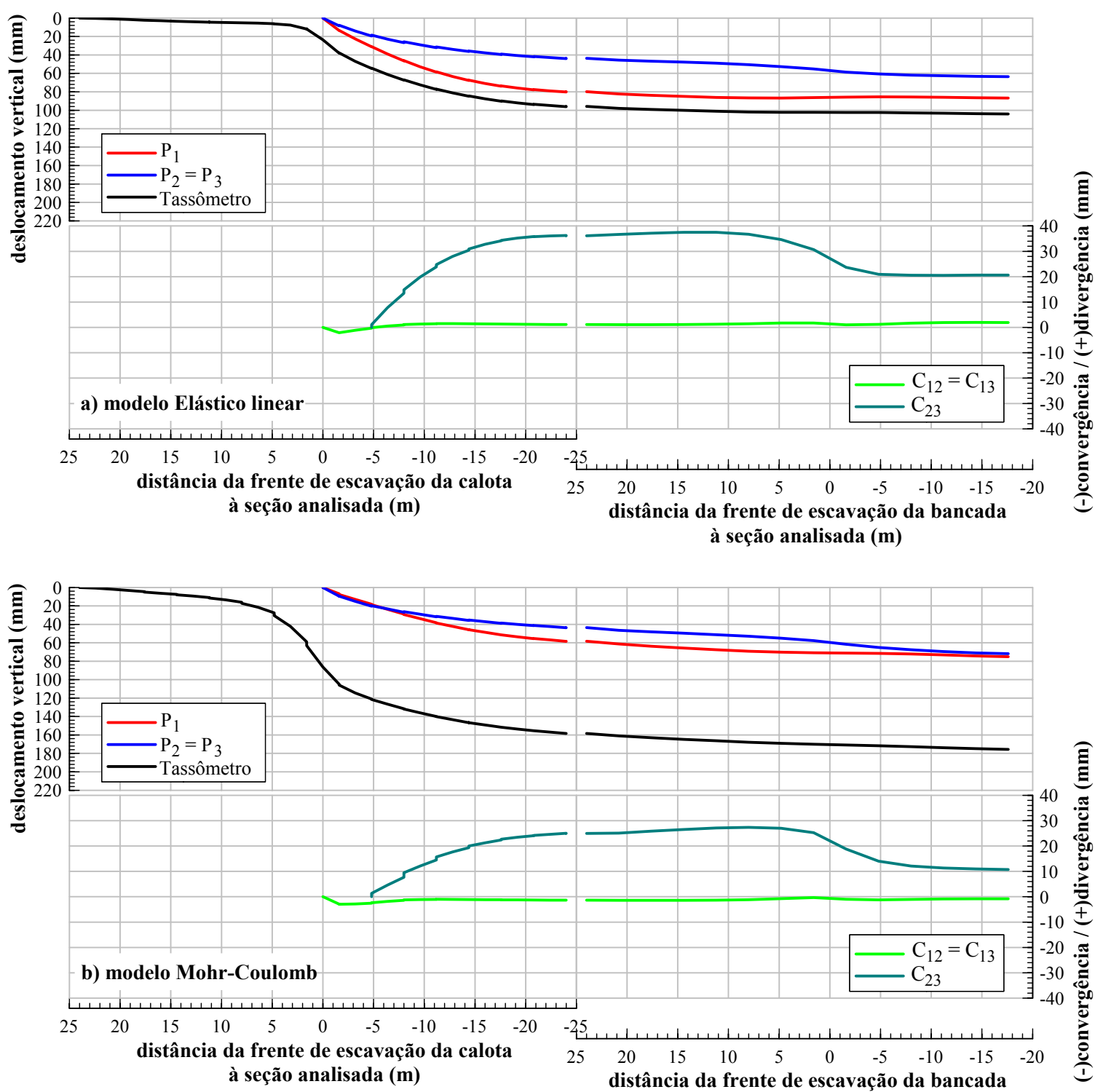
à seção analisada (m)

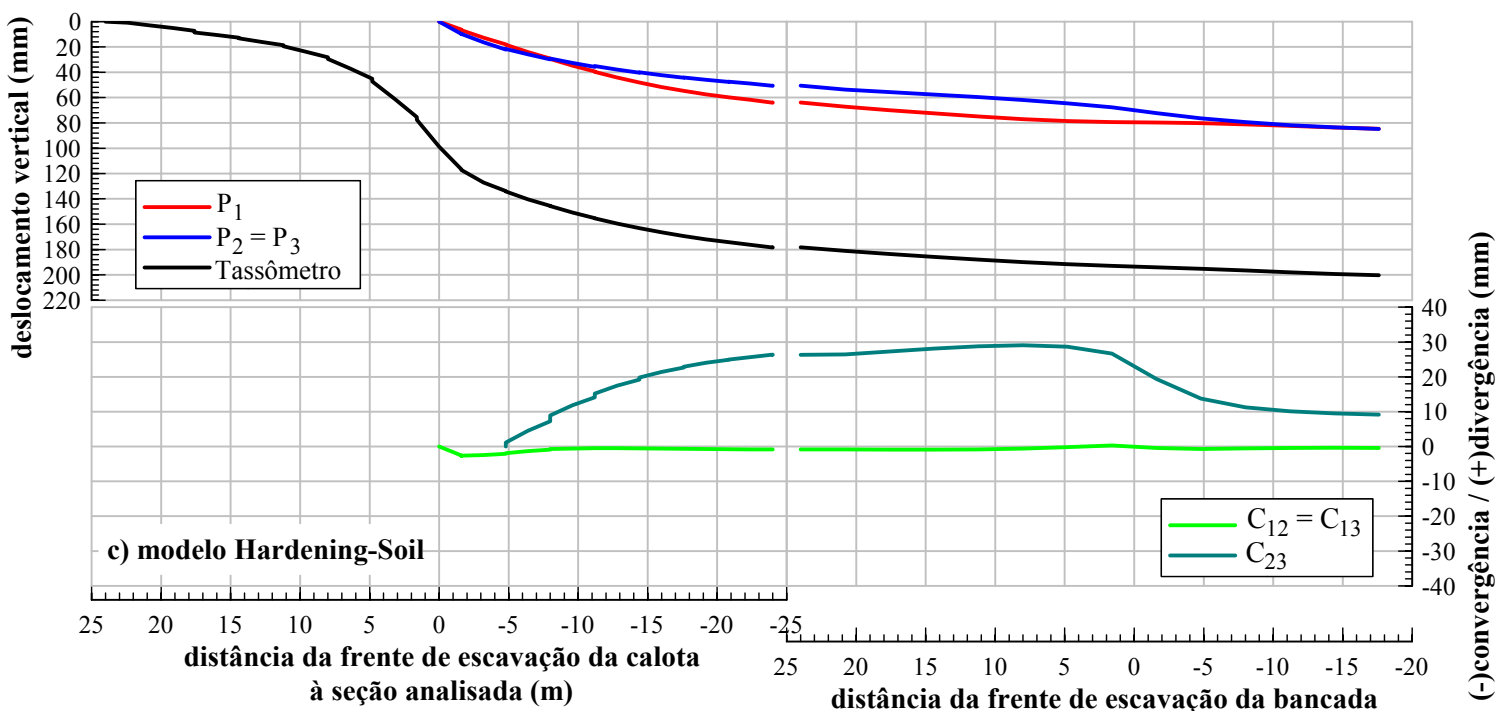
à seção analisada $(\mathrm{m})$

Figura 5.66 - Deslocamentos dos pinos e do tassômetro (maciço mecanicamente homogêneo) 

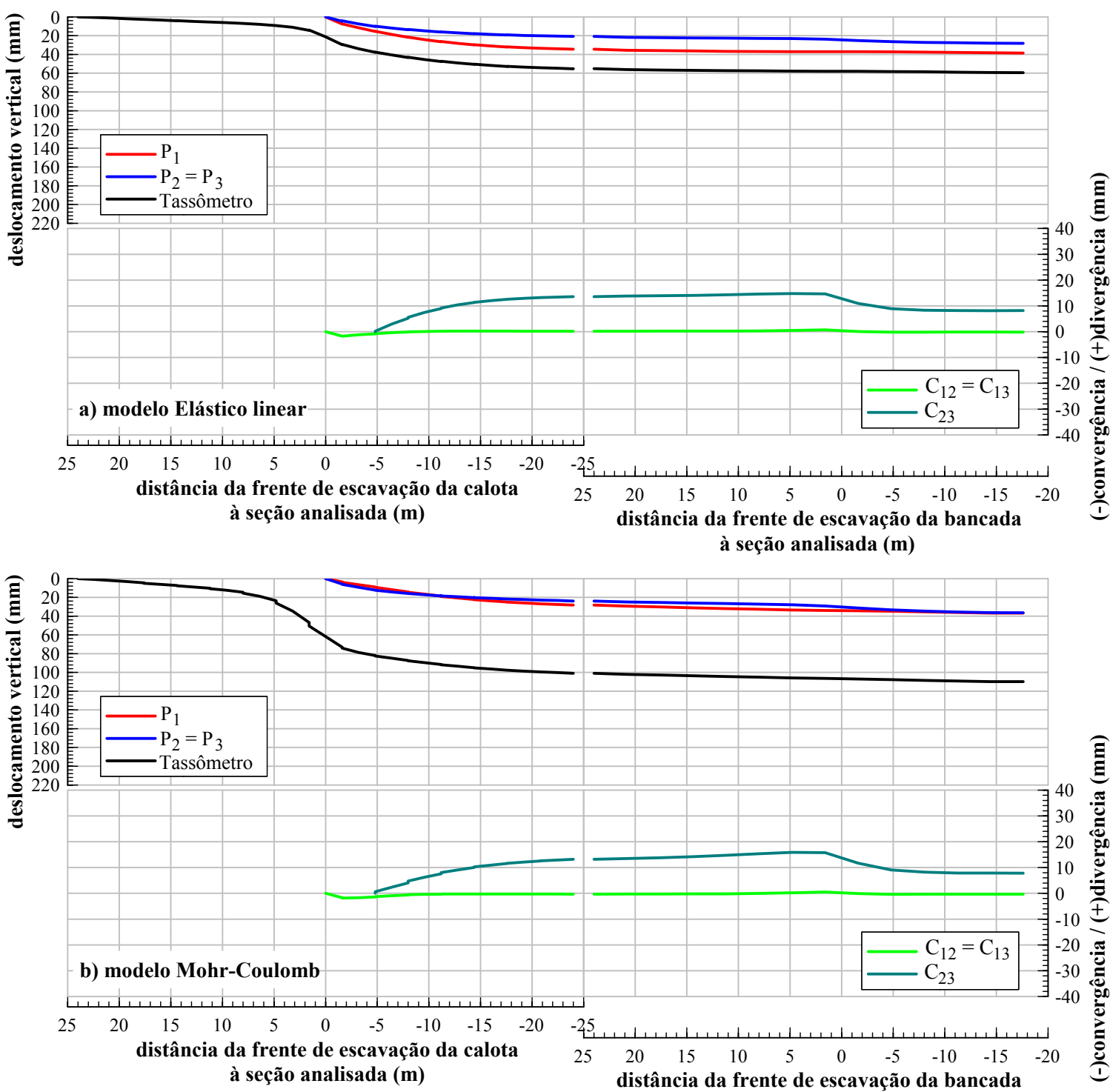

à seção analisada (m)

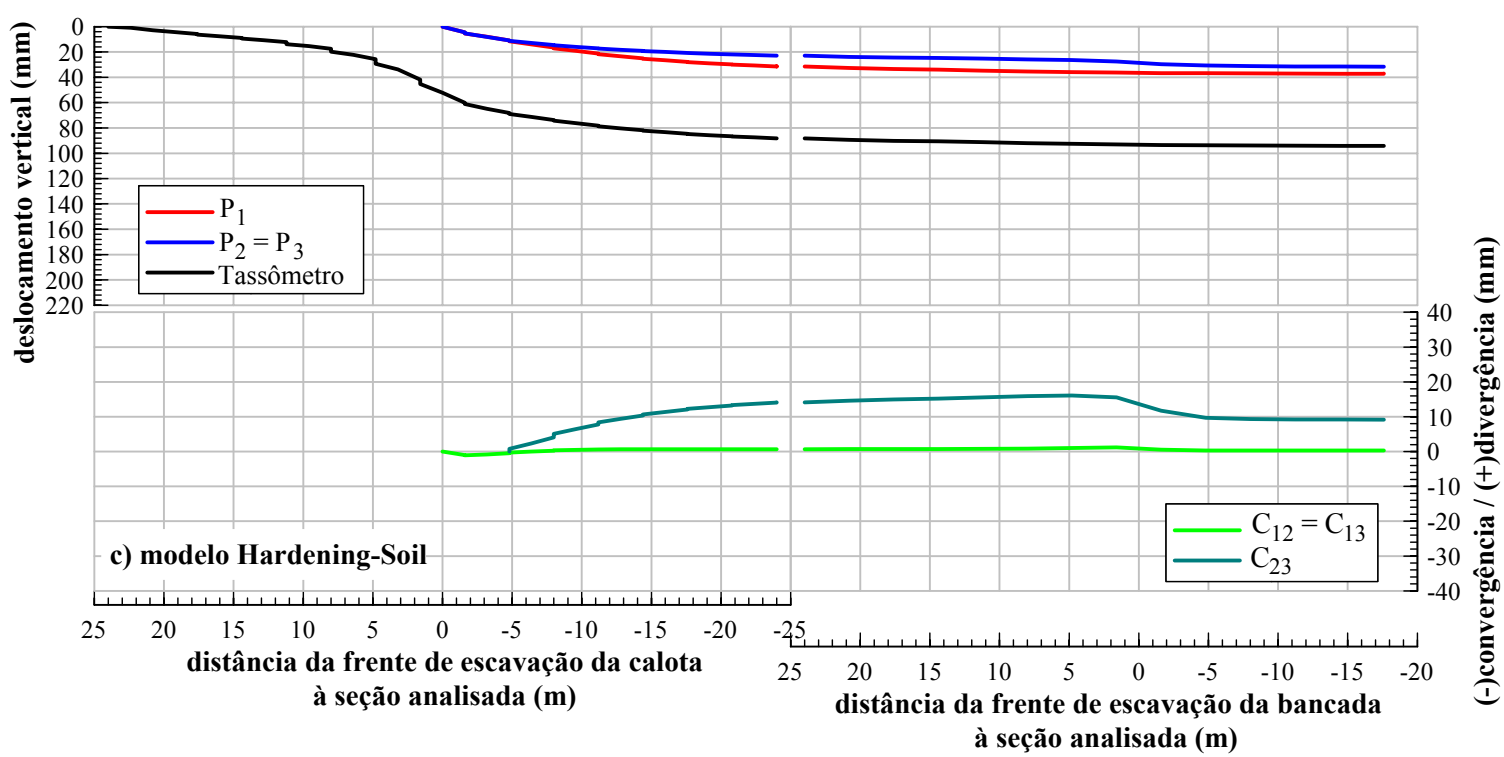

Figura 5.67 - Deslocamentos dos pinos e do tassômetro (maciço mecanicamente heterogêneo) 
Como se pode observar, o pino localizado no teto do túnel estabiliza seus recalques ao término da escavação da calota, continuando sem alterações significativas mesmo após a escavação da bancada. Quanto ao pino localizado na lateral do túnel, há um aumento dos recalques com a passagem da frente de escavação da bancada. O tassômetro possui mesmo comportamento apresentado pelo pino localizado no teto do túnel.

Nota-se que, para a profundidade onde o túnel está localizado, as distâncias dos limites longitudinais da malha de elementos finitos estão satisfatórias. Apenas os deslocamentos superficiais indicam a necessidade de aumento da distância das fronteiras longitudinais.

Após a escavação da calota, a corda inferior $\mathrm{C}_{23}$ apresenta divergência (aumento no comprimento), devido aos deslocamentos horizontais ao lado túnel, como discutido anteriormente ao serem apresentados os resultados em função da profundidade. $\mathrm{O}$ comprimento da corda inferior é estabilizado ao final da escavação da calota, passando a apresentar convergência (diminuição no comprimento) ao ser escavada a bancada.

As duas cordas superiores $\mathrm{C}_{12}$ e $\mathrm{C}_{13}$ não apresentaram alteração significativa de seus comprimentos. Com a passagem da frente de escavação da calota, o recalque do pino no teto do túnel sendo maior que o do pino em sua lateral, combinado com o deslocamento horizontal do pino na lateral para fora do túnel, resultam em um mesmo comprimento para a corda. Com a passagem da frente de escavação da bancada, o recalque apenas do pino na lateral do túnel combinado com seu deslocamento horizontal para dentro do túnel, também não alteram o comprimento das cordas superiores.

O comportamento apresentado é similar para os três modelos constitutivos e para as duas etapas da modelagem.

\subsection{DisCUSSÃO DOS RESULTADOS}

Para a discussão dos resultados deste capítulo, serão comparados os valores dos parâmetros geotécnicos obtidos com a modelagem matemática da presente pesquisa e os valores obtidos por outros autores. Além disso, valores de parâmetros empíricos serão apresentados e comparados com valores usuais para a prática da Engenharia. 


\subsubsection{Parâmetros geotécnicos}

Pinto e Nader (1994b) apresentaram resultados de ensaios triaxiais em amostras indeformadas de um solo residual, coletadas do poço VSE Caxingui durante sua escavação. As amostras coletadas da profundidade de 16 a 20 metros foram caracterizadas como saprólito e seus parâmetros geotécnicos encontram-se na Tabela 5.5, tendo sido determinados a partir dos resultados apresentados pelos autores. Dois tipos de ensaios triaxiais drenados foram executados: compressão por carregamento axial (trajetória de 45 graus), cujo módulo de deformabilidade foi determinado à $50 \%$ da ruptura $\left(E^{\prime}{ }_{50}\right)$; e compressão por descarregamento lateral (trajetória de 135 graus), cujo módulo de deformabilidade foi determinado pela representação de um trecho inicial linear ( $E_{\text {ur }}$ ). Todos os ensaios foram adensados isotropicamente até a confinante de $300 \mathrm{kPa}$.

Tabela 5.5 - Parâmetros geotécnicos obtidos a partir de Pinto e Nader (1994b)

\begin{tabular}{c|c|c|c|c|c}
\hline ensaio & $\begin{array}{c}\mathrm{E}^{\prime} \\
(\mathrm{kPa})\end{array}$ & $\begin{array}{c}\sigma^{\prime}{ }_{\mathrm{c}} \\
(\mathrm{kPa})\end{array}$ & $v^{\prime}$ & $\begin{array}{c}\varphi^{\prime} \\
(\text { graus })\end{array}$ & $\begin{array}{c}\mathrm{c}^{\prime} \\
(\mathrm{kPa})\end{array}$ \\
\hline $45^{\circ}$ & 11.250 & 300 & 0,19 & \multirow{2}{*}{31} & 0 \\
\hline $135^{\circ}$ & 52.500 & 300 & 0,35 & & \\
\hline
\end{tabular}

Para uma tensão confinante de $300 \mathrm{kPa}$, de acordo com a Tabela 5.2 e a Tabela 5.3, os parâmetros adotados para esta pesquisa equivalem a E' ${ }_{50}=19800 \mathrm{kPa}$ e E' ${ }_{\text {ur }}=24990 \mathrm{kPa}$, para a trajetória de 45 graus. De acordo com a Figura 5.45, o módulo E' ur para a trajetória de 45 graus foi estimado como igual ao módulo para a trajetória de 135 graus. Com isto, observa-se que o módulo para carregamento E' 50 adotado para a pesquisa é praticamente o dobro do módulo determinado a partir de Pinto e Nader (1994b), enquanto que o módulo para descarregamento E' ur adotado é praticamente a metade do módulo determinado a partir dos autores. Nota-se que o ângulo de atrito interno determinado é de 31 graus, maior do que o encontrado para esta pesquisa, de 28 graus.

Os parâmetros geotécnicos utilizados pelo Consórcio Projetista da linha 4-Amarela da Companhia do Metropolitano de São Paulo, CVA (2008), para o cálculo do túnel do corpo da Estação Morumbi, encontra-se na Tabela 5.6. A Estação Morumbi fica próxima ao poço VSE Caxingui e está inserida em um perfil geológico similar ao apresentado nesta pesquisa. 
Tabela 5.6 - Parâmetros geotécnicos adotados por CVA (2008)

\begin{tabular}{l|c|c|c|c|c}
\hline & $\begin{array}{c}\mathrm{E}^{\prime} \\
(\mathrm{kPa})\end{array}$ & $\begin{array}{c}\varphi^{\prime} \\
\text { (graus) }\end{array}$ & $\begin{array}{c}\mathrm{c}^{\prime} \\
(\mathrm{kPa})\end{array}$ & $\begin{array}{c}\gamma \\
\left(\mathrm{kN} / \mathrm{m}^{3}\right)\end{array}$ & $\mathrm{K}_{0}$ \\
\hline Solo saprolítico de gnaisse & 40.000 & 28 & 15 & 19 & 0,80 \\
\hline
\end{tabular}

É possível observar que os parâmetros de resistência, c' e $\varphi^{\prime}$, são coerentes com os obtidos pela presente pesquisa. Para o nível de tensão confinante de $463 \mathrm{kPa}$, de acordo com a Tabela 5.2 e a Tabela 5.3, os parâmetros adotados para esta pesquisa equivalem a $\mathrm{E}^{\prime}{ }_{50}=27800 \mathrm{kPa}$ e $\mathrm{E}_{\text {ur }}^{\prime}=32000 \mathrm{kPa}$, para a trajetória de 45 graus. Nota-se que ambos são menores do que o módulo adotado por CVA (2008).

Os valores de módulo de deformabilidade de Pinto e Nader (1994b) e de CVA (2008) foram inseridos na Figura 5.68. De uma maneira geral, observa-se uma coerência entre os resultados.
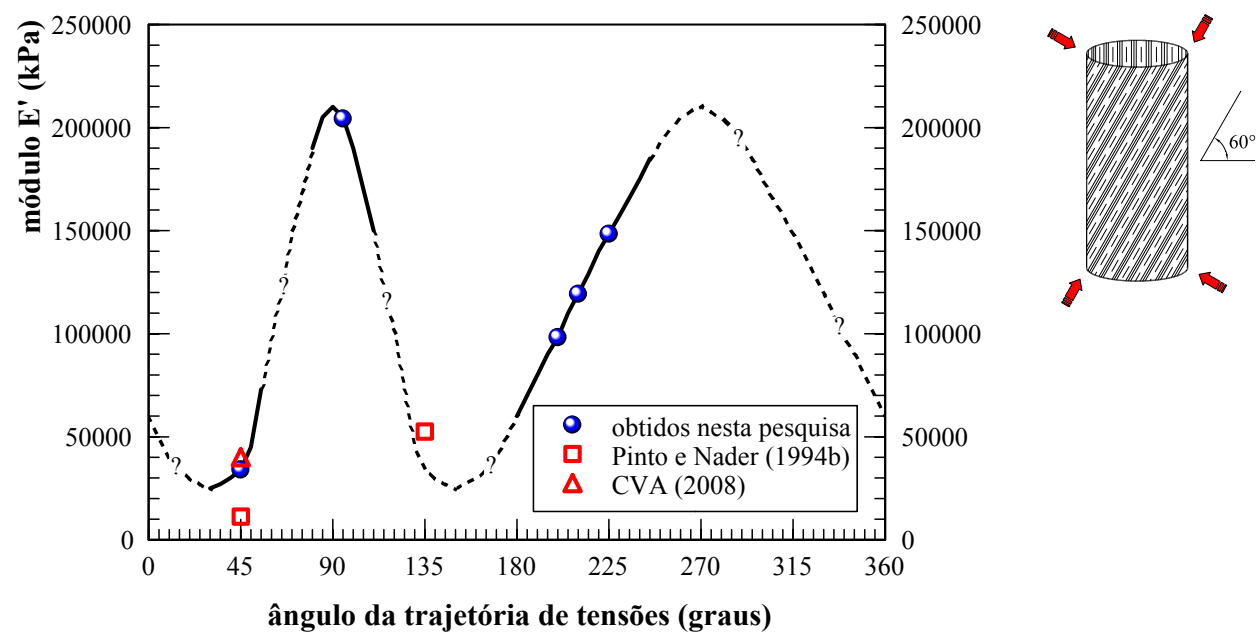

Figura 5.68 - Módulos de elasticidade em função da trajetória de tensões

O formato obtido para a curva aparenta ser válido, pois como a variação dos módulos depende de um ângulo, a curva se assemelha a uma função periódica (um senóide, por exemplo). As foliações metamórficas existentes no solo, inclinadas de 60 graus em relação à horizontal, devem ser as principais responsáveis pela variação dos módulos de deformabilidade. Como ilustrado na Figura 5.68, um carregamento com alteração das tensões axial e confinante que possua uma resultante paralela ou perpendicular aos planos das feições metamórficas, deve ocasionar um comportamento de menor ou maior rigidez. Ou seja, o solo possui comportamento mecânico anisotrópico e as direções paralelas e perpendiculares às foliações são correspondentes às direções principais de deformabilidade. 
Outra observação que convém ser destacada diz respeito à diferença entre o módulo E' ${ }_{50}$ para a compressão por carregamento axial (trajetória de 45 graus) e o módulo E' ur para a extensão por descarregamento axial (trajetória de 225 graus). A formulação matemática dos modelos constitutivos Elástico linear e Mohr-Coulomb, utilizados nesta pesquisa, considera que os módulos de carregamento e descarregamento possuem o mesmo valor, tornando as curvas tensão-deformação coincidentes. Entretanto, o valor obtido para o módulo de elasticidade no descarregamento é aproximadamente três vezes o valor do módulo no carregamento.

A influência da diferença entre os módulos de carregamento e descarregamento em curvas tensão-deformação está ilustrada na Figura 5.69, onde se apresenta o resultado da etapa de adensamento do ensaio de carregamento axial (5). $\mathrm{O}$ ensaio foi adensado com $\mathrm{K}=0,50$ até $600 \mathrm{kPa}$, descarregado e carregado novamente com a mesma relação K.

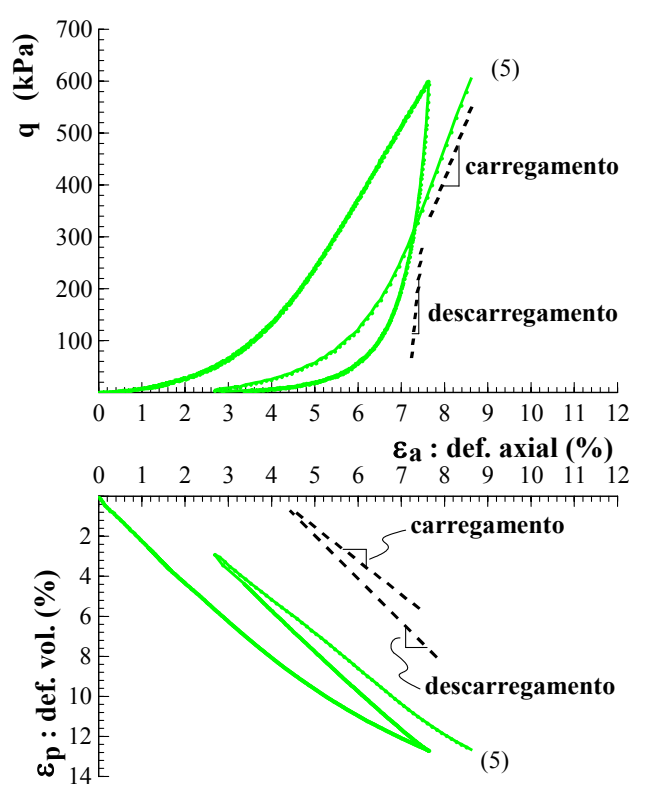

Figura 5.69 - Comparação entre os módulos de carregamento e descarregamento

Negro Jr. et al. (1992b) retro-analisaram módulos de elasticidade tangente inicial de casos históricos de túneis, obtendo a correlação apresentada na Figura 5.70, na qual o módulo em MPa equivale de 4 a 5 vezes o valor do número SPT médio no teto dos túneis. Os números índices indicam o caso histórico analisado. Pode-se observar que a maioria dos túneis analisados encontravam-se inseridos em solos terciários e quartenários (sedimentares). 


LEGENDA
\begin{tabular}{|l|c|c|c|}
\hline $\begin{array}{l}\text { MEETODO DE } \\
\text { ESCAVAÇAO O }\end{array}$ & \multicolumn{3}{|c|}{ S OLO } \\
\cline { 2 - 4 } & TERCIA'RIO & OUATERNÁRIO & PRÉ-CAMBRIANO \\
\hline NATM & 0 & $\square$ & $\Delta$ \\
\hline SHIELD & & $\square$ & $\Delta$ \\
\hline
\end{tabular}

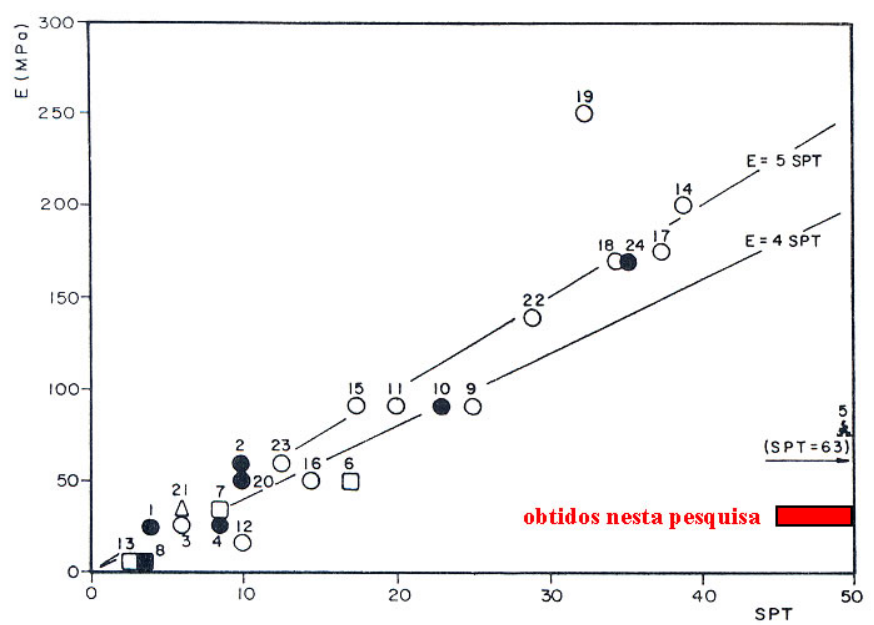

Figura 5.70 - Módulos tangente inicial em função do número SPT médio no teto de túneis, a partir de Negro Jr. et al. (1992b)

Os números SPT do perfil geológico em estudo, de acordo com a Figura 2.6, variam de 45 a 53 ao nível da amostragem. A faixa de variação dos módulos obtidos para esta pesquisa foi inserida na correlação apresentada na Figura 5.70, demonstrando não possuir uma boa concordância com os demais resultados. Isto pode ser causado pela diferente gênese do solo residual, com formação no período pré-cambriano, e pelos seus elevados números SPT. Mas esta incoerência é devida, principalmente, à maneira de obtenção dos módulos de elasticidade. Os módulos tangente inicial sempre resultam em valores superiores aos módulos obtidos à metade da ruptura $\left(\mathrm{E}^{\prime}{ }_{50}\right)$, por exemplo.

\subsubsection{Parâmetros semi-empíricos}

Para a prática da Engenharia de túneis, algumas previsões de comportamento são necessárias em uma etapa anterior à execução de um cálculo sofisticado, como exemplo um que utilize o método dos elementos finitos. Para isso, recorre-se a equações semi-empíricas de fácil utilização, cujos parâmetros são considerados como usuais e normalmente aferidos de acordo com a experiência do projetista. Serão aqui apresentados alguns parâmetros semiempíricos, os quais levariam a resultados coerentes em relação aos obtidos por meio da modelagem numérica desta pesquisa.

Com o intuito de serem utilizados modelos bidimensionais para a simulação da escavação do túnel, foram calculadas as porcentagens de alívio apresentadas na Tabela 5.7. 
Tabela 5.7 - Porcentagens de alívio obtidas para as modelagens numéricas

\begin{tabular}{l|c|c|c|c|c|c}
\hline \multirow{2}{*}{ ponto analisado } & \multicolumn{3}{|c|}{$\begin{array}{c}\text { modelagem com o maciço } \\
\text { mecanicamente homogêneo }\end{array}$} & \multicolumn{3}{c}{$\begin{array}{c}\text { modelagem com o maciço } \\
\text { mecanicamente heterogêneo }\end{array}$} \\
\cline { 2 - 7 } & $\begin{array}{c}\text { modelo } \\
\text { Elástico } \\
\text { linear }\end{array}$ & $\begin{array}{c}\text { modelo } \\
\text { Mohr- } \\
\text { Coulomb }\end{array}$ & $\begin{array}{c}\text { modelo } \\
\text { Hardening- } \\
\text { Soil }\end{array}$ & $\begin{array}{c}\text { modelo } \\
\text { Elástico } \\
\text { linear }\end{array}$ & $\begin{array}{c}\text { modelo } \\
\text { Mohr- } \\
\text { Coulomb }\end{array}$ & $\begin{array}{c}\text { modelo } \\
\text { Hardening- } \\
\text { Soil }\end{array}$ \\
\hline A - teto & 46 & 38 & 38 & 50 & 63 & 57 \\
\hline B - diagonal superior & 17 & 28 & 40 & 21 & 25 & 37 \\
\hline C - lateral (superior) & 0 & -26 & -8 & -39 & -10 & -17 \\
\hline D - lateral (inferior) & 75 & 67 & 65 & 35 & 60 & 73 \\
\hline E - diagonal inferior & 40 & 67 & 60 & -25 & 90 & 40 \\
\hline F - piso & 95 & 85 & 85 & 95 & 85 & 67 \\
\hline
\end{tabular}

Estas porcentagens foram determinadas a partir dos desenvolvimentos das tensões de pontos ao redor do túnel em função do avanço da escavação, apresentados anteriormente. Este alívio é referente apenas à alteração da tensão, podendo ser utilizado em modelagens bidimensionais para a determinação das tensões atuantes no revestimento do túnel. Não é possível, no entanto, efetuar-se uma análise dos deslocamentos causados pela escavação.

O alívio foi calculado como a diferença entre o valor inicial da tensão e seu valor logo após a instalação do revestimento do túnel. Para os pontos localizados no hemisfério superior do túnel (A, B e C), a análise foi feita com a passagem da frente de escavação da calota. Para os pontos localizados no hemisfério inferior do túnel (D, E e F), a análise foi feita com a passagem da frente de escavação da bancada. Para os pontos A, B, E e F, foi analisada a variação da tensão vertical, enquanto que para os pontos $\mathrm{C}$ e $\mathrm{D}$ analisou-se a variação da tensão horizontal transversal.

Um valor negativo para o alívio significa que a tensão sofreu acréscimo após a instalação do revestimento. De maneira geral, os valores estão coerentes, tendo-se em vista os reduzidos alívios para a lateral do túnel, os valores elevados para o piso e os valores intermediários para o teto do túnel.

Observa-se uma marcante variação entre os resultados, mesmo entre a primeira e a segunda etapas da modelagem, o que possibilita afirmar que estabelecer uma porcentagem para o alívio da tensão não aparenta ser um bom método, devendo ser utilizado o método da convergência-confinamento.

O fator de alívio, utilizado nas modelagens bidimensionais, também deve levar em consideração a representação da tridimensionalidade do problema, considerando o impedimento das deformações imposto pela frente de escavação e pelo revestimento já instalado do túnel, não somente a alteração das tensões. 
Quanto à previsão da distribuição transversal dos recalques superficiais, a Figura 5.71 apresenta uma adaptação da curva de distribuição normal (curva de Gauss) invertida, para os resultados obtidos com a primeira etapa da modelagem. A Figura 5.72 apresenta a adaptação da curva de Gauss para os resultados obtidos com a segunda etapa da modelagem.

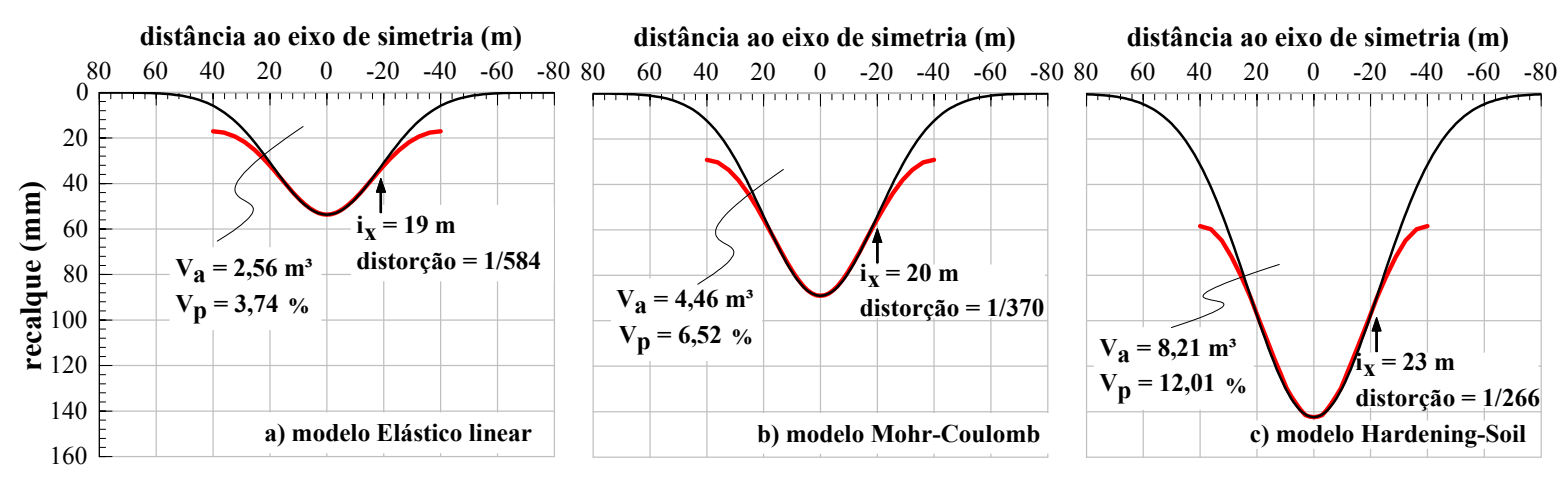

Figura 5.71 - Adaptação da curva de Gauss para representação dos recalques transversais (maciço mecanicamente homogêneo)

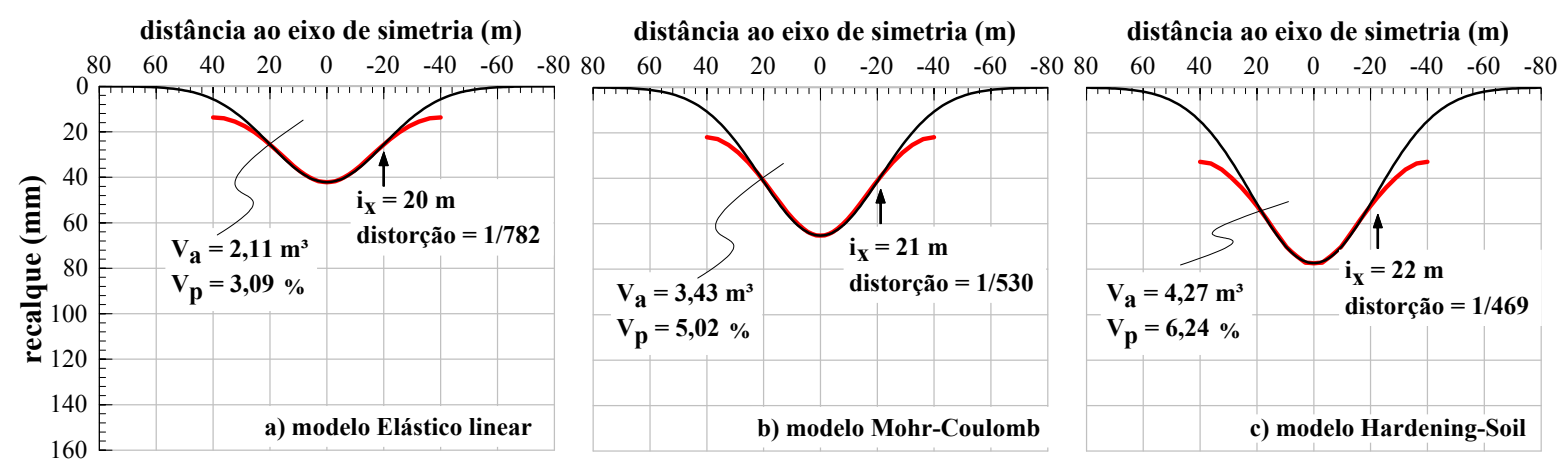

Figura 5.72 - Adaptação da curva de Gauss para representação dos recalques transversais (maciço mecanicamente heterogêneo)

As curvas de Gauss conseguiram representar a distribuição dos recalques transversais internamente aos seus pontos de inflexão $\left(i_{x}\right)$. Externamente a eles, entretanto, os recalques sofreram influência do limite lateral transversal da malha de elementos finitos, distanciandose das curvas de Gauss.

Os recalques superficiais se anularam a uma distância aproximada de $80 \mathrm{~m}$ do eixo de simetria do túnel para os modelos elasto-plásticos e de $60 \mathrm{~m}$ para o modelo elástico. A distância de $80 \mathrm{~m}$ foi prevista anteriormente ao ser estudada a localização da fronteira lateral transversal. 
Observa-se que as distâncias dos pontos de inflexão das curvas variam de $19 \mathrm{~m}$ a $23 \mathrm{~m}$. De acordo com a equação (5.5) e adotando-se os coeficientes $a=1,0$ e $b=1,0$, o valor estimado para a distância do ponto de inflexão é de aproximadamente $19 \mathrm{~m}$, o qual levaria a uma previsão satisfatória.

Os volumes das bacias de subsidência (Va) determinados pelas curvas de Gauss foram igualados aos volumes de perda de solo (Vp), os quais foram considerados como iguais a uma porcentagem da área de escavação do túnel. Para a primeira etapa da modelagem, as perdas de solo variaram de $3,74 \%$ a $12,01 \%$ da área de escavação, enquanto que para a segunda etapa as perdas variaram de $3,09 \%$ a $6,24 \%$.

A faixa de variação das porcentagens de perda de solo foi menor para a segunda etapa da modelagem, com o maciço mecanicamente heterogêneo. Além disso, os valores usuais estimados para $\mathrm{Vp}$ variam de 1\% a 5\%. Estes dois fatos, além de todos os comentários feitos anteriormente sobre os resultados de deslocamentos, levam a crer que a segunda etapa da modelagem obteve resultados mais coerentes.

\subsection{ConClusões SOBRe AS MODElagens NuMÉRICAS REALIZADAS}

A análise dos resultados obtidos com as modelagens numéricas, para o desenvolvimento das tensões e dos deslocamentos em função do avanço da escavação, permitiu validar o modelo confeccionado, estando os resultados coerentes. Ressalva pode ser feita quanto à localização das fronteiras da malha de elementos finitos, as quais deveriam ser mais distantes. A fronteira vertical transversal não apresentaria recalques a uma distância aproximada de 80 metros do eixo de simetria do túnel. As fronteiras verticais longitudinais deveriam ser distanciadas de 18 metros, ficando a fronteira do início do modelo a 42 metros da seção analisada e a do final do modelo a 54 metros, para que a seção analisada pudesse alcançar um patamar de estabilização dos recalques. A fronteira inferior deveria ser aprofundada, para que a restrição aos deslocamentos não interferisse na região abaixo do túnel. Cabe lembrar que o modelo foi criado com um número de elementos finitos próximo ao limite exigido pelo software e que um aumento do tamanho da malha representaria um aumento na quantidade de elementos. 
Por meio da análise do desenvolvimento das tensões, foi possível estabelecer-se uma zona distante de 15 metros adiante e atrás da seção analisada, como sendo influenciada pelo avanço da frente de escavação da calota. Esta zona de influência, entretanto, passa para uma distância de 5 metros adiante e atrás da seção analisada ao ser analisado o avanço da frente de escavação da bancada.

A análise do desenvolvimento dos deslocamentos verticais de pontos do revestimento do túnel demonstrou que a distância de 15 metros para a zona de influência da frente de escavação da calota e a de 5 metros para a escavação da bancada podem ser consideradas satisfatórias. Entretanto, esta influência é propagada até a superfície, onde obteve-se uma distância de 42 metros para a zona de influência da escavação, ao serem analisados os recalques superficiais.

A comparação entre os resultados obtidos com a primeira e a segunda etapas da modelagem permite afirmar que não houve mudanças significativas quanto ao desenvolvimento das tensões com o avanço da escavação. Isto é devido ao arqueamento e à redistribuição das tensões serem governados pela capacidade de mobilização de resistência ao cisalhamento pelo maciço, ou seja, dependerem diretamente dos parâmetros referentes à plastificação e à ruptura (c' , $\varphi^{\prime}$ e $\psi$ ), os quais não foram alterados para a segunda etapa.

Todos os pontos analisados ao redor do túnel sofreram plastificação devida ao descarregamento, nas análises com os modelos elasto-plásticos.

O modelo elasto-plástico com endurecimento (Hardening-Soil) apresentou deslocamentos com a maior ordem de grandeza, tendo-se em vista que suas equações constitutivas possibilitam a plastificação do solo antes da ocorrência de ruptura. O modelo Elástico linear apresentou os menores deslocamentos, justamente por não possibilitar a plastificação do solo. O modelo elasto-plástico perfeito (Mohr-Coulomb) apresentou deslocamentos de ordem de grandeza intermediária.

A principal mudança ocorrida entre as duas etapas da modelagem diz respeito aos resultados obtidos para os deslocamentos. A segunda etapa da modelagem apresentou deslocamentos menores, em razão da alteração dos parâmetros elásticos ( $E^{\prime}$ e v’), tornando o maciço mais rígido.

Apesar de não ser significativa a mudança nos resultados de desenvolvimento das tensões com o avanço da escavação, os resultados para as trajetórias de tensões foram alterados na segunda etapa da modelagem. Uma terceira etapa deveria ser então realizada, a partir dos resultados obtidos com a etapa anterior (novos conjuntos de parâmetros geotécnicos 
e nova variação dos parâmetros em função do avanço da escavação). Outras iterações deveriam ser julgadas necessárias, até que os resultados obtidos para as trajetórias de tensões convergissem. Um estudo com esta magnitude não pôde ser realizado devido ao tempo restrito destinado a esta pesquisa.

Os parâmetros geotécnicos de carregamento, obtidos com os ensaios apresentados no capítulo anterior e utilizados para a primeira etapa da modelagem, estão coerentes com os apresentados por Pinto e Nader (1994b) e por CVA (2008) para o mesmo tipo de solo. Os módulos de elasticidade não puderam ser correlacionados ao número SPT. A estimativa do ponto de inflexão da curva de Gauss a uma distância de 18 metros do eixo de simetria do túnel e a estimativa do volume da bacia de subsidência como igual ao volume de perda de solo e igual a 5\% da área de escavação do túnel, demonstraram ser satisfatórias.

Por fim, é válido ressaltar que as modelagens aqui apresentadas não visaram analisar o projeto ou a obra existentes, tendo-se em vista as simplificações que tiveram de ser efetuadas. Não foram consideradas no modelo numérico algumas peculiaridades existentes em campo, como o aumento da resistência e alteração da envoltória de plastificação devidos ao ganho de sucção decorrente da drenagem da frente de escavação; o aumento da capacidade autoportante do maciço devido ao emprego de enfilagens no arco superior do túnel e de pregagens na frente de escavação; alteração do comportamento mecânico obtido em laboratório devido à heterogeneidade, às descontinuidades e à anisotropia existentes no solo residual em estudo. 


\section{CApítulo 6}

\section{Cossipracober finas}

O solo residual saprolítico em estudo, proveniente de um biotita-gnaisse milonitizado, apresenta planos de descontinuidades com materiais argilosos, tendo sido herdados das fraturas existentes na rocha matriz. Nestas fraturas se estabeleceu um caminho preferencial de percolação, ocasionando um maior grau de alteração em suas faces. Foram encontrados dois tipos de materiais diferentes nestas descontinuidades: um de cor laranja, resultante da alteração do mineral biotita e formado por argilo-minerais micáceos oxidados; outro de cor branca, resultante da alteração do mineral feldspato e formado pelos argilo-minerais caulinita, clorita e esmectita, com comportamento expansivo.

O estudo microscópico permitiu determinar a presença de uma macroestrutura orientada, característica de uma foliação metamórfica resultante de esforços tectônicos compressionais, e a presença de uma microestrutura conformada pelo empilhamento de placas micáceas, envoltas por conglomerados argilosos predominantemente micáceos. Apesar de não ter sido evidenciada cimentação entre as partículas, demonstrou-se que a estruturação existente no solo é governada pelo arranjo das partículas.

O solo apresenta um comportamento mecânico anisotrópico, o qual pôde ser evidenciado pelo formato e inclinação da envoltória de escoamento e pela obtenção de envoltórias de resistência distintas para a situação de compressão e de extensão. Esta anisotropia deve ser remanescente da rocha originária. 
O comportamento da envoltória de escoamento é essencialmente cinemático, não sofrendo grandes variações de rotação, encolhimento e expansão. O escoamento do solo é governado pela perda da estruturação das partículas, e não à mudança do regime elástico para o regime elasto-plástico. Em razão do descarregamento imposto pela escavação do túnel de onde foram coletadas as amostras, e da própria amostragem em si, a envoltória de escoamento se deslocou para a origem do espaço de tensões.

Os valores determinados de 28 graus para o ângulo de atrito interno e de intercepto de coesão nulo são coerentes com os valores típicos de solos siltosos com predominância de partículas micáceas, para ensaios triaxiais de carregamento axial (trajetória de 45 graus).

A principal crítica a ser efetuada quanto aos ensaios triaxiais realizados diz respeito às medidas de deformações dos corpos-de-prova, tomadas externamente à câmara triaxial. Transdutores internos permitem leituras mais precisas e a obtenção de módulos de elasticidade tangente inicial, além de possibilitarem a execução de ensaios com deformação lateral nula.

Não puderam ser realizados ensaios de laboratório com o intuito de analisar a influência da heterogeneidade e da anisotropia no comportamento mecânico do solo.

As modelagens numéricas realizadas para simular a escavação de um túnel foram confeccionadas com o intuito de se aproximarem ao máximo das condições encontradas em campo, no local de onde foram coletadas as amostras do solo em estudo. Entretanto, é importante salientar que as modelagens apresentadas não visaram analisar o projeto ou a execução do túnel em questão, e que os resultados obtidos não representam completamente a realidade, tendo-se em vista as simplificações que tiveram de ser efetuadas. O comportamento mecânico representado pelos modelos constitutivos não incluiu a existência da heterogeneidade, das descontinuidades e da anisotropia do solo; o emprego de enfilagens no arco superior do túnel e de pregagens na frente de escavação não foram avaliados; e não foi ponderado o aumento da resistência do maciço devido ao ganho de sucção decorrente da drenagem da frente de escavação.

A análise das trajetórias de tensões obtidas com a segunda etapa da modelagem numérica sugere que novas iterações deveriam ser feitas, até a convergência dos resultados para as trajetórias de tensões. As novas etapas contariam com novos conjuntos de parâmetros geotécnicos e nova variação dos parâmetros em função do avanço da escavação, determinados de acordo com os resultados da etapa anterior. 
Observou-se grande disparidade entre os resultados obtidos com a primeira etapa da modelagem para os três modelos analisados. O modelo elasto-plástico com endurecimento (Hardening-Soil) apresentou deslocamentos excessivos, devido à possibilidade de plastificação anterior à ruptura; e o modelo elástico linear apresentou os menores deslocamentos, em razão da inexistência de plastificação. Ao ser realizada uma subdivisão do maciço de acordo com as trajetórias de tensões atuantes ao redor do túnel e serem designados conjuntos de parâmetros geotécnicos distintos (segunda etapa da modelagem), os resultados obtidos demonstraram uma maior conformidade entre os três modelos analisados. Além disto, pôde ser superada a deficiência dos modelos elástico linear e elasto-plástico perfeito (MohrCoulomb) quanto à indistinção da deformabilidade nas situações de carregamento e descarregamento. Isto é evidenciado ao se analisar o levantamento de fundo do túnel, comumente excessivo em análises numéricas, sendo que para a segunda etapa da modelagem não foram obtidos grandes deslocamentos.

É importante salientar que a validação da consideração do maciço como um meio mecanicamente heterogêneo necessita de uma análise comparativa com dados provenientes da instrumentação de campo. Para isso, o modelo numérico deveria contemplar todas as questões citadas anteriormente, as quais não foram consideradas para as modelagens apresentadas.

Finalmente, dois aspectos importantes devem ser explicitados:

- o comportamento apresentado para o solo em estudo poderá servir como base para outros solos, de mesmo tipo e formação. Os parâmetros geotécnicos não seriam necessariamente os mesmos, mas os padrões de comportamento poderão ser correlacionados e estimados (como exemplo o formato da curva de escoamento, ou o caráter de variação dos parâmetros elásticos em função da trajetória de tensões); e

- uma metodologia foi proposta para obtenção de parâmetros geotécnicos que propiciem previsões mais condizentes com a realidade. Ela consiste em executar ensaios de acordo com a trajetória de tensões atuante em campo, incorporando os parâmetros assim determinados à modelagem numérica de maneira mecanicamente heterogênea. Sua aplicabilidade deverá ser avaliada por meio de uma análise comparativa com dados provenientes de instrumentação. 


\subsection{Sugestões Para Trabalhos Futuros}

Ao término da presente pesquisa, alguns assuntos permanecem com a necessidade de serem desenvolvidos ou aprofundados, sendo descritos a seguir:

- Quantificação dos minerais presentes no solo, para que sua influência no comportamento mecânico seja melhor analisada;

- Execução de uma campanha de ensaios edométricos com diferentes níveis de tensões para os ciclos de carregamento e descarregamento, para ser estudado o comportamento de acentuação da reta de descarregamento com o aumento do nível de tensões, causado pela predominância do argilo-mineral biotita;

- Realização de ensaios triaxiais com transdutores internos para pequenas deformações, com o intuito de serem obtidos os valores dos módulos de deformabilidade tangente inicial;

- Análise da variação dos parâmetros elásticos em função da trajetória de tensões seguida em ensaio, executando-se um número maior de ensaios triaxiais para que mais trajetórias sejam ensaiadas e com variação do nível de tensões de adensamento;

- Estudo do comportamento anisotrópico do solo, com adoção de valores diferentes de módulos de elasticidade para as direções paralela e perpendicular aos planos de foliação metamórfica;

- Estudo do comportamento viscoso do solo, juntamente com a utilização de modelos constitutivos elasto-visco-plásticos que representem este comportamento;

- Complementação dos resultados obtidos em laboratório por ensaios executados in situ;

- Aperfeiçoamento da modelagem numérica tridimensional, incluindo as melhorias empregadas em campo, com o intuito de serem comparados os resultados obtidos com dados provenientes da instrumentação;

- Inclusão de uma análise de fluxo acoplada à simulação numérica da escavação do túnel, para que sejam incluídas na modelagem as alterações de tensões devidas à drenagem da frente de escavação; e

- Retroanálise probabilística de dados provenientes de campo para comparação dos valores dos parâmetros geotécnicos obtidos com esta pesquisa. 
ASSOCIAÇÃO BRASILEIRA DE NORMAS TÉCNICAS. NBR 6118: Projeto de estruturas de concreto - Procedimento. Rio de Janeiro, 2003. 170 p.

. NBR 6457: Preparação de amostras de solo para ensaio normal de compactação e ensaios de caracterização - Método de ensaio. Rio de Janeiro, 1986. 9 p.

NBR 6459: Solo - Determinação do limite de liquidez - Método de ensaio. Rio de Janeiro, 1984. $6 \mathrm{p}$.

NBR 6502: Rochas e Solos - Terminologia. Rio de Janeiro, 1995. 18 p.

NBR 6508: Determinação da massa específica de grãos de solo - Método de ensaio. Rio de Janeiro, 1982. 8 p.

. NBR 7180: Solo - Determinação do limite de plasticidade - Método de ensaio. Rio de Janeiro, 1984. 3 p.

NBR 7181: Solos - Análise granulométrica. Rio de Janeiro, 1984. 13 p.

. NBR 12007: Solo - Ensaio de adensamento unidimensional. Rio de Janeiro, 1990. $13 \mathrm{p}$.

NBR 13292: Solo - Determinação do coeficiente de permeabilidade de solos granulares à carga constante. Rio de Janeiro, 1995. 8 p. 
NBR 14545: Solo - Determinação do coeficiente de permeabilidade de solos argilosos à carga variável. Rio de Janeiro, 2000. 12 p.

ALMEIDA E SOUSA, J. N. V. Túneis em Maciços Terrosos : Comportamento e Modelação Numérica. 1998. 623 p. Tese (Doutorado em Ciências de Engenharia) - Faculdade de Ciências e Tecnologia, Universidade de Coimbra. Coimbra, Portugal, 1998.

ANJOS, A. P. V. Análise do comportamento tensão-deformação de um solo adensado anisotropicamente e carregado segundo diferentes trajetórias de tensões. 1996. 152 p. Dissertação (Mestrado em Geotecnia) - Escola Politécnica, USP. São Paulo, 1996.

AZEVEDO, R. F. ; PARREIRA, A. B. ; ZORNBERG, J. G. Numerical Analysis of a Tunnel in Residual Soils. Journal of Geotechnical and Geoenvironmental Engineering, ASCE, New York, v. 128, n. 3, p. 227-236, mar. 2002.

BARLA, M. Tunnels in swelling ground: Simulation of $3 \mathrm{~d}$ stress paths by triaxial laboratory testing. 1999. 189 f. Tese (Doutorado em Engenharia Geotécnica) - Politecnico di Torino, Università degli Studi di Genova. Genova, Itália, 1999.

BARLA, M. e BARLA, G. Adoption of triaxial testing for the study of swelling behaviour in tunnels. In: INTERNATIONAL CONFERENCE ON SOIL MECHANICS AND GEOTECHNICAL ENGINEERING, 15., 2001, Istanbul. Proceedings... Netherlands: A. A. Balkema, 2001. v. 2, p. 1375-1378.

BIENIAWSKI, Z. T. Engineering rock mass classifications: a complete manual for engineers and geologists in mining, civil, and petroleum engineering. New York: John \& Wiley Sons, 1989. $251 \mathrm{p}$.

BISHOP, A.W. ; WESLEY, L.D. A hydraulic triaxial apparatus for controlled stress path testing. Géotechnique, London, v. 25, n. 4, p. 657-670, dec. 1975.

CASAGRANDE, A. The determination of the preconsolidation load and its practical significance. In: ICSMFE, 1., 1936, Cambridge. Proceedings... Netherlands: A. A. Balkema, 1936. v. 3, p. 60-64.

CINTRA, J. C. A. ; ALBIERO, J. H. (Ed.). Solos do interior de São Paulo. São Paulo: ABMS/EESC-USP, 1993. 399 p.

COUTINHO, J. M. V. Petrologia do Pré-Cambriano em são Paulo e arredores. 1968. 174 p. Tese (cargo de Professor Catedrático) - FFLCH, Universidade de São Paulo. São Paulo, 1968. 
CVA, Consórcio Projetista Linha 4. Memória de cálculo do túnel do corpo da Estação Morumbi. São Paulo, 2008. 66 p. Código MC-4.16.01.01/6G3-002. Memória de cálculo apresentada à Companhia do Metropolitano de São Paulo, em 19 de março de 2008.

DUNCAN, J. M. ; CHANG, C. Nonlinear analysis of stress and strain in soil. Journal of the Soil Mechanics and Foundations Division, ASCE, New York, v. 96, n. 5, p. 1629-1653, sep. 1970.

EISENSTEIN, Z. A. ; HEINZ, H. ; NEGRO Jr., A. On three-dimensional response to tunneling. In: GEOTECH, 1984, Ontario. Proceedings... New York: ASCE, 1984. p. 107-127.

EMPLASA, Empresa Metropolitana de Planejamento da Grande São Paulo. Carta geológica da região metropolitana da Grande São Paulo. Levantamento de campo e compilação realizada por José Moacyr Vianna Coutinho. [São Paulo]: 1980. 1 carta em 2 folhas. Escala $1: 100.000$.

FRANÇA, P. T. Estudo do comportamento de túneis: análise numérica tridimensional com modelos elasto-plásticos. 2006. 185 p. Dissertação (Mestrado em Engenharia Geotécnica) Escola Politécnica, USP. São Paulo, 2006.

FRANCIS, F. L. ; ROCHA, H. C. Obras subterrâneas civis. In: OLIVEIRA, A. M. S. e BRITO, S. N. A. Geologia de Engenharia. São Paulo: ABMS, 1998. p 439-456.

FRANZIUS, J. N. ; POTTS, D. M. Influence of mesh geometry on three-dimensional finiteelement analysis of tunnel excavation. International Journal of Geomechanics, New York, v. 5, n. 3, p. 243-257, sep. 2005

FRANZIUS, J. N. ; POTTS, D. M. ; BURLAND, J. B. The influence of soil anisotropy and $\mathrm{K}_{0}$ on ground surface movements resulting from tunnel excavation. Géotechnique, London, v. 55, n. 3, p. 189-199, apr. 2005.

FUTAI, M. M. Utilização de conceitos teóricos e práticos na avaliação do comportamento de algumas argilas do Rio de Janeiro. 1999. 133 p. $1^{\circ}$ Seminário de Qualificação ao Doutorado - COPPE/UFRJ. Rio de Janeiro, 1999.

FUTAI, M. M. Estudo Teórico-Experimental do Comportamento de Solos Tropicais Não-Saturados: Aplicação a um Caso de Voçorocamento. 2002. 597 p. Tese (Doutorado em Engenharia Civil) - COPPE, UFRJ. Rio de Janeiro, 2002. 
FUTAI, M. M. e ALMEIDA, M. S. S. An experimental investigation of the mechanical behavior of an unsaturated gneiss residual soil. Géotechnique, London, v. 55, n. 3, p. 201-213, apr. 2005.

FUTAI, M. M. ; ALMEIDA, M. S. S. ; LACERDA, W. A. Yield, strength, and critical state behavior of a tropical saturated soil. Journal of Geotechnical and Geoenvironmental Engineering, ASCE, New York, v. 130, n. 11, p. 1169-1179, nov. 2004.

GALLI, G. ; GRIMALDI, A. ; LEONARDI, A. Three-dimensional modeling of tunnel excavation and lining. Computers and Geotechnics, Amsterdam, v. 31, n. 3, p. 171-183, apr. 2004.

GRAHAM, J. ; PINKNEY, R. B. ; LEW, K. V. ; TRAINOR, P. G. S. Curve-fitting and laboratory data. Canadian Geotechnical Journal, Ottawa, v. 19, n. 2, p. 201-205, may. 1982.

GRAHAM, J. ; NOONAN, M. L. ; LEW, K. V. Yield states and stress-strain relationships in a natural plastic clay. Canadian Geotechnical Journal, Ottawa, v. 20, n. 3, p. 502-516, aug. 1983.

GRAHAM, J. ; CROOKS, J. H. A. ; LAU, S. L. K. Yield Envelop: Identification and geometric properties. Géotechnique, London, v. 38, n. 1, p. 125-134, mar. 1988.

HASUI, Y. Geologia estrutural das rochas na linha 4 do Metrô: Avaliação e síntese dos conhecimentos. São Paulo, 1993. 24 p. Parecer técnico apresentado à Companhia do Metropolitano de São Paulo, em outubro de 1993.

ICDD, The International Centre for Diffraction Data. Powder Diffraction File - PDF 2. 2001. 1 CD-ROM

KUWANO, R. ; JARDINE, R. J. A triaxial investigation of kinematic yielding in sand. Géotechnique, London, v. 57, n. 7, p. 563-579, set. 2007.

LAMBE, T. W. The stress path method. Journal of the Soil Mechanics and Foundations Division, ASCE, New York, 93, n. 6, p. 309-331, nov. 1967.

LAMBE, T. W. ; WHITMAN, R. V. Soil Mechanics. New York: John Wiley \& Sons, 1969. $553 \mathrm{p}$.

LANGER, F. ; STOCKMANN, K. Stability analysis of tunnels using the program Adina. Computers and Geotechnics, Amsterdam, v. 21, n. 1-2, p. 341-351. 1985. 
LIMA, A. P. Deformabilidade e estabilidade de taludes em solo grampeado. 2002. 85 p.

Dissertação (Mestrado) - Pontifícia Universidade Católica. Rio de Janeiro, 2002.

LINS, A. H. P. ; LACERDA, W. A. Ensaios triaxiais de compressão e de extensão na argila cinza do Rio de Janeiro em Botafogo. Solos e Rochas, São Paulo, v. 3, n. 1, p. 5-29. 1980.

LEROUEIL, S. ; VAUGHAN, P. R. The general and congruent effects of structure in natural soils and weak rocks. Géotechnique, London, v. 40, n. 3, p. 467-488, set. 1990.

MACCARINI, M. Laboratory Studies of a Weakly Bonded Artificial Soil. 1987. 323 f. Tese (Phd) - University of London. London, 1987.

MAIR, R.J. e TAYLOR, R.N. Bored tunnelling in the urban environment. In:

INTERNATIONAL CONFERENCE ON SOIL MECHANICS AND GEOTECHNICAL ENGINEERING, 14., 1990, Hamburg. Proceedings... Netherlands: A. A. Balkema, 1997. p. 2353-2385.

MASÍN, D. Laboratory and numerical modelling of natural clays. 2004. $173 \mathrm{f}$. Dissertação (Mestrado em Engenharia Geotécnica) - School of Engineering and Mathematical Sciences, City University. London, 2004.

MEDEIROS, L. V. ; EISENSTEIN, Z. A. A deep retaining structure in till and sand - part 1: stress path effects. Canadian Geotechnical Journal. Ottawa, v. 20, n. 1, p. 120-130, fev. 1983.

METRÔ-SP. Projeto executivo de movimento de terra para os túneis do trecho ButantãMorumbi, Linha 4-Amarela: Planta cadastral, Perfil geológico longitudinal e Métodos construtivos - $\mathrm{km} \mathrm{4,3+40,0} \mathrm{ao} \mathrm{km} \mathrm{4,38+0,0.} \mathrm{2006a.} \mathrm{Código} \mathrm{DE-4.14.04.00/6G3-003-C,}$ emissão em 09/janeiro/2006, última revisão em 09/outubro/2007.

METRÔ-SP. Projeto executivo de movimento de terra para os túneis do trecho ButantãMorumbi, Linha 4-Amarela: Seções tipo de escavação. 2006b. Código DE-4.14.04.00/6G3-006-B, emissão em 09/janeiro/2006, última revisão em 22/junho/2007.

METRÔ-SP. Mapa da rede metroviária. São Paulo, 2008. 1 mapa. Disponível em: $<$ http://www.metro.sp.gov.br/redes/mapa.pdf $>$. Acesso em 01/maio/2008.

MITCHELL, J. K. Soil Mineralogy. In: . Fundamentals of soil behavior. $2^{\text {nd }}$ ed.

New York: John Wiley \& Sons, 1993. Chapter 3, p. 18-40. 
NADER, J. J. Modelos Elasto-Plásticos para solos: o Cam-Clay e sua aplicação a diferentes trajetórias de tensão. 1993. 99 p. Dissertação (Mestrado) - Escola Politécnica, Universidade de São Paulo, São Paulo, 1993.

NAJAR JIMÉNEZ, A. G. Análises tensão-deformação de estruturas de solo grampeado. 2008. 120 p. Dissertação (Mestrado em Geotecnia) - POLI, USP. São Paulo, 2008.

NEGRO JR., A. et al. (Org.). Solos da cidade de São Paulo. São Paulo: ABMS/ABEF, 1992a. 203 p.

NEGRO JR., A. ; SOZIO, L. E. ; FERREIRA, A. A. Túneis. In: NEGRO Jr. et al. Solos da cidade de São Paulo. São Paulo: ABMS/ABEF, 1992b. Capítulo 13, p. 297-362.

NG, R. M. C. ; LO, K. Y. The measurements of soil parameter relevant to tunneling in clays. Canadian Geotechnical Journal, Ottawa, v. 22, n. 3, p. 375-391, aug. 1985.

PACHECO SILVA, F. Uma nova construção gráfica para a determinação da pressão de préadensamento de uma amostra de solo. In: COBRAMSEG, 4., 1970, Rio de Janeiro. Anais... São Paulo: ABMS, 1970. v. 1, p. 219-224.

PARREIRA, A. B. Análises de túneis rasos em solo: o túnel mineiro Paraíso da linha Paulista do Metropolitano da cidade de São Paulo. 1991. 296 f. Tese (Doutorado) - Pontifícia Universidade Católica. Rio de Janeiro, 1991.

PINTO, C. S. Comportamento de alguns solos típicos. In: Curso básico de Mecânica dos Solos. $3^{\text {a }}$ Edição. São Paulo: Oficina de Textos, 2006. Capítulo 16, p. 331-350.

PINTO, C. S. ; ABRAMENTO, M. O pressiômetro de auto-furação de Cambridge (COMKOMETER) - Metodologia de ensaio e exemplo de aplicação a solo residual de gnaisse. São Paulo, 2005. 60 p. Seminário promovido pelo Instituto de Engenharia e pela ABMS, em outubro de 2005.

PINTO, C. S. ; NADER, J. J. Ensaios de laboratório em solos residuais. In: SEMINÁRIO DE ENGENHARIA DE FUNDAÇÕES ESPECIAIS, 2., 1991, São Paulo. Anais... São Paulo: ABEF/ABMS, 1991. p. 166-202. 
PINTO, C. S. ; NADER, J. J. Modelo de análise de tensões e deformações pela superposição de efeitos (modelo SUEF). In: CONGRESSO BRASILEIRO DE MECÂNICA DOS SOLOS E ENGENHARIA DE FUNDAÇOES, 10., 1994, Foz do Iguaçu. Anais... São Paulo: ABMS, 1994a. v. 3, p. 701-708.

PINTO, C. S. ; NADER, J. J. Relatório sobre ensaios de laboratório: amostras indeformadas provenientes do local da futura Estação Caxingui. São Paulo, 1994. 45 p. Relatório apresentado à Companhia do Metropolitano de São Paulo, em dezembro de 1994b.

PINTO, C. S. ; GOBARA, W. ; PERES, J. E. E. ; NADER, J. J. Propriedades dos solos residuais. In: CINTRA, J. C. A. ; ALBIERO, J. H. Solos do interior de São Paulo. São Paulo: ABMS/EESC-USP, 1993. p. 95-142.

PLAXIS B. V. Plaxis 3D Tunnel: Material Models Manual. Netherlands: A. A. Balkema Publishers, 2001. 110 p.

RESENDE, M. et al. Mineralogia de solos brasileiros: interpretação e aplicações. Lavras: Editora UFLA, $2005.192 \mathrm{p}$.

ROCHA, H. C. ; RIBEIRO NETO, F. ; NUNES, N. L. ; SILVA, M. A. A. P. Concebendo estruturas impermeáveis para o Metrô de São Paulo. In: SIMPÓSIO INTERNACIONAL DE IMPERMEABILIZAÇÃO DE ESTRUTURAS SUBTERRÂNEAS, 2005, São Paulo. Anais... São Paulo: [s.n.], 2005. Não paginado. 1 CD-ROM.

ROCHA FILHO, P. Ensaios "in situ” em solo residual. In: SEMINÁRIO DE ENGENHARIA DE FUNDAÇÕES ESPECIAIS, 2., 1991, São Paulo. Anais... São Paulo: ABEF/ABMS, 1991. p. 147-165.

RODRIGUEZ, S. K. Geologia urbana da região metropolitana de São Paulo. 1998. 171 p. Tese (Doutorado) - Instituto de Geociências, USP. São Paulo, 1998.

ROSCOE, K.H. ; BURLAND, J.B. On the generalised stress-strain behaviour of wet clay. In: . Engineering plasticity. Edição: J. Heyman e F.P. Leckie. Editora: Cambridge University Press, New York, p. 535-609. 1968.

SANDRONI, S. S. Solos Residuais. Pesquisas realizadas na PUC-RJ. In: SIMPÓSIO BRASILEIRO SOBRE SOLOS TROPICAIS EM ENGENHARIA, 1981, Rio de Janeiro. Anais... Rio de Janeiro: COPPE/UFRJ, 1981, v. 2, pp. 30-65.

SANTOS, P. de S. Tecnologia das argilas, aplicada às argilas brasileiras. São Paulo: Edgard Blücher, 1975. 340 p. v. 1. 
SCHANZ, T. ; VERMEER, P. A. ; BONNIER, P. G. The hardening soil model: Formulation and verification. In: BEYOND 2000 IN COMPUTATIONAL GEOTECHNICS - 10 YEARS OF PLAXIS, 1999, Rotterdam. Proceedings... Netherlands: A. A. Balkema, 1999. p. 1-16.

SHAHROUR, I. ; GHORBANBEIGI, S. Analyse tridimensionnelle du comportement des tunnels dans des terrains meubles. Révue Française de Géotechnique, Paris, n. 76, p. 17-24. 1996.

SKEMPTON, A. W. The pore-pressure coefficients A and B. Géotechnique, London, v. 4, n. 4, p. 143-147. 1954.

SMITH, P. R. ; JARDINE, R. J. ; HIGHT, D. W. The yielding of Bothkennar clay.

Géotechnique, London, v. 42, n. 2, p. 257-274, jun. 1992.

SOUZA NETO, J. B. Considerações sobre as propriedades geotécnicas de alguns solos residuais brasileiros. 2000.57 p. $1^{\circ}$ Seminário de Qualificação ao Doutorado COPPE/UFRJ. Rio de Janeiro, 2000.

VARGAS, M. Introdução à Mecânica dos Solos. São Paulo: McGraw-Hill, 1978. p. 3-46.

VARGAS, M. Characterization, identification and classification of tropical soils. In: SECOND INTERNATIONAL CONFERENCE ON GEOMECANICS IN TROPICAL SOILS, 1988, Singapore. Proceedings... Netherlands: A. A. Balkema, 1988, v.1, p.71-75.

VAUGHAN, P. R. ; MACCARINI, M. ; MOKHATAR, S. M. Indexing the Engineering properties of residual soils. Quarterly Journal of Engineering Geology, London, v. 21, n. 1, p. 69-84, fev. 1988.

WOOD, D. M. Soil Behaviour and Critical State Soil Mechanics. 2nd ed., New York: Cambridge University Press, 1990. 462 p. 


\section{A pênoices}

Documentos elaborados pelo autor.

Apêndice A - Procedimento para separação das frações Silte e Argila de um solo

Apêndice B - Procedimento de execução dos ensaios triaxiais de carregamento axial

Apêndice $\mathrm{C}$ - Procedimento de execução dos ensaios triaxiais de descarregamento 


\section{APÊNDICE A}

\section{Procedimento PARA SEPARAÇão das FraÇões Silte e Argila de UM SOlo}

Separar $50 \mathrm{~g}$ de solo seco ao ar, passado pela peneira $\mathrm{n}^{\mathrm{o}} 200(0,075 \mathrm{~mm})$, e colocar o solo em um becker com $100 \mathrm{ml}$ de água destilada.

Acrescentar de 3 a $5 \mathrm{ml}$ de solução de hidróxido de sódio a $1 \mathrm{~N}$, agitar por 2 minutos e deixar em repouso entre $2 \mathrm{~h}$ e $24 \mathrm{~h}$. Em seguida, agitar na coqueteleira por $15 \mathrm{~min}$ e transferir para uma proveta de $1000 \mathrm{ml}$.

Nesse momento, pode-se passar o líquido pela peneira $\mathrm{n}^{\circ} 270(0,053 \mathrm{~mm})$. Recomenda-se que isto seja feito nesta etapa, para que o peneiramento seja por via úmida, não danificando a peneira. O líquido resultante na proveta é composto apenas por argila e silte, pois a parcela de areia fina ficou retida na peneira $\mathrm{n}^{0} 270$.

Em seguida, completar a proveta até a marca de $1000 \mathrm{ml}$, agitar a mistura por 2 minutos e deixar em repouso. O tempo necessário em repouso varia para cada solo. Faz-se necessário consultar um ensaio de granulometria por sedimentação, previamente realizado para o mesmo solo, onde se tenha determinado o tempo necessário para que as partículas em suspensão tenham apenas diâmetros inferiores a 0,002 mm.

Depois de decorrido o tempo determinado, remover de 400 a $600 \mathrm{ml}$ do líquido por sistema de sifão e reservar. Repete-se todo o procedimento, até este ponto, por 3 vezes ou até que se tenha certeza que o material restante na proveta seja apenas de diâmetro silte.

Ao líquido separado, adiciona-se ácido clorídrico a $1 \mathrm{~N}$ (o mesmo volume utilizado de hidróxido de sódio), para flocular a argila. A reação de $\mathrm{NaOH}$ e $\mathrm{HCl}$ (hidróxido de sódio e ácido clorídrico) resulta em $\mathrm{H}_{2} \mathrm{O}$ e $\mathrm{NaCl}$ (água e cloreto de sódio).

Remover o líquido por sifão e centrifugar a argila floculada.

Remover o líquido resultante da centrifugação e lavar a argila, para se retirar o cloreto. Repetir por no mínimo 5 vezes. Para verificar se ainda há cloreto, titular uma amostra com nitrato de prata. 


\section{APÊNDICE B \\ Procedimento de ExecuÇão dos Ensaios Triaxiais \\ de Carregamento Axial}

Foram utilizados corpos-de-prova cilíndricos, com diâmetro em torno de 3,8 cm e altura de 8,0 cm, talhados a partir de amostras indeformadas. Para a moldagem, as amostras foram colocadas no talhador e esculpidas cuidadosamente, até obter-se o diâmetro requerido. Em seguida, as amostras foram levadas para o berço, para que as extremidades fossem aparadas até a altura requerida. Depois da moldagem do corpo-de-prova, registrou-se a massa, altura e o diâmetro do corpo-de-prova. Parte do material restante da moldagem foi recolhida em cápsulas para determinação do teor de umidade. A partir destes dados, foram calculados os índices físicos iniciais do corpo-de-prova.

Em seguida foram colocados uma pedra porosa e papel filtro na base e no topo do corpo-de-prova, dispondo o conjunto sobre a base da câmara triaxial. Com auxílio de um encamisador, o corpo-de-prova foi envolto por duas membranas de látex. Acima da pedra porosa superior, foi então colocado o cabeçote responsável pelo contato com a célula de carga. A base e o topo do corpo-de-prova foram vedados com o-rings de borracha. A câmara triaxial foi então posicionada e travada, e a célula de carga localizada internamente no topo da câmara foi posicionada até entrar em contato com o cabeçote.

Após a câmara triaxial ter sido preenchida com água, deu-se início à fase de saturação do corpo-de-prova. Para tal, aplicou-se um fluxo ascendente até que um volume de água três vezes maior que o volume de vazios do corpo-de-prova fosse percolado, ou então até a completa saída de bolhas de ar. O fluxo foi gerado aplicando-se uma contra-pressão de $50 \mathrm{kPa}$ na base do corpo-de-prova e uma pressão confinante de $51 \mathrm{kPa}$. Esta tensão efetiva de $1 \mathrm{kPa}$ é a menor possível, com o intuito de evitar o estufamento da membrana e para que a amostra não sofra adensamento. Cabe lembrar que no topo do corpo-de-prova a contra-pressão é nula (permitida a drenagem) e que a tensão efetiva é igual a $51 \mathrm{kPa}$.

Em seguida, a saída livre de água pelo topo do corpo-de-prova foi então fechada. Após estabilização da contra-pressão, mediu-se o parâmetro $\bar{B}$ de Skempton (1954), fechando-se as drenagens do topo e da base do corpo-de-prova, aplicando-se um aumento de $50 \mathrm{kPa}$ na tensão confinante e medindo-se a variação da pressão neutra gerada. O corpo-de-prova foi considerado saturado desde que o parâmetro $\overline{\mathrm{B}}$ calculado tenha sido maior do que 0,98 . 
Depois de saturado, deu-se início à fase de adensamento, abrindo-se ambas as válvulas de drenagem. Foram realizados dois tipos de ensaios: o CID (Consolidated Isotropicaly Drained) adensado isotropicamente e cisalhado com drenagem; e o CAD (Consolidated Anisotropicaly Drained), adensado anisotropicamente e cisalhado com drenagem.

Os dois primeiros ensaios foram realizados com tensão controlada. Os ensaios seguintes foram realizados com deformação controlada, impondo-se ao corpo-de-prova um deslocamento vertical ascendente. Para tal, um pistão CRSP (Controlled Rate Strain/Pressure) aplicou uma velocidade de deformação de $0,025 \% / \mathrm{min}$. A trajetória de tensões desejada foi obtida controlando-se a tensão confinante.

O adensamento seguiu a trajetória de tensões referente a cada ensaio, com a velocidade citada anteriormente. Ao ser alcançado o nível de tensões desejado, este foi mantido até o dia seguinte, momento no qual se iniciou a fase de cisalhamento. Ou seja, o adensamento teve duração aproximada de um dia.

A fase de cisalhamento se iniciou após serem zerados os valores de deslocamento axial e variação volumétrica, calculando-se as novas dimensões do corpo-de-prova e o valor do índice de vazios. Foi definido como final do ensaio a ocorrência de ruptura do corpo-deprova, tendo a deformação axial variado entre 4 e $12 \%$. 


\section{APÊNDiCE C \\ Procedimento de ExecuÇÃo dos Ensaios Triaxiais \\ DE DESCARREGAMENTO}

Os procedimentos de moldagem do corpo-de-prova são idênticos aos apresentados para a execução dos ensaios triaxiais de carregamento axial.

A montagem do corpo-de-prova na câmara triaxial também é similar à montagem dos ensaios de carregamento axial. Entretanto, o cabeçote utilizado para os ensaios de descarregamento é diferente. Para estes ensaios, a célula de carga é fixada ao cabeçote por um sistema de rosca.

Desta maneira, o cabeçote é capaz de transmitir à célula de carga uma força de tração, gerando uma tensão desviadora negativa. Isto não significa que o corpo-de-prova está submetido à tração, e sim que a tensão horizontal é maior do que a tensão vertical. A tensão desviadora pode continuar a ser decrescida até que a tensão vertical seja nula, momento este em que o cabeçote perde o contato com o corpo-de-prova e a membrana é impelida entre os dois.

Os procedimentos seguintes, utilizados para as fases de saturação, adensamento e cisalhamento, são idênticos aos apresentados para a execução dos ensaios triaxiais de carregamento axial.

Os ensaios de descarregamento também foram realizados com deformação controlada, com uma velocidade de deformação de $0,025 \% / \mathrm{min}$. Foi definido como final do ensaio a ocorrência de ruptura do corpo-de-prova, tendo a deformação axial variado entre 4 e 7\%. 